\title{
SURINAAMS CONTRAST
}


Voor mijn ouders

Omslag: Kappen en vervoeren van suikerriet

(Foto-archief KJTLV nit.1202; fitho Th. Bray) 
KONINKLIJK I.NSTITUUT

VOOR TAAL-, LAND- EN VOLKE.VKUNDE

Caribbean Series 13

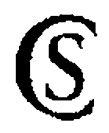

ALEX VAN SIIPRIAAN

\section{SURINAAMS CONTRAST}

Roofbouw en overleven in een Caraibische plantagekolonie 1750-1863

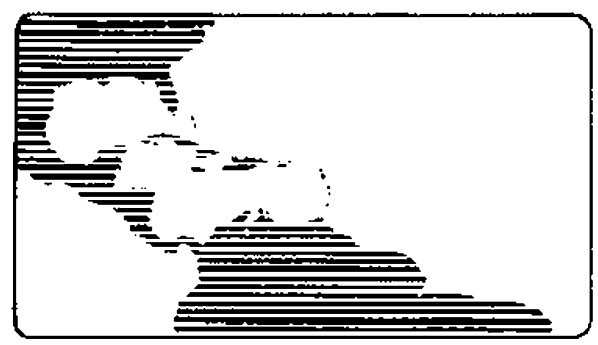

1993

KITIV Uitgeverij

Leiden 


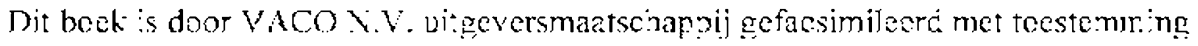
en sedewerking van KITl, V Uitgeveri: die de rechten op deze uitgave bez:t.

afbeclding omslag: I ropenr:.uscum., A:asterdan

Paramaribo: : :aTi 2007

IS3N $978-999[i-0-1076-1$

Uitgegeven door:

KITLV Uitgeverij

Koninklijk Instituut voor Taal-, land- en Volkenkurde

Postbus 9515

2300 RA Leiden

Nederland

\section{CIP GEGEVENS KONINKLIJKI BIBLIOTIIEEK, DEN HAAG}

\section{Stiprian, Alex vas}

Surinatms cor.tas: : roofoouw en overleven :n een Cara:bische plantagekolonie 1750-

1863 / Alex van Stipriaan. - Leiden : KITLV Uitgeverij. - I.I. - (Caribbean series /

Koninklijk Institud voor Tial, I..and er. Volkenkunde, ISSN 0921.9781 ; 13)

Oorspr. ritel: Surinaans contrast : roofhouw en overleven in een Caraïnische piantage-

economie, 1750-1863. - Proefschrift Vrije L'niversieeit Amsterdarn., 1991. - Met

bibliogr., index.

ISBN 90-6718-052-1

Trefw: Suriname ; lar.dhouseconomie.

(C) 1993 Koninklijk Instituut voor Taal-, Lard- en Volkenkunce

No part of this publication may be reproduced or transmitted in any form or by any means, electronic or mechanica, including pholocopy, recordirg, or any information storage and retrieval system, without persission from the copyright owner. 


\section{Inhoud}

Lijst van figuren en tabellen

\section{DEEL I}

Inleiding

1 Hest poliliek-economisch subat 2

2 Het socian'-culturele dishat 6

3 Waarom Suriname? 15

1 Nederland, Suriname en thet Caraibisch gebied lot 1863

1 Surinames posilie in hel Caraibisch gebied 28

2 De Surinaamse plantage-laconomie in vogelvlurht 33

3 Politikke structuur en verandering 37

II Plantages in teweying

1 Regionale verschuivinger 47

2 I.nkale verschuivingen 53

3 Verschuivingen in het plantagebezit 69

III Opbow van de planiage-infrastructur

1 Bolem en klirral 7.4

2 Opbouw van een plantage 79

3 Het belang var de waterhushoudir.g 81

4 Strijd tegen het water 93

IV Produktiefactoren on hur samenhang

1 Slaven als kapitaulgnederen 100

2 Geboux'en en machines 113

3 Grond en gewassen :20

4 Kapilaaigoederen en hur: kwelsbarheid 124

$V$ Ontwikkeling van de produktiviteit

1 De koffiesecto: 128

2 De suikersectcr 134

3 De katoensecto: 140 
VI Innoveren is overleven

1 De koffjesector 146

1.1 Teelt en bewerking van koffie 147

1.2 Innovatie 150

2 De suikersector 16]

2.1 leelt en bewerking van suikerrie: 161

22 De bijprodukten dram en melasse 166

23 Innovatie 168

3 De katoensector 182

3.1 Teelt en bewerking van katoen 185

3.2 lnnovatie 186

4 Surinamers en innovatie i92

DEELL $\amalg$

VII Ontwikkeling ian de kapitarlvoorziening

1 Plantagekrediet na 1750207

2 Het falende negotiatiesysteem 215

3 Het verdere verloop var. enkele negotiatiefeisdsen 225

4 Plantagekrediet in de negentiende celiw 231

41 De katoensector en het Zngels Tussenbestuur 231

4.2 Krediet in de suikersector 240

4.3 De Pariculiere West lredische Bank 246

5 Mecharisatie in de suiker zonder vreemd vennogen 252

VII Wat brengt het op?

1 De kosten 258

2 De baten 262

3 De rentabiliteit 266

IX Continutteit en eigenblang in het maragement

1 De bastiaan 276

2 De blankóficier 28.3

3 De directeur 285

4 De adninistrateur 293

4.1 Enkele topadrniristrateurs in 1824295

4.2 Administrateurs en 'de waarheid' 299

4.3 Administrateursinkomsten 304

$X \quad$ Slavendemografie

1 Bevolkingsgroei 316

2 Mortaliteit 322.

3 Vatalitejt 332

4 Fertiliteit 333

5 Vergelijking met het Caraibisch, gebied 337

6 Creolisering en samenstelling van he: huishouden 340 
XI Veranderingen in de arbeids- er levensomstandigheden van de slaren

] Arbeid 347

2 Voeding 350

3 Kleding en benodigdheden 357

4 Behuizing 359

5 Modische zorg 362

XII De ijzeren zuist wordt gehandschoend

1 Angst en geweld 370

2 Segregatie 375

3 De matht vai de slaver 385

3.1 Weglopen op Vrouvenvli;t ]834-1848 387

3.2 Overplaatsing van slavenmachten 389

3.3 Slaven eisen hum recht op 393

4 Surinatamse siaven als 'proto-peasants' 403

XIII De dyamick van oarrleven

Bijlagen

1 Surinaamse exporl vin suiker, koffie, katoem en cikad 1700-1869

2 Pri's van Surinaamse silker, koffie en katoen in Nederlanc 1740-1864

3 Exportwaarde Suriraamse suiker, koffie en katoen 1740-1864

4 De Surinaamse plantage-economic 1713-1890

5 Financiele balans Surinaamse overheid 1790-1863

6 Waarde van de Surinaänse gidlden 1712-1847

7 Warrand van planlage Lel:ënciaol 1\%45

8 Inrovaties in het kookhuis op Vossenblrg $1822-1862$

9 Opstardightid up pantages

10 Doodsoorzaken

11 Uitdelingen per slaaf

12 Plantagebronnen

Bibliografie 
A.A. van Stipriaan - 978-90-04-25979-9 Downloaded from Brill.com $\odot 4 / 26 / 2023$ 03:31:44PM via free access 


\section{Lijst van figuren en tabellen}

\section{Figuren}

1 Aantallen piantages producerend voo: de expor: 1713-1890 33

2 Exporlwarde Surimamse suiker, ko:fie en katoen 1740-1864

3 Surinamse export van suiker, koffix en katoen 1740/1770-1864 36

4 Verschuiving van iet plar.tagegebied in Suriname :735-1860 48

5 Verschuiving van let bebound areal op Sonerszo:g 1766-1853

6 Infrastructuur van eer, suikerplantage 86

7 Aantal slaven per pantagesector 1752-1852 08

8 Plantagehypotheken Suriname 1753-1792 216

9 Prijsverloop Surinaamse suike, koffe en katoen 1740-1863 265

10 Leeftijdsopbouw planlageslaven ca. 1830 en ca. 1860

11 Gemiddeld exportarsaa: per veldsian 17701554

Tabelien

1 Surinames positie in het Caraisisch gebied: oppervlakte er. bevolking ca. 1775 rri negentiende ecuw 28

2 Aantal suikerplantages diverse Ca:ainische kolnriën ca. 1685 рn ca. $1750 \quad 29$

3 Suiker-en koffieproduktie Ca:aibisch gebied 1775 en 1850

4 Gemiddelde omzet van Surinaamse partages 1745-1862 36

5 Aankel Caraibiscle expor: van suiker, kolie en katoen in $\mathrm{d} \mathrm{l}$ : woridmarkt $1775 \mathrm{en}: 850$

6 Aandeel van de plantagegebieden in inet totaal aantal Surinaamse exportplantages 1730-:860 53

7 Pantage-arcal per sector 1770 en 1862

8 Gemriddelde areaalbezeting ir: do koffiescrto: 1750-1840 60

9 Overige a reaalbezetting, ko fieplaniages $7750-1840$

10 Ceniddelde areaalbezetting in de katcensector 1790-1860 63

11 Overige areaalbezetling op katoerplantages 1790-1845 63

12 Ceriduelde arealbezetting in de suikersector 1750.1840

13 Rotatie op Groot Marseille 1801-1379 66

14 Ove:ige areaalbezetting op suíkerplartages 1740-1850 68

15 Ontwikkeling van het plantagebezit in Suriname 1737-1853 71

16 Gemiddeld aantal siuizen en kokers per plantage 1750-18.30

17 Cemiddelde waarie m impori van siaven in Suriname 1750-1830 $\quad 102$

18 Ceniddelde relatieve waarde-aandeel van siaven per sector 1750-1830 104

19 Cemiddelde relatieve waarde cier plantagegejow wen per sector 1750-1830 119

20 Cemiddeld gelaxeerde akkerwarde per sector 1750-1830 122

21 Cemiddelde taxaticwaarde bewerkte akkers en gewas per sector 1750-1830 123 
22 Gemiddelde relatieve waarde der kapitaalgoederen per sector 1750-1830 125

23 De gemiddelde Surinamse koffieplantage 1750-1862 128

24 Produktiviteit van de gemiddeIde koffieplantage 1750-1862

25 Gemiddelde Caraibische koffieplantage 1789-1830 133

26 Gemiddelde produktiviteit Caraibische koffieslaven 1789-1836 133

27 De gemiddelde Surinamse suikerplantage 1750-1862 135

28 Produktiviteit van de gemiddelde suikerplantage 1750-1862 137

29 Gemiddelde Caraibische suikerplantage 1767-1865 138

30 Gemiddelde produktiviteit Caraibische suikerslaaf $1770-1860$

31 Gemiddelde produktiviteit Caraibische suikerakkers 1801-1862 140

32 De gemiddelde Surinaamse kaioenplantage 1825-1862 141

33 Proxluktiviteil van de gemidd dicle katuemplantage 1825-1862 142

34 Gemiddelde produktiviteit Caraibische katoenplantages 1789-1836 143

35 Type suikermolen en levensvatbaarhe:d van de plantages 1745-1857 174

36 Vussenburg vergeleken met drie 'stoum'-plantages [850-1859 180

37 Plantageberit per sector 1824-1853 199

38 Plantagebezit en stoom 1853

39 Gemiddelde jaarlijkse winst per sláaf per sector in guddens 1760-1862 267

40 Gemiddelde winstontwikkeling in cie suikersector 1760-1862 268

41 Gemiddelde jarlikse winstontwikkeling in cle koffiesector 1770-1850 270

42 Gemiddelde jaarlijkse rentabiliteil per slaaf en per sertor 1760-1862 273

43 Administraties $1824 \quad 29.5$

44 Slavenbevolking Surinanie 1752-1862 311

45 Vrije bevolking van Suriname :752-1862 314

46 Sekseratio van slaven per seclor 1750-1853

47 Natuurlijke bevolkingsannwas per sector 1752-1862 318

48 Mortaliteit plantageslaven 1780-1862 323

49 Gemiddelde leeftijd plantageslaven bij overlijden in ca. 1835 en ca. 1861 326

50 Sekseratio overleden planlageslaven in ca. 1832 en ca. 1861

51 Kindersterfte $1820-1839$ en 1840-1863 330

52 Nataliteit plaritageslaven 1780-1862 332

53 Vuchtbare plantageslaven in populatie 1831 en 1851

54 Kind/vrouw-ratio 1831-1863 334

55 Demografje Carabische slavenpopulaties ca. $: 83.5$

56 Bevolkingsasnwas per sector, Suriname en Cuiara ca. 1835

57 Akkers kost per slaaf 1760-1850 


\section{Voorwoord}

Mijn eerste belangstelling voor de geschiedenis en cultuur van Suriname ontstond door de vele verhalen van Surinaamse vrienden in Nederland. Ik was dus riet geheel onvoorbereid toen ik in 1975 deze (rog net) Nederlandse kolonie voor het eerst bezocht. Desondanks werd ik, op een prettige manier, door Suriname overrompeld. Alles wat enigszins bekend had moeten zijn, was da: rninder dan ik had gedacht en alles wat mij onbekend voorkwam bleck uitcindelijk nog veel ongrijpbaarder dan ik ooit had kunnen vermoeden. Kortom, Suriname had mij in haar greep en zou mij sindsdien niet meer loslaten.

In 1979 maakte ik in het kader van mijn studie niet-Westerse geschiedenis aan de Vrije Universiteit te Amsterdam kennis met de rijke Surinaamse plantage-archieven en de grote onderzoeksmogelijkheden die deze boden. Hier lag een mogelijkheid een deel van het 'mysterie' Suriname zelf op te lossen. Nadat ik was afgestudeerd op en onderzuek over de koffieplantage Somerszorg stimuleerden Heather Sutherland, Peter Boomgaard en Ad de Bruijne mij om op het ingesiagen pad verder te gaan. In de loop der jaren heb ik erg veel van hen gelecrd. Een orderzoeksbeurs van de Stichting voor Wetenschappelijk Onderzoek van de Tropen (WOTRO) maakte het mogelijk drie jaar lang gegevens te verzamelen over Suriraamse plantages in de achttiende en negentiende eeuw. Uiteindelijk verwerkte ik deze gegevens in inijn proefschrift, dat ik in 1991 verdedigde. Dit boek is een bewerkte versie van mijn dissertatie.

Gert Oostindie plbbliceerde ir. 1989 de geschiedenis van twee Surinaamse plantages: Roosenburg en Mon Bijou. Dat boek is een zusterstudie van Surinaams contrast. W:ij hebber. in de loop der jaren veclvuldig - en met veel plezier - met elkaar overlegd en gepuzzeld. De twee studies vullen elkar in grote lijren aar, want waar hij 'de diepte' van twee plantages inging, kon ik 'de breedte' van de gehele plantage-economie onderzoeken.

Een van de stimulansen van onderzoek naar de geschiedenis van nietWesterse samenlevingen is dat het je op de meest uiteenlopende plaatsen doet belanden. Zo kwam ik terecht in de archieven van verscheidene handelsfirma's die in het verleden relaties onderhielden met Surinaamse plantages. Ik ber zeer dankbaar voor alle medewerking die ik heb gekregen 
bij de Algemene Bank Nederland te Amsterdam (archief Nederlandsche Handel Maatschappij), de firma Icotrust B.Y. te Amsterdam (atchief Insinger \& Co.) en de firma Baring Brothers in Londen (archief Baring Brothers). Daarnaast heb ik veel tijd doorgebracht in het Algemeen Rijksarchief in Den Haag, de Cemeentelijke Archieven van Amsterdam en Rotterdam, het Koninklijk Instituut voor de Tropen en de Economisch-Historische Bibliotheek in Amsterdam en het Public Record Office in Londen. Overal heb ik enorm veel medewerking mogen genieten, waarvoor ik de betrokkenen op deze plaats harteljik dank zeg. Verder heb ik dankbaar gebruik gemaakt van het archief-De Mey van Streefkerk dat zich weliswaar bevindt in de James Ford Bell Liorary te Mirneapolis, maar dat mij zeer collegiaal op microfilm ter hand werd geste!d door Ruud Beeldsnijder.

Daamaast ben ik veel dank verschuldigd aan alle instanties in Suriname die mij bij dit onderzoek hebben geholpen. Zonder de moeite die medewerkers en directies van he: Suriraams Muselim, de Dienst der Domeinen, het Staats Archief Suriname en het Centraal Burcau Bevolkingsregister zich voor mij hebben getzoost zou een substantice: deel van dit onkizzoek niet mogelijk zijn geweest.

Ook wil ik op deze piaats de Faculteit der Historische en Kunst Wetenschappen van de Frasmus Universiteit te Rotterdan bedanken, die mij in 1989 in staat stelde opnieuw een onderzoeksreis naar Suriname te maken. Sinds 1986 werk ik met veel plezier op deze fachlteit, en ik voel mij zeer bevoorrecht omringd te zijn door een aantal enthousiaste coliega's, in het bijzonder bij de sectie geschiedenis van agrarisch metropolitaire samenlevingen.

Iet Koninklijk Inslituut voor Taal-, Land- en Volkenkunde in Leiden dank ik in het bijzonder voor de gelegenheid die hel mij bood deze dissertatie in boekvorm uil te geven. De energie die alle betrokken KITLVmedewerkers hierin hebben gestoker. is enorm. Ik ben hen daarvoor dian ook zeer erkentelijk. Met name het zorgvuldige redactiewerk en engelengeduld van Rosemarijn Höste, Marjan Groen en Harry Poeze hebben ex voor gezorgd dat mijn proefschrift werd omgetoverd in een 'echt' boek. Dat neemt natuurlijk niet weg dat ever:tuele fouten en onvolkomentheden tot mijn eigen verantwoordeli,khe:d behoren.

Eigenlijk had ik in dit boek nog een hoofdstuk willen wijden aan de Surinaamse gastvrijheid, met als case-study Peter en Elly Sjak-Shie. Om het boek niet nog dikker te maken dan het al is volsta ik echter met te zeggen dat ik geen warmer nest ker. kn bij de Hasselnooks heb ik het gevoel gekregen in Suriname familie te bezitten, zonder dat van verwantschap sprake is. Beide fanilies geven mij iedere keer dat ik in Suriname ben het gevoel thuis te zijn.

Tenslotte zijn er nog enkele mensen die ik met name wil noemen, omdat 
ik dit boek niet zonder hun medewerking, kritiek, steun en vriendschap had kunnen schrijven. Annet Nugter, Peter Ronteltap. Stariey Wassenaar, Michiel Baud, Jimmy Kigters, Wendeli Angelentina, Willem van Schendel, Nike van Stipriaan Luïscius en Tim Sonne: bedankt. De enige manier waarop ik tot slot mijn ouders kan bedanken is door dit boek aan hen op te dragen, wat ix bij deze met alie liefde doe. 
A.A. van Stipriaan - 978-90-04-25979-9 Downloaded from Brill.com $\odot 4 / 26 / 2023$ 03:31:44PM via free access 
DEEL I 
A.A. van Stipriaan - 978-90-04-25979-9 Downloaded from Brill.com $\odot 4 / 26 / 2023$ 03:31:44PM via free access 


\section{Inleiding}

De Caraibische' geschiedenis nam na de 'on:dekking' dour Columbus eer. nieuwe wending De autochtone Indiaanse bevolking werd gedecimeerd of verdreven, maar darvoor in de plats ontstonden rieuwe samenlevingen, bevolkt door Furopeaner. Afrikanen en later ook Aziatea. Buiter de Spaanse Caraiben vormden Afrikanen de grootste groep; met hun slavenarbeid werder vanaf de zestiende eeuw meer dan tienduizend plantages aangelegd en bewerkt.

Tot halverwege che regentience eeuw vormden deze ondernemingen in veel Caraibische ko'onien de enige produktie-eenheder van belang en bepaalden zodoende het gezich van de nieuwe samenlevingen. Produktie van suker was aanvankslijk hur belangrijks:e activiteit. De daartoe? benodigde echnologie was nog weinig gecompliceced. In de loop der tijd werden de productietechuicken echer steeds geavantertier en verschenen er naast suiker nieuwe exportgewassen zoals koffie, katoen, indigo en cacaco. Het verlangen met handel in deze trojische produkten grote winsten te maken, vormde de grondslag van deze plantägesamenlevingen. In de praktijk werden er inderdaad kapitalen verdiend, maar ook vaak verloren.

De term samerleying is ir, dit verband ironiscis. Typerend voor het Caraibisch gebied waren raciale segregatie, chronisch slävenverzet er: latente dreiging van opstand. Regelmatig werd die dreiging werkeijkheid en wisten slaven zich, joms definitief, van hun ;uk :e bevrijden. Tejgelijkertija trachtte de vrije, hoofdzakeijk blanke bevolk!ng yich als kleine, maar dominante minderheid stande te houden en haar (commerciële) belangen veilig te strllen. Dit deed zij met zeer harde hand en een verdeel-en-heersbeleid. De confrontatie tusser. de verschillencie bevolkingsgroepen hepit er voorts toe bijgedragen dat ir. deze regio gcheel nieuwe, Afro-Caraibische culturen zijn ontstaan. Door al deze ontwikkelirgea biect de Caraibische geschiedenis een zec: dynamische aamblik.

In de historiogratie over de ontwikkeiing van Caraibische plantage-

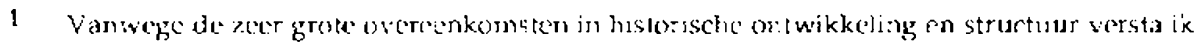
onder Caraibisch (gebieci) njet al'cen de eilanden in de Caraibische Zee, maar eveneens de nabijgelegen Guvanas (Guyana, Suriname en Frans Gisiana) op het vastcland van ZuidAmerika. 
koloriën ${ }^{2}$ tijdens de slavernij is veel vaker de nadruk gelegd op stagnatie en verval dan op dyлamiek en verandering. Zo wordt over de Surinaamse plantage-economie opgemerkt dat de technologie op suikerplantages in de slaventijd vrijwel net zo statisch was als de samenleving in haar totaliteit (Goslinga 1990:230). Elders wordt de ontwikkeling in de twee eeuwer vór de afschaffing van de slavernij gedefinieerd als een immanente statische tendens' (Heilbron 1982:27). Ook invloedrijke Caraibische historici hangen dez.e weinig dynamische opvatting aan. ${ }^{3}$

Deze karakterisering wordt gewoonlijk van toepassing geacht op het geheel van de plantage-economie, maar bij nadere beschouwing blijkt het meestal om de economische en politieke dimensie daarvan te gaan. In historisch onderzoek dat zich specifiek richt op bepazlde aspecten van de plantagekolonic is dit statisch karakter veel minder terug te vinden. Met name deelstudies over de slavernij wijzen op culturele dynamick en processen van sociale verandering (Genovese 1979, Craton 1982, Ward 1988). In deze studie over de Surinaamse geschiedenis wordt onder meer betoogd dat noch de eerste, politiek-economische, noch de tweede, sociaal-culturele, benadering het functioneren en de ontwikkeling van de Caraibische plantagekolonie op afdoende wijze verklaart.

\section{Het politiek-economisch debat}

De zogenaamde moderniseringstheorieën die ra de Tweede Wereidoorlog in zwang raakten, vormden eer belangrijke stirnulans voor onderzoek van niet-Westerse samenlevingen. In deze stucies wordt de geschiedenis van die samenlevingen vrijwel genegeerd en wordt een goed begeleid proces van industrialisatie de belangrijkste voorwaarce geacht om tot een zelfde ontwikkelingsniveau als het Westen te komen (Rostow 1962, Lewis i954).

2 Vanaf nu zal meestal worden gesproken van plantagekoloniën of -cconomieën. In dit onderzock worăt daaronder verstaan een samenkeving waarvan de conomische, geografische, sociale (en politieke) structur: wordt gedomineerd door 'de' plantage. Een plantage is in dit geval exn groutschalige arbeids- en kapitaalinternsiese agrarische underneming, die produceert voor de export.

3 Moreno Fraginals (3985:3) 2jet pas vanaf $: 860$ belangrijke en snelle transformaties optreden in de Cubaanse plantage economie. De voarafgaande anderlalve exuw wordt herog uit door geleidelijke verandering gekenmorkt. Tomich (1989:120-1) stelt za: is dat in het geval van Martinique deze periode zich uitstrekte vanaf de vestiging van de plantage-conomie in de aeventiencle eeuw (16.35) tot halverwege de negentiende eeuw. Volgens hem was het probleem dat the sclf-contained plantation and the organization of labor as slave labor as they had been historically constituted in Martinique hac become the chief obstacles to the transformation of the production process. The slosely integrated technical organization of sugar production and the need to maintain the balance between its various elements, including labor, gave intermal solidity to the sugar plantation and made it resistant to change.' Ouk

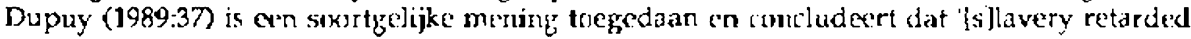
the economy of Saint-Domingue'. 
Met een beroep op de Latijnsamerikanse gesciederis betogen de grondleggers van de neo-marxistische 'Dependencia'-school dat dit model weinig realistisch is. $\mathrm{Zij}$ benadrukken de historisch gecreeerde afhankelijkheidsrol var de niet-Westerse wereld (de periferie) die voorwarde was voor de succesvolle ontwikkeling van het kapilalistische Westen (het centrum/de metropool). Deze verhouding is daardoor van structurele aard en heeft een proces van onderontwikkeling tot gevolg gehad (Frank 1979).

In de Caraibische historiografie heeft deze opvattirg gestalte gekregen in het model van de plantage-economie (Best 1968, Beckford 1972). Volgens deze onderzoekers $w$ as de piantage-ecoromie inet handen en voeten gebonden aan de Europese metropool en daardoor geïntegreerd in de kapitalistische wereldeconomie. ${ }^{+}$Met behulp van gedwongen en strikt hiërarchiscin georganiseerde ar jeid op de plartages werd de metropoo: voorzien van voornamelijk agraxische grondstoffen. De metropool eigende zich de gegenereerde swinsten toe, expo-teerde eindprodukter en kapitaalgoederen naar de plantagekoionic en dictecrde de handelsvoorwaarden waarop deze transacties moesten plaats vinden. Door haar uiterst beperkte economische functie en eenzijdige gerichtheid op de metropool bleef de plantagekolonie geheel afhankelijk van externe initiatieven. Er vord geen interne kapitaalaccumulatie plaats, noch ontwikkelder, zich bancien met andere produktiesectorer. Kortom, er ontstord geen eigen, interne dynamiek die de voorwaarde lad kunnen zijn voor een duurzame, onafhankelijke ontwikkeling.

Ir deze visie moet de basis voo: onderonlwikkeling worden gezoclet in de slavernijperiode en zijn ir hoofizaak de externe verhoucingen bepalend gewees:. Over het eerste iopen de meningen rie: ver uiteen, het tweede, externe, aspect is daarentegen wel bekritiseerd. De athankelijke positie ter opzichte van de metropool wordt door deze critici mede verklaard uit de

4 Historische analyse van de groei van internationale aflankeli;kheidsrelates leiat tot de constructie van wast de Europese wereldeconomic, of wei en (uileinde] ijk) wereldom

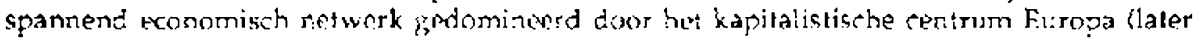
ook de V.S.), wordt genoemd. Een centraa: thema in de discussies over deze wcreidwijde historische ontwikkeling is de vaasg hoe en vanaf wanneer het kapitalisme, of de kapitalistische pronitiktewize, in die wereldeconomie dominart is gevorcien. Daaraciter ligt de vraag of set de produktie- of arbeidsverhoudingen - zoals Marx had gezegd - dan we] de marktverhoucingen zijn die het kapitalisme bepalen. Aanhangers var. de: iaulslgenoemde visie plaatsen het hegin van de kapttalistische ontwikkeling dan ook al in he! Futropa var do vi;ftiende eeuw, waarna het onafwencibaar de gehele wereld veroverde (Wallerstein 1974, 1980, 1989). Anderen zicn pas vanaf het cind van de ach:ticrde ecuw lisopa kapitalistisch worden (Woll 1982). Net name voor de laatster besekent de groei van de kapita'stische wereldeconomie nie! dat daarbinren geen ardere produktiewijzen kunnen plaatsvinden. Integendeel, de wereldeconomie kan ju:st groeien vanwege de dynamiek van articulatic, of koppeling, van verschillence produktiewijzen, waarhij de kapitalistische produktiewijze op den duur vrijwe: al:ijd dominant wordt. Volgens hen is juis: dat ce kern var het onderontwikkelingsproces. 
specifieke klassen, ras- en politieke verhoudingen en structuren in de plantagekolonie (Mandle 1972, 1973, Trouillot 1982, Dupuy 1989).

Een groot bezwaat van deze benaderingen is dat zij weinig inzicht geven in het functioneren van de plantage-economie. $Z i$; lijken op een 'black box', waarvan alleen de 'inpu:' en 'output' bekerd of van belang kunnen zijn. A priori wordt aangesomen dat er gebrek aan ontwikkeling was en dat slavernij leidde tot stagnatie. Een rechtlijnig proces van bloei en verval lijkt de enige beweging te zijn geweest in hes lamelijk vormoloze geheel van de plantagekolon:e. Alleer. wannee: ook de inteue klasse- (en ras)verhoudingen er bij worden betrokien lijkt er sprake van dynamiek. Hoc de produktie precies plats vond in de plantage-economie blijft echter duister. Evenmin wordt duidelijk gemaakt of dit in 1700 op dezelfde wijze gebeurde als in 1800 en of sit overa: hetzelfde was. Tevens belemmert de abstractie van structuren het zicht op de mensen die betrokken waren bij de plantageeconomie, zodat wij niet te weten korren wie welke beslissirgen nam en waarom. Het gevolg is dat er nauwelijks sprake lijkt te zijn geweest van lokale dynamiek.

Ook de, mijns inziens tamelijk vruchteloze, discussie over bet al of niest kapitalistische karakter van de plantage-economie in de slaventijus heelt het zicht op lokale dynamiek in sterke mate versiuierd. Deze discussie levert valk niet meer op dan een éendimensinaal en statisch beeld van de slaverni; en brengt bovendien soms de meest onverwachte ideologische combinaties tot stand (Morrissey 1989:8-9). De kwestie "kapitalistisch-ofniet?' vormi onderdeel van een debat waarin eveneens de onvererigbaarheic van slavernij en innovarie ler sprake wordt georacht. Hierdoor komt het verondersteld statische karakter van de plartage-economie ook weer voor het voetlicin. Dit desat ontstond als reactie op E. Williams' studie uit 1944, getiteld Capitalisn and Slavery (1980). Ilierin betoogt hij da: de Caraibische slavernij gedurende haa: bloeilijd een zodanige kapilaalaccumalatie in Furopa, med rame in Fregeland, tot stand had gehracht dat (mede) daardoor de Industriele Revolutic mogéijk werd gemaakt.

Aan het eind van de achttience eevw waren, aldus Wiliams, de Caraibische plantages ter gevolge van overproduktie en bodenuitputting in verval geraakt, niet meer produktief en onrendabel. Gedwongen arbeid vormde een obstakel voor innovatie en hac daarom zijn largste tijd gehad.

5 Daarachter is de cercier genuemde discussic zichtbast over cie duminantie van de (internationale) marktverhoudingen, dan wel de arbeics- of produktieverhoudingen als bepalend voor het kapitalisme. Voor sommigen is de op siavernij gebaseerde cconomic fcodaal (Cenovese 1976, 1981). Anderen zien deze als volledig geintegreced in de kapitalistische wereldeconomie (Wallerstein 1974), terwill er ook verklaringen 2 :jn die de piantageslavern:j karakteriseren als cen aparte, pre-kapitalistische produktiewijze ('mode of production') die met andere kor. worden verbondend (lindess en J firsl 1975). 
Dat goid tevens voor het hardelsprotectionisme dat zo bepalend was geweest voor de bloeiper:ode van de plantages. Het industrieel kapitalisme dat nu domimant werd, was gebaat bij vije arbeid en vrije markien. Onder druk van deze nieuwe beiangen zou daarom het Britse parlement als eerste de slavenhandel en slavernij hebber afgeschaft.

Naar aanleiding van deze zogenaamde W:iliams-these braken hef:ige discussies os die noy steeds niet zijn uitgewoed. Inmiddels is wel daidelijk dat Williams' verkiaring wat al te generaliserend en mechanistisch is. Zo bleken bijvoorbeeld de industriẹle belangengroepen nog nauwelijks in het Britse parlement te zijn vertegerwoordigd (Drescher 1977). Ook het aigehele verval van de Caraibische plantages worct in twijfel getrokken - er lijkt aan het eind van de achttiende eeuw eerder van opbloei sprake te zijn geweest. Ook de kwestie of vrije arbeid een noodzakelijke voorwaarde is voor innovatite blijkı nog steeds een pun: van discussie.

Hoe dibenloperd de meningen ook zijn, de meeste onderzoekers verklaren de afschating van slaverhandel en slavernij uret uifondering van het element van plartageverval - uit ontwikkeingen die buiten het Caraibisch gebied platsvorden.? He: functioneren en de ejgen dyramiek van de slavenplantage-economie blijven daardoor opnieww grotendeels buiten beeld. Slechis enkeler: wijzen op veranderingsprocessen in de regio zelf (Mintz 1979, Craton 1982, Higman 1984, Ward 1989), Vooral 'undamentele veramderinger. in de were:d van de slaven hebben voigens her de druk on tot afschaffing over te gaan erorm opyevoerd.

Samenvatlend kin wordem gesteid dat eer: visie die sterk de nadruk legt op de rol van externe factoren en verder slechls komt tot structuren er: generalisczende mode'len weinig vrlichtbaar is. Eer beter inzicht in het

6 De stelling dat rond 2800 de Carbibische plankage economieñ inderdaad minder profijtelijk er. incfficiënt waren geworden, of zelfs geheel in verva: geraakt, blijkt nauwelijks houdbaar gezien de grote verschillen binnen de tegjo. Sommige landen hadden rong 1800 al zotn anderhalve cenw grovischalige (suiker)pliantageproduktic achter de rug (Barbados, Martiniçue, Suriname), terwijl andere daarmec pas waren begonnen (Pucrto Rico, Trinidad), of juist gingen expanderen (Cuba, Guyana). Daarnaast wordt aangetoond dat de produktie op s.avenplantages in die tijd nug zee: profijeclijk was (Drescher 1977). Ook bij de :ne!ficientie van de plantayps en de onverenightarheid van siavernij en innovatie worden vrangtekens gezet (Boomgard en Oostindie 1989), gezien de stezds duidelijker aanwijzingen dat planters tijdens de slavernij w'bl ciegelijk gestreeid habben nads produk tiviteitsvernoging coor lecinologische :nnovatie (Watts 1987;. Dat deze visie 'now commands the field', zoals Morrissey (1985:3) stelt is echter overdreven (z:e bijvoorbeeld Moreno Fraginals 1985 en Dupuy 1989).

7 Sommigen leggen de nadruik op de rol van sociaal-relıg:euze bewegingen en veranderende k! asseverhoudingent in Europa (Anstey 1975, Davis 1975, Drescher 1977), anderen wijzen op de veranderende rol van Afrika in de wereldeconomie, waardoor dit continent van arbeidsleverancier grondstuffereproducenf werd (Wolf 1982). Vrijwel iesereen is het er inmidelels over eens dat de afschalfing van slaventandel en siaverni, nice het gevolg was van een veronderstelde algemene achtcruitgarg van de Caraibische plantage-economiern. Andere verklaringen zijn nog voiop onderwerp van discussic (Engermar. 1986). 
functioneren van plantagekoloniën kan worden verwacht van een analyse die zich meer richt op interne ontwikkelingen. Zo'n benadering kan namelijk veranderingen blootleggen en laten zien dat er minstens een samenspel moet zijn geweest van interne en externe factoren. Hiermee wordl het heden en verleden van Caraibische samenlevingen meer recht gedaan en verdwijnt het tamelijk amorfe en bewegingloze beeld dat de historiografie zo lang heeft beheerst.

Het is opvallend dat de studies warin de nadruk ligt op statische structuren en/of de dominantie van externe factoren vrijwel zonder uitzondering zijn gebaseerd op literatuuronderzoek. Omgekeerd putten bijna alle studies die aandacht schenken aan verandering en/of de interne dynamiek van de plantage-econornie vooral uit primaire bronnen. Dit wekt de suggestie dat wie op zoek wil naar dynamiek en verandering in plantageeconomieën tijdens de slavernij zich vooral moe: richten op het archiefmateriaal, dat een neerslag is van de plantagepraktijk.

\section{Het socianl-culturele debas}

Het sociaal-historisch onderzoek van nultiraciale samenlevingen in de Amerika's is in belangrijke mate gestimuleerd door de vraag hoe de huidige verschillen in rassenrelaties moeten worden verklaard. Vrijwel al deze sarnenlevingen zijn enkele eeuwen gedomineerd door plantageslavernij, zodat het voor de hand ligt verklaringen te gaan zocken in de (verschillen in) historische ontwikkeling van dit feromeen. Dat heeft een adntal heftige discussies en klassiek geworden studies opgeieverd.

Fen van de eersten die van zich liet spreken en wiens invloed tot op de dag van vandaag merkbaar is, was Tannenbaum (1946). Hij constateert dat in de Amerika's twee (eigenlijk drie) verschi'lende slavernijsystemen werkzaam zijn geweest. Het eerste was het reatief milde regime in de SpaansPortugese gebieden, het tweede was het extreem harde systeem dat Britten en Nederlanders hanteerden en tenslotte was er het systeem van de Fransen, dat een tussenpositie irnam. De verklaring voor deze verschillen vond Tammenbaum op het institutionele vlak. Spanjaarden en Portugezen hadden namclijk al lang voor de expansie in de Amerika's ervaring opgedaan met slavernij. Zodoencie bestond ten tijde van de vestiging van de plantagekoloniën in het Caraibisch gebied bij hen al een uitgebreide wettelijke en kerkelijke jurisäictie waarin zowel plichten als rechten van slaven stonden omschreven. Slaven waren dus weliswaar onderworpen personen, maar zij genoten wel institutionele bescherming. ${ }^{8}$

8 De lberische kolonisators waren zelf oojt uit Noord-Afrika gekoloniseerd en hadden toen al, vaak aan den lijve, kunnen kennis maken met slavernij. Een slaaf was daarom voor hen wel 
De protestantse Britten en Nederlanders kenden noch wettelijke, noch kerkelijke regels die de slaven bescherming bollen. Siavenwetgeving ontstond bij hen pas in de praktijk van slavenhardel en plantagebeheer en daarin bleek de slaaf niet als persoon, maar als zaak te worden gedefinieerd. De slaat had dan ook geen rechten, alieen plichten. Het gevoly was een rigide slavernijsysteem, want de meesters waren niemand verantwoording schuldig. ${ }^{9}$ Deze institutionele verschillen in de slavernijsystemen leiciden tot fundamentecl andere relaties tussen blank en zwart, die dan ook, volgens Tannenbaum, de uiteenlopende rassenverhoudingen in de Amerika's kunnen verklaren.

Deze Tannenbaum-these kreeg een geruchtmakend vervolg in de studie van S.M. Elkins (1959). Deze stelt dat het Noordwesteuropese slavernijsysteem, met name in de Verenigde Staten, een proces van depersonal:sering bij de slaven in gang had gezet, waardoor zij (en hun nakomelingen) tamelijk detinitieve karaktereigenschappen hadden gekregen. De stereotype 'Sambo' werd onder meer gekenme:kt door kinderijkineid en aflankelijkheid, ais gevolg van de gedwongen aanpassing aan het regime op de plantage, die Elkins als een 'tolal institution' definieert. Ilij zet zijn stelling kracht bij doo: de plantage te vergeijken met cen andere 'total institution': het Duitse concentratiekamp. Om te overleven in dergeli; ke institiatics blijken de beworers, volgens Flkins, tun eigen personnlijkheid te moeter. afleggen er. maken zij zich een dociele houding en infantiel gedrag eigen.

Zowel Tanrenbaum als Elkiass schetsen cius een zeer statisch beeld van de slavernij. Ze kregen dan nok het te:echte verwijt dat dit beeld nauwelijks overeenkomsten vertoonde met de werkelijkheid. H. Hoetink (1972) toont bijvoorbeeld het fundamentele verschil aan tussen de siavernij in Suriname eil Curaçao. bovendien concludeert hij dat de specifieke omstandigheden in de post-slavernij-periode meer bepalend waren voor de latere rassenverhoudingen dan de verschillende slaverrij-ervaringen. Audere kriliekpunten sp de Tanmembaum-these zijn onder meer dat geen rekening was gehouden met het feit dat de alledaagse werkelijkheid vaak hemelsbreed verschilde van de abstracte, institutionele voorschriften. Verder werden in het algemeen grote verschillen geconstateerd birnen de systemen - zowel in plaats als in tijd - en blijkt de economie een veel beslissender

een medernens, zij het mel cen onderworpen siatus. Verder kende de doninante roomskatholieke kerk evencens regels ten aanzien van de behandeling van slaven. 7o diende de mester als cen vader vonr zjin slaven te zorgen on werd het vrijmaken van slaver, gerckend tot een var de 'goede werken' waarmese en christen een plaats in de hemel kon verdienen.

9 De Fransen kenden gern slavenwetgeving. Zij ontwixkeiden de zogenasimde Code Non pas in het vcrlengde van hun bemoeienis met de At'antische s!avenhandel en slavenproduktie, dus vanat de zeventiende eeuw. Wel was ook bij hen de rooms-katholieke kerk een dominant institut, waardoor de slavers toch enige beschernirg genoten. 
factor in de behandeling van slaven dan kerk of staat (Genovese 1965, Davis 1966, Goveia 1970).

Het was echter vooral Elkins die een storm van kritiek kreeg te verduren (zie Lane 1975), die ruim. drie decennia later nog steeds niet helemaal is gaan ligger. De analogie van slavenpiantage en concentratiekanp werd puntsgewijs ondergraven en de stereotype Sambo bleek niet meer dan het beeld dat de meester graag koesterde (Genovese 1967). De belargrijkste - maar waarschijnlijk onbedoclde -.. verdienste van Elkins is echter geweest, dat zijn shockerende stelling een ware onderzocksgolf in gang heeft gezet, die een tot dan toe nog nauwelijks ontdeixte wereld bloot legde. ${ }^{10}$ Dit onderzock concentreert zich op het terrein van slavenverzet en slavercultuur.

In de geschiedschrijving van het verzet kunnen dzie thema's worden onderscheiden. Het eerste is marronage, het weglopen van slaven van de plantages. Deze weglopers stichtten onafhankeijike gemeenschappen en vielen van daar de piantagekoionie aan:

Het tweede thema is meer gericht op ket verzet van slaven binner. de plantage-economie. Dit varieerde van klein, dageiijks verzet, zoals lijntrekken en sabolage, to: en met grootschalige plantage of zelss koluniale opstanden. Tussen de twee belangrijkste onderzoekers op dit gebied, F.D. Genovese en M. Craton, is een discussie ontsta an over de vraag hoe het karakter van let slavenverzet moet worden geinterpreteeru. ${ }^{12}$

10 Hiermee ss overigens nict gereged dat von het verschipnen van Elkins werk geen onderzoek geciaan zou zjjn naar het lever en verzet van siaven. ET bestond ai een aantal klassiek geworden studies op dit gebied. Bijvoorbeeld het werk van G. Freyre (1986) over Brazilië dat in 1933 verscheers, waiarop Tannenbalm zich voor een deel basererde en tat na bijna zes decennia nog steeds wordt herdrukt. Dit vormde tevens de inspisatiebron voor het bekende onderzoek van R.A.J. van Lier (1977) naar de sociale geschiedenis van Suriname. Samenlevirg in een grensgebied werd in 1949 gepublicerrd. Do pas likat erkende studie van C.1.R. ;ames (1984), oorspronikelijk uit 1938, over de s'avenrevolutie op Sain: Domingue mag ook nict onvermeld bl:jven. Laarnaast zou het evermin just zijn te suggereren dat alle na 1959 verschenen slaverrijstudies ontstonden a's directe reactie op de Elkins-these. De toenemende aandacht vonr soriale geschiedenis in het ägemner. heeft daarop ziker ook grote invloed gehad.

Y1 Bekende ondcrzoekers ep dit gebied zijn R. l'rice, M. Campbell, S. Schwartz, S.W. de Groot en W. Hongbergen. Sommigen van hen (hijvoorbeld De Cront er. Price) hebben dasrbij de historiografie nieuwe impulsen gegeven doof het gecombineerde gebruik van orale en geschreven bronnen.

12 Cenovese en Craton zijn het es over eers dat naarmate het Afrikaanse aandeel in de slavenbevolking afnam en he: proces van creolisering op gang kwam, het karakter van het verze! is veratderd. Genovese (1981) duidt dit als een overgang vat pte-kapitalistisch, restauratief verzet van Afrikanen naar revolutimair verzest van Afro-Amerikanen. Di! vormde een onderdeel van en was geinspireerd door de bourgeois-denocratische revoluties in Europa er de Amerika's. Craton (1982) ziet het verzet meer als voortvlocise'. van de interne dynamick van de slaverrij. Voor het einde van de achttende eets zon het verzet, volgers hem vooral een cirecte reaclie zijr: geweest op de uitbuiting en wreedheden op cie plantages. Het waren wanhoopsacties van Afrikaanse slaven die toch riets meer hadden te verliezer. $\mathrm{Na}$ die tjjd keeg het weei meer het karakter van 'peasan' verzet van gecreoliscerde Afro- 
Het derde, recente onderwerp ontstond uit ongenoegen over de bestaande historiografie, waarin alleen aandacht werd besteed aan de verzetsrol van mannen. Vrouwen hadden echter ook deelgenomen en aan het hoofd gestaan van opstanden en marronage. Sterker nog, in het dagelijks verzet op de plantages waren zij zelfs van doorslaggevende invloed gebleken (Mathurin 1975, Beckles 1989), Bovendien zorgden vrouwen voor het levend houder en doorgeven van de verzetslraditie door hun specifieke rol in de religie en in de opvoeding van de kinderen (Bush 1982). ${ }^{13}$

Al deze onderzoeken naar de verzetsgeschiedenis laten zien dat de dociele Sambo en zijn vrouweli;ke pendant Quashiba naar het rijk der fabelen kunnen worden verwezen. Bovendien wordt het statische beeld van de slavernij vervangen door een veel dynamischer (en menselijker) interpretatie.

Het onderscheid in ce studies naar verzet en raar dagelijks leven en culturr heeft natuurlijk iets kinstmatigs. Onderzoex naar verzel is onmogelijk zonder aandach voor de materiële en culturele context en vice versa. I Iet gaat dus meer om een accertverschil dan om echt afzonderlijke benaderingen.

De declstudies die zich speciaal hebben gericht op de slavencultuur tonen al of niet expliciet aan dat de gedepersonaliseerde sianf niet bestond. Hoe was het anders mogelijk geweest dat slaven niet alleen cultureel erfgoed uit West-Afrika in stand wisten te houden, maas daarmee zelfs een geheel nieuwe Afro-Amerikaanse, of Afro-Caraibische cultuur wisten te creëren? De kracht en het complexe karakter van deze culturen en het feit dat de blanken daarmee niet alleen rekening moesten houden, maar er zich in sommige opzichten zelfs aan aanpasten (taal, medische kennis, eetcultuur), laat opn:elw weinig heel van de domme, kincierlijk athankelijke Sambo. ${ }^{14}$

Daarnaast zijn er stidies verschenen die het geheel van de cultuur,

Amerikanen die yoor hun inniddels opgebouwde belangen en rechten opkwamen. Deze visie benadrukt dus vecl meer de onathaakelijke no:ivatie en het eigen initiatief van slaven, al ontkent Craton niet dat zij zeker ook op de hooģte waren yar de revolutionaire ontwikkelingen e.ders in de wereld.

1.3 Daamaast wordt nogal eens beweerd dat de lage geboortenciffers in het Caraibisch gebied deels moeten worden gerien als bewaste verzetsdasd van vrouswen, die liever kozen voor kinderloosheid, abortus en zelfs infanticide, dan met hun nakomelingen de slavernji in stand te houden (Wlite 1985, Dadzie 1990). M. Morrissey (1989) verwerpt dece stelliny echter en wijt de relaticef geringe vruchtbaarheid van vrouwen aan meer materiële ouraken.

14 Zo tonen S.W. Mintz en Price (1976) aan dat de contouren van nieuwe culkurele instituties al in een heel vroeg stadium van de slavernij zichtbaar worden. M. Schuler (1979) beschrijft de complexe religicuze structuur en de invlered van religic op slavenverzet. De rijke Afro. Amexikaanse orale cultuur van vertel- en zangkunst is evenecns uitvocrig in kaart gebracht en geanalyseerd (Levine 1977. Abrahams 1985) en ook daatin worden weer vcel elementen van verzet aangetroffen. 
arbeid en levensomstandigheden op de siavenplartages beschrijven en. interpreteren. Sommigen kiezen het perpectief van een gehele plantageeconomie (Moreno Fraginals 1976, Goveia 1965, Genovese 1976), anderer. bestuderen een enkele plantage (Bennett 1967, Handler en Lange 1978, Craton 1978). Dit is geen eenvoudige opgave, want in de beschikbare bronnen, voornamelijk van planters en koloniale overheden, klinkt de stem van de slaven nauwelijks door. Degeren die hun stempel hebben gedrukt op de archieven waren nauwelijks geïteresseerd in het leven of de mening van de slaven. Hun voornaamste belangen waren orce en rust en een optimale produktie. Toch kan met behulp van onder andere orale bronnen, reisbeschrijvingen, archeologische artefacten, justitiële archieven en kritisch vermogen een belangrijk deel van het slavenleven worden gereconstrueerd.

Zelfs het kille feit dat planters hun slaven voornamelijk beschouwden als kapitaalgoederen waarmee zoveel mogelijk produktie diende te worden gerealiseerd, bleek op den dust onderzoeksmogelijkheder te bieden. Cijfers over produktie en onciertoud van deze 'kapitaalgoederen' werden namelijk vaak zorgvuldig in de plantagejoekhouding en rapporten bijgehouden. Hier bood de opkonst van de kwantitatieve geschiedbeoetening uitikomst. ${ }^{15}$

Hef meeste profijt van deze methode trekken orderzoexers die de demografische ontwikkeling van slaverbevolkingen analyseren en met elkaar vergelijken. Een groot aantal variabelen b'ijkt hierbij van invloed (o.a. soor: plantage, locatic, soort huishoudirg, voeding, ziektes). Hierdoor ontstaa! een steeds gedetailleerder beeld van de leversumsiandigheden en materiële culfuur var de slaven. Bovendien wordt het andee: van vrouwen meer belicht. Fen vooriop:g hoogtepurt in ceze tak van onderzoek werd bereikt met de stucie van B.W. Higman (1984) over het Brits-Caraibisch gebied.

Hiermee is de sociaal-culturele lin van onderzoek in belangrijke mate de politiek-economische lijn genaderd. Zonder geheel voorjij te gaan aan de externe factoren en grote structuren cie van invloed zijn greweest op de historische ontwikkeling van de plantageslavernij, is de nadruk meer komen te liggen op het functioneren en het belang van interne factorer en sociale groepen in die ontwikkeling.

Op dit punt aangekomen rijst de vraag, wat de onderzoeken en debatten van de afgelopen decennia nu hebben opgeleverc en of daarmee het beeld van

15 De hasis voor de:gelijk onderzoek werd gelegò door R.W. Fogel en S.L. Engerman \{1984\}, die met hun kwantitatieve analyse van de Amerikanse slavernij veel aspecten van het materiële leven yan słaven in beeld hebben gebracht. Ook kurnen met behulp van kwantitatieve gegevens veranderingen in de slavernij worden weergegeven, bijvoorbeeld voor wat betreft de arbeidslas! (produktivitcit), voeding, kleding, straffen en zicktcs (Ward 1988, Sheridan 1985). 
de Caraibische plantage-economieën en hun functioneren tijdens de slavernij compleet is.

Het statische beeld van zowel de plantage-economie als van de slavernij legde te grote nadruk op de rol van instituties en externe factoren en een te modelmatige benadering. Het resultaat was een soort amorfe slachtoffergeschiedenis, die weinig onthulde van het eigene van Caraibische samenlevingen en waarmee de historische erfgenamen zich nauwelijks konden identificeren. In reactic hierop werd meer aandacht geschonken a an de rol van interne, Caraibische fartoren en ontwikkelingen. Bovendien werd hierbij in veel grotere mate gebruik gemaakt van primaire bronnen, zodat men dichter bij de historische praktijk bleef. Het beeld dat zodoende is ontstaan blijkt veel dyramischer en doet meer recht aan de geschiedenis van de verschillende Caraibische samenlevingen en hun bewoners.

Toch betekent dit niet dat hiermee de geschiedenis van Caraibische plantagekoloniën tijdens de slaverni; voldoende is beschreven. In de eerste plaats is een onevenredig groot deel van het onderzoek gericht op het BritsCarabisch gebied, zodat de andere samenlevingen in de regio - met wellicht andere onfwikkelingen onderbelicht zijn geblever. Van groter belarg is echter dat het onderzock waaruit een dynamischer en gedifferentieerder beeld naar voren is gekomen zich heeft beperk tot sperifieke, met name sociaal-culturele, aspecten van de plantage-ecoromie. Aan een overkoepelende synthese is men nog nauweijks toegekomen. Het is essentieei om de samenhang tussen alle factoren en veranderingen te bestluderen om 20 tot de kern van het furctioneren van en de veranderingen in de plantagekolonie door te dringen. Het blootleggen van veranderingsprocessen zou nieuw licht kumen werpen op het ontstaan van huidige mechanismen van ongelijkheid, of, zo men wil, onderontwikkeling.

Het is daarom van groot belang riet alleen alle relevante onderdelen van de plantage-economie: te beschrijuen en te analyseren, maar tevens het verband daartussen te onderzocken. Zo blijkt de veranderende compositie van het slavendiect redelijk te kunnen worden gereconstrueerd en neemt het inzicht in demografische veranderingen van de slavenbevolking voortdurend toe. Over de ontwikkeling van de rentabihiteit van plantages, veranderende produktiepatronen, of verschuivende eigendomsverhoudingen is echter nog steeds weinig bekend. Laat staan dat duidelijk is of er verband bestaat tussen al deze ontwikkelingen. Toch ligt het voor de hand te veronderstellen dat de verschillende veranderirgen elkaar hebben beirvloed en he1 moet mogelijk zijn de onderliggende ratio daarvan te ontdekken.

Een ander belangrijk manco in het bestaance beeld van Caraibische plantage-economieën is dat deze vrijwel zonder uitzondering worden beschouwd als een monolithisch blok van snikerplantages. Dit levert opnieuw eer tamelijk statisch en ook scheef beeld op. In de praktijk zijn 
belangrijke verschuivingen opgetreden en gingen duizenden ondernemingen zich toeleggen op andere produkten dan suiker. Het gevolg was dat een groot aantal plantage-economieèn uit meer dan éen sector bestond. Dit kan van belang zijn voor de verklaring van veranderingsprocessen. Verliep bijvoorbeeld de ontwikkeling van verschillende sectoren synchroon of ging dit ten koste van elkaar? Wat was de underlinge verhouding tussen de sectoren? Had dit consequenties voor de slavernij in al zijn aspecten? Wat betekende dit voor de kapitaalvoorziening, de ecologie, de technologie, de machtsverhoudingen?

De ontwikkeling van de plantagekolonie als geheel kan dus onmogelijk worden geanalyseerd zonder aan deze vragen aandacht te besteden. Dit betekent overigens niet dat de reeds verworven inzichten over (sociaie) verandering nu geen aandacht meer behoeven. Waar het om gaat is de samenhang tussen áile factoren te belichten. Daartoe biedt de plantage als centraal underzoeksobject de meest complete en meest voor de hand liggende invalstoek. Daar woonden er werkten de slaven; daar werd kapitaal ge:nvesteerd; laar vond de produktie plaats; daar was het beleir van planters, managers en overheid voelbaar en daax zijn dan ook veranderingen he: meest direct zichtbaar. Kortom, de plantage is de plaats waar, direct of indirect, alle eiementen van de plantage-economie - en hun wisselwerking - kunnen worden aangetroffen.

Merkwaardig genoeg is tol ru toe slechis bij ditzondering voor deze invalshoek gekozen. Wel verschenen er in de ioop der tijd verschillende p’antagemonogra:ieën (bijvoorbeeld Debien 1941, Bennet\} 1967, Craton en Walvin 1970, Craton 1978, Handler en I ange 1978). Bij deze studies blijft het echter de vraag hoe representatief de onderzochte ondernemingen zijn voor het geheel van de plantage-economie.

Deze beperking geldt niet voor enkele recente siudies die niet alleen de plantage centraal stellen, maar teven zijn gestoeld op een bredere empirische basis (Higman 1984, Schwartz 1985, Watts 1987, Ward 1989). Toch schicten ook deze onderzoexen texort. Behoudens een enkele demografische vergelijking :ijkt geen van de auteurs zich bewust te zijn van de aanwezigheid var plantagesectoren anders dan suiker. Aan de slaven wordt terecht veel aandacht besteed, maar bijvoorbeeld de rol van managers, eigenaars en kapitaalverschaffers wordt niet, of slechts spaarzaam belicht. Agronomische, ecologische en technologische verarderingen krijgen vooral bij Watts de aandacht die zjj verdienen; in de andere oncerzoeken worden zij wel behandeld, maar nauwelijks kwantitatief onderbouwd. Daarmee worden belangrijke aspecten en interaciieprocessen over het hoofd gezien en dringer. de onderzoekers niet tot de kern van het functioneren van de plantage-economic door.

Zo signaleren de meeste auteurs weel dat in veel plantage-economieën 
vroeg of laat sprake was van bodemuitputting doo: roobouw, maar zij werken dit gegeven niet verder uit. De consequenties van roofbouw worden door hen alleen gezien op het vlax van dalende produktiviteit. In dit onderzoek zal echter blijken dat processen van coofbouw cruciaal waren voor het functioneren van de plantage-economie als geheel. Roofbouw blijkt kenmerkend te zijn geweest voor plantagelandbouw er had consequenties voor álle produkfiefactoren op de plantage. Slaven werden tot op het bot geëxploiteerd en konden niet voor voldoende nageslacht zorgen. Grond en gewassen werden doodgeteeld zonder volcioende reserve aan te houden. Erorme kap:talen werden aangetrokken, zonder acht te slaan op aflossing en reniebeta.ing op langere termijn. Alie aspecten van het plantagebedrijf werden door een dergelijke manier van ondernemen beinvloed er, hadden op hir beurt ook effect op elkaar. Tegelijk dwong zo'u proces tot verandering, want roofbouw was een per definitie begrensde werkwijze.

De vraag rijst hoe reëel de voorstelling is van zo'n op het ong weirig rationeel proces. Var beiang is dat in tie expanderende Europese wereldeconomie, waarvar ce Carabische plantagekoloniën een onderdeel waren, produktie ondergeschikt was aan handel. Handel vormde de motor van het geheel, daar werder grote en vooral ook suelle winsten gemiakt. De produktie op lange termijn was van minder belang, er konden altijd nieuwe gebicden it: de wereideconomire worder opgenomen. I let is daarom niet onwaarschijnlijk dat elementen van roofbouw ook in andere koloniale produktiegebieden in die tijd kunnen worden aangetroffen. Daarove: kan echter a.jeen een vergelijkende studie witsluitsel geven die ver buiten het huidige bestek valt.

Het is zinvol na te gaan in hoeverre het verschijnsel roofoolw bepalend is geweest voor de structuren en vexanderingen in de plantage-economie. Overheerste roofbouw overal en atijk? Dat ligi niet voor de hand, want het resultaat daarvan zou opnieuw het vertekende beeld opleverer. van recktlijnig verval. Fr moeten dis ook ancere processen dan roofbouw hebben plaatsgehad waardoor de plantage-economie kon veranderen en overieven.

Via een 'actor-oriented' benadering (Long 1990) 'kurnen de tegenkrachten van roofbouw worden geanalyseerd. Deze processen kunnen worden samengeva: als de dynamiek van orerleven. Zoals roofbouw in het algemeen alleen word: gekoppeld aan een specifieke wijze waarop met de grond werd omgegaan, zo workt overleven in de Caraibiche historiografie meestal beperkt tot de bestaansstriju van slaven. Mijns inziens was overleven echter een fundamentel proces von állen die bij de plantageeconomie waren hetrokken. Zo werd na een desastreuze schildencrisis toch weer in de plantage-economie geïnvesteerd. Tevens zal blijken dat ondanks roofbouw de ene sector (suiker) tot nieuwe bloei $\mathrm{kwam}$, een andere (koffie) 
dzarentegen niet. Van groot belang was verder de ecologische bestannstrijd van plantages, waarin sommige het redcien en andere, sorns letterlijk, ten onder gingen. Daarnaast vonden er aanzienlijke verschuivingen plaats in plantage-eigendom, management en koloniaal beleid. Ook de positie en het verzet van slaven veranderde en hun regatieve demografische ontwikkeling sloeg om in een opwaartse trend.

Het zai duidelijk zijn dat het proces van overleven een krachtenspel was met winnaars én verliezers. Het vormce de motor van verandering. De interactie tussen toofbouw en overleven leverde beweging en verandering op en kan worden bestempeld als de dynamiek van de plantagekolonie. De essentie van deze dynamiek is de mate waarin werd zorggedragen voor de reproduktie. Het was inherent aan coofbouw daaraan geen aandacht te besteden. Voorop stond de winst op kurte tcrmijn, zonder te letten op negatieve effecten op langere termijn. Na verioop van tijd warer arbeici, kapitaal, grond en gewassen grotendeels uitgeput en tijdige vervanging had niet plaatsgevonden. Alleen drastische veranderingen, gericht op het herstel van de reproduktie, konden een voortijigg eirde voorkomen. Hierbij vait te denken aan het in produktie nemen van nieuwe gronden en/of produkten, grootscheepse schuldsanering en massale import van nieuwe arbeicisksachier.

In het proces van overleven was de zorg voo: reproduktie juist intrinsiek aanwezig. Thet vormde de noodzakelijke voorwaarie voor het zekerstellen van de toekomst. De produktiefactoren werden gevoed en verbeterd om ook op langere termijn groei mogeijik te maken. Ir praktijk ieidde dit bijvoorbeeld tot investeringen in technologische innovatie en bevordering van de natuurlijke bevolkingsaanwas, maar ook tot slavenverzet dat was gericht op toenemeride onafhankelijkheid. Het kon echter gebeuren dat in dit proces tevee! van de betrokkenen werd geëist, waardoor een voortijdig einde aan de irsparnirgen kwam.

Roofbouw legt vooral de struxturen en het functioneren van het systeem als geheel bloot. Het proces var overleven onthult met name de rol var. alle betrokken 'actoren' daarin. Het gat hier om een accentversch:l, want bij roofbouw zal ook op actoren worden gewezen evenais op structurele ontwikkelingen in het proces van overleven. De strijd tussen roofbouw en overleven vormt het raamwerk van ceze studie waarin de veranderingen in de piantage-economie zo breec mogelijk worden beschreven. Daarbij zuilen zeker verschijnselen als vervai, grovi, stagnatie, dominantic, verzet en afhankelijkikeid aan de orde komen. Deze verwijzen echter naar deelaspecten van de historische ontwikkcling. Waar het om gaat is de vraag hoe mensen onder sperifieke omstandighecer een samenleving zoals de plantagekolonie hebben weten vorm te geven en wat de dyramiek is in dit complexe krachtenspe.. 


\section{Waarom Suriname?}

Ter illustratie en verklaring van voornoemde processen is gekozen voor een case-study van éen plantagekolonie. Door kwantitatieve gegevens op micro-niveau van circa tweehonderd plantages te verzamelen en te combineren is het mogelijk macro-economische uitspraken te doen. Deze worden getoetst aan bevindingen elders in het Caraibisch gebied. Zo wordt de plaats en representativiteit van deze studie in het geheel bepaald en wordt een bijdrage geleverd aan de hiervoor beschreven debatten.

Voor een Nederlands historicus is Suriname een voor de hand liggende keus. Bovendien lijkt de geschiedenis van deze samenleving voldoende aanknopingspunten te bevatten om de hiervoor beschreven wijze van analyseren zinvol te maken. Tevens is het Surinamse bronnenmateriaa! nog zeer weinig onderzocht. De neeste siudies baseren zich hoofdzakelijk op literatuuronderzoek, of beschrijven slechts bepaalàe aspecten van de Surinaamse geschiedenis tijdens de slavernij.

Wanneer het gehed van de piantage-economic ter sprake komt, blijken de meeste auteurs zich te baseren op dezelfde, veelal regentiende-eeuwse, literatuur (me: name J. Wolbers 1861). Het beeid dat daaruit is ontstaan wordt als bekend en vaststaaind verondersteld en ziet er, enigszins gechargeera, als volg $t$ uit. Vanaf de tweede helft van de zeventiende eeuw tot circa 1740 werd in Suriname een groot aantal plantages aangelegd met behulp van uit Afrika geimporteerde slaven. In dat jaar waren er circa 400 plantages met ongeveer 50.000 slever. in bedriff (later zelfs bijna 600, waarvoor in totaal ruim 300.000 Afrikanen werden geïporteerd). I let belangrijkste exportprodukt was suiker, maar er werd ook koffie, cacao en katoen verbotiwd. Halverwege de achttierde eeuw waren de piantages al met zware schulden belast. In het derde kwart van dezelfde eeuw bereikte de plantage-economie haar grootste bioei, maar namen tegelijk de phanters grote kredieten op in Vederland. Tevens mnest de plantageko'onie vepl energie en kapitaal besteden aan oorlogvoering met de rarrons. In 1773 brak op de beurs in Amsterdam een crisis uit, waardoor de met schulden beladen Surinaamse planters fa:lliet gingen. De plantages kwamen ir. handen van Nederlandse schuldeisers, absenteisme was het gevolg en een onomkeerbaar proces van verva! zette in. Eind achttiende eeuw was 'het rijk der planters ten einde, dat der adminisirateurs begint'. 1" Sindsdien werd tot 1863 geen kapitaal meer in de Surinaamse plantage-economie geinvesteerd, zodat $z i j$ steeds verder in verval rankte.

Tot overmaat van ramp braken in Turopa aan hef eird van de achttiende

16 Deze wel haast klassiek geworden zinsncde van Wolbers (1861:312) is vaak letterlijk geciteerd of geparafraseerd (bijy. Van Lier 1977:31; Van de Voort 1973:201) en is daarme een van de vele voorbcelden van hel voortdurend gebruik van decelfde secundate: bronnen. 
eeuw de Napoleontische oorlogen uit en werd Suriname door de Engelsen bezet. De kolonie verloor daardowr haar afzetmarkt en bovendien werd de import van slaven door de rieuwe machthebbers stopgezet. Hierdoor ontstond een steeds nijpender arbeidstekort en werd het verval versneld. Samen met de afschaffing van de slaverr.j in 1863 vormde dit de definitieve nekslag voor de plartage-economie, mede ondiat nooit vernieuwing had plaatsgevonden.

Slaven kwamen in dit verhaal meestal voor als tot op het bot uitgebuite wezens, die in groter getale stierven, of wegliepen om zich aan fe sluiten bij de marrons. Vergelijkingen met andere Caraibische landen werden rauwelijks gemaakt, behalve in de veelgehoorde opmerking dat Surinamse pianters de wreedste en hardvochtigste waren van de gehele regio.

Zoals za: blijken is een groot aantal var de hier opgesomde 'feiten aantoonbaar onjuist. ${ }^{17}$ Daarnaast levert deze voorstelling van zaken eer. tamelijk clichémałig en rechtlijnig beeld op var. bloe: en verval. Veranderingen, voor zover gesignaleerd, worcien alleen in dat licht bezien; erige andere dynamick lijkt niet te hebben bestaan. Of het nu gaat om 1750 of 1850, een piantage was een planiage en en slaaf een slaaf.

Indercaad hebben stagnatie en verval een rol gespeeid in de Surinaamse paantagelandbouw vóor 1863. He: enige serieuze onderzoek dat daarraar werd verricht (Panday 1959) is echter zo rechtlijnig en zo sterk gericht op externe factoren, dat het dacidoor nawwelijks iets verklaart en de werkelijkheid geweld aandoet. 18 Hetzelfde geldt voor de invloed van de

17 De genoemde cij̣ers zijn geen var alle cu:rect. Koffie was lange tijd varel belangrijker dar. swiker. De schitdenlas? rond 1750 was veet minder hoog dan werd aangenomon. De invloed van de Amsterdamse beurscrisis s'erd overschat. Ook in de negentiende eeuw werd kapitaal in de Surinaamse plantage-economie geinvesteerd. Na 1814 werden nog grote aantallen slaven

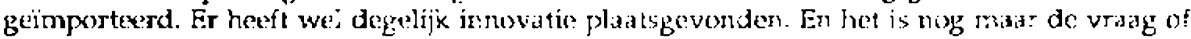
de Surinaamse slavernij de hardste was van de hele regio.

is De wijze waarop soms de waarneid gewe.d word: aangcdaan. mag blijken uit twee voorbeclden. R.M.N. :anday (1959:80) wil laken zien dat na 180 ) de katoenplemtages in verval raken en steit dat 't the largest quant:ties of this product were exported towards the turn of the eighteenth century'. Lit zijn eigen tabellen (pp. 20 en 78) bijikt echter dat rond 1795 I,2 miljoen pond katoen werd geexpotteerd en rond 18252,3 milijon pond. Over de eerste tien jaar van de negent:ende eeuw schrijft Panday dat de sivikerexport toen in een kritieke fase verkeerde, maar dat dit vana! 18:6 ten gocde keerde. Met enkele daartoe uitgezochte jaren illustreert hij dat tussen 1816 en 1821 de export steeg van 5.500 ton tot 10.600 lon (p. 71). Op dezelfde manier valt echter ook ana te tonen dat iussen 1805 en 1811 de export eveneens stieg van 5.200 ton tot 10.000 ton (zje Bijlage 1). De constatcring dat ra 1816 de suikerexport expandeerde is overigens we: correct. Panday schrift dit toe aan concentratie van de preduktic op grotere plantages. "Morevever, the introduction of intensive methods of cuitivation. e.g. the uise of manu:e, planting varielics with a higher cane yiejc, ctc. also contributed towards the expansion' ( $p, 7:$ ). Na 18 I6 werd echter geen enkele ardere wijze of vorm var. bernesting toegepast als daarvixi, de introductio en groxtschalige tnepassing van meer produktieve rietsoorten had a! acn het eirde van de achitiende eeuw plaats gevonden en de belangrijkste oorzaak van de expansie, het gebruik van stoommachincs, wordt door herr niet gernex'ma. 
internationale discissie over de kapitalistische produktiewijze op de Surinaamse historiogratie var. deze periode, wat er toe heeft geleid dat sommigen de Surinaamse plantage-economie gedurende de slavernij als volkomen statisch bestempelen.

De andere invalshoek is overigens ook aanwezig in cie historiografie van Suriname, Evenals in het overige Cara:bische onderzoek werder: de afgelopen decennia bepaalde aspecten van de slavernijperiode special belicht en diepgaand onderzocht. Deze studies, die vooral marronage en slavenverzet als onderwerp hebben ${ }^{15}$, tonen een vee: genuancercier ontwikkeling en geven de Surinaamse geschiecenis een beweeglijker en tegelijk menselijker' gezicht. Ook het onderzoek var J.P. Siwpersad (1979) naar de geschiedenis van de Emancipatie behoort tot deze categorie, al zijn bij hem externe factoren wel van doorslaggevence jetekeris. Hoe gedetailleerci en dynamisch het beeld in deze studies ook is, het geeft geen zicht op het functioneren van de Surinaamse plantage-economie als geheel.

Dit bezwaar geldt tevens voor de studies van Vas: Lier (1977) en C.Ch. Guslirya (1971, 1985, :990). Het eestgenoende onderzoek is inmicidels meer dan veertig jaar oud, mar geldt in brede kring nog steeds ais hét standaarawerk over de Suriramse geschicdenis. Toch word: in de onderhavige studie weinig nat dit werk verwezen. Van I,ier beperkte zich namelijk tot de sociale geschiecienis en besteedde, vooral wat betreft de periode vóor 1863 , nauwelijks aandach: aan economische of landibouwkundige ontwikkelinger. Bovendien, of just daardoor, is het door hem geschetste beeld van de siavemplantage tameijjk statisch. In het werk van Goslinga ortbreekt daarentegen juis: de sociale dimensie, en komen voornamelijk politiex belangrijke personer aan bod. Ook gat zi,n economische analyse niet verder dan bioe: en verval, domineren bij hem de externe factoren en definieert hij het geheel van de plantage-ecoromit als statisch. Beide onderzoekers hebben nauwelijks geput in plantage-archieven.

Tevenals in de res: van de Cardibische historiogralie is das ook in de moderne geschiedschrijving van Suriname tot voor kort sieciats bij u:tzondering gekozen voor de plantage als centraal onderzocksob;ect. Fvenmir heeit er roenenswandige vergelijking piatsgevonden met landen in de regio ${ }^{20}$ Dat mag op zi;n minst merkwardig heter voor een samenleving die eewwenlang door plantage-onderneminger werd gedo. mineerd en bovendien tientallen soortgelijke samenlevinger. in haar

19 Z:e bijvorbeeld de sudies van C. de Beet (:980), H.A.M. Essed (1984), De Groot (:963, 1988-89), S. Hira (1982), hoogbergen (1978, 1985, 1990) en . I'rice (1973, 2976, 1983, 1990).

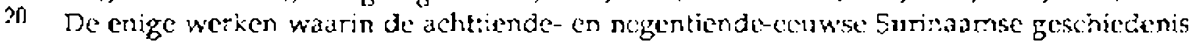
(enigszins) in cen C.araibisch perspectief ivordt geplazts:, zijr die vân Mintz en Price (1985), Price (1979) en - in mindere mate - Siwpersad (1979). Alleen in de studies van H.E. Lamur (1987a) cr. C.5. Oostindic (:989) is van structurcle vergcijiking sprakt. 
ongeving had. Tegelijk blijkt juist voor plantages een rijkdom aan bronnenmateriaal, bij wijze van spreken, voor het grijpen te liggen.

In de jaren zeventig werd voor het eerst een Surinaamse plantage (Catharina Sophia) uitvoerig onderzocht door Lamur (1977) en E. van den Boogaart en 1'.C. Emmer (1977). Zij beperkten zich echter tot het laatste decennium van de slavernijperiode. Bovendien was Catharina Sophia een 'modelplantage' van de koluniale overheid, zodat haar ontwikkeling weinig hoeft te zeggen over die van andere planlages. Iamur ging echler op de ingeslagen weg verder en deed onderzoek naar de plantage Vossenbury voor een veel langere periode. Hij richtte zich vooral op de religieuze cultuur van de slaven op deze plantage (1985), hun demografische ontwikkeling en de rentabiliteit van de onderneming (1987a). De meest diepgravende Surinaamse plantagemonografie tot nu toe is die over Roosenburg en Mon Bijou in de periode 1720-1870 (Oostindie 1989).

Lamur en Oostindie laten beiden zien hoe vruchtbaar het is de plantage als onderzoeksobject te nemen; vijwel alle aspecter van de samenleving zijn op de plantage terug te vinden of er direct mee verbonden. Suriname zelf staat centraal en door vergelijkingen te maken met plantages elciers in het Caraibisch gebied wordt de Surinamse geschiedenis uit hatas isolement gehaald. Bovendien tonen beide monografiën dat de geschiedenis van deze plantages allesbehalve statisch was, of een ondubbelzinnig lineaire ontwikkeling van verval vertoont. Roosenburg en Mon Bijou raakten in de negentiende eeuw inderdaad in verval (Oostindie 1989:305), Vosserburg daarentegen floreerde als nooit tevoren (Lamur 1987a:70).

Dit maakt tevens duidelijk dat de ontwikkeling van een enkele piantage nog niet maatgevend hoeft te zijn voor de plantage-economie als geheel. Het is daarom de bedoeling met deze studie in een leemte te voorzier. Waar met name Oostindie 'de diepte in ging' door de ontwikkeling van Roosenburg en Mon Bijou tot in detail te beschrijven en te analyseren, zal in dit onderzoek worden getracht 'de breedte' op te zoeken door de veranderingen en dynamiek van de piantage-economie als geheel te beschrijven en te analyseren. In grote lijnen kunnen be:de studies daarom als aanvallend op elkaar worden beschouwd.

De veranderingsprocessen in de plantagekolorie en de rol van dominante actoren worden in drie delen beschreven waarbij de constituerende elementen van de p'antage-economie: landbouw, kapitaal en arbeis de basis vormen. In alle drie de deien zullen voortdurend twee constanten worden aangetroffen. De eerste is de onmogelijkheid te spreken van 'de' Surinaamse plantage-economie. Steeds moet namelijk onderscheid worden gemaakt tussen de suiker-, de koffie- en de katoensector. Het zal blijken dat deze drie sectoreri weliswar niet onafhankelijk van elkaar functioneerden, 
en elkaar zelfs diepgaand hebben beïnloed, maar ieder toch een eigen ontwikkeling en dynamiek hebben gekend. Analyse darvan is daarom onontbeerlijk voor een goed begrip van de veranderingen in 'de' plantageeconomie. Die veranderingen - en dat is de tweede constante - zullen steeds in hoge mate bepaald blijken te zijn door de wisselwerking tussen processen van 'roofbouw' en 'overleven'.

In I loofdstuk II blijkt meteen al hoe onhoudbaar het idee van een statische plantage-economie is. Zowel territoriaal als uit een oogpunt van bezitsverhoudinger: was er voortdurend beweging. Voorts wordt in Hoofdstuk III aangetoond dat een deel van de dynamiek van de plantageeconomie samenhing met de typisch Strinaamse infrastructuur var de plantages en hun continue strijd tegen het water.

Iloofdstuk IV laat de samenhang en zwakke plekken zien van ce verschi'iende produktiefactoren, waarna in Hoofdstuk $\mathrm{V}$ hun produktiviteit wordt behandeld. Omschrijvingen als 'statisch' of 'lineaire ontwikikeling' blijken weinig toepasselijk. Daarnaast wordt getoond dat de Surinaamse produktiviteisscijfers tot de hoogste van het Caraibisch gebied behoren.

In Hoofdsiuk VI wordt onderzocht in hoeverre slavernij en technologische innovatie (on)verenigbaar waren. De opvatting dat slechis met vrije arbeid kon worden geinnoveerd lijkt moeilijk houdbaar en evenmin kan de produktiewijze in zijn algemeenheid als statisch worder betiteld. Met name suikerplantages blijken tussen 1750 er: 1850 in belangrijke mate te $z i j n$ verancierd. Suriname was daarin vergeli k baar met de rest van de regio en behoorde zelss iange tijd to: de voorhoede van ianoverende plantageeconomieën.

Vervolgens wordt in Hoofdstuk VII de rol van de kapitaalverschaffers onderzock.t en wordt het overschatte belang van de Ainsterdamse beurscrisis van 1772-1773 belicht. Het bijkt dat de krecietstroom wel aan grote fluctuaties onderhevig was, maar nooit tot stilstand kwar. Bovencien veranderde zijn bron en de richting waarin hij vloeide. De produktieve a anwending van het kapilial verschilde per sector en tevens blijkt irnovatie zoncier vreem.d vermogen te hébben plaatsgevonden. Ook de rentahiliteif van de plantages (I Ioofdstuk VIII) vertoont grote Sluctuaties.

In Hoofdstuk IX komt de rol van he: maragement aan bod en wordt getoond welke belangentegenstellingen van invloed zijn geweest. De continuiteit was vaax ver te zoeken en zowe' de bastiaar als de administrateur blijken cruciale figuren te zijn geweest. In ce Hoofdstukken $X, X I$ en XII worden de slaven centraal gesteld. Hun gedrag en levensomstandigheder. blijken aan belangrijke veranderingen onder hevig te zijn geweest. Een slaar rond 1850 lijkt moeilijk vergelijkbaar mei zijn voorganger halverwege $d_{k}$ achttiende eedw. De materiöse omstantdigheden zijn niet meer deze'fue en de demografische ontwikkeling vertoont eell opgaande ijn, die weinig 
afwijkt van het Caraíbiscine gemiddelde. Wei zijn er opnieuw grote verschillen tussen de sectoren te constateren. Ook is het karakter van het slavenverzet in de loop der tijd fundamenteel veranderd en lijkt er sprake te zijn van de vorming van een 'proto peasantry'.

In Hoofdstuk XIII tenslotte, worden alle ontwikkelingen samengevat en conclusies getrokken. Het wordt duicelijk dat in de interactie tussen roofbouw en overleven de dyramiek van de planłage-economie moet worden gezoch1. Zowel verval als vooruitgang blijken het resultaat. Het begrip 'statisch' wordt tuit de geschiedschr:jving van de plantage-economie geschrapt.

Door de hoofdstukker heen komt de vragg aan de orde of de Financipatie van 1863 gezien de diverse ontwikke'ingen op een 'logisch' tijdstip is gexomen. Ook wordt zoveel mogelijk getracint een vergelijking te maker tussen de Surinaamse en andere Caraibische plantage-economieën om na te gaan in hoeverre Sturiname representatief was en wat de bevincingen betekenen voor de debatten in de Caraibische historiogratie.

Om het onderzoek enigszins binren de perken te houden is gekozen voor de periode 1750-1863. Halverweyge de achttiende eeuw kwam de Surinaamse plantage-economie tot volle wasdom. De cerste marronoorlogen waren achter de rug, het aantal plantages groeide naar een hoogte-punt, evenals de slavenimporien, het geinvesteerd kapitaal en de produktie. Het was in diezelfde periode dat koffie de leidende ro! van suiker overram. Kortom, rond 1750 waren aile elementen aanwezig die bepalend zijn geweest voor de verdere ontwikkeling van de Surinaamse plantagekolonie.

De keuze voor 1863 als eindpunt is evident. In dat jaar werd de slavernij afgeschaft waardoor nieuwe variabelen een belangrijke rol gingen spelen in de plantage-economie. Er kwam ioonarbeid, de plantages kregen concurrentie van een 'peasant sector', de arbeidsmobiliteil ram toe en er werd opnieuw arbeid van buiten de kolonie (nu uit Azië) ingevocrd. Desondanks dient 1863 niet te worden opgevat als een absol:ate scheising tussen twee onvergelijkbare tijdperken. Plantages bleven een belangrijke rol spelen in de economie, arbeidsomstandigheden veranderden slechts langzaam en etnische segregatie bleef kenmerkend voor de koloniale samenleving.

Een tweede noodzakelijke beperking van het onderzoek is dat het zich niet uitstrekt tot 'de stad' (Paramaribo) en 'het bos' (marrons en Indiaren). Di: zou een aparte stucie vergen, en deze onderwerpen zijn deels al uitgebreid behandelc.

Het onderzoek is voor het grootste deei gebaseerd op archiefmateriaal van individuele plantages (inventarisser, taxaties, correspondentie, boekhoudingen) en overheidsarchieven. Waar mogelijk zijn hieru:t aselecte steekproeven getrokken, om vanuit micro-niveau (de piantage) een zo repre- 
sentatief mogeli,k beeld te krijgen van de ontwikkelingen op macro-niveau (de plantage-economie). Dit heeft to: gevolg dat deze studie een sterk kwantitatief karakter hee.t. Het voordeel daarvan :s dat ontwikkeinger. duidelijk in kaart worden gebracht, het onderzoek is herhaalbar en het biedt materiaal vour verdere studie. Een nadee: is dat 'de mers' onder het geweld van de cijfers dreigt te bezwi ker. Waar mogelijk worden daarom tijdgenoter aan het woord gelaten, zodat het (kwantitatieve) geraamte toch ok (kwalitatief) vlees en bloed krijgt.21

Eén ding dient niet uit he: $\infty$ g te worden verloren: alle materiaal waarop dit onderzoek is gebaseerd, werd opgetekend door vertegenwoorcigers var. de blanke machthebbe:s. De slaver kregen ir. de archieven geen eigen stem. Ook al is getracht de slaven zovee: mogelijk in beeld te krijgen, toch blijft het beeld onscherp er: welicht gekieurd. Op dit terrein dieni nog veel onderzoek te worden verricht, waarbi; de osale geschiederis wel eens onontseerlijk zou kunnen zij̧n (zie bijwoorbeeld Guda 1984 en 1985).

Tenslotte nog enkele opmerkir.ger. die belangrijk zijn voor eer. goed begrip van de tekst. Wanneer in deze studie wordt gesproken nver de regentiende eekw, dan word: darmee de periode tot 1863 bedoeld. Onder planters worder. planiage-eigenaars verstaan en, wanreer zij niet apart worden genoemd, ook hun plaatsvervangers, de administzateurs. Tot slot wordt voor het gemak de term 'slaven' gebruikt voor zorwel manren als vrouwen, :enzij expliciet anders vermeld.

21 Mijn dissertatie, waarvan dit bnek eer bewerking is, bevat een lijst met plantages dis in de steekproeven zijn gebruixt. Dit proefschrift is gcdeponeeyd in wetenschappelijke bibliotheken in Nederland en Surinarme. 


\section{HOOFDSTUK I}

\section{Nederland, Suriname en het Caraibisch gebied tot 1863}

Toen Nederland ${ }^{1}$ in 1667 vaste voet $\mathrm{kreeg}$ in Surirame, was dat slechis één stap in een proces van toenemende betrokkenheid in de Nieuwe Wereld. Deze ontwikkeling lag in he: verlengde van de expansie van de Europese wereldeconomie enerzijds en de strijd om de hegemonie binnen die wereldeconomie anderzijds. Varaf de tweede helft van de zestiende eeuw verschoof hei machtscentrum vart het lberisch schiereiland naar Noordwest-Europa, in he: bijzonder Nederland en Engeland. Deze twee landen dankten hun succes mede aan een nieuwe strategie, waarin handel een instrument var de geopolitieke strijd werd (Woif 1982:124).

Deze gecombincerde militaire en economische machtsstri,d speelde zich voror een groot deel af buiten Furopa. Zo werd bijvoorbeeld zout, dat lange tijd uit Spanje was betrokken, van circa 1600 af door Nederlanders zelf uit het Caraibisch gebied gehaalu. En al werd ex voortdurend gevochten tegen de Spaans-Portugese vijard, dit weerhield de Niedexlanders er niet van het transporf tussen Portiggees Brazilië en Europa te verzorgen en de Braziliaanse suiker in eigen land te verwerken. Rond 1620 was meer dan de helft van de Braziliaanse handel in Nederlandse handen (Boxer 1976:54). In 1621 werd de zo voordelige combinatie van oorlog voeren en handel crijver. geinstitutiona:iseerd in de oprichting van de West-Incische Compagnie (WIC). $z$

Deze WIC kreeg van de Staten-Generaal het monopolie op handel en scheepvart met West-Afrika er. de Amerika's, waaronder nok het Caraibisch gebied. Bovendien kreeg $2 \mathrm{ij}$ het recht in het haar toegewezen. gebied oorlog te voeren, vrede te sluiten, gebieden in bezit te nemen en daar de bestuurlijke en rechterlijke macht uit te oefenen. In de decennia volgend op haar stichfing veroverde de WIC voor kortere of langere tijd I'ortugese handelsforten op de Afrikaanse westkust en richtte zij nieuwe op. Ook werden Caraibische eilanden in bezit genomen, waaronder Curaçan, Sint Maarter, Aruba, Sint Eustatius en Tobago. Noordoost-Brazilië werd op de Portugezen veroverd.

Hoewel aan de Nederlandse heerschappij over 'Brasiel' al na drie

1 In deze studie wordt voor het gemak de anachronistische beraming Nederland gebruikt, ook al gaat het surns over de 7.even Venenigde Provinciën, of de Batadise Republick.

2 De Verenigde Oost-indische Compagnie (VOC) was al in 1602 opgeriontan - 978-90-04-25979-9 
decennia een einde kwam (1654) en de WIC aan deze onderneming kapitalen verloor, heeft deze episode verstrekkende gevolgen gehad voor het Caraibisch gebied. Tussen 1636 en 1645 waren de Nederlanders heer en meester in Pernambuco, toen het centrum van de suikerproduktie in Brazilië, en de Amerika's als geheel. Daar maakten zij van nabij kennis met het gecombineerde systeem van groutschalige suikerplantages en Afrikaanse slavenarbeid. Ook de benodigde technologie voor de verwerking van suikerriet leerden zij hier kennen. In het besef dat dit systeem een potentielle goudmijn was, exporteerden zij de opgedane kennis, nu gekoppeld aan Nederlands kapitaal, naar het Caraibisch gebied. Daar kreeg de suikerplantage haar eerste grootschalige toepassing op het Engelse eiland Barbados (Watts 1987:176-231). Met de produktie bemoeiden de Nederlanders zich aanvankelijk niet, des te meer echter met financiering, transport van slaven en produkten, en verwerking en verkoop van die produkten in kuropa.

Toen de Portugezen de Nederlanders uit Brazilië verdreven, verlieten ook de van vorsprong Braziliaanse joden (sephardin) de kolonie. Onder de Nederlanders hadden deze sefarden een belangrijke rol gespeeld in de Braziliaanse suikerplanterij. Met de terugkeer van de Portugezen stonden zij opnieuw bloot an de vervolgingen door de roms-katholieke inquisitie. $Z$ ij verkozen zirh, met hun onschatbare kennis van de suikerproduktie en hun kapitaal, te vestigen in de Engelse en Nederlandse Caraiben. Gevrijwaard van religieuze vervolgingen startten zij daar nieuwe ondernemingen. Suriname was een van de landen waar de sephardim neerstreken en de basis hielpen leggen voor een bloeiende plantage-economie.

Inmiddels was de Spaans-Portugese dominantie gebroken, en woedde een keiharde strijd om de vacänte leiderspositie, tussen Engeland, Frankrijk en Nederland. Dit resuiteerde in diverse vorlogen en voorts in de constructie van sterk protectionistische economische stelsels, met behulp van de Fingelse Navigation Arts, het Franse Exclusif en de Nederlandse Octrooien.

Suriname was een typische creatie van deze periode. In 1650 was het door Engelsen van Barbados in bezit genomen, waarna de basis voor een plantage-economie werd gelegd. In 1667 werd de kolonie door Nederland veroverd, het jaar daarop definitief aan Nederland toegewezen. Na langdurige onenigheid tussen Zeeiand en de Staten-Generaal over de vraag wie het oppergezag in Suriname zou kriggen, werd in 1682 besloten de kolonie over le dragen aan de WIC. De in versukkeling geraakte WIC (Gosilinga 1985:270-1) leek deze last echter te zwaar, zodat zij een-derde aandeel verkocht aan de stad Amsterdam, alsmede een-derde aan Cornelis van Aerssen, heer van Sommelsdijck. Dit trio eigenaren verenigde zich in de Geoctroyeerde Sociëtcit van Suriname, die tot 1795 in stand is gebleven.? 
In een 32 artikelen tellend octrooi, verleend door de Staten-Generaal aan de WIC, werd de relatie tussen Suriname en Nederland voor lange tijd vastgelegd. Dit octrooi, een typerend voorbeeld van monopolistische economische wetgeving, laat er geen twijfel over bestaan met welk doe! Suriname in bezit werd genomen. 20 staat er in de preambule

'het voordeel ende welvaren, dat in gevalle van verhoopt succes van deselve Colonie sal proflueren, door accres van Commercie ende Navigatie, door het debit van veelderhande Manufacturen ende vnichten door het vianufactureren van de rouwe waren, dewelke van daer in retouren herwaerts gebracht ende gemarufactureert wesende, wederom in andere handen gedebiteert ende verhandelt werden door den consinueelen aenbouw en de reparatie van schepen derwaerts vasende [...I' (Wolbers 1861835 )

Verder werd in het twailfde artikel van het octroo: vastgelegd

'Ićlat den Handei en de Vaett op ende van Voorsz. Colonie alleen, sal mogen geschieden, directeiijck uit en na dese Lande [Nederland], ende dat vock vervolgens alle de vuchtem, waren, en gewassen nergens heen, als directi:ijck op dese Ianden sullen mogen worden gesonder, mitsgaders ook alle Behoefter voor de voorsz. Coionie gerequireert, uyt desen Landen ende nergens anders van daen derwaerts werden gebracit' (Wolbers 1861:839).

Daarnaast werd bepaald

'Id]at om de voorsz. Colonie krachtelijck en so veel mogelijk voort te setten en om alle voordee:en, dewelcke hij verhoopt succes van deselve slillen komen af te vloeijen, te doen vallen in de sthoot vatn de Coloniers en Planters aldaer ende van de Ingezetemen van desen staet, derl Jandel en Traffycque op Suriname, ende van daer indistinctelijck liber en open sal zijux aen alle ingezetenen van desen staet, bijuende niettemin geobligeert in conformité van den octroye van: de voornoende Compagnie, deselve Compagnie le erkenne' (Woloers 1861:8389).

Ook over de arbeid in Surirame konder geen misverstanden ontstaan, want in artixel zes werd gesteld

[d]at dewijle de gemelte Colonie niet w'el kan worden voortgeset, dan door middel van Swarte Slaven ofte Negros ende dat niemandt buyten de voorsz. Compagnie in dese ianden bevorght is eenighe? slaven te halen van de kuste van Africa, alwaer alleen in gehandelk werden, soo sal de voorsz. Compagnie geobligeert zijn, aer: de geseyde Colonie jaerlijck te leveren sodanigen aental slaven, als aldaer suiten wesen gerequiree:l' (Wo:bers 1861:837).

Van meet af aan is Suriname een tropisch wingewest geweest dat, met behuip van Afrikaanse slavenarbeid, produceerde ten bate van de Nederlandse economie. Suriname mocht alleen ruwe grondstoffen ('rouwe waaren') en halffabrikaten leveren, die pas in Nederland verder werden bewerkt door suikerraffinateurs en koffiebranders. Deerr (1949:455) schat dat rond 1770 alleen in Amsterdam 110 suikerraffinaderijen in bedrijf warer: Nederlands grootste koffiebrander op dit moment, Douwe Fgherts, is hoogst* waarschijnlijk in 1753 begonnen met de verwerking van Surinaanse koffie. 
Aangezien de Surinaanse produktie uitsluitend in Nederland op de markt mocint worden gebrackt, waren de planters ir. Suriname volledig afharkelijk van de markicondities in dat land. Ook al warer de prijzen caar onvoordelig, toch mochten de produkter: riet elders worcen verkochi. bovendien hadien de Suriraamse planters weinig zicht, laat staan greep, op deze inarkt, omdat - in tegerstelling lo: de gesloten Engelse mark - dezt ook open stond voor buitenlanders. De Nederadedse economie had kunnen expanderen door haar functie als stapelmarkt en dat diende zo te blijver. Met name produkten uit het Frans-Caraibisch gebied werden druk op de Nederlandse markt verinandeld. Zo bleek bijvoorbeeld in de tweede helft van de achttiende eeww dat het aandeel van Surinaamse suiker op de Nederlandse markt niet groter was dan een-derde van het totaal en cat van Surimaamse koffie niet meer dan de heift. Een uizzoncering op het monopolie was melasse, een bijprodukt van suiker. Voor dit produkt bestond in Nederland geen markt en daarom mocht ce melasse in Suriname worder. verkocht aan Anerikaanse scheepskapiteins."

Uit het eerder geciteerde twaalfde artikel van het Octrooi wordt ook duidelijk dat alle transport tassen Nederiand en Suriname moest plaatsvinden met Necierlandse schepen, die ook in Nederland gebouwd en gerepareerd dienden te worder. Een begrijpelijke bepalirg, aangezien Nederiand een belangrijk deel van zijn welvaart te danken had aan het internationale goederentransport en Engeland een steeds grotere concurrent werd. Scheepsoouw en transport konden dis wel enige bescherming en nieuwe impulsen gebruiker. De Amerikaarse schepen waarmee de melasse werd vervoerd vormden de en:ge uitzondering op dit a:tikel. Dat betekende overigens wei een forse irbreuk op het Nederlandse monopolie: bijvoorbeeld in de jaren 1770 voeren ieder jaar gerniddeld 56 schepen naar Nederland en 50 naar Noord-Amerika, al waren de laatste waarschijnlijk wel ecn stuk Kleiner dan de Necierlandse (Van de Voort 1973:240-2).

Ook alle benodigaheden warmes de plantages draaiend en het (luxe) leven van de planters in stand werden gehouden, moesten uit Vederland worden ingevoerd. Het girg hierbij om uiteenlopende goederen als stemen voor de bouw, kiedingstoffen voor de slaven, suikerketels voor de produktie en stoopjes jenever orn cie planterskeel te smeren. Ook hier vormden de Noordamerikaner een uitzondering. Zij brachten tabak, gezouten vis en vee voor de plantages.

Ombat alle produkten in Nederland moesten worden verkocht, kwam ook alle xapitaal daar vardaan, al veranderde dit enigszins in de negentiende ceuw. Hertoe girg de planter eer. relatie aan mut eer: - meestal Amsterdamse - koopman-barkier. Deze verzorgde de verkoop van pro- 
dukten, regelde het transport en de assurantie daarvan, kocht en verzond de plantagebenodigdheden en verleende eventuele voorschotten en hypotheken. Op ieder van deze handelingen verdiende hij een afgesproken percentage provisie, terwijl de planter gerechtigd was wissels op hem te trekken. De rol van zo'n koopman-bankier was dus van cruciale betekenis. IIij zat als een spin in het web van belangen dat tussen Suriname en Nederland was gesponnen, een positie die met de introductie van de rogenaande negotiatiefondsen nog werd verstevigd. In het Brits-Caraibisch gebied werd een identiek systeem gehanteerd; in het Franse daarentegen opereerden de kooplieden in de koloniën zelf (Pares 1960:iii).

In artikel zes van het Octrooi was vastgelegd dat de WIC het monopolie had op de slavenaanvoer uit Afrika, onder de verplichting dat deze altijd voldoende moest zijn. Vanaf het begin echter heeft men niet aan deze kwantitieve eis kunnen voldoen. Tussen 1683 en 1700 hadden de Surinaamse planters ongeveer 45.000 slaven nodig, terwijl de WIC niet meer dan cen-derde van dat aantal in die periode kon aanvoeren (Goslinga 1985:420; Postma 1990:186). Toch duurde het nog tot 1730 voordat de WIC dit monopolie werd afgenomen en de slavenhandel volledig vrij werd gelaten. Het resultaat van de opheffing van dit monopolie was opmerkelijk. Gedurende het monopolie van de WIC kwamen jaarlijks gemiddeld 897 slaver in Suriname aan. De particuliere handelaars wisten er echter tussen 1731 en 1795 ruim twee maal zoveel, namelijk gemiddeld 1.851 per jaar, in Suriname in te voeren. Daarmee had de WIC in feite haar bestaansrecht als handelscompagnie verloren, want in de scheepvaart tussen Suriname en Nederland speelde zij al geen enkele rol meer. Dat zij toch nog tot het einde van de achttiende eeuw bleef bestaan, had volgens Goslinga (1985: 566) te maken met het feit dat de WIC als politiek instrument voor de Staten-Generaal noy wel van belang was. De WIC had, in tegenstelling tot de Staten-Generaal, veel ervaring mel het beheer van de overzeese bezittingen. De politieke en militaire complicaties van de vierde oorlog tussen Fngeland on Nederland (1780-1784) en de kostbare marronoorlogen in Suriname (1765-1793) gingen echter op den duur de capaciteit van de WTC. te boven en noodzaakten de Nederlandse overheid zelf het beheer over de kolonie op zich te nemen. De WIC werd opgeheven (1791) en daarmee veranderde Suriname van een particuliere bezitting in een 'gewone' kolonie.

Het exclusieve systeern, dat de scheepvaart op Suriname in Nederlandse handen moest blijven, was daarmee echter niet ten einde. Met uitzondering van de Noordamerikaanse schepen, werd daaraan ook in de eerste helft van de negentiende ecuw vastgehouden:

'[d]aar was Hollands kapitaal geinvesteerd, daar beschermde ook de Nederlandse Staat de bezittingen der planters. Goldberg, gelieerd aan de Amsterdamse kooplieden en Directeur van de Raad van Koophandel en Koloniën, be- 
schouwde de handel op Suriname als een "eigendommelijken vaatt", zoals iemand "die zijnc afgelegene landgoederen van het nodige vourziel, daarentegen doet afhalen de vrugten van de-zelve".' (De Jong 1966:139.)

Pas in 1848 werd het exclusiviteitsbeginsel losgelaten en de handel en vaart op Suriname opengesteld voor alle landen warmee Nederland 'in vriendschap leefde'.

Tot slot speelde de grote afstand tussen Nederland en Suriname een niet te onderschatten rol in de relatie tussen beide landen. Een reis per zeilschip nam al gauw zes tot acht weken in beslag, waardoor de communicatie zeer traag verliep en controle op de overzeese activiteiten tamelijk moeilijk was. Bovendien was men sterk afharikelijk van de windrichting, zodat het nogal eens voorkwam dat hele vloten tegelijk uitzeilden. I iet gevolg was dat de aanvoer in beide landen vaak uiterst onregelmatig verliep. Wanneer een groot aantal schepen tegelijk met produkten uit Suriname in Nederland aankwam, kon dat de marktprijs sterk drukken en wanneer lange tijd geen schepen met benodigdheden in Suriname aankwamen stegen de kosten van levensonderhoud in dat land tot recordhoogter.

Het transport over lange afstand vormde, vooral in oorlogstij, een kwetsbare schakel in de keten van betrekkingen tussen beide landen. Tussen 1665 en 1816 was Nederland betrokken bij vijf oorlogen met zeevarende mogendheden waarbij de scheepvaart met Siriname werd bedreigd. ${ }^{5}$ Vooral het laatste kwart van de achtliende eeuw was desastreus. Van de plantage Jagtlust bijvoorbeeld werden in de jaren 1784, 1796, $1797 \mathrm{en} 1803$ schepen door de Fngelsen geconfisceerd warop zich een deel van de oogst bevond Daarnaast werden, vanwege de oorlogsomstandigheden, in 1793, 1798 en 1799 in het geheel geen produkten van deze plantage verzonden. ${ }^{6}$

Maar ook in vredestijd was het transport kwetsbaar. Met grote regelmaat werden de schepen door stormen geteisterd, liepen zij vast voor de Nederlandse kusi, of werden door kapers belaagd. Zo zijn lussen 1736 en 1779 dertien schepen met produkten van de plantages Vossenburg en Wayampibo vergaan en werden er nog eens vier gekadp1. ${ }^{7}$ In de negentiende eeuw verdween de piraterij en de schepen werden kennelijk minder kwetsbaar, want van Vossenburg vergingen tussen $i 820$ en 1857 nog maar twee schepen, het eerste bij Zandwoort, het tweede bij Vlieland.

Uit alles blijkt Surinames totàie afhankelijkheid van Nederland. Het enige belang dat Si:iname werd toegekend, was de grootschalige produktie van tropische exportgewassen. Alle benodigde kapitaalgoederen moesten

53665 1667: onrlog met Fingeland; 1672 workig met Engcland (tot 1674) en met Frankrijk (Lot 1678); 1701-1713: oorlog met Frankrijk, als gevolg waarvan in 1712 een Franse inval plaatsvond in Suriname; 1780-1784: corlog met Engeland; 1793-1814: Nederland speelbal in de oorlog tussen Frankrijk en Engeland, als gevolg waarvan Suriname cerst een Engels protectoraat werd (i799-18C2) cn lates door Engeland werd ingelijed (1804-1816).

b Collectie-Insinger \& Co., Notulbuek Biesterbos.

7 EHIR: KA 87, 11,12, 13

8 Surinaams Museum: Collecrie-Brantsen, verantwoorde rakenizg. Stipriaan - 978-90-04-25979-9 
worden geimporteerd, terwijl winsten en economische spir-off aan Nederland voorbehouden bleven. Suriname was bovendien een speelbal van de politieke ontwikkelingen in Europa. De basis waarop een plantageeconomie als de Surinaamse rustte was dan ook wankel en zeer kwetsbaar.

\section{Surinames positie in het Caraibisch gebied}

Hoewel Suriname tot de oudste plantagekoloniën van het Caraibisch gebied behoorde en het in oppervlakte alleen te vergelijken was met Cuba en het latere Brits Guyana, heeft het rooit een prominente plaats in de regio ingenomen. Qua bevolkingsomvang kon het niet in de schaduw staan var Cuba, Saint Domingue of Jamaica en viel het meer te vergelijken met een minuscuul eilandje als Barbados (Tabel 1). Tegen deze achtergrond wekt het weinig verbazing dat de Surinaamse export van suiker achterbleef bij de produktie en uitvoer van Saint Domingue, Jamaica en later Cuba. Wanneer het aantal suikerplantages als criterium wordt genomen, dan blijkt Suriname eind zeventiende eeuw niet veel minder plantages te tellen dan andere Caraïbische koloniër. Fen haive reuw later is hiervan geen sprake meer (Tabel 2). Alleen met dc produktie van koffie bevond Suriname zich gedurende de achttiende eeuw in de voorste gelederen, maar ook hier trad da arna verval in (Tabel 3).

Tabel 1. Surinames positie in het Caraibisch gebied: oppervlakte en bevolking ca. 1775 en negendiende eeus

\begin{tabular}{|c|c|c|c|c|c|}
\hline land & opperviakte & totale & s 1 & $\forall \in n$ & eman- \\
\hline & $\left(\mathrm{km}^{2}\right)$ & $\begin{array}{l}\text { populatie } \\
\text { ca. } 1775\end{array}$ & ca. 1775 & $\begin{array}{l}\text { bij eman- } \\
\text { cipatie }\end{array}$ & $\begin{array}{l}\text { cipatie- } \\
\text { jaar }\end{array}$ \\
\hline Cinba & 114.524 & 171.620 & 44.333 & 192.885 & 1886 \\
\hline St. Domingue & 27.750 & 291.106 & 264.471 & 480.000 & '1791' \\
\hline Jamaica & 10.962 & 216.000 & 192.800 & 311.070 & 1834 \\
\hline Martinique & 1.102 & 85.779 & 71.268 & 90.000 & 1848 \\
\hline Guadeloupe & 1.779 & 85.206 & 72.761 & 95.000 & 1848 \\
\hline St. Croix & 212 & $?$ & 7.566 & $?$ & 1848 \\
\hline Barbados & 431 & 87.614 & 68.548 & 31.150 & 1834 \\
\hline Grenada & 344 & 27.872 & 26.211 & 23.638 & 1834 \\
\hline St. Kitts & 357 & 25.362 & 23.462 & 8.815 & 1834 \\
\hline Antigua & 442 & 40.398 & 37.808 & $29.12 i$ & 1834 \\
\hline St. Vincent & 388 & 13.603 & 11.853 & 22.266 & 1834 \\
\hline Guiana & 214.969 & $?$ & 27.544 & 82.824 & 1834 \\
\hline Trinidad en Tobago & 5.128 & 11.321 & 7.194 & 32.246 & 1834 \\
\hline SURINAMF & 163.265 & 64.544 & 59.923 & 36.484 & 1863 \\
\hline rangorde no. & 2 & 7 & 6 & 7 & 13 \\
\hline
\end{tabular}

Bronnen: oppervlakte: Watts 1987:4; bevolking: Deerr 1949, II:306 en Watts 1987:31121; Suriname: zie Hoofdstuk X.1. 
Tabel 2. Aantal suikerplantages diverse Caraibische koloniën ca. 1685 en ca. 1750

\begin{tabular}{|c|c|c|c|c|}
\hline land & jaar & plantages & jaar & plantages \\
\hline Barbados & 1685 & 345 & 1722 & 499 \\
\hline Jamaica & 1684 & 113 & 1739 & 429 \\
\hline Mártinique & 1687 & 184 & 1736 & 447 \\
\hline Cuadeloupe & 1674 & 101 & 1755 & 335 \\
\hline St.Domingue & 1700 & 69 & 1754 & 539 \\
\hline Suriname & 1700 & ca. 100 & 1750 & {$[4]$} \\
\hline
\end{tabular}

Bronnen: Deerr 1949, Il:114-243; Walts 1987:410-6; Trouillot 1982:335; Bruijning en Voorhoeve 1977:481; ARA: RvP, 293.

Tabel 3. Suiker en kolfieproduktie Caraibisch gebied 1775 en 1850 (tonnen)

\begin{tabular}{|c|c|c|c|c|}
\hline \multirow[t]{2}{*}{ land } & \multicolumn{2}{|c|}{ suiker } & \multicolumn{2}{|c|}{ koffie } \\
\hline & ca. 1775 & ca. 1850 & ca. 1775 & ca. 1850 \\
\hline Cuba & 10.000 & 246.251 & $?$ & 16.646 \\
\hline St.Domingue / Haitì & 62.595 & - & 20.000 & 19.000 \\
\hline Jamaira & 4.3 .355 & 30.605 & 900 & 3.350 \\
\hline Martinique & 12.753 & 19.333 & I8.833 & 74 \\
\hline St.Croix & 10.165 & 7.280 & - & $?$ \\
\hline Cuadeloupe & 8.312 & 16.862 & 4.100 & 188 \\
\hline Barbados & 5.446 & 26.627 & - & $?$ \\
\hline Grenada & 8.784 & 4.945 & - & $?$ \\
\hline St. Kitls & 7.934 & 4.773 & - & $?$ \\
\hline Antigua & 7.38 .5 & 8.551 & - & $?$ \\
\hline St.Vincent & 2.670 & 7.868 & - & $?$ \\
\hline Guiana & 2.593 & 33.340 & 1.500 & 55 \\
\hline Irinidad en Tobago & $1.38 \mathrm{I}$ & 20.526 & - & $?$ \\
\hline Puerto Rico & 1.222 & 81.029 &. & 8.500 \\
\hline SURINAMF, & 6.610 & 14.786 & 7.927 & 298 \\
\hline $\begin{array}{l}\text { afgerond totaal } \\
\text { Caraibisch gebied }\end{array}$ & 200.000 & 540.000 & 55.000 & 50.000 \\
\hline aandeel Suriname & $3 \%$ & $3 \%$ & $14 \%$ & $(1 \%)$ \\
\hline rangnummer & 10 & 9 & 3 & (j) \\
\hline
\end{tabular}

Bronnen: Deerr 1949,1:112-241; Watts 1985:286-321; Van ce Voort 1973:260-2; Irouillot 1982:337; Lkers 1922:277.83; Roth 1929:19, 132; Suivant 1973, II; Van Iogendorp 1801:329, Suriname: zie Bijagge I.

De enige produktiefactor die Suriname zelf bijdroeg aan de plantageeconomie was grond, en daaraan ontbrak het niet. De oorzaak van Surirames ondergeschikte positie binnen het Caraibisch gebied moet daarom voor een belangrijk deel worden gezocht buiten de koionie en lang voor 1750.

De Nederlandse economie was in de zestiende en vooral zeventiende ceuw grool geworden in de overzeese handel en het verzorgen van transport voor andere raties. Verder was haar functie van stapelnarkt voor produkten van buitenlanise producenter van cruciale betekenis en won de 
financiering van buitenlandse bedrijvigheid steeds meer aan belang. Het accent Jag dus veel minder op produktie dan op handel en transport, laat staan dat de economie in belargrijke mate afhankelijk was van 'eigen' koloniale produktie. Integendeel, de Nederlandse markt werd overvoerd met produkten die door anderen waren geproduceerd, maar door Nederlanders aangevoerd. Op deze wijze wist Nederland binnen de wereldeconomie enige tijd een leidende positic in te nemen.

Zoals eerder gezegd, de Engelsen en Fransen probeerden de dominante positie van Nederland te ondermijnen door halverwege de zeventiende eeuw sterk protectionistische wetten uit te vardigen. Nederlandse handelshuizen omzeilden de bepalingen echter door bijvoorbeeld een kantoor in Londen te openen, onder andere Van Neck, Van Notten, Clifford, Baring, Hope, en Van Lennep. Zij bleven het accent leggen op internationale handel, transport en een open stapelmarkt. Niet ten onrechte overigens. De Engelse scheepvaart en hancel waren nog te weinig ontwikkeld om Amsterdam als het certrum van de wereldhandel te kunnen bedreigen. Ondanks de monopolistische weigeving bleven de concurrenten dus nog lange tijd afhankeijk van Nederland. 7o werd zelfs nog in 1721 het grootste deel van het goederentransport tussen Engeland en Franixrijk verzorgd door Nederlardse schepen (Wilson 1966:20). Toen Fr.geland en Frankrijk eenmaal hun eigen handelsnetwerken en vloten hadden opgebouwd ging hun protectionisme steeds meer effect sorteren en werd Nederlands positie ondergraven.

Naas: handel en transport werd financiering van allerhande ondernemingen een steeds belangrijker pijler van de Nederlandse econonie. He: Nederlandse kapitaal werd echter opmerkelijk weinig gebruikt om de eigen Westindische belangen uit te bouwen. De WIC verkeerde bijvoorbereld bijna chronisch in firanciële moeilijkheden. Aanzienlijke kapitalen werden daarentegen geinvesteerd in de grote concurrent Fngeland en haar Westindische koloniën en in mindere mate ook in Trankrijk. Zo werd de enorme expansie van de suikerproduktie van Barbados, de grootste Caraibische producent gedurende de tweede heift van de zeventiende eeuw, mogelijk gemaakt door Nederlandse investeringen en kennis (Sherican 1970:26). Zelfs toen Nederland al lang zijn dominante positie in handel en scheepvaart was kwijtgeraakt, werd van de zeventig miljoen gliden die gedurende de tweede helft van de achttierde eeuw in Caraibische plantages werd geinvesteerd, nog ruim eer kwart gestoken in niet-Nederlandse bezittingen (Van de Voort 1973:265). Op dat moment (1782) had Vederland ook nog 280 miljoen guiden ritstaan in Engeland en 25 miljoen in Frankrijk (Wilson 1966:192).

De belangrijkste drijfveren van Nederland om de economische expansie van haar grootste concurrenten (mede) te financieren waren het veiligstellen van de prominente marktpositie en van de grote aanvoer van 
produkten. Op den duur is dit een mistekening gebieken, want de buitenlandse concurrerten namen hande: en scheepvaart in eigen hand, zodat de aanvoer op de Nederlandse stapelmarkt ineenschrompelde. Bovendien beleefde de concurrentie een economische groei, mede door de positieve resultaten die werden behaald in het Caraibisch gebied. Nederlands economische exparsie was in veel geringer mate gebaseerd op produktie in de eigen Caraíbische koloniën, zodat bijvoorbeeld Suriname bij lange nta niet dezelfde impulsen had gekregen als Saint Domingue of Jamaica. Daarnaast genoten de produkten uit de Engelse en Franse Caraiben grote bescherming op de thuismarkt als gevolg van, onder andere, hoge tariefmuren. De Nederlandse koloniale produkten moesten daarentegen zonder enige bescherming op de thuismarkt concurreren met aanvoer uit het buitenland. 9

Er bestonder nog meer verschiller. tussen Suriname en de andere koloniën in hei achttiende-eeuwse Caraibisch gelpied, die van invloed kurnen zijn geweest op haa: ondergeschikte positie. De samensteiling var de bevolking speelde een rol. Afgezien van de Afrikanen en kleurlingen was de bevolking van de concurserende plantage-economieën duidelijk Frans, Engels of Spaans. De planters waren bovendien voor een belangrijk deel afkomstig uit de elite van hun vaderland en hielder. daarmee ook gemakkelijk contac:. 11) Op die manier konden zi; politieke druk uituefenen om hun Westindische belangen te beschermen. Samen mel rijkgeworden gerepatrieerde planters vormden zij in Engeland de roemruchte West India Interest, een belangrijke politiek-economische pressicgroep.

Hoewel minder beikend, geld thetzelfde voor de Franse suikerplanters, die, gedurende de achttiende eeuw, Saint Domingue tot 'de parel' van het Caraibisch gebied maakten. Trouiliot (1982) laat daarover geen misverstand bestaan:

- Ook Trouililot nocml grbrck aan protectie -- naasl Nederlands verval in de achttiende: eeuw in het algencen en de beurscrises var $1763 \mathrm{cn} 1773$ in het bjjzonder - als een van de verklaringen waarom Suriname, in dil geval als kolfieproduceni, nitt net zo groot is gewurden ais Sisint Domingue:

'Dutch investors shoulc have benefitec' [...] at least as much as their French rivals. They had started cullivation in java before other Europears; they had introduced the drink to New York; and they were the first to have transferred large-scale production to the Caribion. But before the 1750's, no local protectionism covered Dutch manufacturers, and in the second half of the century, Dutchcontrotled colfee production suffered from the general dexline of the Netherlands. Java was far away, the 'traficken' had fewer shjps on the high seas, and Surinam - the only Caribbean colony w'hich, by reason of its size, ionked as if it could produce as much coffee as Saint-Doming ue -- met a series of unexpected problems in the 1760's and 70's." (Trouillot 1982:342.)

:D Duidelijk blijkt dit uit Mintz' beschrijving van Engclse planters, 'many of whom came from already rich families, but who often added to their wealth by their plantation operations. The'ir style of lite daring the maturily of the plantation erd is as famous as was, during certain periods, their political influence at homa.' (Minkz 1985:1691) aan - 978-90-04-25979-9 
'French natives from aristocratic or bourgeois families who had accumulated capital or acquired credit came in growing numbers. [...] The thirty years' peace which followed the Treaty of Utrecht, the surprising growth of French merchant capitalism, and the related sugar boom in Saint-Domingue which reinforced links between the island and specific areas of the metropolis had led many noble Frenchmen to move to the colony. [...] It is in reference to those migrants from "la grande noblesse" $1 . .1$ most of whom had by then quietly returned to France, that a protégé supposedly told Louis XVI in 1788: "Sire, all your court is Creole by alliance".' (Trouillot 1982:371-2.)

Dus ook in de Franse Caraiben bleek de invloedrijke vaderlandse elite ruim vertegenwoordigd en keerden velen in de loop van de achttiende eeuw des te machtiger naar lrankrijk terug.

In Suriname was dit alles in veel mindere mate het geval. Fen studie van de 396 Surinaamse plantages en gronden in 1737 waarvan de eigenaars bekend zijn (Kaart A. de lavaux) leert dat $18 \%$ een eigenaar had met een onmiskenbaar Portugese (joodse) raam, 25\% een eigenaar met een Franse (hugenoten-)naam en nog eens $7 \%$ een eigenaar met een andere buitenlandse, meest Engelse of Duitse raam. Dit betekent dat op zijn minst de helft yan alle plantages en gronden in handen was van mensen die - jn ieder geval van origine - niet afkurnstig waren uit de politiek-economische elite van Nederland. Evenmin is de Nederlandse politiek ooit geconfronteerd met een machtsblok van Surinaamse plantagebelanghebbenden dat ook maar in de verte deed denken aan de Engelse West India Interest.

Natuurlijk waren er wel rijk teruggekeerde planters die een rol in de Nederlandse politiek speelden (Oostindie 1989:310-3; Gülcher 1943:49). Var der Meiden (1987:78-81) spreekt zelfs van een 'pressiegroep van Surinaamse belangen in de kepubliek', Dit was echter niet meer dan een ad-hoc-groepje dat enige keren een rekest bij de Staten-Generaal heeft ingediend. Er is nooit sprake geweesı van een constant aanwezig machtsblok dat op het hoogste niveau het politieke spel naar zijn hand probeerde te zetten ter verdediging of uitbreiding van de Westindische plantagebelangen.

Alle bovengenoemde elementen wijzen op een gebrek aan bescherming van de Nederlands-Westindische belangen, die mede een gevolg was van een andere economische oriëntatie dan in. Engeiand en Frankrijk. Dit beleid vond zijn oorsprong in de periode van groei en dominantie van Nederland binnen de Europese wereldeconomie. Vanuit de optiek van de Surinaamse plantage-economie lijken dus alleen externe factoren bepalend te zijn geweest voor haar relatieve gebrek aan expansie.

Toch is deze verklaring niet afdocnde, want er is wel degelijk in Suriname geinvesteerd en het aantal plantages nam tussen 1700 en 1800 toe van 100 tot 400 . Er zijn dus zeker aanzetten geweest tot een groei waardoor Suriname zich onder de 'groten' had kunnen scharen. Dat het nooit zo ver is gekomen heeft daarom veel meer te maken met interne factoren in de Surinaamse plantage-economie. 
Figuur 1. Aantallen plantages producerend voor de export 1713-189011

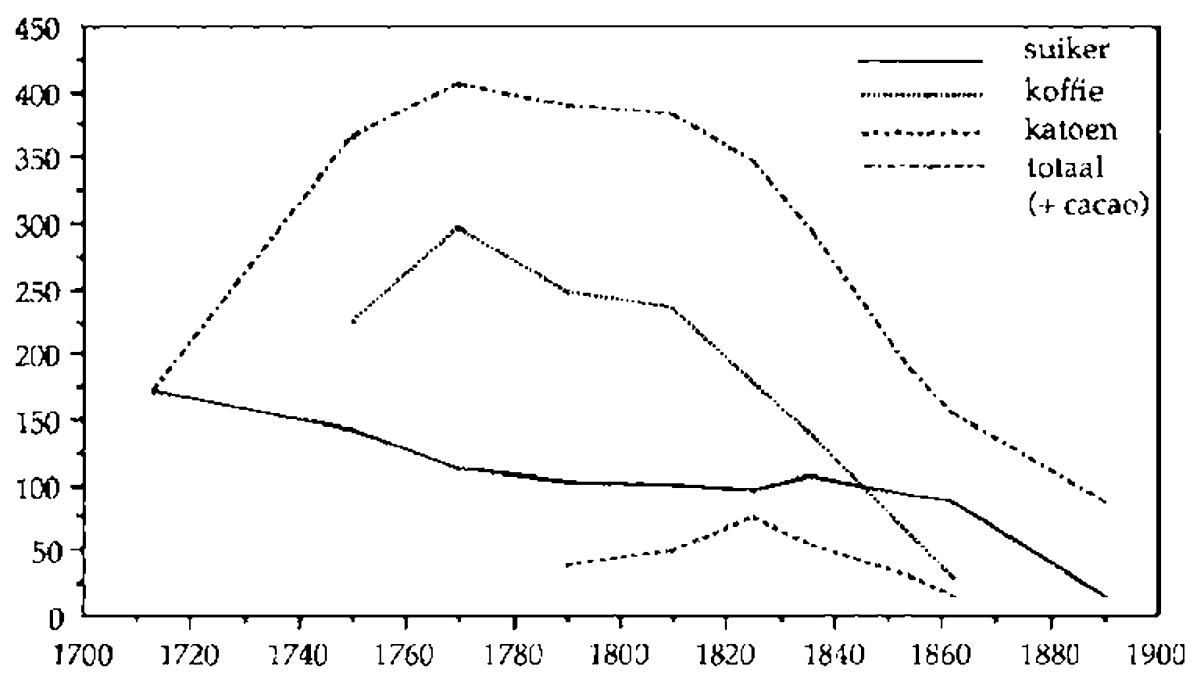

\section{De Surinamse piantage economie in vogelalucht}

Rond 1700 telde Suriname ongeveer 100 plantages, 9 a 10.000 slaven en enkele honderden blanke inwoners. Er waren twee plaatsen van betekenis: de hoofdstad Paramaribo en Joden Savanne, een Portugees-joods dorp ongeveer 50 kilometer ten zuidoosten van I'aramaribo. ${ }^{12} \mathrm{Na}$ een mislukt experiment met de verbouw van tabak, groeide suiker uit tot het enige exportprodukt van belang. De kolonisalie verlicp voorspoedig en in 1713

17 Aantallen plantapes prosiucerend voor de export 17:3-1890

\begin{tabular}{|c|c|c|c|c|c|}
\hline jaar & suiker & kotile & katoen & tetach & \\
\hline 1713 & $: 71$ & - & - & 171 & \\
\hline 1745 & $: 54$ & ca. 140 & - & ca. 294 & \\
\hline ca. 1770 & 311 & 295 & . & 406 & \\
\hline ca. 1795 & 102 & 248 & 39 & 389 & \\
\hline ca. 1812 & 190 & 235 & 48 & 383 & \\
\hline са. 1825 & 95 & 178 & 73 & 346 & \\
\hline 1834 & 205 & 137 & 52 & 294 & \\
\hline 1849 & 88 & 76 & 32 & 196 & \\
\hline 1854 & 86 & 52 & 29 & 167 & \\
\hline 1862 & 86 & 30 & $: 5$ & 131 & \\
\hline 1890 & 14 & - & - & $86 *$ & \\
\hline
\end{tabular}

* inclusiet 72 cacaoplantages

Bron: Bjilsma 1921-22:325; ka art De Lavain 1737 en 1770; ARA: RvP, nrs 293, 583, $598600 \mathrm{en}$ 605-607; Surinanmsche Almarak 1796, 1824 on 1891; Public Record Offics: Treasury 75, $14 \mathrm{en}$ Colonial Office 278, 15; ARA: Collectie Van den Bosch, 161; ARA: MvK 1813-1849, 1135; Koloniale Versiugen 1849, 1854 en 18062.

12 Crnormde gegevens zijn verzameld uit Bruijning en Voorhoeve 1977:464, 481; Cosslinga 1985:295; Van der. Meiden 1987:80. 
waren er al 171 plantages in bedrijf, die gezamenlijk zo'n 6.500 ton suiker produceerden (Bijlsma 1921-22:325 en Bijlage I). In diezelfde periode werd in Suriname, als eerste Caraibische kolonie, koffie geïntroduceerd. Dit gaf de plantage-economie een nieuwe sterke impuls. In de tweede helft van de achtiende eeuw overvleugelde koffie de suiker zelfs als belangrijkste produkt. De opkomst van grootschalig verbouwde katoen aan hef eind van deze eeuw zorgde voor cen nieuwe economische groeiperiode. Alhoewel nooit 70 van betekenis geworden als suiker en koffie, was katoen tussen 1780 en 1840 toch een belangrijk exportprodukt (Figuir 1 ).

Ook de bevolkingstoename in Suriname illustreert de expansie van de plantage-economie in de achttiende eeuw. Rond 1775 was het aantal vrije inwoners gestegen tot ongeveer 2.600 personen (exclusief militairen, marrons en Indianen), het aantal slaven bedroeg ongeveer 60.000 en Paramaribo was uitgegroeid tot een stad van rond 5.000 inwoners (zie verder Iloofdstuk X). ${ }^{13}$

De wijze waarop de plantage-economic zich daarna ontwikkelde laat duidelijk zien hoe moeilijk het is le spreken van een lineair patroon van groei, verval of stagnatie. Zo blijkt dat rond de Fmancipatie (1863) het inwonertal van Paramaribo was verviervoudigd en de vrije bevolking van Suriname zelfs verzesvoudigd. De slavenbevolking bleek daarentegen met twee-vijfde te zijn afgenomen tol ruim 36.000. Op koffieplantages bedroeg hun aantal zelfs nog maax een-tiende van dat in 1775, terwijl op suikerplantages de slavenbevolking echter met een-vijfde was toegenomen. Gemeten naar het aantal plantages lijkt de ontwikkeling van de plantageeconomie een wat rechtijniger patroon te vertonen; expansie in de achttiende eeuw, achteruifgang in de negentiende eeuw (Figur 2). Litgesplitst naar sector blijkt ook hier het beeld gecompliceerder. Zo had de suikersector aan het begin van de achttiende eeuw het maximum-aantal plantages bereikt, terwijl de koffiesector zich toen nog mosst gaan ontwikkelen. Gedurende de rest van de eeuw nam daarop het aantal suikerplantages stelselmatig af, maar groeide de koffiesector met ongekende snelheid. Aan het einde van de achttiende eeuw bleef het aantal suikerplantages gelijk, terwij1 nu de koffieplantages numeriek in verval waren. Tegelijkertijd begon de opmars van de katoenplantages, die een hoogtepunt bereikte in de jaren 1820 , om daarna met eenzelfde snelheid weer aan de terugtocht te beginnen. Op dat ogenblik was de koffiesector al enige decennia onderhevig aan een niet te sluiten teruggang. Het dantal suikerplantages beleefde daarentegen een lichte opleving, om daarna weer gemiddeld iedere anderhalf jaar met één af te nemen (zie Bijlage 4A).

Het hoogste aantal voor de export producerende plantages, ruim 400, werd bereikt in het laatste kwart van de achttiende epuw. Dit getal geeft niet

13 In 1788 blijkt Paramaribo al uitgegroeid te zijn tot een stad met 1.119 huizen (Nassy 1791, II:14). 
Figuur 2. Exportwaarde Suninaamse suiker, koffie en katoen 1740-1864

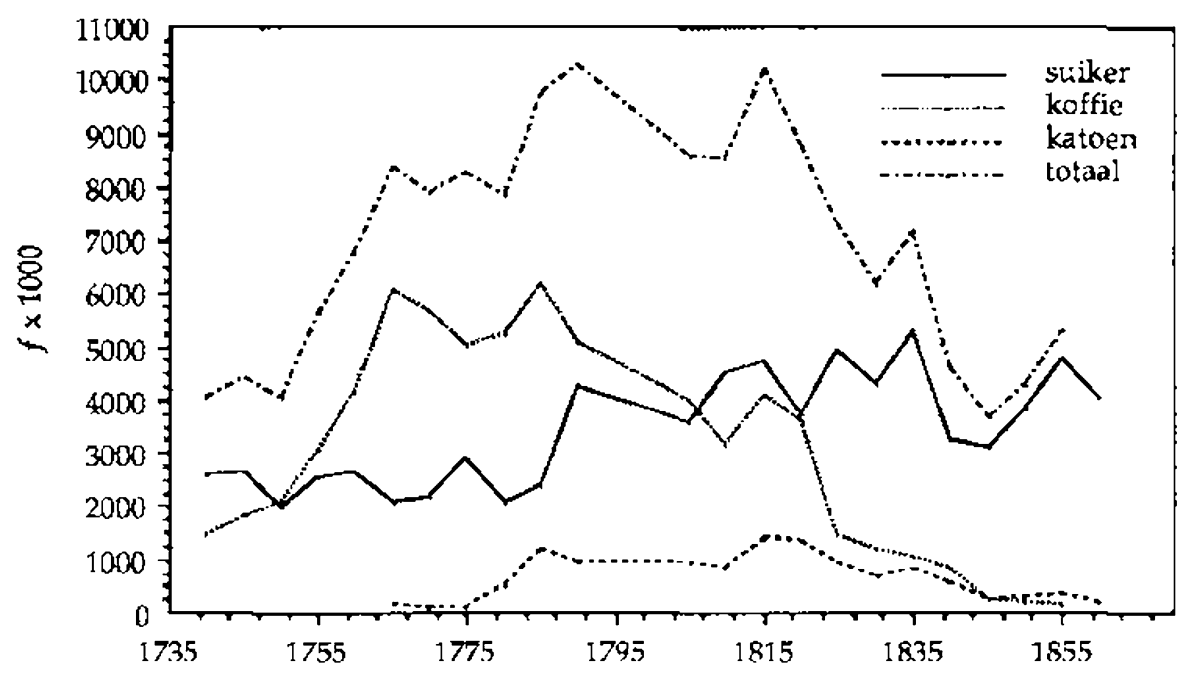

het totaal aantal aangelegde plantages aan. Gedurende de achttiende en negentiende eeuw werden namelijk voortdurend plartages verlaten en nieuwe aangelegd (zie Hoofdstuk Ii). Ook wercien veel suikerplantages omgezet in noutgronden en is een groot aantal koftieplantages overgeschakeld op de verbouw van voedselgewassen (vooral bananen), katoen en suiker. In het laatste kwart van de negentiende eeuw werden bovendien veel onderneminger. ongebouwd tol cacaoplantages.

Het was geen uitzondering dat plantages in han bestaan tot twee maal toe een ander hoofdprodukt verbouwden. Fen voorbeeld daarvan is piantage Kroonenburg aan de Commewi;ne. Rond 1750 startte deze onderneming als koffieplantage, in 1829 werd $z$ ij geheel omgebouwd tot een suikerpiantage, terwijl zestig jaar later cacao het hoofdprodukt blijkt te zijn.14 Ook veranderden plantages in de loop der tijd nogal eens van naam en omvang, wat het traceren bemoeilijkt. Het totale aantal gedurende de achttiende en negentiende eeuw aangelegde plantages, is daarom niet exact vast te stellen, maar komt zonder enige twijfel in ce buurt van $700 .{ }^{15}$

De ontwikkeling van de Surinaamse plantage-economie blijkt nog vee: minder rechilijnig te zijn verlopen warneer ook de plantage-omzet zowei in produkten als in geld - in ogenschouw wordt genomen (Figuren 2 en 3 en Bijlagen 1 en 3). Ordarks he! teruglopend aantal suikerplantages daalde de suikerproduktie in de achttiende eeuw slechts in geringe mate en ging 
Figwur 3. Surinaamse export van suiker, koffie en katoen $1740 / 1770-1864$

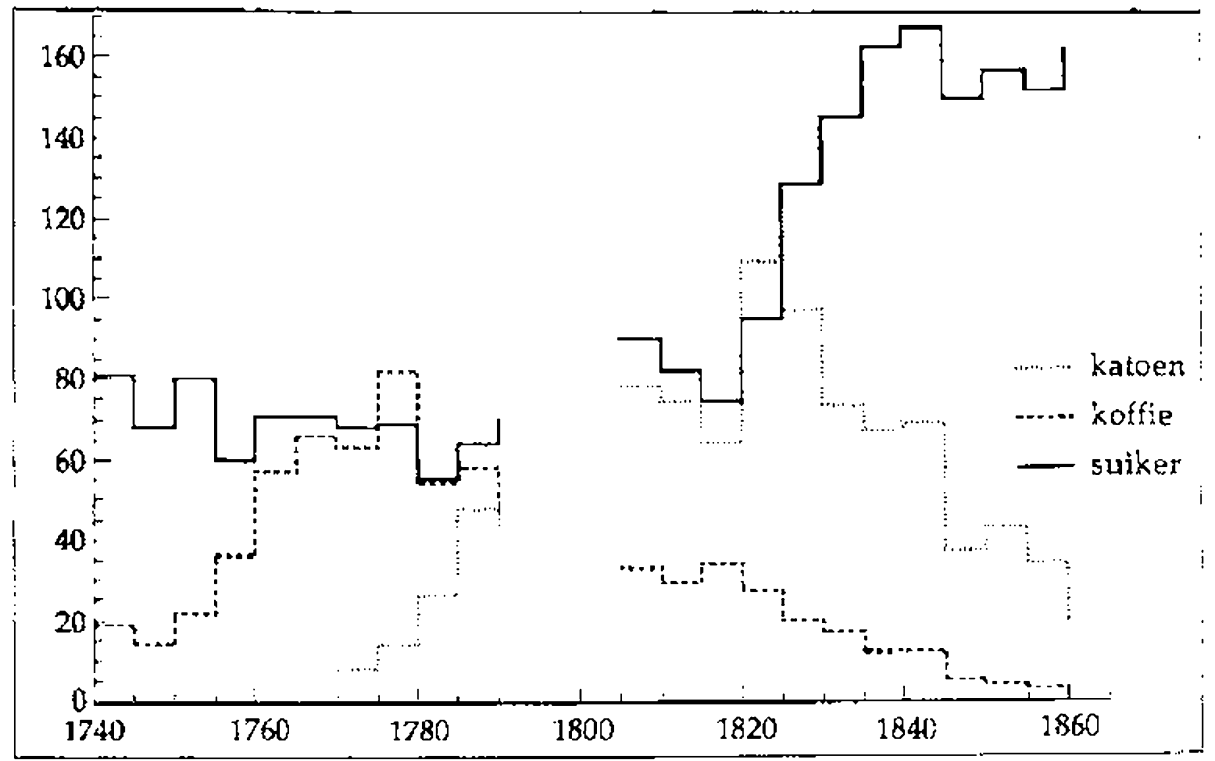

deze in de negentinde exuw zelfs orstuimig omhoog- Vergeleken met 1713 werd in 1862 met een gehalveerd aantal plantages gemiddeld twee-en-eenhalf kee: zoveel suiker gemaakt. In ce koffiesector was het ongexeerde het geval. Daar ging in de achttiende eeuw een explosieve toename van het aantal plantages gepaard met een een nog veel explosiever groeiende produktie: tussen 1745 en 1775 verdubbelde het aantal koffieplantages, terwijl de produktie vervijfvoudigde. In de volgende eeuw nam de pro duktie echter ook sneller af dan het aantal kuffieplantages. De ontwikkeling van de katoenproduktie bleck daarentegen ongeveer gelijke tred te houden met het aantai plantages, afgezien van de jaren 1850, waarin de vermindering van het antal plantages iets sneller ging dan van de produktie. De financiële omzet hing vanzelfsprekend meer samen met de ontwikkeling van de produktie dan met het aantal plantages. Toch verliepen de omzet- en produktietrends riet parallel. Door de grote afhankeijikheid en de ondoor-

Tabel 4. Gemiddelde omzet van Surinaamse plantages 1745.1862 (driejaarlijks gemiddelde)

\begin{tabular}{|c|c|c|c|c|c|}
\hline \multicolumn{2}{|c|}{ soort plant. } & \multirow{2}{*}{$\frac{\text { ca. } 1745}{47.5 b 3}$} & \multirow{2}{*}{$\frac{\text { ca. } 1795}{74.941}$} & \multirow{2}{*}{$\frac{\text { ca. } 18.36}{158.058}$} & \multirow{2}{*}{$\frac{\text { ca. } 1862}{196.640}$} \\
\hline sliiker & $\mathrm{kg}$ & & & & \\
\hline & $J$ & 18.331 & 42.966 & 52.6865 & 53.748 \\
\hline \multirow[t]{2}{*}{ korfie } & $\mathrm{kg}$ & 10.081 & 23.654 & 9.846 & 4.730 \\
\hline & 1 & 10.955 & 25.232 & 8.763 & 3.122 \\
\hline \multirow[t]{2}{*}{ katoen } & $\mathrm{kg}$ & - & 13.052 & 12.346 & 15.070 \\
\hline & $f$ & - & 28.801 & 16.297 & 15.371 \\
\hline
\end{tabular}

Bronnen: zic Bijaagen 1, 2 en $4 \mathrm{~A}$. 
grondelijkheid van de Nederlandse markt vertoonde de omzet in geld een tamelijk autonoom en grillig patroon. De omzetortwikkeling van de gemiddelde plantage is te zien in Tabel 4.

De verklaringen voor de uiteenlopende ontwikkeingen in de Surinaamse plantage-economie zullen in de volgende hoofdstukken aan bod komen. Wel is nu al duidelijk dat de suikersector, ondanks een dalend aantal plantages, de meeste continuïteit vertoonds. Bij koffie en katoen was het afnemend aantal plantages daarentegen tekenend voor het functioneren van de sector als geheel. In deze studie zal dan ook blijken dat de koffiesector in het bijzonder werd gekermerkt donr roofbouw.

Tot slot rijst de vraag in hoeverre Suriname gedurende de periode 1750 . 1863 een voordelige bezitting is geweest voor haar 'eigenaars'. Het antwoord kan kort zijn: meestal moest er op worden toegelegd. Het onderhoud van een ambtelijk en voora' ook militair apparaat, evenals de marronoorlogen in de achttiende eeuw, kostten handen vol geld. Tussen 1770 en 1789, toen de exportwaarde van Surinaarse plantageprodukter een hoogtepun: bereikte (zie Figuur 2), verloor ce WIC als mede-eigenaar van Suriname gemiddeld bijna $f 60.000$ per jaar op deze bezitting (Goslinga 1985:575-8). Toen de Nederlandse - en korte tijd de Engelse - staat de kolonie in eigendom kreeg was het meestal niet veel anders (zie Bijlage 5).

De Nederlandse economie moet echter zeker garen hebben gesponnen bij dit tropisch aanhangsel. Ook al gingen aan het eind van de achttiende eeuw vele Nederlanders de boot in met een belegging in Surinaanse plantages (zie Hoofdstuk VII), toch weegt cit niet op tegen de bijdrage die Suriname aan de Nederlardse economie heeft geleverd. Tussen 2750 en 1863 leverde deze plantage-economie voor een waarde van minstens 600 miljoen gulden aan exportprodukten voor de Nederlandse marxt (cie Bijlage 3). Daarnaast zorgde de Surinaamse plantage-economie voor economische spin-off in Nederland. De fientallen schepen die ieder jaar heen en weer voeren hebben de Nederlandse werven think wat werk opgeleverd. En zeker in kringen van assuradeurs, slaveahandelaren, reders, sulke:raffinadeurs, koffipbranders en leveranciers van plantagebenodigdheden moesen aantrekkelijke omzetten zijn gemaakt. Naar de omvang daarvan valt echter alleen te gissen.

\section{Politieke structuw en verandering}

Van 1682 to hel einde var de achlliende eeuw was Suriname het gezamenlijk bezit van de WIC, de stad Amsierdam en de familie Van Aerssen van Sommelsdijck. ${ }^{16}$ Fer anntal vertegerıwoordigers var. de eigenaars vormde

I6 In 1770 verkocht de familie Van Aerssen van Sommelsdijck hada aandeel in Suriname aan de twee overige eigenaars voor $f 700.000$. In 1791 liep het octroni var de W:C af en werd

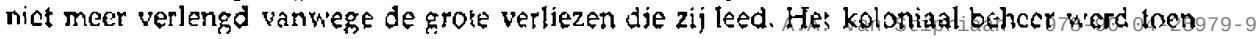


samen de directie van de Geoctroyeerde Sociëteit van Suriname. Deze was gevestigd in Amsterdam en stelde voor het directe bestuur van de overzeese bezitting een Gouverneur aan. Deze was verantwoording schuldig aan de Sociëteit, maar ook de Staten-Generaal moesten zijn aanstelling goedkeuren en legden hem een eed van trouw op. Hieruit blijkt opnieuw dat het oppergezag uiteindelijk toch in handen van de Nederlandse overheid lag. Niet voor niets was de Sociëteit 'geoctroyeerd'.

In Suriname was de Gouverneur de hoogste gezagsdrager. De eveneens door de Sociëteit benoemde commandant van de Sociëteitstroepenmacht kon hem, indien nodig, vervangen. Daarnaast werd de Gouverneur in het bestuur bijgestaan door twee raden: het Hof van Politie en Criminele Justitie, ook wel de Politieke Raad genoemd en het Hof van Civiele Justitie. De eerste was zowel een wetgevend als rechterlijk lichaam, voorgezeten door de Gouverneur. In theorie mocht tet de Gouverneur alleen adviseren, in de praktijk probeerde de laad hem voortdurend beslissingen op te leggen. De tweede raad hicld zich bezig met civielrechtelijke procedures en het toezicht op de 'Gemeene Weide', de openbare weidegrond van de kolonie. De enige jurist in dit geheel was de Fiscal, die in beide raden zitting had en zo een machtig man was. De overige leden van de raden werden gekozen door en uit de vonrnaamste Nederlanders in de kolonie (vrijwel altijd planters) en waren in principe benoemd voor het leven. ${ }^{77}$

De samenwerking tussen Gouverneu: en raden liet veel te wensen over; men was het vaker oneens dan eens. De titel van een recent onderzoek over deze problematiek spreekt voor zich: Betwist bestuuy (Van der Meiden 1987). Een andere historicus, Gos.inga (1985:274), verklaart de ourzaak van dit chronisch antagonisme. De Surinaamse planters verweten de directeuren van de Sociëteit in het verre Nederland alleen uit te zijn op het maken van zoveel mogelijk winst, ongeacht de lokale belangen. Voor hen was de Gouverneur de verpersoonlijking van dit sireven en waren zij zelf degenen die het meest oog hadden voor de belangen van Suriname. Iedere aangekondigde maatrege! werd dan ook in dit licht bezien.

Hoe hypocriet deze houdirg ook mag lijken, toch was zij wel enigszins begrijpelijk. De meeste Gouverneurs kwamen rechtstreeks uit Nederland,

overgenomen door de Raad van Koloniēn, ingeste'd door de Staten-Generaal. Deze Raad en de Geoctroyeerde Sociëleit van Suriname werden in 1795 al weer opgeheven. Daarvoor in de plaats kwam het Committee tol de Zaken van de Coloniën en Bezittingen op de kust van Cuinea en in Amerika, in 1801 opgevolgd door de Raad voor het Bestuur van de West-Indische Bezittingen en Coloniën in Amerika en op de kust van Guinea. Dezc veranderingen waren het gevolg van de politieke ontwikke.ingen in Nederland, toen de Bataafse Republick geheten. Tussen 1802 cn 1815 was Surina me een kolunie van Engeland.

17 De leden van de raden die niet door de snciëteit waren benoemd, werden met bijna algemeen stemrecht gekozen door de blanke inwoners van de kolonie. Voor iedere plaats in de raad werd een dubbeltal gekozen waruit de Gouverneur exn kcus maikte. De niet door de Snciëteit benoemde raadsleden leden waren onbezoldigd. Van beide raden was do Gouverneur voorzitter. De Fiscaal had geen stemsecht. 
7onder enige directe kennis van zaken, maar wel met absolute macht over het bestuux. Bovendien was het verloop onder hen tamelijk groot, onder meer als gevolg van conflicter die op het scherp van de snede werden uitgevochten. Voor de continuïteit in het bestuur was dit zeker niet bevorderlijk. In totaal hebben tussen 1682 en 1795 zesentwintig mannen het Gouverneurschap (soms ad interim) waargenomen. Twaalf van hen zijn gedurende hun ambtsuitoefening gestorven, drie zijn ontslagen en één is door opstandige soldaten vermoord. Iet langst in functie waren J.J. Mauricius (1742-1751), W. Crommelin (1753-1754 en 1756-1770) en J. Nepveu (1756 en 1768-1779). De overige dricëntwintig zijn gemiddeld niet langer dan ruim drie jaar in functie geweest (Wolbers 1861:823-9). Slechts een enkeling is als Gouverneur oud gevorden.

Met uitzondering van een enkele Gouverneur die in Suriname carriere had gemaakt, bijvoorbeeld Nepveu, vormde de planterselite daarom de enige constante in het bestuur en daarmee heeft $2: j$ voortdurend haar macht onderbouwd. In de loop van de achtiende eeuw behoorde een grool deel van deze elite tot de tweede, of zelfs dercie generatie 'Surinamers' en beschouwde zij zicl: a's het belangrijkste 'steunpunt van de koloniale samenlevirg' (Goslinga 1985:283). Zij beschouwde he! daarom als niet meer dan billijk een heslissende stem in het beleici te hebben.

Deze planterselite - die overigens ook vaak innerlijk verdeelut was - is er bijzonder goed in geslaagd voor haar belangen op te komen. Nadat een deel van hen in 175: het ontslag van Gouverneur Mauricius had weten te bewerkstelligen, kwamen in de daaropvolgende halve eeuw nog slechts twee van de tien (interim-) Gouverneurs uit Nederland. De rest was Surinaams ingezetene, met meestal grote belangen in het plantagebedrijf. Een sprekend voorbeeld daarvan was Gouverneur Nepveu, die na zijn overlijden in 1779 een boedel achter'ict, waaronder zes plantages, die getaxeerd werd op bijna anderhalf miljoen gulden. ${ }^{16}$

Rond 1770 bestorid de blanke elite uit ongeveer 70 planters, die samen $40 \%$ van alle plantages in bezit hadden ${ }^{19}$ Dit was de groep - vitgezonderd joden - waaruit de ?eden van de hoogste bestuurlijke organen en sommige Gouverneurs afkomstig waren. Met recht kan daarom de bestuursvorm van het achttiende-eeuwse Suriname worden gedefinieerd als een plantocratie. ${ }^{2 c}$

Tijdens het Engels protectoraat (1799-1802) werd alles bij het oude geiaten en bleef zelfs de Surinaamse Gouverneur, J.F. de Friderici, in functie. In de

\footnotetext{
IB EHB: KA-120, 21 .

is Telling kaa:t Le Lavaux, 1770.

20 Dat uedereen in de Surinanarase samenlevir:g zuch bewust was van de posilic van deze plantocraten, bljjkt onder andere uit het feit da: de slaven van plantage Rust en Werk, oost eigendom van Gouverneur Crommelin, de onderreming onder elkaar 'Granmangron' (Gouverneursgrond) norraden (en an dezclfde reden kregen de plantages Adrichem en 7.org vitiet beide de naam 'Fiskarie' (Fiscaal) (Surinaamscire Almanak 1834). A. A. van Stipriaan - 978-90-04-25979-9
} 


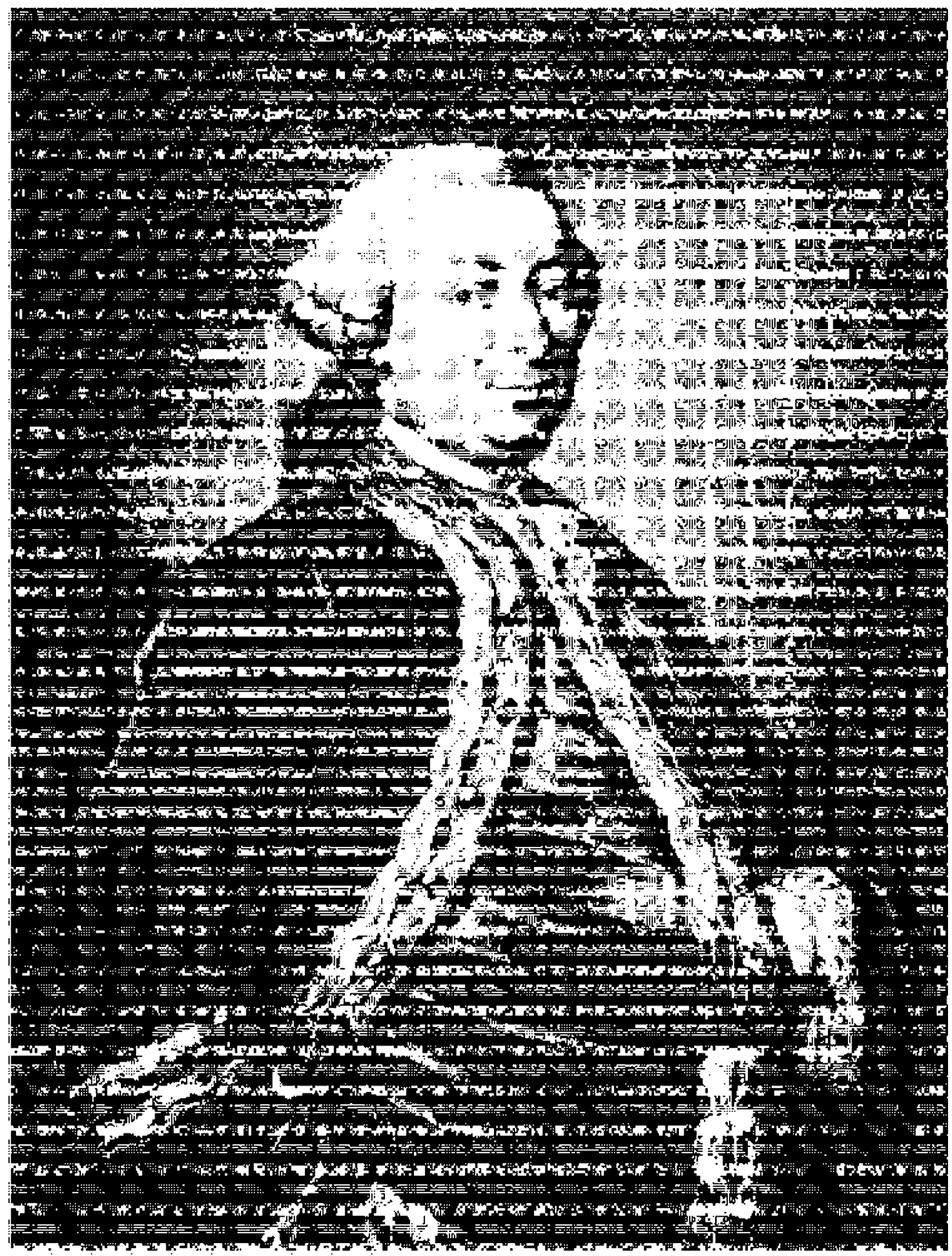

Gouverneu: ]. Nepveu (Foto-archief KiILV nr.20.173a) 
jaren dat Suxinarne daadwerkelijk een Engelse kolonie was $(: 804-1816)$ veranderde dit. Nu werden Engelse Gouverneurs aargesteld - in totaal zijn er vijf geweest, dus continuiteit bleef ver te zoeken - de troepenmach werd volledig Engels en er wercen enxele Engelse ambtenaren benoemd. Voor het overige bieef de politieke structuur intac:, inclusief het chronisch geruzie tussen raden en Gouverneur (Eiraar 1934:32-3).

De meeste oppositie or:stond naar aanleiding van de aanstelling van John Bent tot administrateur-raakwaarnemer/beheerder van alle plantages die in bezit waren van in Nedcrland wonende e:genaars. Deze benoeming was eer. gevolg van het feit dat Nederland op dat moment vijandelijk, in casu Frans, grondgebied was. De aanstelling van Bent gebeurde op gezag van de Engelse overheid, die in Londen de Surinam Absentee Sequestered Property Commission had ingesteld, waaronder Bent ressorteerde. De Surinaamse zaakwaarnemers voor de in het buitenland wonende plantageeigenaars beschouwden Bents aarstelling als een grove inmenging in hun zaken en lieten geen middel onbeproefd om hem zijn work onmogelijk te maken. Zo beschuldigden zij hem onder meer van oplichterij en het aanzeften van slave'u fot opstandigheid en weglopen. De Brifse regering liet zich echter nict beinvloeden door deze aantijgingen." Tock werd, mede onder invloed van de beëindigde oorlogen in Europa, Bents functie in 1814 opgeheven, zodat de Surinaamse plantocratie uiteindelijk toch weer aan het langste eind trok.

Intussen was de planterselite in Suriname volkomen van karakter veranderd. Als gevolg van repatriëring, vererving en bovenal verschulding waren in het laatste $k$ wart van de achtt:ende eerw de meeste piantages in handen gekomen van juitenlandse, meest in Nederland wonende, eigenaars. In 1796 bleek twee-dercie van de eigenaars niet meer in de kolonie te wonen, waarmec het absenteisme cen dominant verschijnsel was geworden ${ }^{22}$ De uitlandige eigresars lieter hun Surinamse bexitingen beheren door zogeraamde administrateurs. De opkomst van deze groep betekende een structirele wijziging in de relaties tüssen de plantage-economie en Nederland. Zoals za: hlijken in Hoofdstuk IX vieler: de belangen van deze administrateurs lang niet altijd samen met die van de eigenaars. Bovendien bekleedcien de adm:nistrateurs de belangrijkste politieke ambten in de kolorie, uitgezonderd die van Gouverneur. In feite waren zij nog mach-

21 We conceive that the alarm of the individuals so circumstanced will be entirely caimed, when they are apprized of the just \& benevolent disposition of Covernment towards them. With respert to the assertions of insurrections \& desertions having been caused amon:g the negroes by Mr. Bents' intervention in the administration of estates, we possess no evidence whatever of the fact; but : $t$ appears in two cases highly honorable to Mr. Bent, reported by him to the Govr \& of which copies have been, transmitted to us, that several negrocs who had been driven to desertion by a course of excessive \& disgraceful cruelty had returred to their owners, in consequence of Mr. Berts humane \& juticious exercise of the power with which he is entrusted by removing the offendiag, ager ts.' (Public Record Office: Treasury 75, 2.)

27 Telling plantagelijst Surinaamsche Almanak 1797:3-57. 


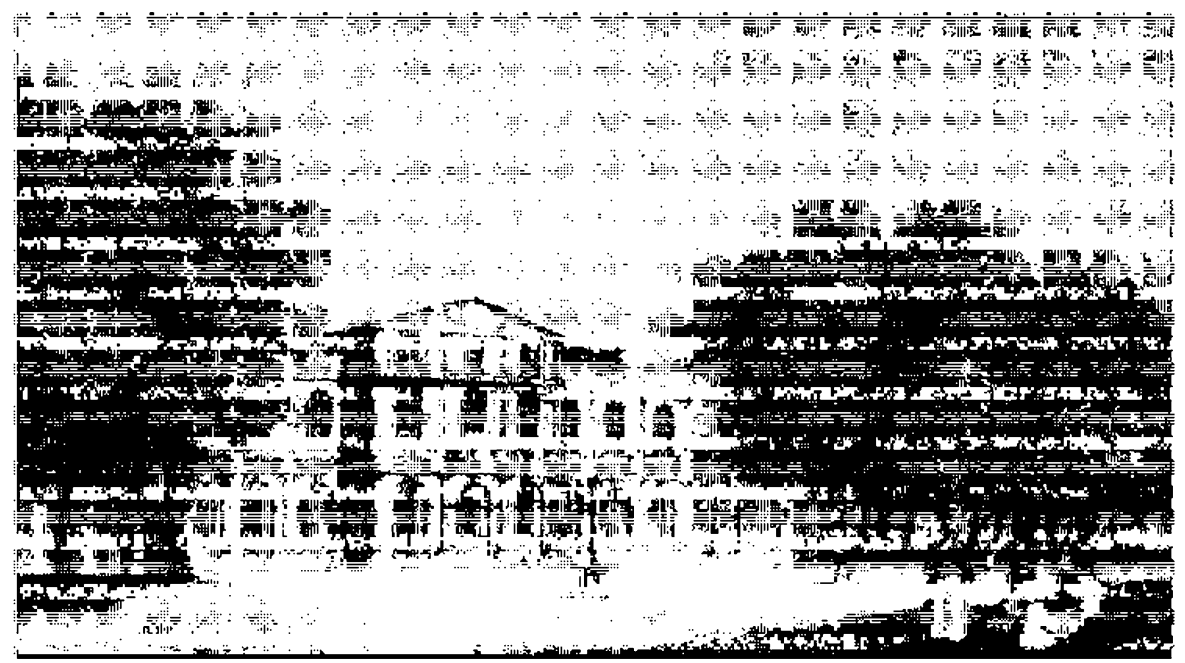

Het Gouvemementshuis te Paramaribo

(Surinaamsche Almanak 1839 t.o. titelpagina) 
tiger dan de vroegere planterselite, want in 1796 beheerden slechts 15 administrateurs - die overigens zelf oox plantages bezaten - $40 \%$ van alle plantages.23

In de jaren $182 \mathrm{C}$ besloot de Nederlandse overheid het bestuur van Shriname te herstructureren. ${ }^{24}$ De grote invloed van de plantocratie diende te worden teraggedronger. en er moest een scheiding komen tussen de rechterlijke en uitvoerende macht. Na enkele interimconstructies kwam er in 1832 een nieuwe regeing, die tot 1865 van kracht is gebleven. De rechtspraak kwam in handen van het Hof var Civiele en Criminele Justitie, waarvan de president en vier leden juristen dienden te zijn en slechts twee leden niet-gegradueerde ingezetenen. De vioegere Politieke Raad werd vervangen door de Koloniale Raad, die bestond uit de Gouverneur-Generaal, een procureur-generaal en een administrateur van financiën (voorheen verenigd in de functie van de Fiscaal en - toch weer - zes leder. gekuzen uit de anzierijkste inwoners vas de kolunie. Opnieuw vormder. zi; in theorie nief meer dan een advisererd college voor de GouverneurCeneraai, maar ir de praktijk mag hur. invloed op het beleid niet worden onderschat. Tegelijk behoorden deze zess raadsleden tot de uitvoerende macht, want zij werden ook aangesteld als heemraden, belast met het bestuur over de (plantage)districten buiter. Paramaribo. In geval var. ordeverstoring en onlusten ir. die distritten kon de Couverneur-Generaal twee Raadsleden ansteller. als gedelegeerde rechters m.et strafbevoegdheid. Het lukte cus niet de plantocratie buiterspel te zetten. De beoogde scheicing van machten werd tenietgedaan doordat deze in de zes gekozer. leden der Koloniale Raad toch weer werden verenigd, ${ }^{25}$ De politiexe macht var de planters/administrateurs vormde daarom nog steeds eer. factor van betekenis, zij het dat deze meer was ingedand dan voorheen. Zo werden uit hun kring nooit meer Gouverneurs benoend (behalve ad interin); die kwamen weer allemal dit Nederland. Fvenmin is hef cieze groep ooit nog gelukt hen onwelgevallige Gouverneurs :e laten ontsian of geheel naa: hun hand te zetten. Dat he: nog wel werd geprobeerd merkte bijvoorbeeld Gouverneur B.J. Elias na zijn benceming in 184?:

'Reeds spoedig ra zijne aankomst zag hij zig verpligt, om sommige ambtenaren en authoriteiten, die hem trotseren wilien, tot hun waar standpunt terug te

23 Telling plantagelijst Surinanmsche Almanak 1797:3-57.

24 in feite was Suriname na 1815 een kroonkojonie van de Nederlardse Koning geworden. Deze had het oppergezag. Fer werd een speciale Mirister van Kolonien aan gesteld, die (tot 1848) alleen aan ce Koning verantwoording schuldig was wor hot ko'oniaal bele.d.

25 Zeer begripelijk cons:ateerde Wolbers dan ook, 'dat hetze:ve veel aanleiding tot misbruiken gaf; want adn de eene zijac, bepaalien de wetgevers (in bei?rekkel:jken zin loch kon men den Kolonizien raad als roodanig beschouwen) zelve, hetgeen zij aan den anderen kant, als uitvoerders (Heer.uraden) moesten vitrigtem of doen bewerkstelligen; zij konden dus wok alle bepaiingen uilteggen, beperken of uitbreiken naar mate hun gezag of belang zulks vorderde.' (Wolbers 1861:675.) Iniormatie over de bestuursregelingen is afkomstig uit Wolbers (1861:671-5), jonkers (1953:128-31), Brijining en Voorhoeve (1977:62-3) en Kunst (1981:245-6125979-9 
brengen, ja zelfs eentge individuen van de in Suriname bestaande magten van zich te verwijderen, aangezien hij weldra de slinksche wegen en middelen begreep, welke zij aanwendden, om hierdoor eene zekeren invloed op hem te verkrijgen, en, ware het mogelijk, zoo doende door hem te heerschen, zoo als wel vroeger in de kolonie had plaats gevonden' (Wolbers 1861:689).

De negentiende-eeuwse Gouverneurs wisten zich dar ook beter geruggesteund dan hun achttiende-eeuwse voorgangers, aangezien zij niet meer te maken hadden met de dubbele loyaliteit aan soms verdeelde bestururslichamen als de Geoctroyeerde Sociëteit en de Staten-Generaal, maar tot 1848 alleen verantwoording schuldig waren aan de Koning en zijn Minister van Koloniën. In de continuiteit van de Gouverneurschappen was overigens niet veel verbetering gekomen. Tussen 1816 en 1863 zijn in totaal dertien Gouverneurs ieder gemiddeld 3,7 jaar in functie geweest. Daarmee bleef de Koloniale Raad met zijn plantersleden de meest constante factor in het koloniaal bestuur.

In dit hoofdstuk werd in vogelvlucht de internationale politieke en economische context behandeld waarin de Surinaamse plantage-economie zich heeft ontwikkeld. Nu al kunnen enkele elementen worden aangewezen die duiden op de samenhang van roofbouw en overleven. De vestiging van Caraibische plantage-economieër. was een gevolg van de strijd om de macht binnen de Europese wereldeconomie. Al deze plantagekoloniën werden slechts geacht grondstoffen ter stimulering van de Europese nijverheid en handel te produceren. Dit duidt op roofbouw, want kapitaalaccumulatie en economische spin-off, ofwel reproduktie, mochten alleen in Europa plaatsvinden.

In het geval van Suriname bieek dit overduidelijk uit de bepalingen van het octroi dat was verleerid aan de Sociëteit, de feitelijke eigenaar van het land. Alle voordelen die de Surinaamse plantage-economie genereerde waren wettelijk voorbehouden aan Nederland. Aan de reproduktie van die plantage-economie werd nauwelijks aandacht geschonken. Dit lijxt voor Suriname in nog grotere mate te hebben gegoiden dan voor de Engelse en Franse plantage-economieën in het Caraibisch gebied. Daar bestond een tamelijk nauwe relatie tussen de planterselite en de machthebbers in het moederland, waardoor de Caraibische belangen konden worden verwoord en de plantage-economieën politieke en economische bescherming genoten. Hun voortbestaan was hierdoor lange tijd verzekerd, wat bevorderlijk was voor hur groei.

In de relatie tussen Nederland en Suriname was daarvan geen sprake. De Nederlandse markt stond wijd open voor Surinames concurrenten, de Surinaamse planters vormden een internationaal allegaartje en een Surinaamse pressiegroep vergelijkbaar met de Britse West India Interest is er nooit gevormd. De voortdurende tegenstelling tussen Surinaamse planters en de machthebbers in Nederland - gepersonifieerd in de Gouverneur - vormde 
waarschijnlijk de belangrijkste constante in de relatie. In feite werd de tegenstelling gekenmerkt door een botsing tussen de krachten var overleven en van roofbouw. De Surinaamse planters wilden hun belangen optimaal beveiligd zien (overleven) en beschuldigden de Nederlandse machthebbers er van alleen $00 \mathrm{~g}$ te hebben voor het eigen, directe voordeel (roofbouw).

In ieder geval is de weinig stimulerende relatie tussen Nederland en Suriname er mede oorzaak van geweest dat de Surinaamse plantage-economie voor Nederland relatief onbelangrijk is gebleven. Dat neemt niet weg dat er wel degelijk sprake is geweest van expansie, maar evenzeer van achteruitgang. Een rechtlijnig proces van bloei en verval was het in ieder geval niet. Daarvoor bleken de ontwikkelingen in de onderscheiden sectoren en periodes te veel uiteen te lopen. 


\section{HOOFDSTUK II}

\section{Plantages in beweging}

Gedurende de achttiende en negentiende eeuw hebben zich grote verschuivingen voorgedaan binnen en tussen de (sub)tropische gebieden waar werd geproduceerd voor de wereldmarkt. Zo was het Caraibisch gebied rond 1775 nog de absolute exportleider wat betreft suiker en koffie. Driekwart eeuw later was deze situatie totaal veranderd (Tabel 5).

Tabel 5. Aandeel Caraibische export yan suiker, koffie en katoen in de wereldmark: 1775 en 1850

\begin{tabular}{lcccccc}
\hline gebied & \multicolumn{2}{c}{ su ike } & \multicolumn{2}{c}{ koffie } & \multicolumn{2}{c}{ ka 1 o en } \\
& ca. 1775 & ca. 1850 & ca. 1775 & ca. i850 & ca. 1795 & ca. 1850 \\
\hline Caraibisch gebied & $89 \%$ & $5 \%$ & $100 \% *$ & $17 \%$ & $3 \%$ & - \\
$\begin{array}{l}\text { Brazilië } \\
\text { Overige }\end{array}$ & 9 & 7 & - & 47 & 5 & \\
totaal & 2 & 58 & - & 36 & 92 & 98 \\
$(x 1.000$ ton $)$ & 225 & $1.530^{* *}$ & 55 & 300 & 270 & 700 \\
\hline
\end{tabular}

* dit cijfer is wellicht iets geflatteerd, maar de hoeveelheden kotíie die op da: moment onder andere uit Mocha, Yemen en Java werden geëxporteerd zijn te verwaarlozen.

* inclusief 260.000 ton bietsuiker.

Bronnen: Deerr :949, I:1 12-241; Cuffee :903:52; Ukers 1922:277-83; Lecomte 1900:269; Oppeì 1902:607; Rustow 1978:137.

In deze periode kwamen ex helangrijke nieuwe suikerproducenten, voora: in Azië, op en begon in Europa de produktie van bietsiiker aan belang te winnen. Het zwaartepunt van de koffieproduktie was verschoven naar Brazilië en Java en in de produktie van relatief nieuwe 'cash crops' als thee en katoen speelde het Caraibisch gebied niet of nauweli;ks een rol.

Ook binnen het Caraibisch gebied hadden zich belargrijke verschuivingen voorgedaan. Zods Tabel 3 laat zien produceerden in :845 Saint Domingue en Jamaica 53\% van de Caraibische suiker. In 1850 was Saint Domingue als suikerproducent verdwenen en had Cuba, met $45 \%$ var de totale produktie, alle anciere koloniën overvleugeld; Jamaica's aandeel was ineengeschrompeld tot slechts $6 \%$. Hetzelfde beeld doet zich voor bi; de koffieproduktie: in 1755 verbouwden Cuba en Puerto Rico helemaal geen 
koffie en driekwart eeuw later namen ze de helft van de Caraípische koffieexport voor hun rekening.

De conclusie dat mobiliteit een van de meest kenmerkende elementen is in de geschiedenis van grootschalige tropische landbouw ligt voot de hand. De verkiaring hiervoor is echter niet zo eenvoudig. Nieboer (1900) en Thompson (1960) wijzen op de begrenzing (en uitputting) van de beschikbare hoeveelheid natuurlijke hulpbronnen. Beckford (1983) legt mecr het accent op veranderingen in de produktierelaties en vormen van arbeidsmobilisatie. Wolf (1982) en Mintz (1985) benadrukken de voortschrijdende integratie van de wereldeconomie in combinatie met een explosieve stijging van de consumptie in Furopa. Watts (1987:539) tenslotte, wordt gefascineerd door 'the lack of synchronisation of economic and environmental trends in the West Inajes'. Het is duidelijk dat de definitieve verklaring nog niet is gegeven, maar dat zowel veranderingen binnen het Caraibisch gebied als in de wereldeconomie van belang zijn geweest.

De Surinaamse plantagekolonie heeft in de regio een tamelijk bescheiden rol gespeeld (zie Tabellen I en 3). Toch hebben ook daar de ontwikkelirgen niet stil gestaan gedurende de achttiende en negentiende eeuw. Er zijn in deze periode drie belangrijke verschuivingen waar te nemen. De eerste is een regionale verschuiving van het plantagegebied in noordelijke en westelijke richting. De tweede is een lokale verplaatsing van het produktieareaal op de plantages zelf, meestal in achterwaartse richting. Tenslotte is er de verandering van het plantagebezit van eenhoofdig, eigendom van een ter plekke wonende eigenaar, naar absenteisme en versnippering.

\section{Regionale verschuivingen}

De oudste plantages in Suriname werden gedurende de tweede helft van de zeventiende eeuw aangelegd langs de bovenlopen van de rivieren in het noordoosten van het land." Ifierdoor probeerden de planters zich te? beschermen tegen de invallen van piraten en vijandige mogendheden, aangezien deze nooit zo ver de rivieren opvoeren. Bovendien waren de wat verder van de kust gelegen gronden (de 'bovenlanden') riet zo drassig en daardoor gemakixelijker in cultuut te brengen. Tegen het einde van de zeventiende en in het begin van de achttiende eeuw begon zich echter een verschuiving in noordelijke richting af te tekenen. Verschillende factoren lagen hieraan ten grondsiag. Een daarvan was dat de planters dan wel steeds beducht waren geweest voor vijandelijke aanvallen vanaf de kust, maar in

1 Hieronder worden die gedeelten van riviexen verstaan die zich in de hoger gesitueerde en meer binnenlands gelegen gedeelten van Suriname bevinden. Le benedenloop van een rivier is dus het gederlte dat denr de laagyelegen kustvlakte stroomt. 


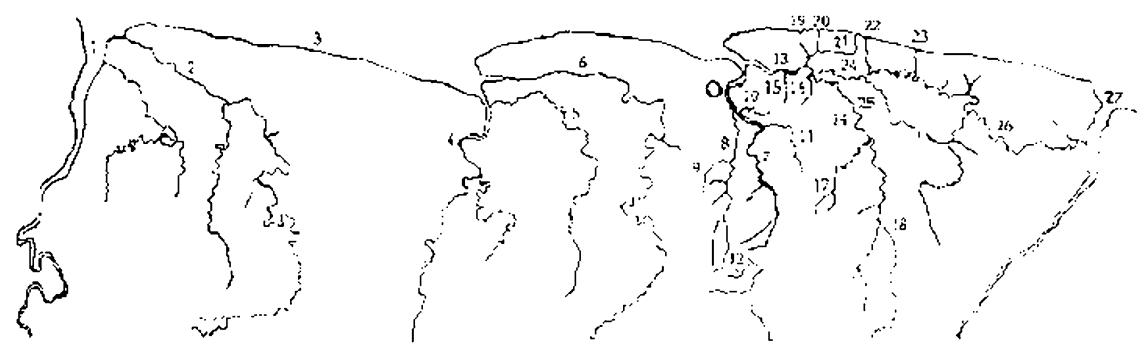

Verklaring van de rivieten en?.

\begin{tabular}{|c|c|}
\hline & Corantijnriv:er \\
\hline & Nickerierivter \\
\hline 3 & Kus: var Coronis \\
\hline 4 & Cosppend me: ivier \\
\hline 5 & Ccesewijnerivier \\
\hline 6 & Sarumaccarivier \\
\hline & Surinamerivier \\
\hline B & Parastvier \\
\hline & Coropinakree'x \\
\hline 10 & l'auluskrevek \\
\hline 11 & Sumauskreex \\
\hline 12 & Maréchalskreek \\
\hline 13 & Beneder-Commewijne \\
\hline 14 & Boven-Commewijac \\
\hline
\end{tabular}

is riser Felerakroek

is commelewanek reek

if Cassewingicakreek

15 "empotiekreek

13 Marazpakrek/kanaal

2.) Nataplcakrepk/hanais]

21 Tapoeripakreek/karaal

22 Notkrestk

23 Viedenbuiger- of Oranjekreek

24 Collucanvie:

24 . Tericativier

26 Coertioliburnver

27 Marouipnerivies

?.aramarilo

\section{ca. 1735}

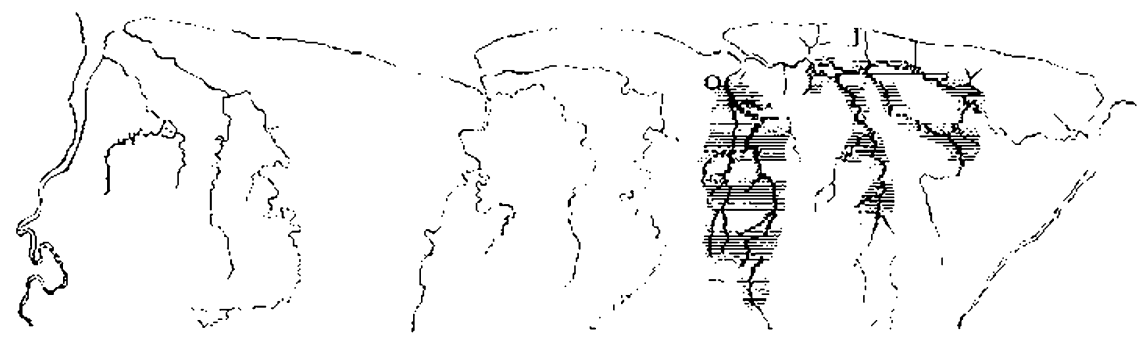



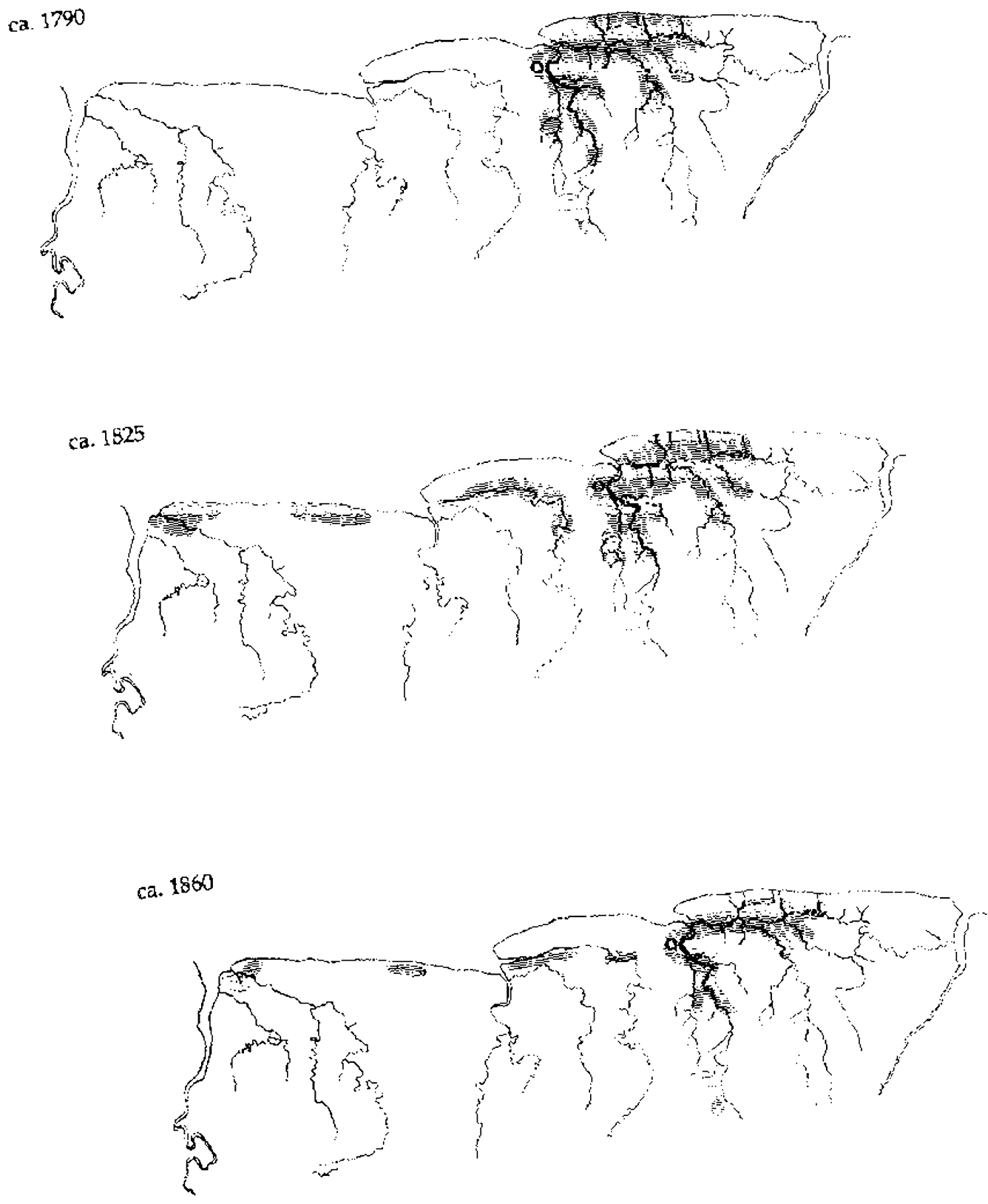
het geheel geen rekening hadden gehouden met eventuele agressie uit het binnenland. In 1678-1679 werden zij wat dat betreft hardhandig met de neus op de feiten gedrukt door de Indianenleider Priary, die de kolonisten de oorlog verklaarde en vele plantages verwoestte. Sinds die tijd is tevens het leger weggelopen slaven, marrors, gegroeid. Deze marrons vestigden zich in de bossen en bestookten van daaruit de plantages. Hoe verder de plantages landinwaarts waren gelegen, des te groter de kans op een overval.

Maar niet alleen de weglopers zorgden voor de verschiriving naar de benedenlanden. Gouverneur (en planter) Nepveu wees er op dat veel plantages werden verlaten en de produktie naar de benedenlanden verplaatst vanwege de snel afnemende produktiviteit van de bovenlarden. Op die relatief hoog geiegen zandgronden kon slechts korte tjjd achtereen met winst suikerriet worden geplant. Daarna moes: zo'n stuk lange tijd braak liggen en dar nog werden de opbrengslen 'a: gaande weg schraalende' (Nepveu 1922-23:342). De produktiecijers uit cie tijd geven Nepveu gelijk. In 1745 bedroeg de opbrengst van in later tijd verlaten plantages in de bovenlanden gemiddeld 86 oxhoofden sulker. De overige plantages produceerden op dat moment ieder daarentegen gemiddeld i56 oxhoofden suiker; een opbrengst die $81 \%$ hoger was. ${ }^{2}$

Het verschuivingsproces richting benedenlanden verliep overigens in fasen. Toi omstreeks 1740 werden eerst alie nog niet gecultiveerde gronden in gebruik genomen in het oude gebied: de siroomgebieden van de I'ara, Suriname (1ot aan Paramaribo en Meerzorg), Boven-Commewijne, Cottica en Perica (Figuur 4A). Daarna brak een voigende fase aan, die cind achttiende eeuw gehee: voltooid was. Gedurende deze periode werden bijna 200 nieuwe (hoofdzakelijk koffie-)plantages aangelegd langs de oevers van de Beneden-Commewijne, Beneden-Surirame (vanaf Paramaribo en Meerzorg), Hoer-Helenakreek (nu Orleanakreek), Motkreek, Vrederburgerkreek (nu Oranjekreek) en de gegraven kanalen van de Warappa-, Matapica- en Tapoeripakreek (Figuur 4B). In het grootste deel van dit nieuwe gebied was Iren aan het eind van de jaren 1750 met ce produktie begononen. Het verder in cultuur brengen var. deze zeer bewerkelijke, want moerassige, benedenlanden werd mogeijk gemaaki door eer: grote kapitaa.stroom uit Vederland. Uiteindelijk zou dit een steen om de nek van veel plarters worden (zie Hoofdstuk VII), mar ni: zorgde he: voor expansie van de plantageeconomie.

Dat het in deze periode niet alleen ging om een uitbreiding, maar ook om een verschuiving van het plantagegebied, blijkt uit het feit dat tussen 1745 en 179654 suikerplantages - grotendeeis in de buverlanden - de produktie staakten. Bovendien waren er voor 1745 ook al 24 suikerplantages 
verdweren. ${ }^{3}$ Deze plantages werden overigens niet aliemaal daadwerkelijk verlaten, voor een deel ging men er zich toeleggen op de houtkap.

In 1770 constateerde Gouvemeur Nepveu dat de verschuiving naar de benedenlanden een bedreiging irhield voor de suikerproduktie. De geringe omvang van de uitgegeven percelen in dat gebied maakten namelijk de installatie van een kostbare watermolen onmogelijk, zudat ex hoofdzakelijk koffieplantages waren aangelegd. Siikerpiantages die ru moesten worden verlaten konden niet elders opnicuw worden opgezet, omdat, volgens Nepver, al:e beschikbare grond inmiddels beze: was. ${ }^{4}$ Dit laatste was niet helemaal waar, want pas in de jaren 1790 werden de viak aan zee gelegen gronden tussen de Warappa- en Vredenburgerkreek voor de opkomende katoenplantages in cultuur gebracht. Voor suiker waren deze gronden echter niet geschikt, zodat rond 1770 de suikerplantages in het bestaande plantagegebied inderdaad muurvast zater, waardoor van uitbreiding fof verplaatsing) geen sprake kon zijn. Nepveu er. zijn neef Louis stelden daarom aan de directie van de Sociëteit van Suriname voor om een nog geheel onontgonnen gebied speciaal voor de suikercultuir in ontwikkeling te taten brengen. $\mathrm{Zij}$ ciachten daarbij aan het stroomgebied van Coppename en Saramacca, geiegen tussen het Surinaamse plantagegebied en de - evereens Nederlandse - plantagekoloniën Berbice en Essequibo. Deze ontginning zou tevens de communicatie tusser de drie koloniën verbeteren. 5

Het doorbreken van het isolement van de verschillerde koionies aan de 'Wilde Kust' door ook het tussenliggende gebied op te vulien, leek een goed idee, vooral omdat Berbice ne: een grote siavenopstand achter ce rug had. Toch duurde het nog zo'r. dertig jaar voor daaciwerkeljjk werd begonnen met het in cultuur brengen van het Saramaccagebied, terwijl dat er in het Coppenamegebied, om niet te achterhalen rederen, zelfs nooit van is gekomen. De voornaamste reden voor het lange dralen was kapitaalgebrek. Halverwege de jarer. 1770 droogde de kapitaalstroom uit Veder:and op (Foofdstuk VII), terwijl op dat moment Nepve:i de voorbereidingskosten - met name het graven van cen karaal naar Saramacca .. schatte op 6 d 8 miljoen guiden.6

Eind achttiende eeuw pakte Gouverneur Friderici de draad weer op en ditmaal met succes. Er werd een verbinaingskanaal gegraven tussen de Surinamerivier en de Saramacca, dat ir 1801 gereed kwam. Yijf jaar eerder waren e: al 28 concessies vergeven (Surinammse Almanak 1796:3-57). Het zal geen toeval zijn geweest, dat precies in de jaren 1796-1799 door Friderici voor bijna 2,4 mi.joen gulden aan zogenaamd kaartengeld werd uitgegeven, 
terwijl in de jaren daarna nog eens bijna één miljoen volgde, waardoor de Surinaamse gulden aan een enorme inflatie onderhevig raakte. ${ }^{7}$

De Friderici's ambities gingen echter verder dan het ontsluiten van alleen het Saramaccagebied. Hij had tevens zijn oog laten vallen op de kuststrook ten westen van de monding van de Saramaccarivier tot aan de Corantijn, het latere Coronie en Nickerie. Ook voor deze gebieden wist Friderici voldoende belangstelling bij planters te wekken om een begin met de ontsluiting te kunnen maken. Door de oorlog in Europa en de eerste Engelse bezetting (1799-1802) leek het er even op dat zijn initiatieven een vroegtijdige dood zouden sterven. Toen Suriname eenmaal daadwerkelijk een kolonie van Fngeland was geworden (1804) kreeg de plantage-economie echter nieuwe impulsen en vooral ook kapitaal. In korte tijd werden in dit nieuwste gebied 68 plantages angelegd (Figuur $4 \mathrm{C}$ ). ${ }^{8}$

De hoop dat nieuwe regio's ook een opleving van de suikercultuur zouden betekenen, ging echter maar zeer gedeeltelijk in vervulling. Slechts vier nieuwe suikerplantages werden aangelegd: drie in Saramacca (Iamburg, Kent en Catharina Sophia) en cen aan de monding van de Suriname (De Resolutie). Alle andere nieuwe ondernemingen produceerden - onder invloed van de gunstige prijzen koffie of katoen. Pas in een veel later stadium zijn ook in Coronic en Nickerie eer zestal plantages (Bumside, Waterloo, Nursery, Hazard, Paradise en Hamptoncourt) van katoen op suiker overgeschakeld.

Overigens ging tijdens deze derde fase (circa 1795-1825), waarin het plantagegebied zich in westelijke richting uitbreidde, het proces van verlating in de oudere gebieden verder. $\mathrm{Nu}$ werden echter niet meer alleen de oude suikerplantages in de boverlanden verlaten, maar ook koffieplantages begonnen te verdwijnen. Tussen 1770 en 1825 stopten 134 plantages definitief met de koffieproduktie. Enkele daarvan gingen zich toeleggen op de verbouw van voedselgewassen of de loutkap, anderen werden omgezet in suikerondernemingen en een aantal schakclde over op katoen. I Jet

7 Om an de geldbehodte se kunnen voldoen lict Couverncur Le Friderici speelkarten van een stempel voorzien, die als papiergeld in roulatie werden gebracht. Daar stond erhler geen enkele dekking tegenover, zodat het om ecn puur inflatoire maatregel ging.

'Bijna bij elk te kurt dat in de loop der tijden in de koloniale kassen ontstond, had men de toevlugt genomen tot het maken en uitgeven van kaartengeld. Fen tijd lang was dil goed gegaan, daar dit kaartengeld, bij gebrek aan ander circulecrend medium, tegen de waarde van klinkende munt werd aangenomen. Er zijn zells voorbeelden van, dat het soms hooger dan contante" klinkende specie gewaarderrd werd. In den Enpelschen tijd echter onderging het eene belangrijke daling; bij de komst van $\Gamma$. Bonham tot het bewind, in 1811, was het kaartengeld zoo laag in waarde gedaald, dal $f 48$ kaartengeld gelijk stond mel een pond sterling of $f$ I 2 dus als 4 tol 1.' (Wolbers 1861:625.)

Op dat moment was er ruim 6.5 miljoen gulden an kaartengeld in onloop (Public Record Office: Colonial Office $27 \ddot{\varnothing}, 13)$.

8 ARA: Collectie-Van Hecckeren; $68 \mathrm{en}$ 69; Surinonmsthe Almanak 1824:45 85. 
Tabel 6. Aandeel van de plantagegebieden in het totaal aantal Surinaamse exportplantages $1730-1860$

\begin{tabular}{lccc}
\hline periode & oude gebicad & nieuwe gebied & nieuwste gebied \\
\cline { 2 - 4 } ca. 1730 & $100 \%$ & - & - \\
ca. 1795 & $60 \%$ & $40 \%$ & - \\
ca. 1825 & $43 \%$ & $43 \%$ & $14 \%$ \\
ca. 1860 & $39 \%$ & $39 \%$ & $22 \%$ \\
\hline Bronnen: Kaar: De Lavaux $1737 ;$ & Surinaamse Almanak 1798 en 1824; Koloniaal \\
Verslag : 860. & &
\end{tabular}

verlies voor de sector als geheel werd bij lange na niet gecompenseerd door de 27 nieuwe koffieplar!ages die in Saramacca en Nickerie in cultuur werden genomer. (Strimaamse Almanak 1798:3-57, 1824:45-85).

N":euwe regio's werden na $: 825$ niet meer ontsloten, terwijl door het voorigaande proces van verlating in ce voorheen aaneengesloten plantagegebieden steeds grotere gaten gingen vallen (Figuur 4D). De suikercultuur kreeg we: nieliwe impulsen, doorciat voortdurend koffie- er. katoenplantages overschakelden op sliker. In 1857 vormde deze groep zelfs eenderde deel van aile suikerplanlages (I lering 1858:bijlage).

De verschuiving van de plantagegebieden in Suriname is in Tabel 6 weergegeven aar verhouding van hu: aandeel in het 1otaa: aantal voor de export producerende pantages.

Het afnemend belang van het oude, dee's hoger gelegen gebied is duidelijk te zien. $\mathrm{Na}: 825$ lijkt de verhouding tussen ce gebieden zich te stabiliseren, afgezien van het nieuwste gebied, dat relatief nog wat in belang toenam door het geringer aantai p.antages dat daar werd veriaten. Joch is het dit laatste gebied nooit gelukt de twee oudere gebieden naar de kroon te steken, laat staan te overvieugelen. I Iet ontsluiter van nieuwe regio's vergde kapitalen en die waren in de negentiende eetw veel minder voorharuden dan in de eeus darvoor.

\section{Lokale verschuivingen}

Verschuivingen op de individiele plantages jlijken zich in Suriname op twee manieren te hebben voorgedaan. De eerste was een trend tot areaalvergroting; de tweede was een achterwaarise verschuiving van het bebouwd areaal, dat wil zeggen van de rivie: vandaan. Rond $: 770$ besloegen de 40 . suiker- en koffieplantages samen een areaal van 162.42: ha., ofwel 405 ha. per plantage. In 1862 besloegen de 131 resterende suiker-, koffe- en xaloenplartages nog 95.20: ha. en dus 727 ha. per plantage (Tabel 7). Wanneer de cijfers per sector worden gedifferentieerd, can is het beeld echter minde: eencuidig. 
Tabel 7. Plantage-areaal per sector 1770 en 1862 (in ha.)

\begin{tabular}{|c|c|c|c|c|}
\hline & \multicolumn{2}{|c|}{ suikgr } & \multicolumn{2}{|c|}{ koffie } \\
\hline & ca, 1770 & ca. 1862 & ca. 1770 & ca, 1862 \\
\hline totaal alle plantages & 83.457 & 62,996 & 77.844 & 25.775 \\
\hline in cultuus & 8.744 & 8.903 & 18.977 & 1.503 \\
\hline totaalgemiddelde plantages & 752 & 733 & 264 & 348 \\
\hline ìn cultuur & 79 & $: 04$ & 64 & 50 \\
\hline \multirow[t]{2}{*}{ areaal } & \multicolumn{2}{|c|}{ katoen } & \multicolumn{2}{|c|}{ samen } \\
\hline & ca. 1795 & ca. 1862 & ca. $1770^{4}$ & ca. 1862 \\
\hline totaal alle plantages & 15.993 & 6.578 & 161.301 & 95.349 \\
\hline in culturur & 3.539 & 1.961 & 27.721 & 12.367 \\
\hline totaalgemiddelde plantages & 410 & 438 & 397 & 728 \\
\hline in cultuur & 91 & 1,31 & 68 & 94 \\
\hline
\end{tabular}

* alleen suiker en kolfie.

Bronnen: 1770-1795: extrapolaties van steekproeven waarbij $n=41$ (suiker), $n=91$ (koffie) en $n=12$ (katoen); Van Sijpesteijn 1854:96-147; Koloniaal Versiag 1862; voor het aantal plantages zie Bijlage $4 \mathrm{~A}$.

Uit deze tabel blijkt dat de gem:ddelde suikerpiantage in de ioop der tijd niet is gegroeid, maar zelss iets kleiner werd; katoerplantages werden gemiddeld iets groter en alieen de omvang van de gemiddelde koffieplantage nam flink toe (bijna een-derde). Toch heeft er wel degelijk ook in de suikersector areaalvergrating plaats gevonden. Ferder werd al opgemerkt dat in 18.53 eenderde van de suikersector uit voormalige koffieplantages bestond. Deze wasen een heel stuk kleiner dan de 'originele' suikerplantages en drukten daardoor het gemiddelde in. I862. De 53 'origine'e' plantages, die zowel in 1737 als in 1857 suiker produceerder, blijken in die periode te zijn gegroeid van gemiddeld $72:$ ha. naar 865 ha., een toename van $20 \% .9$ De meerderheid van de suikerplantages had dus wel degelijk zijn areaal vergroot.

Belangrijke: dan de totale oppervlakte was echter het suikerareaal. Ondanks het feit dat het areai van de suikersector ais geheel in de loop der tijd ruim een kwart kleiner werd, bleef het suikerareaal vri;wel gelijk. Voor de gemiddelde suikerplantage betekende dit een uitbreiding van ruim $35 \%$. Een efficiëntere werkwijze en/of vergroting van het arbeidspotentiee: moeten hieraan ten grondslag hebben gelegen. In Hoofdstukken $V$ en VI word: hierop nader ingegaan.

In de koffiesector zijn in de loop der tijd de kleinere plantages het eerst van het toneel verdwenen, waardoor de gemiddelde grootte van deze ondernemingen toeram. Toch heeft ook in deze sector schaalvergroting 
plaatsgevonden en waren het juist de expanderende plantages àie het het langst hebben volgehouden. Uit een steekproef van zeventien koffieplantages blijkt dat tussen 1760 en 1853 hun gemiddelcie opperviakte groeide van 269 ha. naar 387 ha. In tegenstelling tot de suikersector bleek hun koffieareaal echter nict te zijn meegegroeid. Rond 1780 hadden deze plantages gemiddeld 96 ha. met koffie beplant, terwijl in 1854 h.un gemiddelde koffieareaal slechts 60 ha. besloeg: : Zelfs het wegvalien van de kleinere plantages leidde dus nief tot een stijgirg var het gemiddelde cultuuroppervlak. Grotere efficiëntie en/of uitbreiding van het arbeidspotertieel hebben in deze sector daarom xernelijk niet plaatsgehad.

De gemiddelde katoenplantage lijkt in de loop der tijo nauwelijks te zijn gegroeid. Toch bleker. juist de plantages die in de jaren 1850 nog katoen produceerden hum areaal in de voorafgaande decennia te hebben vergroot. Een steekproef onder tier van hen wijst :it dat hun gerniddelde oppervlax grocide van 450 ha. rond 1825 tot 534 ha. in 1853 . Hun cuituurareal besloeg echter in hef eerste jaar gemiddeld 155 ha., terwijl hef gemidde.d katoenareaal in 1854 niet groter bleek dan 134 ha. Van produktieve groei was dus ook hier geen sprake.11

Om het plantage-areaal te kunnen vergroten, beschikte een planter over twee mogelijkheden. De eerste was het verkrijgen van een concessie op het land acinter de piantage. Met name bij plantages langs de Beneden-Commewijne is dit vaak gebeurd. Dit had echter als groo! bezwaar dat de nicuwe concessies ver van de rivier aflagen en daardoor moeilijk overtollig water konden lozen. Bovendien werden deze gronden vaak doorsneden met zwampen (moeras) en :itsen (zand- of schelpheuvels).

De tweede optie was het verkrigen van land van andere, liefst belencende, plantages. Dit werd vergemakkelijkt toen in de negentiende eeuw steeds meer plantages werden verlaten. Deze wijze van areaaluitbeiding deed zich vooral voor bij suikerplantages, omdat op gronden die nie: meer geschikt waren voor koffieteelt vaak nog wel suiker kon worden geplant. Sommige plantages vertoonden in dit proces van areaalafstoting en -verwerving een grialig verloop.

Ten sprekend voorbeeld daarvan is plantage Roojank, later Toledo genoemd, aan de Surinamerivier. Wat het gri:ige arealverloop van deze plantage heeft veroorzaakt, wordt in de bronner niet verme!d, maar kan ten dele toch worden gereconstrueerd. Deze onderneming behoorde to: de oudste van Suriname en was in 1750 al zeker driekwart eeuw in bedrijf. Op

IC Steekproef ARA: SONA; Van Sijpesteijn 1854:96-147; Kolonical Verslag 1854.

In Steekproef ARA: SONA, 841; ARA: Collectie-van Heeckeren, 98; Van Sijpesteijn 1854:96147; Kolininal Verslag 1854. 
dat moment bedroeg het totaal areaal 730 ha. en rustte er een hypotheek op de plantage van $f 60.000 .12$ Wellicht heeft men aan de verplichtingen daarvan niet kunnen voldoen - de lage produktie in die jaren maakt dit zeker aannemelijk ${ }^{13}$ - zodat de eigenaar besloot zich helemaal toe te leggen op de lucratievere produktie van koffie. Daartoe kon worden volstaan met een veel kleiner areaal. Bijna twee-derde van de grond werd van de hand gedaan en met de opbrengst kon de schuld waarschijnlijk gedeeltelijk worden gedelgd. Kennelijk was dit nog niet voldoende, want in 1782 bleck opnieuw meer dan de helft van hef resterende areaal te zijn verkocht en bleef er nog maar 120 ha. over. Uit de afgestoten gronden werden, ten zuiden van Roobank, twee nieuwe plantages geformeerd: Wijklust en De Verwachting. Begin negentiende eeuw had de koffieproduktie op het te kleine Roobank geen toekomst meer. De onderneming werd toen overgenomen door de Brit O'Ferral, die er - wellicht met Engels kapitaal - weer een suikerplantage van maakfe. Daarvoor was het areaal echter ook te klein en dus werd de buurplantage Nieuwrust, ten noorder van Roobank, gekocht en het geheel omgedoopt in Toledo, met een totaalareaal van 322 ha. Fr werd een stommachine geinstalleerd en de resultaten waren bemoedigend: gemiddeld werden er tussen 1819 on 1828158 oxhoofden suiker per jaar geproduceerd ${ }^{14}$ Deze positieve ontwikkeling beklijfde echter nict, want dertig jaar later bleek de plantage, ondanks nog een kleine areaalvergroting tot 344 ha., te behoren tot de zes slechtst producerende suikerondernemingen van Suriname (Koloniale Verslagen 1857, 1858). Wellicht was her areaal nog niet groot genoeg om optimaal te kunnen produceren.

Niet alle plantages kenden een zo grillige ontwikkeling in de areaalomvang als Roobank/Toledo. Maar da: in het algemeen de arealen niet vastlagen, maar onder invloed van de onstancigheden tamelijk flexibel waren, staat buiten kijf. Schaalvergroting was geen onbekend verschijnsel en lijkt in veel gevallen een voorwaarde te zijn geweest on de produktie langer te kunnen volinouden. Op de lange cuur blijkt het echter alleer in de suikersector vrucht te hebben afgeworpen. ${ }^{15}$

12 GAA: NA, 17677.

13 In de jaren 1750-1753 werd gemiddeld nie: meet dan 59 oxhoofden suiker per jaar geproduccerd op Roobark (ARA: Rvl', 606 en 607).

if ARA: OAS, AvF, 52.

I5 Er zijn weinig kivantjtatieve gegevens beschikbaar die een vergelijking met andere Caraibische plantage-arealen mogelijx majkt. De enige die sporadisch wat cijfers noernt is Watts (1987). Vnigens hem was de gemiddelde suikerplantage op Jamaira in 1774243 ha groot, waarvan 108 ha. onder suiker (p. 345); op Saint Domingue tussen 121 en 162 ho, waarvan de helft tot twee-derde onder suiker (p. 351) en op Cuba [o] fefore 1850, most of the new estates were of a size raniring from 45 to 58 cabal'prias (603 to 777 ha.), though usually much less than one half of this was placed under cane' (p. 488). De Surinaamse suikerplantages behoorden dus tot de grootste in het Caraibisch gebicd maar hadden (rclatief) een veel kleiner suikerareaal. Het rotatiesyste:m in Suriname zal daarin zeker cen rol hebben gespeeld. 
Een andere vorm van territoriale mobiliteit op lokaal niveau was de verschuiving van het bebouwd areaal binnen de onderneming. In het geval van suikerplantages was deze mobiliteit inherent aan de teeltmethode, namelijk rotatie (zie Hoofdstukken V en VI); bij koffie en katoen was daarvan echter geen sprake. Ioch blikk op alle drie soorten ondernemingen het bebouwd areaal in de loop der tijd naar achteren te zijn opgeschoven.

Op koffieplantages is dit proms het meest duiselijk waarneembaar. Men begon op aile plantages met het in cultuur brengern van de dichtst bij de rivier gelegen gronden. Door de ecuwenlange overstromingen was dit het meest vruchtbare en dus meest produktieve deel van een plantage. Bovendien vergernakkelijkte de korte afstand tot de rivier de afwatering van de gronden, het afschepen van produkten en de bereikbaarheid van het gebouwencomplex. Om zo lang mogelijk van deze voordelen te kunnen genieten, bleven, voora: op plantages waar geen rotatie plaats vond, deze gronden vele tientallen jaren achtereen bebouwd. Hoe vruchtbaar ook, op den duur raaklen zij toch volkomen uilgepui, aangezier de grond geen enkele rust of bemesling kreeg. Was het eenmal zover, dan werden een voor eerl de voorste stukken verlater en steecis neer achterwaarts gelegen gronder ir gebruik genomen. Deze waren echter minder vruchtbaar en moeilijker te lozen, waardoor zij nok annmerkelijk sneller uitgeput raakter. Wanneer men eenmaal het midden van de plantage voorbi; was, kwam. het einde van de plantage snel in zicht. Een dexgelijke ontwikkeling heeft zich op vele tientaller, zo niet honderden planiages afgespeeld. Dit is weergegeven in Figuur $5^{16}$, aan de hand van de situatie op de koffieplantage Somerszorg aan de Iapoeripakreek.

ln 1754 verkreeg de heer Somers een concessie van 72 ha. Voortvarend werden de eerste stukken ingepolierti er: na twaalf jaar was al 58 ha. (nrrs 17) met koffie beplant. Halverwege de jaren $: 780$ was de kolfie-aanplant uitgegroeid tot 9.3 lia. (nos 1-11), waren ex nog eens 17 ha beplant met bananer (ñs $12 \mathrm{en} \mathrm{13)} \mathrm{en} \mathrm{had} \mathrm{men} \mathrm{op} \mathrm{de} \mathrm{voorste} \mathrm{stukken} \mathrm{(nrs} 1-5 \mathrm{en} \mathrm{7)}$ katoen :ussen de koffie geplant. Zelfs de vruchtbare voorste gronder. konden een dergelijke intensieve bebouwing niet ten eeuwigen dage verdragen en de darap volgence decennia werden achtereenvolgens de stukken nummers $2,3,4$ en 6 , samen 33 ha., verlaten. Bovendien moesten in 1820 de micidelste stukken nummers 8 en 12 opr.jeuw worden beplant, een bewijs var. hun geringere vruch tbaarheid. De detinitieve bevestiging dadrvar bleek negen jaar later, toen deze akkers het onderhoud niet waardig' mee: waren en moesten worden verlaten. Intussen was ook stuk nummer 2, na 70 jaar dienst te hebben gedaan, voorgoed verlaten en in 1834 gebeurde hetzelfde met nummer 5. Joe definitief dit was bleek toen dit stuk,

16 Degegevens voor Figuur 5 komen uit GAR: Collectie-H hudig, 301,329 en 331. 
Figuur 5. Verschuiving van het bebouwd areal op fomerszorg 1766-1855
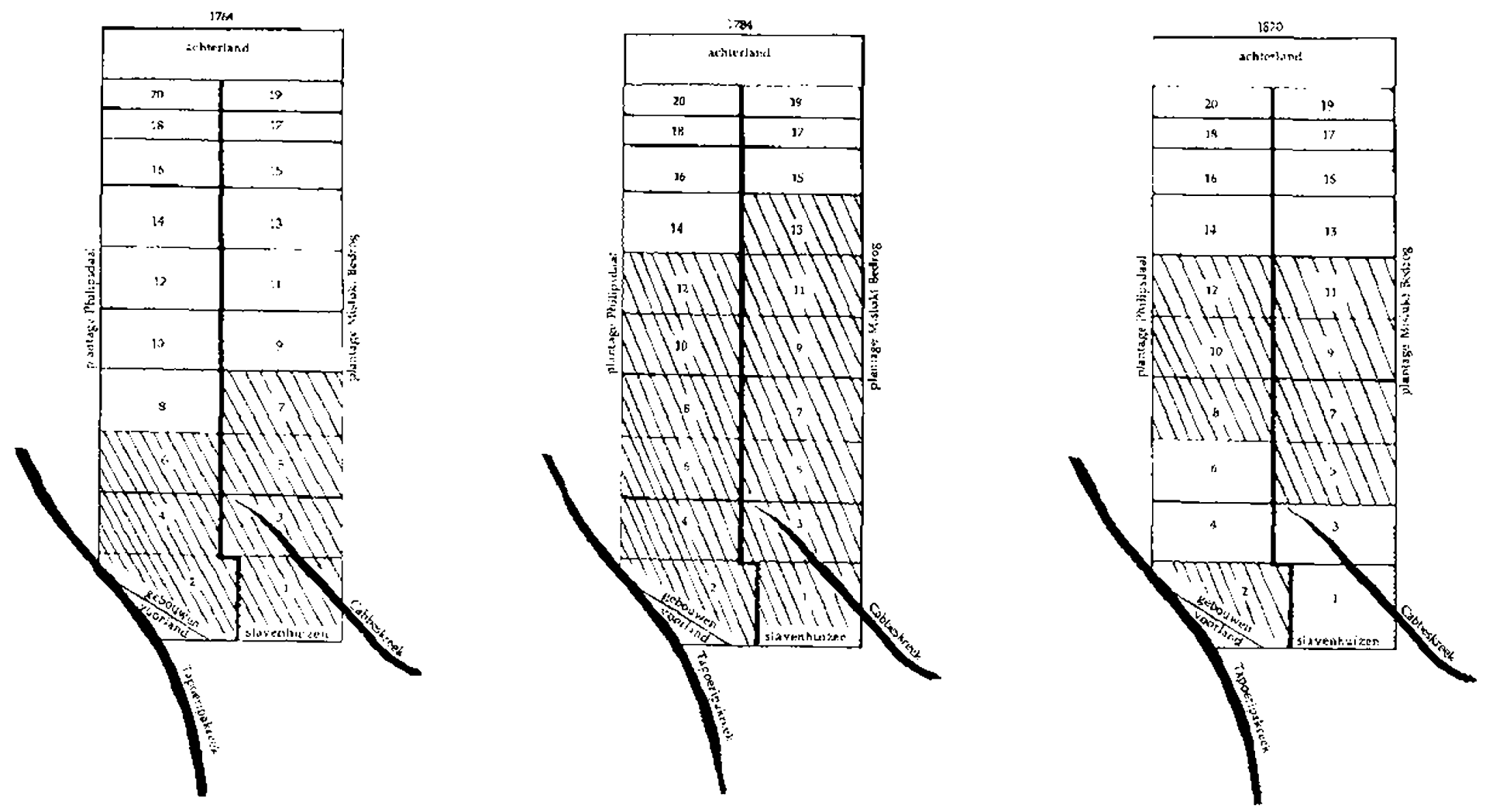

A.A. van Stipriaan - 978-90-04-25979-9 Downloaded from Brill.com04/26/2023 03:31:44PM 

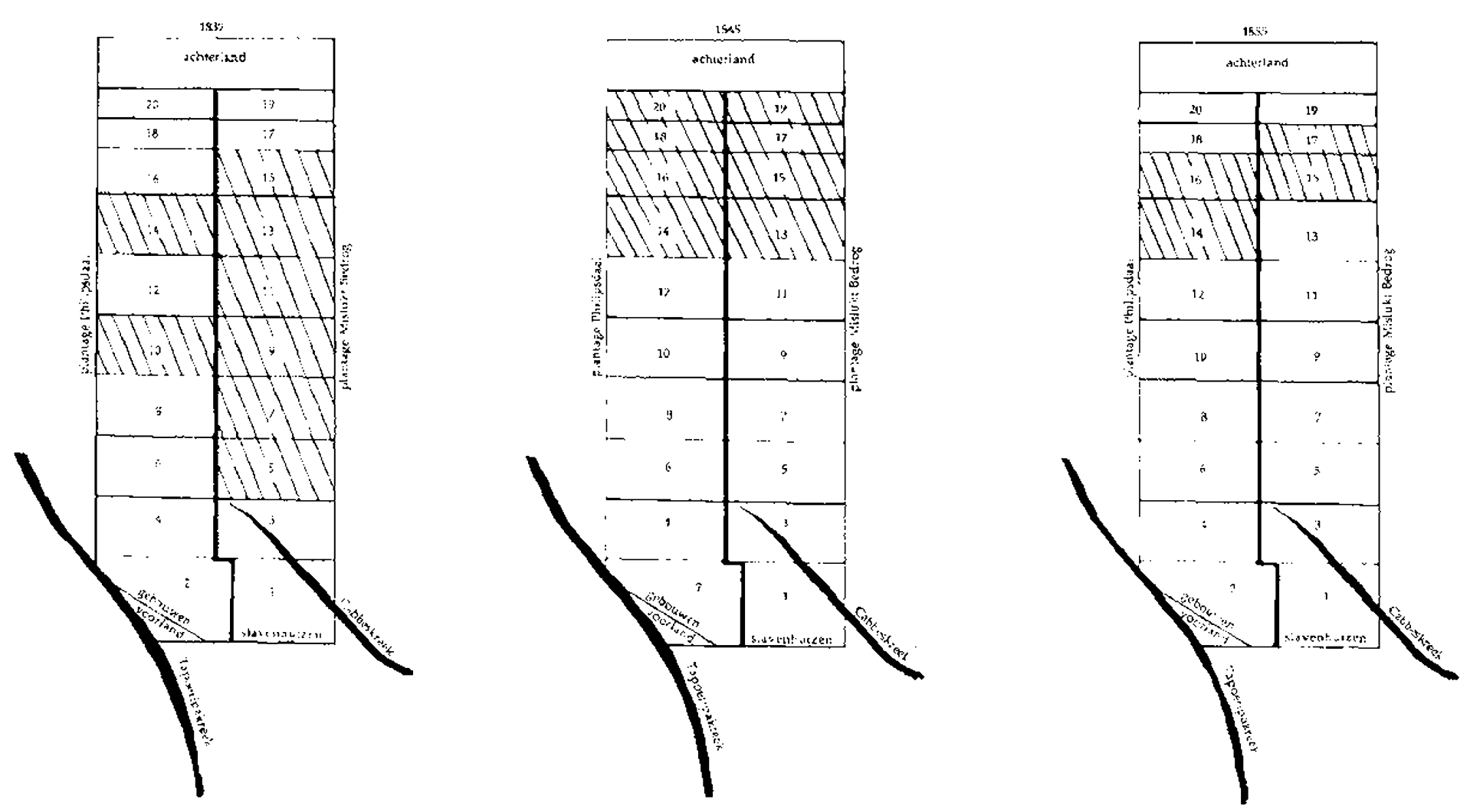
ла elf jaar braak te hebben gelegen, weer met baranen werd beplant. Binnen vier jaar moest men het oprieuw verlaten, omdat de aanplant niet meer wilde aanslaan. Tussen 1830 en 1836 werden de meest achterwaarts gelegen stukken nummers 14-20 aangelegd, samen 47 ha. groot. De resterende middelste stukken $(7,9,10$ en 1I) werden tocn opgegeven. I liermee was het lot van Somerszorg bezegeld, want de laatst aangelegde stukken 18-20 werden al weer na vijftien jaar door schraalte verlaten'.17 Deze korte produktieve periode steekt schril af bij de zeventig jaar waarin de voorste stukken bebouwd waren geweest en geven het kwaliteitsverschil tussen de gronden goed weer.

Aangezien de meeste koffieplantages in Suriname in dezelfde periode zijn aangelegd (1730-1760) is het hierboven geschetste aftakelingsproces in deze secior tamclijk synchroon verlopen. Tot in de jaren 1780 blecf men het cultuurareaal steeds verder uifbreicien. Daarna daalde de onvang weer tot het riveau van de jaren 1770 en schoof het areaal steeds verder naar achteren, getuige de aanzienijke toename van het aantal verlaten akkers (Tabel 8). Daarmee was onomstotelijk het verval in gang gezet.

In de jaren 1820-1840 blijkt het verlaten areaal meer dan te zijn verdubbeld ten opzichte van de periode 1790-1810. Het was toen zelfs al een-derde groter dan het bebouwd areaal. Ook de uitbreiding van het totale plantageareaal tussen 1750 en 1840 met ruim twee-vijfde heeft niet mogen baten. Logischerwijs mag worden verondersteld dat in de laatstc periode alleen nog de minder produkticve midden- en achterlanden in gebruik waren. Daarmee was de aftakeling in deze sector van de Surinamse plantageeconomie onomkeerbaar geworden. Alleen het op grote schal aanleggen van nieuwe koffieplantages had het tij kunnen keren, maar dat is, afgezien van de 27 nieuwe plantages in Saramacca en Nickerie, niet gebeurd.

Tabel 8. Gemiddelde arealbezetting in de koffiesector 1750-1840 (in ha.)

\begin{tabular}{lcccccc}
\hline periode & $\begin{array}{c}\text { totaal } \\
\text { areaal }\end{array}$ & \multicolumn{2}{c}{ koffie-areaal } & \multicolumn{2}{c}{ verlaten areaal } & n \\
\hline $\mathbf{1 7 5 0}-1759$ & 235 & 43 & $(18 \%)$ & 2 & $(1 \%)$ & 30 \\
$\mathbf{1 7 6 0 - 1 7 6 9}$ & 228 & 66 & $(29 \%)$ & 5 & $(2 \%)$ & 31 \\
$1770-1779$ & 295 & 83 & $(28 \%)$ & 6 & $(2 \%)$ & 39 \\
$1780-1789$ & 301 & 90 & $(30 \%)$ & 20 & $(7 \%)$ & 32 \\
$1790-1810$ & 300 & 82 & $(27 \%)$ & 42 & $(14 \%)$ & 39 \\
$1820-1840$ & 335 & 65 & $(19 \%)$ & 90 & $(27 \%)$ & 25 \\
\hline
\end{tabular}

In deze steekproef zijn geen (veel jongere) plantages uit het nieuwste plantagegebied, met name Saramacca, opgenomen, omdat dit hel beeld zou vertekenen.

Bronnen: Steekproef ARA: SONA en SNA; plantage-archieven. 
Overigens bestond het bebouwde areaal op plantages niet alleen maar uit beplanting met het hoofdgewas. Voor een deel werd het in beslag genomen door de zogenaamde kostgronden waarop voedingsgewassen werden verbouwd. Ook werd soms een deel van het areaal gebruikt voor de produktie van een tweede 'cash crop'. De meeste plantages beschikten bovendien over weidegrond voor hel vee. Samen namen deze gronden nog cens 7 a 9\%van het plantage-areaal in beslag (Tabel 9).

Tabel 9. Overige areaalbezetting koffieplantages 1750-1840 (in ha.)

\begin{tabular}{llll} 
periode totaal kostgrond weidegrond & $\begin{array}{l}\text { niet-koffie } \\
\text { cashcrop- } \\
\text { areal }\end{array}$ & $n$ \\
\hline
\end{tabular}

\begin{tabular}{lllllllll}
\hline $1750-1769$ & 230 & 11 & $(5 \%)$ & 5 & $(2 \%)$ & 2 & $(1 \%)$ & 46 \\
$1790-1810$ & 299 & 14 & $(5 \%)$ & 7 & $\langle 2 \%)$ & 7 & $(2 \%)$ & 39 \\
$1820-1840$ & 335 & 12 & $(4 \%)$ & 6 & $(2 \%)$ & 3 & $(1 \%)$ & 22
\end{tabular}

Bronnen: steekproef ARA: SONA en SNA; plantage-archieven.

Kostgronden besloegen 4 à $5 \%$ van het totaal areaal. Hun omvang hing samen met de grootte van de slavenmacht en het gevoerde beleid wat betreft de voedselvoorziening van de slaven. De veestapel op koffieplantages was hoofdzakelijk bedoeld voor de planter of plantagedirecteur, al werd ter beloning of aanmoediging ook wel eens een deel daarvan aan de slavern gegund. Gemiddeld bestond deze uit 15 runderen, 25 schapen en geiten en 10 varkens, terwijl er soms ook nog een paard of ezel rondliep. 18 Voor het onderhoud hiervan was gemiddeid 6 ha. weidegrond beschikbaar.

Voor de grote 'boom' in de koffjesector (vanaf 1745-1750) verbouwden veel plantages naast koffie ook suiker en soms cacao. Rond de eeuwwisseling was katoen enorm in opmars en waren de hoge prijzen van dit produkt voor veel planters aanleiding een deel van hun areaal hiernee te beplanten. Afgezien van de gemiddeld zeven ha. die per plantage aan dit gewas werden gespendeerd, plantie men bovendien vaak nog katoen tussen de koffiebomen. Het koffie-areaal werd zodoende optimaal benut, maar de aanslag die het deed op de veerkracht van de bodem moet navenant geweest zijn. Enige decennia later was deze praktijk al weer verlaten, waarschijnlijk mede uit gebrek aan arbeidskracht.

Toen de koffieculiuur steeds meer een aflopende zaak bleek te worden, kwam er in de jaren 1850 een belangrijk tweede exportgewas bij, namelijk cacao. Er zijn geen cijfers voorhanden hoeveel planters cacao naast koffie zijn gaan verbouwen, noch hoeveel planters volledig op dit gewas zijn overgeschakcld. Wel staat vast dat er geen nieuwe plantages v(x)r dit gewas 
zijn aangelegd. De totale cacao-aanplant in Suriname steeg tussen 1849 en 1862 van 412 tot 1.255 ha. (Koloniale Verslagen 1849, 1862). Op een aantal koffieplantages zal dus cacao de koffie in belang zijn gaan evenaren of zelfs voorbij zijn gestreefd, want op suiker- of katoenplantages werd geen cacao verbouwd.

Door gebrekkig bronnenmateriaal is de areaalontwikkeling in de katoensector minder gemakkelijk te reconstrweren. ${ }^{19}$ De enkele plantages die redelijk zijn gedocumenteerd, lijken cchter een vergelijkbare ontwikkeling te hebben doorgemaakt als de koffieplantages. Zo bleek in 1829 op plantage Carelsdeel aan het Matapicakanaal, sinds eind achttiende eeuw in bedrijf, dat de stukken grond genummerd 1-12 waren verlaten en dat pas daarna het bebouwd areaal begon.20 Logischerwijs betekent dit dat ook hier de voorste landen waren afgeschreven. De inventaris uit 1844 var plantage Anna Catharina, an hetzeifde kanaal, vertoont een meer diffuus beeld. Het totale areaal bestond op dat moment uit een oude en een nieuwe concessie. In de oude concessic liep de nummering van de stukker grond van $I$ to 42 , warvan de stukken nummers $16-26$ waren verlater. Kennelijk was dit het middengedeelte van de plantage. In de rieuwe concessie, die waarschijnlijk dwars op de oude lag, waren ce de stukken genummerd van $A$ tot $R$ en was juist het middengedeelte (E-M) bebouwd en de rest veriaten.21 Dit kan er op duiden dat het aftakelingsproces bij katoenplantages minder eendridig verliep dan bij koffieplantages. ${ }^{22}$ In ieder geval lijkt er wel sprake te zijn geweest van verschuiving van het bebouwd areaal. Dit blijkt eens te meer uit de ontwikkeling van de gemiddelde areaalbezetting van een wat groter aanta: plantages (Tabel 10).

Gedurende de eerste periode waren er rog nauwelijks gronden veriaten en waar dat wel het geval was blijkt het om voormalige koffieplantages te gaan. In de negentiende exuw nam het verlaten areaal echter aarzienlijk toe. In de laatste periode blijken de verlaten gronden een-zesde deel var het totaal te beslaan, terwijl het oppervlak van deze plantages de helft groter was dan in de eerste periode. Het kan niet anders dan dat oox op de katoenplantages een verschuiving van het bebouwd areal heef: plaatsgevonden en, zeer waarschi;nlijk, eveneens naar minder voordelige gronden.

19 Dit is voormamelijk te wijten aan de omstandigheid dat slechts weinig inventarissen van katoenplantages voorhanden zim ea in de wel aanwez:ge exemplaren de verschillende stukken grond niet apart worden gespecificeerd.

X ARA: PWI-Bank, 77.

n Collectie-Insinger \& Co, inventaris 1844 .

2. Het feit dat deze plantage vlax bij zee was gelegen kan eveneens eer, rol hebben gespeeld, bijvowibeeld door de penetratic van zo:dt water. 
Tabel 10. Cemiddelde areaalbezetting in de katoensector 1790-1860 (in ha.)

\begin{tabular}{lcccrrr} 
periode & $\begin{array}{c}\text { totaal } \\
\text { arcaal }\end{array}$ & \multicolumn{4}{c}{ katoenareaal } & \multicolumn{2}{c}{ verlaten areaal } & n \\
\hline $1790-1809$ & $4: 0$ & 131 & $(32 \%)$ & 4 & $(1 \%)$ & 12 \\
$1820-1839$ & 440 & $: 38$ & $(31 \%)$ & 54 & $(12 \%)$ & 8 \\
$1840-1859 *$ & 613 & $: 73$ & $(28 \%)$ & 101 & $(17 \%)$ & 4
\end{tabular}

* De steekproef van deze periode is te klein om aan de ciffers absolute waarde toe $t e$ kennen. De aangegeven trend is echter duidelijk.

In de tabel zijn geen plantages uit het nieuwste (jongere) plantagegebied opgenomen, vanwege de beeldvertekening die hierdoor zou optreden, met uitzondering van éér plantage in de laatste periode.

Bronnen: steekproef ARA: SONA en SNA; plantage-archieven.

De katoensector lijkt sus het spoor van de koffiesector te hebben gevolgd. Ook in deze sector was een deel van het plantage-areaal bestend voor kosten weidegronden en werden er soms ook andere cash crops verbouwd.

Opvallend is de afname van het kostareaal (Tabel 11). Dit was cen gevolg van het feit dat de katoenplanters, door een toenemend arbeidstekort, hun kost van buiten de plantage gingen betrekken om zich volledig op de katoenproduktie te klinnen corcentreren. De weidegrond bleek wel flink toegenomen als gevolg van de groeiende veestapel: rond 1800 graasden op de gemiddelce katoenplantage 72 stuks groot en klein vee, rond 1830 waren dat er gerridacld $102{ }^{2.3}$ Deze toename had waarschijnlijk te maken met de omstandigineid dat in de tweede periode meer planters, met name in Nickerie en Comnie, op de plantages zelf woonden dan voorheen.

Van belang is ook dat er ronc 1800 relatjef veel akkers waren waarop een ander gewas dan katoen werd verbouwd. In aile gevalien ging het hierbij om voormalige koffieplantages die op katoen waren overgeschakeld, maar waar nog zo lang mogelijk van de oude cultuur profijt werd getrokken. Enkele decenria :ater bieek dit areaal drastisch te z:jn afgenomen en concentreerde men zich op de rneeste piantages geheel op de katoenverbouw.

Tabel 11. Overige arcaalbezpting op katoenplantages $1790-184.5$ (in ha.)

\begin{tabular}{|c|c|c|c|c|c|c|c|c|}
\hline \multirow{2}{*}{$\begin{array}{l}\text { periode: } \\
1790-1810\end{array}$} & \multirow{2}{*}{$\begin{array}{l}\text { totanal } \\
\text { areaal } \\
408\end{array}$} & \multicolumn{2}{|c|}{ kos:grond } & \multicolumn{2}{|c|}{ weidegrond } & \multicolumn{2}{|c|}{$\begin{array}{l}\text { misl-katoen } \\
\text { cashcrop- } \\
\text { areaal }\end{array}$} & \multirow{2}{*}{$\begin{array}{r}n \\
\\
-\quad 11\end{array}$} \\
\hline & & 17 & $(4 \%)$ & 5 & $(1 \%)$ & 22 & $(5 \%)$ & \\
\hline $1825-1845$ & 440 & 10 & $(2 \%)$ & 10 & $(2 \%)$ & 8 & $(2 \%)$ & 13 \\
\hline
\end{tabular}

Bronnen; steekproef ARA: SONA en SNA; piantage-archieven.

23 1800: 31 runderen, 24 schapen en geiten, 17 varkens en bij hog, uitzondering een paard; 1530: 35 runderen, 60 schapor en geiten, 5 varkens en 2 paarcen of ezels.

Steekproef weermaal zes kateservlantages (ARA: SONA en SNA; planlagre-archieven). 
De areaalontwikkeling in de suikersector is moeilijker te interpreteren dan bij koffie of katoen. Verschuiving van het bebouwd areaal was daar een. bewust onderdeel van het beleid, omdat er een systeem var. rotatie werd gehanteerd. Bovendien waren de inventarisaties van de gronden op suikerplantages tot de jaren 1770 vaak minder nauwkeurig dan in de periode daarsa. Verlaten gronden bleven nogal eens onvermeld en veelal kwam de nummering van de stukken bouwland in verschillende inventarissen niet met elkaar overeen. Desondanks zijn er toch twce factoren dic kunnen helper. bij de bepaling of verschuivingen van tijde'ijke aard waren (rotatic), of dat het om structurele verlating van uitgeputte gronden ging.

De eerste indicatie is een eventuele toename van het verlaten areaal in de decernia na 1770, toen de inventarisaties nawwkeurige: waren geworden. Wanneer het ramelijk al.'een om rotatie zou gaan, dan zou de omvang van het verlaten areaal in principe constant moeten blijven. De tweede aanwijzing is de eventuele structurele groei van het vaartrenzenstelsel. Dit was een netweri van vaarsloten via welke het transport van en naar het bebouwd areaal plaatsvond (zie I loofdstuk IlI). Warneer er namelijk alieen sprake zou zijn geweest van rotatie dar had dit irenzenstelsel op een gegeven moment zijn maximale lengte bercikt, omdat dan oude, verlaten stukken, dic al met het stelsel verbonden waren, opnieuw in gebruix werden geromen. Blee؛ het vaartrenzenstelsel toch groeien, dan 7ou dit duiden op een siructurele verschuiving van het bebouwd areaal en werd een deel van het plantage-areaal kennelijk definitief verlaten.

Incerdaad blijkt een trend aanwijsiar: cie duidt op een structurele toename van het veriaten areaal (Tabel 12). Tussen 1770 en 1840 verdrievoudigde het aandeel van de verlaten gronden en was uiteindeli;k, net als bij de koffie, zelfs groter dan het cuiturirareaal. Deze gestage groei varn het verlaten areaal, bij gelijkblijvend en later zelfs inkrimperid culturareail, Uuid: er op dat hier ineer aan de hand was dan alleen rotatie. Anders had namelijk de verhouding lussen cultuur- en verlaten areail ongeveer constant moeten blijven. Overigens lijken deze oude suikerplantages niet te hebben behoord tot het meest prodiktieve deel van de suikersector in de negentiende eeuw, want de gemiddelde omvang van hur suikerareaai lag ver beneden het gemiddelde van 83 ha. in deze periode. ${ }^{24}$

Dat de suyxerrietvelden nooit meer dan gemiddeld $10 \%$ van het totale areaal in beslag namen, had te maken met het rotatiesysteem, waarbij een deel van het land in reserve moest worden gehouden. Daarraast werd de omvang bepadd door de beschikbare hoeveelheid slaven. ${ }^{25}$

24 ARA: MvK $1813-1849,1135$.

25 Een steekproef van 10 plantages die rond 1770 ieder meer dan 200 slaven hacden, leert dat daar gemiddeld $16 \%$ van het totaal areaal me! suiker was beplant. Het suikerareaal per slaaf bedroeg 0,56 ha. Een even grote stexkproef rond 1850 laat zien dat toen zejifs gemicdeld 
Tabel 12. Gemiddelde areaalbezetting in de suikersector 1750 -1840 (in ha.)

\begin{tabular}{|c|c|c|c|c|c|c|}
\hline \multirow{2}{*}{$\frac{\text { periode }}{1750-1759}$} & \multirow{2}{*}{$\begin{array}{c}\text { totaal areasl } \\
683\end{array}$} & \multicolumn{2}{|c|}{ suikerareaal } & \multicolumn{2}{|c|}{ verlaten areaal } & $\mathrm{n}$ \\
\hline & & 67 & $(10 \%)$ & 16 & $(2 \%)$ & 27 \\
\hline $1760-1769$ & 754 & 85 & $\{11 \%)$ & 15 & $(2 \%)$ & 28 \\
\hline $1770-1779$ & 743 & $\pi$ & $(10 \%)$ & 35 & $(5 \%)$ & 27 \\
\hline $1780-1789$ & 773 & 75 & $(10 \%)$ & 49 & $(6 \%)$ & 23 \\
\hline $1790-1810$ & $76 !$ & 71 & $(9 \%)$ & 99 & $(13 \%)$ & 20 \\
\hline $1820-1840$ & 801 & 63 & $(8 \%)$ & 116 & $(15 \%)$ & 13 \\
\hline
\end{tabular}

In de steekproef ziin alleen oude stikerpiantages opgenomen, zodat ;ongere plantages (van na :800) het beeld niet vertekenen.

Bronnen: steekproef ARA: SONA en S.NA, planiage-archieven.

De uitbreiding van het vaartrenzenstelsel - tussen 1740 en 1810 verdubbelde de totale lengte var. het vaarste.sel bijna - b.jjkt eveneens te wijzen op een verschuiving van het bebouwd aread, dat vrijwel gelijk bleef. Ilet aantal meters vaartrens per beboluwde hectare groeide van 5410196 meier in deze periode. Das er waren steeds langere vaartrenzen nodig om het bebouwd areaal te bereiken. De richting warin de trenzen en daarmee het bebouwd areaal verschoven bli;kt hieruit ect.ter niet. De mogelijkheid bestaat nameljjk dat de uitbreiding plaatsvond in de breecite en niet raar achteren zoals op ce koffieplantages. Dit kan echter worcien achterhaald door de lengte van de hoofdvaartrens te onderzoeken. Deze lien in de leng:erichting van de plantage, terwij: de dwarsvaartrenzen daar haaks op stonden. Groei van de hoofdvadrtens zou dus en uitbreiding of versch.diving van het bebouwd areaal in achterwaartse richting betckenen.

Gedurerde de tweede helft van de achtiende eenw lijkt hel bebouwd areal zich aarzeiend in achterwaartse richting te bewegen. Halverwege de regentiende eetw is er echter geen twijfel meer mogelijk, de hoofdvaartrens blijkt in ongevee: een eeuw ruim tweemaal zo lang te zijn geworden, van ongeveer $1,5 \mathrm{raar} 3,5 \mathrm{~km}$, terwijl het bebouwd areaal iets was afgenomen. ${ }^{25}$ De verschuiving van het cultuurareaal naar meer achterwaarts gelegen landen op de suikerplantages was daarmee een feit. In de meeste gevallen zal dit ook wen verschuiving hebben betekend naar minder voordelige gronden, zodat mag worden aangenomen dat ook op suikerplantages de voorste grorden uitgeput waren geraakt. Dil wordt bevestigd door de planters van het Landbo:uwixundig Cenootschap De Eensgezindheid (1804:143), die, sprekend over slikerp'antages, rond :800 constateercen dat 'de gronden genoegzaam zijn uirgeput en niet in staat een behoorlijk revenu meer op te leveren'. Dat de suikersector als geheel z:ch desondanks

$26 \%$ van het areaal uit sxikcrgronden bestond, wat overcenkwam met $[1,55$ ha. per slaaf.

26. Steckproef ARA: SONA en SAA; plantage-archieven. 
veel beter wist te handhaven dar de koffie- en katoensector zal te maken. hebben gehad met het gehanteerde rotatiesysteem, de veel grotere omvang van het areaal, een aantal technologische innovaties en wellicht bemesting (zie Hoofdstuk VI).

Toch rijst de vraag in hoeverre het misschien voordeliger was op suikerplantages - met hun relatieve uvervloed aan beschikbaar land - om bij rotatie steeds nieuwe, nog nooit ontgonnen grond in gebruik te nemen, in plaats van oude die een tijd hadden braak gelegen. Dan zou namelijk niet per definitie uitputting de oorzaak van de verschuiving te hoeven zijn geweest. Toch lijkt dit niet erg waarschijnlijk, want er werd wel degelijk 'oud' land, na een braakperiode waarin het stuk onder water werd gezet en de natuur zijn gang kon gaan, opnieuw in gebruik genomen. Het voorbeeld van een deel van plantage Groot Marseille laat dit zien (Tabel 13).

De stukken bouwland genummerd 12, 16, 17, 21, 22 en 23 blijken, na een periode onder kapewerie (secundair struikgewas) te hebben gestaan, weer

Tabel 13. Rotatie op Groot Marseille 18011829

\begin{tabular}{|c|c|c|c|c|c|c|c|c|c|c|c|c|c|c|c|c|c|c|c|c|}
\hline \multirow[t]{2}{*}{ jaar } & \multicolumn{20}{|c|}{ genummerde stukken bouwland volgens inventaris } \\
\hline & 4 & 5 & 6 & 7 & 8 & 9 & 10 & 11 & 12 & 13 & 14 & 15 & 16 & 17 & 18 & 19 & 20 & 21 & 22 & 23 \\
\hline 1801 & $*$ & k & * & - & * & * & • & * & k & k & * & * & k & k & • & * & * & * & & $"$ \\
\hline 1810 & $\bullet$ & k & v & * & $x$ & $\mathrm{v}$ & $v$ & * & * & k & k & * & * & 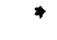 & 4 & k & $\mathrm{k}$ & $k$ & $k$ & $k$ \\
\hline 1826 & $v$ & $v$ & $v$ & $v$ & $v$ & $v$ & $v$ & v & $v$ & $v$ & $v$ & $v$ & $v$ & $v$ & $v$ & $v$ & $v$ & - & * & $*$ \\
\hline 1829 & $\mathrm{v}$ & $\mathrm{v}$ & $v$ & $v$ & $v$ & $v$ & $\mathrm{v}$ & $v$ & $v$ & $v$ & $v$ & $\mathrm{v}$ & $v$ & $v$ & $v$ & $\mathrm{v}$ & $v$ & - & * & * \\
\hline
\end{tabular}

" beplant met suikerriet

$\mathbf{k}=$ kapewerie (braakliggende grond met sec $n$ da ir struikgewas)

$\mathrm{v}=$ verlaten

De gegevens betreffen een cieel van de beboliwde grond.

Bronnen: ARA: SONA, 294; James Ford Bell Library, B1482.

met suikerriet te zijn beplant. De produktie op 12, 16 en 17 bleck in 1826 echter al weer stopgezet en nu werden zij in de inventaris omschreven als 'verlaten'. Hetzelfde geldt voor de kapeweriestukken 5, 13, 14, 19 en 20 die in 1826 eveneens als 'verlaten' stonden geboekstaafd, wat doe: vermoeden dat $\mathrm{zij}$ - na wellicht nog enige tijd tussen 1810 en 1826 bebouwd te zjin geweest nu definitief waren afgeschreven.

Het heeft er dus alle schijn van dat men probeerde zo lang mogelijk oude gronden in de rotatie te betrekken en dat deze pas definitief werden verlaten als het echt niet anders kon. De aanleg van een geheel nieuw stuk bouwland bracht immers oneindig meer werk met zich mee dan het opnieuw in gebruik nemen van een bestaand stuk. Nieuwe stukken vereisten het kappen van zwaar, primair bos plus de aanleg van een compleet nieuwe polder. Dat betekende loossloten graven, dijken opwerpen, een vaarstelsel aanleggen en de hoofdvaartrens verlengen (zie Hoofdstuk III). Oude 
stukken hoefden alleen te worden ontdaan van kapewerie, terwijl de complete infrastructuur van de polder er nog lag. Dat desondanks het bebouwd areaal in cie loop der tijd steeds verder opschoof en er dus steeds nieuwe polders moesten worden aangelegd, kan daarom alleen hebben betekend dat men van de oude stukken niets meer verwachtte.

Dit wordt nog eens bevestigd door de situatie op plantage Vossenburg in de jaren $: 830$ en 1840. Daar had men te weinig slaven om nieuwe inpolderingen op eigen kracht te volbrengen, zodat daarvoor huurslaven moesten worden aangetrokken. Soms kon dat echter jaren duren, want huurslaven waren schaars en duur. Toch gaf men hieraan op plantage Vossenburg de voorkeur in plaats van oude stukken opnieuw in gebruik te nemen. 27

Uitputting hoefde niet per definitie het einde van de suikerproduktie op het betreffende areaal te betekenen. Het is bekena dat op eilandjes als Barbados en Martinique begin aclitiende eeuw de suikergronden al sterk waren uitgeput (Sherician 1970:28-38; Watts 1987:219-23). Toch zijn deze eilander tot op de dag van vandaag suiker blijven produceren en zelfs op een grotere schaal dan in Suriname. $Z_{i ;}$; hebber. het vooral kunnen volhouden door vroegtijdige en grootschaige bemesting. In Suriname is dat echter nauweiijks gebeiurd, met alle gevolgen van dier.

Ook suikerplantages beschikten over kost- en weidegronden. Andere cash crops, met name koffe, werden halverwege de achtiende eeuw in deze sector nog wel aangetroffen, maar zijn daama volledig var de siikerplantages verdwenen. Koffie was in de eerste helft van de achttiende eeuw vaak een bijprodukt op suikerplantages, toen de enige bestaande soort landbouwonciememingen in Suriname. Verbouw en verwerking var beide produkten lieper. echter zozeer uiteen dat op een gegeven ogenblik moest worden gekozen voor éen van de twee gewassen. Dat werd nog eens versterkt toen in de iweede helft van de achttiende eeuw arbeid in de suikersector schaarser begon te worden (zie Hoofdstuk IV). Gemengde plantages met een klein oppervlak zijn toen meestal overgeschakeld op koffie. Bij gemengde ondernemingen met een groot aredal lag het meer voor de hand zirh weer volledig op suiker te concentreren, vanwege de grotere rotatiemogelijkheden. Bovendien stond daar vaak al een zeer kostbare watermolen, wat bij de kleinere plantages meesta: niet het geval was. Vanat eind achttiencie eeuw was in deze sector dan ook vrijwel geen plantage meer te vinden die iets anders dan suiker verboliwde (Tabel :4).

De wisselende omvang van het kostareal werd, evenals bij de koffie, veroorzaakt door toegenomern controle van de koluniale overheid op de aanwez:gheid van voldoende kostgrond voor de slaven teger het einde var 
Tabel 14. Overige areaalbezetting op suikerplantages $1740-i 850$ (in ha.)

\begin{tabular}{|c|c|c|c|c|c|c|c|c|c|}
\hline \multirow{2}{*}{$\begin{array}{l}\text { periode } \\
\overline{1740-1759}\end{array}$} & \multirow{2}{*}{- . } & \multirow{2}{*}{$\begin{array}{l}\text { totaal } \\
\text { areaal } \\
722\end{array}$} & \multicolumn{2}{|c|}{ kostgrond } & \multicolumn{2}{|c|}{ weidegrond } & \multicolumn{2}{|c|}{$\begin{array}{l}\text { niet-suiker } \\
\text { cashcrop-areaal }\end{array}$} & \multirow{2}{*}{$\begin{array}{l}n \\
29\end{array}$} \\
\hline & & & 16 & $(2 \%)$ & 24 & $(3 \%)$ & 7 & $(1 \%)$ & \\
\hline $1790-1810$ & & 728 & 24 & $(3 \%)$ & 16 & $(2 \%)$ & 2 & $(0 \%)$ & 21 \\
\hline $1830-1850$ & & 715 & 17 & $(2 \%)$ & 17 & $(2 \%)$ & - & - & 12 \\
\hline
\end{tabular}

Bronnen: steekproef ARA: SU.VA en SNA; plantage-archieven.

de achttiende ceuw (zie Hoofdstuk X) en concentratie op de exportproduklie door gebrek aan arbeid in de negentiende eeuw.

Opvallend is ook de flink afgenomen omvang van het weide-areaal sinds het eind van de achttiende eeuw. Ingischerwijs hing dit samen met de teruglopende veestapel. De meest dramatische afname deed zich voor onder paarden en ezels. ${ }^{28}$ De simpele verixlaring daarvoor is dat rond 1750 nog veel suikerplantages werkten met een door parden en ezeis aangedreven suikermolen, maar daarna hoe langer hoe meer overschakelden op een water- of stoommolen (zie Hoofdstuk VI). Overigens werden die paarder en ezels ook voor andere karweien gebruikt, zoals het slepen van gekapt hout uit het bos. Naarmate zij echter verdwenen werdan voor deze werkzaamheden meesta! enkcie goedkopere trekossen aangeschaft. Ook het annal schapen en geiten nam sterk as; dit had waarschijnlijk te maken met het feit dat gedurende de eerste helft van de achttierde eeaw de planters nog ir. Suriname woonden en van een goed voorziene dis hielden. Nadat het absenteisme regel was geworden hoefden alleen nog de piantagedirecteurs uit deze veestape: te worden onderhouden en die moesten he! kenrelijx met minder doen. Zo kon ook de weicegrond worcier beperkt.

Overigens kon de Surinaamse veestapel absoluut noch relatief in de schaduw staan van bijvoorbeeid de Jamaicaanse. Laar liepen in 1768 op de 651 suikerplantages totaal 135.753 runderen rond, ofwel 209 per plantage (Craton 1978:36). De gemiddeld 42 runderen, parder en ezels die rond 1750 op Suriraamse suikerplantages ronciliepen steker: hier sckamel bij af. We: dient te worden opgenerixt dat in Jamaica ongeveer de helft van de suikermolens door trekossen werc voortbewogen en dat het vervoer op het eiland voor eer. belangrijk deel met ossewagens plaatsvond. Hoewel onk op Jamaica in de negentiende eeuw de veestapel afnam, bevonden zich daar fop alle plartages) in 1828 nog :47.912 stuks vee; in Suriname bedroeg dat aantal in 1847 niet meer dan 6.959.29 Dit betekent dat de beschikbaarheid van dierlijke mest ook navenart verschilde tussen bejde piantage-economieën 
en daarmee ontbrak in Suriname een van de mogeli; kheden om uitgeputte gronden weer op krachten te laten komer.

\section{Verschuivingen in het plantagevezit}

In de loop der tijd is het plantagebezit in Suriname aan grote veranderingen onderhevig geweest. Verschillende oorzaken lagen hieraan ten grondslag, waarvan politieke en financieel-economische niet de minste waren. Toen bijvoorbeeld in 1667 Suriname in Nederlandse handen kwam, verdween het grootste deel van de aanwez:ge Engelse planters en werd vervangen door Nederlarders. Tijiens het Exyels Tussembestuur (1799-1802 en 18041816), behielden de meeste plantages hun Nederlandse eigenaars, maar kwam er cen hele groep Britse planters jij, die plantages aamlegden in hel nieuwste plantagegebied (Figiur 4C). Religicuze vervolgingen in Europa hebben er verder voor gezorgd dat zich varaf het einde van de zeventiende eeuw sefarcische en asjkenasische joden en Franse hugenoten in cie kolonie. hebben gevestigd.

In de jaren 7751-1775 werd Suriname overspoeld met kapitalal wit Nederland dat een hele nieuwe groes planters aantrok, die, niet gehinderć door ciger kapitaal of kennis van zaken, plantages begon of overnam. Toen de elforie var het buitensporig krediet eenmaa: voorbij was, bieken de meeste van deze plantages met loodzware schulden te zijn belast. De planters waren bij lange na niet in staat orr aan de aflossing daarvan te voldoen, zodat hun bezittingen overgingen in harden van de vaak buitenlandse schuldeisers, meestal zogenaamde negotiatiefondsen, een soot beleggingsfondsen, die hun gelu hadden gestoken in plantagehypotheken (zie Hoofdstik VII).

Eea aantal planters was deze ontwikkelingen echter voor gebleven en had op het hooglepunt van de kapitaalstroom (1764-1773) de bezittingen in Surirame verkocht. Alleer al in de notariële archieven van Amisterdam zijn voor deze periode 59 verkopen van plantages (of de'en daarvan) te achterhalen, waarvan ruim de helft in 1769-1770 plaats vond. In totaal was hiermee een bedrag gemoeid van $f 9.192 .600 .^{30}$ Sommige planters moeten toen met een fortuir naar Europa zija teruggekee:d. Dat er overigens nog veel meer dan de 59 in Amsterdam geregistreerde transacties heoben plaz:sgevonden, jlijkt uit de woorden van Nepreu die in 1770 meldt dat er in zeer korte tija minstens 80 plantages zijn verkocht voor meer dan 12 rriljoen gulden ${ }^{31}$ Driekwart eeuw later deed zich opnieuw een hausse in plantageverkopen voor. Tussen 1849 en $: 862$ werken minstens 49 plantages verkocht voor een totale som van ruim $f 1.322 .000$ (zie Hoofdstuk VII). Deze

31. ARA: SUS, 505. 
veel lagere koopsorn wijst er op dat het vooral om in verval geraakte ondernemingen ging. De kopers waren dan ook voornamelijk Surinaamse planters die op deze wijze hun slavermacht trachtten ujt te breiden.

Een andere vorm van verandexing ir. het plantagebezit vloeide voort uit vererving. Vrijwel iedere plantage was in eerste instantie opgezet door én man. Deze woonde in de kolunie en beheerde zijn onderneming zelf. Vaak kwam de planter eerder te overligden dan zijn vrouw waarna de weduwe en hun kinderen de plantage erfden. Zo'n weduwe met plantagebezit vormde een aantrekkelijke partij voor een andere, ongetrouwde pianter (of gelukzoeker), die door een huwelijk met haar niet zelden zijn bezit wist uit te breiden. Volgens de bijgewerkte kaart van De Lavaux uit 177C, waren in dat jaar $10 \%$ van alle plantages en gronder in het bezit van een vrouw en nog eens $2 \%$ in hander van erfgenamen van een vrouw. Er moeten dus nogal wat aantrekkelijke' vouwen in suriname nebben rondgelopen.

Wanneer er na het overlijden van een pianter geen weduwe (neer) was, werd het bezit onder de andere erfgenamen - meestal de kinderen verdeeld ${ }^{32}$ Als de planiage niet werd verkocht, hieiden de erfgenamen de boedel nogal eens gezamenlijk, dus orverdeeld, an. Vaak gebeurke dit tegen wil en dank, omdat zij het niet eens konden worden over de verdeling, of over de vraag of de piantage nu wel of riet verkocht moest worden. Vererving heest vaak versnippering van het bezit in de hand gewerkf. Zo bleex in :770 (bijgewerkte kaart De Lavaux) $21 \%$ van alle plantages en grorden het eigendom van gezarmenijjke erfgenarnen te zi;n.

Hoe ver die versnippering kon gaan is te zien aan de geschiedenis van plantage Meerzorg aan de Surinamerivier. To: 1733 was deze plantage het ongedeelde eigendon: van I'aul Amsincq en, na zijn dood, var zijn vrouw Anma Verboo:n. ${ }^{33}$ In de daaropvoigende 125 jaar is de plantage rooit

32 Wanreer er in biriname nict diect ertgemamen aanwezig waren, of wanneer zij nog

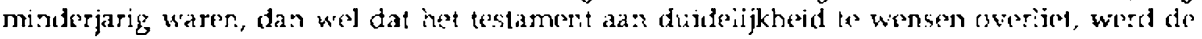
plantage tijdelijk beheerd dont de Onbehecrde Boedels en Wees Kamcr.

33 Deze Anna Verboom was de zuster van de commandeur Verboom idie samen met Van

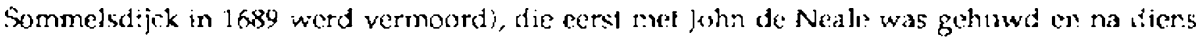
dood met het radislid Faul Amsiner. Haar zoon uif het esrste buwelijk, S.I. do Neale, werd schatrijk door de kof́jecultuur. In Juitsland, waar hij later ging woren, werd hij in de adelstand verheven (O:zdschans Dentz 1946:50). Toen ook Amra Verboum was uverieden kwam de plantage in hander. van hur zonn André cr dochers Maria Ansa en Reinbrandina met hun respectieve echtgenoten $P$. Hurgronje en $P$. Changuion; ieder ontving eer-derde deel. Bij notariele acte beloodden deze crtgenarter hun dandect in de plantage niet te versopen zonder de anderen daarvan in kennis te stellen on aan her. te cerste kr:us to laten tot koper. on wet yoo: de som van $f 50.000$, angczien de plantage w'erd getaxeerd op $f 150.000$. Een halve eeuw Iater (1784) bleken er al zeven aande!en te zijn, waarschijnljjk luater als gevolg van vererving,

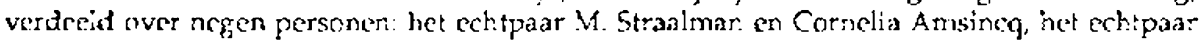
D.j, van Eys en Sara Amsinca, C. van den Helm Boddaerd, Arna Hurgronje, P. Hurgronje, Paul er. Pieter Changuion. Nog driekwart eeuw later (1854) was het aantal eigenaars opgelopen tot 48, verdeeld over meen families, onder wir allewen nog de naam Van Fys 
verkocht en alleen door vererving van eigenaar veranderd. In 1859 bleken er 48 eigenaats te zijn. Sinds he: eirde van ce achttiende eeuw (en wellicht al eerder) woonde geer van de e:genaars van Meerzorg nog in Suriname.

Dit absenteisme is typerend geworden voor het plantagebezit in Suriname, net zoals dat het geval is in de Brise er. Franse Caraiben. Na het einde van de achtliende eeuw is nooit meer dan een-derde van de Surinaamse piantages in handen geweest var ter plekke wonende eigenaars. Verschulding was hier ir belangrijke mate debet aan (zie Hoofdstuk VI), maar het voorbeeld van Meerzorg toont aan dat ook vererving een rol heeft gespeeld. Geen van de erfgenamen voelde zich geroepen persoonlijk het beheer van de plantages in Suriname op zich te nemen. De mate waarin de versnippering van het plantagebezit in Suriname heeft plaatsgevorden is weergegeven :n Tabel 15. Duidelijk bli;kt, hoe de meeste plantages in eerste instantie werden opgezet en/ of bekeerd door cén eigenaar (1737:kolornmen 3 en 4). Daarnaast is hef opmerkelijk, dat de bezitsversnippering rond 1770 ir. het geheel niet toenam (kolom 2) en pas vanaf hef eind van de achttiende

Tabel 15. Ontwikkeling van het plantagebezit in Suriname 1737-1853

\begin{tabular}{|c|c|c|c|c|c|}
\hline jaar & $\begin{array}{l}2 \\
\text { totaal } \\
\text { danta! } \\
\text { pantagrs } \\
\text { en grom- } \\
\text { der. }\end{array}$ & $\begin{array}{l}\quad 2 \\
\text { aandeel } \\
\text { plintages } \\
\text { met meer } \\
\text { dan één } \\
\text { eigenaar } \\
* *\end{array}$ & $\begin{array}{l}\quad 3 \\
\text { aancieel } \\
\text { p'antages } \\
\text { met één } \\
\text { eigenaar } \\
\text { ** }\end{array}$ & $\begin{array}{l}\quad 4 \\
\text { aandeei } \\
\text { plantages } \\
\text { van } \\
\text { eigenaars } \\
\text { met meer } \\
\text { dan én } \\
\text { plantage }\end{array}$ & \begin{tabular}{l}
\multicolumn{1}{c}{$\bar{y}$} \\
aantal \\
eigenaars \\
met meer \\
dan één \\
plantage
\end{tabular} \\
\hline 1737 & 370 & $15 \%$ & $5: \%$ & $34 \%$ & .52 \\
\hline 1770 & 465 & 14 & 47 & 39 & 69 \\
\hline 1796 & 533 & 39 & 22 & 39 & 65 \\
\hline 1824 & 575 & 35 & 26 & 38 & 66 \\
\hline 1853 & 269 & 42 & 33 & 25 & 21 \\
\hline
\end{tabular}

* :nclusief hout- en kostgronder

** deze eigenaars bezitter dis niet meer dan een deel van één plantage

*** negotiatiefondsen zijr. gerekend als één eigenaar

Bronnen: Kaarten De iavaux 1737 en 1770; Surinaamse Almanak 1796 en 1824; Van Sijpesteijn $1854: 96$ 3. 447

voorkwam. Fet bezit van Meerzorg blect overigcns wel beperkt tot een selecte groep, want alle negen families behoorden tut de cite an Nederland. Het ging om de families Hujissen van Kattendijke (adel), Vis (juristen), Borg (adel), Jervey, Fekhout, Balfour van Burleigh (adel?), Van Eys (adel), Van Heeckeren Brandseniurg (adel) en J'aets van Amerongen (adel). De omvang van de respectieve aandelen in de plantage was zerer verschillend en liep uiteen van $1 / 6$ als grootste, tot $1 / 486$ als kleinste. De plantage werd op dat moment $\$ 544.320$ waard geacht, zoctat het kleinste aandeel toch altijd nog en geschatte waa:de vertegenwoordigde van f 1.120 (Brom: ARA: Collectie Berg, 354; EHB: KA 37, 16). 
eeuw een belangrijke rol is gaan spelen. Het proces van vererving zou toch doen verwachten dat dit verschijnsel, na ruim drie decenria, in 1770 moet zijn toegenomen. In absolute getallen was dit ook wel enigszins het geval, maar nog is het verschil met 1796 opmerkelijk. De verklaring is waarschijnlijk te vinden in de economische voorspoed die de Surinaamse plantageeconomie rond 1770 beleefde. IJe: lijki aannemelijk dat in die periode gezamenlijke erfgenamen hun individuele aandelen in een plantage aan een van hen, of een buitenstaander, voor een goede prijs verkorhten. Met de opbrengst konden zij dan zelf een plantage beginnen, gaan renterieren in Suriname of Nederland, of zich in de handel storten. Eind achttiende eeuw was het economisch tij echter volledig gekeerd en werd een - vaak met grote schulden bezwaarcie - plantage ais erfdeel veel meer een last dan een lust. Vrijwel niemand bleek bereid een aandeel in $20^{\prime} \mathrm{n}$ plantage te koper. zodat de gezamenlijke erfgenamen hun beziting niet kwijt konden. Daarmee was de versmippering van he! plantagebezit een structureel fenoneen geworden.

Verhoudingsgewijs heeft de versnippering zich in de negentiende eeuw niet of nauwelijks uitgebreici. Ten dele was dit het gevolg van de plantages die er in Saramacca, Coronie en Nickerie bijkwamen en die opnieuw steeds door één man werden opgezet. Daarnaast werden steeds meer plantages net gedeeld eigendon verlaten, ferwijl dat veel minder het geval was bij ondernemingen met één eigenaar, zexer als hij zelf in Siriname woonde. Dit kan nauwelijks toeval heten. Kennelijk gingen absenteisme en gedeeld eigendom niet samen met eer. produktief beheer (ook Hoofdstuk IX).

In de loop van de achttiende eeuw vormde zich in Suriname een select groepje planters met een grote greep op de plantage-economie. In 1770 bleken 69 planters twee-vijfae van alle plantages en grorden in bezit te

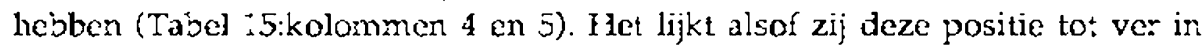
de negentiende eeuw hebben kunnen vasthouden, maar niets is minder waar. Zowel in 1798 als in 1824 was rond $4.5 \%$ var: de plantages en grorden in deze groep (kolom 4) in handen van ongeveer 16 negotiatiefordsen, die voor de som van de schuld een groot deel van de bij hen verhypothekeerde plantages in eigendom hadden gekregen. In de loop var de negentiende euw werden deze fondser. weer geliquideerd of hadden zij huri plantagebezit (deels) afgestoten.

Het verdwi;ner, van de negotiatiefondsen en de afname van het aantal plantages heeft ook het groepje eigeraars met meerdere plantages er. gronden (kolom 5) nink doen sliriker. In 1853 bestond deze groep nog voor een-derde uit negotiatiefondsen en voor de helft it in Suriname wonende planters. De belangrijkste vertegenwoordigers van laatst genoemde groep waren de gebroeders De Mesquita en $S$. de la Parra, behorend tot de oudste plantersfamilies van de kolonie, en de heren H. Wrigh:, W. Macintosh en 
de weduwe van Alexander Cameron, die tot de groep laatstaangekomen planters beinoorden. Afgezien van de weduwe Cameron, waren zij allen teverts belangrijke administrateurs (Van Sijpesteijn 1854:96-147).

Van de machtige achttiende-eeuwse planterselite was halverwege de negentiende exuw weinig meer over. $\mathrm{Nia}$ waren het de administrateurs die de lakens witdeelden, zoals later zal blijken.

De Surinaamse plantage-economie is in verschillende opzichten vrijwel constant in beweging is geweest. $\Lambda$ ls een rode draad loopt daar het verschijnse' 'uitputting' doorheen. De uitgeputte bovenlanden in het oude gebied, de uitgeputte voorste gronden op de individuele plantages en de uitputting van de kapitaalstroom uit Nederland hebben belangrijke verschuivingen in de plantage-economie tot gevolg gehad. Dit alies past bij het roo:bouwproces. Toch zijn er ook kleine aanwijzingen die duiden op een proces van overlever. Het feit daf tot in de negentiende eeuw nieuwe gebieden in onlwikkeling werden genomer, onder mee: door nieuwe groepen planters, betekent dat sommigen nog altijd toekomst zagen in deze sector. Zo wist de groep Britse planters, ook na áloop van het Engels Tussenbestuur, een redeijik weivarend bestaan in Suriname op te bouwen. 7o blijken in i 85433 voor de export prod:ucerende plartages het (mede-) eigendom te zijn van in Suriname woonachtige Britten of hun nakomelingen. Daartoe behoorden enkele van de grootste en mode:nste suikerondernemingen van het land (o.a. Hooyland, Alkmaax, Burnside, Waterloo en Nursery). Daarnaast waren nog 29 plantages (mede) in handen van ter plekke wonende eigenaars van wie familie ook al in de achttiende eeuw in Suriname woonachtig was. Onder hen bevonden zich relatief veel afstammelingen van religieuze vluchtelingen. Het is darom opvallend dat de groep die het meest gericht was op het overlever van (en in) de plantage-economie voor het merendeel bestond uit van origine niet-Nederlanders. Samen beheerden zij een-derde van alle exportplantages (Van Sijpesteijn 1854:96-147).

Ten laatste punt dat wijst op een proces van overleven, was de opkoms: van een nieuwe sector in de tweede helft van de negentiende eeuw. Suriname heeft sinds de achttience eeuw aitijd enige cacao, ais bijprodukt var koffie, geëxporteerd. De achteruitgang van de koffieproduktie eidde tot eer. bloei in de cacaosector. Zo steeg het aantal cacaoplantages tussen 1854 en 189: van 6 raar 71 (Koloniale Verslagen 1854 en 1862; Surinaamse Almanak 1891). In het bestaande plartagegebied was een nieuwe exportsector ontstaan. 


\section{Opbouw van de plantage-infrastructuur}

\section{Bodem en klimaat}

In vele opzichten zijn de Surinaamse plantages uit de achttiende en negentiende eeuw te vergelijken met die in de rest van het Caraibisch gebied. Dat geldt daarentegen niet voor de wijze waarop zij waren opgebouwd. De specifieke geologische en klimatologische on:standigheden van Suriname stelden namelijk andere eisen aan de plantagestructuur dan de meer geaccidenteerde en drogere kilanden in de Caraibische Zee.

Ongeveer vier-vijfde van de Surinaamse bodem bestaat uit vulkanische gesteenten die miljarden jaren geleder zijn ontstaan en zich nu in rust bevinden. Het resterende, en voor dit orderzoek meest relevante, deel is de kuststrook, die zich enjge miljoenen jaren geleder. begon te vormen en nog steeds in beweging is. Deze strook ontstond enerzijds door de rivieren, die zand en grind aanvoerden uit de bergen in het tegenwoordige binnenland, anderzijds door aanslibbing van zee uit. Zo werden achtereenvolgens een savannegordel, een oude en een jonge kustvlakte gevormd. Kenmerkend voor de jonge kustvlakte zijn de anggerekte zand- of schelpruggen (ritsen) die het landschap doorsnijden en daar door de branding van vroegere kustlijnen zijn opgeworpen. Vrijwel alle plantages in Suriname waren in de oude en jonge kustvlakte gesituecrd. Alleen de oudste plantages aar de bovenloop van de Surinameriviez lagen in de savannegordel. Dit waren de plantages ten zuiden van Jodensavanne die het eerst zijn verlaten, of in houtgronden zijn omgezet. Vanaf de tweede helft van de achttiende eeuw waren alle plantages geconcenteerd in de beide kustformaties.

Van der Voorde (1957) heeft een uitgebreide studie van de bodemgesteldheid in de oude en jonge kustylakte gemaakt.

'De Demeraraformatie of de jonge kustvlakte vinden we als een aar.eengesloter. strook van wisselende breedte langs de Surinaamse kus: van de Atlantische Oceaan. In he: Ofosten' is deze strook smal en niet meer dan $30 \mathrm{~km}$ breed; naar het W[esten] toe wordt de jonge kustvlakte geleideijik breder; $z \mathrm{ij}$ is daar tot 100 $\mathrm{km}$ breed. De totale opperviakte bedraagt rond 1.000.000 ha. He! grootste deel van de jonge kustvlaxte bestaat uit een laaggelegen zware klei, die benecien tot iets boven het gemiddelde zeeniveau ligt. Onder natuurlijke umstandigheden staat hij dus onder water; hif is begroeid met een kruidachtige vegetatie, plaatselijk met bos. Deze als zwantp bekend staande terreinen vormen ongeveer $80 \%$ van 
de jonge kustvlakte. P'aatselijk komen in cieze kleivlakte hoger gelegen, zandige, meest langgestrekte lichamen voor, die in Suriname als ritsen bekend zijn. [...]

Ten ZluidenI van de jonge kustvlakte vincen we een strook, waarin verspreid gelegen drogere zandige tot drassere stofíg-kleiige terreinen worden aangetroffen: de eerste in meer gestrekte, de iatste met meer afgeronde vormen. Ir. totaal omvat deze onde kustulakte of Coropinaformatie em strook van rond 1.000 .000 ha. De helft hiervan bestaat uit van nature met bos begroeide droge tot drasse terreinen, die in complexen verenigd :ggen. Deze complexen zijn plaatselijk sterk versneden, waarduor ze soms tuit een groep eilanden bestaan. Tussen en in de complexen vinden we laaggelegen za'ampen, die qua iecftijd grotendeels tot de Demeraraformatie moeten worden gerekend. De breedte van de ouce kustvlakte wisselt op onregelmatige wijze tussen 20 en $70 \mathrm{~km}$.' (Van der Voorde 1957:32-3.)

Het moet een natte bedoening geweest zijn in dit potentiële plantagegebied, want in totaal bestond ce oude en jonge kustvlakte voor bijna twee-derde uit moerasachtige zwampen die onder het zeeniveau lagen. De grïligheid waarmee complexen, ritsen en zwampen voorxwamen, maakte dat de vruchtbaarheid van plantage tot plantage kon verschillen. Een voorbeeld daarvan was het land langs de Commetewanekreek. U:t acht:ierde-eeliwse inventarissen blijkt dat op plantage Saltzthalen minstens twee stukiker. grond door een zandrits werden doorsneden en dat in 1784 in totaal eenderde van het cultuurareaal er schraal bij stond.' Op buurplantage 't Fortuyn wordt nergens melding gemaakt van zandritsen, maar we' van zwampen. Bovendien stond ongeveer een-vijfde van de bebouwde akkers als schraal tot zeer schraal te boek (1782). ${ }^{2}$ De andere buurplantage, Hooyiand, lijkt nergens last van gehad te hebben, want alle akkers stonder. er 'wel' tot 'zee: wel' bij (1762) en van zwampen of :itsen word: nooit melding gemaakl. ${ }^{3}$ Over het licle Surinamse plantagegebied moeten de lokale verschillen dis tamolijk groot geweest zijn

Toch kan in het aigemeen gesteld worden dat ir. Suriname de grootste natuurlijke vruchtbaarheid hoofdzakelijk wordt aangetroffen in de (jonge) kustvlakte.t Hierdoor beperkte het voor de exportlanibouw geschixte gebied zich tot een fractie van Surinames totale territorium. Vandaar dat de omvang van het potentiële plantagegebied waarschijn'ijjk niet eens in de

ARA: SONA, 212.

ARA: SONA, 195, 203, 212 en 295.

4 [N]at:urlijke vruchtbarineid wordt in Suriname slechis gevonden bij recente alliviale kleiałzettingen, dus een moedermateriaal dat langdurig met het zeewater in contact is geweest. Alluviale aizettingen, die tot stand komen door de rivieren afkomstig vit het birnenland van Suriname' Jde savamegordell, bestaan slechts uit verweringsproducten van zeer oude gesteenten en vormen geen vuchtbare gronden. De zandgronden van alluviaie onrsprong, zoals de ritsen, feveren evenmin vruchtbare gronden op.' (Van der Voorde :957:1534.) 
buurt kwam van bijvoorbeeld Cuba. Eerder viel het te vergelijken met Jamaica of Saint Domingue (zie Tabel 1).

De achttiende- en regentiende-euwse planters dachten natuurlijk niet in termen van 'geologische formaties' of 'alluviale kleiafzettingen', maar waren zich toch zeer wel bewust van het voorkomen van verschillende grondsoorten en voor welk gewas deze het meest geschikt waren. Meestal duidden zij de grondsoort aan met de natuurijke vegetatie die er op werd aangetroffen (De Eensgezindheid 1804:31-6).

Verder waren a!le eigentijdse deskundigen het er wel over eens dat koffie en suiker ook op de wat hoger gelegen zandgronden in de 'bovenlanden' konden worden geteeld. Het nadeel daarvan was echter dat deze door de ge-inge diepte van de vruchtbare boveniaag zeer spoedig uitgeput raakten, zodat men genoodzaakt was steeds nieuwe groaden te ontginnen. Zoals eerder bleek was dit dan ook de reden dat ai vroeg in de achttiende eeuw een proces op gang kwam waarbij de oudste plantages in de 'bovenlanden' werden verlaten. Op den dur waren daardoor alie plantages gesitueerd in het volkomen vlakke er enigszins zilte kleilandschap van de oude en jonge kustvlakte.

Vooral wat betreft koffie vormde Surirame hierdoor een grote uitzor:dering op andere koffieproducerende gebieden. Vrijwel overal, van Saint Domingue tot Brazilië (en ook op Java), werd koffie geplant op piaatsen waar suiketproduktie minder goed mogelijk was. Dit waren voornamelijk heuvelacitige gebieden, waar geen sprake was van zware, laat staan verzilte zeeklei. Toch heeft de koffie een tijd lang ijtstekend ged:jd op deze Surinaamse bodem, al is ret niet uitgesloten dat deze atypische lokatie de uitputting van grond en gewas heeft bespoedigd (P.urseglove 1968, 11:463-4).

Ovexigers waren in het algemeen de Caraibische eilander. veel heuveiachtiger dan Suriname, zodal ook daar de suikerplantages niet op vlak terrein gesitueerd waren. Dit veroorzaakte vaak erosieproblemen. Bovendien werd daar slechts bij uitzordering alliviale klei van 'high durability' angetroffen (Watts :987:37). Suriname was daarmee dus duidelijk in het voordeel. Toch was dit slechts relatief, want in het vorige hoofdstuk bleek al dat ook de duurzaamheid van alluviale kleisoorten haar grenzen heeft.

Het klimat in Suriname behoort to: het zogenaamde tropisch regenklimaat. De gemiddelde temperatuur bedraagt $27^{\circ} \mathrm{C}$ en het verschil tussen de minimum- en maximumtemperatur is niet groter dan $8^{\circ} \mathrm{C}$ (Bruijning en Voorhoeve 1977:346). Daarin verschilt het nauwelijks met de test van het Caraibisch gebied (Watts 1987:137). Met de gemiddelde neerslag is dat wel het geval.

Op de Caraibische eilanden lopen de seizoener volkomen anders dan in Suriname en het verscinil tussen de natste en droogste maanden is vee: 
minder groot. Bovendien valt in Suriname bijna tweemaal zoveel neerslag per jaar als op de eilanden. De verdeling in seizoenen wordt in Suriname dan cok afgemeten aan de gemiddelde neerslag:

Kleine Regentijd : begin december-begin februari

Kleine Droge lïd : begin februari - eind april

Grote Regentijd : eind april - hall augustus

Grote Droge Tijd : half augustus - begin december

Deze indeling is de gemiddelde uitkomst van neerslagstatistieken over de periode 1901-1970 (Bruijning en Voorhoeve 1977:340). Blom (1787:4), die dergelijke statistieken niet tot zijn beschikking had, kwam desondanks twee eeuwen geleden al tot eenzelfde indeing, met dien verstande, dat volgens hem de Kleine Regentijd al half november inzette en de Grote Regentijd half april. Toch wordt in de bromen voortdurend me:ding gemaakt van mensen die beweerden dat de seizoenen aan het verschuiven waren en het klimaat structureel was gewijzigd als gevolg van veranderingen in de ecologie. 7.o constateerde de arts Voegen van Engelen (1786-87:20) in 1788, 'dat deeze naauwkeurige en juiste verdeeling in tijdperken [seizoenen] die geregeld wederkoomen, hoe langer hoe onzeekerer geworden is, en nog verder worden zal naarmaate het land meer bewoond en meer bebouwd wordt', Bijna een halve eeuw later verzuchtten de schrijvers van he: jaarverslag van de xoffieplanlage beekvliel dat le steeds kleinere ougsten wel eens het gevolg konden zjjin van 'eene verandering van het luchtgestel' waar legen niets te doen viel. ${ }^{5}$

Het is mogelijk dat het openkappen van ritgestrekte bossen en het op grote schaal drooglegger van moerasses van invloed is geweest op de weersgesteldheid. Waarschijnlijker is echter dat dit soort opmerkingen moet worden toegeschreven aan het wereldwijde verschijnsel dat in de landbouw nu eenmaal altijd wordt geklaagd over het weer. In eer. plantage-economie waar de voorspoed van het gehele land afhing van goede oogsten en waar bovendien neerslag en droogte per jaar sterk konden verschillen, is hel niet meer dan logiscin dat de gang der seizoenen met argusogen werà gevolgd. Was het een anital jaren achtereen droger of natier dan gerniddeld, dan sprak men al gauw van structurele veranderingen in he: klimaat. Dergelijke uitspraken hebben dus weinig waarde voor weersveranderingen op lange termijn; voor de beeldvorming over de jaarlijkse wisselvalligheid van het weer zijn zij echter uitstekend te gebruiken. Geconfronteerd met meer officiële metingen uit die tijd, blijken de opmerkingen van de planters over het weer zeer wel hout te snijden.6 Vele tientallen van dergelijke opmerkingen tonen aan dat van de eerste 59 jaar in de negentiende eeuw 
vierentwintig procent werd ervaren als te droog, zevenendertig procent als te nat en negenendertig procent als normaal of regelmatig. Dat betekent dat in de meeste jaren de weersgesteldheid een bedreiging moet hebben gevormd voor de oogst, al is het ene gewas daar natuurlijk wel gevoeliget voor dan het andere. De invloed van de weersomstandigheden op de produktiviteit komt nog ter sprake in I Yoofdstuk V.

In tegenstelling tot het overige Caraibisch gebied heeft Suriname vrijwel nooit te lijden van aardbevingen of orkanen. In 1766 schijnt een tamelijk lichte aardbeving het land te hebben getroffen (Wolbers 1861:275), terwijl in 1833 een orkaan moet hebben gewoed, die bijvoorbeeld op plantage Zeezigt de kostgronden volledig vernielde en voor ongeveer $f 10.000$ schade aan de gebouwen toebracht. ${ }^{7}$ ware winden die vernielingen aanrichtten kwamen vaker voor. Echt last had men van de regelmatig uitbrekende bosbranden als gevolg van langdurige droogte. Eenmaal begonnen, waren zij zeer moeilijk te blussen. Zo ontstond in februari 1797 een bosbrand die pas in april door aanhoudende regens tot staan werd gebracht (Wolbers 1861:220). Vaak werden hele plantageregio's door zulke branden bedreigd. Dat gebeurde bijvoorbeeld in 1825 aan de Commewijne, war plantage Zotg en Hoop te. maken kreeg met een zware bosbrand,

'welke na drie weken geduurd te hebben tot achter deze plantage is doorgedrongen, [maar] door de onvermoeide pogingen van de geheele slavenmagt versterkt door 23 koppen van andere plantagien $[\ldots]$ is het gelukt de brand af te leiden. Aan blusschen was niet te denken, ook duurde deze verwoesting nog voort zoodat Paramaribo [hemelsbreed op ca. $30 \mathrm{~km}$ alstand] als in een wolk van ronk lag; harteljik verlangde men naar regen. ${ }^{\text {.8 }}$

Gelukkig liep het goed af met deze plantage, maar dat was lang niet altijd het geval. Meer dan eens verbrandde een deel van het bebouwd areaal voordat het vuur kon worden gestuit. Dat gebeurde onder andere op plantage La Singularité, eveneens aan de Commewijne, waar in 1779 werd gemeld dat het complete voorland, ofwel 'rlaym cen vierde van 't generaale land in voorige jaaren verbrand is'.9 Deze branden konden dus grote schadeposten veroorzaken en waren nauwelijks te voorkomen of vroegtijdig te doven. Meestal kon men slechts de regentijd afwachten en proberen de brand zoveel mogelijk van richting te veranderen. Het Surinaamse klimaat was een belangrijke voorwaarde voor het succes van de plantagelandbouw, maar ook een bedreiging daarvan.10

7 Collectie-Insinger \& Co., informaticbock Zeezigt.

8 CAA: PA-600, 544 .

TIIR: KA-120, 21.

to Ook nu nog vormen bosbranden con groot gevaar. 'Onvoorzichtigheid met vuur in het kustgebied bij de aanleg van kostgronden kan enonme schade in het bos veroorzaken, omdat de bomen van het zwamplxis in de veenlaag worlelen en dus bij brand, dic zeer hardnekkig kan 


\section{Opbouw van een plantage}

Plantages beslaan meestal een aanzienlijk oppervlak. Dit maakł de aanieg van goede verbindingen en optimale irrigatic- en drainagestelsels tot een dwingende noodzaak. De aard var deze infrastructurele werken wordt bepaald door het andschap en kimaat waarin zij moeten functioneren. Dit was het belangrijkste punt waarin Surinaamse en Guianese plantages verschilden van andere Caraibische plantages. De lage ligging van de moerassige kustvlakte en de grote hoeveelheid neerslag dwongen de Surinaamse planters tot grote finarciële en bouwkundige inspanningen teneinde het bouwland voor produktie geschikt te maken en te houcien. De complexe infrastructurele werken die daarvan het gevolg waren, hebben eeuwenlang het Surinaamse kustlandschap gedominecrd en vormen nog steeds de stille getuigen van zowel moordende arbeid als technisch vernuft. Tegelijk vormden zij ook eer zwakke piek in de Surinaamse plantageeconom:e. Nict alleen kostte deze infrastructuur veel geld en arbeid, maar de gerir.gste verwaarlozirg van deze werken kon desastreuze gevolgen hebben voor het voortbestaan en welzijn van de plartage er haar bewoners.

Het grootste deel van de Surinaamse plantages is angelegd gedurende de periode dat het land in bezit was van ce Geoctroyeerde Socièteit. Vandaar dat een planter-in-spe zich tot deze instaritie moest wenden voor het verkrijgen var een stuk grond. Hiertoe diende hij een verzoek in bi; het hoogste gezag in Suriname, de Gouverneur. Na uitmeting van de concessie werd dan de grond, onder bepaalde voorwaarden, aan de planter overgedragen. In tegenstelling tot bijvoorbeeld de Brits-Westir.dische koloniër. kreeg hij de grond gratis. Zo betaalde bijvoorbeeid een Fingelse planter op Jama:ca eind achttiende ecuw ien pond sterling per acre land, waarme hi; al de helft var de aanlegkosten had intgegeven nog voor er een spade in de grond was gezet (Deerr 1949, II:333-4).

Hoewel het in feite om een leenverhouding ging kreeg de Surinaamse planter in praktijx zijn grond in allociaal eigerdom (Quintus Bosz 1954:38). In het overdrachts- of eigendomsjewijs, de zogenaamde twarrand, stonden de voorwaarden beschreven waaraan de nieuwe eigenaar van de grond zich had te houder. Wameer hieraan nief zou worden voldaan, zou de grond weer aan de Societteit vervallen. " Ter :'lustratie is in Bijlage 7 de warrand

zijn, omvallen. Aan het eind van hel zeer druge seizuen 196.3-1964 ging in Suririanc op deze wijze nast andere objecten een economish waardirvol bosareaal van ruim 10.000 ha. geheel verloren. Luchtopnamer. van dit brandareaal leerden dat ce oper graszwampen van het kustgebied vroeger al als brandgebieden aangemerkt, op een dergalijke wijze mocten zija ontstaan gedurende de vele ceuwen van Indianse kustbewoning.' (Bruijning, en Voorhorve 1977:84.)

II Zu kon het gebeuren dat na de siavcnopsiand aan de Tempa:iekreck in 1757 de eigenaars van de daagelegen houtgrond Onverwagt deze onderneming 'uyt hoofde der incursien van de 
afgedrukt van plantage Leliëndaal aan de Commewine. Deze warrand is exemplarisch voor a'le plantages in die tijd.

Voor de Societeit lag het primaire belang van Suriname vooral in de groei en bloei van plantages. Jlaar inkomsten bestonden nanelijk uit verschiliende belastingen die op diverse onderdcien van deze ondernemingen, zoals hei dartal slaven, het cultuurareal es de produktie, werden geheven. Zij was er dus bij gebaat dat zoveel mogelijk iand effectiof in bedrijf werd genomen. Vandaar waarschijnli;k dat he! land gratis werd uitgegeven op voorwaarde dat er op de concessie binner, anderinalf jaar eer. woonhuis moest worcen gezet. Kennelijk was de redenatie dat als een planter er eenmaal woonde, hij cok wel de grond zou gaar. cultiveren. De bepaling dat de concessie de eerste tien jaar niet in andere hancen mocht overgaan bevestigt dit. I liermee trachtie de Societeit te voorkomen dat de gronder alleen as speculatie-object zouden dienen, want daar had zij geer. baat bij. Ook de regel dat aitijo twee slaven aar de plantage verbonder. moesten blijven had daarop betrekking; al zal deze bepaing ook te maken hebben gehad met het gegeven dat een total verlaten plantage tot grote overiast bij de buren kon ieicien.

A!gezien van de oppervlakte var het totaie areaal werd in een warrand ook speciale me:ding gemaakt van de lengte van de face of facit, de voorzijde van de concessie. In hei geval van Leliërdaal (zie Bijlage 7) - er de meeste planiages aan de Beneden-Commewijne.. was dat 30 keting. ongeveer 600 meter. Het was van groot belang dit exact vast te leggen, ondat in Suriname vijwe! ace plarrages, met ditzondering van Coronize en erre deel van Nickerie, werden angeiegd langs een rivier of kreek. In dit drassige en dichtbeboste land vornde water die snelste en gemakkelijkste verbinding. Om nu zovee: mogelijk plar.ters hiervar. te laten profiteren en wellicht ook van de grote vruchtbaatheid van ce rivieroevers - werd de toegang tot die rivier voor iedere plantage beperkt geholden. Zodoende kregen de meeste plantages de vorm van een iange, smalle rechthoek met de korte zijate aan de rivier en een kilometers diep achterlanc. Aan de waterkant verrezen ook altijd de piantagehuizen en fabricksgebouwen. Dat was het meest df:cient voor de verscheping van goederen en prokiaken, het vergemakkelijkte de communicatie en het contact met de buren, hetgeen belangrijk kon zijn in noodsituaties. Alleen de ondste plantages in

boschneegers en door hel vertrck der Sidaten troceper. van de post Madagderburg heibende moeten verlaten lenj zilin de siaaven daar van af geroomen; dog bij resolutie van Haar Ed. Agtbare de Heeren Lirecteuren cn Xegcerders deser Colonie in dato $: 8 \mathrm{July}$ i777 is het regt

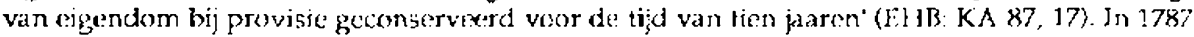
werd opnieuw een verlenging, vân tien jaar algegeven, zodat aan het eind van die pericxle deze houtgrond al vccrtig jaar was verlaten, zonder aan de Sociëteit of haar opvolger, de Nederlankise Stazt, te zi:n vervailen. Het bicek das cen lamelijk leza: bepaling. 
Suriname, uit de tijd dat er nog ruimte in overvloed was, hadden grilliger vormen, inclusief een bredere voorkant aan de rivier.

In 1735 schreef de eigeraresse van plantage Boxel, de wecuwe Boxel-Van Gelre: 'een plantagie rieu aen te leggen is eer. swaar en kostelijck werck (Bijisina 1922-23:53). Ein dat was maar al te waar, zeker in de laggelegen landen var. de jonge kustvlakte. Hier bestond de bodem uit zware, drassige klei, die bij hoog tij van de rivieren en/of bij flinke regenval regelmatig onder water l:ep. Het eerste, en tevens zwarste, werk bij de aanleg van een piantage, bestond dan ook uit het inpolderen van he: land. Een Holiandse 'traditie' werd hiermee in de tropen voortgezet.

Men begon met alle bos op het in te polderen stuk land om te hakken, dit vervolgens te verbranden en achtergebleven stronker, en wortels te verwijderen. Meesta! gebeurce dit in augustlis, tijdens de overgangsperiode tussen de Grote Regentijol en de Grole Droge Tijd. I let gekapte hout was dan al droog genoeg om te verbrancen, terwijl de vruchtbare (veen)toplaag van de grond nog voldoende vockig was on riet door het vuur te worder. aangetast. Wanneer dit was gebeurd werd om het hele stuk een dam, of dijk, opgeworpen.

Om de dam een stevige ondergrond te geven, werd eerst de veenlaag afgegraver en op de toekomstige akkers geworpen, zodat de dam op de steviger kleilaag daaronder kwam te rusten. Tegelijk werd aan de binnenzijde van de dam de zogeraamde loostrens ${ }^{12}$ gegraven, warop later de akkers overtollig regerwater zusden gaan loze:- Met de uitgegraven grond werd can de dam opgebouw' Bij he: optrekken daarvan moest overigens goed worden opgelet dat ex geen stronker of boomwortels achterbleven, aangezien die later wel eeris een lek, of zelfs een dambreuk, tor gevolg konder hebben. Was de irpoldering eenmaa: op deze w:jze to: stand gekomen en was de polder tijcens de Grote Droge Tijd helemaa: drooggevalien, dan volgden nog twee zware taken: het verdelen van de polder in akkers en plantbedden en het aamleggen van goede verbindingswegen voor communicatie en transport op de planlage.

\section{Het belang van de waterhuistouding}

Een polder bestond soms uit meercere stukiken en een stuk altijd uit meerdere akkers. Het aantal akkers in een stuk verschilde per plantage: $\mathrm{Zi}$; werden van eikaar gescheiden door het graven van zogenaarde trekkers, dwars op de loostrenzen. Zo'n akker was echter nog te groot $(0,43$ ha. $)$ om b; de zware Surinaamse regenval voldoende af te kimnern wateren en daarom werd hij op zijn beur: weer opgedeeld in bedden, waarvoor zogenaamde 


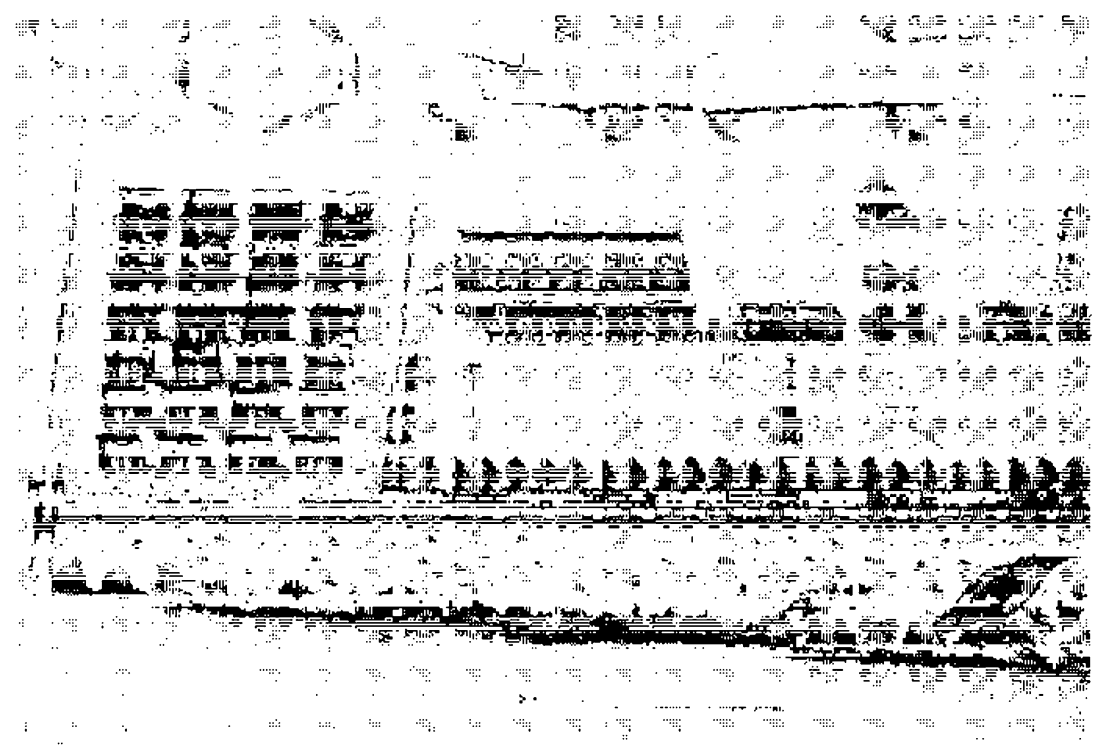

Plantage Hegt en Ster'x (Marquette); warschijnlijk de enige plantage met een windmolen (rechts); in het algemeen voldeden deze in Suriname niet. 


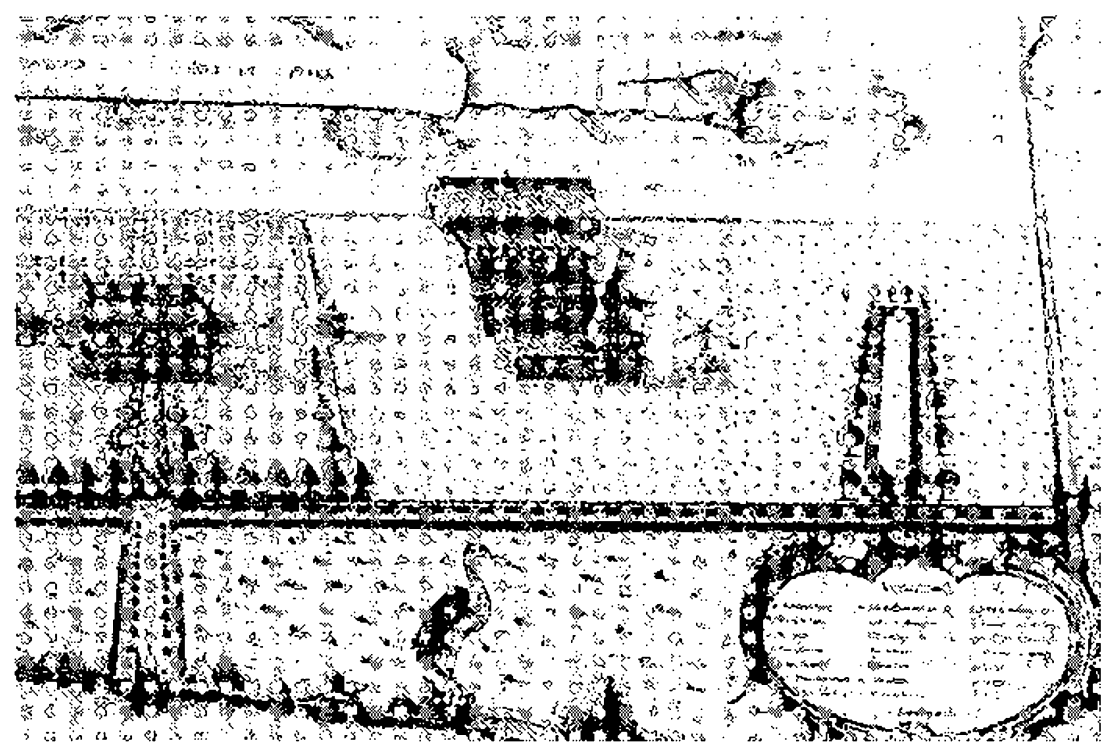

(Ijstorisch Topografische Atids Cameenteijke Anhiefdiensi Amsterdam) 
kleine trenzen werden gegraven, haaks op de trekkers. Alle uitgegraven grond werd gebruikt om de plantbedden op te hogen. Op deze wijze ontstond een ingenieus afwateringsstelsel dat van cruciaal belang was in een dergelijk klimaat en landschap. Het moest dan ook met zorg en regelmaat worden onderhouden. Gebeurde dit niet dan raakte het stelsel binnen de kortste keren dichigeslibd en begroeid met onkruid en kapoewerie.

Een voorbeeld van de intensiteit waarmee het onderhoud moest plaatsvinden verschaft suikerplantage Meerzorg aan de Surinamerivier in 1858 . In totaal waren daar 291 rietakkers (125 ha.) in gebruik. Men kwam er in dat jaar niet aan toe om op al deze akkers de trekkers en kleine trenzen een keer uit te diepen, zodat bijna een-derde pas het jaar daarop aan de beurt kon komen. Belangrijker was echter dat de hoofdlozing, de twee loostrenzen, optimaal bleef functioneren. Die werden dan ook vijfmaal schoon gemaaki. Hun gezamenlijke lengte was minstens $8 \mathrm{~km}$, wat het schoonmaken een arbeidsintensief karwei makkte. Ook de dammen, die de plartage voor overstroming moesten behoeden, werden dat jaar viermaal schoon gemaakt.

Opvallend is dat in de maanden waarin werd geoogst kernelijk geen tijd overbleef om ook nog iets te doen aan het ondernoud van het afwateringssysteem. Alleen in juni was het iets rustiger, want aan het loossteise: werd niet gewerkt en relatief weinig akkers werden geoogst. Wellicht waren de regens in die maand te zwaar voor deze werkzamheder. Daa: staat tegenover dat men in december, naast het uitdiepen en schoonmaken ook nog 'de sluiskreek aan de zijde van pl. Jagtlist welke met modder dichtgespoeld was met de mannegermacht 5 dagen werkzaam [is] gewees: om uit te moddeven. 13 Orgeveer 44 veldslaver. waren dus bijra eer. week bezig met alleen al ce siluiskreek uit te diepen

Naast het afwateringssysteem vormden ook de twansportverbindingen op plantages complexe stelsels. Men kende daarin twee systemen die elkaar orerigens niet uitsloten. Het eerste systeem kwam met name op xoffie- en katoenplantages voor en bestond Lit eer, netwerk van looppaden. In feite waren deze pacen de bovenkanten van de pode:dammen. Over het midden van de planlage liep, van voor nar achter, let zogenaarde middenpad, waar aan weerszijden zijpaden op werden aangesloten. Deze stonden op hun heurt weer in verbinding met de zijdammen langs de grenzen van de plantage. In later tijd werd op sommige koifieplantages naast, of in plaats var., het middenpad een vaaztrens gegraven. In die gevailen was de afstand van het gebouwencomplex, vooraan op de plantage, tot het bebouwd areal te groot geworden om nog iopend te kunnen overbruggen. ${ }^{14}$

it Dit gebeurde bijwoorberd op piantage Nonyt Gedagt (later: Filent aan de Beneden- 
Een dergelijk pad- en dammensteisel nam een niet te verwaarlozen deel van het plantage-areaal in besiag. Om zo min mogelijk bouwland verloren te laten gaan, werder. de zijkanten van cie paden vaak beplant met koffie- of bananenbomen, die met hun wortels de dammer bovendien wat extra stevigheid gaven. Op een gemiddelde 'roffieplantage als beekvliet aan de Cottica nam in 1768 het padenstésel ongeveer 16 ha. in besiag. Op een total areaal van circa 417 ha. betekende dat bijal $4 \%$ van de grond. ${ }^{15}$. Naarmate het bebouwd areaal steeds verder naar achteren opschoof (op Beekvliet was in 1786 al een-viffde van de grond verlaten:6) en ruimtegebrek een rol ging spelen, moet ook de groeiende opperviakte die het padersteisel in beslag nam een factor van betekenis zijn geworden. Suikerplantages, die in de regel veel uitgestrekter waren dan koffie- of katoenplantages beschikten voor de transportverbindingen vrijwe: altjjc over een stelsel van vaartrenzen. Dit was op dezelfáe wijze gestructureerd als het padensetwerk: een hoofdvaartrens over het midden yan de plantage, verbonden met kleinere dwarsvaartrenzen (Figuur 6). Dii vaarsielsel, dat geheel ondijkt was, moest strikt gescheiden blijven van hel afwateringssysleem, omdat zij tegengestelde functies verviduen. Terwijl in het ene systemern de? waterstand zo hoog mogelijk moest bl:jven in verband met de jevaarbaarheid, diende het ander juist zoverl mogelijk water af te voeren naar de rivier. Bovendien was het brakke rivierwater in de vaartrenzen niet goed voor de groei en kwaliteit van ce gewassen.

De vaartrenzen warea met name belangrijk voor het snelle vervoer van gekapt suikerrie:, dat me: piatoociem-vaartuigen (keenponten; naar het fabrieksterreir. we:d gebracint. Daarnaast werd dit steisel ook gebruik: om de wate:moler, warover de meeste suikerplantages eind achttiende eeuw beschikten, aan te drijven. Dat gebelide bij springt:; twee maal in de maand, bij volle en nieuwe maan, wanneet het water in de rivier zijn hoogste stand bereikte. Op ciat moment kon cen maximale hoeveriheid water worden ingenomen. In de hoofdvartrens had men eer. zogenaamde molenkom gemetseld, van 7.0'r twintig meter doorsnede, waarin het watermolenraci hing. Als mer. door de gezakte waterstand in de rivie: het

Commewijne. In 1748 werd een warrand tot aanleg van deze plantage verleend. Tien jaar later lag er al con artwerk var paden, bestaande uit ern middenpad van $2,4 \mathrm{~km}$, twee hoofdpaden over de $2: j$ danmen van de piantage van 1,7 en $2 \mathrm{~km}$ en totaal twir! ig dwarspaden met een geschatte gezamenlijke lengte van $6 \mathrm{~km}$. Het cultuutarcaal expanderde eciter zo sne] dat al in 1766 werd begoanen met de darleg, van een $500 \mathrm{~m}$ lanyge vaa:trens langs het mididmpad 'voor 't laaden van producten'. Begin negentiende eeuw werd de plantage omgebouwd to! een suikeronderneming. $N$ werd eon vartrens langs het hele middenpad gegravern met een lengte van ongever $4 \mathrm{~km}$, in 1853 zelfs ver!engd tot $7 \mathrm{~km}$ (Dienst der Domrinen Surinare; ARA: SONA, 203, 223 en 836; A.RA: SOS\&W 1828-:376, 926-I).

15 ARA: SONA, 227,

16 GAA PA 6CO,54\% 
Figuur 6. Inftastructulir van een suikerplantage

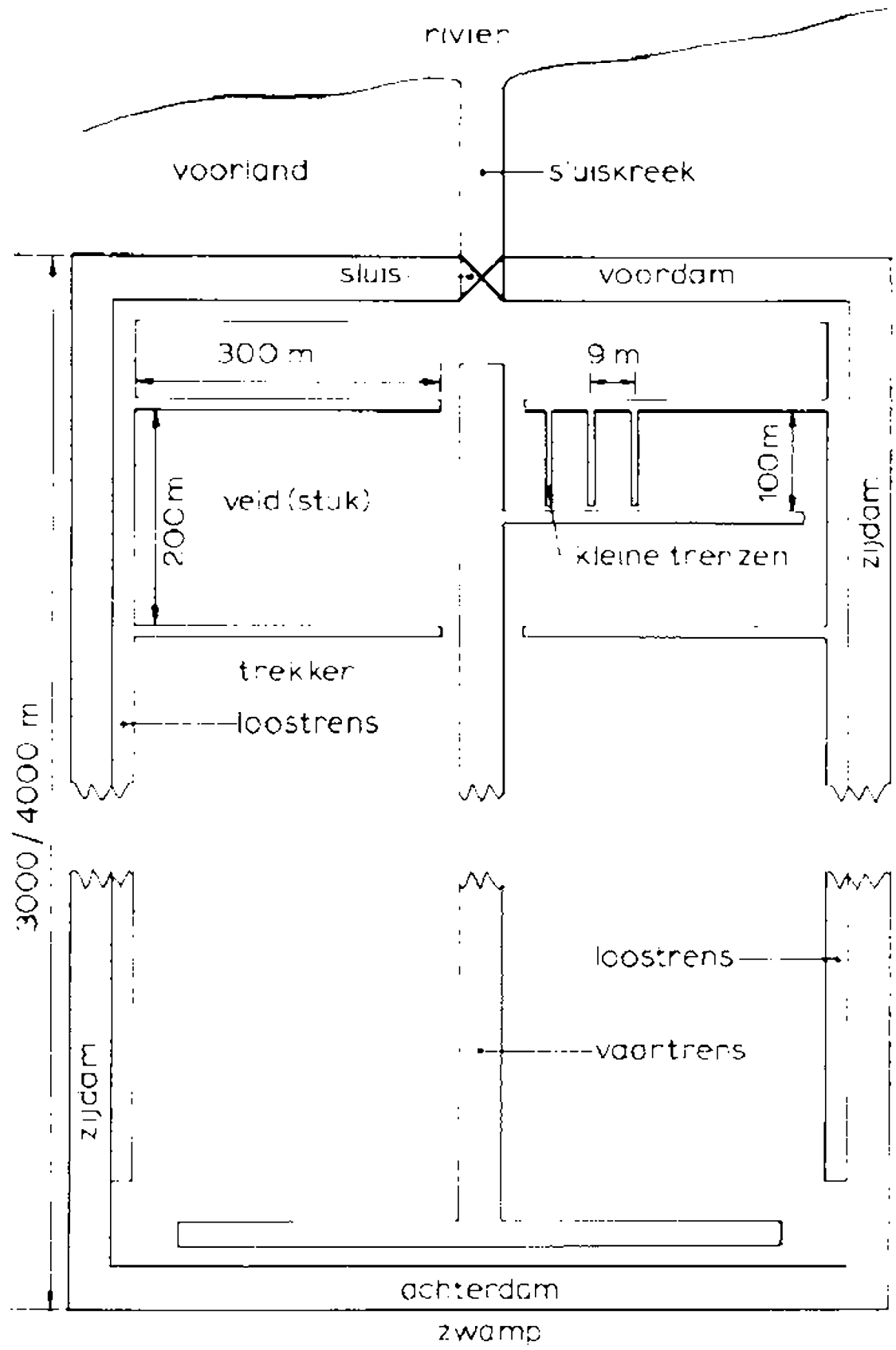

Schematische voorstelling van een polderplantage. De onvang van veldstukken, de lengte van trenzen, en andere maten verschilden uiteraard per plantage (Bruijning en Voorhoeve 1977:361, tekening van R. Boekelman.) 
ingenomen water weer liet terugstromen, viel dit met kracht in de stenen kom en zette zo het molenrad in beweging. Vanwege zijn twee functies werd dit kanaal daarom zowel hoofdvaartrens als molentzens genoemd (Figuur 5).

Evenals voor het padenstelsel gold voor de watersystemen dat, naarmate het bebouwd areaal verder van de gebouwen af lag, het systeem expandeerde. Zo groeide de gemiddelde lengte van de vartrenzen op suikerplantages tussen 1750 en 1810 van ruim 5 raar meer dan $10 \mathrm{~km} .{ }^{17}$

Ondanks gebrek aan cijfermatcriaal wijst alles or op dat de expansic van de watersystemen ook in de negentiende eeuw is verdergegaan. En dat terwijl in het derde kwart van de achttiende eeuw op een gemiddelde suikerplantage al meer dan $16 \mathrm{~km}$ trens was aangelegd en moest worden onderhouden, nog afgezien van trekkers en kleine trenzen. Gemiddeld was een vaartrens zeven en een loostrens vijf meter breed, bij een diepte van ongeveer anderhalve meter. Dat betekent dat in deze periode op suikerplantages gemiddeld $10 \mathrm{ha}$. in beslag werd genomen door de waterstelsels en dat alieen al voor cie aanleg daarvan zo'n 150.000 kubieke meter zware klei was verzet.

Niet voor niets gold het graven van vaaten, overigens altijd alleen uitgevoerd door volwassen marner, $b: j$ de slaven als een van de meest gehate en slopende werkzaamheden. En het hield nooit op, want ieder jaar moesten de voortdurend dichtslibbende trenzen weer worden uitgemodderd en werden er eventueel nieuwe trenzen bijgegraven of oude verlengd. Hoe traumatisch deze siavenarbeid is geweest bli;kt wel uit het feit dat er in de orale geschiedenis van de Saramakarers tot op de dag van vandaag aan wordt gerefereerdi. is

Zowel het loos- als het vaassysteem stond in verbinding mei de rivier. Ten gevolge van het grote getijdenverschil in de benedenwateren van Suriname ( 1 tot 3 meter), konden dit geen open verbindingen zijn. ${ }^{19}$ Als waterkering werden daarom loossluizen en kokers (duikers) gebruikt voor de loostrenzen en eer inneensluis voor de vartrenzen. Kokers warer houten of stenen buizen, waarin een scharnierende klep zich opende ais het water in de loostrens hoger stond dan in de rivier. In aanleg en onderhoud was zo'n koker veel minder kostbaar en bewerkelijk dan een s'uis. De massa

\footnotetext{
17 Steekproef ARA: SONA en SNA, p'antage-archieven.

18 The heaviness of canal-building labor is cited as the specific motive for cscape [van de plantages] in the tradition of several Saramaka class. [...] These widespread stories stand as collective witness to the perception by slaves that this particular form of supervised gang labor - moving tons of waterlogged clay with shovels - was the most backbreaking of tasks they were ralled to acromplish.' (Price 1983:48.)

19 De benedenlopen van de Surinaamse tivieren staan onder juvlocd van eb en vloed, zodat er sprake is van getijdeverschillen. Landiawa arls worden deze steeds geringer. In de Surinamerivier is het getijdeverschil tot bijna hunderd $\mathrm{km}$ landinwadrts merkbaar.
} 


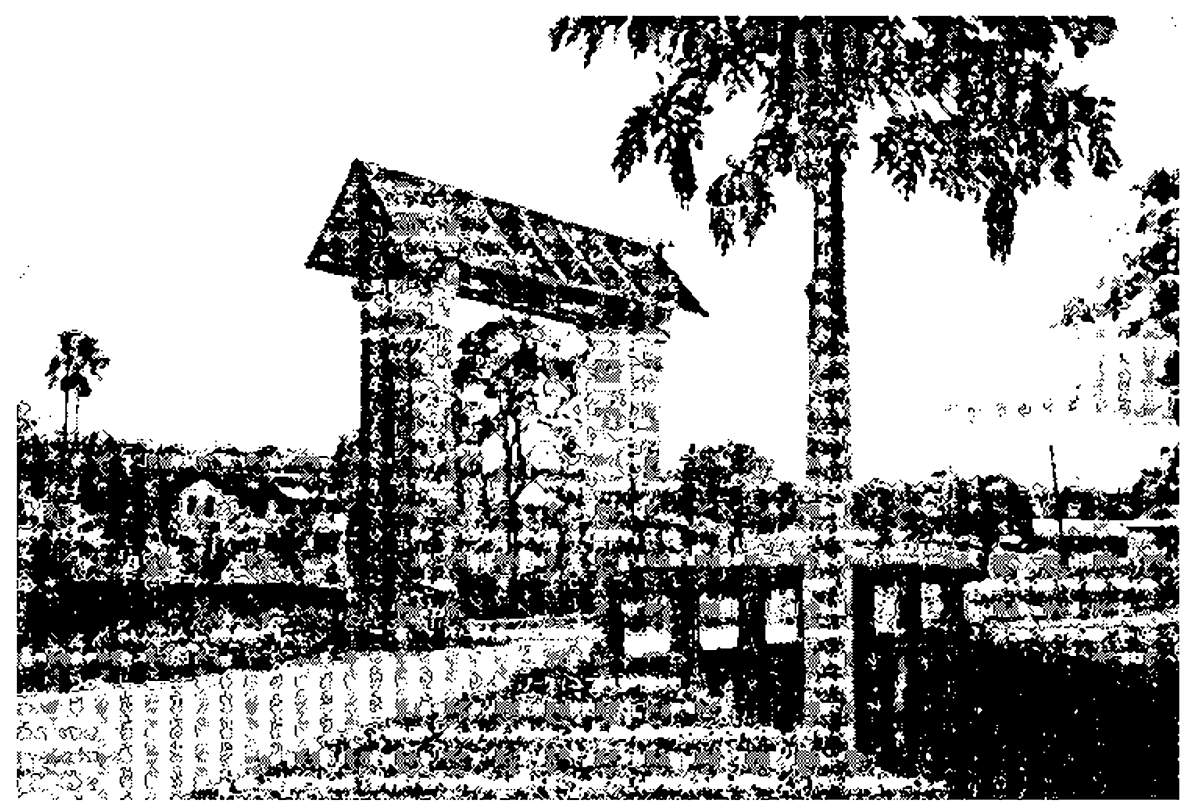

Siuisje plantage Sorguliet (foto Alex van Stipriatan)

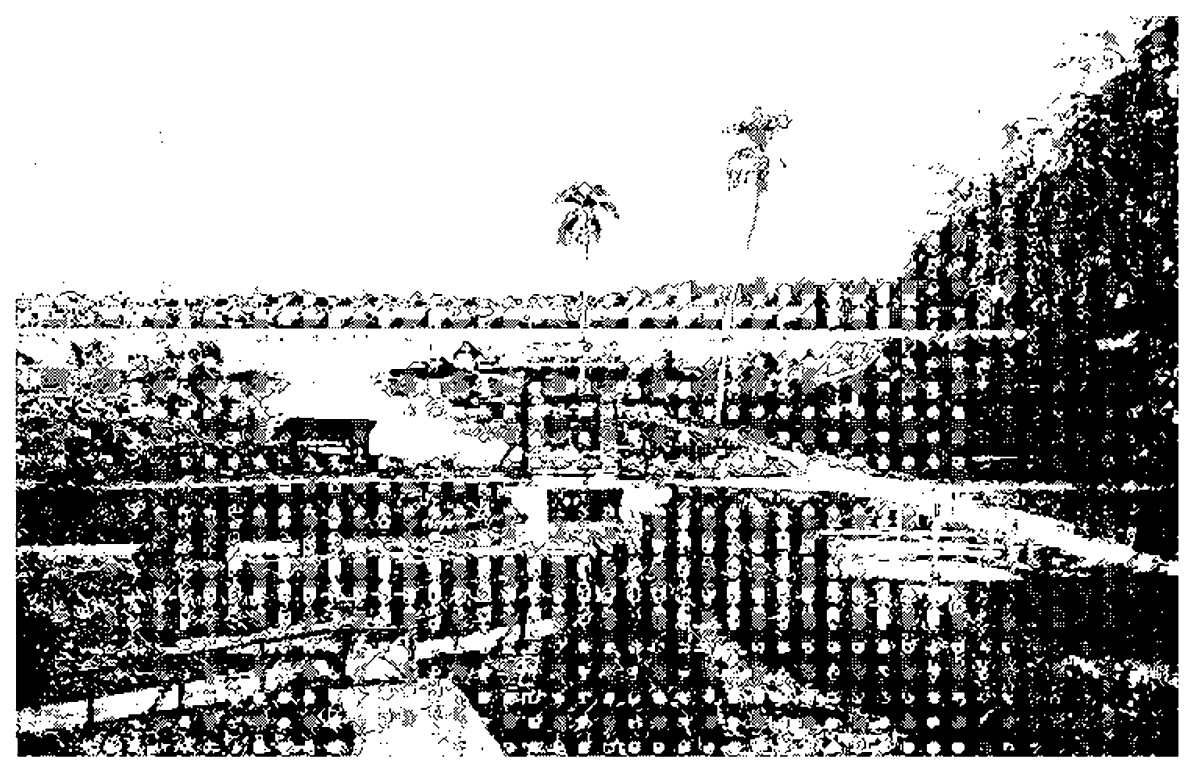

Landingsplaats en slinsje op piantage Mariënburg (Foto-archiet KIILV nr.4599) 
water die hij in éen keer kon verwerken, was echter veel geringer. Wanneer een plantage riet al te uitgestrekt (200-400 ha.) en dus het afwateringssysteem niet al te uitgebreid was, dan kon worden volstaan met eén loossluis aan de waterkant, gesteund cioor enkele kokers op andere vitale plaatsen. Op grotere plantages moesten meestal twee loossiuizen en meerdere kokers worden aangelegd.

Loos- en inneemsluizen waren min of meer identiek, met die restrictic dat de eerste meestal kleiner waren dan de laatste. Het bovenste deel var de sluis bestord uit een stenen opbouw van twee pilaren warop een dakje rustte. Onder dif afdak kon met behulp van een rad een as draaien waaraan een touw of ketting vastzat. Het andere eind van de kettir.g was bevestigd aan ce sluisdeur die, door aan het rad te draaien, op en neer kon worden bewogen in een houten sponning. Anders dan de meeste Hollandse sluizen. bestonden de Surinaamse hit slechts één deru, die bovendien in verticale richting opende of sloot. De vier walkanten, die raar de sluis toebogen (de vleugels) hadden een houten of steren beschoeiing en waren meestal door een brug met elkaar verbonden. Ook de bodem van de trens onder de sluisdeur was met stenen belegd (de rollaag) on uitschuring te voorkomen. Voor grote, geheel steren sluizen waren soms meer dan 100.000 stener nodig, die allemaal uit Nederland werden irgevoerd. Het waren daarom kostbare irstallaties, die per stlix 2 a $4 \%$ van de totale plantagewaarde konden uitmaken (zie ook Hookdstuk IV).

Een cergelijke sluis was, me: inbegrip van cie vieligels, a: gauw 12 meter lang, 2,5 meter breed en vanat de stenen rollaag 5 meter hoog. ${ }^{20}$ Mits goed onderhouden, kon zo'n sluis eeuwenlang meegaar. Naast het bijhouder. van de dammen en trenzen, moesten daarom oox de sluizen en vele bruggen er timba's (loopplanken over de trenzen) regelmatig worder gerepareerd en geconserveerd. Alles bij clkaar vormde dit eer arbeidsintensief onderded van het plantagewerk. Vooral het houtwerk had veel te. lijden van het vochtige Surinaamse klimaat. Bovendien werden de houter. sluisderser en kokers vootdirend bedreigd doo: de zogenaamde paai- of waterworm. Om aantasting van het houtwerk te voorkomen moest een sluisdeur regelmatig worden ingesmeerd met een mengsel van pik, teer, fijngestampt glas, aloësap, talk en terpentijn (De Eensgezindheid 1804::03). Daarnaast moest de deur minstens eens in ce twee weken worcien afgekrabd en schoongemaakt. Om dit oncerhoud zo vlot mogelijk te laten verlopen en in geval van rampen - was er vrijwel altijd eer: reservedeur aanwezig. Dat was bijvoorbeeld ook het geval up de koffieplantage Vrouwenvlijt aan de Hoer Helenakreck. Deze plantage beschikte over een stemen loossluis van

20 I fier zijn de mater gebruikt van de loussiuis op koffiepiantage Vriendsbeleid en Oudersorg aan de Commewijno (ARA: SONA, 706). 
$20 \times 9$ voet (circa $7 \times 3$ meter), die er in 1835 waarschijnlijk al ruim zeventig jaar stond.21 Hij werd dan ook met grote regelmaat onderhouden, evenals de 5 a 6 bruggen over de loostrenzen en de vele tientallen timba's uver de smallere trekkers.

Vrijwel ieder jaar blijken er reparaties te zijn verricht aan onderdelen van de sluis en ook aan timba's en bruggen werd in de meeste jaren gewerkt. Ondanks dit geregeld onderhoud, lijkt de levensduur van een sluisdeur niet meer te hebben bedragen dan zes à zeven jaar. Fn ook dan moest het verwisselen met grote omzichtigheid gebeuren. Het gebeurde nogal eens dat vitale delen van de sluis intussen zodanig waren verteerd dat bij het in- of uithangen van de sluisdeur de hele constructie in elkaar stortte, waardoor slaven werden verwond of zelfs gedood (De Eensgezindheid 1804:137-9). Al deze werkzaamheden maakten het onderhoud kostbaar, zowel materieel (stenen en hout) als in arbeidskracht. Werd het echter achterwege gelaten, dan zou de plantage vroeger of later onherroepelijk onder water komen te staan.

Opbouw en voortbestaan van de Surinaanse plantage-economie waren dus in sterke mate afhankelijk van infrastrucurele waterwerken. Per sector en periode konden echter belangrijke verschillen optreden. Het spreekt voor zich dat de suiker- en sommige koffieplantages met hun dubbele waterstelsels meer aandacht aan aanleg en onderhoud van deze infrastructuur moester geven dan plantages met alleen een afwateringssysteem. Bovendien betekende de voortdurende verlenging van de stclsels als gevolg van het verschuiven van het bshouwd areaal cen steeds grotere verzwaring van deze taak. Deze ontwikkeling valt eveneens af te lezen uit het veranderend aantal siuizen en kokers op de plantages (Tabel 16).

Het verschil tussen de sectoren is opvallend: suikerplantages hadden twee- tot driemaal zo veel sluizen en kokers nodig als koffie- of katoenplantages.

Tabel 16. Gemiddeld aantal shuizen en kokers per plantage 175h-1830

\begin{tabular}{|c|c|c|c|c|c|c|c|c|c|}
\hline \multirow{2}{*}{ periode } & \multicolumn{3}{|c|}{ suiker } & \multicolumn{3}{|c|}{ koffie } & \multicolumn{3}{|c|}{ katoen } \\
\hline & sluis & knker & $\mathrm{n}$ & sluis & koker & $\pi$ & sluis & koker & $\mathrm{n}$ \\
\hline $1750-59$ & 2,0 & 1,4 & 23 & 0,6 & 1,0 & 33 & - & - & \\
\hline $1780-89$ & 1,9 & 1,6 & 19 & $i, 0$ & 0,6 & 27 & - & - & \\
\hline $1820-35$ & 2,6 & 1,4 & 18 & 0,9 & 0,4 & 27 & 0,5 & 1,1 & 13 \\
\hline $1845-63$ & 2,8 & 0,8 & 12 & $?$ & ? & $?$ & $?$ & $?$ & $?$ \\
\hline
\end{tabular}

Bromnen: stcekproef ARA: SONA en SNA; ARA: AvF na 1828, 130; plantagearchieven.

2I In de inventaris van 1764 wordt cen sluis mot exact dezelfde afmetingen beschreven (EHB: $\mathrm{KA}-102,2)$. 
Bovendien is zowel op suiker- als op koffieplantages een trend te bespeuren, waarbij de voorkeur werd gegeven aan sluizen. Alleen in het laatste kwart van de acnttiende eeuw was dat op suikerplantages niet het geval. Waarschijnlijk had dit te maken met kapitaalgebrek, zodat werd volstaan met de installatie van goedkope kokers. Dit kon echter niet anders dan een tijdelijke maatregel zijn, want hoe langer de watersteisels wercien, des te groter diende de capaciteit van de waterkering te zi;n. Bovendien kwam in de suikersector gedurende de negentiende ceuw weer meer kapital beschikbaar zodat ans de noodzaak on kokers door sluizen te vervangen ook daadwerkelijk kon worden voldaan.

Ook op koffieplantages werden, met rame in de jaren 1760 en 1770 , kokers ingeruild voor sluizen. Gedurence de jaren 1750, toen een groot deel van deze onderneminger $z i c h$ nog in de aanlegfase bevond, had men kunmen volstaan met kokers. De expiosieve groei van he: bebouwd areal in ce daarop voigende decennia maakte het irstalleren van sluizen tot een dwingende noodzaak. Bovendien was er tot de eerste heift van de jaren $: 770$ kapitaal ir overvloed.

In de negentiende eeuw bieek, ondanks cie achterwartse verschuiving van het beboliwd areaal, bet aantal waterwerken op koffieplantages to zijn gedaald. Dit werd veroorzaakt door de komst van eer aantal nieuwe ondemeningen, met name in Saramacca, die in de jaren 1820 nog niet toe waren aan uitgebreide waterwerken. Verder makikte de uitputting van een groot aantal oudere koffieplantages vervanging, laat staan uitbreiding, van de waterwerken niet meer rendabel, dit nog afgezien van het feit of er kapitaa: beschikbaar zou zijn geweest. Hun verva: werd hierdoo: natuurlijk eens te meer bespoedigd.

Een groul cieel van de katoenplaniages ferislotle bevond zich, vooral in Coronic en Nickerie, in de jaren 1820 nog in ce opbouwfase, zodat me! erkele kokers kon worderi volstaan. Bovendien lagen de: gronden in beide disfricten hoger dan eiders, ongeveer op het niveau van het hoogste tij, zodat de gronden daar op ratuurlijke wijze loosden en e: geen zware graafwerkzaamheden nodig waren.22 Daarom vormden sluizen daar waarschijnl:jk geen roodzaak. Oudere katoenplantages in het noordoosten van Suriname en vooral voormalige koffieplantages hadden dit echter wel nodig. Zo kad bijvoorbeeld plantage Bacenstein aan de Warappakreek, in de jaren 1760 nog kumnen volstaan me: een enkele koker; in :828 werd daarentegen net twee siuizen gewerkt. ${ }^{23}$

De kostbare en zeer arbeidsintensieve watersystemen en installaties, exclusief de watermolen, bepaaden voor 4 tot $8 \%$ de waarde van een

ARA: $\$ O N A, 222$ an $\$ 41$. 


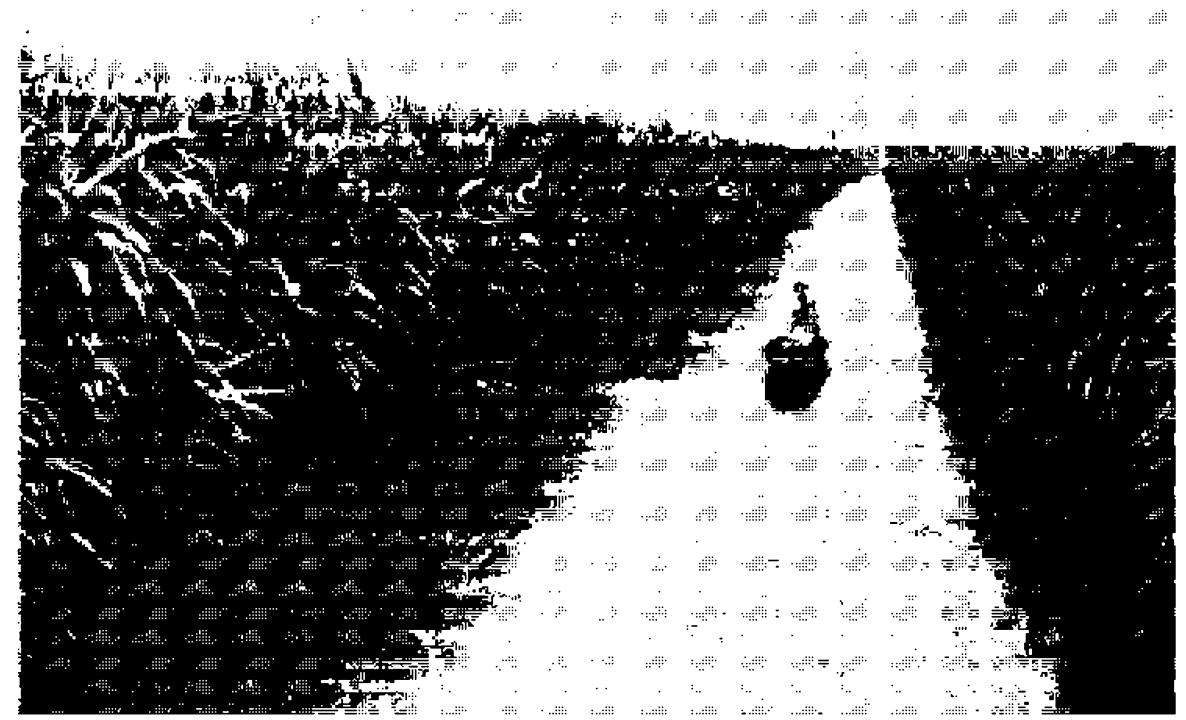

De slikerve'den; een 2 ijtrens op plantage Rust en Werk (Foto-archie؛ KITLV nx.9012) 
suikerplantage. Voor a.le plantages samen kan de waarde var deze infrastructurele werken rond 1775 worden getaxeerd op ongeveer vier miljoen gulden ${ }^{24}$ Bij de meeste andere plantages in het Caraibisch gebied vormaen waterwerken riet eens een post op de begroting. Alleen op Saint Domingue werden op een gegeven moment in bepaalde districten irrigatiekanalen aangelegd (precies het omgekeerde dus van wat in Suriname gebeurde) die in kosten te vergelijken waren met de Surinaamse waterwerken (Watts 1987:299).

De financiële en fysieke last van de waterwerken betekende dat zowel planters als siaven wat dit betreft in de Guiana's slechier af waren dan elders in het Caraibisch gebied. Daarnaast maakte de complexe waterhuishouding de planiages bijzonder kwetsbaar voor velerlei ramipen.

\section{Strijd tegen het water}

Surinaamse plantages werden voortdurend van verschillerde kanten door water bedreigd. Uit de lucht, stoor ove:vloedige regens die de akkers onder water zetten. Uit de rivieren, die steeds dreigden buiten hun oevers te treden en de piantages te overstromen. En tenslotie uit zee, waar de kustplantages van Vicker:e, Coronie en het gebjed tussen de Warappa- er. Vrederburgerkreek chronisch te kampen hadden met áspoeling var de zeekust. Dus waterwerken waren van levensjelang. Maar ook voor de kunstmatige plartagewaterhishouding creigde voo:durend gevaar in de vorm van verwaariozing. I cgio zijn de voorbelden die daarvar getuigen en die vaak eindiger met de totale oncergarg van de plantage. De oorzaken van een verwaarloosde waterhilishouding waren van uiteenlopende aard Enkele voorbeelder. uit de achttiende- en negentiende-eeuwse plantagepraktijk kunnen dat verduidelijken.

Het eerste voorbeeld is de algehele verwaarlozing van suikerplantage De Drie Gebroeders aar de Surinamerivier. Toen in 1769 de eigenaar van deze ondernening, Samue: a Avilar, overleed liet hij aan zijn minderjarige kinderen een uitstekend oncerhoulen piantage achter. Hij had de it29 ha. grote planfage minstens een kwart eenw met veel ondernemingslust bestierd, waarbij bij zijn dood 1:9 ha. in bewerking waren. De waterwerken bestonden op dat moment, raast de gebruikelijke loostrenzen, uit $7,4 \mathrm{~km}$ hoofd-en dwarsvaartrenzen, een inneemsluis en twee loosluizen, die alle naar behoren functioneercien, ${ }^{25}$

Dertien jaar later bleek de plantage volkomen verwaarloosd. De eigenaars

24 Extrapolatie op basis van cen stcekprcef onder 20 suiker- en 32 kotfieplantages (ARA: SONA).

¿ ARA: SONA, 698. 
waren op dat moment nog steeds de gezamenlijke erven van Samuel d'Avilar. Dit zou kunnen betekenen dat er of geen of juist teveel kapiteins op hetzelfde schip waren. In ieder geval had niemand zich veel aan de plantage gelegen laten liggen, zodat het geheel in een desolate staat verkeerde. Bij het minste of geringste stond de plantage onder water. Zowel de loos- als vaartrenzen waren dichtgegroeid, de dammen vertoonden overal breuken en de twee nog resterende sluizen waren defect. I Iet mag een wonder heten dat er nog 32 ha. met suikerriet stond. 26

Desondanks duurde het tot 1791 voor een begin werd gemaakt met het herstel en dat alleen omdat de plantage was verkocht, wat op zich al opmerkelijk was. Op dat moment waren er nog maar 15 ha. met suikerriet beplant en was van alle vroegere waterwerken alleen een simpele koker in bedrijf.27 Ondanks de krachtdadige initiatieven en herstelwerkzaamheden van de nieuwe eigenaars - de heren Vermeulen en De Wilde - produceerde de onderneming vier jaar na de overname nog geen 15 ton suiker, terwijl in de periode 1750-1753 jaarlijks nog meer dan 89 ton werd gemaakt. ${ }^{28}$ Door de aankoop van belendende plantages is deze zwaar verwaarloosde onderneming er uiteindelijk toch nog bovenop gekomen. Was dat niet gebeurd, dan had de plantage, zoals zoveel andere, wa arschijnlijk definitief mocten worden verlaten.

Verwarlozing was ook dikwijls het gevolg van een misplaatst soort zuinigheid van de eigenaars. Vanaf het einde van de achttiende eeuw werd in het algemeen veel minder kapitaal voor de plantages gefourneerd en de meeste eigenaars bevonden zich buiten de kolonie. lets dergelijks was onder andere het geval op plantage Zorg en Hoop aan de Beneden-Commewijne, waar in het begin van de jaren 1830 werd overgeschakelci van koffie- op suikerteelt.

Ondanks herhaalde klachten kregen de administrateurs van deze plantage geen toestemming van de eigenaars om een tweede loossluis te bouwen; de omschakeling naar suiker had al genoeg geld gekost. Toch had het uit de veelvuldige rapporten duidelijk moeten zijn dat bij overvloedige regenval de aanwezige sluis veel te klein was om het overtollige water te lozen. De gevolgen lieten dan ook niet lang op zich wachten. Tjjdens de zware en langdurige regens van 1844-1845 kwam een deel van de plantage onder water te staan. Het gevolg was dat de suikerproduktie zeker vijftien maanden kwam stil te liggen, want het meeste riet was verrot en de rest moest dienen voor nieuwe aanplant.

De directeur, die enige tijd daarvoor nog als 'kundig' was geprezen, had

\footnotetext{
26 ARA: SONA, 256 .

27 ARA: SONA, 276.

28 ARA: W.I. Beziltingen en Kust van Cuinea 1795-1810, W.I. Comité, 104, no. 86; ARA: RvP. 606/6677.
} 
zich de ramp zo zeer aangetrokken, dat hij 'opeens van levenswijze veranderd [is] en zich zoodanig aan d:onkenschap [heeft] overgegeven dat alle werkzaamheden en toezigt is vervallen', ${ }^{29} \mathrm{Hij}$ werd daarop ontslagen. Vervolgens kwam alsnog de toestemming een niewwe sluis te bouwen. Veel onheil had kunnen worden vermeden, wanneer hiertoe eerder was besloten. Nu kregen bijvoorbeeld de slaven te maken met een belangrijke verzwaring van hun arbeidsiast, want welk onheil zich op dit gebied ook voordeed, het waren altijd de slaven die de fysieke gevoigen droegen. Zou het toeval zijn cat het sterfte-overschot, in normale jaren variërend van 1 tot 7 personen, juis: in dit rampjaar (1845) maar liefst 13 personen bedroeg, op een totaal van 242 slaven? ? $^{30}$ Een combinatie van extra-zware arbeid en het uitbreken var. ziektes en voedselgebrek als gevolg van de overstroming, kan daarvan de oorzaak zijn geweest. ${ }^{31}$

Een slagvaardiger beleid had dit wellicht kumer voorkomen, everals het abrupte einde van de carritre van ce plantagedirecteur die aan te drank raakte. De oogst was in ieder geval totaal mislukt. Ook in de daaropvolgende jaren was de produktie aanzienlijk lager dan voorheen: in de periode $1842-$ 184 werd op deze plantage jaar.jjks gemidde'd 263 ton suiker geproduceerd; in de jaren 1847-1849 bedroeg dat niet meer dan 184 ton. ${ }^{32}$

De ramp op Lorg en Hoop was eenmalig en volledig te wijten aan menselijk falen. Maar er waren ook plantages waar de strijd tegen het water een eelwenlang gevecht tegen de bierkaai was. Door ce extreem lage igging van sommige gronden had een aanlal plantages chronisch te lijden van wateroverlast. Wanneer daar de bepoldering en afwatering niet consequent in optimale ronditie werden gehouden, waren de gevolgen direct merkbar. Dat was bijvoorbeeld het geval met de plantages an de Pauluskreek, eerr zijtak van de Surinamerivier.

In 1752 had daar op de suikerplantage Bleyendaal, die beschikte over twee loossluizen en trenzenstelsels met een gezamenlijke lengte var. bijna $21 \mathrm{~km}($ (), zo'n 10\% var de bebouwde grond 'veel geleeden door 't waater'.33 Anderhalf jaar later bleker. er zelis twee houfer sluisjes te zijn bi;gebouwd, maar was opnie:1w 9\% van het cultulrareaal 'door 't waaler verdronken'. ${ }^{34}$ Bleyendaal gold als een goed stuk land, alleen diende men door haar lage ligging voor:durend alers te blijven op wateroverlast. Bovendien moest daartoe steeds extra kapitaal worden uitgetrokken. En dan nog was het vaak

3i Al te snelle conclusies mogen hier overigons niet aan worden verbonden, want hoge stefte-overschotten kwamen wel epers vaker voor; puur toeval ijjk: het ech:er evennin.

32 GAA: PA-60D, 544.

33 ARA: SONA, 193.

34 ARA: SONA, 691. 
een hopeloze strijd, want toen in 1830 Suriname te kampen kreeg met buitengewoon 2 ware regens, was 'deeze plantagie onder de geene wier aandeel in de ramp vrij aanzienlijk is', 35 Ook het jaar daarop kwam de plantage door overvloedige neerslag tweemal onder water te staan.

Ondanks het probleem van de lage ligging, hadden deze rampen beter kunnen worden opgevangen, indien met meer volharding en kapitaal van de eigenaars in Nederland de strijd tegen het water was volgehouden. Zo werd na langdurige discussies over het al dan niet verlaten van de plantage rond 1835 besloten toch door te gaan en de zaken met nieuw elan en geld aan te pakken. En wat blijkt: 'de waterloozing voldoet op den duur en boven verwagting, zoo dat zelfs deeze plantagie geene zo nadeelige invloed als andere heeft ondervonden van het buitengewoon vochtig jaargetijole [van 1836]',36 De resultaten waren meteen navenanl, want terwijl de gemiddelde produktie in de periode 1830-1834 op 80 ton suiker per jaar lag, werd dat in de periode 1835-1839 op gemiddeld 133 ton gebracht, waarna het ook in de jaren 1840 niet meer onder dit niveals is gekomen. Het kon dus wel.

Fen ander verschijnsel dat van grote invioed is geweest op het verval van de waterhuishouding trad op toen, in de negentiende eeuw vooral, steeds meer plantages werden verlaten. Daardoor traden bijvoorbeeld, opnieuw, aan de Pauluskreek grote problemen op. Van de tien plantages waren in 1831 alleen nog Bleyendaal en 't Eylant in produktie. Zij moesten nu samen zorg dragen voor de bevaarbaarheid van de hele kreck. Aangezien dit slechts gedeeltelijk lukte moesten zij nu bovendien, vanwege de mocilijker bereikbaarheid, verhoogde vrachtprizzen betalen aan de pontevoerders die de geproduceerde suiker kwamen a:haien. ${ }^{37}$

Nog veel groter bleken de problemen in het gebied tussen de Warappaen Vredenburgerkreek te zijin. Zo waren langs de Tapoeripa halverwege de achttiende eeuw 25 (koffie)plantages aangelegd. Hiervan bleken in $1853 \mathrm{nog}$ maar twee in bedrijf te zijn. ${ }^{39}$ Een van die twee was plantage Somerszorg. Deze koffieplantage grensde aan plantage Misluki Bedrog die rond 1840 was verlaten. Vanaf dat momer: had he: water viij spel op de verlaten gronden en werd Somerszorg bedreigd. Voortdurend moest de dam tussen beide ondernemingen worden verbreed, verhoogd en met bamboe beplant, om te voorkomen dat het brakke water ook Somersyorg you aantasten. ${ }^{39}$ In 1848 werd door de slaven van Somerszorg tussen de twee plantages zelfs speciaal een poldertrens van ruim twee $\mathrm{km}$ lengte gegraven om het opdringende water af te leiden. Het mocht echter niet baten, wart ook in de daarop-

ARA: SONA, 691.

ARA: SONA, 692.

ARA: SONA, 692.

Surinaamse Amanak 1833 en 1845; Van Sijpesteijn 1854;134-5.

GAR: Collectie-Hudig, 340/341 
volgende jaren moesten steeds weer breuken in de dar. worden gedicht en werd hij voortdurend verhoogd. Al deze inspanningen moesten bovendien worden verricht met een slavenmacht die gestadig in omvang afnam. Mede als gevolg hiervan besloot men in 1857 de strijd te staken en werd ook Somerszorg verlaten.

Ook de zee tenslo:te, kon een grote bedreiging voor piantages vormen. In het bijzonder de districten . Nickerie en Coronie hadden ernstig te lijder van afkaiving var. de kust, die Seder jaar zo'n dertig meter lardinwaarts opschoof (Teenstra 1835, 11:126). Aangezien veel plantages met hun voordammen aan zee lagen, was de ondermijning daarvan een constante zorg. Voor de oudste, direct ann zee gelegen katoemplantages van Nickerie bleek dit op den duir een ongelijke strijd. Eer voor eer werden zij, vanwege het wegspoelen van de grond, verlaten. De :aatste was Good Intent, die in 1858 door de zee werd verzwoIgen (Heckers 1923:84).

Ook aan de noordoostikust, tussen Warappa- en Vredenburgerkreek, kampte men met dif probleem. 'Lo scirreven bijvoorbeeld in 1830 de administrateurs van de katoenplantage Anna Catharina, dat

'de afspoeling der zee, waarvan dezelve te allen tijale bli;kt te lijden gehad te hebben, in cie voorgaande jaren zoo sterk was toegenoomer dat een nieuwe polder niet ver van het woonhuis moest worden aargrelegd, hetgeen drie maanden extra werk heeft gekost. [Ir. 1835 was het dezelide oorzaak die] 't wel weder noodzakelijk makke om, ca. 80 kettingen $[1,7 \mathrm{~km}$ ] van huis af, de dam in te trekken, warciour ben paar stukker: katoer:llandj zouden verloren gaan. ${ }^{140}$

In 1844 bleek toch aliveer een-vijfche van de nieuw aangelegde polder te zijn. weggespoeld. Het proces was nawweijjks te stuiten. legelijk bedreigde ook een tegengestelde ortwikkeing de plantages uit zee, name:ijk dichtslibbing van kreek- en kanaalmondingen. Hierdoor kwamen ook de meer landinwaarts geiegen plantages in problemen. Alle hadden zij hun alwatering in de relatief smalle kreken, die op hun beurt weer in zee loosden. Doo:dat de kuststrook voortdurend in beweging was, kon het gebearen dat na een storm of springuloed de monding van zo'n kreek in een kiap met zand en slib werd dichtgeslagen. Het gevolg was dar dat de afwatering van alle plantages langs die kreek werd gestremá.

Zo bieek ir. 1842 de genele moncing van de Motkreek bij springvloed door een schelper.bark te zijn dichtgeslagen. In het jaarverslag van de caar gelegen katoenplantage Leezigt werd vermeld dat daarcioor grote werkzaamheden aan de waterlozing moesten worden verricht er. geen van de sluizen en kokers meer functioneerde. Tot overmaat van ramp kwamen he: jaar daarop de regens veel te vroeg, waardoor de plartage onder water kwam te staan en de compiete slavennacht, in plaats va: met de katoenproduktie, 
bezig was een opening naar zee te graven. 41

Ook hier bleef het vechten tegen de bierkaai, want zeven jaar nadien (1850) bleek de waterlozing nog steeds gebrekkig. Men besloot twen de zaak drastisch an te pakken door de monding van de kreek tot aan zee uit te graven. Hiertoe werden alle werkbare mannen van Zeezigt en buurplantage De Dageraad ingezet, samen ongeveer 250 slaven. In $1851 \mathrm{kwam}$ dit immense karwei af. Nog hetzelfde jaar bleck het Sisyphusarbeid te zijn geweest, omdat 'eene stort van de Modderbank de zandbank had vervangen'. 42 Het was een uitzichtloze strijd, waarin vroeg of laat ook deze twee plantages het onderspit zouden moeten delven; alle ardere ondernemingen aan de Motkreek waren toen namelijk al lang verlaten.

Ondanks de goedkope en vruchtbare grond maakien de complexe waterwerken de Surinaamse plantages knstbaarder, kwetsbaarder en arbeidsintensiever dan elders in het Caraibisch gebied. Door de verschuiving van het bebouwd areaal ten gevolge van roofbouw moesten de waterwerken steeds meer worden uitgebreid. Hierdoor nam de kwetsbararheid van de ondernemingen toe. Door geologische en technologische verschillen deden deze ontwikkelingen zich het meest voor in de suikersector en het minst in de katoensector. Overal gold echter dat zorgvuldig en regelmatig onderhoud van de waterwerker essentieel was voor het functioneren en voortbestaan van de plantages. Onduidelijke bezitsverhoudingen, absenteïsme en misplaatste zuinigheid leiduen exhter vaak tot verwatoring en vormden zo cen bedreiging voor de continuitcit. Daarnaast makte het proces van verlating de strijd tegen het water steeds zwaarder, waardoor deze ontwikkeling eens te meer werd versneld.

De strijd tegen het water, zo specifiek aan de Surinaamse plantagekolonie, is een van de duidelijkste voorbeelden van de wisselwerking tussen processen van roofbouw en overleven. Gebrek aan aandacht voor de reproduktie van de infrastructurele werken belekende onherroepelijk het einde en dit einde trok tevens cen steeds zwaardere wissel op degenen die trachtten te overleven.

De strijd tegen het water herft ook de Nederlandse samenleving altjd gekenmerkt. Het is daarom navrant te moeten constateren dat het daar een wereldberoemd succes is geworden, terwijl de mislukking in de kolonie uiteindelijk juist de achteruitgang heeft bespoedigd.

4 Collectie-Insinger \& Co., informatieboek Zeezigt.

42 Collectiz-Insinger \& $\mathrm{Co}$, informatisbotk Zeezigt. 


\section{HOOFDSTUKIV}

\section{Produktiefactoren en hun samenhang}

Wanneer de zeifvoorzieringslandbouw van Indianen, marrons en vrije negers buiten beschouwing wordt getaten en ook aan de tamelijk geringe ambachtelijke nijverheid in Iaramaribo wordt voorbijgegaan, dar blijft tot ver in de negentiende eeuw in Suriname de piantage als enige produktieeenheid over. Dour de eenvormigheid en cominantie van deze produklieeenheden kreeg de Suriraamse samenleving een zeer eenzijdige struciuur en werd het en typische plantage-economie.

De plarters trachtten zoveci mogelijk van hun ondernemingen autarkische produktie-eenheden te maken. Het hele groeiproces van zaadje of stekje tot transportklaar produkt was op de plantage geconcentreerd. Voedselgewassen voor slaven en staf werden voor een belangrijk deel zelf verbouwd. Het onderhoud van gebouwen, sluizen en vaartuigen werd zoveel mogeijk door de eigen ambachtsslaven verricht, bij voorkeur met timmernoul uit het bos achter de plantage. Kortom, de mate wazin het produkticproces birnen de plantage-onderneming werd geintegreerd, was bijzonder groot: van stekje tot in suiker verpakte vaten en van voedselverbouw tof sluisonderhoud

Volledige autarkie was erhter onmogelijk. Oppervlakkig onderhoud verrichtien de piartagebewoners zelf. Gecompiiceerder zaken werken aan specialisten van butter de plantage uitbesteed. Er is dus altijd een groep geweest - waarvan de omvang nauweijjks is vast te stelien - die als molenmakers, metselbazen, koperslagers en artsen een goed belegde joterham heeft verdiend aan de plartages.

Bovendien werd de afhanke.ijkheid van specialisten in de loop der tijd steeds groter, onder rree: als gevolg van arbeidsschaarste op de plantages, toenemende zorg voor de s'aven en meer gecompliceerde technologie. Zo werd in de negentiende eeuw, vooral op suike:plantages, steeds meer voedsel betrokken van gespecialiseerde kostplantages; het werd meer gebruikelijk om zwangere slavirnen in kraamk:inieken te laten bevallen in. plaats van op de plantage; timmernout werd geleverd door 'gepacificeerde' marrong; het transport van produkten naar de stad kwam in handen van gespecialiseerde pontevoerders; voor het onderhoud van stoommachines was men vee? meer afharkelijk van deskundigen dan dat bij de achtierde- 
eeuwse water- en beestermolens het geval was. Zaken die alle voorheen in veel grotere mate door de p.antagebevolking zelf werden gedaan.

Een veel groter obstakel voor zelfvoorziening en eigen initiatief vormde de buitensporige afhankelijkheid van overzeese import. Alles wat niet op de plantage zelf werd ge(re)produceerd - variërend van slaven en bouwstener. tot suikerkelels en zout - moest van ver worden ingevoerd met alle kosten en risico's van dien. Afgezien van de definitief gestopte slavenimporten in de negentiende eeuw, is die importafhankelijkheid nooit verminderd. Deze paradox van een in hoge mate zelfvoorzienende ondernemirg, die tegelijk sterk afhankelijk was van buitenlandse import, was inherert aan de mercantilistische structuu: waarin de kolonie diende te opereren. Bovendien weerspiegelt het de strijdige jelangen var. Siurinaamse planters en Nederlandse kooplieden. Een pianter behalcie de meeste winst bij hoge produktprijzen en zo goedkoop mogelijke produktiemiddelen. Een koopman daarentegen wilde niet alleen hoge prijzen voor de plantageprodukten, maar eventeers voor de kapitaalgoederen (en diensten) die hij aan de planter leverde.

In wezen kan vrijwel alles wa: zich op een plantage bevond gerekend worden tol de kapitaalgoederen, aangezien alles in het teken stord van de produktie en tevens een geldelijke waarde vertegenwoordigde. Voor de duidelijkheid zijл zij in drie categorieën verdeeld: slaven; gebouwen en machines; en grond en gewasser. Hun ontwikkeling, onderlinge samenhang en xosten van onderhoud belichten in belang:ijke mate de werking yan het Surinaamse piantagebedrijf, alsmede een aantal zwakke plekker. in de plantagestructiur.

\section{Slaven als kapitaalgoederen}

I let doet vreend aаr. om arbeid te definierren als kapitaalgoed. Toch is dit noodzakelijx roo: een goed begrip van ce achttiende- en negentiendeeeluwse plantage-economie. Juridisch waren slaven in Suriname niet meer dan werktuigen die var elders werden aangevoerd. Op hen was dan ook niet het personenrecht, maar het zakenrecht van toepassing. Typerend voor de opvatting var de slaaf als kapitaaigoed was de wijze waarop een slavenaankoop tot stand kwam.

Ein Sclavenhalter [...; Jässt täglich von seinen Sclaven, die er an Bord hat, ind die sich von 2 bis auf 300 belaufen, einen Trupp von 70 bis 80 , der aus Mann und Weib, Knaben und Märchen von unterschiedlichen Alter besteht; vor. einer Steuermann ode: Schilfschirurgus, in Begleitung von einigen Matrosen, in der Colonic [Paramaribo] ganz. nackend herumführen und nur selten werden den erwachsenen Frakenspersonen die Theile veriüllt, cंje die Schaamhaftigkeit $z$ i: verbergen gebietet. Hat nun jemand lusst zu kaufen, so lässt er dem Steuermann den Trupp Halt machen, und sucht sich nach belieben aus. Vor 
dem Kaufe wird jeder Sclav sehr genau besehes; vor allem wird die Reinheit der Zunge, als ein untrüg.jches Kennzeichen der Gesundheid, untersucht, dann kornmt die Reihe an die Füsse, die man aufheben und stark niedertreten, die Arme aber mit einem schmelier. Schlag von sich strecken und eben so wieder zurückziehen lässt, um zid seben, ò sie nicht etwa lahm sind, oder sonst einen Fehler haben, da man beim Finkauf der Srlaven hauptsächlich auf gesunde und gerade Gliedmassen Riirksicht zu nelmen ha:; und im Nothfall wird eher eir Fenler an den Füssen übersehen, als an den Armen und Händen. Gebrechen arn der Füssen werden aber um. so leichter vertiehen, da man sich aft genöthiget sieht, den Wicggelaufenen und wieder eingefangenen Sclaven cinen Fuss dicht unterm Knie segzunehmen', ]

Na de verkoop kregen de slaven de initialen van de plantage, of van de eigenaar aan wie rij voortaan behoorden, in hin huid geb:and en werden $z$ ij van een rieuwe naam voorzien (Van Stipriaan 1990:26-31). Deze zeer rationele gang van zaker doet in nie:s derker aan de wijze waarop vije arbeid wordt gemobiliseerd en kan alleen worden vergeleker. met de manier waarop ook andere kapitaalgoecieren worden aangeschaft. Vandaar de keuze on in dit hoofdstuk de slaven te scharen onder de kapitaalgoederen. ${ }^{2}$

Slaven waren een kostbaar bexit en bepalater. daardoor vorr een belangrijk deel de warde var. cen plantage. Nict alleen vergde hin aanschaf vecl geld, ook kreger. slaven op de plantage een zekere meerwaarde, al raar gelang de beroepstraining die $z i j$ daar ontvingen en de functie die zi;

1 Vertaling vau dit archä̈sche Juits: 'Een slavenhaler [...]. laat dagelijks uit de slaven die hi; aan boord heeft en dia 2 tot 300 [personen] uitmaken, een grocp van 70 tot 80 [halen], bestaande wit mannen, violiwer, jongens en meisjes van verschillende leoftijden [en] dexr cen stuurnan of scheepschirdrgijn, onder begeleid:ng van enige matrozer, geheel naaki door do kolonie [I'aramaribo] rondleiden en sleckts zelden wordt van de vol wassen vrouwspersonen die delen bxdekt, waarvan se zedigheid gebicd dat zij verbugen blijven. Heeft nu iemand zin ke kopen, dan last hij de stisurnan de troep hal: houden en zoekt nat: be'ieven uis. Voor de koop wordt icciere slat zeer grondig bekekcri; als cerste wordt onderzocht of de torg wel schoon is als onbetwistbate bewijs var: gezondhed; dan komen de voeten an de bcurt, dic zij moeten optillen en weer krachtig neerzettom, wasma de arnen snel gestrekt en ingetrok'ken moeten w'orden om te zien of zij niet enigszins lam zi;n dan wel cen mankement hebben, aar.gezien men bij het kopen van slaven hoofdzaks:lijk rokening dicnt tt? houcim met gezonde? en rechte Indematen; in geval van nood wordt ecrder ecn mankement aan de voeten door de vingers gezien, dan aan arnen ch handen l... J, omdat men zich vaak genoodzaakl ziet bij weggelopen

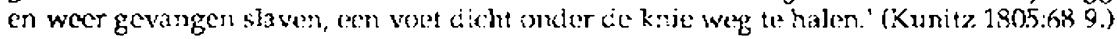

Kunitz. whkt hier de suggest:e alsof het afhakken van voeten en benen bi; weggelopen slaver. een wijdverbreid gebruik zou 2 :jn. Len stcckproef in de slavenlijsten van 54 plantages in het laatste kwart van de achlliende enew leer: exhter dat van de 8.166 daar aanwezige slaven slechts 8 een been of voet misten en 9 te boek stonden als mank of aan een been lam. Alle 17 gevallen betroffen overigens vol wassen manner. uik cen totaal yan 2.844.

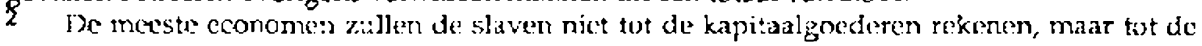
factor arbeid. Het is echter een 'jewus:e keuze van mij geweest bat in dit honfdstuk niet be doen, orm duide:ijk te maken hoe de planters in dic tijd de economische en juridische positic van slaven defiriecrden. Dat $i n$ de overige hoofdstukken de slaven wel als arbeicasfactor worden gedefinieerd is het gevolg van de zogenaande slavenparadox: voor de wet en in de plantageboekhouding golden slaver. als roerende goederen, in thet lever: van al.edag werd just en beroep gedaan op hur mens zijn. 
uitoefenden. Hoe groter het belang van een slaaf voor de produxtie was, des te hoger de kapitaalwaarde cie hij of zij vertegerwoordigde. Vandaar dat ambachtsslaven en basja's (zwarte opzichters, ook officiers genaamd) het hoogst werden gewaardeerd en oude, afgeieefde slaven het laagst.

Het waren echter niet aileen rationele produktiviteitsnormen die de waarde van een slaaf bepaalden. Mulatten werden bijvoorbeeld in he: algemeen hoger getaxeerd dan 'volbloed'-negers en de vrijwel niet produktieve huisslaven hoger dan veldslaven. De geprivilegieerde status en positie die deze slaven kregen toegemeten, steiden de planters in staat een verdeel-enheers-politiek te voerer, die de controle op de totale slavenbevolking zeer vergemakkeli;kte. Toch blijft het opmerkelijk, dat dit ook werd uitgedrukt in een hogere geldwaarde. Dat zou er op kunnen duiden dat voor planters het bezitten van mulattensiaven goid als een statussymbool, zodat het toch niel uitsluitend rationeie overwegingen waren die de waarde vam een slaaf bepaalden.

Hoe de waarde van te slaven als kapitaalgoed was samengesteld, kan het beste worden verduideiijkt aan de hand van eer voorbeeld. Zo blijkt uit de taxatie van suikerplantage Vredenburg aan de Parakreek, dat in 1772 de :40 personen tellende siavenbevo'king samer. $2 i, 5 \%$ van de totale waarde van deze onderneming uitmaakte. Dit was enigszins bereden het gemiddelde (Tabel 18). De hoogst getaxeerde saa: was Klaas: $f$ l.500. I lij was officier (basja) en timmerman en bovendien in Suriname geboren (creovi), wat hem waardevoller maakte, want meer aangepasi, dan een Afrikaan met dezelfde kwalificaties. Na her. voigden Jakje, eveneens timmerman, en Iouisa, nuismeid en naaister, ieder met een warde van $f 1.200$. De overige

label 17. Gemiddelde waarde en in:port van slaven in Suriname 1750-1830

\begin{tabular}{lccccc} 
periode & $\begin{array}{c}\text { taxatie- } \\
\text { waarde }(f)\end{array}$ & $n$ & koopprijs $(f)^{-}$ & $n^{*}$ & $\begin{array}{l}\text { gemiddelde jaarlijkse } \\
\text { slavenimport }\end{array}$ \\
\hline $1750-1759$ & 475 & 40 & 235 & 68 & 2.641 \\
$1760-1769$ & 501 & 39 & 258 & 81 & 3.443 \\
$1770-1779$ & 614 & 57 & 268 & 63 & 2.521 \\
$1780-1789$ & 509 & 13 & 468 & 7 & 469 \\
$1790-1799$ & 629 & 21 & 613 & -4 & 1.133 \\
$1800-1809$ & $729^{* *}$ & 26 & $803^{* *}$ & 24 & 985 \\
$1820-1829$ & 544 & 20 & $734^{* * *}$ & 25 & $\ldots .500^{* * *}$ \\
\hline
\end{tabular}

* $n=$ aantai verkopinger.

* deze prijs is in Surinaamse guldens die op dat moment minder waard waren dan Nederlandse; da wisselkoers is hela as nict bekend.

*** 1817-1826.

Bronnen: taxaties: steekproef in ARA: SDNA er. SNA er in plantage-archieven; koopprijs: Goslinga 1985:615-9 en plantage-archieven; slavenimport: P'ostma 1990: 186-212 en eigen schatting op basis van Tabellen 44 en 47. 
ambachtsslaven en huisslavinnen werden getaxeerd op $f 800-1.000$ per persoon. De veldslaven kende men een waarde toe van $f 400-800$ en de veldmeiden $f 350-600$. Oude en gebrekkige slaven die nog wel lichte karweitjes konden doen schatte men op $f 100 \cdot 300$, terwijl aan totaal onproduktieve slaven in het geheel geen waarde werd toegekend. Nog niet volwassen slaven werden, afhankelijk van leeftijd en beroepstraining, getaxeerd van $f 50$ voor cen baby, tot $f 500$ voor Adonis, de foetoeboy (huisknecht en loopjongen) ${ }^{3}$

Vrouwen werden gemiddeid een kwart lager getaxeerd dan mannen. Bovendien bevonden zich op de plantages in het algemeen minder vrouwen dan mannen. Beide verschijnselen duiden er op dat de waarde van een slaaf vooral werd bepald coor zijn produktievermogen. Aan het reproduktievemogen werd kennelijk minder waarde gehecht.

Een vergelijking tussen de getaxeerde waarde en de aankoopprijs van slaven (Tabel 17) :evert opme:kelijke verschilien op. Hierb:j dient echter te worden vooropgesteld dat deze cijfers niel geheel icientiek zijn samengesteld. In de taxatiewaarde zijn alleen voiwassen slaven (mamen en vrouwer:) begrepen, in de koopprijs ook de kinderen. Daar staat legenover dat de gemiddelic taxatieprijs wordt gedrukt door het aandeel daatin van oude slaven zonder waarde, terwijl alle koopslaven een prijs hadder. Dexe verschillen heffen elkaa: grotendeels op

De belangri;kste oorzaak van het waardeverschil was daarom de eender genoemce meerwaarde die een slaaf kreeg als gevo!g van beroepstraining, huidskleur en geboortegrond. Daarnaast mag een speculatieve opwaardering in de taxatie niet worden uitgesloten. Zo blijkt de gemiddelde koopprijs tussen de jarer 1750 en 1770 gestegen te zijn met $14 \%$, de taxatiewaarde daarentegen met $29 \%$. Le grote slavenimporten in die periode maken het uiterst onwaarschijnli;k dat de latstgenoemde stijging zou zijn veruorzakt door een betekenende vermeerdering per piantage van het andeel de: mulatten en andere dure er geprivilegieerde slaven. Specuiatie en wellicht fraude met de taxaties liggen voor de hand. In hoofustuk VII wordt daarop nader ingegaan.

Hoe het ook zij, in de jaren 7800 zakte de taxat:ewaarde, terwijl toen juist de koopprijs, als gevolg van sterk verminderde aanvoer, dramatisch was gestegen. Dit zou kunnen Guiden op een meer realistisch taxatieniveau dan in de periode daarvoor. Tevens zal een rol hebben gespeeld dat door de, sinds 1775, gekelderde slavenimporten het meest produktieve deel van de siavenpopulatie niet voldoende werd angevuld, zodat de gemiddelde waarde daalde. Tegelijk begon zich een trend af te tekenen waarbij de toegevoegde meerwaarde die een slaaf op de plantage kreeg steeds minder 
Tabel 18. Gemiddelde relatieve waarde-aandeel van slaven per sector $1750-1830$

\begin{tabular}{|c|c|c|c|c|c|c|c|}
\hline \multirow[t]{2}{*}{ periode } & \multicolumn{3}{|c|}{ suikerplantages } & \multicolumn{3}{|c|}{ koffiepiantages } & \multirow[t]{2}{*}{ totaal } \\
\hline & $\begin{array}{l}\text { gemiddeld } \\
\text { aantal } \\
\text { slaven }\end{array}$ & $\begin{array}{l}\text { relatief } \\
\text { getad: } \\
\text { waarde }\end{array}$ & $\mathrm{n}$ & $\begin{array}{l}\text { gemiddeld } \\
\text { aan:al } \\
\text { slaven }\end{array}$ & $\begin{array}{l}\text { telatief } \\
\text { getax. } \\
\text { waarde. }\end{array}$ & $n$ & \\
\hline $1750-1759$ & 136 & $36,9 \%$ & i7 & 83 & $32,7 \%$ & 29 & $34,2 \%$ \\
\hline $1760-1769$ & 148 & 37,8 & 5 & .22 & 32,2 & 28 & 34,1 \\
\hline $1770 \cdot 1779$ & 154 & 28,9 & 19 & 158 & 29,5 & 29 & 29,3 \\
\hline $1780-1799^{*}$ & 109 & 30,7 & $: 1$ & 228 & 30,3 & 23 & 30,4 \\
\hline $1800-1809$ & 138 & 31,4 & 10 & 116 & 37,3 & 16 & 35,2 \\
\hline $1820-1829$ & 137 & 43,2 & 9 & 105 & 32,8 & 13 & 48,9 \\
\hline
\end{tabular}

- gelet op de geringe omvang van de steekproef zijn deze decennia samengenomen.

De gemiddelde slavenaartallen verschillen met die van de Tabellen 23 en 25 , vanwege een iets andere periodisering en een veel keinere steekproef in deze tabel. Zij moeten daarom hier nie: ais absoluut worder. opgevat.

Bronnen: steekproef AIRA: SONA en SNA; plartage-archiever.

opwoog tegen de schaarste van dit kapitaalgoed. Dit dreef de taxatiewaarde en in nog veel grotere mate de koopprijs weer omboog. Zo zeer zelfs, dat de koopprijs de taxatiewaarde ging overtreffen, al zai de achteruitgang van het meest produktieve deel van de slavenbevolking daaraan mede debet zijn geweest.

Tussen 1808 en 1816 werd de slavenimport in Suriname door de Engelser. geheel stopgezet. Kwantitatief zowel als kwalitatief ging de slavenpopulatie daardoor snel achtertit. Tussen 1817 en 1827 werden we: weer vele dui. zenden nieuwe slaven ingevoerd, maar dat kon niet verhinderen dat de waarde van de slaven enorm was gecaald. De grote vraag en ce semilegale wijze waarop deze nieuwe importen plaatsvonden - via niet-britse of Nederlands-Caraïbische eilander. - maakte de aanschaf bovendien erg kostbaar. Na die tijd vonden geen importen mee plaats en werden piantages vrijwel niet mee: getaxeerd, zodat verdere negentiende-ceuwse gegevens over de waarde van dit kapitarlgoed ontbreken.

Tussen suiker- en koffieplantages bestond geen verschil in de taxatiewaarde van hun slaven. De mate waarin de slaven bepalend waren voor de waarde van een plantage verschilde daarenteger wel per sector en fluctieerde bovendien in de loop der ijid.

Gedurende de jaren 1750 en 1760 was het aandeel van de slaven in de taxatiewaarde van beide soorten plantages tamelijk stabiel; alleen lag het op suikerplantages iets hoger dan bi; koffie, vanwege de grotere omvang van de slavenmaclit (Tabe: 18). In de jaren 1770 werden de relatieve waarde en omvang van beide soor:en slavenmachter. vrijwel gelijk. Allecr. was het aandeel van de slaven in de taxatiewaarde var. de plantages licht gedaald. 
Dit was waarschijnlijk het gevolg van de eerder aangestipte speculatieve opwaarcering van de plantages, met name in de periode 1768-1774, wáarbij de waarde van andere kapitaalgoederen, zoals grond, sterker was gestegen dan van de slaven. Gedurende de daaropvolgencie twee decenria was het gemiddeld aanta' slaven op beice soorter ondernemingen aanmerkelijk gedaald, maar bepaalden zij weer in iets grotere mate de totale taxatiewaarde.

Van de eeuwwisseling af begon zich het vervai in de koffiesector af te tekenen. Het gemiddeld aanta: slaven bleef daien, terwijl het in de suikersecto:, ra 1816, weer flink onhoog ging. Opvallend is ook de vee! grotere vermeerdering van de relatieve waarde van de slaven op koffieplantages dan op suikerplantages. Ook dit was een gevo.g van het verval, doorciat in de koffiesector andere kapitaagoederen, grond en gewassen, drastisch in waarde verminderden.

Al deed de suikersestor het beter dan de koffiesector, toch gingen ook daar in de jaren 1820 de slaven in veel grotere mate de waarde van de ondernemingen bepalen. Hier was achteruitgang niet de oorzaak, maar de al langere tijd heersence slapte in de handel in plantages. Het aarbod was groot, de vraag gering, zodat de kapitaalgoederer adnmerkelijk in waarde daalden. Aleen voor slaven gold dit niet, zij bleven een veelgevraagd en schaars kapitaalgoed, waardoor tun relatieve waarde stegg. Meestal werden in de negertiende eeuw plantages al.een nog gekocht vanwege de daaraan verbonden slaven. In feite girger zi; daarom, bi; verkoop, v:ijwel $100 \%$ van de reële plantagewaarde uitraken.

Bij sterk arbeidsintensieve ondernemirgen zoals plantages, was een consiante aanver van slaven van cruciaa: beiang. De WIC verloor zelfs haar monopolie op deze hanciel in :730 toen zij riet meer dan die vourwaarde kon voldoen. Van die tijd af werd de handel opengesteld voor particuliere handeiaars, die inderdaac Surirame tot het begin var: de jaren 1770 vrij constant or van voldesende siaven hebben voorzien. Zodra de planters echte: hun kredietwaardigheic verloren, stokte ook de siavenimport. Dat deze situatie meteen exnstige gevolgen had, blijk: wit de woorden van twee belar.grijke Surinaamse administrateurs, C. Graafland en A. Gootenaar, die in 1778 opmerkten dat

'de Colonie Jaarlijks een annver van ruym 5000 Slaven noocig heeft, om de afgestorvene en oude te st:ppleeren, [maar] seedert Anno 1774 tot Anno 1777 incluys, en dis iri Vier Jaaren ciat getal niet is adngeuragt, Ja, in het laatste Jaar geen $600^{\prime}:$

Bij een jaarijkse bevolkingsaframe in die tijd var 2 tot 3\% (Tabel 47), was dit een zeer bedreigende situatie voor de plantages. Toen daar in de jaren 
1780 geen verandering in kwam bleken dan ook tal van suikerplantages aver een te kleine slavenmacht te beschixken om het bebouwd areaal voldoende te kunsen bewerken (Biom 1787:55).

Ook op koffieplaritages werd het germis aan slavenimporten gevoeld. Zo bleek bijvoorbeeld bij de plantages Maria's Lust en Visserszorg, dat in 1780 en 1791 ieder bijna een-vijfie van de bebouwde grond had verlaten 'door gebrek aan slaven'.5

Ondat inmiddels de meeste Nederlanders zich uit de slavenhandel hadden teruggetrokker, werd opnieuw een mercantilistisch begirsel overboord gezet en mochten voortaan ook buitenlanders Suriname van slaven gaan voorzien. Deze hadden uitstekend in de gaten hoezeer men in Suriname om siaven verlegen zat en wislen daarom hoge prijzer: te bedingen. ${ }^{6}$

Het onderzoek naar de omvang van de Surinaamse slavenimport is nooit verder gekomen dan het jaar 1795 (Postma 1975a, Goslinga 1985), zodat het lijkt alsof na dat jaar geer slaven meer werden ingevoerd. Niets is echter minder waar. Zo zijn bijvoorbeeld tussen 1 mart en 17 augustus 1799 660 slaven ingevoerd met drie Amerikaanse en dertien Deerse schepen. Ook uit plantage-archieven over deze periode blijkt, dat tot 1808 de aanvoer zeker niet stil stond. ${ }^{7}$ Het liquiditeitsprobleem op veel van ce plantages werd omzeild door de slavenhandelaars in natura te betalen. Zo wercien bijvoorbeeld de 36 gekochte slaven var piantage De Nieuwe Grond betaald met koffie van 41 tot 53 cent per pond, tot een bedrag van $f 775$ tot 850 per persoon. In total kostten deze aankopen daa:um ongeveer 65.000 pond koffie, wat overeenkwam met b:jna een hele jaaroogst..8 Aangezien op deze. manier de produkten raar buitenlandse markten verdwener, werd hiermee wederom een mercartilistisch principe ondergraven.

In 1808 schaften de Engelsen in al hun Westindiscie bezittingen, waatonder op cat moment Suriname, de slavenhandel met Árika á. Ook na de

5 ARA: SONA, 252, 708.

s Dat bleek bi; voorloeld uit een brie? van administrateur J. Rocherteau (1790). 'Intusschen zijn er twee Statiaanse barquen met Slaaven binnen geloopen, dan naauwelijks aan l'aramaribo [geland] off de geheele Arrasoeners waaren verkegt, zelve tot hooge prijsen, en welke waarschijnlijk aanhouden zullen zo lang de Nationaie scheepvast geen aanvon geproportioneerd aãn de behoefte van de Colonie zal brengen. De Engelsche welke zedert de laatste drie Jaaren hun Slaven zenden hebber zig tot een Regel gesteld, onse apeleyd gaende te houden, en daar door de hooge Prijgen te maintineseren, want hin toevoer slegts mest kleine vaartuygen waat mede 70, 80 à 90 Slaaven om de twee à drie Maanden gejezigd, vinden Zij bij hun adnkomst altoos een graagte die hun overlaat de Prijsen willekeurig te fixeeren.' (GAR: Collectie-Tudig, in6n.)

7 Een steekproef onder tien piantages in de periode 1798:807 laat zien dat per ondermeming genniddeld ruim 20 Afrikaanse slavern werden adngekocht, dat wil zeggen ongeveer $13 \%$ van hun totale slavenbevolking. Bovendien geidt voor het merendeel van dez: plantages dat de: gegevens slechts een paar jaa: van deze periode besiaan.

8 Collectie-Insinger \& Co., Nutulboek Biesterbos. In die periode werd op De Nicuwe Grond jaarlijks ongeveer 75.000 pond ko?fie geproduceerd. 
teruggave van de kolonie aan Vecierland in 1816, werd het verbod gehandhaafd. Er werd zelfs in Suriname een gemengd Nederlands-Brits gerechtshof geïnstalleerd dat op de naleving van het verbod moest toezien. In praktijk kwam daar echter niets van lerecht. Inter-Caraibische slavenhandel was namelijk niet verboden en vooral Franse handelaars maakten daarvan handig gebruik door zogenaamd slaven aan te voeren van de Frans-Westindische eiander. In werkelijkheid waren deze slaven echter pas oniangs uit Afrika geimporteerd (Fmmer 1974:107).9 Het is niet onwaarschijnijk, dat naast deze openlijke, semilegale aanvoer in Paramaribo een aantal slaverhandelaars hun waar wist binnen te smokkelen via de vele kreekjes en rivieren langs de lange Surinaamse kustljin. Slechts éenmaal is een dergelijk schip opgebracht (Emmer 1974:106). Op zich een bewijs dat dit inderdial voorkwam. Voor de rest stond de lakse houding van de marine en het Vederiandse gouvernement er borg voor, dat zulke handelaars vrijwel ongestoori hun gang konden gaan. ${ }^{\circ}$ De plantersbelangen wogen voor de koloniale overheid zwaarier dan de door Engeland afgedwongen abolitie. Toch kreeg uiteindelijk de Engelse regering haar zin, toen in 1826 werd besloter. in Surirame slavenregisters aar te leggen. Daarin moesten alle slaven worden opgetekend en vervoigens moest iedere mutatie worden biggehoucien. Dit raakte eer. effectief einde aan de slavenimporten.

In de periode 1816-1827 hadden de planters ecliter flink geprofitee:d van de 'verse' aanvoer uit Afrika. Afgaand op de omvang van cie totale slavenpopulat:e in 1813 en 1827 en het gemiddeld sterfte-overschot in de tussenliggende jaren, moeten er tusser. 1816 en :827 zo'r 12.000 slaven in Surirame zi;n ingevoerd." In deze periode waren de siavenaankopen groter dan in de jaren rond 1800.12 De suikerplartages trokken meer voordeel van de nieuwe :mporten dan de koffieplantages. Er was in deze jaren dan ook wee: meer kapitaal beschikbaar. Een aantal schulden was

9 I.ammints (:982:189) schrijft dat op die maxier alle'en al tussen 1819 en 1821 bijna 7.000 slaven van ongevecr ten Caraitische eitandon in Suriname waren aangevocrd.

10 Emmer (1974:109-10) schrijft hierover: 'Hct is dan ook geen wonder, dat dcze rechters zich in ex? heogst onangenane? positje voelden. De werkloos? leid, waartoe zij gedoend waren, was in het geheel geen gevolg van het nntbreken van illegale slavenhandel in Suriname, zoals Jen Haag decd voorkomen, maar van laaxbaar onvo'doende patrouilleactiviteit van de Nevderlandse inarine. De Gouverneur van Suriname liet de marine zo min mogelijk uitvaren. Soms was er t:jdens de aflossing van het eskader voor lange tijd in het geheel geen oorlogsschip in de haver van Paramaribo.'

11 Dit cijfer is tut stand gexumen up basis van de berolkingsaanivas in de plantagesectoren tussen 1813 en 1836 (Tabel 44) en het sterfte-overschot in die sectoren (Taxel 47), waarbij het laatste voor de katoen- en houtsector is gesteld op 0 . Rekening houdend met marronage en manumissie resulteer: dan enn gelal van ca. 12.000 .

12 Een stepkproef onder zes suiker-en vier koffiepiantages in de periode $1816-1827$ toont dat de suikeronderneminger. gemiddeld bijna 31 en de koffieplantages ruim 14 Afrikaanse staven aankochten. Samen bettéxent dat gemiddeld 2]\% varn hun slavenbevolking. 
kwijtgescholden en in het algemeen was de suikersector minder met schulden belast geweest dan de koffiesector (zie Hoofdstuk VIn).

De vraag is nu wat er gebeurde met de arbeidsvoorziening, nadat in 1827 aan de slavenimport definitief een einde kwam. Tot aan de Emancipalie heeft de Surinaamse slaverpopulatie a:tijd te kamper gehad met een sterfte-overschnt, $z$; j het in afnemerde mate. Het gevolg was dat het lotaal aantal slaven voortdurend daalde. Het is daarom zeer opmerkeijk dat in de loop van de negentiende eeuw, vooral na 1827, de slavenpopulatie van de suikersector flink toenam.

Gedurende het derde kwart van de achttiende eeuw werden vele miljoenen guldens in de Surinaamse plantage-economie gepompt. Het grootste deel daarvan kwam ten goede aan de koffiesector, zodat daar de mogelijkheid om slaven te kopen het groots! was. De koffieplantages hadder natuurlijk ook meer siaven nodig, omdat zij merendeels nog in hun opbouwfase verkeerden. Het gevolg was dat in die periode het aantal koftiesiaven met $132 \%$ toenam. In de suikersector daarentegen, nam de populatie met $1.3 \%$ af door het verdwijnen van dertig ondernemingen.

Rond 1770 bereikten de slavenimporten en daarmee de totale plantagepopulatie een xwantitatief hoogtepunt. Van dat moment af tot circa 1816 konden de sterk gedaalde - en tijalelijk zelfs geheel gesiopte - siavenimporten het chronisch sterfte-overschot onder de slaven bij lange na niet compenseren, zodat het total aanial piantageslaven dramatisch daaide. Bovendien kwam de nicuwe katoensector er bij, die niet alleen zijn aandeel

Figuu: 7. Aantal siaven per planiagesector :752-1862

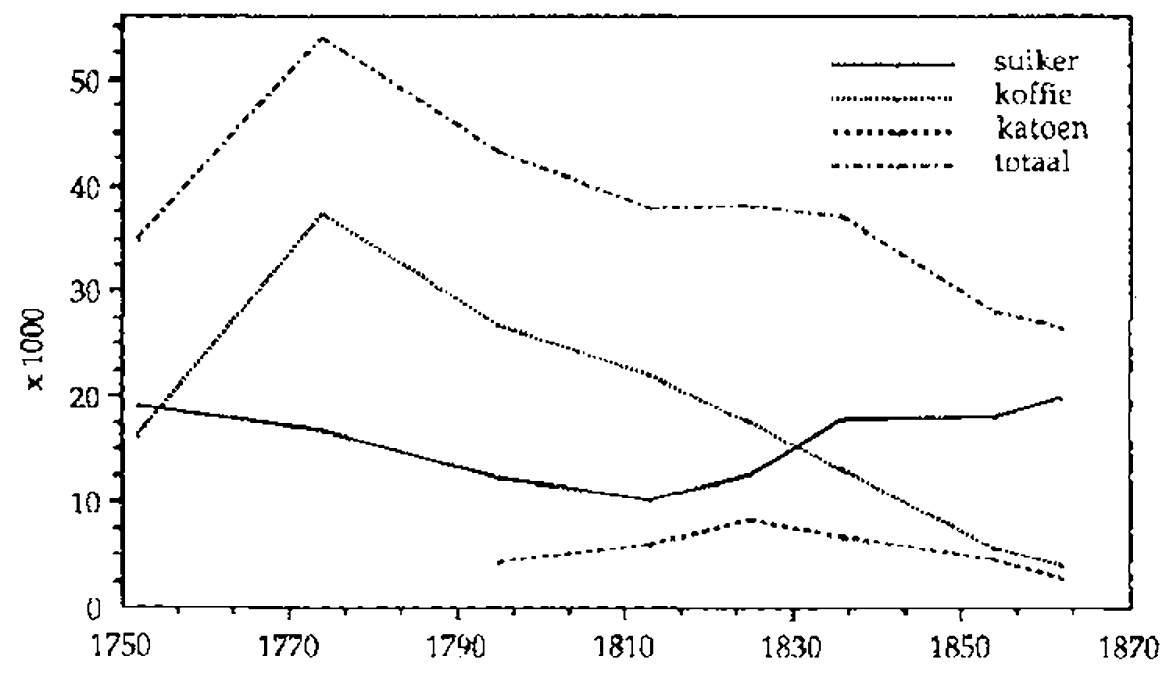


in de importen opeiste, maar bovendien siaven wegzoog uit de andere twee sectorer, vooral uit de koffiesecto:.

De achteruitgang in de koffiesector, die eind achttiende eeur op gang was gekomen, xwam in eerste instantie de arbe:dsvoorziening van de twee andere sectoren ten goede. Tussen 1770 en 1825 werden in total 143 koffieplantages verlaten, waarvoor er slechts 26 in de plaats kwamen. Een aantal van deze voormalige koffieplantages schakelde over op een ander produkt (katoen, suiker, hout of kost), maar het merendeel werd daadwerkelijk verlaten. De hierbi; vrijkomende arbeid werd maar al te graag door de twee andere sectoren overgenomen. In combinatie met de nieuwe slavenimporten gedurende de jaren 1816-1826 konden daardoor de populaties van zowel de suiker- als de katoensector aanzienliik groeien.

Begin jaren 1830 trad ook in de katoensector het verval in en werden, evenals in de koffiesector, steeds meer plantages gedurende de daarop volgende cecennia verlaten. Tussen 1827 en 1862 stopten 199 plantages met de verbouw van koffie of katoen. De uitstool van arbeic als gevolg daarvant, compenseerde niet alleen het sterfte-overschot, maar stelde de suikersector zelfs in staat om de arbeidsmach met $45 \%$ uit te breiden. In feite profitecrde de suikersector zelfs nog mee: van het verval in de andere sectoren, want een aantal koffie- en katoenplantages wist hum kwijnend bestaan nog te rekken donr hun slaven als arbeidsploeg aan suikerpiartages te verhuren.

Toch is het de vraag of alle vrijkomende arbeid voldoende was voor de expanderende suikersector. Twee voorbeelden uif de plantagepraktijk kunnen dit verdilidelijken. Het eerste is plantage Potribo aan de BovenCommewijne. In 18.6 bevonden zicn daar 66 slayen. Ondanks de aankoop van 30 nieuwe slaven gedurende de daaropvolgende jaren, bleek in I828 de totale populatie :och weer te zijn gedaald tot 54 slaven, van wie niet meer dan 21 in het veld werkten. Aangezien dit veel te weinig was, werden zij terzijde gestaen door 12 inuurslaven van de koffieplantages Beekviet en Zorg en Toop. Drie jaar later werd de koffieplartage. Nicuw Roeland, van dezelfde eigenaars, verlater en de slaven overgebracht naar Potribo. Daarmee felde de plantage plotsklaps 155 slaver. Desondanks klaagden de administrateurs in 1843 dat de bevolking weer tot 115 slaven was gereduceerd en dat ex al enige ;aren met humrslaven werd gewerkt teneinde de reveruen in stand te houden'.13 De eigenaars toonden zich daarop bereid geld uit te trekker. voor de aankoop van slaven, maar ondanks de vele plantages die werden verlaten is dat nooit gelukt. ${ }^{14}$ Lo waren er

13 GAA: PA-6OD, 544 .

14 in 18.45 moest op deze plantage 20 ha. busland worden ing, ${ }^{2}$ polkerd en beplant. Aangezien dit de krachten van de eigen arbcidsmacht verse te bovcr ging, werd besloten, speciaal voor dit karwei, nog eens tien ext:a slaven te huren. Toch boden ook huurslaven op de lange duur geen uitkismst en bovendien was dit cen kostbare a angelegenheid. Daarom reserverercien die 
in 1863 op deze plantage nog maar 81 slaven over cie de vrijheid kregen. is

Een tweede voorbeeld van de gespannen Surinaamse arbeidsmarkt is de suikerplantage Vosserburg, eveneens aan de Boven-Commewi;ne. Deze plantage, die een stuk groter was dan Potribo, telde in 1822235 slaven. Twintig jaar later bicek de bevolking zelfs uitgegroeid tot 263 slaven, exen negentiende-eeuws hoogtepunt voot deze onderneming. Om die groei van 28 slaven te kunnen realiseren, had men echter in de tussenliggende periode totaal 123 slaven moeten aankopen. Aangezien dit een zeer kostbare zaak was, besioot men varaf 1843 van verdere aankopen af te zien. Or.danks de niet geringe omvang van de Vossenburgse slavenpopulatie, werd ook op deze plantage gebruik gemaakt van huurslaven, vooral wanneer er extra$z$ ware werkzaamheden moester. worden verricht. Zo werden in 1829 de molen- en vaartrenzen uitgebaggerd met behulp van 25 zogenaamde delvers, die voor een periode van vier tot zes weken waren gehuurd van ene Sanches. Vijf jaar later werden van verschillende kof fieplantages opnieuw twintig slaven gehuurd, ditmaal voor de aanleg van een nieuw stuk bouwland. Toer men in 18.35 deze uitbreiding wilde vervolgen, duurde het tot eind 1838 voor zicin een gelegenheid voordeed om hiertoe twintig huurslaven te contracteren. Hetzelfde gebeurde in 1852, toen men tot eind 1855 moest wachten op een ploeg huurslaven.

Een jaar later, toen opnieuw een stux land in cultwur mues: worden gebrach:, besloten de administrateurs het over een ardere boeg te gooien. Huurslaven waren duur gebleken en moeilijk te krijger, zodat de werkzaamheden toch met de eigen slavenmach: moesten worden uitgevoerd. Voor de eigenaars stond de continuitteit van de suikerproduktie primair en daarom werd het voedseiareal terug gebracht var 53 naar 21 ha. De werkvermindering die dit voor de slaven opleverde kon worden besteed aan het onderhoud en de uitbreiding van het suikerrietareaal. De krappe arbeidsmarkt noopte de beheerders tot deze matregel, hoewel cit een flinke stijging betekende van de onkosten voor slavenvoedsel, da: nu moest worden aangekocht. It

De voorbeelden van Potribo en Vossenburg tonen aan dat het, ondanks de arbeid die vrijkwam wit de andere sectoren, toch nief eervoudig was om in de suikersector aan voldoende slaven te komen. Hicr ditent echter wel

eigenaars in 1849 f 20,000 om de opgeheven suikerplantage Des Tombesbrig, alleen vanwege de 82 daaraan verbonden slaven, op te kupen. Uiteincielijk kwam het daar echter toch nist van, omdat de plantage op het laatste moment riet in veiling werd gebracht. Ook daarna is het niet meer gelukt nieuwe slaven te kopen, hetgeen duid: op een gispannen arbeicsmarkt (CAA: J'A- $(X)(), 544$ ).

15 CBBS: emancipatieregisters.

16 Alle informatie over Vossenburg: Surinaams Museum: Verslagboekjos en verantwoorde rekkeningen van de betreffende jaren. 
een kanttekening bij te worden geplaatst. Zowel Potribo als Vossenburg behoorden tot de oudste suikerplantages van de kolonie. Wanneer echter onderscheid wordt gemaakt tussen soortgelijke en in de negentiende eeuw nieuw aangelegde of op suiker overgeschakelde plantages, dan blijki het de nieuwe plantages veel beter dan de oude te zijn gelukt hun slavenmacht uit te breiden. Van alle suikerp'antages in 1857, die ook al in 1813 werkzaam waren als suikerplantage of anderszins, hadden de oude in het laatstgenoemde jaar gemiddeld 121 en de nieuwe gemiddeld 120 siaven per plantage. In 1857 bleek dit op oude suikerplantages te zijn toegenomen tot 170 , op rieuwe daarentegen tot maar liefst 255.17 Nog sprekerder was de ontwikkeling van de toen tien grootste suikerplantages. Van deze top-tien behoorden alleen Hooyland en Santa Barbara tot de oude suikerplantages. Alkmaar, 't Vertrouwer en Rust en Werk waren alle drie rond 1750 aangelcgd als koffieplantage en schakelden pas na 3810 over op suiker. De resterende vijf plantages, Waterloo, Catherina Sopnia, De Resolutie, Nursery en Burnside, waren aile pas in de negentiende eeuw aangelegd. Kennelijk was er in het nieluwe deel van de suikersector mee: kapitaa: beschikbaar om slaver te kopen dan in het ouce deel. Aan verschil in arbeidsbehoefte zal het niet hebben gelegen, want overal werd luidkeels over het arbeidstekort geklaagd.

De relatieve arbeidsscharste maakte slaven tot een dulr kayitaalgoed. Omdat de pianters voornameli;k waren ge:̈nteresseerd in ve:dsiaven kan het prijsniveau van deze soort arbeiders worcien beschouwd als de beste indicatie voo: de gespannen Surinaamse arbeidsmarkf. Opnieiw verschaft plantage Vossenburg het duidelijkste voorbeeld.

In de jaren 1760 knstter veldslaven voor deze piantage gemiddeld $f 280$. In de jaren 1790 bleek dit al gestegen te $z$ :jn tot $f 610$ en in de jaren 1820 tot f650. Na de definitieve importstop werd in de jaren 1830 op Vossenburg voo: een veldslaaf gemiddeld $f 1.000$ uitgegeven en in het daaropvolgend decenrium zelfs $f 1.200$ tot 1.400 (Van Stipriaan 1989:111). In minder dan een eeuw was de prijs van een veldsiaaf vervijlvoudigd. Ook huurslaven waren duur. Afgezien van voeding en huisvesting bedroeg in de jaren 1820 de huurprijs per slanf én guider per dag. Later werd $f 1,25$ het standaardtarief. Dat dif fink kon oplopen blijkt uit het feit dat sommige partages meer dan $30 \%$ van hun totale inkomsten aan huursiaver. besteedden. 18

Arbeid was schaars en daarom duur. Twee zaken lagen aan die schaarste ten grondslag. Er kwam in de ioop van de negertiende eeuw toenemende

i7 Public Record Office: Trcasury 75, 14 en T'ubie Reccord Office: Colunial Office 278, 15; Hering 1858: appendix.

13 GAR: Collectie-Hudig, 330, 33i; Surinaams Museum: verantwoorde rekering 1838; (;AA: PA fin), 544, 545a; AIRA: JWI Bank, ]\$4. 


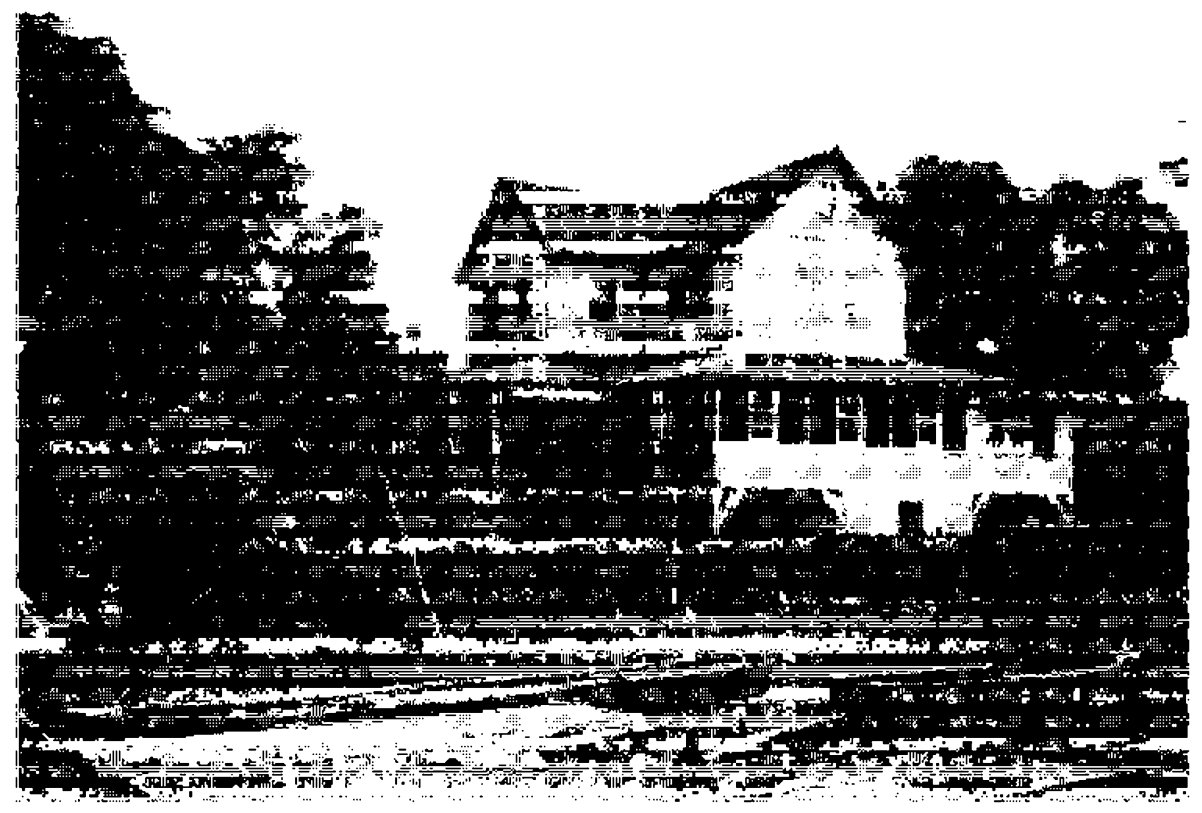

Woonhuis op plantage teperpol (Fote dex van Siprian) 
aandacht voor het lot van de slaven, vooral sadat de slaverhandel definitief was stopgezet. De koloniale overheid voerde een aantal regels in die de exploitatie yan de slaven aan banden iegder, zoals bijvoorbeeld een verbod op nachtarbeid (zie ook I Ioordstuk XI). Op de naleving van die regels werd bovendien veel meer dan voorheen toegezien. Deze taakverlichting van de slaven viel samen met een stijging van de optrengst per plantage in de suikersector (Tabel 27). Dit is tever.s de tweede verk!aring voor het arbeidstekort. De introductie van enkele belangrijke innovaties in de suikerfabrieken op de plantages - waarvan de stoommachine niet de minste was - makkte de uitbreiding van het suikerrietareaal mogelijk en uit een standpunt van optimaal gebruik zelfs noodzakelijk. De toch al zeer arbeidsintensieve suikersector kon daarom de instroum van grote groepen slaven gemakkelijk aan en za: in feite altijd te springen om meer arbeidskrachten.

Dit alles leidde, vooral in de negentiende eeuw, tot een zeer grote mate van mobiliteit binnen de Surinaamse plantage-economie. Ifet bedd van een volstrext bewegingloze slavenmaa:schappij wordt daardoor teniet gedaan. Gehuurde arbeidsploegen pendelden van de ene naar de andere plantage en complete populaties werden, soms meerdere maien, naa: ardere ondernemingen overgep.aatst. Zo zijn alleen al in 1831-1832 van tenminste 20 plantages de slavenmachter, samen 1.057 slaven, naar eiders verplaatst. Tussen 1851 en : 862 gebeurde hel zelfde met minstens 4.595 slaven van 47 plantages, circa $15 \%$ van de Surinaamse plantagebevoiking, die hoofdzakelijk naar suikerondernemingen werder! overgebrach. ${ }^{\text {i9 }}$

Het vaak geopperde idee, dat een overvloedige aanwezigheid van goedkope slavenarbeid in Caraibische plantage-economieèn een obstake: vormden voor efficiënte produktie en technologische vernieuwing (zie Boomgaard en Oostinciie 1989:4), gaat in ieder geval voor de negentiende. eeuwse suikersector van de Surinaamse plantage-economie niet op. Het omgekeercie was zelfs het geva: slaven waren schaars en duur en werden Liat eens te meer door efficiëntere produktie er. lechnologische vernieuwing (Van Stipriaan I989:112-3).

\section{Gebouwen en machines}

Bij het opzetten var. een plantage werd in eerste instantie voistaan met de bouw van enkele provisorische optrekjes. Wanneer de eerste aanleg en aanplant gereed warer gekomen, ging men over tot he: neerzetten van de definitieve gebouwen. Deze waren vrijwel altijd van hout, maar de belangrijkste gebolwen rustter op een slenen voet (fundameat) of stenen newten (pilaartjes). De plantagegebouwer. kunnen worden ingedeeld in drie 
categorieën: gebouwen voor het dagelijks leven en onderhoud van de plantagebewoners, opslagloodsen en fabrieksgebouwer.

Tot de gebouwen uit de eerste categorie behoorden natuurlijk de woningen. Met name het woonhuis van de eigenaar was vaak een trots en luxueus gebouw in karakteristiek Surinaamse stijl (Temminck Groll 1973). Met de toename van het absenteisme werd zo'n planlagehuis steeds vaker de verblijfplaats van de administrateur. Normaal gesproken woonde deze in de stad, maar wanneer hij de onderneming kwam inspecteren, of als hij in de Grote Droge Tijd het benauwde Paramaribo wilde ontvluchten, nam hij zijn intrek in de voormalige woning van de eigenaar, die toen ook meestal diende tot huisvesting van de plantagedirecteur.

In schrille tegenstelling hiermee stond de behuizing van de slaven. In de achttiende eeuw waren het merendeels eenvoudige hutten met palmbladeren bedekt, in de negentiende eeuw meer en meer houten blokwoningen, waarin aparte vertrekken waren afgescheiden, in een stijl zoals die heden nog te zien is op plantage Mariënburg.

Naast het plantershuis stonden meestal cen of twee zijgebouwen, waarin zich de keuken en allerlei voorraadkamers bevonden. Ook beschikten de meeste plantages in de negentíende eeuw over een zickenhuisje voor de slaven, die overigens met even veel recht onder de opslagloodsen had kunnen worden gerangschikt. Voor de sanitaire behoeften van de plantagestaf waren er verder nog zogenaamde gemakhuisjes.

Opslagloodsen waren er in soorten en maten op de plantages. De grootste en meest kostbare waren de tras-, koffie- en katoenloodsen. Trasloodsen waren grote gebouwen waarin het uitgeperste suikerriet (tras) als brandstof voor het suikerkoken werd opgeslagen. Zo was bijvoorbeeld op plantage Woutvliet, later Livorno geheten, aan de Surinamerivier in 1770 een nieuwe trasloods neergezet, met een afmeting van $37 \times 7,5$ meter, die werd getaxeerd op $f 14.500 .{ }^{20}$ Daarmee bepaa:de dit gebouw $20 \%$ van de waarde van alle bedrijfsgebouwen op teze plantage.

Koffie en katoenloodsen waren hoge gebouwen, met een of meer verdiepingen, die werden gekenmerkt door de grote hoeveelheid aangebrachte luiken ter bevordering van de luchtcirculatie. Hier werden de bewerkte produkten bewaard en ondergingen zij hun laatste droging. Beneden bevonden zich grote bakken op sleden, die naar buiten konden worden geschoven als het niet regende, om de daarin opgeborgen koffie of katoen te laten drogen. Voor of raast deze loodsen waren altijd een of meerdere stenen vloeren aangelegd, waarop de geoogste produkten hun eerste droging ondergingen. In veel koffieloodsen vond ook het zogenaamde stampen 
plaats, zodat dit gebouw niet alleen voor opslag diende. Dergelijke loodsen bepaalden in hoge mate de waarde van het gehee! aan bedrijfsgebouwen. Zo beschikte bijvoorbeeld de katoenplantage Anna Catharina aan het Matapicakanaal over een twee verdiepingen tellende katoenloods van $10 \times 25$ meter, die in $: 806$ werd getaxeerd op $f 21.000$, of $40 \%$ van de totale waarde van de bedrijisgebouwer. 21

Andere gebouwen die ook tot de categorie opslagioodsen kunnen worden gerekend en op vrijwel iedere plantage voorkwamen, waren: stallen en hokken voor runderen, paarden, schapen, varkens, geiten en pluimvee; cen duivenhok; het botenhuis - een soort overkapping over de sluiskreek, waaronder korjalen, ponten en de tertboot, varend equivalent van een rijhig, lagen opgeborgen - en een zogenaamd korenhuis als bergplaats van maïs.

Daarnaast beschikte vri;wel iedere plantage nog over een timmerioods, op suikerpantages cok vaak kuiperloods genaamd die in feite in alle drie de categorieër kan worden ondergebracht. In dit gebouw verrichtten de ambachtsslaven namelijk allerlei reparaties en de kuiperslaven maaxten er suikervater. Tegelijk was het ook de bergplaats voor de gereedschappen, terwijl er meestal op zolder een kamertje was afgeschoten tot logies var de blankofficier(s).

De categorie fabrieksgebouwen verschilce per type plantage. Op koffie. plantages kan hiertoe de zogenaamde rrorsloods worden gerekend, waarin de menarie met wasbak (installatie om de koffie var. zijn schil te ontdoer.) en de koffiebreekmo:er. stonden opgesteld. lers dergelijks was op katoenplantages de katoenwerk- of maalloods, waar zich de katoenpers, menarie en trapmolens bevonden. In de negentiende eeuw werden op de meer geavanceerde katoenplantages in dit gebouw ook de stoommolens geplaatst. ${ }^{22}$ Dergelijke katoen- en koffiewerkloodsen waren in de regel iets minder groot en kostbaar dan bergloodsen. ${ }^{2.3}$

De meest kostbare en gecompliceerde fabrieksgebouwen waren celhter te vinden op suikerplantages. Zij bestonden uit een molen-, cen kook- en een dramhuis. Op plantages met een water-, of later stoommolen, vormder. molen- en kookhuis altijd een geheel. Dit was dan het grootste en kostbaarste gebouw van de hele onderneming. Daar waar gebruik werd gem.aakt

2I ARA: SONA, 296.

22 Zo beschikte bijworbeeid plantage De I kersteling aar. de Warappakreek in 1844 over een katoenwerkloods van $27 \times 12,5$ meter, watrir. onder mer stondex opgesteid: ern nieuwe Engelse stoommolen (6 pk), cen oude stoommoien, eer. kathenpers, een katoenwaaimolen, twee Engelse katoenmolens met houten rollers en twee gewone katuer.mulens (AKA: SOB\&W i8281876,3029 ).

23 Koffieplantage Jagtlust aan de Surinamerivier, beschikte b:jvoorbccld in 1780 over een tweeverdiepingen hoge koffieloods $(30 \times 12,5 \mathrm{~m})$ ret een geschatte waarde van $f 19.500$ en een nisuwe morsiouds $(38,5 \times 5,5 \mathrm{~m})$ die werd getaxeerd op $f 11.400$ (ARA: 5ONA, 706). 


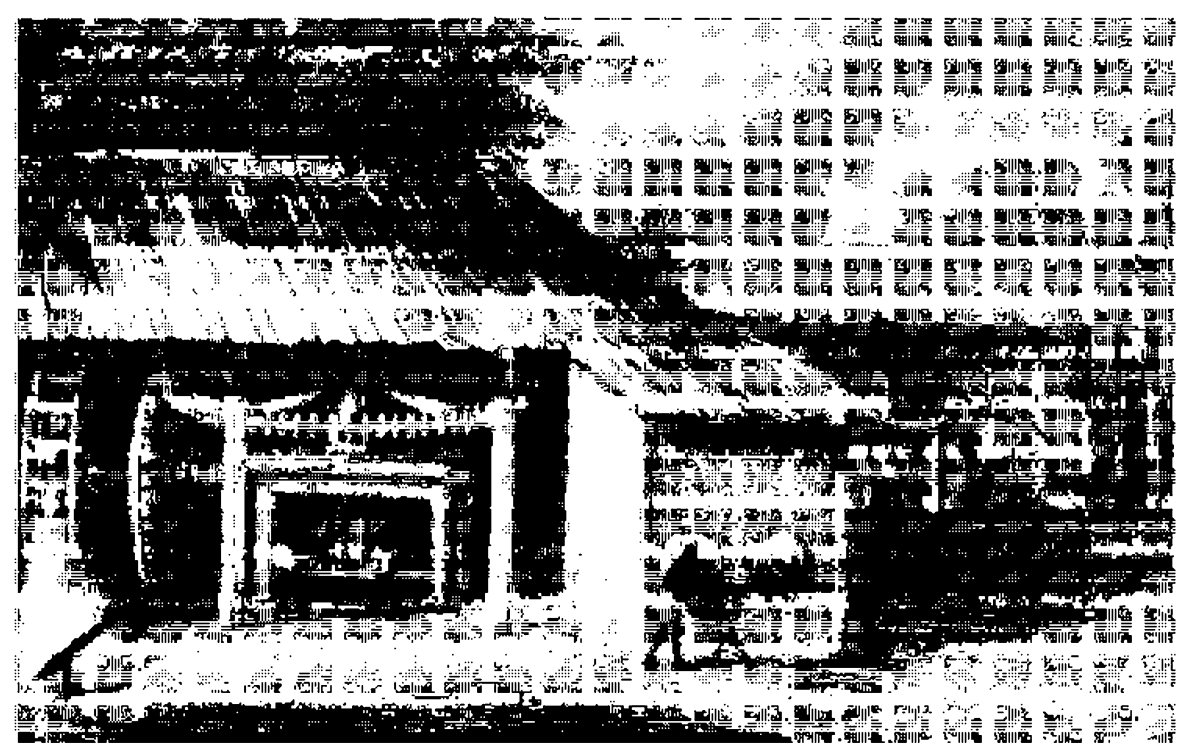

Walermalen om suiker te persen (Benoit 1980 foto 57) 
van een beestenmolen, waren molea-en kookhuis var elkaar gescheiden en minder kostbaar. Het waar deverschil thissen beide soorten molens wordt het best geillhstreerd aan de hand van de taxatie van plantage Vredenburg aan de Para in 1769. Deze plartage beschikte namelijk over zowel een beesten- als een watermolen. De eerste was in dat jaar nog geen vier jaar oud en werd geschat op $f 15.000$. Daar moesten nog wel de 32 paarden die voor de drijfkracht zorgden bij worden opgeteld, zodat het totale bedrag uitkwam op $f 22.000$. Fr was geen apart kookhuis, dat zat al inbregrepen bij de watermolen, maar de waarde van zo'n gebouw kon worden gesteld op circa $f 10.000 .24$

Zo'n beestenmolen was vri; eenvoudig van constructie: aan de koge as van de middelste van die cylinders waar het suikerriet susser. werd geperst (de rolcers) waren dwarsbalken bevestigd, die zo laag hirgen, dat de trekdieren dje de as ronddraaiden, e: twee aan twee aan aangespannen konden worden.

De constructie van een watermolen was heel wal gecompliceerder. Allercerst was er de gemetselde stener: kom, het waterreservoir - op Vrecenburg 30 meere lang wasin het waterrad in beweging werd gezet. Dit was cen achtkantig scheprad, met een diameter van ruim 10 meter, dat door de val van het waler in de kom in beweging werd gezet en daarmee tevens het zogenaamcie bonkelrad, dat aan de as van het scheprad was bevestigd, cieed ronddraaien. De taiden van alt bonkelrad greper in de tanden van het haaks daarop l:ggende kamrad, dat daardoor de as van de middelste roller in beweging zette (zie ook Hoofdstuk VI). Al deze constructies waren, in ieder geval in de achttiende eeuw, van hout, evenals de muren van het gebouw.

In hetzelfde complex bevond zich ook het kookhiis. Dit was grotendee's van steen, in verband met de grote vuren onder de batterij met suikerketeis waarin he: uitgeperste suikersap werd gekookt. De rook werd algevoerd door twee gemetselde schoorstemen. Nasst de kookbalterij stond het zogenaande harbekot (6x10 meter), een houten stellage wasrop de vaten suiker konden witle'ken. Dit geneel overdekte complex werd op Vredenburg getaxeerd op $f 68.000$. Dearnaas: was er nog een, deels uit steen opgetrokken, dramhuis, waar een ruw soort rum (dram) werd gedistilleerci. Dit dramhuis werd geschat op $f 4.000$, zodat het total var de fabrieksgebouwen op Vredenburg uitkwam op een waarde van $f 94.000$, of $34 \%$ van de totale taxatie. ${ }^{25}$

Aangezien er geen taxaties bekend zijn van plantages mel cen stoommachine, is niet na te gaan in hoeverre de komst van dergelijke werkltigen

24 Bijvoorbccld op de nabij gelegen plantage Bleyendad werd in 1768 het vrij nieuwe koukhuis getaxecrd op 10.925 (ARA: SONA, 227).

25 Tolale taxat:e: $f$ 278.26́5 (ARA: 5ONA, 697). 
het aandeel van de suikerfaioriek in de totale waarde van de plantage is gaan beinvloeden. Waarschijnlijk is dit echter wel, gezien de grote hoeveelheid geld die met de installatie daarvan gemoeid was. Zo werd rond 1830 besloten een stoummachine te plaatsen up plarfage De Drie Gebroeders aan de Surinamerivier. De eigenaar, E. yan Emden in Suriname, bestelde daartoe in Nederland bij de firma Van Vlissingen \& Dudok Van I leel

een stoommachine van laage drukking van nu:m tien paardenkracht en horizontale suikermolen met verbinding op de machine geheel compleet $f 15.365^{26}$

Daarmee was Van limden er rog niet, want voor de overtocht en installatie van het geheel moest nog eens $f 10.413,30$ worden betaald, terwijl er bovendien een compleet nieuw stoomhuis diende te worder gebouwd.

Fen van de zaken dic suikexplantages een stuk duurcier makte dan andere ondernemingen, was het grote aantal benodigde stenen. Zowel in de uitgebreide waterwerken a!s in de fabrieksgebouwen, waren duizenden stenen verwerkt, die al.emaal uit Nederland kwamen. Alleer. al voor het opzetten van de stoommolen op De Drie Gebroeders werden de volgende materialen geimporteerd: 1.200 vuurvaste stenen, 60.000 'wal graauwe moppen', 120 vaten kaik en 60 vaten cement, samen voor $f 4.000 .27$ In dit geval ging het om een eenmalige aitgave, maar ook voor het normale onderhoud moesten dergelijke kostbare materialen regelmatig worden aangevoerd. ${ }^{23}$

Een belangr:jk verschil tussen koffie- on suikerpiantages was de mate waarin de bedrijfsgebouwen de waarde van een onderneming bepaalden (Tabel 19). De ingewikkelde constructie en de grote hoeveelheid verwerkte stener maakten alleen al het molen-en kookhuiscomplex meer waard dan de gezamenlijke bedrijfsgebouwen op koffieplantages. Hetzelide go:d voor de waterwerken, die op suikerpiantages uitgestrekter en groter in aantal waren dan op andere ondernemingen.

Op beide typen plantages steeg de re:atieve waarde van de bouwwerken gedurende de tweede helft van de ach:tiende eeuw. Ererzijds was dit op suikerplantages het gevolg van de vervanging van de beestenmolen door een kostbaarder watermolen, terwijl in de koffiesector de groei var de plantages uitbreiding van de becijifsgebouwen noodzake.ijk makkte. Anderzijds was de stijging een gevolg van de gedaalde relatieve waarde van andere kapitaalgoederen. Gebouwen waren in de taxaties nauwelijks onderhevig aan speculatieve opwaardering. Hun waarde werd min of nieer ais een vast

36 Surinaams Museum: Collectie-Brantsen, Verslagboekje 1832.

27 Surinaams Museum: Collertie-Brant5en, Verslagboekje 1832.

28 Dat bleek bijvoorbeld uit de kasrekening van plantage Rustenburg aan de Perica, waar in 1857 ruim $16 \%$ van de sitga ven werd besteed aan stenen, kalk en cement, zonder dist er nieuwe gebouwen of sluizen in die perinde werden neergezel (ARA: PWI Bank, 180). 
Tabel 19. Gemiddelde relatieve waarde der plantagegebouwen per sector $1750-1830$

\begin{tabular}{|c|c|c|c|c|c|}
\hline \multicolumn{6}{|c|}{-} \\
\hline periode & $\begin{array}{l}\text { totaal } \\
\text { bedrijfs- } \\
\text { gebouwen }\end{array}$ & $\begin{array}{l}\text { molen-en } \\
\text { kookhuis }\end{array}$ & $\begin{array}{l}\text { woon- } \\
\text { huis }\end{array}$ & $\begin{array}{l}\text { water- } \\
\text { werken }\end{array}$ & $\pi$ \\
\hline $1750-1759$ & $19,6 \%$ & $13,5 \%$ & $3,9 \%$ & $5,2 \%$ & 17 \\
\hline $1760-1769$ & 24,5 & 37,6 & 3,3 & 5,6 & 15 \\
\hline $1770-1779$ & 26,9 & 18,7 & 2,7 & 6,7 & 19 \\
\hline $1780-1799 * *$ & 27,0 & 18,3 & 2,6 & 8,2 & 11 \\
\hline $18100-1810$ & 28,0 & 18,0 & 2,2 & 6,1 & 10 \\
\hline $1820-1829$ & 24,3 & 16,3 & 1,4 & 4,3 & 9 \\
\hline \multicolumn{6}{|c|}{ koffie } \\
\hline periode & $\begin{array}{l}\text { totaal } \\
\text { bedrijfs- } \\
\text { gebouwen* }\end{array}$ & $\begin{array}{l}\text { \{abrieks- } \\
\text { loodsen }\end{array}$ & $\begin{array}{l}\text { woon- } \\
\text { huis }\end{array}$ & $\begin{array}{l}\text { water- } \\
\text { werken }\end{array}$ & $\bar{n}$ \\
\hline 1750.1759 & $10,4 \%$ & $5,1 \%$ & $2,5 \%$ & $1,3 \%$ & 29 \\
\hline $1760-1769$ & 12,2 & 6,6 & 2,2 & 1,7 & 28 \\
\hline $1770-1779$ & 14,8 & 7,8 & 2,2 & 1,7 & 29 \\
\hline $1780-1799^{* *}$ & 15,3 & 9,3 & 2,5 & 2,6 & 23 \\
\hline $1800-1810$ & 15,5 & 13,6 & 2,5 & 3,0 & 16 \\
\hline $1520-1829$ & 16,6 & 10,3 & 1.5 & 2,2 & 13 \\
\hline
\end{tabular}

* inclusief molen- en kooxhuis of fabrieksloodsen, slavenhuizen en vaartuigen, exclusief woonhuis en w'aterwerken.

* gelet op de geringe omvang van de steekproef zijn deze twee decennia samengenomen.

*42 koffie- en morsloods

Bron: ARA: SONA en SNA.

gegeven beschouwd, slechts afhankelijk van de reële conditie waarin zij zich bevonden. Na de speculatieve hausse van slaven en grond en gewassen rond 1770 daalde de waarde van deze kapitaalgoederen, met een stijging voor de bouwwerken als gevolg.

De achteruitgang van de relatieve waarde der bouwwerken in de jaren $1820^{29}$, was het resultaat van langdurige verwaarlozing. Door kapitaalgebrek en het feit dat het Engels Tussenbestuur het contact van absente eigenaars met hun Surinaamse bezittingen had belemmerd, was er lange tijd niets gedaan aan ver- of nieuwbouw. En als er in die periode kapitaal voorhanden was, werd dit gebruikt om de slavermacht weer op peil te brengen; de gebouwen konden ruyg wel even wacliten.

Overigens was op geen van de suikerplantages in de steckproef al een

7 Dit lijkt niet van toepassing op de bedrijfsgebouwen van koftieplaniages, maar ook daar was van achteruilgang sprake. Alieen werd het gemiddelde opgevijzeld door een aantal nieuwe plantages, met slame in Saramacca. 
stoommachine geplaatst. Ongetwijfeld zou dit in de jaren 1820 de relatieve waarde van de bouwwerken hebben vergroot.

Opmerkelijk is de daling op suikerplantages in de negentiende eeuw van de waarde det waterwerken. Anders dan in cie achttiende eeuw werd namelijk aan het vaartrenzenstelsel geen waarde meer toegekend. De reden daarvan blijf duister. Daarnaast werd natuurlijk in het algemeen in de jaren 1820 de relatieve waarde van de bouwwerken gedrukt door de aanzienlijke waardestijging van de slaven (Tabel 18).

Met name op koffieplantages verkeerden in de regentiende ecuw vecl gebouwen in een tamelijk depiorabele staat. Alleen wanneer het echt riet meer anders kon werd er geld a an hun onderhoud besteed, waarbij het woonhuis de absolute sluitpost vormde. Heel duideijjk wordt dit genlustreerd door de situatie op plantage De Nieuwe Grond. In I780 verkeerden de gebouwen allemaal nog in uitstekende staat. ${ }^{30}$ Halverwege de jaren 1820 moesten er forse reparaties worden yerricht aan de koffie- en morsloodsen, dienden de daken van de slavenwoningen compleet te worden vernieuwd en stonden het ziekeninuis, een zijgebouw en het woonhuis op instorten. De eigenaars gaven toestemming om de nodige reparafies te verrichten, zij het 'met de vilerste zuinigheid'. Dat gold echter niet voor het woonhuis waarin de directeur verbleef en ook de bouw van een nieuwe rij slavenwoningen moest nog maar even worden ixitgesteld. Desondanks verzuchtten de Nederlandse eigenaars in 1830:

'dat aan de gebouwen zoo vecle onkosten hebber. moeten gedaan worden is een invretende kanker voor pene plantage, die reeds door de omstardigheden agtersit gaat'. 3 :

En dan was De Nieuwe Grond een piantage die het nog tof 1860 heeft weter vol te houden.

\section{Grond en gervassen}

Bij het taxeren van plantages werd ook aan de grond en de gewassen een kapitaalswaarde toegekend. Bij grond ging het in feite om twee soorten, namelijk het bewerkte en het niet-bewerkte deel van het plantage-areaal. In principe had de riet-bewerkte grond geen wards, angezien bij de uitgifte van de concessies het gehele, nog onbewerkte areaal voor niets aan de planter in eigendom was gegeven. Toch werd ook het onbewerkte deel var het areaal in de taxaties een zekere waarde toegekenc. Afgezien van het eventuele hout dat er op stond, werd hierin de potentiële mogelijkheid uitgedrukt de grond ooit te bebouwen, of aan expanderende buurplantages te

30 ARA: SONA, 704

31 Collectie-Insinger \& Co., brieventook 
verkopen. De werkelijke waarde bleek overigens pas toen met de vestiging van vele tientallen nieuwe plantages in de benedenlanden schaarste aan grond begon te ontstaan en er daadwerkelijk verkopen plaatsvonden. Graafland en Gootenaar, twee beiangrijke planters en administrateurs, slelden dan ook in 1778 dat met name de laatst gevestigde groep planters wel dankbaar mocht zijn voor de gratis uitgegeven grond. Alleen al in het Matapicagebied was op die manier, volgens hen, de planters voor zo'n twee. miljoen gulden aan grond in de schoot geworpen. 32

Inderdaad warer er rond 1770 planters die met de verkoop van een deel van hun areaal een klein fortuin verdienden. Zo verkocht J. Passa.aigue, eigenaar van plantage Beekenhorst aan de Beneden-Commewijne, in 1768 ruirs 48 ha. onbebouwde grond aan de buurplantage Hoopwijk en ruim 19 ha. aan de andere buurplaniage Vrouweavlijt, voor een totaal bedrag van bijna $f 25.000 .33$ Overigens liepen de prijzen van onbewerkte stukken grond filnk uiteen. Van zes verkopen tussen 1768 en 1774 bleck de hoogste prijs $f 171$ per akker $\left(0,43\right.$ ha.) en de laagste $f 15$ te zijn geweest. ${ }^{34}$

Het ligt voor de hand dat de waarde van de grond die wel in bewerking was apart en hoger zou worken getaxeerd. Deze landerijen hadder namelijk al daadwerkelijk bewezen produktief te zijn en bovendien was er geirvesteerd in aanleg en onderhoud van trenzen, trekkers, bedden, dammen en paden. Gedurende het derde kwart van de achttiende eeuw werd echter in de taxaties geen prijsonderscheid genaakf tussen bewerkte en unbewerkte grond. De priseurs (taxateurs) stelden eenvondig een akkerprijs vast die zonder onderscheid gold voor het totaal areaal. Vanat circa 1780 kwam dat ondersche:d er wel. Voor de onbewerkte grond werd toen een aparte prijs opgesteld, terwijl die van de hewerkte grond was opgenomen in de waarde van het daarop staarde gewas.

Gedurende de jaren 1760 en 1770 werd er bij taxaties druk gespeculeerd met de grondprijs. Dat de waarde zo: oploper. was niet verwonderlijk. In die periode was vrijwel alle geschikte grond in de bestaande plantagegebieden uitgegeven en werd daarmee dus een schaars kapitaalgoed. Dit kan echter de indruk niet wegnemen dat van deze omstandigheid bi; sommige plantagetaxaties buitensporig gebruik werd gemaakt. Op suikerplantage Vrceland aan de Surinamer:vie: werd bijvoorbeeid in 1765 de akkerprijs geschat op $f 12$; in 1766 werd dat $f 20$ en in 1770 zelfs $f 90.35$ Tabel 20 toon: dat het niet overal zo extreem was.

GAA: Archicf 5028, Hande' port. 5

GAA: NA, 12720.

34 Naast Betkenhorst waren dat Belwaarde, 257 akkers a f 25; Bruynsburg, 194 akkers à f 15; Goudrijn, 238 akkers à $f$ 65; en Boxel, 320 akkers aे $f 97$ (GAA: NA, nrs. 12878, 12724, I2729, 12740).

35 ARA: SONA, mrs. 222, 22.4, 698 . 
Tabel 20. Gemiddeld getaxeerde akkerwaarde per sector 1750-1830

\begin{tabular}{lcccccc}
\hline periode & suiker $(f)$ & $\mathrm{n}$ & koffie $(f)$ & $\mathrm{n}$ & katoen $(f)$ & $\mathrm{n}$ \\
\hdashline $\mathbf{1 7 5 0 - 1 7 5 9}$ & 15 & 17 & 18 & 29 & - & \\
$1760-1769$ & 17 & 15 & 26 & 28 & - & \\
$1770-1779$ & 33 & 19 & 57 & 29 & - & \\
$1780-1799^{*}$ & 17 & 11 & 34 & 23 & $?$ & \\
$1800-1810^{*}$ & 19 & 10 & 22 & 16 & 27 & 5 \\
$1820-1829$ & 4 & 9 & 4 & 13 & $?$ \\
\hline
\end{tabular}

* gelet op de geringe omvang van de steekproef zijn deze twee decennia samengenomen.

* deze prijs is in Surinamse guldens, dic op dat moment minder waard waren dan Nederlandse; de wisselkoers is helaas niet bekend.

Bron: steekproef ARA: SONA en SNA.

Deze tabel maakt duidelijk dat de algernene akkerwaarcle - in feite de waarde van de onbewerkte grond - afhankelijk was van het soort plantage. Zo startten de koffie en suikersector in de jaren 1750 ongeveer op hetzelfóe niveau. Aangezien in die periode koffie echler gold als het produkt van de toekomst, steeg de waarde van de grond in die sector daarna veel sneller dan bij suiker. Gedurende de jaren 1760 was de stijging nog geleidelijk en min of meer in overeenstemming met de toegenomen schaarste van deze produktiefactor. In het daarop volgend decennium bleek de geschatte akkerprijs echter te zijn verdubbeld. Grond was nog steeds schaars en de eerder genoemde grondverkopen gaven aan dat de werkelijke markiwaarde ook hoog was. Toch had de opwaardering een sterk speculatief karakter. Dat bleek toen in de volgende decennia de kredieten - die aan de taxaties gekoppeld waren - opdroogden en de akkerprijs meteen kelderde, terwijl grond nog steeds een schaars goed was. Begin negentiende eeuw was alleen de akkerprijs op katoenplantages relatief hoog (maar wel in gedevalueerde Surinaamse guldens), in verband met de grote verwachtingen die men ten aanzien van dit gewas koesterde.

In de jaren 1820 bleek aan grond, zowel in de koffie- als in de suikersector, nauwelijks nog enige waarde te worden toegekend. De achteruitgang van de koffiesector was toen duidelijk; de suikersector zat echter weer in de lift. Toch was ook daar de akkerprijs laag, omdat de marktwaarde van plantages toen voornamelijk nog werd bepaald door de aanwezige slaven. Bovendien was grond geen schaars goed meer door het grote aantal verlaten plantages en de ontsluiting var nieuwe gebieden in Saramacca, Coronie en Nickerie. Ook is het niet uitgesloten dat de enorme groei van het definitief verlaten areaal op de plantages zelf de algemene akkerprijs heeft gedrukt.

De taxatiewaarde van bewerkte grond bedroeg, logischerwijs, een veelvoud van de algemene akkerwaarde (Tabel 21). Dat was echter niet het enige verschil, ook anderszins verliep de waarde-ontwikkeling niet parallel aan 
Tabel 21. Gemiddelde taxatiewaarde bewerkte akkers en gew'as per sector 1750-1830

\begin{tabular}{lcccccc}
\hline periode & suiker $(f)$ & $n$ & koffie $(f)$ & n & katoen $(f)$ & n \\
\hline $1750-1759$ & 50 & 17 & 371 & 29 & - & \\
$1760-1769$ & 71 & 15 & 436 & 28 & - & \\
$1770-1779$ & 96 & 19 & 521 & 29 & - & \\
$1780-1799^{*}$ & 119 & 11 & 311 & 23 & $?$ & \\
$1800-1810^{* *}$ & 265 & 10 & 322 & 16 & 224 & 5 \\
$1820-1829$ & 146 & 9 & 213 & 13 & $?$ & \\
\hline
\end{tabular}

- gelet op de geringe omvang van de steekproef zijn deze twee decennia samengenomen.

* deze prijs is in Surinaamse gildens, die op dat moment minder waard waren dan Nederlandse; de wisselkoers is helaas niet bekend.

Bron: steekproef ARA: SONA en S.VA.

die van de onbewerkte grord. Opmerkelijk was bijworbeeld het enorme waardeverschil tussen suiker-en koffie-akkers. Waarschijnlijk hing dit samen met het feit dat suikerriet zo'n 16 maanden ra planting al kon worden geoogst en een rietakker niet langer dan 10 aे 15 jaar achtereen produktief was. Een kofffieboom gaf pas in zijn vijfde of zesde jaar de eerste behoorlijke oogst, zodat bijvoorbeeld het vervangen van een dode of zieke kolfieboom veel kostbaarcer was dan vervanging van een stuk suikerriet. Bovendien werd met een koffie-akker en een kuffieboom veel langer geproduceurd dan met een suikerstuk.

Toch vond men kernelijk de waarde van de suikerakkers aan de lage kant geschat, want de gehele tweede helft van de achttiende eeuw bleef deze stijgen. In ieder geval had het niet te maken met een eventuele sperulatieve opwaardering, want in tegenste.ling tot de algemene akkerwaarde zette de stijging ook na de jaren 1770 door. Het te lage litgangspunt in de jaren 1750 was waarschijnlijk veroorzaakt door het absolute dal waarin de suikerprijs zich op dat moment bevond (Bijlage 2) en de enorme aandacht waarin de koffiesector zich mocht verheugen, en die ter koste ging van de stiker.

De plotselinge verdubbeling van de waarde der suikerakkers in het cerste decennium van de negentiende eeuw was, naast het feit dat het hier on gedevalueerde Surinaamse guldens ging, het gevolg van de algemene vervanging van he: Creole-riel door hel veel hoogwaardiger Otaheite-riet. Toen het nieuwe daar af was en de onverkoopbaarheid van de plantages alle kapitaalgoederen behalve slaven in waarde deed dalen, zakte in de jaren 1820 ook de suikerakkerprijs, al bleef het altijd nog flink boven het hoogste achttiende-eeuwse peil.

De taxatiewaarde van de koffie-akkers makte een andere ontwikkeling door. In de jaren 1750 was deze waarde al hoog, zeker wanneer in aanmerking wordt genomen dat een aanzienlijk deel van de koffiebomen op dat moment rog niet volwassen was. Naarmate in de jaren 1760 en 1770 dit 
deel steeds kleiner werd, steeg de taxatfewaarde. Gedurende de laatste twee decennia van de achttiende eeuw begon het verval in de koffiesector zich al af te tekenen. De bomen waren over hun hoogtepunt heen en de grond begon sporen van uitpuiling te vertonen. Fors dalcnde akkerwaardes waren het gevolg. Vlak na de ceuwwisseling bleef de taxatiewaarde enigszins stabiel door de verschuiving van het bebouwd areal naar nieuwe, maar minder vruchtbare, stukken land, meer achterop de plantage. De opnieuw forse waardevermindering in de jaren 1820 geeft aan dat dit slechts korte tijd respijt bood, al zal ook hier de algemene waardevermindering van de kapitaalgoederen een rol hebben gespeeld.

Van de taxatiewaarde der katoenakkers kan niet vee! meer worden gezegd dan dat die rond 1800 het best te vergelijken was met koffie in de jaren 1750. De sector was nog zeer jong, maar men had er hoge verwachtingen van zodat het waardeniveau tamelijk hoog lag. Toch lag het ruim onder dat van koffie, omdat het bij katoen niet zo lang duurt voor de boom vrucht draagt en de produktieperinde van een katoenboom ook aanmerkelijk korter is.

In het verloop van de mate warin grond en gewassen de waarde van een plantage bepaalden zijn de eerder gesignaleerde trends (Tabellen 20 en 21) weer terug te vinden, zij het dat de cijfers nu worden beïnvloed door de relatieve waatde van de andere kapitaalgoederen. De relatieve gemiddelde waarde van grond en gewassen in de suikersector in de periode 1750-1829 daalde van meer dan $20 \%$ tol ruim $16 \%$, terwijl in de koffiesector er een daling van ruim $42 \%$ tot ruim $18 \%$ is war te nemen. Het is opvallend dat de speculatieve waardevermeerdering van de grond rond 1770 de totale waarde van suikerplantages meer heeft beïnloed dan die van koffieplantages. Waarschijnlijk had dit te maken met de opbouw van de plantages, die bij suikerondernemingen tamelijk stabiel was, maar bij koffie-ondernemingen nog voortdurend groeide, zodat de waarde van de kale grond eenvoudig meegroeide. Bovendien waren suikerplantages veel uitgestrekter, waardoor cen waardevermeerdering van de grond zwaarder meetelde.

Eén ding is duidelijk: in de koffiesector werd de waarde van de plantages in veel grotere mate bepaald door de grond en gewassen dan in de suikersector. De waardevermindering in de negentiende eeuw van dit kapitaalgoed had dan ook een veel negatiever effect op de totale waarde van de koffieplantages dan van de suikerondernemingen.

\section{Kapitaalgoederen en hun kwetsbaarheid}

De drie hiervoor behandelde kapitaalgoederen hebben voor het grootste deel de waarde van de plantages bepaald in de achttiende en negentiende eeuw (Tabel 22). De rest van de gekapitaliseerde goederen (kolom 'overig' in Tabel 
22) bestond uit het woonhuis, de irhoud van de gebouwen en de overige in gebruik zijnce gronden, zoals kostakkers en weidegrond. Ook onderhielden relatief veel suikerplantages in de jaren 1750 nog een aantal koffie-akkers, waardoor de categorie 'overige' $2,3 \%$ hoger is dan in de volgende decennia. Hetzelfde geldt rond 1800 voor koffiep?antages, die er toen vaak nog een aantal katoerakkers bij hadden.

Daarnaast werd de waarde var. suikerpiantages voor enige procenten bepaald door het (trek)vee, maar met het verdwijnen van de beestenmolens liep dit terug van $3,5 \%$ is. de jaren 1750 to: $1,3 \%$ in de jaren 1820 . Verder waren de oorlogen in de jaren 1780 en 1790 er de oorzaak van dat grote hoeveelheden suiker, melasse en koffie lange tijd op de plantages bleven liggen en zodvende werden meegetaxeerd, wat opnieuw ir de rubriek 'overig' is verwerkt.

Ifel is duidelijk dat de waarde van de plantages in de loop der tijk aan grote veranderingen onderhevig is geweest. In de jaren 1750 waren suikerplantages ongeveer anderhal: maal zoveel waard als koffiepiantages. De laaiste waren dan ook merendeels nog in hur opbouwfase. In het daaropvolgend decennium was het verschil echter geheel verdwener. en

Tabe: 22. Gemiddelde reiatieve waarde der kạpitaalgoederen per sector 1750-1830

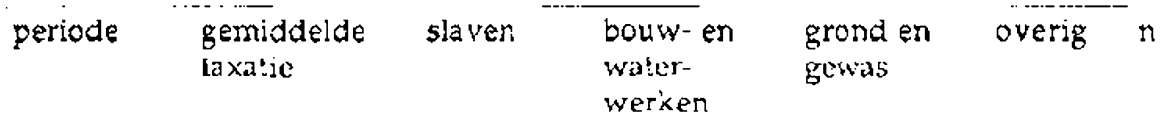

\begin{tabular}{|c|c|c|c|c|c|c|}
\hline \multicolumn{7}{|c|}{$\mathrm{suj}$ iker } \\
\hline $1750-59$ & $: 49.977$ & $36,9 \%$ & $21,8 \%$ & $20,2 \%$ & $18,1 \%$ & 17 \\
\hline $1760-69$ & 177.384 & 37,8 & 30,1 & 19,0 & 13,1 & 15 \\
\hline $1770-79$ & 285.223 & 28,9 & 33,3 & 25,6 & 12,2 & 19 \\
\hline $1780-99^{*}$ & 183.207 & 30,7 & 35,2 & 17,9 & 16,2 & 11 \\
\hline $1800-10$ & $(301.424)$ & $3 \pm, 4$ & 34: & 21,0 & $: 3,5$ & 10 \\
\hline $1820-29$ & 117.520 & 43,2 & 28,0 & 16,7 & $: 2,1$ & 9 \\
\hline \multicolumn{7}{|c|}{$k o f f i e$} \\
\hline $1750-59$ & 38.859 & 32,7 & 11,7 & 42,7 & 12,9 & 29 \\
\hline $1760-59$ & $: 75.760$ & 32,2 & 13,9 & 43,2 & 10,7 & 28 \\
\hline $1770-79$ & 288.538 & 29,5 & 16,5 & 44,9 & $9,:$ & 29 \\
\hline $1780-99^{*}$ & 207.523 & 30,3 & 17,9 & 40,0 & 11,8 & 23 \\
\hline $1800-10$ & $(254.729)$ & 37,3 & 18,5 & 29,8 & 14,4 & 16 \\
\hline $1820-29$ & $\$ 9.757$ & 52,8 & 18,8 & 18,7 & 9,7 & 13 \\
\hline
\end{tabular}

- gelet op de geringe omvang van de steekproef z:jn deze twee decennia samen. genomen.

Het taxatiebed:ag van 18301810 is tussen haakjes geplaatst, omdat afwijkend van de andere taxaties het hier gaat om Surnaamse guldens die op dat moment mirder waard waren dan. Vecerlandse; de wisselkoers is helas niet bekend.

Bron: steekproef ARA: SONA en SNA. 
was ook de waarde van suikerplantages nog iets gestegen als gevolg van uitbreidingen en vernieuwingen, vooral wat betreft slaven en molens.

In de jaren 1770 schoten in beide sectoren de taxaties plotseling omhoog met meer dan $60 \%$, om daarna vrijwel even hard weer te kelderen. Alle kapitaalgoederen (bouwwerken en grond - met name in de suikersector zelfs buitenproportioneel) werden in die jaren 1770 flink opgewaardeerd. Niet toevallig gebeurde dit precies in de periode dat de kredietstroom naar Suriname het omvangrijkst was. De hoogte van het krediet was namelijk afharkelijk van de hoogte van de taxaties. Na enkele euforische jaren droogde de kredietstroom echter weer op en daalden ook de taxatíes. Een geur van speculatie, on riet te spreken van fraude, hangt rond deze periode. In Hoofdstuk VII wordt hierop nader ingegaan.

In alle tijden en op alle plantages vormden slaven een van de meest kostbare, maar tegelijk worden aangevoerd en de lange aanvoerlijnen waren kwetsbaar in geval van oorlog, storm, piraterij of verkeerde wind. Bovendien daalde van halverwege de jaren 1770 af de aanvoer en werd hij onregelmatiger. Mede als gevolg hiervan werden slaven in de loop der tijd steeds duurder. Deze negatieve ontwikkeling van het arbeidsaanbod speelde zich bovendien af in een situatie die werd gekenmerkt door een chronisch sterfte-overschot in de kolonie. Ondanks de vrijkomende arbeid uit die delen van de plantageeconomie die werden verlaten, was daarom vanaf het laatste kwart van de achttiende eeuw het arbeidsaanbod vrijwel nooit voldoende.

Een factor van betekenis waren ook de gebouwen en waterwerken, die op suikerplantages geruime tijd het meest waardebepalende kapitaalgoed vormden (Tabel 22). Dit kapitaalgoed kende eveneens zijn zwakke plekken, waarvan de eerder ter sprake gekomen kwetsbaarheid van de waterhuishouding niet de minste was. Maar ook het onderhoud van de overige bouwwerken had met problemen te kampen. Weliswaar hoefde het hout waaruit een gront deel van de gebouwen was opgetrokken niet van buiten de kolonie te worden geimporteerd, het werd wel steeds minder op de plantages zelf gevonden. Het moest daarom worden aangekocht van gespecialiseerde houtondernemingen of van marrons, hetgeen een stuk duurder was. Alle andere materialen, van stenen tot en met spijkers, teer en sloten, moesten uit Nederland worden ingevoerd, met alle risico's van dien. Met name de kostbare en gecompliceerde molens en kookhuizen op suikerplantages waren daardoor kwetsbaar, want tijdens de oogstperiodes hing alles af van hun vermogen om continu te functioneren. Hoe meer er bovendien in de loop der tijd werd gemechaniseerd, des te groter werd de kwetsbaarheid, want zelfs de reparateurs moesten uit Furopa worden gehaald. In feite kwamen vrijwel alle benodigdheden tot onderhoud van de kapitaalgoederen uit het buitenland. Dat betekende niet alleen bouw- 
materialen, maar evereens een deel van het voedsel, k'eding en gebruiksvoorwerpen voor de slaven en verder alle gereedschappen, werktuigen, machines en onderdelen. ${ }^{36}$

Eigenlijk waren grond en gewassen het enige kapitaalgoed dat riet hoefde te worden geimporteerd, $z i j$ hei dat de gewassen oorspronkelijk van buiten de kolonie kwamen. De constante beschikbaarheid van dit kapitaalgoed betekende echter nog niet dat het onkwetsbaar was. Zoals op iedere landbouwonderneming was deze produktiefactor sterk afhankelijk van niet te beïnvloeden verschijnseien als regen, zonneschijn en insectenplagen. Daarnaast werden, vooral in de koffiesector, grond en gewassen zo intensief geëxploiteerd, dat $z i j$ na verloop van tjjd volledig uitgeput raakten. Men had dus de kracht ran deze produktiefactor sterk overschat. De dramatische waardedaling (Tabellen 20-22) vormde daavvan een ireurig bewijs. In de negentiende eeuw waren de plantages vaak alleen om hun slavenmacht gewild. In die tijd werd de intrinsieke waarde var de ondernemingen dan ook vrijwel geheel door de aarwezige slaven bepaald. Dat was nauwelijks een vertrouwerwekkende ontwikkeling te noemen voor een plantageeconomie die om zich heen geconfronteerd werd met de afschaffing van de slavenarbeid.

36 Een voorbeeld is suikerpla:itage Libanon aan de Cotsica. In de periode $1836-1842$ werd daas van de totale uitgaven $25 \%$ bestecd aan de aankoop van benodigdheden in Nederland. Daamaast werd nng eens $20 \%$ besteed bij een leverancier van plartagebenodigdheden in Suriname, die al zijn spu!len eveneens uit het buitenland betrok. De overige uitgaven gingen op aan belastingen, personele kosten, en hout en bananen voor de slavert. Voor zover vall na te gaan is het voorbeeld van libanon representatief en laat het zien dat voor het onderhoud van de kapitaalgeteren Surinaamse plantages in roge mate afhanke jijk waren van buitenlandse impurt (CAA: PA-646, 59). 


\section{HOOFDSTUK V \\ Ontwikkeling van de produktiviteit}

Tussen 1750 en 1850 vertoonde de wereldmarkt voor tropische produkten een sterke groei (Tabel 5). Het aantal Surinaamse plantages dat voor deze markt produceerde, had echter al rond 1770 zijn hoogste punt bereikt (Bijlage 4). Als de Surinaamse plantage-economie haar plaats als producent wilde behouden en bij dalende prijzen (Bijlage 2) financieel wilde overleven, dan was het noudzakelijk de produktiviteit van deze exportondernemingen drastisch op te voeren.

\section{De koffiesector}

In het tweede kwart van de achttiende eeuw werd de koffie voor een deel nog geproduceerd op suikerplantages. Rond 1750 was de koffieteelt echter uitgegroeid tot een zelfstandige sector binnen de plantage-economie (Tabel 14); in de loop van de daaropvolgencie twee decennia werd de scheiding compleet. Deze ontwikkeling naar produxtspecialisatie kan worden aangemerkt als een eerste vorm van efficiëntieverhoging. Alle aandacht, energie en middelen konden nu aan esn produkt worden besteed. De gemiddelde plantage in de knffiesector ontwikkelde zich toen ais weergegeven in onderstaande tabel.

Gelet op het feit, cat rond 1750 de scheiding tussen suiker- en koffiesector nog niet helemaal compleet was, zal in werkelijkheid de produktie van de

Tabel 23. De gerniddelde Surinaamse koffieplanlage 1750-1862

\begin{tabular}{rrrrrrr}
\hline periode & slaven & \multicolumn{2}{l}{$\begin{array}{l}\text { aandeel } \\
\text { veldslaven }\end{array}$} & $\begin{array}{l}\text { koffie- } \\
\text { areaal (ha.) }\end{array}$ & $\begin{array}{l}\text { aantal } \\
\text { kofficbomen }\end{array}$ & $\begin{array}{l}\text { koffie- } \\
\text { produklie (kg) }\end{array}$ \\
\hline ca.1750 & 71 & 41 & $(58 \%)$ & 35 & 33.810 & 8.174 \\
ca.1770 & 126 & 65 & $(54 \%)$ & 76 & 85.804 & 19.941 \\
ca.1790 & 108 & 50 & $(46 \%)$ & 86 & 105.780 & 23.654 \\
ca.1810 & 93 & 45 & $(48 \%)$ & 82 & 108.240 & 12.592 \\
ca.1825 & 98 & 46 & $(47 \%)$ & 63 & 91.854 & 13.418 \\
1836 & 94 & 43 & $(46 \%)$ & 41 & $?$ & 9.846 \\
1854 & 97 & 38 & $(39 \%)$ & 50 & $?$ & 4.687 \\
1862 & 105 & $?$ & & 41 & $?$ & 3.574 \\
\hline
\end{tabular}

Bron: zie Bijlage $4 \mathrm{C}$. 
gemiddelde koffiep'antage in dat jaar iets lager zijn geweest. Voor het overige blijkt, dat het koffie-areaal - en daarmee het bomenbestand en de produktie - tot de jaren 1790 groeide. Daarna ram het echter even strel weer af. Alleen gedurende de jaren 1850 groeide het gemiddeide koffie-areaal weer iets, maar dat was alleer. een gevolg van het feit dat in die jaren alleen de grootste koffieplantages zich nog konden handhaven. De omvang van de slavenpopulatie bereikte $2:$ in de jaren 1770 zijn top en daalde toen als gevolg van stagnerende siavenimporten ra 1775 . Vooral het produktieve deel van de populatie, de veldslaven, werd hiercoor sterk uitgedind. Rond 1800 en zeker in de jaren 1820 nam de aanvoer van slaven weer flink toe, zodat het aandeel var: de veldslaven minder snel caalde. Van 1827 af werden echter definitief geen slaven meer ingevoerd, zodat in 1854 niet eer.s twee-vjifde van de slavenmacht tot de veldslaven behoorde. De gemiddelde omvang van de populatie op een koffiepiantage leek te zijr. toegenomen, maar ook dat was alleen her gevo:g van het overblijven van de grotere ondernemingen. Wat betekenden deze ontwikkelirgen voor de produktiviteit?

Tot de jaren 1790 blijkt de produktivileit, afgezien van de bomen, voortdurend te zijn gestegen. Daarbij dient echter wel te worder aargetekend dat de koffieproduktie rond 1770, waarschijnlijk ten gevo:ge van slechte seizoenen, relatief laag was voor die periode. Uitgaande van de produktie rond 1775 was het riveau in 1790 al weer gedaaid.' Dat is niet zo verwonderlijk, want de bomen werden steeds ouder en de grond begon uitputtingsverschijnselen te vertonen. Na 1790 ging de produktiviteit van de

Tabe: 24. Produktiviteil van de gemiddelde kuffiep'antage 1750-1862

\begin{tabular}{|c|c|c|c|c|c|c|}
\hline \multirow[t]{2}{*}{ periode } & \multicolumn{4}{|c|}{ produk:ie per (in kg) } & \multicolumn{2}{|c|}{ één veldslaaf bewerkt } \\
\hline & slaaf & $\begin{array}{l}\text { veld- } \\
\text { slaaf }\end{array}$ & $\begin{array}{l}\text { hectare } \\
\text { koffie }\end{array}$ & $\begin{array}{l}\text { koffic- } \\
\text { boo:n }\end{array}$ & $\begin{array}{l}\text { hectare } \\
\text { koffie }\end{array}$ & $\begin{array}{l}\text { koffie- } \\
\text { bomen }\end{array}$ \\
\hline ca. 1750 & 113 & 199 & 234 & 0,24 & 0,9 & 825 \\
\hline ca. 1770 & 358 & 293 & 262 & 0,23 & 1,1 & 1.262 \\
\hline ca. 1790 & 219 & 473 & 275 & 0,22 & 1,7 & 2116 \\
\hline ca. 1810 & 135 & 250 & 154 & 0,12 & 1,8 & 2405 \\
\hline ca. 1825 & 1.37 & 292 & $2: 3$ & $0,1.5$ & 1,4 & 1.997 \\
\hline 1836 & 105 & 229 & 240 & $?$ & 1,0 & $?$ \\
\hline 1854 & 48 & 122 & 93 & $?$ & 1,3 & $?$ \\
\hline 1862 & 34 & $?$ & 88 & $?$ & $?$ & $?$ \\
\hline
\end{tabular}

Bron: Bi;lage 4C.

1 De gemidde?de jaarproduktic in :774-1776 bedroeg bij een gelijkblijvend aankal plantages $26.872 \mathrm{~kg}$ per plantage. E: van u:tgaande dat $00 \mathrm{k}$ de overige gegevens gelijk bleven be:ekent dat een gemicidelde produktie per siad! van $213 \mathrm{~kg}$, per veldslaaf van $395 \mathrm{~kg}$, per hectare koffie var. $354 \mathrm{~kg}$ en per koffirelorom van $0,31 \mathrm{~kg}$. 
grond en de bomen zelfs zo hard achteruit, dat in 1810 de (veld)slaven, bij een sterk teruggelopen aantal, per hoofd veel minder produceerden dan voorheen.

Rond 1825 geven de produktiviteit van zowel (veld)siaven als grond en bomen weer een lichte opleving te zien. Voor een deel was dit het gevolg van de kornst van een aantal rieuwe koffieplantages, in Saramacca. Daarnaast waren in de meeste gevallen de voorste gronden op de plantages nu definitief verlaten en werden nieuwe gronden op het middenstuk van de plantages in produktic genomen. Het is logisch dat die in eerste instantie beter vrucht afwierpen dan de volkomen uitgeputte oude gronden. De opleving was echter van tijdelijke aard, aangezien deze gronden minder vruchtbaar waren en ze ook geen rust werd gegund.

De enige remedie tegen de dalende produktiviteit var. de plantages, was het opvoeren van het aantal bomen per akker. De opbrengst per hectare kon daardoor tijdelijk worden verhoogd; op langere termijn verliep de uitputting van de grond hierdoor natuurlijk eens zo snel.

In driekwart eeuw was het gemiddeld anntal koffiebomen dat op een akker werd geplant met meer dan de helft toegenomen. Bovendien plantte men eind achttiende celiw op veel plantages katoen tussen de koffie. Met het zelfstandig worden van de katoen als aparte sector gebeurde dit niet meer na 1800, maar toen werd het gemeengoed de koffie te laten overschaduwen door bananebomen. Ad deze extra bomen deden een zwaar beroep op de veerkracht van de bodem.

Overigens produceerde men niet alleen (te) lang met dezelfde stukken grond, maar ook met dezelffe bomen. Ook dat was niet bevorderlijk voor de produktiviteit, want nadat een koffieboom rond het vierde jaar volwassen was geworden, bereikte hij rond het twaalfde jaar zijn absolute produktietop. Na het achttierde jaar begon de boom merkbaar minder vrucht te geven. Toch blecf men er mee vercier produceren, om de improduklieve periode tot het vierde jaar te vermijden. Pas wanneer eer boom echt 'op' was werd hij door jonge aanplant vervangen.

Op een efficiënte plantage diende de overgrote meercierheid van de bomen zich in de produktieve leeftijosfase sussen 4 en 18 jaar te bevinden. Rond 1770 , toen het koffie-areaal nog flink expandeerde, was ciat ook inderdaad het geval; $64 \%$ var. de bomen was 4 tot 18 jaar oud. De gemiddeide leeftijd van de bomen was toen bijna ideaal te roemen. Het zal dan ook geen toeval zijn, dat halverwege de jaren 1770 de Surinaamse korfieproduktie een absoluut hoogtepunt bereikte (Bijlage I). In plaats van de bomen daarna massaal te vervangen, bleef men ex verder mee produceren, met als gevolg dat rond 1825 twee-derde van de bomen al meer can veertig jaar oud was. Hoe ver dat kon gaan, bleek op plantage Vrouwenvlijt, waar 
in 1843 ruim de helft van de bomen tussen 76 en 87 jaar oud was. ${ }^{2}$

Een dergelijke uitputtende teeltwijze moest onherroepelijk leiden tot het definitieve verval van de koffieplantages. Toch had eind ackttiende eeuw de invloedrijke landbouwkundige Anthony Blom al de nodige aanwijzingen gegeven hoe het ook anders kon. Hij stelde voor om, als in de suikersector, een rotatiesysteem te hanteren, in dit geval van 18 jaar. Uitgaande van een gemiddelde koffieplantage van 215 ha., adviseerde hij niet meer dan 82 ha. daarvan te beplanten met ten hoogste 1.164 koffiebomen per hectare. Warneer de ecrst geplante bomen ongeveer vijftien jaar geworden waren, zo stelde Blom, 'zal een oplettend planter veeiligt eenige voortekenen van vermindering bespeuren' in de produ'xtiviteit. De planter had dan nog zo'n drie jaar de tijd voor de bomen definitief over hun top heen waren en kon intussen een nieuw stuk grond in cultuur brengen en. de jonge aanplant daarop tot volwassenheid laten komen. Na eer. produktieve fase yan achttien jaar kon dan het oude stuk worden verlaten. Het vourdeel daarvan was 'dat men zyne plantagie altoos vervu'd zal zien met jonge, en jeugdige boomen, welken in hun vollen vruchtbaarheid zyn (Blom :787:209). Bovendien werd de grond niet doodgeteeld, zodat ra achttien jaar rust het oude stuk opnicuw in gebruik kon worden genomen en even produktief was als daarvoor.

Deze achttienjarige rotatiecyclus was waarschijrlijk de best denkbare oplossing voor het probleen van de dalence produxtiviteit. Bovendien werd het door Blom gepubliceerd in een tijd dat het nog niet te laat hoefde te zij.. In praktijk b.ijkt het voorstel echter nooit te zijn overgenomen. Men bleef lange jaren met dezelfice gronden en dezelfde bomen produceren totdat de weg terug definitief was afgesneden. Aan dit ciesastreuze beieid lag eerst geldhonger, later juist gebrek aan geld en arbeid, ten grondslag. Tot de jaren 1780 werd de voortdurende expansie ingegeven door de wens zo sne: mogelijk rijk te worden. Hoe meer gronden in proukktie werder genomen, des te eercier zou dit doel zijn bereikt. In plaats daarvan zaten de meeste koffieplanters aan he: eind van de achttiende ceuw echter opgescheept met enorme schulden en een terugloperd aantal produktieve slaven. Nu werd het zaaix zoveel mogeli;k uit de plantages te halen, tegen zo min mogelijk kosten. Overstappen op een rotatiecyclus wilde mer. niet, omdat dit enige jaren derving van inkomsten zou betekenen. Oprieuw hao m.en alleen oog voor de korte termijn.

De planters negeerden ook Bloms advies niet meer dan 1.164 bomen per hectare se plarter. Varaf eind achttiende eeuw steeg hel gemiddelde hier ver boven en werder er bovendien bananen tussen de koffie geplant. Op zich was dit wel een heilzame maatregel, omdat hierdoor zowel gronci als 
bomen tegen de directe inwerking van de zon werden bescinermd. Het had echter gepaard moeten gaan met een vermindering van het aantal koffiebomen per hectare in plaats van een voortdurende vermeercering.

De produktiviteif van de slaven was gedurende de achttiende eeuw ongetwijfeld een resultante van hun arbeidsvermogen. Gedurende het derde kwart van de achtiende eeuw groeicle de produktie veel sneller dan het aantal slaven, terwijl in het laatste kwart van die ecuw de daling van de produktie langzamer ging dan die van de slaven (Tabel 23). Om die hoge produktiviteit te bereiken, moesten de koffieslaven rond 1790 ongeveer tweemaal zo hard werken als hun voorgangers in 1750 (Tabel 24). In de negentiende eeuw was het arbeidsvermogen van de koffieslaven riet meer doorslaggevend voor hun produkt:viteit, want deze was nu volkomen afhankel:jk geworden van het produktievermogen van grond en bomen.

Het is niet overdreven te stellen, dat van het moment af ciat de koffie een zelfstandige sector in de Surinaamse plantage-economie was geworden, mislukking onvernijdel:; $k$ was ten gevolge van hef korizichtig beleid dat van het begin af is gevoerd. Tusser. 1750 en 1790 werden de plantages steeds meer volgeplant, zodat aan hes eind van de jaren 1780 al twee-vijfde van het areaal was bebouwd, inclusief kostgronden, en $7 \%$ verlaten. Er werd veel te lang met dezelfcie grond en bomer geproduceerd, zodat de produktiviteit onherroepelijk daalde. Om dit tegen te gaan werden de akkers steeds dichter beplant, wat de achterilgang eens te meer heeft versneld. Rotatiecycli hadden dit verval wellich: niet heiemaa: kunnen voorkomen, maar in ieder geval in hoge mate kunnen vertragen. Daartoe hebben de planters zich. echter de tijd niet gegund, terwij] het hen later aan de benodigde fysieke en. financiële ruimte ontbrak.

Ilet is de vraag hoe de dalende produktiviteit van de Surinaamse koffiesector zich verhield tol de rest van het Caraibisch gebiec. De schaarse gegevens hierover maken een vergelijking niet erg eenvoudig. Suriname was de oudste koffieproducent van het Caraibisch gebicd, op de voet gevolgd door de Franse eilanden. De Surinaamse koffie-'boom' kon echter riet in de schaduw staan van die op Saint Domingue. Rond het midden van de achttiende eeuw produceerden beide plantage-econonieën een vergelijkbare hoeveelheid koffie. Tegen het einde van die eeuw was de Surinaamse export verdrievoudigd. Maar Saint Domingue produceerde op dat moment bijna vijfmaal zoveel als Suriname en voorzag daarmee in $60 \%$ van de westerse behoefte (Trouillot 1982:337).

Deze enorme expansie was veroorzaakt door grote groepen nieuwe planters ('petits blarks' en 'gens de couleur') diex het zich niet konden veroorloven een suikerplantage te beginnen. Voor de aanleg van een koffieplantage was echter siechts eer-zesde deel van het kapitzal voor een suiker- 
Tabel 25. Gemiddelcie Carâibische koffieplantage 1789-1830

\begin{tabular}{|c|c|c|c|c|}
\hline land & jaar & $\begin{array}{l}\text { aantal } \\
\text { plantages }\end{array}$ & $\begin{array}{l}\text { slaven per } \\
\text { plantage }\end{array}$ & $\begin{array}{l}\text { produktie pet } \\
\text { plantage }\end{array}$ \\
\hline St. Domingue & 1789 & 3.117 & $\mathrm{ca} .40$ & $9.218 \mathrm{~kg}$ \\
\hline Suriname & 1790 & 248 & 138 & 23.654 \\
\hline Jamaica & 1808 & 607 & 97 & 18.148 \\
\hline Suriname & 1810 & 235 & 93 & 12.592 \\
\hline Dominica & 1827 & 216 & 30 & 2.709 \\
\hline Guiana & 1830 & 80 & 94 & 30.954 \\
\hline Suriname & 1825 & 178 & 98 & 13.418 \\
\hline
\end{tabular}

Bronmen: Dupidy 1989:21; Trolillot 1982:337-47; Higman :984.68-70, 699; Schomburgk 1840:60-3; Mandle 1973:18; Williams 1975:3; Bijlage 4C.

Tabe! 26. Gemidalelde produktiviteit Caraibische koffies]aven 1789-1836

\begin{tabular}{lrrr}
\hline land & jadir & totale ;rnduktie & produk:ic per slataf \\
\hline St. Doningue & 1789 & 28.731 ton & $230 \mathrm{~kg}$ \\
Suriname & 1790 & 5.856 & 219 \\
& & & \\
Jamaica & 1808 & 11.016 & 187 \\
Trinidad & 1810 & 112 & 65 \\
St. Vincent & 1810 & 8 & 6 \\
Guiana & 1810 & 4.589 & 261 \\
Suriname & 1810 & 2.959 & 135 \\
& & & \\
Guiana & 1820 & 4.252 & 365 \\
Dominica & 1827 & 593 & 91 \\
Suriname & 1825 & 2.388 & 1.37 \\
& & & 329 \\
Guiana & 1830 & 2.476 & $: 05$ \\
Suriname & 1836 & 1.349 & \\
\hline
\end{tabular}

Bronmen: Dupuy 1989:21; Irodillot 1982:337-47; Aigman 1984:68-70, 699; Sxhomburgk 1840:60-3; Mar:dle 1973:18; Williams 1975:3; Bijlage 4C.

plantage nodig, zodat de rieuwkomers zich massaal op deze sector hebben geworpen (Trouillot :982:348-9). Dit verklaart ook de veel geringere omvang van deze piantages in vergelijking met Surirame (Tabel 25), waar men door de grote beschikbaarheid vaa veemd vermogen gedurende het derde kwart van de achttiende eeuw in stact was veel grotere plantages op te zetren. De produktiviteit van de slaven lag echter in beide plantage-economieër op een vergelijkbaar niveal.

Door de slavenrevolutie op Saint Domingue in de jaren 1790 storte daar 
de plantage-economie ineen. In de Engelse plantage-economieën en Cuba was men er als de kippen bij om de opengevallen plaats in te nemen en begon men nu ook met de produktie van koffie. ${ }^{3}$ De Surinaamse plantageeconomie kon hier niet bij aansluiten ten gevoige van de grote financiële moeilijkheden waarin $z \mathrm{ij}$ op dat moment verkeerde. De koffiesector was toen al driekwart eeuw in bedrijf er inmiddels op zijn retour.

De plantages in de Fngelse koloniën waren, wat betreft de slavenmacht, ongeveer even groot als de Surinaamse, mar een heel stuk produktiever. Op het moment dat de Jamaicaanse koffiesector zijn grootste bloei doormaakte (rond 1810) behaalden de slaven daar echter niet dezelfde produktiviteit als in Suriname enige decennia eerder. Dit kan zowei hebben gelegen aan een minder hard arbeidsregime als aan een agere vruchtbaar* heid van de bodem in Jamaica. In Guiana daarentegen bereikten de produktiviteit van plantages en slaven hoogten die men ir het buurland Suriname nooit had gekend. Dit zou veroorzaakt kunnen zijn door betere teelmethoden - rotatie, bemesting - maar daarover is niets beikend. Daarnaast maakt een vergelijking van demografische gegevens tussen de twee landen (Tabel 56) het niet waarschijnlijk dat de veel hogere prociuktiviteit van Guianese koffieslaven werd bereikt door grovere exploitatie.

Een vrij algemene tendens in de Carałbische piantage-economieën was wel dat koffie een typisch 'boom'-produkt was: na een grote expansie volgde vrijwel onherroepelijk de terugval. Alieen in landen waar het een 'peasant crop' werd (Haïti, Jamaica) bleef een redelijke produxtie bestaan. ${ }^{4}$

Kennelijk hebben de koffiesectoren van de Caraibische plantage-economieën een geheel eigen ontwikkeling gekend, die overal werd gekermerkt door roofbouw. In de twee volgende hoofdstukken wordt hierop nader ingegaan. De suikersectoren vertoonden in ieder geval een veel constanter beeld.

\section{De suikersector}

Tussen 7750 en 1863 liep het aantal suikerplantages in Suriname terug van 141 naar 86. In de tusserliggende periode kwamen er 49 suikerondernemingen bij, zodat total 104 plantages waren gestopt met de suikerteelt. 5 Desondanks is in dieze:sde periode de totale suikerproduktie verdubbeid (Bij-

3 Guiana had, tixen het nog in Nederlandse handen was, ook al koffie geproducrerd, maar nu werden vele rieuwe plantages aangelegd.

4 De enige uitwondering hierop vormt Brazilië, waar de produktie steeg van één ton in 1800 tot nim 140.000 ton in 1850, alle geproduceerdop slavenplantages (Ukers 1922:277). Tot op de? dag van vandaag is dit land 's werelds grootste kofficproducent.

5 ARA: RvP, 6U7; Surinaamse Almarak, 1796:3-57 en 1824:45-85; Van Sijpesteijn 1854:46147; Kuloniaal Verslag 1862. 
Tabel 27. De gemiddelde Surinaamse suikerp'antage 1750-1862

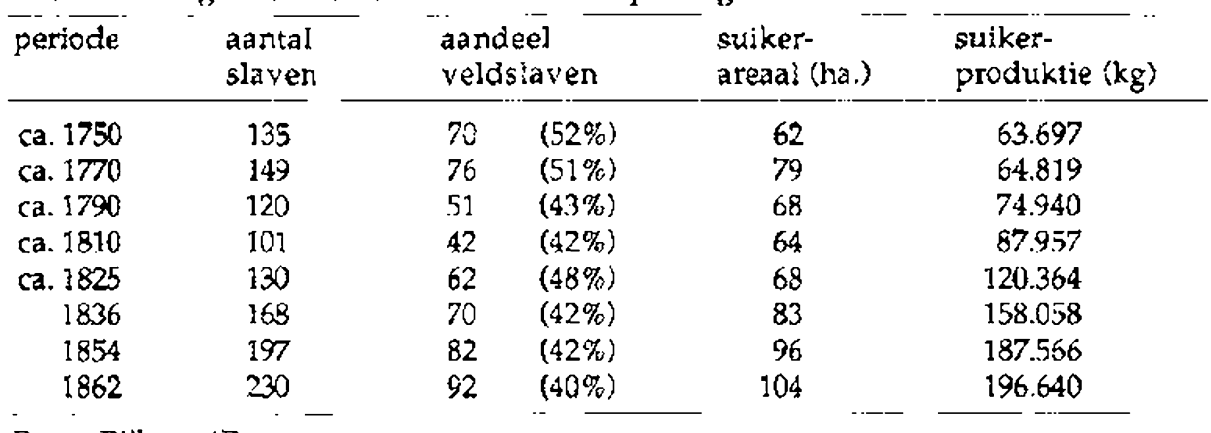

Bron: Bijlage $4 \mathrm{~B}$.

lage 1). De sector als geheel moet dus veel produktiever zijn gaan werken.

Als gevolg van gunstige krecietŕaciateiten en grote slavenimporten, was het derde kwart van de achttiende eeuw voor de Surinaamse suikerplantages een groeiperiode. Het is opmerkelijk dat dif niet meteen leidde tol cen navenarte produktieverhoging. Waarschijnlijk gingen alle inspanningen in verband met de expansie ten koste van de suikerproduktie. In de daropvolgende periode waren de kredietvoorwarden, evenals ir de koffiesector, dramatisch verslechterd. Er konden nauwelijks slaven meer worden aangekocht, zodat hun aanta: afnam. De grotere bewerkelijkheid van het chiltuurareaal - in vergelijking met koffie en katoen - noopte de suikerplanter de omvang daarvan aar. fe passen aan het aantal veldslaven, dat als bij de koffie, proportioneel was afgeromen. Deze tendens zette zich tot begin negentiende eeuw voort. Opvallend genoeg had dit geen enkel negalief effect op de produkfie, die voortdurend blese stijgen. Kennelijx wierpen de irvesteringen uit de periode voor $\$ 775$ r.u hur vruchten af, ir. het bijzonder de vervanging vat beestenmolens door watermolens. Boverdien werd eind achttiende eeuw een nieuwe rietsoort geîntroduceerd, die een hoger rerdement had.

Verruimde kredietmogelijkheden en verbeteringen in de produktie maakten in de regentiende eeuw een nieuwe fase van expansie moge.ijk. Zelfs het aanderl van de veldslaven siexg even, :oer, tussen 1816 en 1828 weer op tameliji grote schaal slaven werden ingevoerd. $\mathrm{Na}$ de definitieve importstop nam dit rrest produktieve deei van de slavenibvolking weer proportioneel af. Evenals in de koffiesector, was dit cen contra-produktieve tendens. Voor het overige ontwikkelde de produkiviteit in de suikersector zich daarentegen tameijik voorspoedig (Tabe: 28).

Opvallend is we: het absolute dieptepunt in de produktiviteit rond 1770. In afwijking van de koffiesector, kan dit niel hebber. geiegen aan voor dit gewas ongurstige weersomstandigheden, want rond 1775 was de produktie 


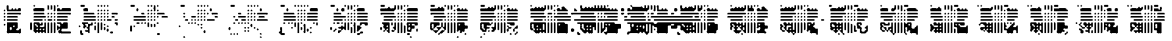

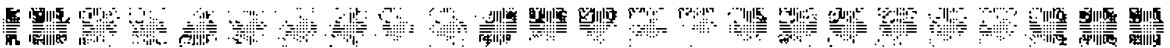

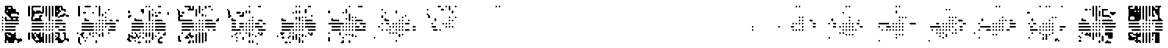

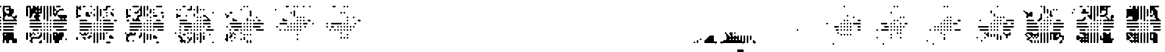

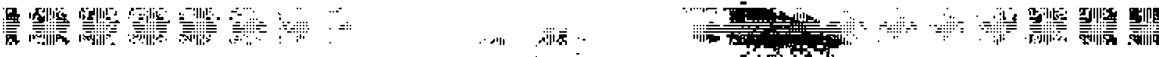

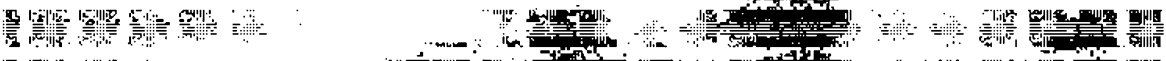

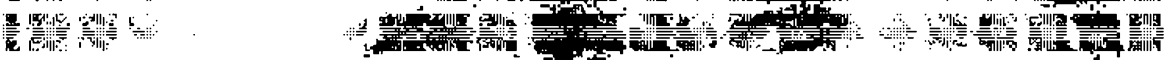

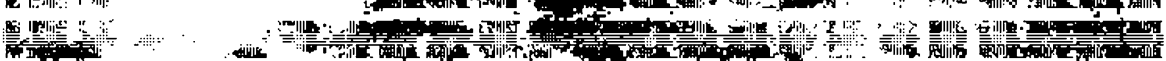

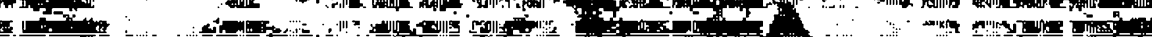

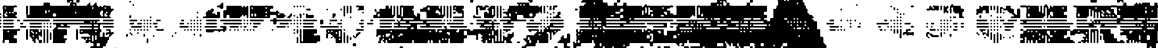

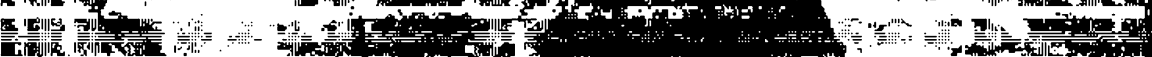

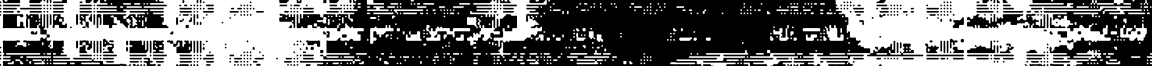
of

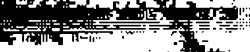
Hity Fon

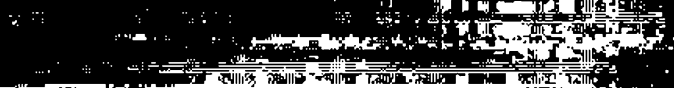

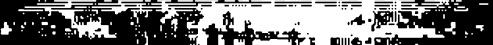

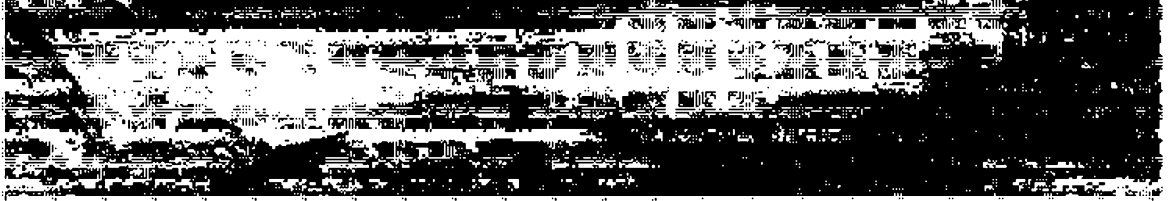

Fen negerwaning (Benoil 1980 foto 51) 
nog steeds van hetzelfde niveau (Bijlage 1). Waarschijnlijk had de daling meer te maken met cie eerder geconstateerde uitbreidingen waardoor de produktie enigszins werd verwaarloosd. Een steekproef onder 17 plantages in de periode 1756-1765 en 1766-1775 lijkt deze veronderstelling te bevestigen. ${ }^{6}$ I let totale areaal dal deze planlages in bewerking hadden, inclusief kosigronden en pas ingepolderd lard, bleek in die korte tijd met gemiddeld $29 \%$ (van 94 ha. naar 121 ha.) te zijn vergroot. Fen belangrijk deel van de arbeid moet in die jaren zijn gewijd aan het inpolderen van land, aanleggen van de complexe inizastructuur en plantklaar maken van de nieliwe gronden. Aangezien het aanial (veid)slaven minder sterk was toegenomen dan de omvang van het cultuurareaal is het goed mogelijk dat men aan he! onderhoud yan het laatste minder toekwarn.

Daarnaast zou ook een rol kunnen hebber: gespeeld - en dat geldr tevens voor de koffiesector - dat rond 1770 de slavenimporten een absoluut hougtepunt bereikten, zodat het anntal onervarer slaven op de plantages relatief groot moet zijn gewcest. Dif zal het produktiviteitsniveau zeker hebben aangetast.

Iabel 28. Produktiviteit van de gemiddelde suikerplantage 1750-1862

\begin{tabular}{|c|c|c|c|c|}
\hline periode & slaa! $(\mathrm{kg})$ & $\begin{array}{l}\text { roduktie } \\
\text { vedslizaf (kg) }\end{array}$ & hectare sujker* & $\begin{array}{l}\text { hectare sujker } \\
\text { per veldsladf }\end{array}$ \\
\hline ca. 1750 & 472 & $9: 0$ & 1.027 & 0,9 \\
\hline ca. 1770 & 435 & 853 & 820 & 10 \\
\hline ca. 1790 & 625 & 1.459 & $\therefore 102$ & 1,3 \\
\hline ca. 1810 & 871 & 2094 & $\therefore .374$ & 1,5 \\
\hline c. 1825 & 926 & 1.941 & 1.770 & $\therefore 1$ \\
\hline 1836 & 947 & 2.2 .58 & 1.904 & $i, 2$ \\
\hline 1854 & 954 & 2.294 & 1.951 & 1,2 \\
\hline 1862 & 855 & 2.147 & 1.899 & 1,1 \\
\hline
\end{tabular}

* de totale jarproduktie gedeeld door het totale rietareaal.

Bron: Bijlage 4 B.

Verschillende innovatics hebben er voor gezorgd dat na 1770 de produktiviteit var de rietakkers voortdurend is blijven stijgen. De produktiviteit van de slaven steeg geruime tijd zelfs nog sneller, en nie: aileen door het effect van technologische vernieuwingen. Vooral de veldslaven werder, bij gebrek aan voldoende arbeidskrachten, gedwongen steeds harder te werken. Ook het toenemend aantal rietakixers dat een veldslaaf moest onderhouderl wijst daarop. De nieuwe siavenimporten aan het begin van de jaren 1820 gaven de veldslaven weer wat rust, maar daarna zette de trend xich voort. 
Tabe! 29. Gemiddelde Caraibische suikerplantage 1767-1865

\begin{tabular}{|c|c|c|c|c|}
\hline land & jazr & $\begin{array}{l}\text { aantal } \\
\text { plantages }\end{array}$ & $\begin{array}{l}\text { slaven per } \\
\text { plantage }\end{array}$ & $\begin{array}{l}\text { produktie per } \\
\text { plantage }\end{array}$ \\
\hline Martinique & 1769 & 286 & $?$ & 33 ton \\
\hline Guadeloupe & 1767 & 415 & $?$ & 19 \\
\hline St. Domingue & 1789 & 793 & $?$ & 95 \\
\hline Grenada & 1776 & 125 & 146 & 73 \\
\hline Jamaica & 1774 & 775 & $?$ & 56 \\
\hline Tobago & 1775 & 84 & ? & 22 \\
\hline Suriname & 1770 & 111 & 149 & 65 \\
\hline Jamaica & 1804 & 859 & 208 & 92 \\
\hline Trinidad & 1808 & 272 & 53 & 26 \\
\hline Suriname & 1810 & 100 & $10:$ & 88 \\
\hline Jamaica & 1833 & 646 & 260 & 97 \\
\hline Guiana & 1831 & 221 & 287 & 266 \\
\hline Frans Cuiana & 1840 & 29 & 120 & 108 \\
\hline Suriname & 1836 & 105 & 168 & 158 \\
\hline Jamaica & 1854 & 427 & - & 164 \\
\hline Trinidad & 1848 & 193 & - & 104 \\
\hline Guiana & 1847 & 200 & - & 185 \\
\hline Guiana & 185.3 & 173 & - & 262 \\
\hline Cuba & 1850 & 1.442 & $?$ & 199 \\
\hline Suriname & 1854 & 91 & 197 & 188 \\
\hline Barbados & 1860 & 500 & - & 68 \\
\hline Guiana & 1861 & 173 & - & 336 \\
\hline Jamaica & 1865 & 300 & - & 84 \\
\hline Cuba & 1860 & 1.365 & ca. 125 & 349 \\
\hline Suriname & 1862 & 86 & 230 & 197 \\
\hline
\end{tabular}

Bronnen: Deerr 1949, I:112-241; Watts 1987:410-6, 485-99; Oostindie 1982:169; Moreno Fraginals 1985:5; Adamson 1972:167; Green 1976:221; Sheridan 1989:79-81; Schomburgk 1840:60-3; Mandie 1973:18; Higman 1984:68-70; BijTage 4B.

Tussen 1836 en 1854 groeide de slaverproduktivitejt nauwelijks meer. Kennelijk had zij het maximum bereikt. In het zicht van de Emancipatie daalde zij zelfs. Het is niet onwaarschijnlijk dat de slaven toen nie: meer bereid waren een even grote arbeidsprestatie te leveren en hun werk enigszins hebben yerwaarloosd. De eveneens gedaalde produxtiviteit van de akkers lijkt dit te bevestigen.

De hele periode 1750-1863 overziend, heeft he: er alle schijn van dat in de suikersector een doelmatiger en daarmee produk!iever beleid is gevoerd dan in de koffiesector. Ook hier was sprake van gronduitputting, maar de grootte yan de plantages en het gehanteerde rotatiesysteem voorkwamen dat de produktie daaronder te li;den had. Bovendien werd de produktiviteit 
voortdurend opgevoexd, als gevolg van een vrijwel continu proces van innovatie, zoals uit het volgende hoofdstuk zal blijken.

In vergelijking met de rest van het Caraibisch gebied hebben de surinaamse suikerplantages, wat betreft het gemiddeld aantal slaven, waarschijnlijk altijd tot de middelgrote behoord, al is het moeilijk om er op basis van de gegevens iets definitiefs over te zeggen (Tabel 29). De gemiddelde produktie van de Surinaamse suikerplantages lijkt zelfs tot de hoogste van de regio te hebben behoord. Alleen aan hef eind van de slavernij legde Suriname het duidelijk af tegen de meest produktieve plantage-economieër van dat ogenblik: Cuba en Guiana. Het ligt voor de hand dat dan ook de arbeids- en akkerproduktiviteit in Suriname hoog moet zijn geweest.

Tabel 30. Gemiddelde produktiviteit Carabische suikerslaaf $1770-1860$ (kg/slaat)

\begin{tabular}{|c|c|c|c|c|c|}
\hline land & ca. 3770 & ca. 1810 & ca. 1820 & ca. 1830 & ca. 1860 \\
\hline Barbados & 195 & 148 & 186 & 242 & $?$ \\
\hline Jamaica & 460 & $4 \div 3$ & 474 & 413 & - \\
\hline Grenada & 422 & 462 & 521 & 539 & - \\
\hline Antigua & $?$ & 267 & 4.31 & 362 & - \\
\hline St. Vincent & $?$ & 590 & 727 & 781 & - \\
\hline Irinidad & - & 488 & 531 & 851 & - \\
\hline Guiana & $?$ & $2 \$ 0$ & 437 & 926 & - \\
\hline Cuba & $?$ & $?$ & $?$ & $?$ & ca. 3.000 \\
\hline Suriname & 435 & 871 & 926 & 941 & 855 \\
\hline
\end{tabular}

Bronnen: Ward 1978:206: Oostindie 1989:128; Higman 1984:68-70; Mandle 1973:18; Deerr 1949, I; 112-241; Bijlage 4B.

liet blijkt inderdaad (Tabel 30) dat de Surinaanse suikerslaven een zeer hoge produktiviteit hebber gekend. Gedurende de eerste decennia van de negentiende eeuw zelfs hoger dan in enige andere (Brits-)Caraibische plantage-economie. Alleen Cuba overtreft Suriname op den duur verre. De vraag doet zich nu voor of de Stirinaamse suikerslaven, vooral in de negentiende eeuw, werden gedwongen veel harder te werken dan elders. Het zou kunnen, want wanneer wij de sterftecijfers rond 1835 in ogenschouw nemen dan blijken die het laagst bij de minst produktieve slaven (Jamaica en Barbados) en het hoogst bij de zeer produktieve (Guiana en Suriname). Toch dienen wij hier niet te snel conclusies aan te verbinden, want niet tuevallig behoorden de Surinaamse en Guianese suikersectoren tot de technologisch meest geavanceerde in de regio en was in Jamaica en Barbados het tegenovergestelde het geval (zie I loofdstuk VI). Het is daarom goed ook de akkerprodiktiviteit h:crbij te betrekken (Tabel 31).

Dan blijkt dat ook wat dit betreft Suriname veel produktiever was dan andere plantage-eronomiern, voorzover dit natmurlijk op basis van deze summiere gegevens kan worden vastgesteld. Zelfs het altijd ten voorbeeld 
gestelde Cuba werd rond 1860 nog door de Surinaamse plantages achter zich gelaten. Alleen de technologisch meest geavanceerde plantage-economie op dat moment, Guiana, deed het veel beter. Waarschijnlijk was de hoge suikerproduktiviteit van Suriname daarom meer een afgeleide van de grootschalige toepassing van nieuwe technologie - in de achttiende eeuw watermolens, in de negentiende eeuw stoonkracht - dan van grovere exploitatie van de slaven.

Tabel 31. Gemiddelde produktiviteit Caraibische suikerakkers 1801-1862

\begin{tabular}{llc}
\hline land & periode & produktie per ha \\
\hline Jamaica (4 plantages) & $1801-1834$ & geongst areaal \\
Suriname (17 plantages) & $1810-1830$ & 1.813 \\
Guadeloupe & ca. 1835 & 2.808 \\
Suriname & 18.36 & ca. 2000 \\
& & 3.182 \\
Trinidad & 1808 & totaal rietareaal \\
Suriname & 1810 & 1.526 \\
Trinidad & 1824 & 1.374 \\
Suriname & 1825 & 917 \\
Trinidad & 18.32 & 1.770 \\
Suriname & 1836 & 1.375 \\
Cuba & 1860 & 1.904 \\
Guiana & 1862 & 1.861 \\
Suriname & 1862 & 2.931 \\
\hline
\end{tabular}

Bronnen: Deprr 1949, I:112-241; Ward 1988:89; Higman 1984:701; Watts 1987:286; Adamson 1972:179; Oostindie 1982:169; Bijlage 48.

\section{De kntoensector}

Zoals koffie voor 1750 eer. beiar.grijk bijprodukt was op suikerplantages, werd katoen in de jares 1780 een belangrijk bijprodukt op koffieplantages. Fen steckproef onder 29 kofficplantages in de periode 1785-1795 wijst uit dat 16 daarvan ook katoen verbouwden. Vier hadden katoen tussen de koffie geplant en de overige hadden, naast hun gezamerlijk koffie-areaal van 1.173 ha, nog eens 258 ha. apart met katoen staan. ${ }^{7}$ Het is daarom ondoenlijk om in die tijd al een zelfstandige katoensector te onderscheiden. Pas na 1810 begon deze sector vorm te krijgen. Naast de ongeveer twintig nieuwe katoenplantages die gedurence de voorafgaande twee decennia langs de 
noordoostkus: waren verschenen, werden toen dertig katoenplantages aangelegd in Nickerie en Coronie. Bovendien vervingen de plantages met katoen tussen de koffie het eerste gewas door bananen en werd op plantages met gescheider. koffie- en katoenarea'en katoen het hoofdprodukt. ${ }^{8}$

Dat katuen zich van bijprodukt tot hoofdprodikt ontwikkelde had zowe! een positieve als een negatieve achtergrond. Negatief was het beginnend verval in de koffiesector, waardoor cen aantal planters het meer lucratieve katoen naast koffie ging verbouwen om te overlever. Dit deel van de katoensector on wikkelke zich dus ten koste van de koffie. Daarnaast was er de positieve stimulans die uitging van de Engelse bezettirg var. Surirame (1799-1816), waardonr de belargstelling van Britse ondernemers en kapitaal voor deze kolonie werc gewekt. Als gevolg van de Industriële Revolutie was er een grote vraag naar ruwe katoen ontstaan. De aanleg van enkele tientallen nieuwe katoenplantages in Sxiriname, coo: voornamelijk Schotse p'anters, was het gevolg.

Van het moment af dat de katoen een zelfstandige secto: was geworden, heeft de gerniddelde plantage zich als volgt ontwikkeld (Tabel 32).

Tabel 32. De gemiddelde: Surinaanse katoenplanłage 1825-:862

\begin{tabular}{|c|c|c|c|c|}
\hline periode & $\begin{array}{l}\text { aartal } \\
\text { slaven }\end{array}$ & $\begin{array}{l}\text { aandel:' } \\
\text { veldslaven }\end{array}$ & $\begin{array}{l}\text { katoen- } \\
\text { areaal (ha) }\end{array}$ & $\begin{array}{l}\text { katoen- } \\
\text { produxtie }(\mathrm{kg})\end{array}$ \\
\hline ca. 1825 & 114 & $(50 \%)$ & 138 & 14.452 \\
\hline 1836 & 126 & $(48 \%)$ & 128 & 10.967 \\
\hline 1854 & 55 & (46\%) & 130 & 14.079 \\
\hline 1862 & 370 & $?$ & 131 & 12.365 \\
\hline
\end{tabular}

Bron: Bij'age 4D.

In de perode 1825-1862 ijjkt de katoensector niet het verval van de koffiesector te vertonen, maar evenmin de expansie van de suikerplantages (afgezien van het gemiddeld aantal slaven per plantage). De onvang van de produktie en het katoenareaal bleven $\mathrm{min}$ of meer op hełzelfde peil, de slavenpopulatie per plantage groeide en het proportionele aandeel van de veldslaven ontw:kkelde $z$ :ch in dezelfde richting als bij de ande:e twee sectoren, zij het op eer iets hoger riveau, omdat deze secto: jonger was.

8 Een voorbecid hervan is plantage Fredorikslust aan de Warappakreek. Aangelegd in cie jaren 1750 als kotfepiantage bestond in $1801 \mathrm{de} 139 \mathrm{ha}$. culteurarcaal nog vorr $55 \%$ alleen uit koffic, $14 \%$ uit akke"s met kof́lie, waartussen katoen was geplant, en $31 \%$ uit louter katoenakkers. In 1827 bleck het cultuurareaal te zi'n gegroeid tof 187 ha., waaronder zich. gcen gemer.gde akkers meer bevorden en waarvan $71 \%$ net katocr en $39 \%$ met kolitie was beplant.

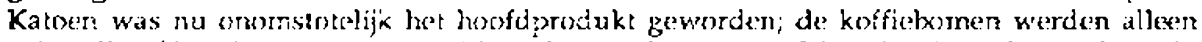
gehardhaafd zolang $z \mathrm{ij}$ rog voldoende vrucht gaven. Wal dat jetreft spraken de produktiecijfers van 1827 voor zich: $5.586 \mathrm{~kg}$ koffie en $22.103 \mathrm{~kg}$ katoen (ARA: SONA, 294 en B40; ARA: OAS Stlikken godrponerdi bij hestuursarchieven, 7) 
Toch was ook in deze sector sprake van verval. Het aantal plantages daalde dramatisch en alleen de grootste ordernemingen hielden het in deze afvalrace vol. Dit verkiaart de stijging van het aantal slaven per plantage, maar is tevens en waarschuwing dat de ontwikkeling van de produktiviteit met het nodige voorbehoud dient te worden bekeken.

Tabel 33. Produktiviteit van de gemiddelde katoenplantage 1825-1862

\begin{tabular}{|c|c|c|c|c|}
\hline \multirow[t]{2}{*}{ periode } & \multicolumn{3}{|c|}{ produktie pex } & \multirow{2}{*}{$\begin{array}{l}\text { hectare katoen } \\
\text { per veldslaaf }\end{array}$} \\
\hline & slaa! $\{k g\}$ & veldslaaf (kg) & ha. $(\mathrm{kg})$ & \\
\hline ca. 1825 & 127 & 254 & 105 & 2,4 \\
\hline 1836 & 87 & 180 & 86 & 2,1 \\
\hline 18.54 & 91 & 199 & 108 & 1,8 \\
\hline 1862 & 73 & $?$ & 95 & $?$ \\
\hline
\end{tabular}

Bron: Bijlage 4D.

De eerste periode genoemd in Tabel 33 blijk meteen de meest produxtieve te zijn geweest. Eer. groot deel van de plantagegronden was nog jong, evenals de bomen, en rond 1825 waren de seizoenen voor de katoenteel: buitengewoon gunstig. Dit laatste in tegenstellirg tot $1835-1836$ toen er van veel te natte seizoenen sprake was. Dat was echter niet de enige recien waarom de prouluktiviteit na 1825 sterk terugviel. Ruim twee-vijfle van de kafoenplantages was ooit begorner als koffieplantage, en was daarom als katoenonderneming wel ;ong, maar de gronden waren al veel langer in gebruik en raakten als in de koffiesector uitgeput. ${ }^{9}$ Fen duidelijk vontbeeld hiervan is plantage Frederikshust waar in 1801 rog averwegend koffie werd verbouwd en er geen akkers waren verlaten. Zesendertig jaar later was het bebouwd areaal, nu yoornameijk katoen, met $10 \%$ ingekrom.pen en het verlaten areaal uitgegroeid tot maar liefsi $28 \%$. En cat terwi; de slavenmachl met niet neer dan 5\% was afgenomen. De voorgeschiedenis als koffieplantage zal in dit aftakelingsproces een doorslaggevende rol hebben gespeeld. ${ }^{10}$

Ook andere negatieve verschijnselen uit de kofficsector deden zich op katoenplantages voor. Zo bleken de katoenbomen op plantage Vaderszorg en Careisdeel gemiddeld zestien jaar oud te zijn, terwijl algemeen werd aangenomen dat na zes of zeven jaar de boom beter door jorge aanplant kon worden vervangen (Teenstra 1835, 1:288)."1 Evenals bij de koffieplantages, werd op een dee: van de katoenplantages te lang met dezeifde grond en bomen geyroduceeri. De dalende procikktiviteit die daar-

9 Telling op basis van Surinaamse Aimanak 1824:45-65 en ARA: OAS Stukken gevdeponcerd bij bestuursarchieven, 7 .

10 ARA: SONA, 294 en 840; ARA: OAS Stukken gedeponeerd bij bestuursarchieven, 7.

II ARA: PWI Bank, 27. 
van onvermi;delijk het gevolg was, werd op dezelffe wijze als in de koffiesector opgevangen, namelijk door het aantal bomen per akker te verhogen.

Op plantage Anna Catharina werd het aantal bomen per hectare in de loop der tijd mexr dan verdubbeld. Dit is waarschijnlijk een algemene trend geweest. In combinatie met het feit dat de meest produktieve katoenplantages het langst zijn blijven produceren, verklaart dit waarschijnlijk de lichte opleving var de produktiviteit na 1836 . Verschillende innovaties (Hoofdstuk VI), met name op de nieuwe katoenplantages in Coronie en Nìckerie - meest van Britse eigeraars - kunnen daar overigens ook toe hebben bijgeciragen.

In ieder geval is op een belangrijk deel yan de katoenplantages het funeste beleid uit de koffiesector voortgezet, met alie gevolgen van dien. Helaas ontbreekt het aan voldoende materiaal om een uitgebreide vergelijking met het overige Caraibisch gebied te kunnen maken. Voor zover mogelijk is da: gedaan in Tabel 34 .

Tabel 34. Gemidde'de produktiviteil Caraibische katoenplantages :789-1836

\begin{tabular}{|c|c|c|c|c|c|}
\hline land & jar & $\begin{array}{l}\text { totale } \\
\text { produktie }\end{array}$ & $\begin{array}{l}\text { produktie } \\
\text { per piantage }\end{array}$ & $\begin{array}{l}\text { slaven } \\
\text { per plantage }\end{array}$ & $\begin{array}{l}\text { produktie } \\
\text { per slaaf }\end{array}$ \\
\hline St. Domingue & 1789 & 2.614 ton & $3.312 \mathrm{~kg}$ & $?$ & $?$ \\
\hline Trinidad & 1810 & 37 & $?$ & $?$ & $6.3 \mathrm{~kg}$ \\
\hline Cuxiana & 1810 & 4.470 & $?$ & $?$ & 185 \\
\hline Grenada & 1820 & 40 & $?$ & $?$ & 11 \\
\hline Gidiana & 1820 & 2.902 & $?$ & $?$ & 234 \\
\hline Suriname & 1825 & 1.055 & 14.452 & $\$ 14$ & $: 27$ \\
\hline Guiana & 1830 & 1.022 & 40.889 & 241 & 170 \\
\hline Suriname & 1836 & 570 & 10.967 & 126 & 87 \\
\hline
\end{tabular}

Bronnen: Dupuy 1989:21; Marte 1984:81; Higman 1984:66-70;701; Schomburgk 1840:60-3; Mancle 1973:18; Bijlage 4D.

Opnieuw blijkt Guiana Suriname in de negentiende eeuw verre te overtreffen in produktiviteit. Waarsihijnlijk was daar evenals in de suikersector de mechanisering verder gevorderd. Wellicht werden ex ook produktievere tedtmethoden toegepast - bemesting, andere variëteiten - en had de katoensector daar niet te lijden van de roobouweffecten uit de koffiesector. Bij gebrek aan informatie bijft het echter speculeren. Wel is duidelijk dat ook in Guiana de katoenproduktie langzamerhand verminderde. Begin jaren 1840 werd er jaarlijks nog maar 13 ton van dit produkt geëxporteerd (Mancle 1973:18). Waarschijnlijk hee:t de concurrentie van de 
Verenigde Staten, waar de katoen een enorme groei coormaakte, de Caraíbische produktie de das omgedaan.

In het algemeer kan ten aanzien van de produktiviteit in de Surinaamse plantage-economie worden geconcludeerd dat zowel bij koffie als katoen al spoedig na het volwassenworden var deze sectoren het hoogtepunt was bereikt en het verval inzette. Een korlzichtig beleid, gekenmerk! door roofbouw, maakte dit verval onomkeerbaar. Alleen in de suikersector kon men door innovaties de prodiktiviteit blijverd opvoeren. Dit duidt er op dat men in deze sector oog had voor de reproduktie. In de koffiesector had men dat ten enenmale niet. Dit veroorzaakte bovendien een negatief uitstralingseffect in ce katoensector. Het begint er daarom op te lijken dat koffieplanters uit een heel ander hout waren gesneden dan suikexplanters. In ieder geval kenden de dr:e sectoren een zeer verschil.ende ontwikkeling. Daarmee liep Surirame overigens geneel in de pas met de overige Caraibische plantage-economieën. Wat betreft de stijgende shikerproduktiviteit en de achteruitgang in de kolfie- en katoensectoren lijkt Suriname zelfs bijna voorop te hebben geiopen. 


\section{HOOFDSTUK VI}

\section{Innoveren is overleven}

Van het midden van de achttiende eeuw af is de vraag in West-Europa naar produkten als koffie, suiker en katoen explosief gegroeid en werden de grenzen van het technologisch kunnen steeds verder veriegd. Bovendien was begin negentiende eeuw de slavenhandel met Afrika door de meeste Europese landen officieel afgeschaft en werden nieuwe produktiegejieder voor tropische exportgewassen ir. gebruik genomen. Het ligt voor de hand dat het samengaan van deze ontwikikelingen moest leiden tot innovatie in de Caraibische plantage-economieën, althans als deze nun prominente positie als producenten voor de wereldmarkt wilden behouden.

De groei van produktiviteit en innovatie zijn onlosmakelijk met elkaar verbonden fenomenen. Daarbij moet echter onderscheid worden gemaak: tussen locatie en docl van de innovatie. Op plantages kon namelijk én in de teelt (op het veid) én in de verwerking (de iabriek) worden gemoderniscerd. Daarnaast kon innovatie of primair gerich: zijn op rendementsverioging, of op arbeidsbesparing, al zal het onderscineid tussen deze twee niet aitijd even duidelijk kunnen worden gemaakt. In dit hoofdstuk zal daarom worden onderzocht in hoeverre in de Surinaamse plantage-economie eer. innoverend beleid is gevoerd en om welke soort innovaties het daarbij ging.

De uiteenlopende ontwikkeling van de produktiviteit in de verschillende sectoren van de Surinaamse plantage-economie madkt het noodzakelijk ook het innovatiebeleid per sector te behardelen. Continuiteit en kennis van de bedrijfstak zijn fundamentele voorwaarden voor een innoverend beleid. In de stikersector was vecl meer sprake van continuiteit dan in de koffiesector. De veronderstelling ligt daarom voor de hand dat kennis en continuiteit in de suikersertor meer aanwezig waren dan in de koffiesector.

Het verloop van de bezitsverhoudingen in Suriname lijkt cit inderdaad te bevestigen. Een steekproef wijst uit dat van familienamen van eigenaars van 57 stikerplantages in de periode $1750-1769$ bijna twee-derde (63\%) onk a: voorkwam onder de plantersfamilies uit de jaren 1730 . Bij de eigenaars van 120 kolfieplantages in dezelfde periode bieek siech:s twee-vijfde (4t\%) tot de oude plantersfamilies te horen. Wanneer dit deei van de steekproef wordt beperkt tot de 78 plantages die pas rond 1750 werden aangelegd, dan blijkt 
ongeveer twee-derde (64\%) van de koffieplanters nieuw in de kolonie te zijn.' Aangezien in die periode het absenteïsme nog riet dominart was, moet daarom de continuiteit in het beheer - en daarmee de bedrijskkennis in de suikersector groter zijn geweest dan in de koffiesector. Daarnaast hadden Nederlanders in het algemeen al sinds het begin van de zeventiende uw kennis gemaakt met grootschalige commercië.e suikerłee.t in Brazilië en het Caraibisch gebied, terwijl ze 'koffie alleen kenden als 'peasant crop' op Java.

Een andere vraag is in hoeverre slavernij en fechnolngische innovatic verenigbaar zijn. Een veel gehoorde bewering is dat de overvloedige aanwezigheid van goedkope slavenarbeid een obstakel vormde voor innovatie en/of dat slaven niet in staat zoulen zijn geweest met hoogwaardige technologie om te gaar. (zie Boongaard er. Oostindie 1989:4). De komst van vrije arbeid zou, volgers deze redenatie, innovatie pas mogelijk maken, zodat dit een van de redener zou zijn geweest slavenhandel en slavernij op te heffen. Een van de voo:waarden voor deze verondersteiling bleek in ieder geval in Suriname al niet op te gaan: van het einde van de achttiende ceuw af heerste er een chronisch arbeidstekort en waren slaven diur (zie ook Van Stipriaan 1989:94-118).

\section{De koffiesector}

Suriname was het eerste land in het Caraibisch gejied vaar uit Java afkomstige koffie voor de exportproduktie werd geplant. Over de wijze waarop deze plant rond :712 in Suriname zijn intrede deed, doet het volgende verhaal de ronde. Een zilversmid, genaamd Hansbach, had zich als tuinier van Gouverneur Van der Veen enige kolfieplantjes weten toe te eigenen. De Gouverneur had deze plantjes waarschijnlijk gekregen van de flortus Medicus in Amsterdam. I Jansbach: rou allus de expste gewest zijn die de koffieplantjes ging kweken. Fij moet daa: weinig genoegen aan heboen beleefd, want hij was zwaar aan de drank en had daarij 'een zeer indefferent humeur omtrent geld en goed'. De planter S.I. de Neale, wiens vader nog eervoudig als matroos Niels in Suriname was gekomen, wist met behuip van drank en geschenken Hansbach eer. paar plar.tjes af te trogge.en, die hij op zijn plantage Nieuwe Levant aan de Cottica plantte. Hij breidde stelseimatig de aanplant uit, zelfs over meerdere plantages en werd daar uiteindelijk schatrijk mee. Zo rijk zelfs dat hij, teruggekeerd in Europa, zijn lever eindigde als Nederlandse gezant in Prisen, wonend in een paleis, verheven tot graaf De Neale er in hofkringen bekend ais le roi de

I Steekproe! AKA: SONA. De plantersnamua zijn vergeleken met de namen voorkomend op de kaart van A. de Lavaux uit 1737 . 
Suriname' (Gülcher 1943:53). Wat van dit verhaal ook waar mag zijn, een ding staat vast: koffie werd in de loop van de achttiende eeuw de moneymaker' bij uitstek.

\subsection{Teelt en bewerking van koffie}

In Suriname werd koffie gekweekt met zaad. Blom (1787:163) meldt dat men het in zijn tijd ook al probeerde met stekken, maar tevergeefs. Voor het verkrijgen van zaailingen (jonge plantjes) werden of rijpe vruchten van de bomen gehaald en in kweekbedden gezaaid, of men liet de natuur haar gang gaan door van de boom gevallen vruchten ter plekke te laten ontkiemen. In het laatste geval werden de zaailingen ra enkele weken alsnog op kweekbedden overgeplant. Deze zogenamde koffieplantsoenen liet men opgroeien in de schaduw var banarebonen, tot zij ongeveer een jaa: oud en een halve meter hoog warer. Tegen die tijd konden $\mathrm{zij}$ worden uitgezet op de koffie-akkers, war zij werder. geplant op bedden van 6 tot $i 0$ meter breedte en 200 meter lengte.

Bij de aanleg van die plantbedden moest goed worden opgelet dat zij een regelmatig oppervlax kregen. Zo niet, dan bleef er water op staan en kwamen de bomen niet tot volle wasdom. Vervolgens werden met behulp van stokken op jeder bed drie a vier rijen plantgaten gemaakt, waarin de plantsoener. met kluit en al werden gepont. Om te voorkomen dat de plant dood zou gaar, was inet zaak de perworte: rechtstandig in het plantgat fe plaatsen, watna de aarde met de voeten werd angestampt. Na iedere twee koffiebomer. werd een bananeboom geplant, Lie de jonge koffie tegen de felle zon moest beschermen. Vier of vijf jaar later verwijderde men de bananeboom weer (althans in de achttiende eeuw), omdat de koffieboom dan werd geacht zelf sterk genveg te zijn en de banaan teveel voedsel zou onttrekken aan de grond ter koste van de kófie.

De wijze waarop de koffieboom - in feite een heester - verder word opgekweekt is warschijnlijk in de loop der tijd aan verandering onderhevig geweest. Volgens Blom was het in zijn tijd de gewoonte de koffie op sén stam te iaten opgropien door de andere loten er at te breken. Boverdien ilet men de boom riet hoger worden dan circa twee mete:. Volgens Blom waren dit tegengestelde bewerkingen, want door de eerste schoot de boom extra hoog op, terwijl de tweede hem juist aag hield en dit is zekerlijk niet overeenkomstig met de gezonde natiurkunde' (Blom 1787:206). De planters van het iandbouwkundig genowschap De Lensgezindheid (1804:57) deelden deze kritjek, mar stelden dat deze praktijk inmidals fot het verleden behoorde. $7 \mathrm{ij}$ lieten de groei van de bomen nu geheel over an het natuurlijk verioop er. constateerden zelfs dat de bomen nu meer en langer vrucht gaven. Het is echter de vraag of deze observatie correct was; in ieder geval moeten de hoge bomen het plukken sterk hebben bemoeilijkt. Deze 


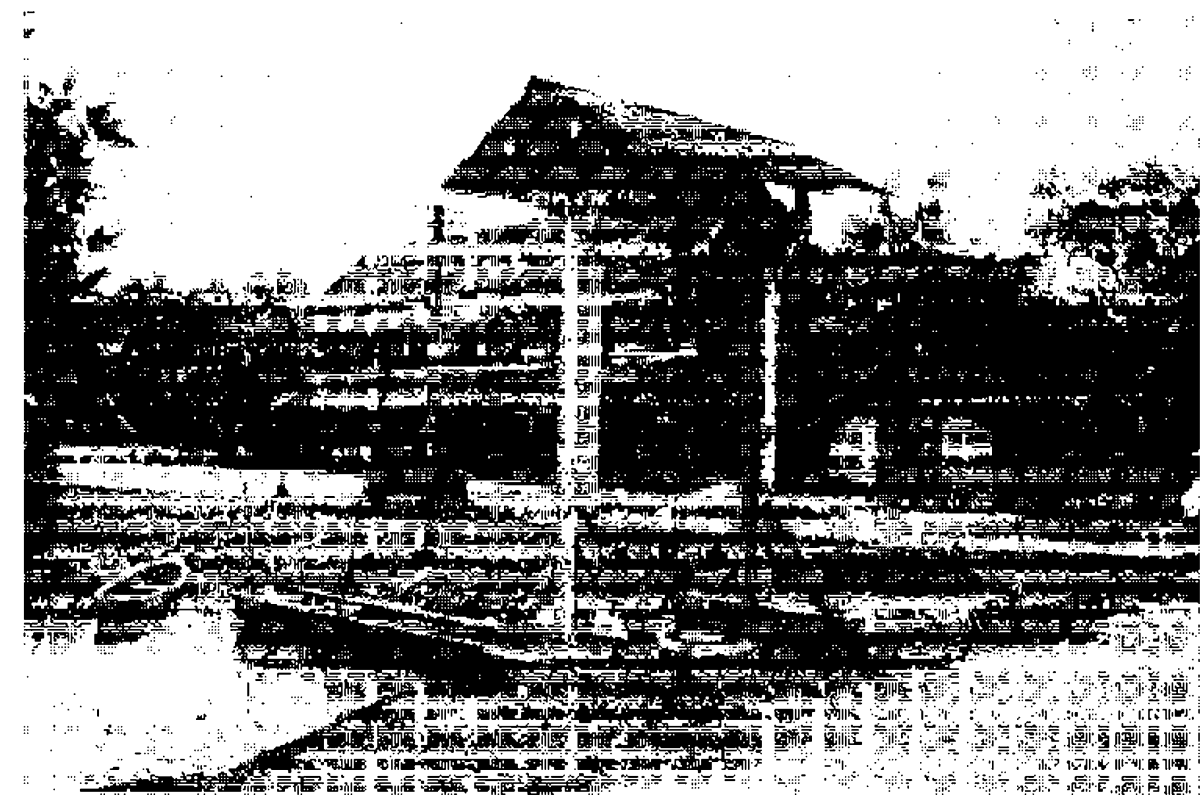

Kofficloods, ảrcgerij en sl:isje op plantage l'eperpot (Soto Alex van Stipriaan) 
praktijk zal dan ook geen gemeengoed zijn geworden, want M.D. Teenstra (1835, I:250-2) merkte op dat men in het algemeen de bomen op drie of vier stammen liet opgroeien, maar dat zij wel op manshoogte werden afgetopt.

In hef tweede of derde jaar nadat de boom was geplant, begon hij vrucht te dragen. Als cerste $\mathrm{v}$. scheen de witte blousem, waarna in zes maanden de vrucht rijpte van groen tol donkerrood. In dic vrucht of bueba - Teensira spreekt van een peul - zitten twee pitten omgeven door een vlicsje. Dit zijn de eigenlijke koffiebonen. In Suriname bloeide de koffie tweemaal per jaar, in maart/april en in september/oktober. Zo waren er jaarlijks dus ook twee oogsten: de zogenaamce voorpluk (in het 'voorjaar') en de rapluk ('najaar'). Drie jaar na de eerste vruchtzetting was de boom volwassen en kon men tot en met het twaalfde jaar rekenen op en maximale produktie. Daarna begon die langzaam af te nemen.

Het onderhoid van de kof́je-akkers em -bomen was tamelijk irtensief en vereiste natuvkeurigheid. Meestal werd de koffie geplant in de Kleine Regentijd, omdat dan de omstandigheden voor een voorspoedige groei het best warem. Dat gold echter nok voor allerlei onkruid, zociat van het begin af flink moest worden gewied, zonder daarbij het jonge plantje te beschadigen. De eerste par jaar moest dit volgens blom (i787:180) jedere zes weken worden gedaan, daarna kon worden volstaan met eens in de drie maanden te wieden. Al nadr gelang de beougde groeiwijze muest de boom verder eens per jaar worden afgetopt en twee maal gesnoeid. Ook diende men de bomen iweemal per jaar te 'zuiveren', wat het verwijderen inhield var. overtollige loten, dood hout en 'vogelkaka'2 en uitroeien van mierennesten en houtluizen.

De koffievruchten werden met de hand geplukt, waarbij er goed op moest worden toegezien dat de onrijpe bieven hangen. Per dag plukte eer slaaf gemiddeld $40-50 \mathrm{~kg}$ van dergelijke vruchten, die werden verzameld in eer. baskiet (mand). Aan het eind van de dag werd deze op het hoofd naar het fabriekscumplex gedragen; surms wel een uur lopen. Daar a angekomen moesten de slaven nog tot diep in de nacht de koffie bewerken.

Allereersi werd de geplukte koffie enkele dagen in een stenen bak met water te weken gelegd om de bocba los te maken. Daarna werd deze in de breekmoler gebroken, zonder de twee er in zittende bonen to beschadigen. Van daaruit viel de gekneusde vrucht op een lang houten ronster (menarie) warlangs een aantal slavinnen stond opgesteid. Deze hadden tot taak de koffie net zolang over de menarie rond te wrijven - onder voortdurend bespoelen met water - tot de boeba los'iet en de bonen tussen de latjes doorvieler. Daaronder liep een gemetselde goot naar een stenen wasbak,

2 Vogelkaka is een parasitterence plant (als klimop), die alleen yoorkomt op koffie- en sinaasappelbumen en afxomslig is van zaadjes in de viggelpoep. 
waarin de bonen opnieuw een nacht werden geweekt om de gelei-achtige substantie die hen omhulde los te maken.

De volgende dag werden de bonen, onder voorldurend roeren, van dit vruchtslijm ontdaan en op grote stenen vloeren (de drogerij) uitgespreid om in de zon te droger. Na ongeveer een week ging de koffie voor verdere droging naar de zolder van de kofficloods. De koffie was dan nog in lichte mate vochtig, zodat daar een zekere fermentatic plaatsvond, die later een kenmerkende eigen smaak opleverde. Al te zeer mocht de koffie echter ook niet broeien, in verband met brandgevaar en ongedierte, zodat hij tweemaal daags moest worden omgeschept (verschoten). Was de koffie eenmaal 'zolderdroog' dan werd hij rogmaals een paar dagen op de drogerij in de zon gelegd, om de laatste restjes vocht er iit te trekken.

Tot dat moment bevond zicl: om de koffiejoon nog steeds cen soort vliesje (de binnenste vruchtwand). Deze werd nu losgemaak: door de bonen enige tijd te stampen in de zogenaamde koffiemat, een lange, hardhouten boomstam, met tien tot twintig daarin uitgeholde gater. ${ }^{3}$ Na het stampen werd in de zogenaamie waaimolen het vliesje van de koffie afgeblazen. Tenslotte werden bonen in zeven of wanner. nog eens van de laatste ongerechtigheden ontciaan en moest de gebroken koffie er wit worden gesorteerd. Pas dan was de koffie klaar om in balen verpakt en verzonden te worden.

\subsection{Innovatie}

Tot halverwege de ach:tiende eeuw waren Suriname, Martinique en Saint Domingue waarschijnlijk even groot als koffieproducenten (Trou:llot 1982: 336-7) en werd verder alleen nog op Guadeloupe en in. Guiana (Berbice, Essequibo en Demarara) koffie verboliwd. Na die tijd lieter Martinique en met name Saint Domingue Suriname ver achter zich. Rond $1800 \mathrm{kwam}$ Jamaica er als belangriike koffieproducent bij en ook Ciuiana was inmiddels Suriname gepasseerd. Alleen al in het Brits-Caraijpisch gebied waren toen zo'n 95.000 slaven bij de kuffieproduktie betrokken (I Iigman 1984:71). Marti-

'Tit stampen geschicdt ten allen tijde na den afloop van het gewone dagwerk, en om het stelen te belet ten, worder de Vegers meerendeels in de losds opgexloten, zoodat men onder cene? allergeutigste zweetlucht bi:na geen' adem kan halen, en als in hot fijne stof verstikt; [...] en desniettegenstaande gaat dit stampen ter allen trjde met een Negergezang of liever gejoel en gedruisch gepaard. Bij elken vijzel staan twee Negers, ter weerzijden van de koffijmat ixin, welke met zware van hard hout gemaakte stampers (matlo tikki), bijna zoo lang als eene handspaak, met een' knop aan ieder einde, beurtelings in den vijzel stampen, en den bast in 25 a 30 stowten losmakin, waarna ecne Negermeid de grstainpte kiffij uit de mat komt halen, en eene andere meid of een jongen weder een baksi vol ongestampte koffij er in draagt.' (Tecnstra $1835, \mathrm{I}: 26 \mathrm{j}-1$.

Nist iederen lijks overigens Teenstra's negatieve ourdeel over de slavenzang te hebben gedeeld. Zo schreef de voormalige plantagedirecteur Kunitz (1805-287): 'Während den nächtlichen Arbeiten pflegen sich die Sclaven mit Singen die Zeit zu verkürzen Lnd dann hört man Virtuosen und Virtuosinnen alier Art: 
nique, Guadeloune en Suriname waren toen al duidelijk op thun retour, terwijl op Saint Domingue/Haïti en Jamaica koffie de belangrijkste cashcrop werd var de ex-slaven. In de loop van de eerste helft van de negentiende eeuw kwamen er bovendien enkele beiangrijke producenten bij, namelijk Cuba, San Domingo en Puerto Rico.

Over hel technologisch niveau van de Caraibische koffieplantages worder in de literatur vrijwel geen uitspraken gedaan." Alleen Trouillot (1982:347) stelt dat dit op Saint Domingue an hef eind van de achtiende eeuw vergelijkbaar was met het peil in de suikersector. In Suriname daalde echter de produxtiviteit van de koffieplantages na 1800 , terwijl die van suiker juist steeg. Dit schept dus geen al te hoge verwachtingen over het technologisch niveak op de koffieplantages.

In ieder geval hebben de Surinaamse koffieplantages in hun aanlegfase geprofiteerd van technologische verworverheden uit de suikersector. Vrijwel alle koffieplantages werden nameli; aangelegd in de moerassige benedenlanden, zodat de kennis die in de suikersector was opgedaan met de techniek van het inpolderen goed van pas kwam. Naarmate cind achtfience eeuw de afstanden op koffie-ondememingen toenamen door areaalexpansie en verlating werden, in ravolging van de suikerplantages, op sommige plantages ook vaartrenzen gegraven. Fet transpont op de onderneming werd hierdoor sterk vergemakkelijkt. Desondanks bleef deze innovatie tot een minderheid (30\%) van de koffieplartages beperkt.

Het is duidelijk dat pas een vaartrens werd aangelegd toen de koúfieplantages hin volie wasdom hadden bereikt en het verval nog geen dominant verschijnse' was geworder, tussen 1775 en 1800. Toch was het kennelijk voor de meeste koff:eplantages niet zinnig, of mogelijk, om deze innovatie in te voeren. Hef versch:1 in grootle tusser: de plantages met en zonder een vaartrens bevestigt dit. Ilantages inet een vaartrens waren rond 1800 gemiddeld 360 ha. groot en telden 133 slaven. T'lantages die niet to: de aanley daarvar waren overgegaan hadden son een gemiddelde omvang van 270 ha. en 101 slaven. ${ }^{5}$ Ifet ligt voor de hand dat beide factoren bepalend waren voor het al dan niet aanlegger, van zo'n iransportsysteem.

Fen andere belangrijke innovatie buiter de koffiefabriek was de infroductie van schaduwbomen rond 1800 . Voo: die tijd werden alleen de jonge boompjes tot hun volwassenineid beschadiwd met bananebomen. Wat de planters er toe heeft gebracht om begin negentiende eecw massaal de koffie

4 Zelfs ten gedegen onderzoek als dat van Watts (1987), waarin vele tientallen bladzijden worden grewijd aan de ontwikkrling van de suikertechnologis in het Caraibisch gebied, rept met geen woord over de koffiecultuur, of de stand van de technologie in deze sector.

5 Areaalcijfers: Surinamse Almanak 1796; slavenpopulaties: Public Record Office: Colonial Office $278,15$. 
met bananen te gaan overschaduwen is niet bekend.6 In ieder geval bevestigt de moderne theorie dat het voor gebieden met een klimaat als het Surinaamse een zeer verstardige matregel was. ${ }^{7}$ Toch kleefden er ook nadelen aan deze nieuwe praktijk. Volgens Teenstra $(1835,1: 251)$ werden door 'eene overdrevene winzucht' veel te veel bananebomen geplant en beschadigden zij door hun geringe stabiliteit nogal eens de kofficbomen. Het eerste punt zou in het algemeen wel eens de reden geweest kunnen zijn om bananen tussen de koffie te planten, zoals dat daarvoor met katoen was gebeurd.

Met de bananen konden niet alieen de siaven worden gevoec, wat de exploitatiekosten drukte, maat bovencien zorgde de verkoop aan suikerplantages voor een aanvultend inkomen (zie Iloofdstuk VIII). Aangezien de administrateurs $10 \%$ van deze inkomsten als provisie opstreken, zouden zi; wel eens de motor achter deze innovatie kurmen zijn geweest. Het gebruik van de banaan als schaduwboom was daarom een innovatie die het behoud van zowe de koffieboom ais een voordelige balans ter goede kwam, tegelijkertijd stond echter eer tevee! aan bananebomen de koffie in de weg en dat deed een extra beroep op het voedend vermoger, van de grond.

Van bemesting is op Surinaamse koffieplantages nauwelijks sprake geweest. De enige vormen van natuulijke bemesting waren de gesnoeide bladeren van koffie- en bananebornen die men op de akkers liet liggen en de klei die met enige regelmaat uit de trenzen werd gebaggerd er. over de bedden verspreid. Eiders in het Caraîhisch gebied werd al in de achttiende eeuw gebruik gemaakt van koeiemest en compost en later ook guano. ${ }^{\bar{\gamma}}$ In Suriname bleef men - ondanks bewijzen van het tegendeel - er steeds van uitgaan dat de natiurlijke vruchtbaarheid van de bodem ruim voldoende was om die zonder hulpmiddelen tot in lengte van dagen te blijven bebouwen. Vandaar dat men vele tientallen jaren achtereen met dezelfde

6 Rond 1800 moet het gebruik al up tamelijk grote schaal zijn ingeburgerd, maar toch was nog niet iedereen van het nut ove:tuigd. Zo schreven de planters van De Fensgezinibeid (1804:54) 'dat veele Surinaamsche landbouwers van begrip zyn om Bananen in de Koffy te planten, voorgevende dat dezelven de Koffyboomen voor de sterke zon bewaren, en de sterke of schrale winden afweren; maar wy kcuren zulks volstrekt af, om reden dat de Koffyboum de sterke zon wel verdragen kan, en de wind, als ook Ge zon, de landen en de Gewassen vruchtbaar makkt".

7 Zo schrijft Purseglovs (1968, 11:464) dat exen klimaat waarin 'rainfall is excessive, temperatures are too high [...) and possibly where there is a prolonged scason of many hours of bright sunlight [zoals in Suriname], it is advisable to use shade to sustain regular yields and prevent over-bearing'.

$8 \quad 20$ schrijft Debien (1956:99) over het achttiende-eeuwse Saint Domingue: 'Le gérant apporte à la fumure une méthode très méticuleuse. Son souci est d'avoir le plus de fumier possible et toujours à portice des pièces caféiers. Il le fait monier dans la belle saisinn et entasser en des fosses a fond de terre battue et recouvertes d'un toił léger. Le fumier n'est pas répandu mais enfoui, mèlé a des vases, à des terres de costiere en une sorte de compost. Les viejlles pratigues de I'Furope ne se perdent pas toutes a Saint-Domingue: 
grond bleef produceren, die bovendien met steeds rnee: bomen werd beplant en waar de zon tijoens de achttiende eeuw vrij spel had. Rotatiecycli en bemesting zouden zee: nuttige innovaties zijn geweest, maar hebben nooiz ingang gevonder.

Van het derde kwart van de achttiende eeuw af zijn de Surinaamse koffieplanters een techniek gaan hanteren die de dalende produktiviteit van de bomen moest tegengaan. $\mathrm{Zij}$ zagen dat na het twaalfde jaar een koffiebonm minder vrucht begon te ciragen. Om dit tegen te gaan werd de boom dan zwaar gesnoeid, waardoor hij een jaar lang geen koffie droeg. Daarna produceerde hij echter 'weer gedurende drie of vier jaaren behoorlijk vruchten' (Blom 1787:165-6).

Deze techniek leek dus uitkomst te bieden en wera eind achttiende eeuw zo ver doorgevoerd, dat mer alleen nog hef joomstomjje liet stan, de rest werd weggekapt. Niet voor niets sprak men van 'op stomp kappen'. Het duisde dan overigens wel zo'n drie tot vier jaar voor de boom weer volledig vruchit droeg. Hij produceerde dan inderdaad meer dan voor het op stomp kappen, maar mirder dan een jonge boom in de kracht van zijn lever. Men prefereerde echter het resultaat op korte teraijn boven het langduriger en arbeidsintensievere herplanten op nieuwe gronden. De troosteloze aanbiik van eindeloze rijen boomstompies werd zo van het cinde van de achttiende eeuw af een normaal verschijnsel op Surinaamse koffieplantages. Een steekproef over le periode 1770-1850 wijst uit dat, ondanks het op stomp kappen, de produktiviteit per koffieboor. daalde van gemiddeld 0,3 tot $0,1 \mathrm{~kg}$ per jaar-

Er dient wei te worden bedacht dat de achteruitgang ratuurlijk ook in de hand werd gewerkt door gronduitputting. Toch is de daling van de boomprodukiiviteit vooral tussen 1770 en 1790 zeer opvallerd. Het bomenbestand was voor een groot deel op stomp gekapt. ${ }^{\circ}$ lr de jaren 1830 en 1840 vond een verdere cialing var de boomprodiktiviteit plats, zij hel minder duidelijk dan eind achttiende ceuw. Waarschlijnlijk was dit cen gevolg van het in gebruik nemen van de middelsie en achterste plantagestukken, waar nieuwe bomen waren geplant en wellicht ocix al weer op stomp waren gekapt. Wanneer een boom nauweijks meer vrucht faf kon het op stomp kappen tijcielijk resp:jt bieden; op de lange duur bleek het toch to een aanzienlijke vermindering van de produktiviteit te leiden.

9 Een voorbeeld daarvan was plantage Groningen aan de Tapoeripakreek, waar in 1784 ruim een-derte van de bomen ( 26 ha.) met een gemiddelde leeftijd van 21 jaar, op stomp was ge:kapt (ARA: SONA, 2633).

10 De administrateur van eer plantage schrijst letterlijk: de koffiebomen 'zijn in de laatste drie jaaren zwaar gekapt geworden en deeze kapping heeft middelerwij] ook tot de minderheid der vrugten medegewerkt (GAR: Collectic i judig, 318). 
Een andere innovatie die de produktiviteit mogelijk kon opvoeren was het invoeren van nieuwe koffievariëteiten. Van het begin af had men in Suriname maar én koffiesoort geplant: de Coffea Arabica. Het is niet onwaarschijnilik dat al die miljoenen bomen te herleiden waren tot de oorspronkelijke plantjes van Hansbach uit 1712. Tot het einde van de negentiende eeuw is er nooit op grote schaal een nieuwe variëteit geintroduceerd.

Toch waren er in de negentiende ecuw wel planters dic zich met deze kwestie bezig hielden. Zo overwogen de administrateurs van plantage Beekvliet in 1832 jonge plantjes uit Saint Domingue of Cuba te laten opsturen.11 Het is er nooit van gexomen, maar bijvoorbeeld op Jagtlust aan de Surinamerivier experimenteerde men daadwerkeljjk met nieuwe variëteiten. In 1838 had men daarvoor special wit Santiago de Cuba bonen laten overkomen en op de plantage geplani. Daarnaast werden er proeven genomen met 'Mocha-kofficbomen'.12 Het kan toeval zijn, maar in het eerste jaar (1843) dat deze rieuwe bomen volledig vrucht gaven was de oogst groter dan ooit. In de periode : $836-1842$ bedroeg de gemiddelde opbrengst per jaar $19.362 \mathrm{~kg}$. In 1843 bleek tot 30 september a: $34.368 \mathrm{~kg}$ te zijn geplukt en hing er nog kotfie aan de bomen. ${ }^{3} \mathrm{Na}$ die datum is er echter geen correspondentie mee: aangetroffen, zodat over de verdere ontwikkelingen van dit experiment niets is te zeggen. Wei is zeker da: Jagtlust tot het kleine groepje koffieplantages benoorde dat tot aan de Enancipatie in bedrijf is gebleven.14

I Het zal duicelijk zijr. da! er, gelet op de algehele siiuatie in die jaren, niet zoveel innovatiemogelijkheden waren op de koffievelden. Bovendien werden allen nieuwe technieken ingevoerd die op korte termijn vrucht afwierpen. Ironisch genoeg leidden juist op stomp kappen en de banaan als schaduwboom op de lange duur tot een verminderde produktiviteit. Arbeidsintensieve en tijdrovende irnovaties, rotatie, bemesting en nieuwe variëteiten, die op langere termijn de produktiviteit hadden kunnen handhaven of verhogen, oleven daarentegen acinterwege.

Gebrex aan innovatie op het veld betekende niet dat ook in het fabriekscomplex alles bij het oude blcef. Sterke: nog, dit faurickscomplex en de hele

11 Zij vroegen zich namelijk af 'of het ook mogelijk was, dat de kuffijboun zelve verbasterd was en of het misschien van nut zoude zijn, om indien mogelijk, uit Saint Doringue of Cuba ander plantzoen te ontbieden, maar al waare het zeket, da: dit van goed gevolg zijn zoude, dan nog zouden er veele jaaren verlopen, voor men nierover in hel groot reness giscden uitslag konde hebben'. Die vele jaren van proefneminger waren de administratears echter riet gegund, want in 1836 besloten de eigenaass deze plantage te sluiten en de slaven over te brengen naar een van hun suikerplantages (GAA: I'A-601), 544).

12 Het is hierbij overigens de vaag of het echt on: een nieuwe variëteit ging of eveneens om Arabica.

13 Collectie-Insinger \& (o)., notulboek.

14 CBBS: slaventegisters. In de jaren 1890 was lagtiust de grootste cacaoproducent van Suriname en werkten er 191 Aziatische en 69 Creoolse contractarbeiders (Kolonianl Versing 1894 en Van Capelle $1901: 48$ ) 
wijze waarop de koffiebewerking plaatsvond, was op zich al een innovatie. De Surinaamse koffie was afkomstig uit Java, zodat waarschijnlijk ook de kennis over dit gewas daar vandaan kwam. Op Java was de bereidingswijze echter zeer simpel, vrijwel geheel handmatig en 'droog'. In het Caraibisch gebied onderging de koffie langduriger en meer complexe bewerkingen, die bovendien voor een deel waren gemechaniscerd. Door het gebruik yan water en hel lichte fermentatieproces van de koffie sprak men van de Westindische of 'natte' bereidingswijze, met de zo kenmerkende 'blauwe boon' als resultaat. Deze werd verre superieur geacht aan de lavaanse koffie en maakte daardoor ook een betere prijs (Ament 1836:1-2; Van Hall 1933:219). Het is niet bekend of deze bereidingswijze in Suriname is ontstaan of op Martinique, waar de koffie ongeveer tegelijkertijd is geintroduceerd.

Overigens werden de gemechaniseerde onderdelen van de koffiebewerking pas in de loop van de achttiende eeuw ontwikkeld. Zo schreef Blom (1787:183) dat in zijn tijd alleen de grotere koffieplantages beschikten over cen breekmolen en dat op de kleine de koffievruchten werden gekneusd door deze met de hand over een stener vloer te wrijven. Fen steekproes wijst uil dat in het laatste kwart van de achttiende eeuw $31 \%$ van de plantages geen breekmolen had. Fen tweede steekproef laat echter zien dat na 1820 alle plantages over een breekmolen beschikten. ${ }^{15}$ Een-derde daarvan had zelfs een dubbele breekmolen, terwijl dat in Bloms tijjd slechts bij $10 \%$ van de plantages voorkwam.

Hoogstwaarschijnlijk was de breekmolen een innovatie die pas rond 1770 werd geïntroduceerd, want in geen van de plantage-inventarissen wordt vóór die tijd een dergelijk apparaat vermeld. ${ }^{16}$ Zo'n breekmolen was zeer eenvoudig van constructie en bestond uit een gegroefde houten rol van ruim een meter lang die rond een as draaide en over een iets langer, eveneens gegroefd stuk hout liep. Via een trechter werd de koffie van bovenaf op de roller gestort, die door enkele slaven werd rondgedraaid en zo de koffic kneusde. Fen dubbele breekmolen werkte volgens hetzelfde principe, alleen was de roller verbonden met een ronde schijf waaromheen een snaar liep, die een tweede roller in beweging zette welke ook over een gegroefd stuk hout liep. Zodoende kon in dezelfde tijd een dubbele hoeveelheid koffie met hetzelfde aantal slaven worden gekneusd. Vergeleken met slaven die koffie met de hand over steen moesten wrijven, betekende

15 Sterkproef 1: ARA: SONA $(n=39)$; steekproef 2: ARA: SONA, SNA en plantagearchieven.

16 Wolbers (1861:318) vond in het journatl van Ciouverneur Nepveu (1770): 'In 1769 werd dour ern Fransche Molenmaker, Simeon, eene machine gemaakt, eene soort van molen, waardoor de koffij, nadat zij geplukt was, van de roode bast werd ontdaan en van de grijj afgezonderd. Daar de machine redelijk wel voldeed, onwing hij hiervoor van eenige koffijplanters, die zich daarto verbonden hadden, eene belooning van $f 12$ à $/ 1500$. 


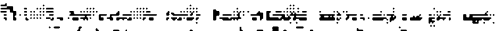

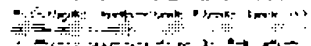

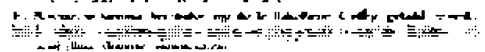

$i_{1},+\cdots$,

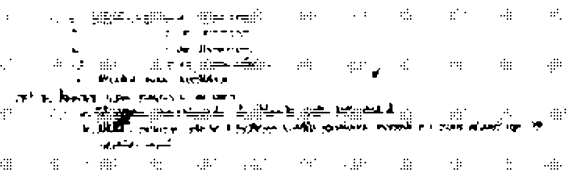

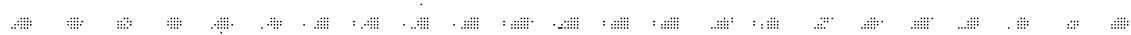

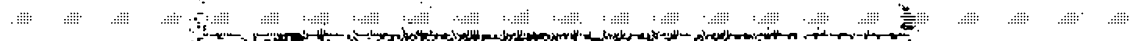
-

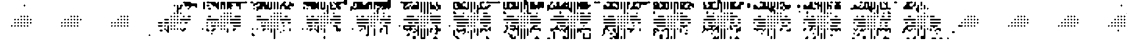

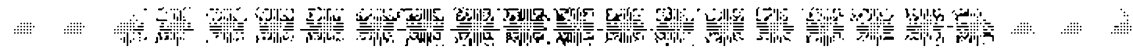

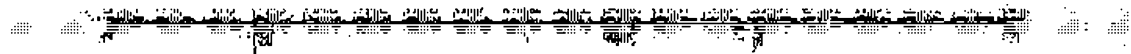

舟

.

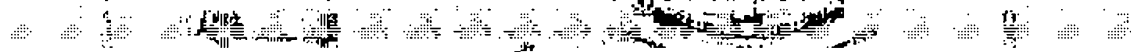

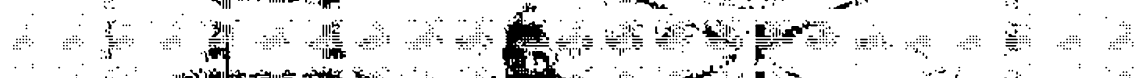

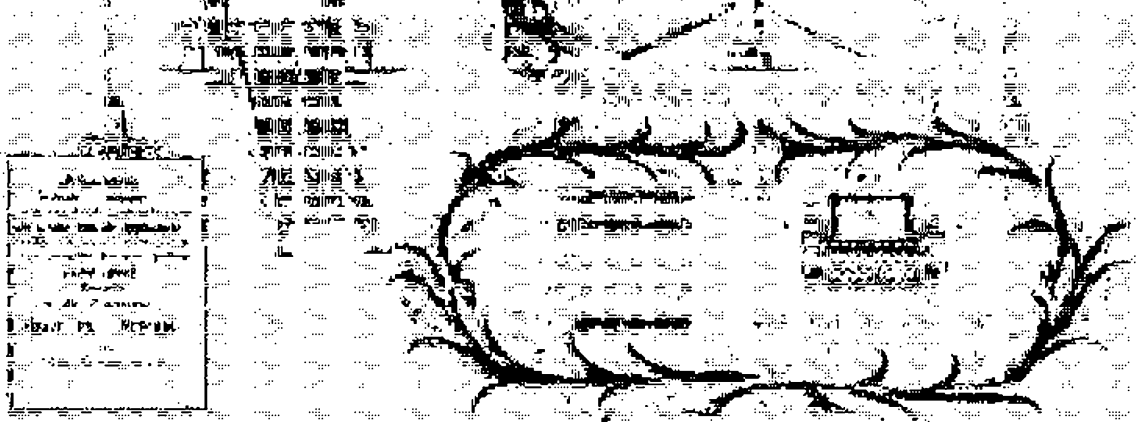

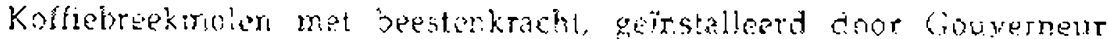

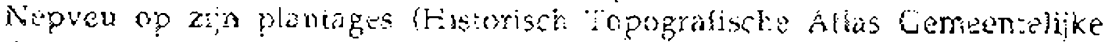
Arohiofienst Amsemenu; 
de komst van de breekmolen een erorme besparing in tijd en arbeid. Het toenemend gebruik var. de dubbele breekmolen zette deze trend voort. Daarnaast voorzag men in de negentiende eeuw de roliers steeds meer van koperbeslag, waardoor de koffiebast me: meer gemak kon worden gekneusd (Teerstra 1835, I:258).

Een andere structurele innovatie van de breekmolen, namelijk de vervanging van menselijke spicrkracht als aandrijving door een andere energiebron, heeft daarentegen nooit ingang gevonden in Suriname. Wel hebben er experimenten plaatsgevonden. Zo bleck in 1774 Gouverneur Nepveu op al zijn vijf koffieplantages een breckmolen te heiben geïrstaileerd met een raderwerk voor paarden. 17 Verder roemt Teenstra (1835, 1:258) de plantages Mijn Vermaak en L'Aventure, waar de breekmolens eveneens met beesten moesten worčen aangedreven, maar bij gebrek van milezeis wordt dit thans door Negers rondgedraaid. Waarschijn'jijk is het gebrek aan beesten, of kapitaal om die te kopen, een beiangrijke reden geweest dat deze innovatie geen navolging heeft gekreger.

Toch blifft hel vreemd dat men, bij het sleeds toenemende arbeidstekort, in ieder geval op de grotere plantages niel naar andere energiebronnen heeft gezocht Zo bleek bijvoorbeeld de voormalige su:kerplantage Des Tombesburg in 18.53 te zijn orgezet in een rijstplantage, voorzien van een :ijstpelmolen aangedreven donr een waterrad (Van Sijpesteijn 1854:112-3). Zo'n ri;stpelmolen kwam sterk overeer. met een koffiebreekmo'en, zodat wateraandrijying - warmee men op suikerplantages al sinds begin achttiende eeuw ervaring had - binren de technische mogelijkheden van de koffieplantage lag. Kennelijk wogen de aanlegkosten van een watermolen, trens en siuis nie: op tegen de te verwachten arbeidsbesparing. Op Des Tornibesburg was dat geen probleem geweest, omdat deze, als voormalige suikerplantage, al over zo'n waterwe:k beschikle.

Naast waterkracht werd in de negentiende ceuw stoomkracht een reële mogelijkheid tot arbeidsbesparende innoviaties. Van de vroege jaren i 820 af, en wellicht al cercier werden ir. Furopa en Amerika met stoom aangedreven koffiemachines geprodureerd. 18 Deze ontwikkeling bleef in Suriname niet onopgemerkt, want al in 1828 schreef Kuin (88-9) da: in Suriname op de plantages Kroonenburg er. Sporksgitt zulke machires waren geïntalleerd en 'buiten verwachting' functioneerden. Volgens hem was dit zee: in het voordeel var de siaven, want het spaarde arbeid uit en de nachtrust hoefàe er niet voor te worden opgeofferd. Deze plantages vormden echter een uitzondering op de regel. Bovendien zijn beide in een later stadium

17 FHB: KA-120, wrs. 11-14.

18 In $1822 \mathrm{kreeg}$ Nathan Reed in de USA het patent op een stoom aangedreven 'coffee buller' en in 1831 begor, fohn Whitmee \& Co. met de produktie van colfee plantation machinery" (Likers 1922:729). 
overgeschakeld op de produktie van suiker. Zelifs in de late jaren 1850 zijn er nooit meer dan vier stoommachires werkzaam geweest in de koffiesector. ${ }^{19}$ Waarschijnlijk was in de negentiende eeuw het verval op de koffieplantages al te ver vourzgeschreden om de invoering van deze tamelijk kostbare innovatie nog rendabel te kunnen maken.

In de rest van het bewerkingsproces van koffie herft verder nooit enige innovatie van betekenis piaats gevonden. Toch waren daartoe wel mogelijkheden. Zo leende de waaimolen zich uitstekend om door andere dan menselijke spierkracht te worden aangedreven. Dit apparaat bestond namelijk uit een simpele houten kast, die van voren voor de heift open was en waarin een met de hand bewogen, soort houten propeller ronddraaide. De gekneusde koffie werd er van boven, via een trechter, ingestort en viel in een bak. Tijdens de val werden de gebroken schilletjes var de koffie door de wind van de propeller weggeblazer. Daama werden de bonen nog ens met de hand gewand. Misschien dat in de achttiende eeuw de technologie nog niet aanwezig was om dit proces verder te mechaniseren. In het tweede kwart van de negentiende eeuw bestonden dergeljike stoomaargedrever. werktuigen zeker wel (zie Cardoso 1977:187).

Mechanisering van het stampen van de koffie behoorde al in de achttiende eeuw tot de mogelijkheden. Zo maakte Gouverneur Nepveu al in 1770 gewag van een kleine, spiraalsgewijze wrijmmolen, lopend in een soort ton, die de bast afpelde en de bonen minder plette (Wolbers 1861:318). Toch is deze vinding, waarop de directie van de Sociëteit van Suriname in 1768 patent had verleend, nooit op grote schaal in gebruik genomen. 20 juist me: deze vinding kon echter hetere kwaliteit, ivant minder gebroken, koffie worcien afgeleverd en het zeer arbeidsintensieve en ongezonde stampwerk werd vermeden. Boverdien had de concurrentie in Saint Domirgue deze innovatie wel al in de achttiende eecw geintroduceerd. ${ }^{21}$ Dat dit in Suriname niet is gebeurd heeft waarschijr:lijk inel behoud- of gemakzucht var. de koffieplanters te maken gehad. Ook in ncgentiende ecuw veranderde dit niet, want in 1847 kende. Surirame waarschijnlijk slechts én plantage, Jagtlust, waar dit karwei door een pelmachine was overgenomen die 'ongeloofelijk snel werkte' (Boekhouct 1874:71). In dit geval kan echter ook een breekmolen zijn becioeld.

\section{Koloriale Verslogen 1855-1862}

20 'Directeuren hadden reeds vroeger in 1768 zekeren timmernan, J.M. Augersirin, een octrooi van 6 jaren verleend tot het maken van een bijzonder soort van molens. Op hel schenden van dat verleend octrooi was eene boete van $f 6000$ gesteld. (Wolbers $1861: 318$.)

21 Zo schrijít 6 . Debien dat een pianter in het bezin a avait fait pïer les cafés dans dess surtes d'auges en bois qui faisaient l'office de mortiers [koffiemat], naais il en vint vite aे un moulir: qui ne faisait pas astant de besogne mais çui fatiguait moins les noirs. Le manque de maind'veuvre et son prix poussaient a developperr les machines:' (Ijebien 1956-101-2.) 
In éér. opzicht lijkt in Suriname zelfs het omgekeerde van inrovatie te zijg opgetreden. In de achttiende eeuw beschikten veel plantages over een koffieloods, waar van binnen naar buiten een soort houten rails liep, rustend op stenen neuten. Over deze rails werden houten bakken geschoven, waarin de vochtige koffie lag opgeslagen. Al naar gelang de weersomstandigheden schoof men de bakken naar birnen of naar buiten om de koffie te laten drogen. Zonder deze praktische vinding moest de koffie steeds met de hand worden versleept. In Brazilië worden deze schuifbaxken tot op de dag van vandaag gebruikt; in Siriname waren $z i j$ al in de negentiende eeuw in onbruik geraakt. Het waarom blijft een raadsel, want zij werden riet, zoals elders in de regio, vervangen door stoomdrogers. Ook Teenstra (1835, I:261) observeerde dit verschijnse:, maar gaf er geen verklaring voor. Het is niet unwaarschijnlijk dat het en gevolg was van de algemene verwaarlozing van koffieplantages in die tijd.

Behalve de introductie van de (dubbele) koffiebreekmolen is er in de Strinaamse koffiebewerking dus nauwe.ijks geinnoveerd. De veronderstelling dat kapitaaigebrek hieraan ten grondisiag heeft gelegen ligt voor de hand. Toch geldt dat in feite alleen voor de invoering van dure stoommachines in. de negentiende ceuw, Op Saint Domingue, cr, waarschijnlijk ook Jamaica, waren in de achtilende eeuw tarrelijk simpele breekmolens, voor tbewogen door niet meer dan éćn trekdier, algemeen in gebruik (Trouilht 1982:346). Gebrek aan trekd:eren in Suriname kan de oorzaak niet zijn geweest, want er liepen voidoende runderen rond op de koffieplantages.

Ook moet het mogelijk zijn geweest om watermolens van verlaten suikerplantages over te nemen. De technologie was bekend en van eind achttiende eeuw af kumen de prijzen noo:t exorbitant hoog zijn geweest. Zelfs in he: kapitaalarme Costa Rica beschikten rond :840 een aantal koffispiantages uver molens en machines die werden aangecireven door waterkracht (Cardoso 1977:185).

Daarnaast werden in de loop van de negentiende eeiw steeds eenvoudiger werktuigen uitgevonden, die weinig kostten en een grote arbeicisbesparing opleverden. Jamaica was daarvan een sprekend voorbeeld. Daar werd in een overs.eidsrapport ove: een cergelijke uitvincing gemeld dat de lage kosten en the simplicity of the machine puts it in the power of the rudest artisan to construct it for himself 22 'Zulke simpele apparaten hadden

22. Important innovatiors in the tecrnigues of coffee processing in the post-emancipation perind reduced the amount of capital nexded in preduct:on. in 1840 an irventor, John Humber of St. Ann, had invented a machine which combined the peeling and wirnowing processes, and prepared eight tierces ( 64 cwts.) of dzied coffee par day. The capital cost of the machine was estimated at about $f .80$ compared with $€ 400$ for the old mill. There were ecenomies in the operating costs as wel., e.g. to produce 100 tierces or $800 \mathrm{cwts}$. of coffee required 78 man days 
ook in Suriname kuanen worden gebridikt, maar misschier. kwamer. zij juist te laat.

Gebrek aan xapitaal en arbeid zullen bepaalde innovaties in de kof́iesector zeker hebben verninderd en daarmee hel verval bespoedigc. Toch moet de oorzaak waa:schijnlijk dieper worden gezocht. Jostindie (1989:24850) suggereert dat de koffieplanters, door gebrek aan kapitaa: en arbeid, geen andere keus hadden dan 'doorboren' met dezelfde grond en bomen en dat innovaties niet binnen hun berejk lagen. Irij ziet in het Braziliaanse Vassourasdistrict in de regentiende seuw en soortgelijke ontwikkeling als in Siriname en schrijet dit toe an een onontkoombare cyciss die inherent zou zijn an de koffiecultuur. Deze universeie korfiecyclus werd gekenmerkt door 'een vicieuze cirkel: het verwoesten van oerbos om koffie te verbouwen, om schuides at te lossen en wee: nieuwe kredieten te krijgen voor nieuwe slaven om meer bos te verwoesten en meer koffie te planten' (Oostindie 1989:249-50). Inderdaad heeft zich in Suriname, Jamaica en Vassouras een derge.ijke cyclus voorgedaan. Ioch is he: opmerkelijk dat in diezelfue plantage-econonieèn zoin cyclus thet, of veel minder opirati in de suikersector. Bovendien kozen op Jamaica an Saint Dorringue de ex slaven - die deze cyclus toch met eigen ogen hadden klinnen aanschouwen - juis: voor kotfie als hun niewwe cash crop:

In deze verkiaring vormt in feite de schuldenlast van de koffieplarter de verklaring var de cycius. Zowel in Suriname als in Vassouras en Jamaica gingen de koffieplanters op een gegeven moment onder torenhoge schulder. gebukt. Het maken van schulcen is echter niet inherent aan een produktieve koffiecu'tulir, getuige ce massale koffieproduktie van Jamaicaanse en Haïtiaanse peasants. Het verval - inclusief gebrek aan innovatie - moet daarom eercier worden gezocht in de menialiteit van de korficplanters. Ex blijkt dan een opmerkelijke overeenkonst te bestaan tussen Suriname, Jamaica, Saint Domingue en Brazilië.

Aan het begin van dit hoofdstuk werd ai aangetoond dat het merenderl van de Surinaamse koffieplanters niet behoorce tot de gevestigde piantersfamilies. In Hoofóstuk VII zal blijken dat die rieuwre plarters vaak zeer eenvoudige gelukzoekers waren die niet geninderd door kennis of eigen kapitaal, maar wel met overmatig krediet uit Nederland, zich op het nieuwe produkt koffie hejben geworpen. Snel rijk worden door maximale produktie was hun devies. Zorg voor de langere termijn was aar hen riet besteed.

Op Saint Dornirgue waren het de vrije rmulatten en 'petit blancs' cile zich met de koffiecultüur bezig hielden. $2 i j$ werken door de machtige blanke

compared with 1,050 man cays in the old mili. A special committec of the leyislature reported that the simplicity of the machine puts it in the power of tise rudest artisan to construat it for himselif": (Williams 1475:3.) 
suikerplanters verhinderd tot dezelfde status en rijkdom op te klimmen en vonden in de minder kapitaalintensieve koffieplantages - die buiten de suikerregios waren gesitueerd - een midde: om tot de kringen van de suikerbaromen door te dringen. lijikdom was het enige middel om door de gevestigde macht serieus genomen te worden, zodat deze koffieplarters voornameli;k uit warer. op snelle, aansprekende successen (Trouillot 1982: 349-63). Hiet plantagebeheer op lange termijn schoot er zodoende bij in.

Ook in Brazilië was koffie het produkt waarmee nieuwkomers de concurrentie met de gevestigde suikerplartocratie aargingen en hun positie trachtten te ondermijnen. Een goedgevulde beurs vormde hier eveneens het beste wapen in de strijd om sociaai-politieke invloed (Stein 1953:331). Maxima:e koff:eprodiaktie was daarom een vereiste.

De situaije begin negentiende ee:iw op Jamaica tensiotte, lijkt bijna eer. replica van de ontwikkelingen in Suriname gedurende ket derde kwart van de achttiende eeuw: de koffieplanters bestonden uit nieuwkomers, zorder ervaring met plantagebeheer in het algemeen, of de koffiecultuur in het b:jzonder. De meesten hadden geen kapitaal van zichzelf, maas pushed their way into the society of the sugar barons' door zich met schuiden te overladen (Rodriquez. 1961:20-1). Bovendien werd het geleend kapitaal niet altijd even prodiktief aangewend, zodat deze sector na enige tijd in onoverkomelijke moeilijkheden xwam.

Gebrek aan inrovatie en verval van de koffiesector in de verscinillende Caraibische plantage-economiën haciden dus weing van doen met een aan het gewas inherente cyclus. Des :e groter was daarentegen de invloed van 'omhooggevaller' planters die grote haast hadcen om. rijk te worden en zich daarom aan de toekomst van de cultuur weinig gelegen lieten ligger. Surinaanse en Frans-Caraibische plante:s lijken caarbij als de cerste koffieprodacenten de toon te hebben gezet.

\section{De suikersector}

Fvenmin als koff:e was stiker een inheerns Surinaams gewas. Het was er pas met de koms? van de eerste Engelse planters, afkomstig van Barbados, in 1650 gë̈ntroduceerd. Daarmee werd het wel het oucste exportprodukt van de kolonie.

\subsection{Teelt en bewerking wari suikeriet}

Suiker werd in 1650 in Suriname geintroduceerd. Het riet werd gewoonlijk in de Kleine Regent:jd geplant. Hiextoe werden de afgesneden toppen van volwassen rietstengels gebruikt die, in verband met de waterlozing, op plantbedden van $10 \times 100$ (of 200) meter werder gepoot. Dwars over de 
bedden werden, met een tussenruimte van circa 1,5 meter, lianen boesititei), gespannen, waarlangs de slaven plantgeulen groeven. Wanneer deze riet allemaal even breed (ca. $30 \mathrm{~cm}$ ) en ever diep (ca. $25 \mathrm{~cm}$ ) waren, dan konden $z \mathrm{ij}$ een drachl zweepslagen verwachten, aldus de voormalige plantagedirecteur Kunitz (1805:317). In iedere plantgeul werden, verspringend, drie rijen riettoppen gelegd, zoals men dat noemde 'in 't verband'. Was dit gebeurd, dan werden de plantgeulen oppervlakkig dicht gemaakt en verschenen na ongeveer vijf dagen de eerste spruiten boven de grond. Na een maand was het riet al meer dan een halve meter hoog, terwijl het in het algemeen een totale lengte van 3 tot 4 meter bereikte.

De eerste paar maanden moest er regelmatig worden gewied en aarde in de plantgeul gewerkt ('grond aangeven').23 $\mathrm{Na}$ zes maanden waren de onderste bladeren van de stengel verdord on werden deze er af gehaiald en tussen de rietrijen gelegd ('riet trassen'). Dit bleef men lecere vier à vijf weken herhaler totdat rond de twalfde maand de blacierkroon zo cich.t was dat men er niet meer door kon en er ook geen onkruid meer opkwarn. Iot de vijftiende of zestiende maand werd het riet dan verder met rus: gelaten (Blom 1787:46).

Daarna kon het oogsten beginnen. Het was zaak dit op het juiste moment te doen, want als het riet nog niet heiemaal rijp was bevalte het sap in de stengel nog teveel water en leverde het nauwelijks suiker op. Liet men daarentegen het rijpe riet te lang op het veld staan dar schoten er ;onge scheuter. uit de stengel die daaraan sap onttrokken. Het sap in de stengel ging daarop bederver, en uiteindelijk rotte cie hele plant weg. Een stuk met zulk riet moest dar oprieww worden beplant en had geen suiker opgeieverd. Overigens kon het riet beter iets te lang dan te kort op het veld staan. Als men het maar niet zo ver liet komen als op plartage Hamburg (Saramacca), waar in: $82815 \%$ van al het rict verrot op de akikers lag, omciat het al 31-33 maanden oud was. ${ }^{24}$

Met scherpe 'houwers' (kapmessen) werd het riet vlak boven de grond afgekapt, zodat alleen een stompje (de stoel) met de wortels overbleven. Wanneer er toppen voor nieliwe aanpiant nodig waren, dan werden de di:ie

De mecst lastige soorten onkruid waren volgers Teenstra (1835, I:205) op uitgeputte gronden twee soorten savannegras, 'baboen nefi' (het mes van de baviaan; Scieria-soort), zo genoemd vanwege di messcherpe zijoen en het 'mossonjo'-gras (Imperata con iracta). Over het latste schreef hij: De . Vegers binden deze mossonjon in bosjes, om er mede te tooveren en diefstallen te ontdeikken. [...] Verder herft s.en up goede vruchtbare gronder bij duizencien van andere planten, als: het lastigste wied, het zuogersande foeriman ltoriman: Desmodiumsoort], eene Negerbenaming, welke roo veel als veriklikker beteekent; hetzelve hecft veel overeenkomst met peterselie, haar stckelig zaad met weerhaken klesft den voorbijganger dadelijk aan, zoodat men er ligtelijk door verJades wordt, vooral under de Negyers, die op iets dergelijks zcer opmerkzaam zijn.'

24 ARA: SONA, 84]. 
of vier bovenste leder van de stengel gesneden; zo riet dan kapte men alleen het topje met de bladerkroon er af. Deze bladeren werden in rijer tussen de rietstuelen neergelegd (tras in roo halen) om uit te drogen. Was dat eenmaal het geval dan werd het ter plaatse verbrand, waarbij men goed moest opletten dat het vuur niet oversloeg naar nog niet geoogste rietstukken.

Dit tras branden had als voordec: dat er vruchtbare as op de akkcrs achterbleet, maar daar stond tegenove: dat de bovenste humuslaag en vaak ook de rietstoelen exnstig door het vuux werden aangetast. Sommiger. verbrandden het tras daarom in de droge kleine trenzen. Het daarir opgeschoten orkruid werd zo verdeigd, de waterlozing geschoond en de met as vermengde kiei kwam bi; uitbaggeren van de trenzen alsnog op de akkers (Teenstra 1835, I:204). Deze methode was wel arbeidsintensicver.

Intussen waren de gekapte retstengels in drie of vier stukiken gehakt, met bladeren tot hanteerbare bossen samengebonden en op de hoofden varl de slaven raar de rietporter in de vartrenzer. gedragen. Vandaar wercien de ponten naar het abrieksscomplex geboond, waar het :iet binnen een etmaal moest worden uitgeperst, anders ging het suikersap ve:zuren. Tijdens de oogst was de plantage ciar. ook continu in bedrijf.

$\mathrm{Na}$ het trasbrancen en vervangen van gesto:ven rietstoelen door nieuwe aanplant (suppleien) verschener. na er:ige dager. weer nieuwe scheuten aarl de stoelen er. begon de kele cyclus opnieuw. Deze 'rieuwe' plant noemde men de tweede krop. Al naar gelang de vruchtbaarheid van de grond en de concitie van het riet kon deze cyclus meerdere jaren worden herhaald. Op vruchtbare kleigronden was het, met name in de achttiende ee:tw, zeker niet ongebruikelijk om tot de twaslfde krop door te telen. ${ }^{25}$ Wel r.am in het algemeen bij oudere kroppen de suike:produktie steecs meer af.

Wanneer het gekapie riet op het fabriekstersein was aangekomen veriiep de verdere bewerking ais volgt. De samengebonden bossen rietstengels werden in de molen twee maal tussen zware collers uitgeperst. Van daar stroomde het sap (likker of lika) via eea goot en een houten bak (sisser) raar de batferij. ${ }^{2 t}$ Dil was een soort stemen oven waar hovenin vier enorme open kookketels (kapa) achter elkaar waren ingemetseld. Onde: dit ketelwerk brandde een gront vuur, ciat werd gevoed met de uitgeperste en gedroogde rietstengeis (keentras). In de eerste ketel (inneemkeiel) die 1.500 tot 1.800 liter kon bevatten, werd de lika aan de kook gebracht onder toevoeging van enige kalk or. de suikerkorrei na het koken wat meer hardheid te geven.

Tijdens het kookproces - di: duurde 1,5 tot 2,5 uur larg - kwam een

25 Zelfs kwamen ex wel 170 (plantage Merveille) en 19̈e (plar:age Lumerburg) kroppen voor, wat befekent dat 20 \% 25 jaar van dezelfde s:ocl werd g,oogst (ARA: 50 NA 207 en 221)

26 Teerstra (1835, :221) schrij:t da! men aan deze ruim twee meter boven de grund lopende

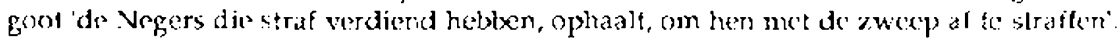




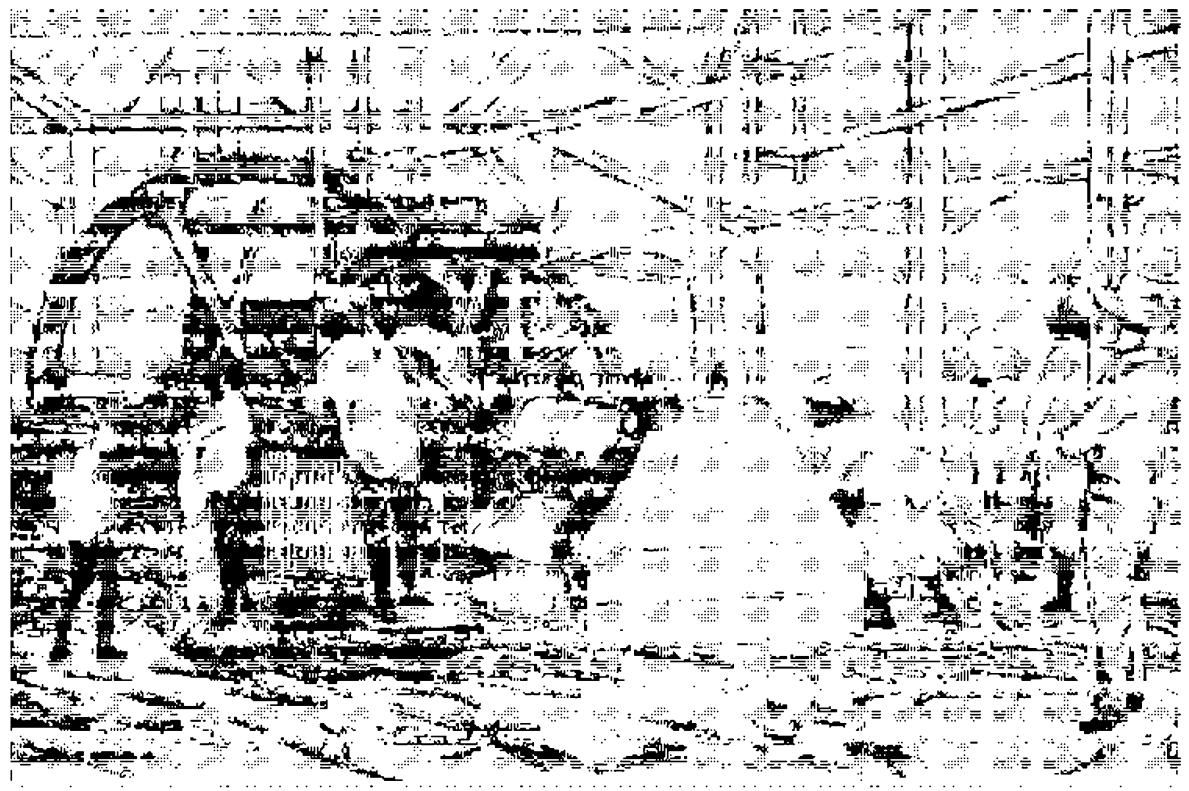

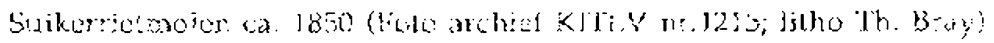


viezig schuim boven drijven, dat er met een soort grote koperen schuimspanen werd afgeschept. Daarna werc de juist riet geheel kokende lika overgeschept in de volgende, jets kleinere, ketel, weer afgeschuimd en overgeschept, tot de laatste er. kleinste ketel (de test) was bereikt en de lika nelemaal schoon en ingedikt was. De lika was nu verkook: tot een stroperige massa, die op precies hel juiste moment uit de test moest worden overgeschept in zugeraamde koelders om af te koelen en te kristalliseren. ${ }^{27}$

Eenmaai afgekoeld werd de nog tamelijk stroperige suiker in vaten gestort, waarvan de onderste duigen enigszins van elkaar af stonden, zodat hij verder kon uitlekker. ('axeren). Hiertoe werden de vaten op een soor: houten rooster (barbekot) geplaatst met daaronder een bak om de uitgelekte stroop op te vanger. Na zes a zever. weken was de suiker voldoende gelaxeerd om verzondes te worden. Overigens bleef ce siker ook tijdens de overtocint naar Europa nog uitlekken, waardoor een gemiddeld gewichtsverlies optrad van ongeveer $14 \%$. Vandaar dat de sulker niet te lang in de kolonie mocht blijven. Warmeer, zoais in :782, door oorlog geen transpor: mogelijk was, stonden duizenden vaten suiker te verdrogen, die later met verlies moester worden verkoclit (B:om 1787:74).

Het werk op suikerplantages was vaak gevaarijk; regelmatig ixwam he: voor dat een slatef zichzelt tijdens het rietkappen verwondde, doordat zijr. houwer ditschoot. Aan rog veel grotere risico's stonden degeren bloot, die in de molen of het kookhuis moesten werken. Zo gebeurde het wel eens dat een slaaf tijdens het insteken van het riet tussen de rollers var de molen bekneld raakte. Ook als gevolg van straffen schijnt dit wel voorgekomen te zijn. ${ }^{28}$ Voor zo'n noodgeval stond altijd een bijl gereed om de beklemde ledemaat a! te haiken en zo te voorkomer. da: de slad he'emaal tussen de rollers zou worden meegetrokken. Daarnaast beschikten veel plantages ook over een zogenaamaie noodderur, dis men tiissen de tardwielen var de molen kon laten vallen, zodat deze abrupt werd stopgezet.

27 'Laar dit cern najuwkeurig toezigl veressch!, zoo wordt de beste, door de ondcrvinding geleerd hebbende kookneger aan de test geplaatst, fen einte het tijdstip, wanneer do kristallizatie of greinwording daar is, waar to nemen. Kookt hij sie lika te lang, zoo verkrijg! de slijmsuiker te veel lijvigheid, en kan door deze le hooge trekking (zoo als men he! hier nowmt) niet genoeg laxeren, terwijl de grein verknokt, on de sijjmstof onyemeen taai wordt. De lika niet genoeg gekookt hebbencie, of niet hoog genoeg getrokken zijnde, zoo wordt er geere genoegzame hoeveelheid grein gevorma cn de suiker laxcert tz vecl.' (Tecrnstra $1835, ;: 230$. .)

48 Er diende, volgens sommige planters, of te worden toegezicn dat de opzichters geen Neger of Negerin, aan of op den Molenstoel staande, aldaar met de zweep sla; maar zulix een slaaf straf verdiend hebbende, moet men hem van den Molenstoel wegnemen en op eene geschikte plats iatur: straffery; want dexur diergelijke onvonorzigtigheders geschiceden dikwijls ongelukken; de Slaaven krijgen hunne handen tusschen de Rolders, gelijk gebeurd is op eene Plantaadie in de Kivier Suriname, alwaar een Veger zijn' arm tot aan de schouders door dergelijke zweepslagen verloren heet' (De Fensgezindheid 1804:12.2). 
Het meest impopulaire karwei voor siaven was het voecien en opstoken van de vuren onder de kookketels. Vaak werden daartoe dan ook gestrafte slaven gebruikt. Zo behoorcle het voor siaven op koffie- en katoenplantages tot de zwaarste straffen verbannen te worden naar een suikerplantage, om daar voor langere tijd 'aan het stookgat geketerd' te worden.

In het kookhuis liepen de slaven het reeste gevaar op de batterij, het grote, stenen fornuis, waarin de suikerixetels hingen te koxen. Een kleine onoplettendheid kon er de corzaak van zijn dat een slaaf uitgleed en in zo'n ketel terecht kwam. Dat overkwam bijvoorbeeld de jongen Vergenoegd in 1824 op plantage Vossenburg. De verantwoorde rekening van dat jaar vermeldt niet meer dan 'in de test gevallen en verbrand'. 29 Het was echter niet alleen onoplettendheid of vermoeidheid die dergelijke bedriffsongevallen veroorzaakten. Ook hier kon het straffen van de suikerkokers, of louter dreigen daarmee, de slaaf letterlijk zo uit zijn evenwicht brengen dat hij in de ketel vie! en een gruwelijke dood stierf. ${ }^{30}$

\subsection{De bijprodukten dram en melasse}

Tijdens het bereidingsproces van suiker ontstonden twee afvalprodukten: het schuim in de kookketels en de uitgelekte stroop van de vaten suiker op het barbekot. Lit het scluim werd een sterke drank, dram, gedistilieerd. Het tweede afvaiprodukt, meiasse, werd voor een deel gebruikt als zoetstof in de kolonie, terwijl de rest raar Nooxd-Amerika werci geëxporteerd war men er :um uit stookte.

Dram werd verkregen door het van de suikerketels geschepte sch:im ongeveer een week in open vaten te laten gisten, waarna het werd gecistilleerd (gestijld). Dit gebeurde in een gesloten, op een formuis gemetselde ketel, van hetzelfde formal als een inneemketel, waar van boven een buisje uitstak. Dit buisje was verbonden met een slang die spiraalsgewijs door een bak voortdurend ververst koud water liep. Als het vocht ir. de ketel aan de kook werd gebracht steeg het naar boven en stroomde door het buisje de slang in, waar het snel afkoelde. Het resultaat was dram, een ruw soort rum met een hoog alcoholgehalte. Wat ir. de ketel achterbleef, de loowin, werd oprieiw gestijld en gaf een krachtiger soort dram dan de eerste. Niet voor niets kreeg het de naam 'kill devil' (kelduivel). Dram werd louter geproduceerd voor lokale consumptie door de laagste sociale

29 Surinaams Museum: Collectie-Brartsen, verantwoorde rekening Vossenburg, 1824.

30 'Eveneens is het gelegen met de Suikerkokers: hen te slaan of te dreigen, terwijl zij op de Batierij vikis den Kolel staan, is de groulste onvoorzigligheid; dikwijls gebeurt heat, wasrvan maar al te veel voorbeelden zijn, dat zulk een Neger, bevreesc, in den kokende Slikker valt, en waarvoor dan zeer weirig hilp is. Een Suikerkoker straf verdiend hobbende, dient zijne kastijding buiten het kookhuis te geschieden.' (De Eensgezind heid 18ח4:122-3.) 
klassen, 31 De meer verfijnde rum werd tot begir negentiende eeuw in Suriname niet gemaakt. De daarvoor benodigde werktuigen waren niet aanwezig en, wat belangrijker was, in Nederland bestond geen markt voor deze drank. Tot zijn verbazirg constateerde Teenstra (4.835, 1:238) dan ook dat de Surinaamse planters rum importeerden die was geproduceerd door hun collega's elders in het Caraibisch gebied. Door de komst van Britse planters in Suriname kwam in de negentiends ceuw de rumproduktie toch op gang, hetgeen leidde tot een sti;gende export van deze drank na 1840.32

Belangrijker dan dram on ram was de produktie van melasse. Deze zoete stroop werd verkregen uit de laxerende vaten suiker op het barbekot. In de bodem van de vaten werden drie holle rietstokjes gestoken war de stroop dootheen xon sijpelen. Via houten goten onder het barbekot stroomde de melasse dan naar een grote, gesioten (tegen diefstal) bak, de zogeraamde melassiejak, die vaak een inhoud van 10.000 lite: had. Gemiddeld verkteeg men uit vie: kg suiker één 'iłer melasse.

Was dram iouter voor binnenlands gebruik, van de melasseproduktie werd rond $70 \%$ geëxporteerd. Samen leverden deze bijprodukten belangrijke neverinkomster op voor ate suikerplantages. In de negentiende eeuw was het zeer gebruikelijk dat een-vijfde van de totale inkomster afkomstig was uit de verkoop var dram en melasse. Vaak hieider zij daarmee de Surinaamse kasrekening in evenwicht.

3) Blom (1787:76) schreef h:erover: 'deeze drank is soor lieden die caaraan niet gewoon zyn gantsch niet aangenaam, ook wurd dezelve weirig anders, als coor suldaaten, mattoozen en negers gedronken; op de plantagiën is he: gebruiklyk de negers daarvan tweemal 's weeks, on somuylen meermaalen, de quantiteit van eer glaasje te geeven, waarvan $2 y$ alten groote lie:hebbers zyn'. Hoc gruet blijkt dit Blums advies (1787:79) unn under ardere 'bij het stooken van de dram, me: argus oogen [ic] loeren, zo als men spreekt, dat de negers darvan niet steelen; dit weeten zy 20 beherdig te coen, dat mer, er zig over verwonderen moet, en somwrylen is het naau wkeurigsle toezich! noch riel genoeg om het fe beletten'.

32 Surinanuse rumexport $1835: 362$

$\begin{array}{lrrr}1835 & 263.391 \text { liter } & : 849 & 284.870 \\ 1836 & 59.701 & 1850 & 110.806 \\ 1837 & 31.571 & : 851 & 2.46 .335 \\ 1838 & 6993 & : 852 & 305.892 \\ 1839 & 916 & : 853 & 357.338 \\ 1840 & 249.450 & : 854 & 508.416 \\ 1841 & 297.592 & 1855 & 472.236 \\ 1842 & 295.340 & 1856 & 380.207 \\ 1843 & 109.133 & 1857 & 424.931 \\ 1844 & 116.404 & 1858 & 492.198 \\ 1845 & 77.047 & 1859 & 429.545 \\ 1846 & 15.596 & 1860 & 692.454 \\ 1847 & 211.661 & i 861 & 699.010 \\ 1848 & 278.182 & 1862 & 684.161\end{array}$

Bronnen: Hering 1858, Ill:bijlage 3 (export :835-1857); Koloniale Verslagen 1858-1862 (produktie) 


\subsection{Innovatie}

In de historiografie van het Caraibisch gebied is altijd veel aandacht besteed aan de technologie op suikerplantages. Wanneer het echter gaat om innovatie lijken de meeste oncierzoekers alleen geïnteresseerd te zijn geweest in negentiende-eeuwse uitvindingen als de stoommolen en de vacuümpan. Hierdoor is de indruk ontstaan alsof voor 1800 de suikertechnologie statisch was en pas met de introductie van stoomkracht de eerste innovatie sinds ceuwen haar intrede deed. Wat betrett Suriname dient dit beeld in ieder geval te worden bijgesteld. ITet zal blijken dat de negentiende-eeuwse vernieuwingen onderdeel vormden van een proces dat al sinds de aanleg van de plantage-economie in gang was gezet.

De eerste innovakie die in dit opzicht van belang was, deed haar intrede op het moment dat het suikerplantagegebied ging verschuiven van de hogerge:egen zandgronden naar de lagergesitueerde Stirinaamse kustvlakıe. De oplossing die werd gevonden voor het in cultuur brengen van deze moerassige gronden bestond in de aanleg van polders. De introductie van een dergelijke vorm van landwinning, met rijn grootschalige en gecompliceerde drainage- en vaursystemen, is een innovatie van betekenis gewerst. Niet alleen konden door deze vernieuwing de vruchtbare en dichter bij Paramaribo gelegen laagiarden in produktie worden genomen, maar bovendien vloeiden andere vernieuwingen er uit voort, zoais plantagetransport via vaartrenzen en waterkracht als energiebron voor ce moien. Tegelijk kieefden er echter ook twee belangrijke bezwaren aan deze innovatie.

In de poiders was het gebruik van plantbedden, doorsneden en begrer.sd door een heel stelsel van afwateringskanaaltjes en greppels, cen absolute vereiste. Ploegen was kifrdonr ten enenmale onmogelijk. De enige gelegenheid waarbij de ploeg kor. worden gebruikt, was wanneer bij het verlaten van een akker de kleine trenzen werden opgevild en de grond op het hele stuk moest worden omgeslagen (Blom 1787:52). Dit verklaart dat op sommige plantages toch wel eens een ploeg kon worden aangetroffen. Jammer genoeg voor de slaven is voor de geringe toepasbaarheid van dit werktuig nooit een aiternatief gevonden, zodal het omslaan van eer stuk grond altijd met de houweel (de tjap) moest gebeuren. Dit was cen zwar en zeer arbeidsintensief karwei.

Het tweede nadeel van poiders waren de zware en altijd terugkerende graaf-en baggerwerkzaamheden aan de trenzer. Voo:al ce suixexplantages met hun dubbele waterstelse:s deden een nief te onderscinatten aansiag op het arbeidsvermogen van de siaven. Aanleg, onderhoud en uitbreiding kostten enorm veel tijd en arbeid, wat ten koste ging van de directe suikerproduktie. Bovendien is het niet onwaarschijnlijk dat de zware polderarbeid 
de levensduur van de slaven bekortte. Nergens was namelijk het sterftecijfer 20 hoog als in de suikersector. Deze innovatie is daarom in geen enkel opzicht arbeicisbesparend te noemen. Voor de produktiviteit van grond en suikerriet was het daarentegen zeer stimulerend.

Rietkappen vormde evencens en zeer arbeidsintensieve activiteit. Tot ver in de twintigste eeuw is men er echter nergens in de wereld in geslaagd hicrij enige vorm van mechanisatie toe te passen. Er is dus green sprake van geweest dat in dit opzicht slaven de technologische vooruitgang in de. weg zouden hebben gestaan. Wel wordt beweerd dat riet oogsten met slaven minder efficiënt gebeurde dan met vrije arbeiders. Met slaven zou men het hele jaar door hebben moeter. oogsten, omdat zij niet konden worden weggestuurd, terwijl met vrije arbeiders de oogst in een par maanden kon worden geconcentreerd (Boomgaard en Oostindie 1989:9-10). In Suriname was indercaad tijdens de slavernij geen sprake van geconcertreerde suikercampagnes', maar evenmin werd het getele jaar door geoogst. Twee natuurlijke oorzaken lagen hicraan ten grondslag. Watermolens koncer. alleen werken in de dagen rond volle en rieuwe mar., wanneer het springtij was. Dit betekende een concentratie var. de oogstperiodes, maar wel verspreid over het gehele ;az:. Tegeli;k verhinderden de zware tropische regenperiodes zo'n spreiding en kon er gedurende ongeveer drie maanden per jaar niet worden geoogst. In be achttiende eeuw duurcie deze periode gemiddeld 3,1 maanden, in de regentiende eeuw bleck dif se zijn terug gelopen tot 2,8 maanden. Dat laatste is merkwaarcig, omdat toer: de meeste suikerplantages met een stoommoien werktem, die op ieder gewenst moment kon malen.33 Dit zou - onder veel voorhehoud - kunnen betekenen dat de planters door tekort aan arbeid werden gedwongen de oogsten uit te smeren over een langere periode, tot in de ongunstige regenijiden toe.

Een geh.ee! andere, naliwelijks innoverend te noemen, maas wel arbeidsbesparende, maatregel, was het langer produceren met dezelfde rietstoel. In plaats van na iedere oogst nieuw riet te planten, wat zeer arbeidsintensief was, kon men de stengel zonder veel inspaining sleeds opnieuw voor een volgende krop laten opgroeien. De nadelen daarvan waren echter verminderde opbrengsten en uitputting van de grond. Tot begin achttiende eeww was dit zoger.ammde ratooning in het gehele Carainisch gebied de gewoonte geweest. Naarmate de grond hierdoor uitgepust raakte, werd deze praktijk echter verate: - in het bijzonder op de Brits-Westindische eilanden - en ging men er toe over het riet na iedere oogst te herplanten (Watts 1987:4045). Het getuigt van de relatief grote vrucitbaarheid van de Siriraamse

33 Steekprex:I van 37 ongstjamen in de arhttiende eeuw op de plantages Vosscnbury, Wayam. pibo, Aurora en Waterwijk en $71 \mathrm{ong}$ stiaren in de negentiende eenw op de piantages Vossenburg, Livorno, Groot Marseille, Catharina Sophia, Rustenburg, Kroorenburg, Linenburg, Meerzorg, Lodewijxsbure, I a Singularité en Wolffs Capocrica (Bronnen: plantage archieven). 
bodem dat het in dit land nooit zover heeft hoever. komen. Er lijkt zelfs van een tegenovergestelde trerd sprake te zijn geweest, want een steekproef geeft aan dat in de negentiende eeliw het aandeel van oudere kroppen toenam.

In de tweede helft van de achttiende eeuw bestond ongeveer vier-vijfde van het suikerrietareaal uit de eerste tol en met vierde krop. Rond 1750 lijkt de vijlde krop de gangbare limiet to zijn geweest: minder dan een-tiende van het areaal had een oudere krop. Op dat moment waren een aantal plantages op hogergelegen zandgronden a: zo uitgeput dat produktie met een oudere dan de derde krop volstrekt niet meer rendabel was ${ }^{34}$ Rond 1770 waren de meeste van deze plantages verlaten. Dit was echter niet de enige reden voor de opmerkelijke stijging naar $18 \%$ van het aandeel der oudere kroppen. In deze periode was men zo drik bezig met de uitbreiding van het cultuurareaal, dat er, ondanks het gestegen aantal slaven, geen tijd of mankracht overbleef om na de vierde of vij:de krop nieuw riet aan te planten. Dit vergrote aandeel van otidere kroppen leidde bovendien tot de lage produktiviteit van de rietakkers in deze periode.

Rond 1790 was het aandeel van de eerste vier kroppen groter dan ooit. Kennelijk beperkte men zich, als veertig jaar daarvoor, tot de meest produktieve kroppen van he: riet. Het is niet onwarschijn1:; $k$ dat de planters hiertoe werden gedwonger door gronduitputting en eventueel degeneratie van de rietsoor. waarmee al enkele eeuwen werd geproduceerd. Voor de produxtiviteit was het dan ook eer. gelukkig toeva: dat juist in die tijd een nieuwe rietsoort $\mathrm{n}$ het Caraibisch gebied algemeen ingang vond.

In de loop van de negentiende eeuw nam de produktie met oudere rietk:oppen toe. Vlak voor de Emancipatie was zelfs meer dan eeri-derde van het areaal van de vijfde krop of ouder. Het chronisch arbeidstekort dwong planters zo lang mogelijk met dezelfde rietstoel te blijven produccen, wat hen het arbeidsintensieve herpiarten bespaarce. Dit was overigens typisch een maatregel geboren uit nood, want het was verre van produktief. Kennelijk werden de plant en de grond zo uitgeput door de lange produkticcyclus, dat bij de vijfde krop nog maar iets meer dar de helft werd geproduceerd van de capaciteit van het origineel..$^{35}$

Diverse malen kwam al ter sprake dat eind achttiende eeuw een nieiwe suikerrietvariëteit in Suriname werd geinntroduceerd. Samen met de constructie van polders is dit de belar.grijkste innovatie buiten de suikerfabriek geweest. Sinds de invoering van suikerriet in Brazilië en het Caraibisch gebied werd al mel dezelfce variëteit geprodiceerd, het zogenaamde Creo-

34 Blom (1787:51) constateerde: 'in de boven- of zandgronden kan men het riet maar tweemaal snyden, langer brengt het te weirig op om de kosten te konnen goedmaaken'.

35 Steekproef ARA: SONA en S.NA; plantage-archieven. 
leriet. In de loop der eeuwen bad dit riet aan kracht en produktiviteit ingeboet, zodat van de jaren 1780 af overal in het Caraibisch gebied nieuwe rietsoorten werden geintroduceerd (Watts 1987:432-3).

Als eerste ging men hiertoe over op de Franse eilanden Martinique, Guadeloupe en Saint Doningue. Vandaar verspreidde het zich over de Spaanse eilanden en Suriname, terwijl in de jaren :790 nieuwe rietsoorten cok op de Britse eilanden werden ingevoerd. De nieuwe variëteiten waren uif verschiliende landen afxomstig, wat dujdelijk blijkt uit de soormamen: Otaheite (Tahifi), Bourbon (Ile de Bourbon, Mauritius) en Bataviaas of Moluks riet. Waarschijnlijk ging het echte: om hooguit twee verschillende soorten.

De grote stimulator achter deze innovatie in Suriname was de bekende planter en latere Gouverneur Friderici, die :n 1789 kosten noch moeite spaarde om de nieuwe soorten ujt Martinique te laten overixomen (Blom 1801:69). Na aankonst verspreidde Friderici de noviteil onder 'byzondere inwoonders van de ko:orie, zodat de heie suikersector op den duur van het niewwe riet kon protiterer. Waarschijnlijk was roni 1800 de invoering algemeen geworden, want in verscilillende plantage-inventarissen uit die: tijd wordt daarvan melding gemaakt. ${ }^{3 t}$ Het is niet helemaal duidelijk of er één, dar. wel meerdere nieuwe soorten werden geplan:, want afwisselend sprak men van Oostindisch, Moluks of Otaheits riet. Waarsch:jni:jk ging het toch orn éen soort, want uiteindelijk bleef aileen. de naam Otaheiterie: in gebruik (zie Purseglove 1972:216; Oostincie 1989:31),37

Volgens tijggeroten kleefde er echter een bezwaar aan deze innovatie: de nieuwe rietsoort deed eer groter beroep op de roedingskracht var. de bodem. ${ }^{38}$ Of dit een versnelde rotatiecyclus tot gevolg heeft gehac is niet bekend; in ieder geval werd er niet extra bexnest. I let exige waar de planters zich om bekommerder. was cie verhoogce produktiviteit van de nieuwe rielsoort, die inderdaad aanzienlijk was (Tabel 28).

36 Vermeldingen daarover zijn te vinden in de inventarissen van onder meer de plantages Groot Chatillon (Suriname), Libanor. (Cottica), Soribo (Perica) en. Fooyland (Boven-Commewijne) (ARA: SONA, 292 en 295). Het zal uverigerns nog wel cven heblen ged aurd voordat het gehele cultutrareaal in de suikersector met de nieuwe rietsoort was beplant. De suike?produxtie moest gewoon doorgaan, dus niet alie nieuwe aanpiant kon meteen voor toppen worden gekapt. Op de vier hier gentuemde piantages was rond is00 gernidueld $44 \%$ van het suikerareaal met de nieuwe eieisonr: beplart. De grootste prociuktiviteitsstijging; hlijkt dan ook platats te vinden na 1810 .

37 Dit wordt bevestigd dour blum (1801:70) die sprak over 'fet Nieuw aangebragte OostIndische, Moluksche of Otanejtsche Ric:'-

3o Volgens Blom (1801:70) word het nieuwe riet hoger en had het meer 'sappen' nodig. Hij raadde dan ook aan de planten verder uiteen te zetten dan bij het Creoleriet de gewoonte was gewest. Of dal inderdaad gebeurde is niet bekend. Onk Watts (1987:435) merkte up dat "[t]heir only reputed disadvantages were that they were supposed to gjuc rise to soil depletion more curickly and that they did not respond well to ratooning. However, the lat!er proposilion shorid $d \mathrm{~b}$ interpreted in a re'atively sense only. ' (Mijn cursivering-] 


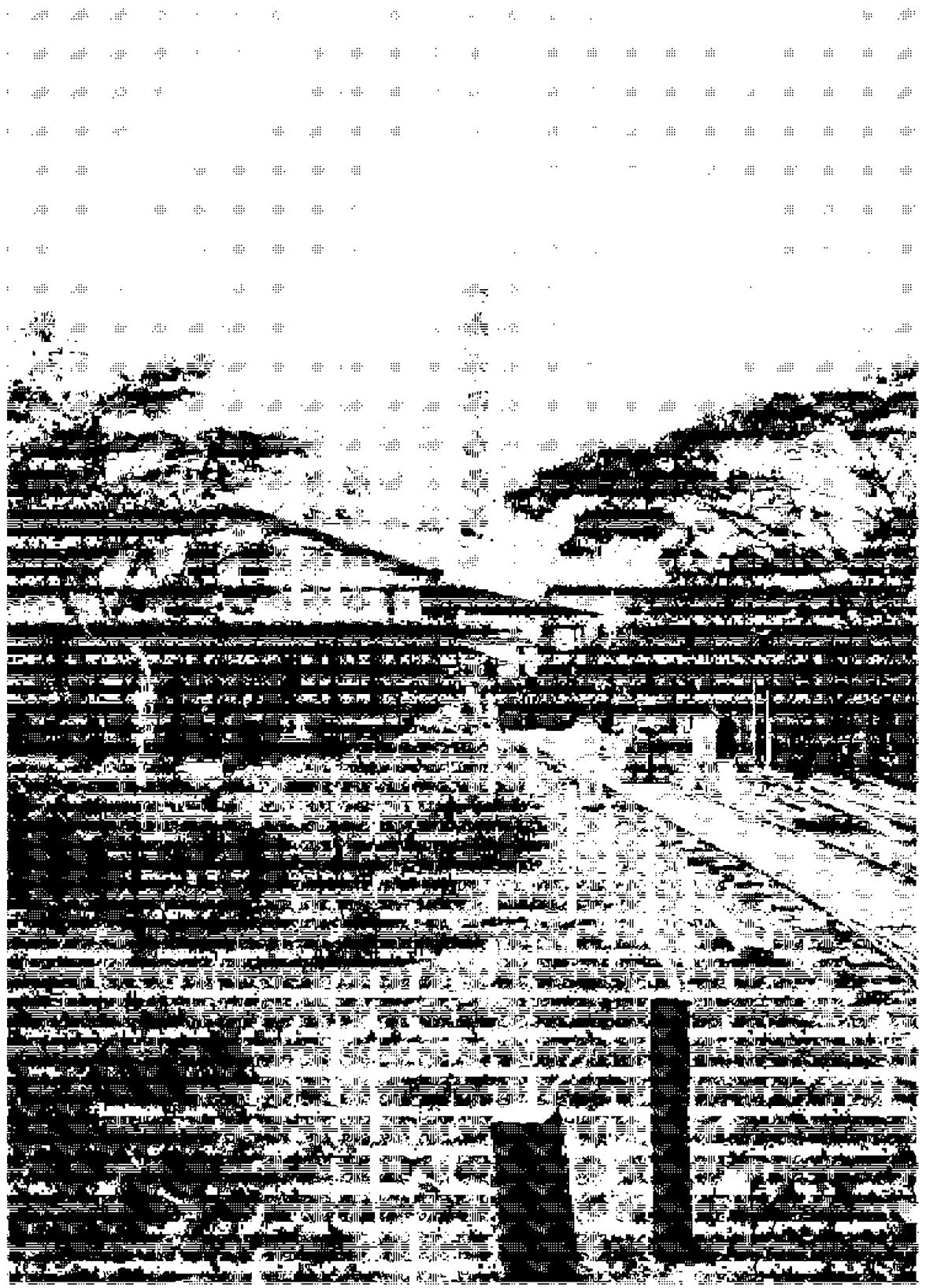

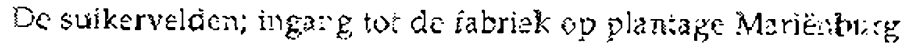

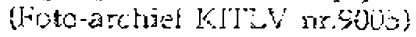


Een laatste innovatie buiten de fabriek betrof het transport. Op de oudste plantages werd het gekapte riet met kleine ossewagens naar de molen gebracht. Naarmate op steeds meer plantages vaartrenzen werden aangelegd, verdween dit transportmiddel en schaxelde men algemeen over op houten, platbodem vaartuigen die met behuip var vaarbomen cioor slaven werden voortbewogen. Deze zogenaamde keenponten maten ongeveer $11 \times 3$ meter en vereister nogal wat onderhoud. In de negentiende eeuw werden zij daarom op veel plantages vervangen door ijzeren rietbakken, die soms door trekdieren in plaats van slaven werden voortgetrokken. Zowel in onderhoud als in trekkracht leverde dit dus een arbeidsbesparing op.

Ook het transport op het fabrieksterrein veranderde. Volgens eer. anorieme auteur (Aantekeningen 1856, I:301) was de eigeraat van plantage Visscherszorg (Beneden-Commewijne) al in 1794 bezig machires te installeren die het riet dit de ponten naar de molen en de tras van de molen naar de trasiondsen transpozteerden alles zonder daartoe menschenarbeid te bezigen'. Van dit vroege experiment is nadien echter noo:t meer jets vernomen. He: duurde tot de jaren 1850 voordat stoomaangedreven cane er trash carriers meer algemeen in georuik kwamen. In 1857 hadden 16 van de 90 suikerplantayes $(18 \%)$ dergelijke transportbanden geïnstalleerd (I Iering 1858, III:appendix). Zeer geavanceerde plantages maakten rond 1860 ook getbruik van spoorrails voor het transport.

Zo werd op de overheidsplantage Catharina Sophia (Saramacca) het gekapte riet met zeven ijzeren rietponten naar het fabrieksterrein gebracht. Daar aangekomen zorgder. bijna 300 meter spoorrails, drie wagons, twee cane carriers, een trasafvoerder en een traselevator voor snel en arbeidsextensié transport naar ce molen en de trasloodsen. Daarnaast was nog eens 175 meter spoorrails ge'egd tussen de fabriek en de scheepssteiger aan de waterkant. ${ }^{3 *}$ Deze plantage vormde echter een vitzondering.

De belangrijkste innovaties in de suikerfaibiek hebben plaatsgevanden in de molen. De oudste suikerplantages waxen indertijd begorner met een zogenaamde beestennolen, aangedreven door trekossen en muilezels. Naarmate suikerplantages meer en meer in de lager gelegen kustvlakte werden aangelegd, deed zich de mogelijkheid voor de rivier ass energiebron te gaan gebruiken. De grolere getijdeverschillen van de rivieren in de berederllanden makten de installatic van een watermolen aartrekkelijk, ook al kon daarmee niet meer dan maximaal 16 dager. per maanu (gedurende springtij) worden gemaien. Dergelijke molers bleken veel meer riet te kunnen verwerken en bezaten een grotere perskracht dan de beestenmolens. Een belangrijk nadeel waren echter de hoge kosten die miet de 
installatie van een watermolen gepaard gingen. Vooral de tienduizenden benodigde bouwstenen, die uit Europa moesten worden geïmporteerd, maakten het tot een dure aangelegenheid. Vandaar dat de invoering ervan slechts geleidelijk plaatsvond en op enkele plantages de beestenmolen tot ver in de negentiende eeuw in gebruik is geblever. ${ }^{40}$

Ofschoon niet de enige oorzaak is het opvallerd dat plantages met een beestenmolen minder kans maakten de tana des tijus te weerstaan dan die met een meer geavanceerde molen. Een steekproef onder 43 plantages die in de periode 1745-1760 suiker produceerden illustreert dit (Tabel 35). Van de veertien plantages in de steekproef die het jaar 1857 niet haalden, werkten niet minder dan twaalf rond 1750 met een beestenmolen; tien daarvan hadden dit tot het eind toe voigehouden. Van alle hier betrokken plantages maakte $81 \%$ op zijn minst eenmaal de overschakeling naar een meer geavanceerd soort molen. De helft daarvan vond plaats gedurende de tweede helft van de achttiende eeuw. Bijna een-vijtde van deze plantages wisselde in de periode :745-1857 zelfs twee keer var type moien. Duidelijk blijkt dat plantages die nooit iznoveerden geen kans maaxten het midden van de negentiende eeuw te halen. De meerderheid innoveerde echier wel. I Iet is daarom evident dat de toepassing van nieuwe molentechnologic in de achttiende eeuw een even normal verschijnsel was ais in de negentiende eeuw.

Tabel 35. Type suikermolen en levensvatbaarheic van de plantages 1745- 857

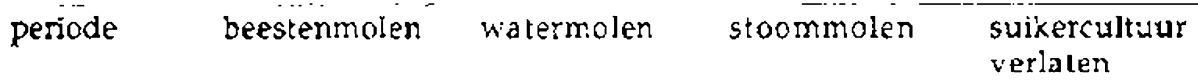

\begin{tabular}{lrrrr}
\hline $1745-1760$ & 34 & 9 & - & - \\
$1775-1780$ & 15 & 26 & - & 2 \\
1857 & - & 11 & 18 & 14 \\
\hline
\end{tabular}

Fvenals de watermolen verliep ook de invocring van de stoommolen geleidelijk. De eerste twee werden warschijnlijk rond 1815 ge:̈nstalleerd op de plantages Alkmaar (Beneder-Commewijne) en De Resolutie (Suriname), : Nog geen twee decenria later beschikte al $28 \%$ van de suiker-

40 In 1832 werkten nog, 8 van de 108 suikerplantapes met een beestenmolen (Teenstra 1835 , 1:82). Overigens hoe?dc niet alleen kapitaalgebrek de overschakeling op waterkracht te verhinderen, de lokatie van de plantage kon ook een rol spelen.

41 Tot 1813 producecrde Alkmaar in ieder geval nog, cacan (Public Record Office: Treasury 75,14 ). In 1819 werd op deze plantage al bijia $100.000 \mathrm{~kg}$ sliker gemaakt (ARA: OAS AvF, 319). In datzelfde jaar noteerde een bezocker: 'Op deze plantaadje was de stoommachine van den suikermolen desect, men was berig deze te herstcilen, en tevers het kuokhuis te verleggen, weike beide werken zeer vee'i moeike, en duizenden gu'der:s kostten' (Van Lennep Coster 1836:92).

Plantage De Resslutic was pas rond 1300 angrelegd. Volgens Kuhn (1828:15) had het a! var. 
plantages over een of meerdere stoommolens. Daarmee beinoorde Suriname tot de meest innoverende plantage-economieër van het Caraibisch gebied ${ }^{42}$ In 1862 werkte zelfs twee-derde van de Surinamse suikerplantages met een stoommolen (Koloniaal Verslag 1862).

Evenals bij de watermoler speelden kostenoverwegingen een zeer belangrijke ro: in de beslissing op de nieuwste technologie over te schakelen. Aanschaf en installatie kostien al gauw $f 30.600$ (zie het voorbeeid van De Drie Gebroeders in Foordstuk IV). Toch was dit, met name in de beginperiode, niet de enige reden waarom sommige planters voorlopig afzagen van een dergeiijke aanschaf. 7o werd op piantage Groot Marseille (Cottíca) in de jaren 1824-1828 ruim $f 20.000$ besteed aan de totale vernieuwing van de watermolen en het kookhuis en werd tegelijkertijd meer dan $f 70.000$ winst aan de eigenaars uitgekeerd. ${ }^{43}$ Voor dat geld had mer. gemakke.ijk een eenroudige stoommachine kunnen installeren. Waarom men er in dergelijke gevallen toch niet toe overging, verwoordide een Surinaamse administrateur in 1829. I lij bleek de voorkeur te geven a an eer moderne watermolen,

'omdat het uit zee: wieinige stukken zamengesteld is, en bij voorkomende mankementen dadelijk kan gerepareerd worden met er een veservestuk in plaats te zetten, waardoor men weinig tijd verliest, daar met stoommachinen er ter. eerste groote ongelukken door het springet der ketels kunnen veroorzaakt worden, en ten tweede soms stukken jreken kunnen, waarvan men geene reservestukken hee!t of soms weken en maanden daarnaar wachten moet, zonder te kunnen malen, om dip reden is het onk dat eenige weinjge plantagien zoo als Houtuin een dubbele stoommachine hebben welke in cas van nood dadelijk in werking kan gebrag: worcien, maar zulks vordert een cubbeld uitschot ea dubbelde sletage en onkosten var. reparatie'.44

het begin harer aanlegging een stoomwerxluig', maar dat is niet correct, want in 1806 stond het er in jeder geval rog riet en werd er zelfs nog geen suiker verbourvd (ARA: SONA, 296). In 1819 produceerde de plantage cchter ai ruim $120.000 \mathrm{~kg}$ suiker (ARA: OAS AvF, 319).

42 In de jaren 1835-1839 waren de belangrijksic Caraibiscile 5:1ikerexporteirs kin wolgorde van exportvolume): Cuba, Jamaica, Guadeloupe. Martiringe, Barbados en Trinidad (Watts 1987:500). Over Cuba zegt deze auteur: 'not until 1835-40 did the rate of construction of steam mills become anything other than a trickle'; op lamaica 'some convers:on to steam milling took place, so that by 1850, 108 of the c 500 estates were stearn-driven'; 'the initial moves to ivards its adoption in the French ives: Indies toox place after a major earthquake in 1843 had destroyed a large proportion of the existing small milis in Guadeloupe'; op Barbados 'smal:, old-style factories producing nusscovado suģar, continued to prevail, and as late as 1894, steam power was to be found in only one out of every five of these'; en tenslotte op Trinidad was sprake var. 'the readinuss with which estate owners proceeded to introduce many of the new factery techniques which already had been tried out in Chiba' en dat wiss na 1850 (Watts 1987:486-99),

43 James Ford Bell Library: B1482.

4. Collectic-Insinger \& Co.: Infurmaliebock, bricf 16-3-1829 
De gebezigde argumenten zijn zeker niet die van een aartsconservatief, maar getuigen var een rationele kijk op de zaak. Eens te meer geldt dit wanneer bedacht wordt cat ook de technologie van de watermoien niet had stilgestaan. ${ }^{45} \mathrm{Op}$ een groeiend aantal plantages met zo'n molen werden de verticaal staande rollers horizontaal geplaatst, wat meer perskracht gaf, verving men zoveel mogelijk alle houten onderdelen door ijzeren en werd soms zelfs een dubbel waterrad ingehangen om de molen nog meer kracht te geven. ${ }^{46}$

Deze veranderingen kwamen de produktiviteit zonder meer ten goede. Arbeidsbesparend waren zij echter niet. De enige vernietwing waarvoor dit wel gold, was de introductie van de trasdraaier of doubleuse. Deze bestond uit een gebogen schild dat aan de andere zijde van de rollers werd geplaatst. Wanneer de rietstengels tussen de eerste en tweede roller waren doorgelopen keerde dit schild de stengels automatisch terug voor een tweede persing tussen de tweede en derde roller. Dit spaarde het werk wit van een paar slaven die dit voxrheen met de hand hadden moeten doer.

Stoommolens kunnen, in tegenstellirg tot watermolens, worden beschouwd als arbeidsbesparend. Watermolens konder. slechts zestien dagen per maand draaier, zodat tijdens het oogstem en malen dag en nacht moest worden doorgewerkt. Het was hepaaid geen uitzondering, dat een deel var. de slaven ir deze periocies 36 uur achtereen in fouw was. Een stoommoler. kon echter op ieder gewenst moment draaien. Het werk kon daardoor veel beter worden gespreid, zodat de aanslag op het arbeidsvermogen van de slaven minder hevig was. Een onderzoek van de koloniale overheid onthulde dat in de periode :838-1842 op een groep van negen plantages met een watermolen ir totaal $13,5 \%$ meer slaven waren gestorven dar. geboren. Op een even grote groep planłages met een stoommolen bleek het sterfteoverschot in diezelfde vi; $;$ jaar 'slechts' $6,4 \%$ te hebben bedragen ${ }^{47}$

45 Bijvoorbeeld 'op Jomburg heeft men thans [1829] een wate:werk geplaatst waarvan de watermolen of scheprad geheel van jjzer is buiten de scheppers; dit rad door het watcr gedreven alsmede donr zijne eigene zwarte, draait veel sne.ler en met veel merr kragt rond als een houten scheprad daar het dezclfde kragt op ce cilincers uitoefent als het vijing rad bij de stoommachinen, de rodders of cilinders leggen horisontalal en het is eer piaisier de rietstokken donr deze gekneust te zien doorloopen' (Collectie-Insinger \& Co.: Informatipinok, brief 16-3-1829).

46 Een bijkomend voorceel van de molen met horizontaje rollers was dat In de suiker. moolens welker roiders horisnataal leggen, kunnen er zelden ongelıkken voorvallen, daar de rietstoppers, er de stokken op eene geïnclineerdc tafel, of schuifbank leggen, variwaar zij tusschen de rolders geschoven worden. Deze werkieden kunnen dus nooit hurne handen tusschen de rolders klemmon, welk niet zeluen b:j staande rolders voorvait, zij breken het riet mede geregelder en kunnen steeds op hunne gehele 'engte werken.' (Collectie-Insinger \& Co.: Informatieboek, brief 16-3-1829.)

17 ARA: MVK, A792. 
Nog opvallender is het verschil wanneer de demografische ontwikkeiing van een plantage wo:dt onderzocht vóór en ná de installatie van een stoommolen. Op Meerzorg (Suriname) vond deze innovatie plaats in 1827 . Gedurende de tien daaraan voorafgaarde jaren stierven gemiddeld 18,1 slaven per jaar, waar slechts 7,0 geboorles legenover stonden. In de periode 1838-1842 was de gemiddelde sterfte per jaar gedaald tot 10,2 personen en werden 10,0 kinderen geboren. ${ }^{13}$ Hoewel ook andere factoren deze posifieve ontwikkeling kunnen hebben be:nvloed, is het toch een duidelijke indicatie van het arbeids- of iiever levensbesparende effect van deze innovatie

Daarnaast werd op sommige plantages steenkool in plaats van hout of tras geintroduceerd als brandstof voo: de stoommachine. Ook dit was een arbeidsbesparende maatregel, want bijvoorbeeld op Meerzorg ging men daartoe over 'ter bezuiriging van handen om b:andhout te kappen' (Teenstra 1835, I:223). Len bijkomend voordeel was de grotere hitte die steenkool gaf, in vergelijking met hout, zodat het brandstofgebruik daalde. Daar stond tegenover dat in Suriname geen steenkoo: werd gewonnen, zodat men van dure import afhankelijk werd.

Vrijwel alle innovaties in het moiengebouw resultee:den in een vergroting van de rietverwerkende- en perscapaciteit van de molen. Dit betekende dat in dezelfde tijd meer suikersap moest worden verwerkt. De consequentie daaryan was dat ook het kookhuis in de loop der tijd de nodige vernieuwirgen onderging. Een indicatie daarvan was het toenemend aantal ketels op de balterij. lien steekproeí van 15 achttiende en 13 negentience-eeliwse plariages toont aan dat de meeste piantages warer. begonnen met een ketelwerk bestaande uit vier of vijf ketels, die ieder apart werden gestookt. I.ate: in de achttiende eeuw werden de ketels zodanig achter elkaar geplaatst, cat één viur voor alle keteis volúoende was, de zogenaamde Jamaica-train. Hierdoor xon op brandstof worden bespaard. Een enkel ketelwerk bleek echter steeds minder aan de vereiste capaciteit te volioer, zodat steeds meer plantages een dubbel ketelwerk gingen installeren. Dit betekende da: er cok twee slookgaten en twee schoorstenen moesten komen. Bovendier. werden deze stookgaten in de negentiende eeuw niet meer louter van steen gemaakt, maar beslagen met ijreren platen, die de hitfe beter vasthielder. Ook hier blijkt de negentiende-eeuwse ontwikkeling eer. voortzetting te zijn geweest van een proces dat al in de achttiende eeuw in gang was gezet.

Typisch negentiende-eeuws waren een drietal andere innovaties in de suikerfabriek: de introductie van het centrifugetoestel, de ventilatiemachine en de vacuümpan. Het eerstgenoemde apparaat werd rond 1850 geinstalleerd op de plantages Visserszorg (Beneden-Cormmewijre) en La Rencontre 
(Suriname). ${ }^{49}$ Zeven jaar later beschikten ook de plantages Goudmijn, Kent, Waterloo en Paradise over een dergelijke machine (Hering 1858, III: appendix). Zo'n centrifugetoestel zuiverde, met behulp van middelpuntvliedende kracht, de melassestroop uit de gekristalliseerde suiker. Voor de benodigde energie kon worden volstaan met een $4 \mathrm{pk}$ stoommachine. De totale aanschafkosten kwamen daarmee op ongeveer $f 6.500 .50$

Een ventilatiemachine werkte met hetzelfde doel, maar was door haar simpele constructie minder snel en grondig. Voor zover bekend, was de enige plantage die over zo'n apparaat beschikte Zorg en Hoop (BenedenCommewijne), waar het in 1848 voor de somma van $f 1.743,49$ in Europa was aangeschaft.51 Overigens was men in het buurland Guiana al sinds 1832 met deze vormen van gemechaniseerde suikerzuivering aar: het experimenteren. Op Cuba vond de introciuctie ongeveer op dezelfde tijd plaats als in Suriname (Moreno Fraginals 1976:117-8).

Van meer revolutionaire aard was de introductie van de vacuümpans in het kookhuis. Dit toestel was al in 18.3 uilgevonden, maar werd pas van de jaren 1830 af door suikerplanters in gebruik genomen. Hef principe berustte, in plaats van op open, op gesloten suikerketels, vacuümpans waarin de verdamping sneller en bij veel lagere temperaiusen plaatsvond. Bovendien was de hoeveelheid suiker die uit het sap werd getrokken groter en van betere kwaliteit dan de suiker gestookt in open ketels, de zogenaamde muscovado (Watts 1987:424). Op Jamaica vonden de vacuampans nauwelijks ingang, omdat deze techniek de produktie van rum verhinderce. Op Cuba kwamen deze installaties echter van de jaren 1840 af tamelijk algemeen in gebruik (Watts 1987:486-97). In Suriname beschikten in de jaren 1850 slechts twee of drie van de meest geavanceerde plantages (Waterioo, Catharir.a Sophia en wellicht Buitetirust) over zo'n installatie en duurde het tot de jaren 1880 voor kan worden gesproxen van cen meer algemene invoering. 32 Toch was het duidelijk dat plantages met een vacuümpansysteem veel produk:iever waren dan die rmet een oud ketelwerk. De trage invoering zal daarom een gevolg zijn geweest van de hoge kosten die met de aanschaf en installatie gepaard gingen.

In een aantal Caraibische plantage-economieën werd het kostenprobleem en de steeds toenemende capaciteit van de machinerieën opgelost door de oprichting van centraalfaorieken. Op de Franse eilanden en Cuba kwam dit systeem var het midder. van de negentiende eeuw a: algemeen in gebruik. Ook deze ontwikkeling is aan Suriname rie: voorbiggegaan, want begin jaren 1850 was een dergelijke centraalfabriek opgericht op Buitenrust (Bene-

49 Surinaams Museum: Collectie-Brantsen, vers!agbsekje 1851.

50 Surinaams Musetum: Collectie-Branisen, vers!agboek; 1851.

51 GAA: PA-600, 544.

52 Hering 18.58, Ill: appendix en Koloniaal Versiag 1884 
den-Commewijne). De nabijgelegen plantages Johan en Margaretha, Maasstroom en Berlijn, met een gezamenlijk areaal van bijna 1.000 ha. en zo'n. 550 slaven lieten daar centraal hun suikerriet verwerken (Van Sijpesteijn 1854:126-7). Over de machines waarmee deze fabriex was uitgerust is niets bekend, maar het ligt voor de hand dat deze van de modernste soort zullen zijn geweest.

Ook de plantages Catharina Sophia en Waterloo kunnen als centraalfabriek worden aangemerkt. Niet alleen beschikten zij over de meest geavanceerde installaties, maar ook hun omvang kwam overeen met die van Buitenrust. In de loop van de negentiende eeuw hadden beide ondernemingen via het annexeren van buurplantages hun areaal weten tit te breiden var. 250 ha, naar 850 ha. ieder en zij beschikten in 1857 over slavenmachten var 480 en 720 personen (Hering 1858, III: appendix). De benodigde financiële ondersteuning was voor beide plantages uitzonderlijk gunstig, want Catharina Sophia was een overheidsp:antage en Waterloo werd geleid coor eer, der twee erfgenamen van de schatrijk gestorven James Balfour. ${ }^{5.3}$

Ifet lijdt geen twiffel dat in Surinaamse suikerfabrieken innovatie een normaal verschijnsel was. In 18.57 stonien op bijna $10 \%$ van de ondernemingen moderne suixerbewerkingsinstallaties, variërend van centrifugetoestellen tot vacuümpans. Twee-derde van de plantages lief zijn suikerriet door stoommolens uitpersen. Zij beschikter. gemiddeld over 240 slaven (Hering 1858, III:appendix). Betekert dit dat de resterende plantages niet bereid of in staat waren te innoveren? Voor de meerderheid van ceze groep zal dat inderdaad zo geweest $z i j n$. Bij twee-derde $\langle 21\rangle$ van deze plantages daalce tussen 1833 en : 853 het gemiddeld aantal slaven van 130 raar 116 (Surinaamse Almanak 1834:67-111; Van Sijpesteijn 1854:96-147). Zij warer dus riet eens in staat hun arbeidspotentiec! op peil te houden, laat staan dat zij over de middelen beschikten om innovaties in te voeren.

Dan resteerde r.og een groep van zeven plandages die in diezelfde periode hun slavenmacht wel wist uit te breiden (van gemicideld $: 68$ naar 252), maar er ordanks hun ruimere middelen niet toe kwamen op stoom over te schakelen (Surinaamse Almanak :834:67-1:1; Van Sijpesteijn :854: 96-147). Desondanks stord ook daar de tijd niet stil en werder in de suikerfabriek vele veranderingen ingevoerd. Een duideijk voorbeelc van zo'n plantage was Vossenburg (Boven-Commewijne), waar tussen 1820 en 1860 een groot aantal veranderingen plaatswond (Bijlage 9). Men bleex op deze piantage bijna voortdurend bezig te zijn geweest de installaties in de suikerfabriek te

53. Bij zijn dond lie: Balfour, die rijk was geworden met hout, katoen en suiker, in Surjname een kapilani na van minstens $f 312.000$. Daarnaast bestond 2 ijn exferis uit 8.45 slaven en verl onroerend goed, waaronder plantage Waterloo, twee katoenplantages en. een houtgrond mef (x) gezamenlijk? waarde van $f(646226$ (ARA: SOB\&W 1828 1876, 83i). 
verbeteren, ter verhoging van het rendement. Vernieuwing was er dus zeker, alleen was men er (te?) laat en te zuinig mee. Wel moet worden gezegd dat het plaatsen van een molen met horizonta.e ijzeren rollers en het inhangen van een dubbel scheprad eer recielijke compensatie vormden voor het niet-installeren van een stoommolen.

Toch hadden de eigenaars van Vossenburg niet zo zuinig hoeven doen, want in de periode 1820-1860 kregen zij samen ieder jaar gerniddeld $f 20.000$ winst uitgekeerd. ${ }^{34} \mathrm{Als}$ zij enkele jaren met wat minder genoegen hadden genomen, had er gemakkelijk een stoommachine kunnen worden aangeschaft. Als nu de produktiviteit van Vossenburg met een slecht producerende plantage (Rustenburg), een middeimatige (Meerzorg) en een topplantage (Catharina Sophia), alle drie voorzien van een stoommachine, wordt vergeleken, dan is, gezier het wirstniveau, de beslissing van de eigenaars van Vossenburg beter te jegrijpen (Tabe! 36).

Tabel 36. Vossenburg vergeleken met drie 'stoom'-plantages 1850-1859

\begin{tabular}{lcccc}
\hline plantage & jaren & $\begin{array}{l}\text { gemicid. } \\
\text { jaarlijkse } \\
\text { produktie }\end{array}$ & $\begin{array}{l}\text { gemidd. prod. } \\
\text { per geoogste } \\
\text { hectare }\end{array}$ & $\begin{array}{l}\text { natiaurlijke } \\
\text { bevolkings } \\
\text { groei }\end{array}$ \\
\cline { 3 - 5 } Rustenburg & $1850-58$ & 93 ton & $3.029 \mathrm{~kg}$ & $-16,1 \%$ \\
Meerzorg & $1857-59$ & 297 & 2.987 & $+4,2$ \\
Cath. Sophia & $1854-58$ & 587 & 4.237 & $-13,8$ \\
Vossenburg & $1852-56$ & 260 & 2.784 & $-4,2$ \\
\hline
\end{tabular}

Bronnen: plantage-archieven.

De axkerproduktiviteit van Vossenburg was de laagste van de vier plantages, maar vergeleken met Meerzorg en Rustenburg niet onrustbarend slechter; de totale produktie was ongeveer van het niveau van Meerzorg en lag ruim boven l:et landelijk gemiddelde (Tabel 27). Or.darks het gebruik van een watermolen was het sterfte-overscho! relatief laag, wat te danken was aan sterk verbetercie slavenzorg. Kennelijk waren de eigeraars van Vossenburg daarom tevreden met het peil waarop de plantage produceerde. Waarom zouden zij streven naar het niveau van Catharina Sophia als zij ieder jaar een aardig inkumen uit de plantage trokken en tegeiijk de continuiteit van de onderneming garandeerden door noocizakelijke vernieuwingen te financieren? Zorder exige inspannir:g van betekenis incasseerde in deze periode de kleirste aandeelhouder van Vossenburg in Nederland gemiddeld $f 1.209$ per jaar en de grootste $f 3.420 .55$ Op Catharina Sophia was een 30 pk stoommachire gekocht voor bijna $f 51.000$, men had te kampen met een aareer.schakeling van technische defecter. en de schuld bedroeg op

54 Surinaams Museum: Collectie-Brantsen, verantwoorde rekening.

55 Ter vergeiijking: de plantagedirecteur op Vossenburg verd iende rond :840 f1.600 per jaar. 
een gegeven moment rond driekwart miljoen guiden. Toen deze was kwijtgescholden lag de winst in de jaren 1858-1862 op hetzelfde niveau als dat van Vossenburg, gemiddeld rond $f 20.000 .56$ Uit maakt het relatieve conservatisme van de eigenaars van Vossenburg heel wat begrijpelijker.

Het is niet eenvoudig uitspraak te doen over het innoverend karakter van de Surinaamse suikersector in de gehele periode. Zonder enige twijfel werd op het grootste dee: van de plantages die in de jarer 1850 suiker produccerden een beleid gevoerd dat niet als conservatief kan worden bestempeld, getuige het feit dat op twee-derde van de plantages met een stonmmolen werd gewerkt. Daarnaast rnaakte bijna een-vijfale var de plantages gebruik van cane en trash carriers en op een-tiende van de ondernemingen stond een toestel waarmee suike: werd gezuiverd. Slechts twee plantages werkten met het vacuümpansysteer. en er was niet meer dan één centraalfabriek, waaraan drie plantages hun suiker leverden. Andere fabrieksinnovaties dan de installatie van een stoummolen kwamer. dus slechts op een kleine minderheid var. de plantages voor. Verder had men aan het begir van deze eeuw massaal de overstap gemaakt van Creolenaar Otahciteriet, was op het grootste deel van de plantages in de tweede helft van de achttiende ecuw de beestenmoien vervangen door cen watermolen er waren in het kookhuis en de watermolen ook de nodige verarderingen doorgevoex:.

Dit alles neemt niet weg dat tussen 1750 en 1860 evenvee: suikerplantages werden verlaten als er in cat laatste jaar werkzaam waren. Een steekproef onder twintig vas die verlaten suikerplantages wijst uit dat twee-derde van hen rond 1770 nog met een beestenmolen werkte. Dit wijst opnieuw op het verband tussen innovatie en overlevingskans, a: vormde de beschikbaarheid van kapitaa: daartue natuurlijk de belangrijkste voorwaarde. Dit alles heeft tussen 1750 en 1860 geletid tol eer afvalrace, die de staikersector in de jaren 1850 een innoverender aanzien gaf dan in de jaren :75C. De vraag is nu in hoeverre de Su:naamse suikersector halverwege de negentiende eeuw in de pas liep met andere Caraibische suikerproducenten.

Eerder werd al aangetoond dat wat betreft de introductie en verspreiding van stoommolens Suriname tot de eersten behoorde. Ook met de introductie van de centralfabriek, met vacuümpansysteen, in 1850 was Suriname vlot. Alleen Guadeloupe was eerder (1845), terwijl Cuba (1863), Martinique (1868) en Trinidad (1872) heel wat later de eerste centrales introduceerden. Op Jamaica had men er al rond 1845 mee geëxper:menteerd, maar dit werd een rnislukking (Watts 1987:486-99). Alleen Guiana was de

56 Suriraams Muse:um: Collectie-3rantsen, verantwoorde rekening 1852-1857; Koloniale Verslagen 1856-7862: Van den Boogaart en Fmmer 1977:205-25. 
anderen ver vooruit. Centrales kende men daar niet, maar alle 173 suikerplantages waren in 1853 van stoommolens voorzien. De vacuümpan was er a! in 1833 geintroduceerd en twintig jaar later werkte een op de zes plantages met zo'n systeem. Mechanische transportbanden waren gemeengoed en een-tiende van de plantages gebruikte stoompompen voor de akkerd:ainage (Adamson 1972:161-73).

Afgezien van Guiana behoorden de Surinaamse suikerplantages, vrijwel tot aan de Emancipatie, tot de meest geavanceerde en produxtieve van het Caraibisch gebied (Tabellen 29-31). De omvang van de gehele Surinamse suikersector kon echter nict in de schaduw staan van die der concurrenten. Bovendien zorgden in de jaren 1850 de instabiele simatie en het uitblijver. van nieuwe kapitaalimpulsen ex voo: dat Suriname in deze periode de race met haar mededingers definitief verloor. Waarschijnlijk heeft de naderende Emancipatie potentiële investeerders in Nederland weerhoiden hun geid te steken in de verdere expansie en modernisering van de Surinaamse suikersector, terwijl dit voor 1850 we: was gebeurd (I loordstink VII).

De concurrenten hadden daarvan geen last: in Guiana had men de limancipatie al achter de rug, op Cuba was die nog niet in zicht. De Guianese planters hadden in de jaren 3840 de beschikking gekregen over grote kapitalen - onder andere afkornstig var de compensatiegelden voor de vrijgemaakte slaven - die de basis vormden voor de grootscheepse modernisering van de suikerpiartages (Aciamson 1972:173; Green 1976:203). Ook op Cuba kreeg de innovatie var. de siukersector pas vaart toen er aanzienlijke kredieten yoor loskwamen in de jaren 1850 (Wasts 1987:489). Juist op het moment dat de concurrentie dus de middelen kreeg om weer een nieuwe sprong voorwaarts te maken, gebeurde dat in Suriname niet gezien de onzekere vooruitzichten.

Hiermee is niet gezegd dat de Surinaamse suikersector ooit nog de omvang van de Cubaanse had kunnen everaren, inaar wellicht wel die van Guiana. En zelfs al was de omvang kleiner gejleven dan van het butarland, dan had men in ieder geval dezelfde rendementen per plantage kunnen bereiken en dzarmee misschien het voortbestaar veiliger gesteld. Niu was daarvoor geen geld en werd de in gang gezette ontwikkeling vrij abrupt gestopt. Dit maakt het verzet van de Surinaanse pianters tegen de Emancipatie en de eindeloze discussies over de hoogte van de compensatiegelden (Siwpersad 1979:170-89, 244-64) een siuk begrijpelijker.

\section{De katoensector}

Van de drie belangrijkste exportgewassen in Sirriname was katoen het enige inheemse. De Indianen gebruikten het al exuwen lang om er stof en hangmatten van te weven. Waarschijrlijk was dit echter nict de variëteit die op 
de plantages werd verbouwd voor de exportproduktie. Teer.stra (1835, I:2659) onderscheidt namelijk naast de exportsoorten speciaa' het 'bokke- of liever Indiaansch katoen'. De katoen op de plantages kwam waarschijnlijk uil andere delen van de Amerika's.

De eerste Surinaamse katoenaanplant van enig belang vond waarschijnlijk plaats in 1752 op plantage Felix a an de Matapica (Teenstra 1835, I:264). Het was echter pas var de jaren 1780 af dat de aanplant en export van enig belang begonnen te worden. Door de Industrië:e Revolutie in Engeland, die mechanisch spinnen en weven in grote textieffabrieken mogeli; $k$ had gemaakt, zat men in Europa rond 1800 te springen om ruwe katoen. Veel Caraibische plantage-economieën hebber. op deze vraag ingespeeld en zijn op grote schaal katoen gaan verbouwen. Rond 1810 waren alleen a! in het Brits-Caraibisch geb:ed ruim 41.000 slaven bezig met de produktie hiervan (Higman :984:7:). Katoer heeft echter nergens de omvang van koffie, laat staan suiker, kimren evenaren. Alleen in het zuiden van de Verenigde Staten werd 'king sugar' opgevoigd door 'king cotton'.

Het waren opnieuw de Frans-Westindische eilarden waar de katoenverbouw in eerste instantie het meest grootschalig were aangepakt. Zo waren er in 1789 op Saint Domingue 789 katoenplantages in bedrijs (Dupuy 1989:21) en de gezamenlijke produxtie van ce crie Franse eilanden moet in. 1775 al 2.204 ton hebben bedragen (Oppe: 1902:31). Toen op Saint Domingue de revolutie uitbrak werd in het gehele Caraibisch gebied al ongeveex 8.000 ton xatoen geproduceerd (Oppel 1902:607), warvan ongeveer cen kwart op de Britse eilanden (Drescher 1977:57). 7eventig jaar later bedroeg de totale Westindische export niet meer dan 1.575 ton (Lecomte 1900:269). Aan het begin van de negentiende eeuw was de katoenproduktie in het Franse en Britse Caraibisch gebied al over het hoogtepunt heen en iegde men zich weer geheel toe op de suiker (en koffie). ${ }^{57}$ Alleen Guiana bereikte pas rond 1810 zijn grootste produktie, terwijl Suriname nog ater was met een exportpiek in de jaren 1821-1827, toen jaarli;ks gemiddeid 1.153 ton katoen werd uitgevoerd (Mandle 1973:18 en Bilage 1).

57 Werd bij de behandeling van de Caraibische koffieproduxtie al geconstateerd dat daaraan in de historiografic natiwel:jks enige andach! is besteed, me: ka:oen is dat nog minder hel geval. Fr is vrijwel niets te vinden over exportcijfers per land, aantallen betrokken plantages en slaven, geïnesteerd kapitaal. Het lijkt alsof de Caraibische katoenproduktie nauwelijks enige betekenis hoeft gehas. Toch betrok Fr.geland, de groutste achttiende-ceuwse importeur van kaloen, in $1766-87 \mathrm{~b}$ :jna $57 \%$ van haar import nit het Carainisch geoied en nog eens $13 \%$ uit Brazilic, op een totaal van ruim 7.400 tor. De resterende $30 \%$ kwam uit Turki,e (Dress:her 1977:57). 


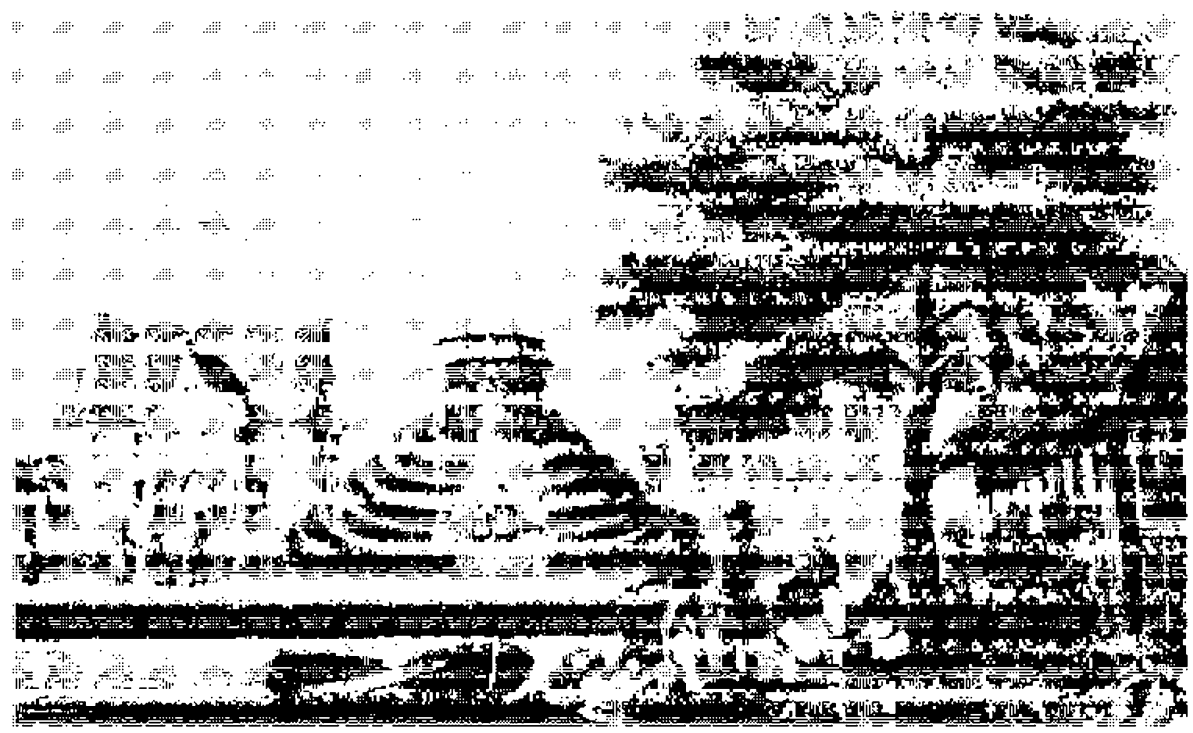

Een kakenplärtegge aan hel Matapicakanaal

(Surinamsch: Almanak 1840 \%.o. titelpagina) 


\subsection{Teelt en bewerking onn katoen}

Evenals koffie en suiker werd katoen in Surirame op plantbedden geteeld. Men gebruikte hiervoor zaad, al was ook het stekxen bekend. De laatste methode werd door de deskundigen eciter als iriferieur afgedaan. 58 op de bedien werden drie tot vij: rijen kuiltjes gernaakt, waarin enkele zaadpitten werden gelegd en vervolgers met aarde toegečekt.

Ook voor katoen gold de Kleine Regentijd a!s de beste periode om te zaaien. Kort daarna diende men al te beginnen met wieden, ondat het welig tierende orkruid anclers de kwetsbare katoenplant zou verstikken. Doordat per kuiltje meerdere pitten werder gezadid kwam soms meer dan een piantje op. De overtollige spruiler: moestru dan worder: verwijderd.

In het algemeen werd katoen in Suriname a.s meerjarig gewas gexweekt, waardoor het onderhoud nogal aan dat van koffic doet denken. Fvenals koffie bioeide katoen tweemaai per jaar en werd ook deze heester getopt er gesnoeid. Een beiangriik verschil niet koffie was dat katoer al na neger. maanden vrucit begor te geven en het aftoppen al ra ce eerste maand moest beginnen. Gebeurde dit riet, can was de katoen al na vier maander. meer dan drie meter hoog, had nauwelijks vertakkingen in de breedte en. kon dan bygevolg zeer weinig vrugten geeven' (Blom 1787:219).

Over het sroeien van de katoen bestond geen eenstemmigheid. Sommigen kapten na verloop van tijd alle takken af, tot op ecr. halve meter boven de grond (het op stomp kappen bij de koffie); anderen verwijderden aiteen het dode hout en weer anderen 'laten de takicen mar zo groeyer als de Natuur wil (De Fensgezindheid 1804:66). Wel aigemeen was het gebruik om de katoen op meerciese stammer. op te kweken. Dit in tegenstelling tot Guiara, waar dit op één stam gebeurde. Ook bij katoenbomen verminderde de opbrengst aarmate zij ouder werden. Na zes of zeven jaar te hebben geproduceerd waren zij aan vervanging toe (Teenstra 1835, 1:281-8).

De katoenboom, begon in augustus-september bloesem te dragen. Binner. 48 unr viel deze er af, om pláats te maken voor de vrucht, die vervolgens anderhalve maand later kor: worcen geougst. Deze vauchl bestond uit

'eenen driekanten groenen bolster me: zwarte stippen, zijnde deze bolster bij de openbersting, warvoor de wind zeer dienstig is, zoo groot als een duivenei, berstende alisdan in 3 à 4 devien open en vertomende erie sneeuw witte vlok, welke de eigenlijke boornwol of katoen is, in welker miciden zich eenige bruinachtige, langwerpige zaadpitten bevinden' (Teenstaa 1835, 1:275).

Wanneer de katoen was geoogst, wat inhield da: de witte vlokken uit de bolster waren gepiukt, werd deze op een stenen droogvloer uitgespreid om in de zon te drogen. Deze zogenaarnde vuile katoen zat dan nog vol 
zaadpitten. Na de droging werd de katoen daarom tussen de twee rollers van een molentje gehaald waardoor het grootste deel van de pitten er uit werd geperst. Daarna werd, als bij de koffie, de katoen op een menarie uitgespreid en net zo lang door een aantal slavinren met tamarindetwi;gen beslagen tot ook de laatste zaadpitjes tussen de latten van de menarie waren doorgevallen. Bij al deze handelingen was het zaak dat de pijjes niet braken, of dat er enkele in de katoen achterbleven, want de daaruit lopende zaadolic verminderde de kwaliteit van de katoen in belangrijke mate. Was men hierme klaar dan kon de katoen in balen worden geperst en verzonden.

Van de drie belangrijkste Surinaamse exportgewassen lijkt katoen het meest kwetsbaar te zijn geweest. Het seizoen hoefde maar jets te nat of te droog te zijn en de oogst mislukte. Bovendien werd het gewas nog al eens geplaagd door de katoerwurm of rups. Deze vertoonde zich vooral gedurende de regentijden en had het met name op jonge bomen gemunt, 'kunnende in eenen nacht geheele katoen velden verslinden' (Teenstra 1835, I:285). Zo bleek plantage Zeezigt aan de Motkreek tussen 1824 en 1850 zeven misoogsten te hebben gexad door slechte weersomstandigheden, drie keer geteisterd te zin dour een wurmenplaag en eenmaal 'buitengewone verwoestingen door de witte katoen- of schiddluis' te hebben meegemaakt. ${ }^{59}$

\subsection{Innodatie}

In het laatste kwart van de achttierde eeuw was de katoen meestal een bijprodukt op koffieplan:ages. Pas na:800 groeide de verbouw van dit gewas uit tot een zelfstandige sector in ce Surinaamse plantage-economie. Als laatkomer kon deze sector dus profiteren van technologische verworvenheden in de andere sectorer er. van de nieuwste technologie in het algemeen.

Wat betreft de anleg van ce plantage-infrasinuctuar blijkt dit inderdaad op te gaan. De lange ervaring die men in Suriname had opgebouwd met de constructie van polders kwam de katoensector zeer te słade. Sierker nog, de omschakeling op somimige plantages van koffie raar katoen betekende dat men zich op die ondernemingen met de aanleg van een infrastructiur nict hoefde bezig te houden, want die was immers al anwezig. Fen innovatie was het daardoor natuurlijk niet, maar het vereenvoudigde wel de opbouw van de katoensector. Ook blijkt het gemak van een vaartrens voor het transport op katoenplantages al snel te zijn onderkend. Zo wijst een steekproef onder negen plantages in de jaren 1820 uit, dat vier van hen over zo'n kanaal beschikten.6 ${ }^{6}$

Aan de andere kant heeft men in de katoensector soms ook negalieve produktiemethoden dit de koffiesector overgenomen. Zo bieef rnen ook 
hier soms te lang met dezelfde bomen produceren en het stelselmatig verhogen van het aanial bomen per akker was in de katoensector evenmin een orbekend verschijnsel. Daarnaast was er ook var: rotatie en/of bemesting geen sprake. 61

Iet enige aspect van de katoenprod:kktie waarbi; innovatie buiten de fabriek plaatswond, waren de experimenten met en (waarschijnlijk) grootschalige toepassing van nieuwe variëteiten. De meest gebruikte katoensoort in Suriname was de zogenaamde z.wartzadige. Volgens Teerstra (1835, I:265) was deze echter in zijn tijd 'merkelijk van deszeliss oorspronkeiijke waarde verbasterd'. In diezelfcie periode experimenteerce de planter I. Tyndail daarom op zijn plantage Sealand (Coronie) met een hoogwaardiger soort zwartzadig katoen. De kwaliteit daarvan moet eer, stuk beter geweest zijn dan de oude soort, want bij verkoop in Nederland bleek deze katoen de helft meer op te brengen (Teeristra 1835, 1: 276).

Naast 'verbastering' en hogere prijzen, waren nox de steds terugkerende insektenplagen aanleiding op zoek te gaan naar betere katoenvariëteiten. 7.eezigt (Moikreek) bijvoorbeeld biepk zowel in 1826 als in 1828 door de katoenwurm te zijn overvallen. In 1830 begon men daarom proeven te nemen met groenzadige Bourbonsche katoenpitten, volgens Teenstra (1835, I:265-6) een andere benaming voor de bekence Amerikaanse Sea Islandkatoen. De wurmbestendigheid van deze variëteit bleek echter in praktijk tegen te vallen, maar cie katuen bracht bij verkoop wel $10 \%$ meer op. ${ }^{62}$ In de districten Nickerie en Coronie werd op dat moment de Sea Island al algemeen getecld en gold deze als de beste onder de katoensoorten: 'dezelve is langdradigg en ongemeen sterk van krimp' (Teenstra 1835, I:266).

De grootschalige tnepassing van deze en andere nieuwe variêteiten bleef overigens niet beperkt tot de Britse planters ir. de nieuwe katoer.districter. van noordwest-Suriname, mâar drong ook in het 'oude' katoengebied, de noordoostkust, door. Zo bestond halverwege de jaren 1830 op Arna Catharina (Matapica) een-zevende van de 344 ha. katoen uit Sea Island en werder. proeven genomen met Laad van De Zwarigheid (Vredenburgerkreek).63 Op De Iferstelling (Waappakreek) was in 1844 van ce 129 ha katoen $40 \%$ be plar: met katoer 'van Surinaamsck zaad', 30\% met Sea Island en nog cens

61 In Benjamins en Srellenan (19]4-17:401) valt te lezen: 'Het iuit de katoen verijijorde. zaad werd in Suriname niet verwerkt, maar op hoper geworpen en nadertand als mesistof soms weer op den akker gebratint'. Dit valt echter te betwijifelen, want de deskundige 'Teenstra \{1835, I:275) schrijft over hetzeifde verschijnsel: 'He! is te bejammeren, dat neen de olieachtige pitten, waarvan men, behaive de oic, zecr smakelijke en voedzame koeken voor he! vee bekomin hai, als nietswaitrdigen a:va: in kuilen, die: een verpestenden stank geven, laia: verrotter:

6: Collectie-Insinger \& Co.: notulboek Zeczigt.

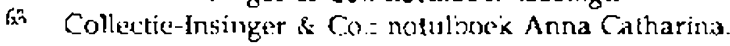


30\% met 'Bents katoenzaad', 64 Het lijdt daarom geen twijfel dat gewasinnovatie een vertrouwd verschijnsel was in de Surinaamse katoensector.

Het aantal bewerkingen dat katoen na het oogsten moest ondergaan, was veel geringer dan bij suiker of koffie en bovendien minder complex. Als bij koffie vond droging van de katoen plaats op stenen vioeren in de buitenlucht. Het is opmerkelijk dat daarnaast verschillende plantages gebruik maakten van schuifbakken, terwijl die op dat moment in de koffiesector totaal in onbruik waren geraakt fi $^{\circ}$

Het malen van de katoen, het scheiden van pluis en zaadpitten, kwam in feite het meest in aanmerking voor innovatie, omdat het al enigszins was gemechaniseerd. Deze bewerking gebeurde namelijk met zogenaamde trapmolentjes. Zo'n molentje werd door één persoor bediend en bestond uit twee nauwaansluitende, liggende houten rollers, verbonden met een kruk en ieder draaiend om een as, zoals de wringer van een ouderwetse wasmachine. De assen waren ieder door touwen verbonden met een trapplank op de grond, zoais bij een trapnaaimachine. Door het om beurten intrappen van de trapplanken gingen de assen - er dus de rollers drajien. De geplukte katoen werd tussen de rollers, dic tegen clkaar inliepen, gestoken, rolde aan de andere kan! in een zak en de afgescheiden pitter vieler op de grond. Op deze wijze kon een slazf per dag zo'n 15 a $20 \mathrm{~kg}$ zuivere katoen afmalen (Teenstra 1835, I:290). In de jaren 1820 beschikten de plantages gemiddeld over 22 van dergelijke trapmolentjes. 66

Deze werktuigen pieegden een grote aanslag op het arbeidsvermogen van de slaaf. Toch kwam er in ce constructie nauwelijks enige verardering.

In allen geval zijn de kleine molens, algemeen in gebraik, van een gebrekkig zamer.stel, dat den arbeider zeer zeker tweemaal zoo veel kracht doet uitoefenen, als noodig zou zijn met een beter model. Op de Nikeric kust, waar het maaksel dezer werkiuigen, hoewer van dezelfde soort, minder geurekkig is, en metalen krukken in gebru: 2 :jn, geeft een neger 40 à 45 pond katoen in plaats van 30 à 35 pond, zoo als in Maiappica.' (Lans 1842:83.)

Inderdaad bleek bijvoorbeeld plantage Ox:ord (Coronie) in 1826 over 24 katoenmolens met 'ijzeren cranks' te beschikken. ${ }^{67}$ Het bijft raadselachtig waarom zo'n uiterst simpele innovatie in het oude katoengebied geen navolging vond. W.H. Lans, die ook in ander opzicht de - voornamelijk Britse - katuenplanters van Coronie en Nickerie meer innoverend vond

64 ARA: SOB\&W 1828-1876, 3029.

65 In iexder geval maaklen respectievelitk in 1828 en 18:44 de ook verder goed geoutilleerde plantages Alsimo en Anna Catharina gebruik van een dergelijk systeen (ARA: SONA, 841; Collectie-lnsinger \& $\mathrm{CO}$, inventaris A.C.),

66 Steekproef 7 plantages in ARA: SONA en SNA en plankage-archieven.

67 ARA : SONA, 839 
dan de planters in het oude gebied, begreep in leder geval riets van deze 'halsstarrige' holidir.g. Kapitaalgebrek kan in dit geval niet de reçen zijn geweest, want het ging om te verwarlozen bedragen. Het erige verschi] tussen noordoost- en noordwest-Suriname was cat de kacoenplantages in het eerste gebied voomameij]k absente Vederlancise eigenaars hadden en in het niewwe gebied hoofzakelijk ter plekke wonende Britse eigenaars.68 Wellicht waren de Britse pianters meer op de hoogte van de, voornamelijk Engeistalige, vakliteratuur. Waarschijnijker is echter dat hun veel grotere aanwez:gheid op de plantages zorg droeg voor een efficiënfer gebruik van de arbe:dskrachten.

Ook wat betref: ingrijpender innovaties in het katoenmalen lijkt het aar. wezig zijn van de plantage-eigenaar een beiangri;ke rol te inebben gespeeld. Dat bleek onder andere uit de enig traceerbare achttiende-eewwse innovatie op dit gebied, die we:d aangetroffen op plantage Meerzorg (Tapoeripa). Deze onderneming was in de ;aren 1750 als koffieplantage aargelegd er. van begin jaren 1760 tot 1792 eigerdom var hel in Suriname wonende echtpaar I Laterman. De heer J.D. llatterman hecitte groot belang aan een éficiente anpak op zijn ordernening, wat al bljjkt uit hel ftit dat hij in 1765 speciaal uit Nederland een 'tuinman' liet overkomen voor het beheer op de plantage. Deze thinman was Anthony Biom, cezelfde die zou uitgrocien to: de meest gezaghebbende achtiende-eeuwse auteur over Surinaamse landbouwaangelegent.eden (zie Oostiudie en Van Stipriaan 1991: 136-47).

Gedvrexde de jaren 1780 werd Meerzorg als eei der eerste van een koffienaar een katoenplantage omgebouwd. Ook technoiogisch liep Meerzorg voorop, want naast de gebruikelijke kotoentrapmolens vermeldt de inventaris van 1792 ook een 'dubbelde ca!toenmoolen', welke 'moet door muylesels ongedreeven worder:'6" Het prir.cipe van deze rolon was gelijk aan dat, van eer: beestenmolen op suikerplar.tages en de construct:e was geheel van hout. Ter versteviging waren echter alle vitale onderdelen met jyzeren banden of platen beslagen, op zich al aen vernieuwing. In plaats van drie suikerrollers, zette dif 'gaande werk' twee rijen van twaals molentjes in beweging waar langs zitbarker: voor de slaven waren getinmerd. Daarnaas: was er nog een molen - warschijnlijk aangedreven door hetzelfde gaande werk - voor tien 'insteekers', ofwe; waaraar. tien slaven tegelijk katoen konden malen. Met eer. minimum aan inspanning konden hier dus tegelijkertijd 34 siaven katoen prepareren. Zonder twijfel was hier sprake van een belangrijke irnovatie.??

$6 x$ Van de 50 katoenplantages in het 'olde' katcengcbied was $16 \%$ in 3ritse handen en $68 \%$ van de eigenairs was absent; in Cormie en . Vickerice lagen dexe percentages op $97 \%$ en 33\% (Surinamise Almanah 1824:45-85:.

69 ARA: SONA, $27 y$.

70 Oner het verdere verloup va: phantage Mecrzorg is alleen bekend dat mef de doud van 
Veel navolging heeft het echter niet gekregen, want van twintig katoenplantages in de periode 1800-1830 bleken slechts vier van iets anders dan trapmolentjes gebruik te maken. ${ }^{71}$ Het is weer opmerkelijk, dat alle vier deze plantages eigendon waren van in Suriname residerende Britten. Op een van deze ondernemingen, Leasowes (Coronic), bleck volgens de inventaris uit 1822 ook een beestenmolen te zijn geînstalleerd. Desondanks werden in een andere loods 'thans 24 katoen moolens opgericht'.72 Dit waren hoogstwaarschijnlijk trapmolentjes, zodat de veronderstelling voor de hand ligt dat de beestenmolen niet naar tevredenheid functioneerde. Gebrek aan trekdieren, een algemeen probleem in Suriname, zou de reden geweest kunnen zijn. Misschien ook waren de problemen die plantage De Zwarigheid had met zijn katoenbeestenmoler van vergelijkbare aard als op Leasowes.

Op De Zwarigheid (Vredenburgerkreek) stond een door ossen aangedreven molen die plaats bood aan zestien slaven die ieder gemiddeld 50 pond katoen per dag konden malen. Toch voldeed de molen volgens Teenstra (1835, 1:290) minder goed dan de gebruikelijke trapmolentjes,

'ais zijnde meer kustbaar, zoowel in de daarstelling en het onderhnud, als in de dagelijksche werkzaamheden. Breekt ex iets, of is er een os, die volstrekt niet trekken wil, gelijk hier meermalen het geval is, onder alle zweepslagen en alle aangewende pogingen liggen blijft, dan staal het geheele [molen]w'erk en staan dus ook alle Negers stil. Breekt er daarentegen een trapmolen, dan staat er slechts een neger stil, en dit nog slechts voor eene korte poos, aangezien metr van deze kleine molens altijd in reserve heeft. Zoodat deze aanhoudendheid var 35 ponden het op den duur van 50 ponden w'int.'

Ook de gietijzeren molen uit Liverpool op De Herstelling (Warappa), voortbewogen door vier muilezels en werk verschaffend aan tien slaven, die ieder gemiddeid 100 pond per dag konden malen, voldered niet erg. Hij liep te snel en te zwar, zodat de pitten werden geplet en de zaadolie de katoen bedierf. Teenstra (1835, I:290) hield het daarom liever op trapmolens dic, volgens hem, het minste uitval kenden en de beste kwaliteit katoen opleverden.

Over de stoommolen op plantage Perseverance (Coronie), waaraan slechts twee slaven werkten die samen 900 pond per dag produceerden, sprak Teenstra opmerkelijk genoeg geen oordeel uit73, noch over katoen-

mevrouw Hatteman in 1792 de plantage eigendom werd van de geldschieters in Nederland. Of uit de reden was waarom de plantage in verval raakte is net meer te achterhalen, maar in ieder geval lag de produktie in de negentiende ceuw ver onder het landelijk gemiddelde.

71 Steekproef 20 plantages in ARA: SONA en SNA cn plantage-archieven.

72 ARA: SONA, 834.

73 Deze $6 \mathrm{pk}$ molen 'gaf slechts aan twee Negers plaats om te malen, staande regt tegen elkander over, kunnende, volgens zeggen van den vriendelijken eigenaar Harvie, ieder Neger 450 ponden, dus te zamen 910 ponder katoen [...] in eenen dag af malen. De wol zelve loopt over 
stoommolens in het algemeen. F.ders in zijn boek somde hij wel alle voordelen op van suikerstoommolens, terwijl de racielen daarvan, kostbaar en kwetsbaar, hetzelfde warer. Toch moeten de stoommolens grote voordelen hebben geboden aan katoenplantages. Niet alleen konden twee slaven evenveel katoen malen als 26 collega's met trapmolentjes, ook spaarde de machinale waaier het vermoeiende en arbeidsinfensieve katoenkloppen uit.

Teenstra stond echter niet alieen in zijn afwachtende houding, want de katoenstoommolen heeft in Suriname nooit op grote schaal ingang gevonden. De eerste moet al in de jaren 1820 zijn geïnstalleerd7 7 mar in 1853 bleken slechts acht van de 31 overgebleven katoenplantages over zo'r machine te beschikken, evenwichtig verdeeld over hef oosteli;k en westelijk plantagegebied (Van Sijpesteijn 1854:96-147). Waarschijnlijk had men het geld niet om zo'n kostbare installatie aan te schatsen.

Ter illus:ratie het voorbeeld van het Amsterdamse handelshuis Insinger \& Co. dat in de jaren 1820 een winstgevende toekomst zag weggelegd voor de Surinaamse katoen. Het kocht daarom de bij Insinger verhypothekeerde katoenplantage Anna (atharina (Matapica) in voor de som van de schuld. Tevens verleende het aan de eigenaar van plantage Zeezigt een hypotheek van $f 200.000$. Beide ondernemingen behoorden tot de grootste var. Suriname, met ieder 350 a 400 slaven en 350 ha. katoen. ${ }^{75}$ De schuld var. Anna Catharina werd lit de boeken geschrapt en de plantage leverde in de periode 1830-1843 jaarlijks een winst op van gemiddeld $f$ i0.000. Kenrelijk stimuleerde dit cie innovatie, want niet alleen werd er druk met verschillende katoenvariëteiter. geëxperimenteerd, ook werd de katoenbewerking gemechaniseerd. Zo verscheen er in 1838 een 'katoenzuiveringstoestel', waarschijnlijk een soor: waaimolen die het katoenk'oppen verving, en aan het eind van de jaren $1840 \mathrm{kwam}$ er eer. stoommachine.

Op Zeezigt werden eveneens veel proeven genomen met verschillende katoensoorten, mar tot esige mechanische innovatie kwam het daar nooit. De financiën van deze onderneming boden daartoe dan ook geen enkele ruimte. De in : 824 afgesloten hypotheck met een rente van $6 \%$ had tien jaar later moeten zijn afgelost. In 1840 stond de schuld echter nog steeds op hetzelfde niveau en was men al blij wanneer de rente kon worden voldaan. Toen daarop de katoenprijzen begonnen te daien lukte zelis dat niet meer, zodat in 1860 de totale schu.d bleek te zi;n opgeloper. tot ver over de zes ton. Deze situatie rodigde niet it tot kostbare innovaties.

\footnotetext{
jizeren kammen, ten einde zich egaal te scheiden, terwijl de rollers of cilinders door stevige borstelbrassen schoon gehouden worden; vervolgens komt de katoen in ecnen door de machine gedreven wordendien wajijer, welks kleppen het katoen over exn rix)ster ronddraaijen, en op die wijze zuiveren.' (Teenstra 1835 , l:292.)

74 Die van Perseverance was in 1829 al volop in bedrijf (Teenstra 1835, I:292).

75 Aile gegevens over Anna Catharina en Zevezigt: Collewtie-lnsinge: \& Co.: notulboeken.
} 


\section{Surinamers en innovatie}

Hoe kan nu in het algemeen de houding ten anzien van innovatie worden gekarakteriseerd van degenen die bij het Surinaamse plantersbedrijf waren betrokken? Voor het beantwoorden van deze vraag dient allerecrst onderscheid te worden gemaakt tussen de houding van de planters en die van de slaven, aangezien de belangen van de ene groep niet noodzakelijkerwijs parallel liepen aan die van de andere. Eenvoudig is dit onderscineid niet, omdat alles wat slaven aanging werd opgetekend door blarken. Bovendien kon het uiten van een duidelijke eigen mening gevaarlijk zijn voor een slaaf. Liever hield hij die in het algemeen voor zich en maakte zich.zelf zo onzichtbaar mogelijk. Dit gaf sommige blanken weer de gelegenheid ongelimiteerd allerlei twijfelachlige meningen over slaven te debiteren.

Dat dergelijke dubicuze opinies wijdverbreid konden zijn, maar niet door iedereen geaccepteerd, blijkt uit eer. opmerking van de landbowwkundige C.J. Itering (1858, If:1). Sprekend over de introductie in Suriname. van hoge-druk stoommachines, zei hij veel tegenwerking van planters fe hebben ondervonden, 'onder het voorwendsel dat de negers te $7.0 r g e l o o s$ zijn om deze werktuigen te behandelen: Hering deed ce opvatting van de planters dus af als een voorwendsel. D:t was echter tamelijk uitzonderlijk, want als er in algemene zin over de slaven werd gesproken dan was de communis opinio in de achttiende- en negentiendereeuwse bronnen, dat zij lui, zorgeloos, dom, orhandig en onwillig waren. Dit impliceert dat zij inderdaad ongeschiki zouden zijn voor het werken met nieliwe, meer gecompliceerde technologie. I Iet is daarom een vraag in hoeverre slaven in praktijk inderdaad een obstakel hebjen gevormd voor de modemisering van het plantagebedrijf.

In het algemeer ligt het voor de hand dat slaven bijna varzelfsprekend gekant waren tegen veranderingen die hen door bianken werden opge-legd. Per slot van rekening hadden de belangrijkste irgrepen in hun jeven hen niet veel goeds opgeleverd en in ieder geval bracht verandering altijc grote onzekerheid met zich mee. Dit wordt duideliik geillustreend door de veelvuldige weigering van slavenmachten in de negertiende eeuw om naar andere plantages te veriuizen wanneer de eigen piantage werd verlaten. Ook veranderingen in het management leidder. regelmatig tot massaal weglopen en/of verzet (zie voor beide I loofdsluk XII). In een situatie var afhankelijkheid, zoais de slaverrij, is het begripelijk dat slaven eerder geporteerd waren voor de zekerheid van het bekende, dan de onzekerheid van weer onbekende omstandigheder.

Daar staat tegenover dat nooit enig slavenprotest werd verromen dat gericht was tegen de invoering van nieuwe plantagetechnologie. Kennelijk werd dit door hen niet als becreigend of arbeidsverzwarend ervaren. Ook 
van de kant van de planters werd ir. de dagelijkse plantagepraktijk geen geluid gehoord als zouden slaven en moderne tecinologie niet kunnen samengaan, tenzij als excuus voor hin eigen onwilligheid of onvermogen, zoals blijkt uit de woorden van Hering.

In de discussie over hel aanschaffen van een stoommachine op Vossenburg bijvoorbeeld werder vitgebreid de voors en tegens van zo'r: werktuig tegen elkaar afgewogen. Daarbij werd met gen woord gerept over eventuele vijandigheid van de siaven tegen de komst van een stoommachine, terwij: dat bij anciere veranderingen altijd een uitvoerig punt van overweging was. Ook de vraag of slaven wel in staat zouden zi;n met de macininerie om te gaan was geen purt van discussie. In vrijwel iedere slavenlijst van plantages met stoommachines kan dan ook een zwarte 'machirist' of 'ingenieur' worden aangefrolfen. Op plantage Rlistenburg (I'erica) had zelfs een slaaf die functie gekregen, die ooit was opgezadeli met de naam Trobie (lastig, ruziezoeker). ${ }^{76}$ Deze Trobie was in ieder geval in 1861 als machinist op Rustenburg werkzaarn, terwijl daar al sinds 1858 ook Chinese contractarbeiders werkten. Geen van hen had exiter een functie ais ambachtsman, ingenieur of machinist; eens te meer een bewijs dat slaven en gecompliceerde technologie zeker samengingen en vrije arbeid daarvoor geer. dwingende noocizak vornce. ${ }^{77}$

Wel is het waar dat hoe gecompliceerder de machinerieën werden in de loop van de negentiende eeuw, hoe meer da planters jij rampen een beroep moesten doer. op gespecialiseerde technici. Dit had echter niets te maken met onbe'k wamheid van ce slaver; aij waren evenrin als het blanke management voor dergelijk speciaistische taken opgeleid. Het is dan ook geen toeval dat vrijwe: alle experts die op tat gebied in Siriname werkzaam waren afkomstig waren uit het technologisch meest geavanceerde land ter wereld, Engeland. ${ }^{78}$

Een goed voorbeeld van het samerspel tassen slaver en specialisten er. de voordelen die dit de betrokkeren opleverde, is oprieuw te vinden op plantage Vossenburg. In 1851 werd daar gerapporteerd dat

'de nieuwe houten stoel yoor den molen was geheel gereed en afgewerkt; dit [...] werk was door eigene ambachtsriegers verrigt; hierdour [... waren enige Honderde Guldens bespaard, die anders aan eenen baas haciden moeten worden

\section{ARA: PWI Bank, 179.}

7 Hek ging overigens niet alleen om suikerpiantages, oox op katocnplantages met moderne apparatuur were deze doo: sliven bediend. Zo sonien bijwoorbeeld up plartage Ize Herste:ling in 1 e.44 twee stoommolens, een (stocm aangedrever?) katoenwaimnkn er cen katoerpers, die alie door slaven werden behandeld, terwijl een van de $z$ warie bastiaans evereens te bock stond als ingenieur (ARA: SOBS\&W 1828-1876, 3079).

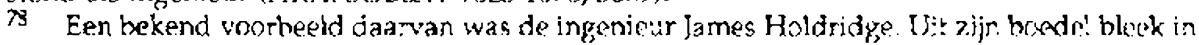
1841 dat hij de laalste jaren voor cen t:ental verschillendo plantages werkzaam was gewecst (ARA: SOB\&W :\$28-1876, 1563). 
uitbetaald: als eene belooning voor hun goede werk, hadden H.H. Adminislrateuren aan de Plantagie timmerlieden $f 50$ ten geschenke gegeven. De oprigting van den nieuwe stoel [waartoe de moien geheel moest worden losgemalkt en uiteengenomen] zouden H.H. Administrateuren voorzigtigheidshalve door eenen Ingenieur laten doen, daar dit zeer naaliw luistert en de minste afwijking van het waterpas, het breken der kammen van de rolders ten gevolge zou kunnen hebben. ${ }^{79}$

De constructie van cen zo vitaal onderdeel ais de molenstoel werd dus geheel overgelaten aan de ambachtsslaven 80 Alleen de specialistische kennis die was vereist voor het waterpas installeren dazrvan was niet op de plantage aanwezig. De enige redenen om van dit werk speciaal melding te maken waren dan ook financiële.

Uit het gemiddeld aantal ambachtsslaven op plantages in de loop der tijd blijkt evenmin dat met de vooruitgang van de techniek de afhankelijkheid van her afneemt. Op suikerplantages waren zowel in de jaren 1750 als in de jaren 1850 gemiddeld ruim twaalf ambachtsslaven werkzaam. 81

Kortom, in theoric konden veel blanken er van overtuigd zijn dat zwarten dom, onhandig en lui waren, in praktijk bleken zij er geen enkele moeite mee te hebben dat diezelfde domme negers hun machines bediencien. En waarschijnlijk naar volle tevredenheid, want geen van beide partijen heeft daarover ooit klachten geuit. Bij hoge uitzondering wilde een planter daarom zelfs wel eens toegeven da: let in werkelijkheid met de kundigheid van slaven bepaald niet slecht was gesteld. ${ }^{2} 2$

Wie mocht denken dat de blanke auteurs van de achttiende- en regen-

79 Surinaams Muse'um: Collectie-Bran:sen, verslagboekje 185 :

8. De 'houten stoc!' waar in dit citaal sprake van is, was de gehele constructie warin de drie rollers van de molen rustten. Dit moest zeer stevig en soiide zijr., want de druk die ex onder het malen op kwam te staan was zeer groot. Bij cen watermoler. 'rust cee cene as van het waterrad op een ander hout gevaarte, de kleine stoel genaams, gn de andere as op de galy, zynde een vierkant stuk hou!, behoorende aan den grooten stoel. Aan de as van dit schep of water-rad, is een bonkelrad, dat weder in kam-rad loopk; dit kam-rad is vast aan de as van de middenste cylinder, waar door het rie: gemaalen wordi, en welke men De Koning noemt; men heeft aan alle Suikermolens I...] drie cylinders, welken men Rolders noernt; ieder heeft boven aan een kran.s met tanden, of rad wclken in elkanderen loopen, zo dat, wanncer de middenste rolder in beweegirg komt, dan brengt die de beide and're rolders mede: in beweging, en de molen gaat, zo als men spreekt.' (Blom 1787:58.)

81 Steekproef jaren 1750: ARA: SUNA $(n=30)$; jaren 1845-1862: plantago-archiever $\{n=14)$. Op koffieplantages was het gemiddeld aantal ambachtsslaven in de jaren 17507,1 (n=36) en in de jaren 1830-1850 6,8 ( $n=12)$. Onder de ambachtsslaven zijn begrepen de bastiaans, ondat die meestal ook en ambacht kenden, de timmerlieden, kujpers, metselaars, smeden, machinisten en ingenieurs. Niek diaronder begrepon zijn suikerkokers, omcat dite voor het overige vijiwel aitijd als veldslaven te boek stonden. Hun aantal bedroeg 3 tot 5 per plantage.

82 Zoals de anonymus die rond 1770 opmerkte: 'Da: men hier niet Zegge, dat die siaave onbekwaamer zijn als blanke. Men zou sulks kunnen toe stemmen van de veldslaaven maar iedere plantage heeft swarte officiers, Timmer neegers kuijpers, metzelaars, en andere huijs slaaven, [...], die wel soo bekwaan om riet te zeggen bekwaamer als b.anken zijn.' (ARA: SwS, 337; geciteerd in De Eket 1984:82.) 
tiende-eeuwse bronnen eensluidend positief zouden oordelen over het ondernemersgedrag van hun rasgenoten komt bedrogen uit. Kwalificaties als lui en dom werden vaker op hen toegepast dan dat de loftrompet werd gestoken. ${ }^{83}$ Inderdaad valt het niet te or.tkennen dat bij bestudering van de Surinaamse geschiedenis dergelijke negatieve karakteristieken voor de hand liggen. Toch kan dat niet de gehele waarhejd $x:$;n omdat naast stilstand en lethargie ook vernicuwingsdrang en experimenten voorkwamen. Het becld dient te worden genuanceerd.

Wat bijvoorbeeld te denken van de planter-dominee B. Duvoisin, dic op zijn plantage Breukelerwaard in 1753 ru:m 170 boeken in de kast had staan. Naast bijbels en psalmboeken behoorden daartoe geschriften over toneel, kunst, geschiedenis en liefde (Plaisirs et Chagrins de l'Amours), terwijl een praktisch werk als l'Ingénieur Pratique evenmin ontbrak. ${ }^{84}$ Duvoisin moet er op zijn verafgelegen plantage aan de Boven-Commewijne menige arond mee hebben doorgebracht. Ook het echtyaar Schelling bezat op hun plantage Dordrecht in 1768 een aardige bibliotheek waar-onder allerlei filosofische en natuurkundige werken. Daarriast beschikten zij over een microscoop, een telescoop, een luchtpomp, brandspiegels, een kompas en verschillende globes. Dic zullen er niet alleen voor de sier hebben gestaan en duiden op een serieuze wetenschappelijke belangstelling. ${ }^{45}$

De innoverende activiteiter. van de Gouverneuzs Nepveu en Friderici werden al eerder genoemd en ook Anthony Blom kwam al meerdere malen ter sprake. Deze landbouwkundige leefae van 1765 tot zijn dood in 1807 in Suriname. In die periode klom hij op van 'tuinman' to: aciministrateur van zeven plantages en schreef hij enkele degelijke en kritische werken over de Surinaamse plantageiandbouw. Onder de ruim 20 boeken die hij naliet,

83 Een paras vourbeclde: mogen dit illusireren. In 1736 schreef Couverncur J. Raye: 'Maar let is of den heemel tot stral van deese colonie alle mensen schoon nog soo vigiland in Europa, hier comende met iuyheit stra:t, 't is ongelooflijk hoe men alles op oc lange baan tragt te schuive" (geritesers in Van der Mejden 1987:86). in 1778 schreven de bekende planters Graafland en Gootenaar over de betrokkenen bij hel Surinaarnse plantagebedrijf aan beide zijden van de oceaan, dat zij in het algemeen 'wijnig of gecne kennisse negte crvaarentheyd van de Surinaamsche handel, de gestelulued der plantagien aldaar, en het geene daartoe verder betrekkelijk is, brsasten, onk daar ic lande tot hunne agendarissen hobhen goskld lieden, dic eeven wijrig de vereischte qualifeiten hadden en 500 al nogtans groote misslaagen begingen" (GAA: arch. 5028, landel port. 5). Lern halve ecurv la ter schreef de absente plantage-eigenar G.P.C. van Breugel dat zijn herhazlde instructies aan de administrateurs in Surirame worden ontvangen, nedergelegd on men gaa: de ouden gang ondat iet iets buitengewoons zou zijn meerdere moeite aar. te wenden dan nuodig is" (KJT: Collectie-Van Breugel). Dat ook ra de Fmancipatie dergelijke geluiden konden worden opgetckend til de mone van gerenommerde personen bleek in 1900 toen de landioouwkundige $H$. van Capelle tijdens eer studiereis door Suriname tut de conclusie kwam, dat over het algencen onder de Sirinaamsche planters weiniz samenwerxing tocstat en dat men op vele ondernemingen wrinjy, rekening houdt mel de ervaringen, op andete plantages verkregen' (Va) Capelle 1901:3-4).

84 ARA: SONA, 194.

85 ARA: SONA, 227. 
bevonden zich de bekende geschriften van J.J. Hartsinck, De Laet, J.B. Labat, G.F. Raynal en vele werken over planten en kruiden, waaronder dat van C. Linnaeus (zie Oostindie en Van Stipriaan 1991:138-9). Er bleken dus wel degelijk mensen in Suriname te zjjn - en zeker riet de minst invloedrijke die niet beantwoordden aan het clichébeeld van dom en lui.

Ook niet alle planters konden worden beschuldigd van gemakzuchtige domheid. Zo was er rond 1800 in het Matapicagebied een genootschap van planters actief onder de naam De Fensgezindheid. Iedere veertien dagen, 'uitgezonderd in de Koffijplukken', kwamen de 23 leden bijeen om te discussiëren over allerharde problemen aangaande het plantagebedrijf. De 'verhandelingen' die daaruit resulteerden werden gebundeld en gepubliceerd in 1804.

Begin jaren 1820 werd in de Surinaamse Almanak een prijsvraag uitgeschreven over de kwestie 'Welke zijn de geschiktste middelen, om voortaan het verlaten van Plantaadjes, te weeg grbragt door het uitputten van den grond, voor te komen?' De twee beste inzendingen zouden met een gouden en zilveren medaille worden beloond. ${ }^{86}$ Over de inzendingen is helaas niets bekend. Wel werd enige jaren daarna (1829) een nieuw landbouwkundig genootschap opgericht onder de naam Prodesse Conamur ('wij trachten nuttig te zijn'). Bij de oprichting bestond het gezelschap uit zestien leden, later kwamen er nog elf bij, en zaten in het bestuur onder anderen procureur-generaal E.L. van Heeckeren, de landbouwkundige Teenstra en $\mathrm{H}$. Klint, een der grootste administrateurs van Suriname. Naast discussies over allerlei agrarische kwesties ondernamen de leden diverse experimenten, onder andere met verschillende gewasvariëteiten, met een 'machine ter uitmaling van zwampgrond' en met het gebruik van de ploeg (Var Heeckeren 1832:9-17).

Een andere indicatie voor de interesse in het lar.dbouwkundig onderzoek vormen de lijsten van Surinaamse intekenaars op de boeken van leenstra (1835) en Hering (1858), beiden aanhangers van een moderne, wetenschappelijke benadering. Voór de verschijning van het eerste werk hadden in Suriname al 156 personen op het boek ingetekend, onder wie $21 \mathrm{knop}$ lieden, 9 ambachtslieden, 31 plantage-eigenaars en administratelirs en 25 directeurs. Op Hering, die alleen over de suikercultuur schreef, werd ingetekend door 20 eigenaars en administrateurs en 18 directeurs. Bovendien kochten ook 4 werktuigkundigen en 14 plantage-opzichters dit bepaald niet gemakkelijke boek. Dit betekent dat nu ook de lagere echelons van het plantagemanagement belang gingen stellen in moderne landbouwmethoden (of nu pas in staat waren zo'n boekwerk aan te schaffen). ${ }^{87}$

87 Zeyer opmorkelijk was dat zich ander deze gruep de Chineste opuiehter van de contract- 
Het leek er op of men in Suriname op landbolwkundig gebied zelfs zeer vooruitstrevend en ontvankelijk voor iedere nieuwigheid was. Teenstra en Hering zouden echter de eersten zijn geweest om dit te ontkennen. Zo moest het bestuur van Prodesse Conamir, waaronder Teenstra, in i832 tot zijn leedwezen constateren dat het genoutschap niet meer can 23 betalende leden telde, wat werd oegeschreven aan 'eene overgroote en algemeere onverschilligheid ten aanzien van ons werk' (Van Ileeckeren 1832:31). Ook Hering (1858, II:1) laat zich in zi;n boek voortdirend uit over de geringe betrokkenheid van Surinaanse planters bij landbouwkundige ontwikkelingen en zelfs zegt hij meerdere malen door hen moedwillig te zijn tegengewerkt.

Zo ontstaat een beeld van een samenleving met hoogstwaarschijnlijk eer. minderheid die actief belangstelling toorde voor landbouwkundige verrieuwinger. en een meerderheid die daar passief tot afwijzend tegenover stond.

In de meeste koloniën van het Caraibisch gebied werd al van de tweede helft van de achttiende ceuw af gewerkt me: verschillende vormer: van bodemverrijking (Watts 1987:435; Ward 1988:88) ${ }^{\text {s8 }}$ In Suriname is daarvan nauwelijks sprake geweest. Gootenaar verwoordde in 1770 het algemeen gevoelen in Suriname in dit opzicht, toen hij schreef: 39

'Onze colonien a an de vaste kus! van America zijn met exn zeer vrugtbaare grond gezeegent; de ondervinding van ruym een eeuw bewaarheyd zulks, als zijnde in al dien tijd nog nimmer eer.ige mest op de akkers gebragt en leveren niet te min middelijk vrugten uyt:.

Deze tamelijk triomfantelijke bewering lijkt er op te duiden dat de enige vorm van bemesting die wel in Suriname werd toegepast, het op de akkers verspreiden van bagger uit de trenzen en snoeisel var de gewassen, meer toeval dan beleid was, of comweg gemaxzucht. Gootenaars idee dat de produktiviteit zonder verdere bemesting niet werd angelas!, werd in de koffieen later ook, in mirdere mate, de katoensector volkomen geloochenstraft. Alleen de suikersector had daarvan geen last. Daar was altijd geroteerd, braakliggende akkers werden onder water gezet (een extra vorm van natuurlijke bemesting) en het plantage-areaal was ir het algemeen veel groter.

arbeiders op Catharina Sophia, Chenuzens Linsixsay, bevond die hooguit vier jaar daarvoor in Suriname was aangekomen en kennelijk a! in staat was deze gecompliceerde materie in het Nielerlands te lezen.

80 Ward (3988:88) schrijft over 'amaica: 'By the 1830s fifty tons of manure per acre of plant canes had become the standard, compared with only twenty or thirty tons in the :770s."

BG ARA: SvS, 508 . 
Wat betreft andere innovaties, variërend van de massale introductie van nieuwe gewasvariëteiten tot mechanisatie en vervanging van de energiebron, bleek de suikersector de mees! en katoen de minst dyramische van de drie sectoren te zijn. Natuurlijk vormde de beschikbaarheid van kapitaal een belangrijke factor, maar het was de ondernemersmentaliteit van de p'anters die de doorslag gaf. Continuäteit op langere iermijn was misschien niet voor de hele suikersector kenmerkend - daarvoor werden in de loop der tijd toch ook teveel suikerplantages verlaten - maar wel voo: een belangrijk deel. Daarvan get:igden de relatieve continuiteit in het eigendom, de gestadige, maa: niet aflaterde irtroductie van dure kapitaalgoederen ais watermolens, dubbele ketelwerker, stoommachines en andere apparatuur. Ook wat betreft het opnemen van krediet zal blijken dat suikerplanters voorzich.tiger waren dar. koffieplanters en daarmee opnieuw toonden meer oog te heiben vour de continuiteit (I Ioofdstuk VII).

Koffie was daarentegen eer. typisch 'boom'-produkt, dat cen ander soort ondernemers aartrok. Voor het Carajbisrt gebied was het een nieuw produkt, de produktiemethode was rieuw en de planters waren gieuw. Snelle expansie met veel geleenc kapitaal moest leiden tot sneile winsten. Innovaties werden a'leen nutijg gevonden als zij de produktie versnelden en niet kostbaar waren. De handaangedreven xoffiebreekmolen werd daarom wel en de beestermolern riet ingevoerd. Contininteil lijkt daarom in het woordenboek van kofficpianters niet te zijn voorgekomen, zodat de sector al gauw over haar hoogtepunt en door haar geld heen was.

Rond 1800 kondigoe de k.stoen zich als nieuwe 'boom'-sector aan. Doordat deze voor een deel voortkwam uit he koffiesector werd in het oude katcengebied een deel van de fouten uit die sector herhaaid, zoals uitputtende exploitatie van grond en gewas en te weinig oog voor innovatie. Wat betreft het laatste bleek de soort eigenaar, Brits en ter plekke wonend, een beiangri,ke roi te spelen. In het algemeen heeft het soor eigerdom een belangrijke rol gespeeld bij inrovatie in de negentiendeecuwse Surinaamse plantage-economie. Absenteisme en negotiatiefondsen hadden daarbij een opvallend negatieve invloed (Tabelies 37 en 38).

In de jaren 1820 was het dosenteisme in de suiker- on katoensector geringer dan bij koffie, evenals de invloed van Nederlandse negotiatiefondsen. Britse eigenaars waren in die twee sectoren meer vertegenwoordigd dar. in de koffie. Die Britse aarwezigheid was her gevo'g van de periode dat Suriname onder brits bestuur had gestaan. Een hele groep nieuwe planters uit dat land was toen in Surirame neergestreken en had hel grootste deel van zijn kapilaal gestuken in de veelbeloverde katoensector. Maar ook de suikersector, die begin negentiende ceuw nieuw elan begon te vertonen, werd door de Briften niet over het hoofd gerien. 
Tabel 37. Plantagebezit per sextor $1824-1853$ (in \%)

\begin{tabular}{|c|c|c|c|c|c|c|}
\hline \multirow{2}{*}{ eigenaar } & \multicolumn{3}{|c|}{$\begin{array}{llll}1 & 8 & 2 & 4\end{array}$} & \multicolumn{3}{|c|}{1853} \\
\hline & koffie & suiker & katoen & koffie & suiker & katoen \\
\hline absen: & 73 & 63 & 42 & 54 & 60 & 69 \\
\hline ter plekke & 27 & 37 & 58 & 46 & 40 & 31 \\
\hline negotiatiefonds & 34 & 27 & 12 & 20 & 19 & 7 \\
\hline Brits & 5 & 11 & 49 & 16 & 11 & 38 \\
\hline
\end{tabular}

Bronnen: Surinuamse Almanak 1824:45 85; Van Sijpesteijn 1854:96-247.

Tegelijk was het voor de meesten van hen ook duidelijk dat de koffiesector als afgedaan kon worden beschouwd.

Als gevolg van de voor 1800 opgebouwde sch,uldenlast was het absenteïsme en de invloed van negotiatiefordsen in de koffiesector het grootst. De nog ;onge katoensector kende een dergelijk verleden rauwelijks, zodat beide factoren daar van vee minder invloed waren. De situatie in de suikersector bevond zich daariussenin, maar daarbij dient te worden aangetekend dat de gestegen verwachiniger: in deze sector nieuwe negotiatiefordsen, met kapitaal, hadolen aangelokt.

Dertig jaar later bleken in de suikersector de bexitsverhoudingen reatuwelijks te zijn verancierd, opnieuw een teken van continuïteit. De koffie- en de katoensector hadden daarentegen duidelijke en aan elkaar tegengestelde veranderingen ondergaan. De koffiesector was al decennia lang op zijn retoun, zodat alleen de grotere en/of beter beheerde ondernemingen het nog, volhielcien in de ;aren 1850. Kennelijk boekten ter plekke wonende er/of Britse eigenaars de beste resultater, want het aandeel van deze groepen steeg opmerkelijk. Het aandeel rar. de fondsen was weliswaar gelijk gebleven, maar het is de vraag of dat le maken had met beter beheer. Waarschijnlijker is dat zij meer financiële spee:-uimte hadden dan individuele absente eigenaars om nog zo lang mogelijk wit de planiages to halen wat er in zat. Ir: de katoensector bleek het abserlieisme? in 1853 flink te rijn toegenomen, terwijl de Britse invloed was gediald. Door insektenplagem en overstro-

Tabel 38. Plantagebezit ex stoom 1853 (in \%)

\begin{tabular}{|c|c|c|c|}
\hline eigenaar & $\begin{array}{l}\text { suiker-en } \\
\text { katoen- } \\
\text { piantages }\end{array}$ & $\begin{array}{l}\text { suiker- } \\
\text { plantages }\end{array}$ & $\begin{array}{l}\text { aandeel hierin } \\
\text { in bezit van } \\
\text { fondsem }\end{array}$ \\
\hline
\end{tabular}

\begin{tabular}{|c|c|c|c|}
\hline ter piekke en/uf Brits (met stoom) & 33 & $3 \%$ & \\
\hline absent en niet-Biits (met stoom) & 18 & 21 & $(2 i)$ \\
\hline ter piekke en/of Brits (zonder stoom) & 14 & 6 & - \\
\hline absent en niet-Brils (zonder stoom) & 34 & 35 & (42) \\
\hline
\end{tabular}


mingen, dalende prijzen en een stijgende schuldenlast was deze sector in verval geraakt. Bovendien was de eerste generatie Britse planters nu grotendeels overleden en bood de sector voor de erfgenamen geen perspectiever meer, zodat een groot aantal piantages werd verlater. Hierdoor daalde het britse aandeel en - everals in de koffiesector an het eind van de aclitiende eeuw - nam het absenteisme flink toe.

let waren de Britten en de eigesiars ter pickke die een overheersende invloed hebben gehad op de introductic van moderne technologie. Alle negen stoommolens op katoenplantages waren door planters uit deze twee groepen ingevoerd en van de 31 suikerplantages die $\mathrm{in} 1834$ met stoommachines werkten waren die in 22 gevallen die machires door een Britse en/of ter plekke wonende eigenaar geplaatst.90

Ondanks de relatieve aframe van de groep ter plekke wonende en/of Britse eigenaars (Tabel 37) is het duicelijk, dat ook in de jaren :850 deze groep nog steeds bepalend was voor de modernisering van de Surinaarnse planfage-economie (Tabel 38). Ile: wek: dan ook geen verbazing dat de tien suikerplantages die in de periode $1855-: 86:$ voorkwamen in de top-vijf van meest producerende ondernerminger in handen waren van deze groep. ${ }^{41}$ Negotiaticfondsen als bezitters van plantages hebben duidelijk belemmerend gewerkt op de modernisering. Hun aandeel in de suikerpiantages zonder stoom was tweemaal zo groot als in die met een stooramachine (Tabe. 38).

De vraag is natuurlijk waarom plantages van ter plekke wonende en/of Br:tse eigenaars zoveel inmoverender waren dan ce rest. Wat betreft de Britse eigenaars is een aantal verklarir.gen mogeli;k. In de eerste plaats waren $z i j$ afkomstig tit het meest gëndustria!iseerde land ter wereld, dus meer vertrouwd met mecharisat:e en innovatie ir: hel algemeen. In de tweede plaats konden zij zich spiegeien aar het voorbeed hur landgenoten in Surinames buurland Guiana, waar zich gedurerde de eerste helft var de negentiende eeuw de meesi geavanceerde suikersector var het Caraibisch gebied bevond. De eerste stoommachine werd daar onstreeks 1803 geinstalleerd (Adamson 1972:171) en gedurende datzelfde decennium werd door de Fngelsen het emorme bedrag van circa 200 miljoen gulden in deze nieuwe xolonie geïnvesteerc (Drescher 1977:94).92 Dit maakt duidelijk dat de Engelse kapitaalmarkt open stond voor investeringen in Cara:bische piantage-economieën. Het ligt voor de hand dat de Britse planters in Suriname daar ook gebruik van hebben gemaakt.

Niet-Britse ter plekke wonende eigeraars waren eveneens veel innove-

90 Van Sijpesterin 18.54:96-147: Temstra 18.35, 180-1; Surmacms? Aimmak 38.44:67-111.

91 Koloniale Versiagen $1855-1861$.

92 Het pond ster'ing is hier gerekend tegen twaalf guiden. Drescher (1977:94) spreekt van 15-18 miliken pond. 
render dan hun absente collega's. Erg vreemó is dat niet. Een ondernemer die in eigen persoor. zijn onderneming leidt zal allicht meer oog hebben voor wat goed is voor het bedrijf (en daarin waarschijnlijk ook sneller beslissen) dan de eigenaar in een ander werelddeel die voornamelijk zit te wachter op zijn winstuitkering. Bovendien bleek de helft van de betrokken plantages in handen te zijr. van personen die tot de oude plantersfamilies behoorden en zich voorgoed in Suriname hadden gevestigd. ${ }^{93}$ Het maken van sneite wirsten om rijk naar Europa terug te keren kon hun driffveer daarom niet zijn, zodat langeire)-termijn-investeringen meer in de overweging werden betrokken. Daarnaast waren er kennelijk voor deze groep volibende mogelijkheden op de lokale kapitaalmark: om dergelijke investeringen te fiancierer: ( $z$ : $\mathrm{Coofd}$ stuk VII). Bovendien waren een aantal vark deze planters levens machiige admisistrateurs (C.J.A. Busch Reitz en T.J. Eyken Sluyters) die waarschijnlijk genoeg geld hadden verciend om de irnovaties uit eigen zak te sekostiger.

Absente eigenaars en in het bijzorder de negotiatiefor,dsen waren in het a.gemeen veel terug:houdender met innoveren. $Z$ :j bevonden zich ver van de plaats waar de produktie to: stanc krvam, interesseerden zich het meest voor lage kosten en hoge verkoopprijzen en waren, na de schuldencrisis van eind achttiende celw, bevreesd voor nieuwe investeringen. Bovendien liep in ret algeneen . Nederlank in die tijd bepaald niet vorop als het ging om technologische innovatie.9 Sterker nog, verhovdingsgewijs is de kolonie het moederland vooriit geweest. De Nederlandse rijverheid heeft pas laat de overstap gerraakt van wir.d-, water-en beestkracht naar stoom. In 1850 bestord slechts $10 \%$ van de industriële krachtoronnen wit stoom, daarna steeg het tot $80 \%$ in 1890 (Var. Lente 1990:6). In Suriname was daarentegen al $35 \%$ van de 189 plantages die in 1855 in bedrijt waren voorzien van stoumkracht (Kolonial Verslag 1855). Met name het geavanceerde karakter van de Surinaamse suikersector was voor het midden van de negentiende eeuw zerr on-Nederlands.

Een minderheid van de 'Surinaamse' planters is dus actief bezig geweest met innovatie, met a's voortrekkers ter plekke wonende en/ot Britse plantage-eigenaars. $Z_{\mathrm{ij}}$ concentreerden zich op innovatie in de suiker-en, in iets mindere mate, de katoensector. Het gevolg was dat de suikersector een steeds moderner aarizien kreeg (ouderwetse ondernemingen vielen af) en

93 Celbasierd op Van Sijpesteijn 1854:96-147. Onder deze pianters k:ınnen oude namen worden aangetroffen als D.B. de Nesquita, l. de la Parra, Sanches en J. Vogt.

44 Van Lente (1990:5-7) sclirijut dat in Nederland industry by and large remained a smallscale affair for most of the nineteenth century. During the 1820 s and 30 s some large mechanized factories were se: up in shipjuilding and sugar refining. After 1850 a few more large industrial firms made their appearance (textiles, paper making). But industrialization on a significant scale took place only after 1890 . Bovendict werden vrijwel alle innovaties van buiter Nederiand ingevord. 
lange tijd in de pas kon lopen met geavanceerde suikereconomieën in de rest van het Caraibisch gebied. Van de katoensector hield het meest moderne deel het het langst vol; van de koffiesector was in 1863 vrijwel niets meer over.

Dit hoofdstuk heeft daarom drie belangrijke conclusies opgeleverd: de tegengestelde ontwikkelingen in de drie sectoren van de Surinaamse plantage-conomie zijn in belangrijke mate bepaald door het verschill in 'type' planter, slaven vormden geen obstakel voor technologische verandering en innoveren bleek een levensnoodzaak. 
DEEL II

A.A. van Stipriaan - 978-90-04-25979-9 Downloaded from Brill.com@4/26/2023 03:31:44PM via free access 
A.A. van Stipriaan - 978-90-04-25979-9 Downloaded from Brill.com $\odot 4 / 26 / 2023$ 03:31:44PM via free access 


\section{HOOFDSTUK VII}

\section{Ontwikkeling van de kapitaalvoorziening}

De Surinaamse piantage-econom:e was incertijd in ontwikkeling gebracht in de hoop dat hef een jucraticve ondernemirg zou zijn. Het lijkt of daar niet $z o$ veel van terecht is gekomen, want in verschillende onderzoeken word! gewezer op cie sleckte financiële situatie waarin Surinazmse planters ai in he: tweede kwart van de achttiende eeuw zouden hebien verkeerd (Van de Voort 1973:86; Gos:inga 1985:328). Meestal wordt dan verwezen raa: de inleiding op het regotiatieplan van W.G. Deutz, waaxin ivordt gesproken van het 'geknackt credit', en op een memorie die zou dateren uit 1741. Daarin werden de bezittingen van de planters in Suriname geschat op 50 miljoen guiden, maar hun schu!den zouden nog boven dit bedrag uitkomen (Van de Voort 1973:254).

Dergelijke uitspraken en schattinger: zijn echter nooit met harde cijfers gestaafd en lijken op zijn minst overdreven. Het is een feit dat cie WIC, bij wie de planters to: omst:eeks:735 hun slaven op krediet kochten, rond :750 in een weinig gorissante finarciële positie verkeerde. Het slechte betalingsgedrag van de planters zal hieraan mede debet zijn geweest.: Toch komer de twee auteurs cie zich het meest met deze materie heboer. beziggehouden, J.P. van de Voort en Goslinga, met geen enkel kwantitatief bewijs waaruit inderdaad zou kunnen blijken dat planters in de periocie voúr 1750 het water tot aan de lippen stond.

Ilet valt enigszins bu:ter. het kader van dit orderzoek om uitgebreic op deze kwestie in te gaan, maar uitgaande van de situatie rond 1750 , moeten er toch enige kwantifatieve kantekeningen worden geplaatst bij de voorafgaande periode. In de eerste plaats dient te worden bedacht dat de WIC na 1740 de levering van slaven aan Surinaamse pianters geheel moest overlaten aan particuliere hardelaars. Verder is nergens in de plantagearchieven van na 1750 sprake van piantageschulden aan de WIC, dan wel van aflossingen of schuldsaneringen. Er kan daarom gevoeglijk van wo:der. uitgegaan, dat rond 1750 de planters niet (meer?) in het krijt stonden bij de WIC. Daarentegen had iedere planter een financiëe relatie met een koopman-bankier in Nederland, meestal in de vorm van een rekering-

1 Een aantal typerende voorbeclden van het siechte betaingsgecirag wordt beschreven in Poofdstuk VIIi, rone? 
courant. Deze persoon trad op als een soort commissionair voor de planter in Suriname en voorzag hem, in ruil voor de verkoop van plantageprodukten, van alle benodigdheden en kapitaal. Wanneer nu de financiële omstandigheden werkelijk zo hopeloos waren als men wil doen geloven, dan zouden de schulden per rekening-courant of hypotheek aan deze, voornamelijk Amsterdamse, kooplieden rond het midden van de achttiende eeuw tot dramatische hoogten moeten zijn gestegen. Enkele steekproeven onder planfages die rond 1755 nog nief in een negotiatieverband zaten en tenminste 20 jaar in bedrijf waren tonen echter aan dat het met die schulden nogal meeviel. Bij de koffieplantages bedroeg de gemiddelde schuld $f 32.000$, bij een gemiddelde taxatiewaarde van bijna $f 105.000$, voor de suikerondernemingen waren de cijfers $f 32.000$ en $f 129.000 .2$

Bij de ordste koffieplantages lag de gemicdelde schuld aan de kooplieden in Nederland nog onder een-derde van de geschatte waarde van de plantages en bij suikerplantages zelfs bereden een kwart. Noch de planters, noch de kooplieden zullen hier lang van wakker hebben gelegen. Integendecl, de kooplieden zullen deze situatie zelfs hebben gestimuleerd. Zolang de planters namelijk een schuld van befekenisvolle omvang bij hen hadden uitstaan, waren zij iccier jaa: verzekerd van de renfe-inkomsten hierover en tevens van de vaste aanvoer van plantageprodukten. Dit bracht enige stabiliteit en continuiteit in de relatie tussen kooplieden en planters. Dat moet de kooplieden niet onaangenaam zijn geweest, aargezien de planters anders iedere keer met een andere koopman in zee zouden kunnen gaan en hen tegen elkaar konden uitspeien. Dat dit niet denkbeeldig was blijkt bijvoorbeeld uit de veran:woorde rekeningen van de eigenaat van de plantages Vossenburg en Wayampibo. In de periode voor 1727 was er kennelijk een relatie met het handelshuis van $T h$. Passalaigue geweest, want in datzelfde en het daaropvoigende jaar wordt de schuld per rekeningcourant aan hem afbetaald. Tegeilikertijd wordt op dat moment eer relatie onderhouden met zowei het huis van $\mathrm{M}$. Broen \& $\mathrm{Zn}$. als met Van Nuys \& Meernout. ${ }^{3}$

Toch is het idee van het 'gekrackt credif' niet geheel uit de lucht gegrepen. Alleen was er niet zozeer spraixe van een achteruitgang in de kapitaalvoorziening, als wel van een tekort daarin door de plotseling vergrote vraag rond het midden van de jaren 1740. Dit was het gevolg van de veelbelovende toekomstmogelijkhedern die de koffieteelt leek te bieden, waardoor velen een nieuwe plantage wilden opzetten. Precies in die tijd kwam het fort Nieuw Amsterdam gereed aan de monding van de BenedenCommewijne, zodat nu ook langs deze rivier zonder geviar voor buiten- 
landse overvallers nieuwe ondernemingen konden worden aangelegd.4 Van die nieuwe mogelijkheid werd flink gebruik gemaakt, want in totaal werden in de jaren 1740 en 1750 in het Beneden-Commewijne- en Matapicagebied zo'n 150 koffieplantages aangelegd. Hierdoor nam de vraag naar Nederlands kapitaal aanzienlijk en vrjj plotseling toe.

De Nederlandse kooplieden hadden wel oren naar een forse uitbreiding van de: Surinamse plantage-economie. De voorheen prominente positie van Vederland als internationale stapelmarkf van tropische produkten werd namelijk steeds meer door het buitenland ondergraven (Van de Voort 1973:89-90). Vergroting van de aanvoer uit Suriname zou deze neerwaartse trend wellicht kunnen keren, of in ieder geval vertragen. Het hiervoor benodigde kapital en het risico waren echter te groot om aileen door de Hollandse koopman-bankiers te worden opgebracht.

Het toeval wilde echter dat onder Nederlandse beleggers na 1750 veel kapitaal vrijkwam als gevolg van omvangrijke schuldaflossingen door de overheid en beperkle binnenlandse beleggirlgsinogelijkheden (Fritschy 1988: 42-3). Ilet viel de kooplieden dan ook nict moeilijk om deze beleggers over te halen lum geld te steken in zogenaamde negotiaticfondsen, waarmee onder meer de litbreiding van de Surinaamse plantage-economie werd gefinancierd. I-Iet functioneren van deze negiotiatiefondsen zou bepalend blijken te zijn voor de ontwikkelingen in de Surinamse plantage-economie gedurende de tweede helft van de achttiende eeur.

\section{Plantagpkredipt na 17.50}

Een negotiatie was in wezen niets anders dan een beleggingsfonds. Het initiatief tot oprichting kwam van een koopman-bankier, die daartoe een 'plan van regotiatie' opsteide. Hierin stond vermeid hoe groot het fonds zou worder, hoeveel rente er werd betaald (reestal 5 a $6 \%$ ) en werden verdere bepalingen opyesomd. Zo'n fords werd volgestort door beleggers, die daarvoor zogenaamde obligaties ter grootte van $f 1000$ onivingen. Fvenals bij staatsobligaties werd hierop jarlijks rente uithetaald en verden rij ла verloop van tijd afgelost door uitloting. Het fonds werd beheerd door de koopman-bankier die daartoe door de beleggers werd benoemd als directeur. Daarnaast werden uit het midden van de ooligatiehouders enke!e commissarissen gekozen, die een a twee keer per jaar bijeenkwamen om na te gaan of de directeur hun belangen goed behartigde.

Ve koopman op zijr: beurt steide het in het fonds gestorte kapitaal ter

4 Dat hieryan ook gretig, gebruik werd gemaakt blijkt wit een stcekproef onder 12 plantages langs de Beneden-Conmewijnc, die allemaal tussen 1744 en ?/SC hun warrant ontvingen (Dienst der Desneinen Surinime). 
beschikking aan Surinaamse planters voor plantage-investeringen. ${ }^{5}$ De geïnteresseerde planter liet hierop zijn plantage taxeren en mocht clan bij het fonds geld opnemen tot een maximum van (meestal) vijf-achtste van de getaxeerde waarde. De planter verplichtte zich vanaf dat tijistip voortaan al zijn produkten alleen naar deze koopman te sturen, iecer jaar de vastgestelde 5 of $6 \%$ rente le betalen en (meestal) van het tiende jaar af te beginnen met een jaarlijkse aflossing van $10 \%$ van het geleende kapitaal. De plantage gold als onderpand voor de lening - het was dus eigenlijk een soort hypotheek - en de planter moest daarom aantonen dat er geen anciere hypotheken op de plantage rustten. Bestaande ieningen werden daarom aitijd met de negotiatielening afgekocht.

Het voordeel voor de koopman-fondsdirecteur was dat hij over alle handelingen die hij voor de planter verrichtte een bepaalde provisie mocht vragen. Zo verzorgde hij de assurantie van het transport over zee (provisie $0,5 \%)$, verkoop van de produkten $(2 \%)$ en aanschaf van alle plantagebenudigdheden (ungeveer 1\%). Niet zelden vord alle transpor: ook nog met zijn eigen schepen plaats.

Op het eerste gezicht leex dit negotiatiesysteem zeer werkbaar en redelijk waterdjcht. Bij nacere beschouwing, maar daar kwam men pas later achter, zaten er echter twee zwakke plekken in de overeenkomst. De eerste was de koppeling van het hypothecair kredjet aan de geschatte warde van de plantage, die voor het grootste gedeelte werd bepaald door se produictiefactoren. Waarschijnilijk is men er van uitgegaan dat de waarde van de produktiefactoren een garantie was voor het produxtieniveau, maar men verga: dat niets zo wisselvallig is als de oogst en het prijspeil van tropische plantageprodukten. Het was echter de produktie-opbrengst waaruit rente en aflossing van de lening moesten worder betaald. Bovendien kon een pianter telkens oprieuw zijn plantage later taxerer. en bij een hoger uitgevallen schatting - wat meestal het geval bieek te zijn een groter krediet tol de nieuwe vijf-achtste waarde bedingen. Dit werkte corruptie van planters en taxateurs, vaak coliega-planters, in de hand.

De tweede zwakke plek in het systeem was de koopman, die als een spin

5 Dit betekent riet dat er alleen voor Stirinaamse planters negotiaticfondsen werden opgericht. (ook voor andere Caraibische plantagekoluniën kwamen dergelijke fondsen in Nederland tot stand (vcoral voor Berbics, Grmada, Tóbaģo er de Deense Caraiben) evenals voor ardersoortige buitenlandse ondernemingen (zie Van de Voort 1973:269-323). Orrdat dezc echter buiten het bestek van dit onderzoek vallen, wordt de beschrijving hier beperkt tot de 'Surinaanse' negotiatiefondsen. Ter vergelijking: volgens een 'Nota van diverse buyter:landsche Negotiatiën uit ongeveer :775, was er op dat momen! in de Republiek ruim 142 miljoen gulden genegotiëerd, waarvan ongeveer $40 \%$ voor het Caraibische gebied (CAA: PA$600,1266)$. In de beginperiode van de plantagenegotiaties wisten de bejegyers niet in welke plantages het fonds investeerde; iater was dat we: het geval (Van der Meulen 1904:516). Ook wachtte een fondscirccteur niet altijd tot de negotiatie was voltekend, maa: verstrekte soms op voorhand a! en hypotheck (zie bijvoorbeeld Oostindise 1989:357). 
in zijn web zat zonder zelf veel risico te lopen. Hij investeerde het geld van anderen en had er in feite weinig belang bij dat de schuld van de planter ooit zou worden afgelost. Hij zou dan namelijk zijn klandizie en daarmee

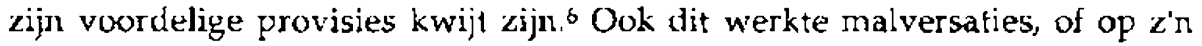
minst verwaar lozing van de belangen der obligatichouders, in de hand.

Men had gewaarschuwd kunnen zijn, want de cerste de beste negotiatie die werd uitgegeven (1753) verkeerde na vier jaar al in een deplorabele toestand. Dit was de negotiatie onder directie van W.G. De1stz, die begonnen was met een kapitaal van éér miljoen gulder. Zowel van planters-als van beleggerszijde bestond echter zoveel belangstelling voor de negotiatie, dat deze in korle tijd uitdijde tot een totaal van $f 3.756 .000$ aan uitgegeven obligaties, met 89 plantages als onderpand (Van de Voort 1973:95). Bij de dood van Deuk in $175 \%$ bleek hij echter boven dit genegotieerde bedrag nog eens bijna $f 9100.000$ aan de planters te hebben geleend zonder daarvoor obligaties te hebben uilgegeven en zonder dat daar nieuwe onderpanden tegenover stonden. In dit geval was de fondsdirecteur overigens te goeder trouw, want waarschijnlijk bestond het niet genegotieerde bedrag wit de achterstallige rentebetalingen van plariters die Deutz :it eigen beurs aan de obligatiehouciers had uitbetaald om het fonds geen slechte naam te bezorgen (Van de Voort 1973:96), Vandaar dar verschillende koopliecien het niet lang na Deutz toch aandurfden ook met een negotiatiefonds voor Surinaamse planters te komen, zij het op kleincre schaal.

Intussen was de directie van het conds-Deutz overgegaan op de gebroeders Jan cr Theodoor van Marselis die de vordering van $f 900.000$ op de planters overnamer voor $f 400.000$. 7i: namen de zaken streng ter hand en weigerden de planters nog langer wissels op hun naam te iaten trekken a's daar geen harde garanties tegenover stonden. Zo niet, dan werden de wissels niet geaccepteerd en moesten de planters 25\% 'profestwisse!' betaien. Bovendien moesten in 1763 de plantages in deze negotiatie beginnen met het aflossen van kapitad. Vele pianters bleven ook daamee in gebreke, zodal de gebroeders Van Marselis er toe overgingen plantages te laten verkopen of onder secquestratie (gerechtel:jke beslaglegging) te steller. Toen tensotte, evencens in 1763, de. Amsterdamse beurs een crisis kreeg te verwerken, leek het verschijnsel negotiatiefonds, a'thans wat betreft de Surinaamse planters, een voortjjcige dood te sterven.

Het tegendeel bleek echter het geval: van 1765 tot 1775 kwam een ware hausse aan negotiaties op gang die alleen al voor Surinaamse planters bijna 30 miljoen aan beleggirgskapitaal wisten aan te trekken. Kennelijk brandde

6 Dit betekent niet dat de koopmar-bankicr geen enkel risico liep. Soms nam hij zelf ern flink aantal obligaties af, of hij decd (tL) grote yoorschotten aan de planter zonoer dat deze

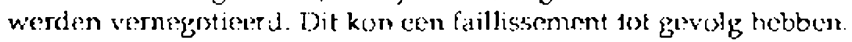




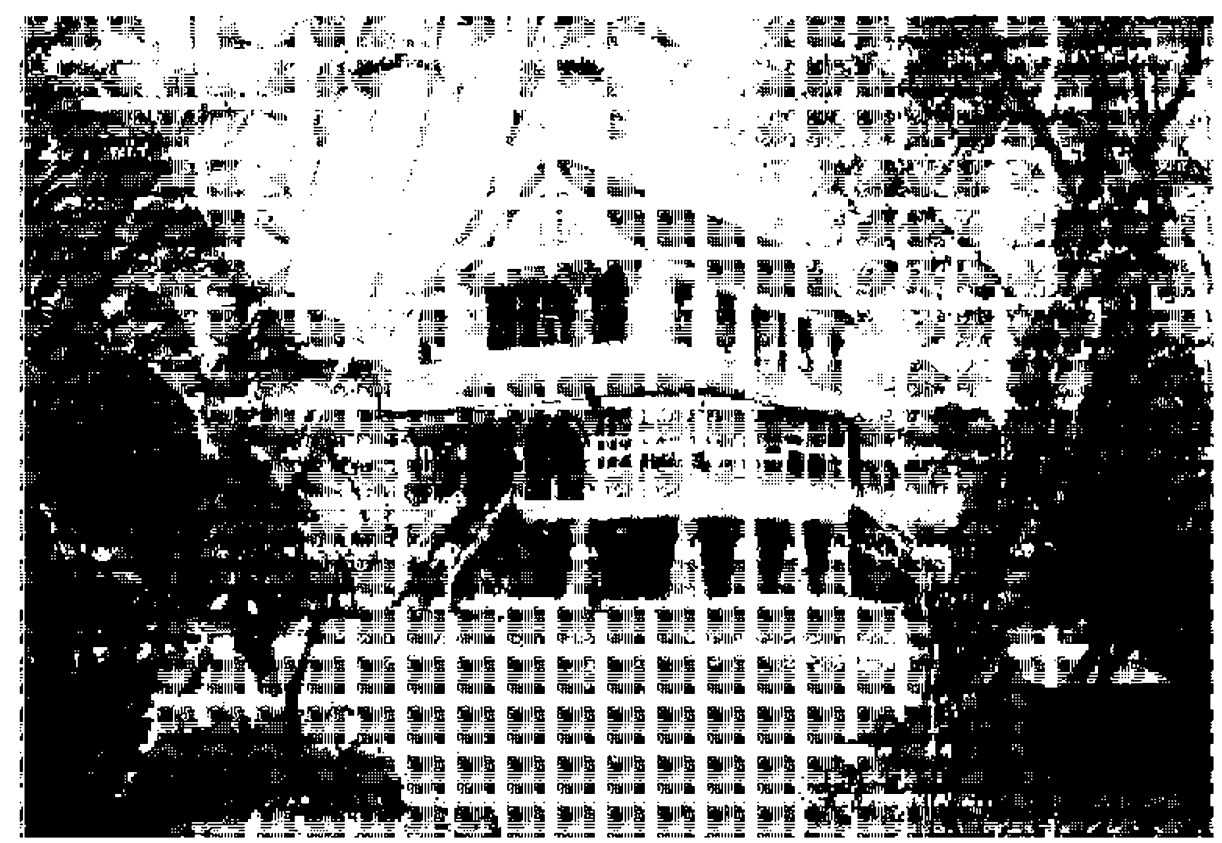

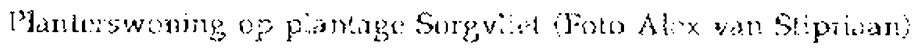


het overvloedige kapitaal de Hollandse belegger in de zak en leken, ondanks de slechte ervaringen met het Deutz-fonds, de Surinaamse piantages toch. een aantrekkelijke belegging. Daar dient overigens wel bij te worden aangetekend dat het achttiende-eeuwse beleggingsklimaat er niet een was var. 'safe and sound investments', maar een sterk speculatief karakter vertoonde. De Amsterdamse beurs uit die tijd is dan ook wel eens omschreven als de meest geavanceerde sperulatiemarkt ter wereld 'on which much airy wealth had heen made and lost' (Wilson :966:195).

Twee vooraanstaande Surinamse planters, tevens agendarissen (vertegenwoordigers) voor regotiaties, Graafland en Gootenaar, schreven in 1778 een memorie over de negotiatiehausse die zij zelf in de kolonje hadden meegemaakt. Deze werd volgens hen gekenmerkt door het volkomen ontbreken var. enige terughoudendheid bij de geidschieters.? De fondsdirecteuren konden zo gemakkelijk beleggingskapitaal aantrekken, dat er nauwelijks werd toegezien op welke plankages en aan wie krediet werd verlecrd en of de bepaingen van de negotiatic wel wercien nageleefd. Door het gemakkelijke krediet leek het alsof het de Surinamse plantageeconomie voor de wind ging. Dit gai de eennaa: in gang gezette ontwikkeling een zelfversterkend effect, zociat nog veel meer negotiaties werder. afgesloten. ledere koopman wide wel een negotiatiefonds opzetten, 'door baadtsugt verlukt' en on de veeibelovende winsten niet aan de concurrentie te laten.

De agendarissen in Suriname werden daardoor steeds meer onder druk gezet door de fondsdirectenren toch vooral met nog niet vernegotiererde piantages te komen, 'sommige sig bexlaagende dat men hun niet spoedig genoeg aan hypotheecquen hielp'. Het gevolg was dat op een gegeven moment het krediet de planters bijna moest worden opgecirongen. Wie wilde hoefde maar een kik te geve: om krediet te krijgen voor het starten van een rieuwe plantage, waardoor 'eyndelijk de geringste ja ambachts lieden in planters gemetamo:phoseerd wierden'. Zo verscheen ir die jaren 1760 een geheel nieuwe groep planters ten tonele, zorder een cent eigen kapitaal en zonder enige kennis van zaken.

Door dit alles veranderde de Surinaamse piantagekolorie in korte tijd drastisch van aanzien. De nieuw aangelegde piantages legden zich zorder uitzondering toe op de verbouw van koffie, het produkt van de toekomst. Alle aandacht ging naar deze nieuwe branche die in korte tijd de suikersector volkomen overvleugelde. Gebouwen in de kolonie, met uitzondering van de slavenwoningen, werden zeer lixueus opgezet of verfraaid als loonbeeld van de nieuwe rijkdom. Volgerıs zeggen kenden 
deze hun weerga in het Caraibisch Gebied nipt. ${ }^{8}$ In diezeifde periode bereikte ook de slavenaanvoer - en daarmee het inwonertal van de kolonie - een. absoluut hoogtepunt. De keerzijde van de medaille was natuurlijk dat ook de schulden van de plar.tage-economie drastisch vermeerderden.

Tot de komst van de negotiaties was gemiddeld $f 32.000$ kennelijk de limiet tot waar een plarter bij de Hollandse koopman-bankier in het krijk kon staan. Van het moment af dal de koopman-bankier niet meer zelf het krediet behoefde op te brengen, maar daarvoor het spaargeld van anderen kon gebruiken, had hij er klaarblijkelijk geen enkele moeite meer mee dat planters veel dieper in het rood gingen staan. Zo biijkt de gemiddelde schuld van vernegotieerde suikerplantages in korte tijd (1755-1770) meer dan verdrie- en van koffieplantages zelfs bijna vervi;fvoudigd te zijn. ${ }^{9}$ Alle tot dan toe betrachte voorzichigheid bij de kredietverlening verdween als sneeuw voor de zon in het licht van het geweldige kapitaaloverschot in Nederland en de hooggespannen verwachtingen ten aanzien van de koffiecultuur in Suriname. Vergeten waren de weinig positieve ervaringen met de negotiatie-Deulz. Iedere pianter die zi;n verhypothekeerde plantage opnieuw en hoger liet taxeres kon onveranderlijk rekenen op een navenante stijging van zijn krediet. I Iet is begrijpeli; $k$ dat de planters niet aarzelden hun plantages meercere malen te laten taxeren.

Fen duidelijk voorbeeld hiervan is plantage Bieyenhoop aan de Cottica, waar al sinds eind jaren 1730 koffie werd geteeid. Haiverwege de jaren 1750 rustte op deze plantage eer. hypothecaire ening van $f 20.000$ bij he: handelshuis van de weduwe $\mathrm{L}$. Thijm. De waade van de oncerneming werd geschat op $f$ 107.77:.10 Tussen 1765 en 1773 sloot de toermalige eigenaar Loseken eerst een negotiatielening af bij het fonds van Hardenhoorn en wat later bij Hermael \& Van den Bosch. In die periode werd de piantage viermaal getaxeerd, waarbij de waarde steeg van $f 135.193$ in 1765 tot $f 303.308$ in $1773 .:$ Deze spectacuaaire waardevermeerdering in iets meer

8 Volgens een onbekend schrijver uit die tijd, die mijns inziens niemand anders dan Couverneur Nepveu kan zijn geweest, was het duidelijx 'ciat de planters doorgants in pragt er. weejde den een boven den anderen willen uytsteeken, (zo)dat de praģt en de kostelijkheid en overvloed van Geboliwen nergens in de West Indien de weerga heeft' (geciteerd in De Beet 1984:84). Overigens heeft Nepves zeif zich wat dal betreft ook nict onteiluigd gelaten, want Kunitz. (1805:53) schrijft over diens huis (waarschijnlijk aan de waterkant) te Paramaribo: '(Es) ist eins cer schonsten breternen Hauser in der Colonic. Der verstorbene Golverneur J. Nepveu hat es von Grund aus neu aufbauen lassen, und nocin mit 2 Seilenflugeln vermehrl. Es soll uber 100.000 fl. gevostet haben'. Ook Nassy (179:139) schrijt dat het overvloedige krediet werd gebruikt ors de kolonie 'uitwendig te versieren' en. dat de planters 'op hunne plantagien, zo in nood elooze gebcuwen, als in prachtige tiinen, de besten van gansch Amerika te bryen gaande, sene muitenspoorige werlde aan den dag leiden'.

9 Steekproef GAA: NA.

10 GAA: NA, 10272; ARA: SONA, 692.

11 ARA: SONA, 222 en 700 . 
dan zeven jaar was voor een deel het resultaat van de forse uitbreiding van de produktiefactoren. Veel meer nog was dit echter het gevolg van een algehele, speculatieve opwaardering, misschien eerder zelfs nog van corruptie van de zijde der taxateurs, al valt dit laatste nooit te bewijzen. Zo steeg de gemiddelde warde van een slaaf met $50 \%$, terwijl een niet onaanzienlijk deel van hen nog nauwelijks aan de plantage-arbeid gewend was en de koopprijzen gelijk waren gebleven. De gemiddelde waarde van een koffie-akker steeg met $59 \%$, ondarks het feit dat in 1773 bijna de helft van de bomen nog te jong was om al volwaardig vrucht te dragen. Fn tenslotte bleek de waarde per akker generale grond zelfs gestegen te zijn met $173 \%$, zonder dat daartoe enige aanleiding was. Het ljjdt dan ook geen twijfel dat deze prijsopdrijving bedoeld was ter verkrijging van meer kredief.

Deze opzet slaagde inderdaad, want ce negotiatielening steeg van $f 75.000$ naar $f$ 195.000.12 Met dit geld is waarschijnlijk de oude hypotheek afbetaald ( $f$ 20.000), zijn er rieuwe gebouwen neergezet (maximaal $f 40.000$ ) en werden slaven aangekocht (maximaal 86 slaven voor $f 22.360$ ). $\therefore$ Wat met het resterende kapitaal van meer dan een ton is gebeurd blijf een raadsel. Gezien de vele berichten wit die tijd over hot leefklimat, lijki het echter verre van uitgesloten dat dit is opgegan aan conspicuous consumption'.14

Overigens had in deze periode op Bleyenhoop ook het koffie-areal een forse uitbreidirg ondergaan, van 41 naar bijna 70 ha. Toch was de hiermee gerealiseerde produktie bij lange na niet voldoende om aan de rente- en a!lossingsverplichtingen te kunnen voldoen. Het gevolg was dat de totale schuld in 1778 al opgelopen was tot $f 280.318$. Hoe desast:eus de situatie was geworden blijkt uit het feit dat in hetzelfde jaar de inkomsten uit koffie $f 9.496$ bedroegen, de uitgaven voor de plantage $f 6.798$ en de rente van de schuld $f 16.819 .35$ Ioe het de plantage verder is vergan is nies bekend. Meestal werd in zo'r geval een onderneming of door het negotiatiefonds ingekochi voor de som van de schuld, of hij werd pubiek verkocht, bijna altijd voor en fractic var de laalst getaxererde wareic.

De ontwikkelingen rond Bleyerhoop vormden geen uitzondering in die jaren, maar zijn eerder kenmerkend von deze perinde waarin in korte tijd de plantages flink werden opgewaardeerd: van gemiddeld $f 183.187$ tot

\section{Van de Vonst 1973:289; EHB: KA-8.}

13 Het kapitaal voor de gebouwen is gebaseerd op de stijging in hun getaxeerde waarde. Het kapitaal voor de slavenaaskupen is gebaseerd op hun gestegen aantal met daarin verdis. mnteerd een jaarlijks steríe-overschnt van $4 \%$, vermenigvild igd met de gemiddelde koopprijs van $f$ 260,- (zie Tabel 18).

14 Jiet luxe-leven van veel planters wordt inisschien hot best geillustreerd door P. van Akeren, rigenaar van Dordrecht, die zich regelmatig van zijn plantage naar de stad liet vervoeren onder begeleiding van 'walthoorens on Clarinetten op de tentboot' (GAR: CollectieHudig, 7).

15 EHB: KA-8. 
$f 311.607$ in het geval van koffieplantages en van $f 185.119$ tot $f 277.099$ bij suikerplantages. ${ }^{16}$ Bovendien blijkt de waardestijging in de koffiesector duidelijk groter te zijn geweest dan bij suiker. Hoe speculatief de opwaardering was blijkt uit de grote waardestijging van de onbewerkte grond. Eerder bleek al dat na de jaren 1770 deze taxatieprijs weer fors daalde, terwijl grond nog even schaars was als voorheen (Tabel 20).

Als gevolg van de taxatiestijgingen waren ook de plantageschulden tot dramatische hoogten opgelopen. Rentebetaling over dergelijke bedragen vormde een veelvoud van de jaarlijkse opbrengsten. Kapitaalaflossing was voor de meeste planters riet meer dan een droom, voor de obligatiehouder was het achterwege blijven daarvan een nachtmerrie.

Opnieuw zijn de verschillen tussen de koffie- en suikersector opvallend. Op suikerplantages waren de taxaties relatief minder hoog opgedreven, zodat ook de schild relatief minder snel groeide. ${ }^{17}$ Een enkele onderneming lukte het zelfs zo nu en dan iefs van het geleende kapitaal af te lossen. Kennelijk had men het in deze sector wat voorzichtiger aangepakt en liepen schuld en rentabiliteit iets mincer ver uiteen dan op koffieplantages. Dit lijkt overigens te worden weersproken door de hoogte van de negotiatieleningen van beide ondernemingen. Bij suikerplantages bedroeg het laatst genegotieerde bedrag inderdaad vijf-achtste van de laatste taxatie, terwijl dat bij koffie siechts iets meer dan de helft was. ${ }^{15}$ Dit had echter nieis te maken met een meer terughoudend beleid van koffieplanters, maar was een gevolg van de snelle schuidstigging boven de vijf-achtste waarde. Dit roopte de koffieplanters er toc met nog veel hogere taxaties te komen; nief zozeer om een hogere negotiatielening af te siuiten, als wel om het vertrouwen in de solvabiliteit van het onderpand te bestendigen. Hoezeer deze taxaties op lucht waren gebouwd werd duidelijk op het tijdstip dat plantages moesten worden verkocht. Van 15 koffieplantages bleek de gemiddelde koopprijs slechts $37 \%$ te bedragen van de gemiddelde leatste taxatie. ${ }^{19}$ Helaas antbreken vergelijkende cijfers voor suikerondernemingen.

Bij dit alles dient wel te worden bedacht dat de totale schuld niet mag worden gelijkgesteld aan het totaai geinvesteerde kapitaal. Een groot deel van de schuld boven het genegoticerde bedrag bestond uit achterstalige interest en kan dus niet als investering worden beschouwd. Waar precies de grens lag tussen geleend kapitaal en renteschuld is echter met geen mogelijkheid vast te stellen.

Een opvallend onderscheic tussen de koffie- en de suikersector vormde ook de verdeling van de kapitalstroom per sector. Van de 3:3 plantages

16: Steckproxef GAA: NA en plantage-archicven.

17 Steekproef GAA: $N$ A en plantage-archieven.

18 Steekproef GAA: NA en plantage-archieven

19 Steekprof GAA: NAA en plantage-archieven. 
waarvan het zeker is dat $z i j$ bij een negotiatie waren betrokken of via andere kanalen een hypothecaire lening hebben ontvargen, bleek slechts $20 \%$ suiker te verbouwen en $80 \%$ koffie. De werkelijke verdeling rond 1775 was echter $30 \%$ suikerpiantages en $70 \%$ koffie, zodat de koffiesector oververtegenwoordigd was bij de geldschieters. Daar staat tegenover dat suikerplantages grotere bedragen ontvingen. Lit de bekende negotiatiebedragen blijken verhypothekeerde suikerplantages gemiddeld bijna $f 125.000$ te hrbben ontvangen, tegen bijna $f 90.060$ per koffieplantage. Warneer dit echter wordt omgeslagen over de gehele sector, dar resteert gemiddeld per koffieplantage ruim $f 77.000$ en pe: stikerplantage nog geen $f 65.000 .20$ Natuurlijk moet daar wel aan worden toegevoegd dat de koffiesector nog in ontwikkeling was en dus meer startkapitaa: kon gebruiken, maar daar staat tegenover dat de suikersector inderijd was opgebouwd zonder een dergelijke overvloed aan kapilaal. Boverdion werder: mel de negotiatieleningen ook schulden uit het verleden afgedaan. I Io he: ook zij, het is duidelijk dat de suikersector als geheel minder bezwarad an de negentiende eeuw kon beginnen dan de knffiesector.

\section{Het falende negotiatiosysteem}

Wanneer in de literatuur wordt gesproken over de teloorgang van de Surinaamse plantage-economie gedurende het laaste kwart van de achttiende eetw wordt vrijwei aitijd nen prominente plaats ingeruimd voor de Amsterdamse beurscrisis van 1773. Mede door deze crisis zou de krediefkraan zijn dichtgedraaid en het vertrouwen in de solvabilifeit van de plantages strurtureel zijn geschokt. Het ligt voor de hand dat de obligatiehouders in Nederland door de crisis danig werden opgeschrikt, maar of dit de oorzaak is geweest van de desastreuze financiële situatie waarin zich een groot deel van de plantages aan het eind van de eeuw bevond, is twijfelachtig.

Bij rader oncierzoek van ce negotiatiefordsen worden de darwijzingen steeds sterker dat de beurscrisis van 1773 als cesuur in de kredietverlening minder vanzelfsprckerd is dan altijd werd aangenomer. Het was nameljk niet de eerste crisis die de $\Lambda$ msterdamse beurs teisterde, ook in 176.3 was var een beurscrisis sprake gewcest. Niettemin vond juist in de jaren daarna de grote 'boom' in negotiatiefondsen p'aats. In de tweede plaats werd in 1771 dus ruim voor de crisis - een opmerkelijke uitspraak genoteerd door agendaris Adriaan Gootenaar, die sprak van het 'manquement van 't Crediet alhier, hetgeen alstoen gantsch was gedaald' (Hucig 1922:36). In de derde plaats bleken de verontruste obligatiehouders pas in de tweede helft van de

20 In werkelijkheid zullen de genegotieerde bedragen hoger zijn geweest dan de hier genoemde gemiddelden, omdat lang niet altijd het hoogst genegolieerde beclrag bekerd is. 
Figuur 8. Plantagehypotheken Suriname 1753-1792

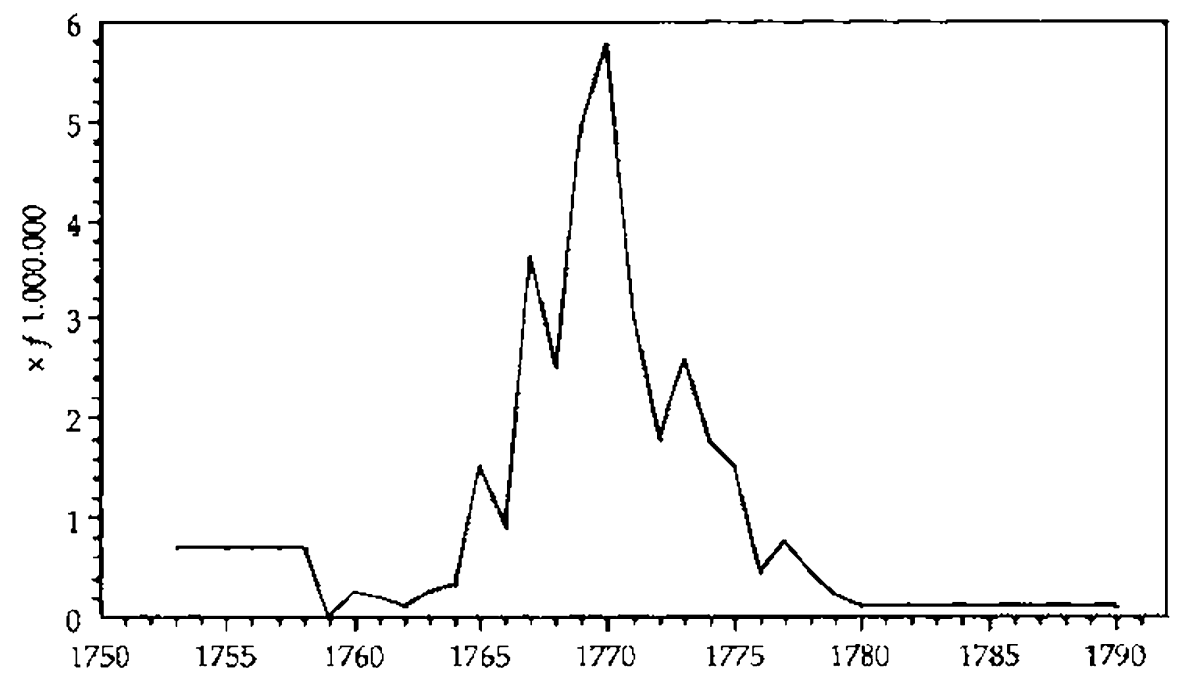

jaren zeventig stappen te ondernemen tegen de beheerders van hun belegd vermogen, in casu de fondsdirecteuren. Fn tot slot bleken ook in 1774 en 1775 nog voor enke'e tientallen Surinaamse plantages hypothecaire kredieten te zijn afgegeven. Kortom, reden geroeg wat dieper op de financiële gebeurtenissen in de jaren zestig en zeventjg in te gaan.

Begin jaren 1760 blijkt het hypothecaire plantagekrediet nog niet erg groot te zijn (Figurur 8). Gemiddeld vloeide een kwart miljoen gulden per jaar naar Suriname waarvoor circa zes plantages een hypotheek kreger. $\mathrm{Na} 1764$ expandcerde de kapitaalstroom spectaculair en bereikte een absoluut hoogtepunt in 1770 , toen 5,8 miljoen guiden zijn weg vond raar Surinaamse plantages. In die tussenliggende jaren was voor zo'n 200 plantages een hypotheek afgesloten. In 1771 halveerde de kapitaalstroom plotsklaps en in $1772 \mathrm{kromp}$ hij rog eens met twee-vijfde in. In die twee jaar werden slecht 24 plantages verhypothekeerd.

Begin 1773 bereikte de crisis op de Amsterdamse beurs haar hoogtepunt. Op de kredietverlening bleek dit echter geen invloed te hebben, want die groeide weer met twee-vijfde en voor ongeveer 25 plantages werd een hypotheek afgesloter. In 1774 en 1775 verminderde de kapitalstroum weliswaar opnieuw, maar kwam daarmee niet of nauwelijks onder het niveau van bijvoorbeeld 1772 of 1765 . Dit kapitaal werd onder meer gebruikt voor nieuwe hypotheken op zeker 33 plantages. Pas sinds 1776 , dat is drie tot vicr jaar na de crisis die eind 1772 begon, droogde de kapitaalstroom plotsklaps op tot niet meer dan ecn-viffde van het niveald in 1775 . Gedurende de rest 
van de achttiende eeuw vloeide daarna druppelsgewijs bij elkaar nog zo'r 2,5 miljoen gulden aan hypothecair krediet naar de piantages. Dit stons echter in geen enkele verhouding tot de periode voo: I7\%6 toen dergelijke bedragen in minder dan een jaar tijd werden overgemaakt.

Waar hef hier om gaal is ciat het tijustip warop deze dramatische ommekeer plaals vond, doet vermoeden dat het niet de beurscrisis is geweest die daaraar debet was. Tussen 1765 en 1770 werden de meeste piartagehypotheken afgesloten: zcker 17,5 miljoen guiden voo: minstens 200 plantages. Daarnaast werden nog zeker 26 hypotheken opgehoogd voor minimaal 1,8 miljoer. gulden.21 Dit betrof in hoofdzaak, minstens $85 \%$, koffie-ondernemingen. Ir. vrijwel al ceze hypotheker. was de bepaling opgenomen dat gedurende de eerste periode, variërend van 8 to: 10 jaar, alleen rente hoefde te worden betaid. Daarna moest ook het geleende kapitaal worden ágelust, meesta in porties van $: 0 \%$ jaarlijks. D:t betekende dat deze plantages tussen 1773 en 1780 moesten beximuen met het aflossem var hun schuld en dat ir. 1790 de hypotheken geinesl cienden te zijr afge'ost. De voortdurend stijgende knffieprijs tussen $: 764$ en 1770 \{zie Bijiage 2) leek hiertoe een solide basis te vormer. Hier:n ixwam ech.ter verandering toen de prijs van de koffie dramatisch begon te dalen van 110 cent per kilo in 1771 iot 56 cen: ir. 1775 en ook is. de jaren 1776 en $17 \% 7$ niet neer boven de 60 cent ujtikwam. Hier stond slecrts een liçite produktiestijging van circa $: 3 \%$ tegemover (zie Bijlagen 1 en 2).

Nu begon de hoogte van de schuldsom, als gevolg van de veel te hoge taxaties, een rol te spelen. In hoevere de beleggers op de hoogt: zijn geweest van de specuatieve opwarderingen on fraudes met taxacies blijft de vraag. De Hollandse fondsdirectelren moeten dit wel hebben geweten. Zo werden al in 1764, naar aanleiding var de uit de hand gelopen negotiatie-Deutz, verscherpte instructies voor de priseurs (taxateurs) uitgevaardigd en moest iedere taxatie worden voorgelegd aan bet Hof van Politie als gevolg van 'gepleegde kunstenarien in het priseren' (Wolbers 1861:261). Toch schreef in 1766 de planter W. Kemieùy aan de Kotterdamse koopman F.W. lludig al weer over de 'opgesmrukte prisatien' in verband met de negotiatie-Var! de Poll, waarbjj zo'ri 20 plantages werden verhypolhekeerd (J. I Iudig 1922:36). Dit bleek slecints het begin te zijn, wart enige jaren daarna werd bekend dat omgekochte priseurs plartages op cirje- tot viermaal hun werkelijixe waarde

2: Van de Vuurt 1973:bijlage XXVIl; CAA: NA. Overigens dient aan alle hier genoendie genegotieerde kap̧italen geen absolute waarde te worden gehecht, want niet alle bedragen en regotiatics z:jin bekend. Anderzijds zijn in de hier genoemde bedragen crikelc dubbeltellingen verwerkt, zodat hiermee de afwijking enigszins is bijgesteld. De werkelijke bedragen zullen nooit minde: gewees! z:jn dan de hier genoemde en waarschijnlijk ten hoogste $10 \%$ meer. (Z:e. cok Van de Voort 1973:182-4.) Dit verklaert tevens het veelvuldig gebruik van termen ais 'minstens' car 'zekrer', voors!gaand aan a:le genoemcle getailen. 
hadden getaxeerd. Ook bleken verhypothekeerde plantages meerdere malen als onbelast te zijn verkocht. Het Hof van Politie vaardigde verschillende plakkaten uit tegen deze praktijken en in 1771 en 1773 werden zelís frauduleuze priseurs gestraft (Wolbers 1861:303-4).

Daarnaast bleken ook niet alle agencarissen betrouwbare vertegenwoordigers van hun Hollandse opdrachtgevers te zijn, zoals ene La Croix, bij wie niemand tevergeefs aanklopte voor het trekken van wissels op zijn baas. De Nederlandse koopman-bankiers in Nederland moeten van deze kwalijke praktijken op de hongte zijn geweest. Dat blijkt onder meer uit het Journaal van Gouverneur Nepveu (1770-1779), die vermeldde dat in 1770-1771 drietot viermaal zoveel wissels onder protest, dat is niet gehonoreerd en vermeerderd met een boete van 25\%, naar Suriname waren geretourneerd als voorheen (Wolbers 186::305). Dit verhinderde de Hollandse kooplieden echter niet om tussen 1771 en 1775 nog eens ruim 10,6 miljoen gulden aan hypotheken te verstrekken. Hieruit blijkt opnieuw dat het ook deze kooplieden alleen om hun eigen beiang te doen was, want de wissels werden op hen prive getrokken, terwijl de hypotheken voortkwamen uit de beleggingen van derden, de obligatiehouders in de negoliatiefondsen.

Ook wat betreft de negotiaties die I follandse knoplieden voor andere Caraibische plantagegebieden oprichtten blijkt 1773 niet het wezen:ijke keerpunt in de kredietverstrekking te zijn geweest. Tussen :766 en 1772 werd door beleggers in Nederiand zeker 22,5 miljoen gulden in dergelijke fondsen vastgezet (gemiddeld 3,2 miljoen per jaar). In de jaren 1773-1776 wisten de kooplieden toch ook nog 7,6 miljoen voor deze fondsen aan te trekken (gemiddeld 1,9 miljoen per jaar). Daarna droogde ook hier de kapitaalstroom plo:sklaps op (zie Van de Voort 1973:268-323).

Wanneer aile Westindische negotiatiefondsen in Nederland worden samengenomen, dan blijkt in de periode $1765-1772$ gemiddeld zeker 5,8 miljoen gulden per jaar te zijn uitgezet en in de periode $1773-1776 \mathrm{r}$ :im 3,4 miljoen. Fen opmerkelijke daling, dat wel, maar niet te vergelijken met het jaarlijks gemiddelde van de periode 1777-1780, dat niet eens 0,5 miljoen bedroeg. De crisis in Amsterdam van 1772-1773 leidie kennelijk wel tot een grotere terughouciendheid in het beleggen in Westindische obligaties, maar de werkelijke crisis in de krecietverlening sloeg pas aan het eind van de jaren 1770 toe. Dit lijkt veeieer te wijten aan de structuur van de kredietverlening zelf dar. aan een conjuncturele be'xrscrisis.

Het wekt daarom verbazing dat Van de Voort (1973:199), de kenner bij uitstek van deze problematiek, stelt dat het fiasco van de Westindische negotiaties niet zo snel aan de dag zou zijn getreden en veel minder diep zou hebben ingegrepen als de beurscrisis er riet was geweest. Het omgekeercie lijkt waarschijnlijker: als de crisis eerder had toegeslagen dan was veel onheil voorkomen en het fiasco minder groot geweest. In 1773 was het 
kwaad al geschied en bovendien al zo lang ingeburgerd dat ook in de jaren daarna nog op vaijwel dezelfde voet kon worden doorgegaan. Pas toen de obligatiehouders in Necieriand eind jaren 1770 in de gaten kregen dat zi; hun belegde kapitaal waarschijnlijk nooit meer zouden terugzien, sioeg de vlam in de pan en droogde de kapitaalstroom abrupl op.

Toen het eenmaal te laat was, wis: men ook in Suriname meteen waar de schoen wrong en werd de oorzaak van het falende negotiatiesysteem niet toegeschreven aan de beurscris:s, maar aan het kredietsysteem zelf. Dit blijkt onder meer uit een schrijuen van de planter $A$. Salontha van Salonthay uit 1776-1777, warir hij stelde dat de warde var een plantage en daamee het krediet, geixoppeld had moeten worden an het vermogen om de interest te kunnen betalen.22 In 1379 vaardigde Gouverneur Nepveu een nieuwe 'notificatie' uit over het taxeren van plantages en opnieuw biljk: men hee! goed te hebben geweien wat ex fout was geweest aan het systeem. Hij constateert dat de taxaties geen 'solice grord vormen vocor de kredietverlering, maar dat de hoogte van hes kredie:

welke op eene reeds vrigtgevende plantagie gegeven kar worden, moeten worden gecalculeert er: opgemalkt uit hel provenue der producten en revenuer, gefixeerl op en middelbaare caiculatie van de giantiteit en prijs der producten, en wit vergelijking, van het employ dat van dat proverue in een voorhancien zjinde geval moet worden gemaakt'. ${ }^{23}$

Vijftien jaar te laat legt Nepveu hier precies de vinger op de wond. Indien de waarde var de plantage - en daarnee de hoogte van de hypotheek gekoppeld zou zijn geweest aan de gemiddelde produktie vermenigvulaigd met de gemiddelde prijs die daarvoo: kon worden gemaakt, dan hadden de kredieten nooit zo hoog kunren oplopen en had men rente en afiossing kininen voldoen.

Een kenmerkend voorbeeid van het slechte functioneren van het regotiatiesystrem was het fords onder directie vau: R. IJagemar. Deze negotiatie was in 1770 opgericht met een kapitaal van $f 530.000$, waarvoor zes plantages waren verhypothekeerd. Gedurende de eerste vier ;ar werd aan de obligatiehouders $f 106.985$ ( $=5 \%$ ) rente uitgekeerd, naar a: in 1774 werd de betaling stopgeze:. Dit was zeer begrijpeli; $k$, want in die vier jaar had de netto-opbrengst van de opgestuurde produkten slechts $f 60.962$ bedragen. Van de enige suixerplantage(!) waren in alle jaren produkten verzonder., maar niet voldoence om de volleoige rente te betalen; van de overige (xoffie)plartages waren geduremde een of zelfs meerdere jarer. in het geheel geen produkten opgestuurd. Var het begin af bleven de planters dus in 
gebreke. Hierop, na 1775 , kwamen de obligatiehouders ir. actie. Officieel hadden zij echter niets met de planters te maken en stonden alleen in relatie met de fondsdirectie. Met behulp van een andere koopman-bankier, Marcus van Arp, daagden zij daarom Hageman voor de rechter. Wellicht was deze toch ook niet geheel zuiver op de graat geweest, want hij werd uit de directie gezet. Van Arp werd daarop gerechtigd de directie over te nemen. Onder zijn leiding werd de enige suikerplantage voor de som van de schuld voor het fonds ingekocht en werden de overige plantages, waarschijnlijk voor spotprijzen, van de hand gedaan. ${ }^{24}$

Deze affaire was zeker geen uitzonderlijk geval. Ook andere fondsen waren op het moment dat de beurscrisis titbrak al in problemen door het volkomen in gebreke blijven van Surinaamse planters. ${ }^{25}$ Dit toont aan dat he: niet de crisis was die de negotiaties de das heeft omgedaan, maar dat het hele systeem van meet af aan op drijfzand was gebouwd.

Niet alleen in Suriname, maar ook in Necier.and werd mistruik van het kredietsysteem gemaakt. Dat bleek toen eind jaren zeventig veel obligatiehouders in het geweer kwamen iegen de iondsdirecteuren en een aantal van hen beschuldigde van wanbeheer, eigenbelang en fraude. Dat dit niet ten onrechte was, blijkt al ait het feit dat de koopman-bankiers het zo ver hadden laten komen. Hun von:zichtigheid was op siag verdwenen toen zij het krediet aan de planters niet meer firanciexden met eigen middeien, maar met de spaargelden van derden. Plotseiing was het geen probleem meer wanneer de plantageschulden (ver) uitstegen bover de tot dan toe geharteerde liniet van circa $f 20.000$. Het eigenbelang werd echter door de koopman-bankiers nog steeds nauwlettend in het oog gehouden. Vaak ging dit ten koste var. de rentabiliteit van de verhypothekeerde plantages en daarmee uiteindelijk ten koste van de obligatiehouders.

In feite haalden de fondsdirecleuren de planters hel vel over de oren. Zo was het gebruikelijk om de planters voor hun jestellingen 20 tot $25 \%$ bover de Nederlandse kostprijs te laten betaler. (Quirtus Bosz 1971:1/1). Daarnaast rekende een fondsdirecteur provisie over de verkochte plantageprodukten en voor het aanbrengen van de assurantie tijciens het transport, dat bovendien nogal eens met zijn eigen schepen plaatsvonc. Hoe lucratief dergelijke hypotheekcontracten waren voor de koopman blijkt uit de sanctie die e:

24 KIT: Collertie-Van Rreugel: Intime Berig!

25 Hełzeifde gebelide bijvoorbeeld met zes plantages die in 1769 en 1770 werden verhypothekeerd bij een fonds onder directie van Lever \& De Bruyne. In de jarer 1770 tol en met 1774 hadden deze piantages $f 93.732$ aan rente moeten opturengen. In plaats daarvan kwamen $z i j$ niet verder dan / 38.360. Aan het ejad var de eec $w$ bleck een decl van deze plantages te zijn verlaten en waren de overige van de hand gedaan (CAA: NA, 12739; Surinaamse Almanak 1796:3-57). 
voor de planter op stond als hij naar een ander fonds wilde overstappen. Meestal diende hij dan $2 \%$ var de hypotheeksom als boete te betalen. ${ }^{26}$

Een fondsdirecteur, zoals bijvoorbeeld F.W. Hudig, genoot het meeste voordeel van het gedifferentieerde rentetarief dat hij hanteerdt. Zo kregen de obligatiehouders bij I Iudig 5\% rente op het genegotieerde kapitaal, maar vroeg hij de planters $6 \%$ over de totale schuld inclusief achierstallige rente. llet verschil stak hij in eigen zak. Ook toen vier van de bij Hudig verhypothekeerde plantages eind jaren 1770 de sente niel meer konden opbrengen en deze daarom werd gehalveerd, bleef dit lucratieve verschil gehandhaafd: 2,5-3\% per obligatie en 3-3,9\% van de totale schuld voor Hudig. .7

Eén van die vier was plantage Somerszorg (Tapoeripa) waarvoor Hudig in 1769 een hypotheek sioot en vernegotieerde voor $f 150.000$. In 1778 bleek de schuld te zijn opgelopen to' $f$ 192.442. Het verschil was door Hudig privé geleend. In die tien jaar betaalde hij jaarijks $5 \%$ rente over $f 130.000$ aan de obligatiehouders, maar vroeg hij aan de eigenaar van Somerszorg 6\% over de volle $f 192.442$. Zodoende kon I hudig alleen al in $1778 f 4.046$ a an rente in zijn zak steken. Op de door hemzelf geinvesteerde of licver geleende $f 42.442$ betekende dat een niet onaardige rentabiliki: van bijna $10 \%$.

Op zich is dit systeem van goedkoop geld lenen en weer cuurder witzetten in de bankwereld volkomer. gearcepterrd geraakt. Onder de fondshouders in Hudigs tijd was dit daatentegen zeer ongebruikelijk. In vrijwel alle plannen van negotiatie was het rentepercentage dat planters betaalden en oibligatiehouders ontvinger op papier aan elkaar gelijk. Dat de praktijk anders was, bleek toen de obligatichouders van een der fondsen onder directie van het huis van Harman van de Poij \& Comp. in 1777 geen genoegen meer namen met de gang van zaker.

In dit fonds, genaamd Letter $A$, was sinds 1766 door obligatiehouders $f 2.41 \% .000$ belegd, warvoor 21 plantages (slechts I suiker!) een hypothee' hadden gekreger.. In 1777, het jaar waarin de eerste kapitaalaflossingern hadden moeten plaats vinden, werd gesproken over de 'disfavorabelen staat der Vegotiatie'. Volgens de directie was dit te wijten aan een ongelukkige samenloop van omstandigherien. Veel planters hadden geen rente kunnen betalen als gevolg van een misoogst in de koffie en de age prijzen van dit produkt. Vexder waren twee van de verhypothekeerde plantages (Montpellier en Montauban) door marrons overvallen 'die den Eigenaar vermoord, veele slaver. weggevoerd en de producten geruineerd hadden'. Hierdoor had men deze plantages voor een gering bedrag in veiling moeten brengen, 28 
Het gevolg van dit alles was dat in 1774 in plaats van $6 \%$ nog maar $4 \%$ rente aan de obligatiehouders werd uitgekeerd en van 1775 af zelfs maar $2 \%$. Natuurlijk speelden de calamiteiten in Suriname een rol, maar er was meer. Zo was ook in de jaren voor 1774 nopit de afgesproken $6 \%$ uitbetaald op de obligaties, maar steeds 5 of $5,5 \%$. Volgens de voorwaarden van de negotiatie mocht Van de Poll inderdaad $1 \%$ achterhouden voor de 'nodige kosten en onverhoopte schade op deeze Negotialic', maar eens in de vijf jaar moest dit restant alsnog worden uitgekeerd. Dit was nooit gebeurd, noch was er ooit verantwoording over afgelegd.

Veel drukker makten de obligatiehouders zich echter over het feit dat de schuld van de planters aan Van de Poll inmiddels 3,5 ton boven het genegotieerd en dus verhypothekeerd kapitaal was gestegen en dat Van de Poll deze schuld preferent maakte boven de negotiatieschiild. Volgens hen hoorde deze schuld heiemaal niet thuis in de boeken van de negotiatie, maar was dat een privézaak van Van de Poll. Behalve natuurlijk a.s zij er ook de vruchten, in de vorm van rente, var hadden kunnen plukken, maar dat bleek niet het geval. De planters moesten namelijk rente betalen over de totale schuld, maar de obligatiehovders ontvingen alieen remte over het genegoticerde deel daarvan (de vijf-achtste van de getaxeerde plantagewaarde). Tegelijkertijd werden zij we. gedebiteerd voor 'gemanqueerde producten', ofwel het bedrag warmee de schild boven de vijfachtste uitsteeg. Dit waren echter door de fondsdirectie voorgeschoten gelden warmee de obligatiehouders riets te maken hadden.

Volgens de tamelijk verijnig opgestelde 'Reflexien' van twee ontstemde obligatiehouders, ook wel geinteresseerden genaarnd, de heren I'loos van Amstel en Blomberg, klopte er niets van deze situatie en warer de directewren van het fords alleen wit op eigen gewin. Zelfs spraken zij van geiden die de 'Heeren Directeuren [...] ten onrechte na zich neemen'29 Dat was cen niet geringe beschuldiging, mar het moet gezegd dat de wijze van boekhouder zeker niet ir. het nadeel van Van de Poll was. Overigens had de directie de forse, en in het openbaar gepubiceerde, kritiek we:licht kurnen voorkomen door een minder arrogante houding ten optichte van haar kianten aan te nemen. De ontstemde obligatienouders hadden ramelijk voor de openbaarmaking van hun grieven eerst nog verschillende malen. mondeling overleg gepleegd met de directeuren, maa:

'het uiterste, waar toe Hun. Ed. te brengen wadren [was] eene algemeene belofte, van de erreuren, die er mogten zyn, by de volgende Termyn van cie cetaling der Interessen, en dus in den Jaare 1778 te redresseeren, zich tot het doen var. eenige verdere Rekening ongehouden ourdelende. [7.j]] onttrokken zich ook van eenen 
onderhandeling, die met minder eclat de zaak tot een gewersclit eirde hadden kumnen brer:gen. ${ }^{30}$

De resultaten van de kritiex der obligatiehouders zijn nief bekend. In jeder gevai werden de directeuren niet uit hun functie ontheven en evenmin is ooit extra geld aan de obligat:ehouders uitgekeerd. Het enige wat het latsigenoemden misschien heeft opgelevexd, is dat sinds 1781 iets meer openheid werd betracht in de verantwoording van het fondsbeheer. Nadere beschouwing daarvan doet echter vermoeden da: de fondsdirectie gewoon op de oude voet is verdergegan. Anders is het moeilijk te verklaren dat in de periode 1782-1791 de gemiddelde jaarijkse netto-opbrengst var. de door Van de Poll verkorhte plantageprodukten f 51.899 bedroeg en er gemiddeld zo'r $f 45.000$ rente aan de obligatiehouders werd uitgekeerd. 3 : Het verschil was veel te groot on: als onkosten voor cie fondsadministratie te kunner: worden opgevoerd; evenmin werden hiemee obligaties afge.ost.

Dat de verhoudingen inmiddeis volledig waren scheefgegroeid, blijk: uit hef feit dat de renie die in deze periode werkelij; betaald had moeten worden gernidde.d bijna $f 209.200$ per jaar bedroeg. 32 Desordanks werden er toch nog obligaties afgelost, zij het tegen een koers beneden de nominale waarde. Het berodigde kapitaal kwarn uit de verkon? van plantages. 7 o werden tusen 1780 en $: 793$ vier plantages verkocht voor een total bedrag van $f 145.570$. Na aftrek van ce vele onkosten konden daaruit 204 obligaties worden afgelost voor circa 50\% van de waarde. Lit de verkoopprijs var de plantages blijkt overigens nog eens hoe het hele negotia:iesysteem op drijfzand was gebouwd. Begin jaren 1770 werd de gezamenlijke waatde van deze vier ondernemingen nog op $f 557.748$ getaxeerd. 33

Ook op de oudste en grootste negotiatie, het fonds onder directie van Jan en Theodoor van Marselis ( $v / h$ Deutz), kwam eind jarer 1770 een storm van kritiek en: werden niet mis te verstane beschuldigingen geuit ${ }^{34}$ In de kwart eeww dat dit fonds bestond lad de directie nog nosit financieile verantwoording afgelegd an de obligatichouders. Fn dat terwijl Van Marselis a: zeker twee decennia jaarlijks $1 \%$ van he: genegotieerd kapitaal had ingehouden. Aangezien hef girg om een genegotieerd vermogen van f 3.756 .000 , beliep het door Van Marselis niet verantwoorde bedrag al gauw meer dan zeven ton. ${ }^{35}$

\footnotetext{
3. Surinaams $N::$ sei:m, 1360 .

3) GAA:PA-690, 544; E:HB: KA.538.

32 (IAA: PA-6OO, 544.

33 CAA: PA-6[D, 544; FEAB: KA-8.

34 De kritiek werd verwoord in een anonicme open 'Brief van een Lirechts fieer aan zym Correspondent te Amsterdam', die eind 1779 werc gepubliceerd (Surináams Museim, 1358).

35 CAA: PA-600, 1266.
} 
De grootste grief van de obligatiehouders betrof echter het feit dat zij volkomen in het ongewisse waren gelaten over eventuele verkopen van verhypothekeerde plantages of nieuw afgesioten hypotheken. In zulke gevallen zou namelijk de directie minstens $2 \%$ provisie op de hypotheeksom hebben genoten. Opening van zaken hierover was daarom wel het minste wat de obligatiehouders konden eisen.

Een onderzoek in de notariele archieven toont aan dat deze kritick volkomen terecht was. In de jaren 1760 en 1770 bleken minstens 23 piantages te zijn overgegaan naar een ander negotiatiefonds. Met de nieuw verworven hypotheek werd dan de schuld bij Van Marselis afgelost. Daanaast hadden in ieder geval vier nieuwe plantages eer hypotheek gekregen. Dat het daarbij om flinke bedragen ging blijkt uit de afrekeningen van 8 van de 23 vertrokken plantages. Gezamenlijk beliepen die ruim $; 670.000 .36$ of de obligatiehouders hier ooit achter zijn gekomer, dan wel alsnog een financiële tegemoetkoming van Van Marselis hebben gekregen, vermeldt de historie niet. Al zouden de in opspraak geraakte fondsdirecteuren uitzonderingen zijn geweest, dan nog is de invloed daarvan moeilijk te onderschatten. Van zes directies is het zeker dat zij in problemen kwamen. Twee van hen kregen zware kritick van hun obligatiehouders te verduren, maar bleven in functie (Gebr. Var. Marselis en Van de Poll); twee werden uit de directie gezet (P. Rijdenius en R. Hageman) en twee gingen zeifs failiet (Hermael en Van den Bosch en A ter Borch). Gezamenlijk hadiden zij voor ongeveex 165 plantages hypotheken afgesloter en 13,5 miljoen gulden vernegotieerd. Hiermee strekte hun invloed zich uit over zeker een-derde van zowel de kapitaalstroom als van de piantages, ${ }^{37}$

Ook var de zijde de: planters is, na de euforie gedurende het derde kwart van ce achttiende ceuw, forse kritiek geieverd op de eigenbelang aajagende fondsdirecteuren. Het duidelijkst werd dit verwoord door cen anoniem schrijver die rond 1828 in Suriname zijn bezwaren tegen het negotiatiesysteem op schrift stelde. 38

In de eerste plaats keerde kij zich tegen de algemene bepaling dat de planters verplicht waren hun produkten alleen via de koopman-bankier in Nederland te verkoper, ook al kon eiders een betere prijs (of minder onkosten) worden gemaakt. Men was totaa: a:hankelijk van de woonplaats en persoon van de fondscirecteur 'en zijne opvolgers die dikwijls nog onjekend zijn en van wier goede trouw zich alzoo niet eens iets denken laat'. De planter voelde zich daarom door het verplichte consignatiesysteem 
tot een dief van zijn eigen portemonnee gemaakt, door mensen die hij weinig vertrouwde.

In de tweede plaats keerde ceze schrijver zich tegen het gebruik dat de fondsdirectie de schepen aanwees waarmee het transport van de plantageprodukten moest plaats vinden. De directeuren konden namelijk vaak voordelige afspraken maken met bepaalde reders, of zij hadden zelf schepen in de vaart. Hicrbij hadden zij nict het belang van de plantages op het oog 'welke zij alleen beschouwen als het middel om hunne schepen te bevoordeelen'. Gebonden planters moesten dar ook de volle vrachtprijs betalen, terwijl niet-gebonden collega's, soms bij dezelfde schippers, 30-40\% korting konden bedingen. Bovendien lagen de produkten van vernegotieerde plantages door deze rege'ing soms tijden opgeslagen, in afwachting van het voor hen bestemde schip. Verlies in volume en xwaliteil waren het gevolg.

Tot slot van deze memorie constateerde de schrijver somber dat een fondsdirecteur geen enkele trarsactic verrichtte voor een plantage zonder daarvoor provisie in rekering te brengen. Soms bleek hij zelfs ook nog deelgenoot te zijn ir de 'assurantie compagnien' waarbij het overzees transport was verzekerd. Kortom, zo stelde deze planter terecht, een eenmaal vernegotieerde plantage is nooit meer in staat zich op eigen kracht uit de wurggreep van een fonds te bevrijden.

\section{Het verdere verloop van enkele negotiatiefondsen}

Ondanks het feit dat veel negotiatiefondsen in act derde kwart van de achttiende eeww in problemen kwamen en de obligatiehotiders hun beleggingen drastisch in waarde zagen verminciexen, verdwenen de meeste fondsen niet direct van het toneel. Aan de hand van drie voorbeelden zal het verloop van dergelijke fondsen worden besproken in een poging enig licht te werpen op hun rentabiliteit. $\mathrm{Er}$ is geen reden om aan te nemen dat de gekuzen vourbeelder. een uitzonderlijke ontwikkeling hebben doorgemaakl, maar bij gebrek aan meer ciffers kat! hun representaliviteit niet worden vasigesteld.

In 1769 werd een negotiatiefonds opgericht onder directie van de heren Clifford en Chevalier te Amsterdam. ${ }^{39}$ Spoedig, ra de oprichting hadden beleggers voor $\{2.535 .000$ aan obligaties gekocht en waren er zestien koffie-

39 Het is onduidel;jk in hoeverte dit fonds iets ie maken had met het bankiersinuis Clifford \& Zn., waarvan het faillisscment eind 1772 de aanleidirg was tot ce Amsterdamsc beurs-

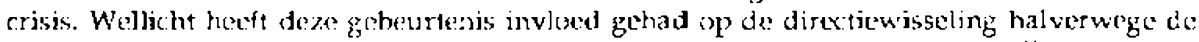
jaren 1770 , toen het fords verder beheerd werd door De Neufville en De Wolff, later alleen onder directie van $P$. de Wolff. Begin negentiende eeuw kwam de directie in handen van

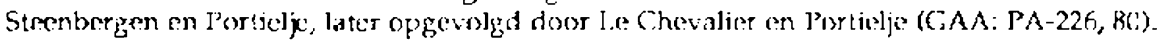


en drie suikerplantages verhypothekeerd 40 De kleinste hypotheek bedroeg $f 25.000$ en was als enige in 1784 afgelost. 41 De grootste hypotheek, $f 300.000$ werd afgesloten op de plantages van de planter J. Caucanas. Daarvan bleek in 1783 de totale schuld te zijn opgelopen tot $f 932.392 .{ }^{42}$ Naast De Onderneming hebben de resterende plantages in de loop der tijd nog $f 97.495$ afgelost.

Een aantal ondernemingen werd op den duur voor de som van de schuld ingekocht, en soms direct verlaten, en een aantal kon voor een geringe prijs worden verkocht. Liteindelijk bleek dit fonds in 1825 nog slechts vier plantages in handen te hebber. In dat jaar werd een commissie aangesteld or deze plantages 'tot efferheid en liquiditeit te brengen en te verkoopen.' 43 Dat dit geen gemakkeli;ke opgave was, bleek toen pas eind jaren: 1830 kopers werden gevonder. voor drie van de vier plantages, waarop de vierde zonder meer werd verlaten. ${ }^{44}$

In de 52 jaar lussen 1772 en 1825 is tot 1801 aan de obligatiehouders ieder jaar enige rente uitgexcend en darma gemiddeld om het andere jaar. Met de binnengekomen aflossingen waren bovendien 358 van de 2.505 obligaties afbetaald tegen gemiddelc slechts cen-derde van hun oorspronkelijke waarde. De nie: afgeloste obligaties hadcien in die jaren total $f 495$ aan rente ontvangen, warmee zij gemiddeld juist niet $1 \%$ per jaar hebben gerendeerd. Bij een rente van $6 \%$ had dat eigenli;k f 3.120 moeten zijn, nog afgezien van de initiële belegging van $f 1.000$ die had moeten worden afgelost. 45

Over de firma Harman van de Poll \& Comp. is ai het een en ander gezegd. Iun belangrijkste negotiaties waren ondergeoracht in twee fondsen genaamd Letter $A$ er: Leiter $C$. Deze waren in respectievelijk 1766 en 1769 opgericht met een gezamer.lijk belegd vermogen van ongeveer f 3.900 .000 . Hiervoor ontvingen 31 plantages (waaronder 3 suiker-) eer. hypotheek. Twee decennia later bleken twee plantages, door verandering van eigenaar, hun schuld te hebben a:gelost en waren d:ie plantages voor geringe bedragen per veiling verkocht.46 Ir. dat jaar (1787) was de gezameniijke

40 Dit waren de koffieplantages De Onderneming ( $v / \mathrm{h}$ Mneite en Zorg), Sans Souci, I.eydershoop, La Sangsize, Vice Bouteille, Tourtunne, Coresburg, Dordrecht, leliendaal, Viug: en Trouw, Fackertshoop (v/h Fyy?te), Crommelinsgift, De Coede Hoop, Breda, A la Bonheur en Coed Succes en de suikerplantages Dijkveld, Groot Chatillon en Cannawapibo.

41 Dit was plantagt De Onderneming (CAA: NA, 16344).

42 GAA: NA, 16341.

43 Bijvoorbeeld plantage Dijkveld werd begin jaren 1770 nog circa f 320.000 waard geacht.

Begin negentiende eec w werd hij echter verkoch voor / 15.000 (CiA: I'A-226, 80).

44 Surinaamse Almanak, 18.34-184.4.

45 GAA: PA-226, 80.

* Ilet ging ́nierbij orn de twee duor marrons overvailen plar:lages en plantage Loopwijk die in 1770 nog $f 136.193$ watard werd geariat, mare in : 780 von slechts $f 29.700$ van de hand ging. 
schuld van de resterende 26 plantages gestegen tot boven de zes miljoen, inclusief achterstallige interest.

Om nog iets van het verdwenen kapitaal terug te zien, werden in de daaropvolgende decennia nog eens acht plantages in de verkoop gedaan en de rest door het fonds ingekocht. Het laatste gebeurde omdat men van een aantal plantages nog goede verwachtingen had en sommige plantages niet verkoopbaar bleken. Vijfentwintig van deze plantages waren rond 1770 samen nog getaxeerd op ruim 5,5 miljoen gulden. Nog geen twee decennia later werden zij niet eens 1,8 miljoen waard geacht. 47

In 1840 bleken nog slechts drie suikerplantages (waarbij één omgebouwde koffieplantage) in bedrijf te zijn. Gedurende de voorafgaande decennia waren de overige ondernemingen verlaten, de slaven op de resterende bedrijven overgebracht en de gronden zoveel mogelijk verkocht. De negotiaties $C$ en $A$ waren intussen, in 1819 en 1829, omgezet in Sociëteiten van Eigendom. Dit betekende dat de obligaties waren geconverteerd in aandelen, waarop alleen dividend behoefde te worden uitgekeerd als de situatie dat toeliet. Zo werden de 1.780 overgebleven obligatics ir de regotiatie $A$ waarvoor ooif $f 1000$ was befaald - ir. 1829 afbetaald met $f 8,65$ per obligatie en omgezet in 'een Bewijs van Een Zeventienhonderdtagtigste aandeel' 48

Blijkbaar waren in de periode 1777-1829 toch nog 637 ob'igaties van regotiatie A afgelost. Waarschijnlijk zijn hiervoor de oporengsten van verkochte plantages gebruikt. Het lijkt uitgesloten dat deze obligaties voor de nominale waarde zijn afgelost; een- tot twee-vijfse van de oorsprorkelijke waarde zal, gezien de ervaring met anciere piantages, dichter in de buurt liggen.

In die periode van 52 jaar is op de niet ágeioste obligaties van negotiatie $A$ in 1o:aal $f: 143$ rente per obligatie betaald, ofwel een gemiddelde jaarlijkse rentabiliteit var. $2,2 \%$. Indien hef niet afgeloste kapitaal daarvan wordt afgetrokken resteert echter een rentabiliteit van nog geen $0,3 \%$. Nadat de obligaties waren omgezet in aundelen is nog drie keer een dividend van tien gulden uitgekeerd en daar bleef het verder bij:" De marginale resultaten in deze periode sioten verdere betalingen volkomen uit. 50

De rentabiliteit van obligaties in regotiatie $C$ was groter. Waarschijnlijk werden geen obligaties uitgeloot, want zo nu en dar. werd eer. deel van het kapitaal per obligatie afgelost. Toen in 1821 de obligattes werden omgezet in.

GAA: $P A-600,545$ en $545 A$.

FHB: KA-538.

EHB: KA-538.

50 De totale netto-opbrengst voor dezc Societeit in de periode $1831-1849$ bexdroeg niel meer dan $f 3.120$ of gemiddeld $f 164$ per jaar. Voor een belangrijk deel was dit te wijten aan de enorme kosten die de omschakeling van koffic- raar suikerproduktic mct zich mecbracht op piantage Zorg en Hoop. In totaal bleek met deze omschakeling ongeveer $f 170.000$ gemoeid te zijn gewe'st (CAN: $Y A-650), 545)$ 
aandelen hadden de bezitters daarvan sinds $1770 f 1.765$ aan rente en $f 550$ aflossing ontvangen. Daarmee had de oorspronkelijke investering gemiddeld 2,6\% per jaar gerendeerd. In de jaren daarna werd op de aandelen nog zesmaal dividend uitgekeerd, in totaal voor $f 110.51$

In 1863 viel voor beide negotiaties definitief het doek. De plantages werden verkocht en met de opbrengsten daarvan plus de Emancipatievergoeding van $f 300$ per slaaf werden de crediteuren in Suriname ten dele afbetaald. ${ }^{52}$ De aandeelhouders hadden toen al enige decennia geen dividend meer ontvangen.

In 1777 werd een negotiatiefonds opgericht onder directie van Pieter Biesterbos te Amsterdam. Bij dit fonds was het gezamenlijk plantagebezit van Irederik Berewout verhypothekeerd, bestaande uil de kúfieplantages Jagllust en De Nieuwe Grond in Suriname en tweeëneenhalve plantage in de buurkolonie Berbice. Ondanks het frit dat deze negoliatie dus na de grote hausse werd opgericht, wat een behoedzamer beleid zou doen veronderstellen, werd zij al na tien jaar ongezet in een Sociëteit van Eigendom. Hiextoe werden de obligaties geconverteerd in 360 akten van aandeel. Kennelijk was de schuld ook hier zo gestegen dat men liever genoegen nam met een onzeker dividend, dan met de gefixeerde rente en aflossingen die toch nooil werden betaald. ${ }^{53}$

Inderdaad lijkt de structuurverandering geen slechte zaak te zijn geweest voor de andeelhouders, want gedurende de exrstvolgende decennia werd steeds $3-8 \%$ dividend uitbetaald per aandeel van $f 1000$. Deze positieve gang van zaken zal mede het resultaat geweest $z$ ijn van cen vooruitziend beleid van de fondsdirectie, die inmiddels was overgegaan op H.A. Insinger en H. van de Poll Harmansz. ${ }^{54}$ Zo trokken zij in de jaren voor de afschaffing van de slavenhandel met Afrika voor Jagtlust en De Nieuwe Grond bijna $f 50.000$ uit voot de aanschaf van 55 nieuwe slaven. Bovendien blijkt dat $z \mathrm{ij}$ in 1799 de administrateurs toestemming gaven om, indien Suriname en Berbice in Engelse handen mochten vallen, de produkten te sturen naar een bevriend handelshuis in Londen 55

\footnotetext{
51 ARA: Aanwinsten 1985-5.

52 EHB: KA-37.

53. Litgaande van eer gerregotieerd kapitaal van $f 360.000$ (gebaseerd op net aantal aandelen in 1787) en een rente van $6 \%$, moeston de plantages jaarlijks $f 21.600$ a an interest opbrengen. Gemiddeld kwam dit neer op een bedrag van f 3.927 per plantage. Jagtlust en De Nieuwe G,rond kwamen grezamen]ijk tussen 1777 en 1787 echler niet verder dan ecn jaarlijkse? netto-opbrengst van gemiddeld $f 1.857$ (Collectic-Insinger \& Co., Notulboek Biesterbos).

54 Biesterbos had om gezondheidsredenen in 1791 de directie aan hen moeten overdoen, $B i j$ zijn terugtreden klaagden de commissarissen dat zij bij Biesterbos nocit voldoende gelegenterid hadden gekregen de boeken te controleren 'ende zij dus niet anders als macr figuranten waren geweest'; inmiddels een bekend verw'ijt (Collectie-lnsinger \& Co., Nouiboek Biesterbos).

55 Collertie-Insinger So Co. Notulboek Biesterbos.
} 
$\mathrm{Na}$ de oorlog met Engeland en de definitieve toewijzing van Berbice aan deze mogendheid verkocht het fonds de bezittingen in die kolorie voor $f 392.695$ (93\% van dat bedrag bestond uit de opbrengst van de 261 slaven). Over bleven dus de plantages Jagtlust en De Nieuwe Grond in Suriname. De eerste werd in 1818 eveneens verkocht en wel aan de beheerder in Surirame, administrateur G.N. Lincix. Deze stond bekend als een zeer vermogend man en dat bleck ook toen hij prompt de gevraagde $f \mathbf{8 0} .000$ op tafel wist te leggen.56

Ook deze verionop gethigt van een ef́ciciënt beleid van de Societeitsdirectie, want uifgaande van de taxatiewaarde van beide plantages in 1780 , had Jagtlust na 1787 per jaar niet meer gerendeerd dan gemidield 1,6\%, terwijl De Nieuwe Grond op een gemiddelde van $5 \%$ uitkwam. ${ }^{57}$ De aandeelhouders konden zich eveneens gelukkig prijzen, want raast het gewone dividend van $3-6 \%$ ontvingen $z i j$ uit de opbrengsten van de verkochte plantages in de jaren 18:7-1819 nog eers f 800 per aandeel.

Ook in de jaren daanna ging hiet goed net de Sociëteit der Plantage De Nieuwe Grond en werd tot en met 1826 dividend uitgekeerc. Van dat jaar af ging het minder vourspoedig met de plantage. De oorzaken waren reeksen siechte seizoenen (met teruglopende oogsten als gevolg), veroudering van de gronden en de s'avenmacht (waardoor de produktiviteit daalde) en de slechte koffiepri;s.5* Dividerd werd niet meer uitgekeerd en in plaats daarvan werd de aandeelhouders in 1831 gevraagd $f 50$ per aandeel te storten om he: ontstane kastekort aan te zuiveren en achterstallig onde:houd aan de plartage te kunnen plegen. Op 18 aandelen na werá indercaad aan dit verzoek volciaan; zelfs kreger: $2 i$; tussen $: 839$ en 1841 het geld weer teruggestort. Dit kon echter niet voorkomen cat in 1846 de aandeelhouders weer hetzelfde verzoek kregen voorgelegd, waaraan zij op 52 aandeler. ra opnieuw voldeden.

Evenals in de rest van de Surinaanse koffiesector bleek ook op deze piantage langdurig roofboliw te zi; gepleegd en was de achteruitgarg structureel. ${ }^{59}$ De produktiecijfers alieen al laten geen andere conclusic toe dan dat

56 Collectie-Insinger \& Co.. Notulbork Bicstribos.

57 In 1780 werd Jagtlust getaxeerd op $f 287.798$ en De Nieuwe Grond op $f 222.281$, welke bedragen voor het gemak hier als geinvesteerd kapital worder beschouwd. De reltoopbrengsten (inkomsten minus witgaven in Nerterland) bodromen voor de gehole poritode 17881817 f 134.199 er. $f 331.0: 3$ (ARA; SONA, 704 en 706; Collectie-Insinger \& Co., Notulboek Biesterbos).

58 Collectic-Insinger \& Co., Voululbock 3iesterbos.

59 Ook de directie schref het verval niet meer soe aan tjojelijkc of extcrne factoren, want in 1851 meldde zij 'dat de boomen wel hadden geleden, zoodat een overgroot aantal vooral van oude bownen dowi was gegaan en dat dientengevoige 20 nieuwe akkers met knst waren beplant om later koffy op te kunnen aanbrengen. De omstardigheid dat juist zoveele oude boomen moten worden weggcnomer doet ons vreezen dat het aanplanten van jonge en het aanbrengen ven nieuwe gronder. misschicn reds iroeger hud moeten goschieden' [mijn cursivering] 
grond en bomen waren 'uitgewerkt': in de periode $1778-1787$ werd gexniddeld per jaar 48.003 pond koffie van deze plantage verkocht en waren hiettoe bijna $79 \mathrm{ha}$. in cultuur gebracht (611 pond/h.a); in de jaren 1845-1854 werd per jaar gemiddeld nog maar 13.934 pond geoogst van 51 ha. (274 pond/ha.). Bij de lage koffiepri;zer van de regentiende eeuw resulteerde dit in de jaren 1850 in een gemiddeld jaarijks verlies voor deze plantage van rond $f 12.000 .6$ :

Voor de Sociëteit van Figendom was teze situatie onhoudbaar en men besloot tot opheffing. In 1856 werd de plantage voor $f 25.000$ verkocht aan de familie De Hart in Suriname. Met dit kapitaal kregen de trouwe aandeelhouders die in 1846 hadden bijgesprongen rog $f 75$ per aandeel uitgekeerd. Daarna werd de Sociëteit geliquideerd. In totaa! was op een aandeel in zeventig jaar $f 2.575$ uitbetaald, zodat het jaarlijks gemiddeld $3,7 \%$ had gerendeerd. ${ }^{61}$ De $f 1000$ waarvoor de obligatie ooit was aangeschaft zag niemand echter ooit terug, zodat de werkelijke rentabiliteit per aandeel 2,3\% bedroeg.

De drie hier behandeide voorbee'der laten zien dat de fondsen in de loop der tijd steeds meer zijn ingekrompen. Van de 55 plantages die zij in de jaren 1770 in handen hadden, waren er rond 1840 nog maar ach.t over. Ir. de loop der jaren waren totaal 28 plantages verkocint en de rest was verlaten. Ir. feite hebben de foncisen zich zelf dus opgegeten. Voor de obigatie- of aandeelhouders heeft de verkoop van plantages echte: als positief effect gehad dat zij toch nog een deel van hun geld hebben teruggezien.

Voor de . Nederlandse beleggers zijn deze fondsen daarom een wisselend succes gebleken. Sommigen zagen hun investering beloond met een redeijjk rendement (Van de Poll-regotiatie C en regotiatic-Biesterbos), anderen women or vrijwel niets bij (Van de l'oll-negotiatie $\Lambda$ ), of legder er zelfs flink op toe (negotiatie-Clifford en Chevalier). Voor de Surinaamse plantage-economie waren de fondsen ra cen cerste forse impuls - contraproduktief. $\mathrm{Nog}$ in de hoogtijdagen gaven zij aanleiding tot fraude, corruptie en 'conspieuous consumption', sinds ce schuldenerisis werden grond en arbeio volkomen uitgewrongen om maar enigszins aan de verplichtingen tegemoet te komen. Ook drongen de :oncisdirecteliren er sinds die tijd voortdutend op aan op de plantages toch vooral de uiterste zuinigheid te betrachten. Niet alleen leidde dit tot achterstallig onderhoud en verwaarlozing, met vaak dramatische consequenties, maar bovendien vormde deze houding een belemmering voor innovatie. Loals in het vorige

(Collectie-Insinger \& Co., Notulbock Biesterbos).

60 Collectie-Insinger \& Co., Notulbuek Biesterbus en ARA: SONA, 704.

61 Collectie-Insinger \& Co., Notulbork Biesterbos. 
hoofdstuk al bleek, behoorden ce negotiatiefondsen niet voor niets tot de minst innoverende plantage-eigenaars van Suriname. Daarnaast had de schuldencrisis tot gevolg at het vertrouwen van Nederlandse beleggers in de Surinaamse plantage-economie voor zeer lange tijd zwaar was geschokt.

Planters noch een groot deel der beleggers hebben daarom in het algemeen vee! voordeel gehad bij hun relatie met de fordsen. Dat de fondsen nog zo lang zijn blijven bestaan had te maken met de, vaak terechle, hoop van de beleggers nog iets van hun geïnvesteerde geld terug te zien. De voornaamste reden was echter dat de kooplieden dir als fondsdirecteuren fungeerden hun voordelige provisiehandel niet wilden opgeven. Het is ondoenlijk te berekenen hoeveel zij a an hun functie hebben verdiend, maar het lijkt zeer waarschijnlijk dat zij er aardig zijn uitgesprongen.

\section{Plantagekrediet in de negentiende ceus}

Zo gedetaileerd als het bronnenmateriaal is over de kredietverlening aan Surinaamse plantages ir de tweede helft van de achttiende eeuw, zo schars en vaag is het voor de eerste helft van de negentiende eeuw. Fen diepgaarde beschrijving var de regentiende-ceuwse kapitaalstroom is daarom niet mogelijk; er zijn alleen encele trends aan te geven.

Twee duideilike verschilien tekeren zich af in vergelijking met de achttiende eeuw, namelijk de plaats waar de kapitaa'stroom vandaankwam en de sectoren waarin het kapitaal werd geinvesteerd. In de ach.ttience eeuw was al het krediet uit Nederland afkomstig. In de negentiende eeuw kwam daar echter kapitaal uit Groot-Brittannië bi; en werden nu ook in Suriname zelf kredieten aan piantages verstrekt. Daarnaast was de achttierde-eeuwse kapitaalstroom voor he: grootste deel raar ae koffiesecto: gevloeid, maar door het snelle verval hiervar. veranderde ook dit in de negentiende eeuw. Gedurende de eerste decenuia werd het krediet vooral gebruikt om de katoensector op te bouwen. In het tweede kwart van de negentiende eeuw werd het kapitaal vooral in de weer opjoeierde suikersector geinvesteerd. De totale omvang van het negentiende-eeluws krediet is niet bekend. Fen ding staat echter buiten kij:: het was nooit meer dan een kabbelend beekje in vergelijking met de storfvloec aan kapitaal die Sur:name in de jaren 1760 en 1770 overspoelde.

\subsection{De kntoensector en het Engels Tussenbestuur}

In het laatste decenium van de achtiende eeuw werd de basis voor een zelfstandige katoensector gelegd met de aanleg van een aantal nieawe plantages aan de mondingen van de Warappa-, Matapica-, Mot- en Vredenburgerkreek. Deze plantages werden opgezet door in Suriname woonachtige 
planters en zijn waarschijnlijk ook door hen zelf gefinancierd. Niet iedereen in Suriname was berooid uit de schuldencrisis tevoorschijn gekomen. In feite was juist daardoor een nieuwe elite ontstaan. Dit waren de zogenaamde administrateurs die voor in Nederland verblijvende eigenaars, veelal fondsen, de plantages in Suriname beheerden.

Deze administrateurs bestuurden vaak meerdere plantages tegelijk en mochten daarvoor $10 \%$ van de geoogste produkten en $10 \%$ van de verkopen in Suriname incasseren. Dit legde hen geen windeieren, zodat zij in de jaren dat vee! met schulden bezwaarde plantages voor spotprijzen van de hand werden gedaan hun slag sloegen en zelf planter werden. Ook dit bleek vaak een lucratieve bezigheid, want nu deze plantages niet langer een torenhoge schuld torsten en de prijzen van de produkten behoorlijk waren aangetrokken, bleken vele ondernemingen nog zeer rendabel te zijn. Een paar adminstrateurs waren daarin zelfs zo gelikkig dat zij genoeg kapitaal hadden vergaard om te investeren in het lucratieve produkt katoen.

Zulke administrateurs waren hijvoorbeeld H.M. Wolff en W.L. van Ommeren die rond 1800 enkele tientalien plantages beheerden vour absente eigenaars. Met de inkomsten die ăit opleverde kochı Wolff één suiker-en drie koffieplantages. Daarnaast startte aij zelf twee katoenplantages aan de Motkreek. ${ }^{62}$ Hij moet in die tijd goed hebben geboerd, want tevens trad hij op als kredietgever voor andere plantages. 63 Ook Van Ommeren had als administratelr genoeg kapitaal weten te vergaren om enkele koffic- en katoenondernemingen op te kopen en zelf drie katoenplantages aan te Jeggen. Bij zijn overlijden in 1806 was hij de trotse eigenaar van in ieder geval acht plantages, d:e een geschatte waarde vertegenwoordigden var 1,2 miljoen Surinaamse gulden. De drie door hem zelf opgezette plantages namen daarvan zeven ton voor hun rekening. Dit zai niet het bedrag zijn dat hij es zelf in had geinvesteerd, maar het geeft een indicatie van de hoeveelheid kapitad die er mee was gemoeid. 64

Tussen 1799 en 18:6 stond Suriname vr:jwel onafgebroken onder beheer van Groot-Britfannië. Plartage-eigenaren die een dergelijke oniwikkeling hadden zien aankomer, waren tevoren al in contact getreden met Britse handelshuizen on de Furopese zaken, tegen een bepalde provisie, waar te laten nemen. Degenen die een dergelijke regeling niet hadden getroffen,

\section{Surinaamse Alnanak 1796:3-57}

63 Zo leende hij in 1802 f 50.000 aan de piantages Peekvlick, Zorg en Hoop, La Patience en Argent Court en Maria's Lust, alle ingekocht door het fonds van Van de Poll Letter A. Waarschijnlijk was dit bestemd voor de financiering van slavenaankopen (CAA: PA-6M, 544). 64 De koers van de Surinaanise gulden in dat jaar is niet bekend maar zal in de buurt van eenderde van de Nederlandse guIden hebben ge.egen (zie Bijlage 6) (ARA: SONA, 296; Surinaamse Almanak 1796:3-.57). 
werden door het Continentaal Stelsel en onder Britse druk gedwongen dit alsnog te doen. Er waren echter ook alternatieven, die vooral in de beginjaren op waarscijinlijk redelijk grote schaal zijn gejruikt. Een daarvan was het ontduiken van de Britse en Franse controle door gebruik te maken van valse scheepspapieren, charteren van neutraie schepen en het opgeven van valse eindbestemmingen. Dat bleek bijvoorbeeld in 1800 toen de in functie gelaten Gouverneur Friderici werd betrapt op fraude. Op een officieel uitgexlaard schip met Surinaamse produkten bestemd voor Fngeland, 'was discovered a second set of papers signed by Gov. Friderici [...] by which she appeared bound to Bremen'.65

In het aigemeen !eden de eigenaars in Nederland veel schacie var de gecompliceerde internationale situatie. Hun inkomsten, voo: zover deze via Engeland binnenkwamen, warer gering en soms zeifs nihil. De uitgaven waren daarentegen hoog, omdat de administrateurs in Suriname wel wissels op hen bleven trekker. Daar kwam bij dat de wisselkoers steecis onvoordeliger werd, want voor een pord sterling werd in Nederland $f 12$ betaald, maar in Suriname steeg dit, door gebrek aan contanten, toi $f 48$ in 1811. i6 Dit ales dwong de absente eigenaars hun administrateurs in Suriname tot de grootste zuinigheid aan te spozen. Zo verboden de directeuren van de ncgotiatie-Van de Poll hur administratelirs 'zonder eenige uitviugten' nog langer wisse's op 'hun naam te trekken. Boverdien moesten de plantage-onkosten tot 'volstrekte en onvermijdelijke noodzakeijkheid' worden beperkt. Bij uitzondering kregen de administrateurs daarom toestemming plantageprodukten in Suriname zels te verkopen om daarmee de kosten te dekken. 67

Terecht liefen de absente eigenaars ir hun orders enig wantrouwen doosklinken ten aanzien van het uitgavenpatroon van de administrateurs. Zij waren er zich waarschinlijk wel van bewust dat zij met deze maatregel de kat op het spex bonden, maar hadden geen andere keus. De toch al moeizame controle op hel doen en laten var de administrateurs verdween vrijwel geheel nu deze zelf korden bepalen welk deel van de plantage-

65 Public Record Office: Coinnial Office 278, 6. He: gebruik van de I'risisische vlag schiint vaker te zijn voorgekomen, want ook de eigenaars van de plantages Vossenburg en Wayampibo lieten hun schippers daarvan gebruik maker. Ook deze slujproute hickd echter op 'dewijl de keizer van Marccco met deere reemogendheid geen trac:aat hebbende, in ": hoofol heefi gekregen, die schecpen te neemen, gelijk recds aan verscheidene is overgekomen, en het niet te denken is, dat Pruisen hierover een harnas zal aantrekken, dewijl de schade zijne onderdanen niet direct betreft, en de koning [van Prdisen] rniet zal verkiener, jaarlijks tribulit aan den Maroccaan op te bresgen om zijne vlag vrij to kopen'. Alsnog besloten toen de cigenaars van Vossenb:irg en Wayampibo om de zaken voortaan via een Engels handelshuis te laten verlopen 'waartoe ons nia visk de prijzen encouragueren' (Surinazms Museum: CollectieBrantsen, verantwoorde rekening ?805).

to GAA: PA-60X, 545; Wolbers 1861:365; Lammens 1582: 43.

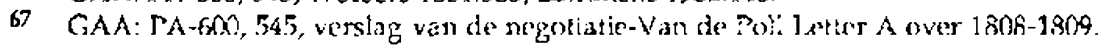




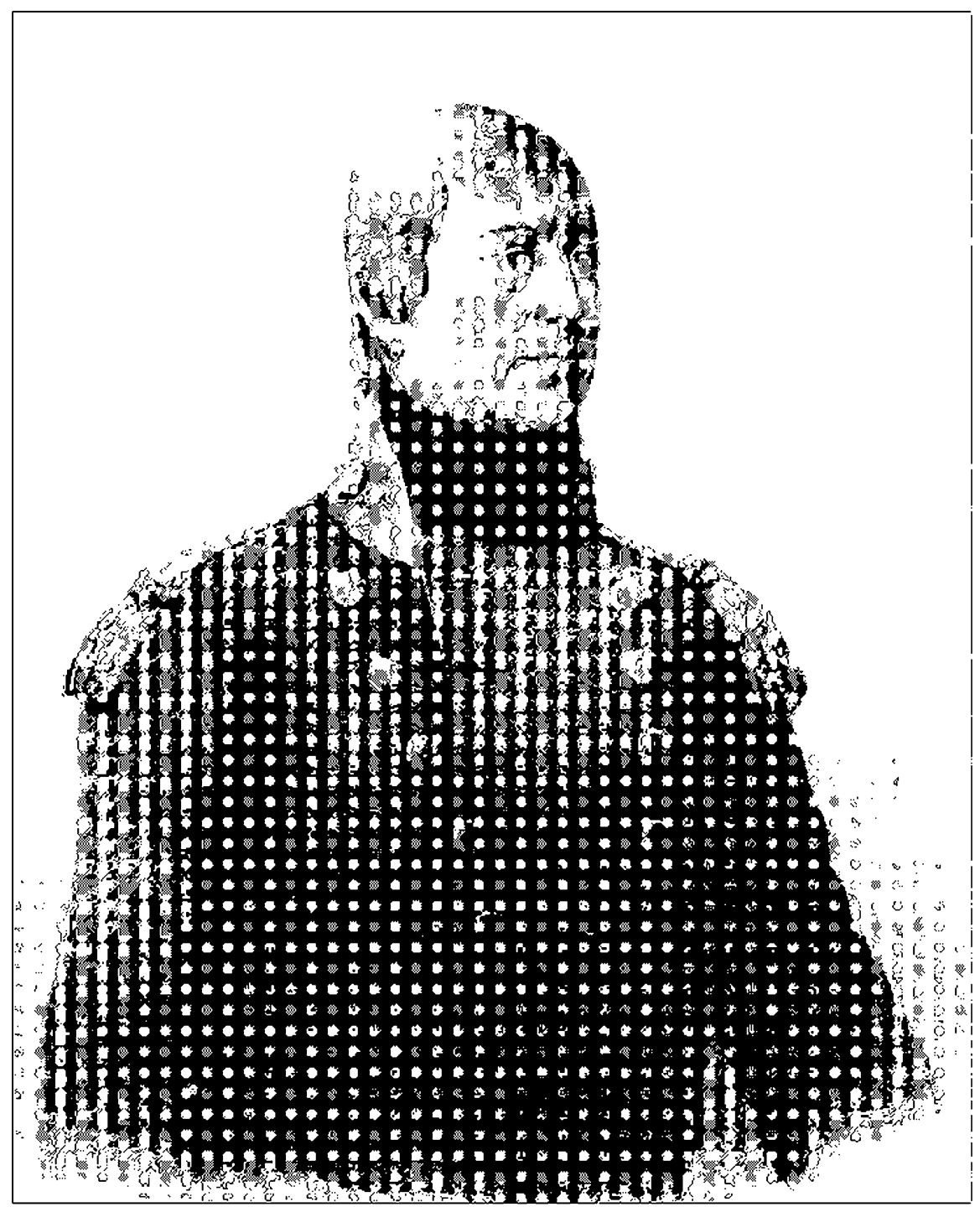

Gouverneur J.l. de lidderici (loto-archiet KIILV nr.20.174) 
produktie in Suriname moest worden verkocht. Aangezien de administrateurs $10 \%$ van de in Suriname geïncasseerde gelden als provisie mochten houden, werkte de maatregel sterk in hun voordeel. Voor zover tot dan toe nog rente en aflossingen werden betaald voor yerhypothekeerde plantages, bleven die nu geheel achterwege.

Het laatste werd mede in de hand gewerkl door een besluit van de britten in 1812 om personen die niet aan hun hypothecaire verplichtingen voldeden niet meer gerechtelijk te laten vervolgen. De redenering was dat de gelden toch maar naar vijandelijk gebied stroomden en de planters konden het niet helpen dat Nederland voor Surinamse produkten was gesloten. Wel werd daarop de controle verscherpt op de verscheping van alle plantageprodukten naar Groot-Britannië. Het gevolg var deze maatregel was echter dat een aantal Surinaamse planters zich nu voorgoed van de negotiatiefondsen bevrijd voelde en het er in Suriname flink van nam. Zelfs werden nieuwe schulden gemaakt bij Engelse handelshuizen, die, volgens Wolbers (1861:562), 'vederom vourschotten gaven en wel in ruime mate'.

Deze handelwijze van Surinaamse planters en administrateurs ten koste van de geldschieters in Europa, ging de pasbenoemde Engelse Gouverneur Bonhan te ver. Op zijn voorspraak werd daarom in 1813 een soort superadministrateur aangesteld in de persoon van John Bent. Deze moest cr op toezien dat de administrateurs regelnatig verantwoording aflegden van hun plantagebeheer, dat zij alleen in Suriname produkten verkochten wanneer de financiële situatie van de plantages dat vereiste en dat voor het overige de produkten netjes werden geconsignee:d aan Londense handelshuizen. Dit stuitte natwurlijk op veel verzet bij de administrateurs. $\mathrm{Zij}$ probeerden Bent op alle mogeijke manieren te dwarsbomen, onder andere door hem te betichten van fraude en corruptie. Het hieip hun echter niets; Bent bleer in functie. ${ }^{68}$

Tegelijk met bents aanstelling in Suriname was in Londen een orgaan in het leven geroepen dat controle moest houden op de verkoop van Surinaamse produkten door Engelse handelshuizen. Deze Surinam Absentce Sequestered Property Commission diende de belangen van de Nederlandse eigenars en geldschieters te bewaken en de hun toekomende gelden in bewaring te houden. Uiteraard bestond deze Britse belangenbehartiging niet uit pure liefdadigheid, want zowel Bent als de commissie kregen het recht respectievelijk 2,5 en $5 \%$ provisie van de produktie en vervolgens de verkoopopbrengst op te eisen. Het achterliggende idee was orn geen kapitaal in verkeerde (lees Franse) handen terecht te laten komen en tevens goodwill te kweken bij Nederland wanneer dit land van de Fransen zou zijn bevrijd. 69

69 Public Record Offica: Ireasury 75,2. 
Intussen bleven de administrateurs in Suriname grote druk uitoefenen op de Britse overheid om de voor hen irritante en kostbare supervisie van Bent te doen opheffen. In het licht van de naderende vrede tussen Engeland en Nederland besloot de Britse regering in juni 1814 aan dit verzoek te voldoen. De Surinamecommissie in Londen bleef echter nog tot 1816 in functie. ${ }^{70}$

Er moet gedurende die periode veel geld in Suriname hebben gecirculeerd, want ondanks alle maatregelen werd de meerderheid van de produkten toch in Suriname verkocht. Dit lijkt althans de enig mogelijk conclusie wanneer de Surinaamse exportcijfers worden vergeleken met de geringe verkopen van plantageprodukten geregistreerd door de Surinamecommissie in Londen. ${ }^{71}$ Het verschil moet dus in Suriname op de markt zijn gebracht en door buitenlandse schippers zijn opgekocht.

Hoe ruim de kredieten van Britse handelshuizen aan Strinaamse planters zijn geweest is moeilijk na te gaan. Alleen van het Londense huis Baring Brothers \& Co., waarmee enkele tientallen Surinaamse plantages in relatie stonden, rijn enige gegevens beschikbaar. In 1803 bleken 26 Surinaamse eigenaars bij hen in het krjit te staan voor $£ 26.737$ (ongeveer $f 320.840$ ), ofwel ruim $€ 1.000$ per persoon. Daarnaast had Baring Brothers nog eens $£ 6.255$ tegoed van kooplieden in Suriname. In totaal had de firma op dat moment bijna $£ 531.000$ uitstaar: in de Britse koloniën, dus het Surinaamse aandeel was gering. ${ }^{72}$ Onder de 'colonial bad or doubtful debts' die deze firma in de jaren 1815-1820 boekte, kwamen nog maar acht Surinaamse eigenaars voor met een gezamenlijke schuld van $₹ 2.547$. Alleen de eigenaars van plantage Frederiksburg aan de Commewijne hadden eer schuld opgebouwd die deed denken aan het achttiende-eeuwse krediet, namelijk $£ 53.500$ (circa $f 642.000$ ). Daarmaast stonden Surinaamse kooplieden nog voor $€ 5.841$ bij Baring Brothers in het krijt. ${ }^{73}$

Afgezien van plantage Frederiksburg lijken deze bedragen riet te duiden op een ruime kredietstroom richling Suriname. Dit wordi nog eens bevestigd in een brief van John Bent uit 1813, waarin hij schreef:

70 Wolbers 1861:586; I'ublic Record Office: Treasury 75, 7.

71 Zo werd in de periode oktuber 1813-april 1815 door de commissie mad v(w) 70 plantages de verkoop van produkten bijgehouden, mel een totaal volume van 6.669 oxhoofden suiker, 1.499 balen koffie en 362 balen katoen. De Surinaamse export bedroeg daarentegen alleen al in 181413.484 oxhoofden suiker, ongevner 26.675 balen koffie en 5.537 balen katoen (1'ablic Rexxord Office: Treasury 75, 10 en 11; ARA: Collectie-Van den Bosch, 166).

72 Guild Hall: Baring Brothers, Mss. I8324, AC 8 A2.

7.1 Guild Hall: Baring Brothers, Mss. 18324, AC 8 A2. Hoeved dowr deze firma in de parcn 1804-1814 is uitgeleend, is niet bekend. Grote kapitalen zulien het niet zijn geweest, want dan hadden zij al binnen de genoemde periode moeten zijn terugbetaald en dat lijkt, gezien de vroegerc ervaringen, niet erg waarschi[n] ijk 
that no claim of any British House upon any of the properties is registered in the Court of Policy at Paramaribo, which is the established evidence of mortgages according tot the laws \& usage of the colony of Surinam. [...] [I]t would seem that the advances alledged to have been made by the merchants in London can hardly be to any very great amount. ${ }^{74}$

Toch had Bent het misschien niet helemaal bij het rechte eind. Hij rept in deze brief alleen van koffie- en suikerplantages, terwijl het buiten kijf staat dat juist in deze periode, net Brits kapitaal, een serie nieuwe plantages in Suriname is aangelegd die in hoofdzaak katoen verbouwden. Van 1800 af hadden zich in de nog niet ontgonnen gebieden van West-Suriname, die later de districten Nickerie en Coronie zouden gaan heien, verschillende planters uit Grenada gevestigd. In 1801 waren aan hen al zeker dertien warrants verstrekt. In 1814 bleken er zeifs al twintig plantages in bedrijf te zijn die merendeels katoen produceerden. ${ }^{75}$

Na de overdracht van Suriname aan Nederland in 1816 richtten de planters uit Nickerie zich tot de Nederlandse Koning met het verzoek hen te ontheffen van de verpirchting alle in- en uitvoer via Nederland met Nederlandse schepen te moeten doen. Door de verre afstand tot Paramaribo en de nabijheid van het nu definitief britse Demarara en Berbice, was het voor hen reel voordeliger hun handelsrelatie met Engeland te blijven voortzetten. Bovendien, zo weet Wolbers (I861:544) te melden, was het kapitaal waarmee deze in hoofdzaak Britse planters hun p'antages hadden opgezet afkomstig van Engelse en Schotse handelshuizen. De omvang ervan is niel bekend. Overigens werd het verzoek van deze planters ingewilligd, waarbij waarschijnlijk de meest doorslaggevende reden was dat de Britten in Berbice en Demarara aan Vederiandse planters hetzelfde hadden toegestaan. ${ }^{75}$

Waarschijnlijk hebben niet alleen de Britse planters in Nickerie toestemming gekregen in relatie te blijuen me: Britse handelshuizen, maa: alle Britse plantage-eigenaars in Suriname. Dit bevoordeelde hen wel ten opzicinte van de andere planters, die aan de .Vederlandse markt gebonden bleven. Zij konden nu kiezen welke markt voor hen het voordeligst was, zowel voor de afzet, als voor het aantrekken van kapitaal. Lo stond in 1829

\footnotetext{
74 Public Record Oflice: Treasury 75, 2.

75 Dienst der Domeinen Suriname; Herkers 1923:82.

76 Des te opmerkelijker is het dan om acht jar 'ater de brocr van de Sur: naamse Gouvemeur te horen verzuchten: 'llet ware :ntusschen te wenscher, dat er buiten het huis van Colin Campbeli Dent \& Comp. dat thans eene voor de Vickeri nadeelige mnnopolie kan handhaven, nog andere huizen beskoten aun de planters gclden op te schicten (Van Heckeren 1826:55). H loc Ëngels deze naas ook mag klinken, Teenst:a (1835, 11:125) spreekt over dezelfde

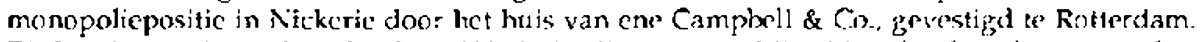
Dit kan haast nict anders dan hetzelfde huis zijn geweest. Misschien dat deze firma zowel in Londen als in Rotterdam xantoren had, wat niel onvers tandig geweest zou zijn, gezien de grote bclangen die zij onk buiters N:(ktrite in Surjuame had.
} 
de katoenplantage De Zwarigheid (Vredenburgerkreek), die Brits eigendom was, in relatie met Baring Brothers. ${ }^{77}$ Daarentegen ging de Engelsmar Robert Cooke, eigenaar van de niet ver daarvandaan gelegen katoenplantage Zeezigt aan de Motkreek een relatie aan met Insinger \& Co te Amsterdam. Deze Cooke liet in 1823 de bestaande hypotheken (bij een Britse firma?) ontbinden en sloot een nieuwe hypotheek bij Insinger ter grootte van $f$ 200.000. Precies zoals een halve eeuw daarvoor gebruikelijk was geweest, werd hiervoor een negotiatie in het leven geroepen, waarvoor 200 obligaties hun weg vonden onder Nederlandse beleggers. Het stimulerende voorbeeld dat Britse handelshuizen en planters in de Surinaamse katoensector hadden gegeven leek een voldoende garantie te vormen voor deze belegging.

Op basis van welke calculatic de hoogte van het hypotheekbedrag was vasigesteld is niet bekend. Erg overdreven zal het niet zijn geweest, gezien de voordelige staat waarin de plantage zich bevond: rond 300 ha. katoen, bewerkt door zo'n 400 slaven en een jaarlijkse produktie van meer dan 50.000 kilo. ${ }^{78}$ De rente van de hypotheek bedroeg $6 \%$ en de aflossing moest direct ingaan, te beginren met $f: 5.000$ in 1824 , oplopend tot $f 25.000$ in 1833 . In tien jaar diende het krediet dus te zijn afbetaa:d.

Toch had het optimisme wel enigszins kunnen worden getemperd, wanneer men wat nauwkeuriger de ontwikkeling van de katoenprijs had gevolgd. In 1818-18i9 bracht een kilo katoen in Nederland nog ruim twee gulden op; in 1824-1825 was dit tot de helft gedaald. Daarnaast moest er waarschijnlijk toch ook veel aan de plantage worden verbeterd, want ondanks een recordoogst waren in het eerste het beste jaar na de afsluiting van de hypotheek de uitgaven ruim $f 5.000$ hoger dan de inkomsten. ${ }^{79}$

Tegen deze achtergrond wekt het dan ook bijna geen verbazing meer dat deze negotiatie dezelfde uitz:chtloze weg ging als achitiende-eeuwse voorgangers. De katoenprijs bleef dalen tot een voorlopig dieptepunt van 80 cent per kilo in 1831. In plaats van vrij le zijn van hypotheek in 1833 lag de schuld toen ai ruim $f 17.000$ boven het oorspronkelijk afgesloten beciag. ${ }^{30}$ Fen kwart eenw ater bleek de totale schnld te zijn uitgegroeid tol $f 622.710$, waarvan een-zesde bestors uit voorschotten van de fondsdirectie. Steeds lagere katoenprijzen en een reeks van rampen waren aar deze ontwikkeling debet. 8 : Van de jaren 1840 af werden dan ook pogingen ondernomen

\footnotetext{
77 Guild Hall: Mss. 18321/HC 4.10.1.

78 Collectie-Insinger \& Co., Notulboek Zeezigt.

79 Collectie-Insinger \& Co., Notulboek Zeezigt.

Bo Collectie-Insinger \& Co., Notulboek Zeezigh.

8: Nog afgezien van de schommelingen in de katemprijs hews het 7eeezigt in het algemewr. niet erg meegezeten gedurende har 35-jarige relatie met Insinger. Tussen 1824 en 3844 werd de plantage driemaal overvallen door een insekterplaag, en keer geteisterd door een orkaan en cen keer door langdurige regerss onder water gezel. Daarnaast heeft men zeker iwaalf jaat
} 
de plantage te verkopen. Zo ver kwam het echter niet, omdat de Gouverneur daartoe zijn toestemming weigerde uit angst voor opstand onder de slaven. Deze waren ramelijk met de bevolking van buurplantage De Dageraad in de loop der tijd één gemeenschap var. ongeveer 800 zielen gaan vormen die niet gescheiden wilde worden. ${ }^{82}$ Noodgedwongen moest Insinger, dat inmidiels formeel eigenaar was geworden, de relatie met Zeezigt voortzetten. Uiteindelijk heeft de firma waarschinijik met liquidafie gewacht tot $1863 \mathrm{om}$ tenminste nog de Frnancipatievergoeding voor de siaven in de wacht te kunnen slepen, die voor 450 slaven rond $f 135.000$ moet hebben bedragen.

De vraag rijst waarom men in het geval van Zeezigt toch weer koos voor een negotiatie met haar gefixeerde rente en aflossingen en niet voor de al lang bekende en veel minder dwingende vorm van aandeelhouders in eer. Sociëteit van Eigendom. Waarschijnijk was de laatste constructie toch niet aantrekkelijk genoeg on: voldoerde beleggers mee te lokken. Ook kan het succes van de katoen in de beginperiode sommigen de ogen hebben doen sluiten voor de lessen wit het verleden. Snelle winsten leken opnieuw binnen handbereik. Voor de opbloeiende suikersector werden in diezelfde periode eveneens weer enkeie negotiaties afgesloter, zoals nierna za: blijken. Het is niet onmogelijk dat Nederlandse kapitaaibezitters, na de Franse bezetting, hun geld weer wilden beleggen en niet wars waren van speculatie. ${ }^{83}$ Daarnaast zal ook het feit dat uit Groot-Briktannië, de grootste economische macht ter wereld, veel kapitaal in de Surinaamse katoensector was gestoken, zeker vertröwen hebien geschonken.

Dit laatste roept de vraag op hoe dan de finamciering van Britse katoenplanters in Suriname uit Grool-Briftamië steefl platsgevonden en of het hen even s'echt is vergaan als de planter Cooke. Ileiaas vait deze vraag bij gebrek aan bronnenmateriaai niet te beantwoorden. Het enige dal met zekerheid is vast te sielien is dat de achteruitgang van de katoensector in de laatste decennia voor de Emancipatie de Britse katoenplanters even hard heeft getroifen als de Nederlandse. Ir. 1824 was de vertegenwoordiging van beide nationaliteiten in deze sector half om half, in 1853 toen al meer dan de helft van de plantages was verdwenen, bieek die verhouding nog precies hetzelfde. ${ }^{84}$

De enige incicatie dat het niet :edereen is vergaan als Rojert Cooke, is de loopbaan van James Balfour. Deze had in Suriname zijn eerste kapizaa:

moeten vechten tegen wandelende zandbasker. die de monding var de Mokkreek b:okkeerden.

82 Collectic-Insinger \& Cu. Notulboek Zeezigs.

\& Zie bijvoorherld H. Roiand Hoist-Van des Schalk 1002.52. Bovendien gat pen ardere (eventueel risicovolle) koloriale belegging, de pas opgericht Nederlandse Handelmaatschappij, maar een vaste rente van $4,5 \%$ op laar aandeler.

84 Surinaamse Almanak 1824-45.85; Van Sijpestrijn 1854:96-147 
vergaard in de houtkap en begon daarmee de suiker- (eerst ook nog koffie-) plantage Waterloo in Nickerie. Daamaast kocht hij eveneens in Nickerie de katoenplantages Forgue en Providence. Deze aankoop kan nauwelijks een financiële strop zijn geworden, want bij zijn overlijden in 1841 liet Balfour een kapitaal na van $f 300.000 !^{85}$

Twee dingen zijn duidelijk ten aanzien van de ontwikkeling van de Surinaamse katoensector. In de eerste plaats bleek het vooral Brits en Surinaams kapitaal te zijn geweest waarmee deze sector werd opgebouwd. Gezien de uiteindelijke achteruitgang van de sector lijken deze financieringsbronnen dezelfde weg te hebben gevolgd als het achttiende-eeuws krediet uit Nederland, met name voo: de koffiesector. Toch is deze veronderstelling niet gehcel juist. In tenminsie cen deel van de sector blcck het kapitaal produktief te zijn aangewend, getuige de introductie var. verschillende innovaties, waaroncer de stoommachine. Het was echter onvoldoende remedie tegen de voortdurend dalende prijzen en de reeksen calamiteiter waarmee deze sector te kampen kreeg. Daarnaast bleek uit het voorbeeld van Zeezigt - war geen innovaties hadden plaatsgevonden opnieuw hoe funest de negotiatie was als financieringsvorm voor een plantage. In dit geval schoter niet alleen de planter en de beleggers, maar ook de fondsdirectie er bij in. Voor het overige ieek het bijra een getrouwe kopie van de vernegotieerde koffieplantages een haive eeiw ecrder.

\subsection{Krediet in de suikersector}

Fvenals de katoen kende ook de suikersector gedurerde de eerste decennia van de negentiende eeiw een periode van bloei. Vergeleken met de jaren 1810-1819 steeg de gemiddelde jaarlijkse export in het daaropvolgende decennium. met $47 \%$, terwij: de gemidcelde prijs ongeveer gelijk bleet (Bijlagen I en 2). Voor de opjouw en de bloei van de katoensector waren grote, maagdelijke stukken land in gebruik genomen. Dat was in de suikersector veel minder het geval. Slechts vijf plantages begonnen op werkelijk nieuwe cu.tuurgrond en niet eens alle vijf direch met de verbouw van suiker. 36 Daamaast was er echter een groeiend aantal koffieplantages die in deze periode werd omgebouwd tot suikerplantage. Ook werd in deze tijd de stoommachine geintroduceerd en beschikte in 1833 al meer dan een kwart van de suikerondernemingen over zo'n krachtbron. Voor di: ailes was natururlijk veel kapitaal nodig. De vaaag is waar dit kapitaal vandaan kwam.

85 ARA: SOOB\&W 1828-1876, 834

86 Dit waren Hamburg, Kent en Catharina Sophia in Saramacca (de laatste eerst korte tijd koffie), Waterloo in Vicixerie (waar raast de suiker eerst ook koffie werd verbouwd) en De Resojutie aan de monding van de Surinamerivier (eerst kntte lija katuen). 
Het blijkt dat ook in de suikersector de Britten een belangrijke rol hebben gespeeld. In de periode van het Engels Tussenbestuu: hielden de meeste Britten zich nog bezig met de katoencul:uur en bezaten zij niet meer dar $7 \%$ van de suikerplantages. In 1824 was dit aandeel echter al gestegen tot bijna $20 \% .{ }^{87}$ Nog veel opmerkelijker was nun aandeel in de aanschaf var stoommachines. In 1833 bleek slechts $4 \%$ van de plantages die niet over een dergelijk warktuig beschikte in Britse handen te zijn, terwij $50 \%$ van de plar. tages die wel met 5tcom werkte Brits eigendom was (Teenstra : 835, I:9-83).

Het is onmogeljjk een schattirg to maken hoeved kapital bliervoor is gefoumeerd uit Groot-Brittanaie, ondat de gegevens hierover ontbreken. Fvenmin is bekend hoeveel ir. Surirame geaccumuleerd kapitaal hiervoor is georuikt. Een indicatie voor het niveau van de gepleegde investeringen vormen echter de installatiekosten var. een stoommachine. Een behoorlijk apparaat kostte in die periode $f 15$ a 20.000 , terwijl het trarsport, de installatie en het aarpassen van de fabrieksgebouwen dit bedrag nog eens verdubbeidem. 8 . Dit beteken: dat voo: de 28 plantages die in 1833 var stoomkracht waren voorzien al minstens een miljoen gulden was gesper:deerd. Ifet werkelijke besiag moet eckter vee] hoger zijn geweest, war: alieer ai de totale kosten die de ombouw van koffie raer siaker op plantage Zorg on Hoop mot zich nesebrachten bedroegen $f 170.00089$

Fen tweede opvallend aspec: van he: gemodernisee:de deel van de suikersector was dat $65 \%$ var de plantages ir handen was van ter plekke wonence eigenaars, waarvan bijna een-vijfce riet-Brits. Dit beteken: da: er, evenals in de katoensector, cok lokaal kapitaa: aanwezig was voor suikerplanters. Rond 1817 werd jijroorbeeld kottieplartage Zoelen aan de Commewijne omgebouwd tot een suikerplartage. De hiertoe benodigde financiën werden inderdaad op de Sirinaamse kapitaalmar'xl gevonder. De eigenaresse va: Lueien, de weduwe De Meynertzhagen sloot een hypotheek af bij Wolf:ng, waarsch:;nlijk koopman, te Paramaribo voor een bedrag van Sf 250.000 (f 143.000) ${ }^{95}$ Over de voorwaarden van de hypotkeck is verder niets bekend, al zal de rente wel het in Suriname maximaal toegestane percentage van $8 \%$ hebben bedragen. Ruim drie jaar later werd deze nypotheek a. afgelost, omda: een voordeliger krediet in Nederiand werd gevonden.

Een sweede voorbeeld van Surinaams krediet is de suikerplantage Livorno aan de Surinamerivier, waar in 1835 werd besloten de nog steeds opererende beestenmolen te vervangen door eer stoommolen. Op da: moment rustte op deze plantage al een ir: Suriname afgesloten hypotheek van ruim $f 72.000$. Er werd nu een tweede hypotheek opgemaakt var.

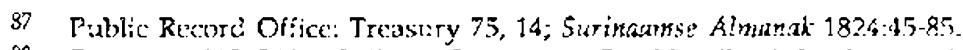

$\$$ Teenstra 1835, I:224; Collectie Insinger \& Co., Notuliook Jag!lust cr. Anna Catharis:a.

BG GAA: l'A-6UU, 54 .

9C FHB: KA -735 . 
$f 46.000$ bij de kooplieden Van West en De Hart te Paramaribo. De rente bedroeg $8 \%$ en het hele bedrag moest in vier jaar tijd, te beginnen in 1836, zijn afgelost. Wat hiervan terecht is gekomen is niet bekend.91 Beide voorbeelden duiden ex op dat Jokaal Surinaams krediet kon worden aange trokken wanneer in Suriname wonende (suiker)planters hiermee een specifiek doel voor ogen hadden.

Het optimisme aangaande de Surinaamse suikercultuur in de jaren 1820 liet ook kapitaalverschaffers in Nederland niet onberoerd. Fr werden zelfs nieuwe negotiaties opgericht, al valt het direct op dat hierbij geen van de oude handelshuizen met Surinaamse belangen betrokken was. Een voorbeeld daarvan was de firma Van den Broeke \& Walraven, 'administraeuren van Leeningen in de West-Indien te Amsterdam, [...], welke eerst in den loop van dit jaar [1820] is opgerigt'. ${ }^{92}$ De firma richte toen een negotiatiefonds op ten behoeve van een hypotheek op plantage Zoelen. Deze was $f 260.000$ groot, met een rente van $5 \%$. De aflossing diende in 30 jaar te zijn afgerond, te beginnen met $f 7.000$ in $1821 \mathrm{cn}$ oplopend tot $f 13.000$ in 18.50 . Op de uitgelote obligaties, al sprak men van aandelen, moes: bovendien rog een premie worden betaakd var $1 \%$ in 1821 , oplopend tot $37 \%$ in 1850 . Hierop gaf Van den Broeke \& Walraven 220 aandelen' van $f 1000$ en 80 van $f 500$ uit, waarop overigens uitdrukkelijk werc vermeld dat de fondsdirectie niet persoonlijk aansprakelijk kon worden gesteld. ${ }^{93}$

De heren hadden zich dus keurig ingedekt en hoefden ook overigens niet te kiagen, want op het verhypothekecrde bedrag mochten zij meteen al $5 \%$ 'remedie' en 2,5\% provisíe, samen $f$ 19.500, inhouden ${ }^{94}$ Dit betekent dat de eigenares van Zoelen reëel riet meer dan $f 240.500$ ter beschixking kreeg. Ook in de achttiende eeuw was deze praktijk gebruikelijk, het hoge percentage echter niet. Toch was dit nog niet het enige, want Van cien Broeke \& Walraven mocht bovendien nog eens $7,5 \%$ 'remedie \& provisje' rekenen over de jaarijikse aflossing en opnieuw $1 \%$ over de jaarlijkse som van rente plus premie plus afussing pius remedie en provisie. Door deze bepalingen was de werkelijke rente die vour de hypotheek van Zoelen betaald moest worden $7,1 \%$, waarvan dus $2,1 \%$ voor ae directie van het fonds. En dat alles nog afgezien van de gebruikelijke provisies die zij mocht rexenen, zoals $2 \%$ over de verkochte produkten, $0,25 \%$ voor het bezorgen van de assurantic en $2 \%$ 'voor het montant der in de te kopene plartagebehoeftens'. 95 In de behartiging van hun eigenbelangen deden deze heren dus niet onder voor hun achttiende-eeuwse collega's.

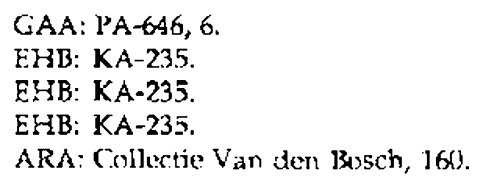


Het precieze verloop van deze negotiatie is niet bekend, maar wel is duidelijk dat al na zes jaar de negotiatie werd geliquideerd en de obligaties afgelost voor $49 \%$ van hun werkelijke waarde. 96 De schuld werd voor een onbekend bedrag overgedaan aan de weduwe Linck. In 1833 bedroeg de kapitaalschuld nog $f 182.981$ en de achterstallige rente $f 39.501$. Drie jaar later werd deze schuld voor slechts $f 30.000$ overgenomen door de Sociëteit van Eigendom der plantages Anna Catharina en Jagtlust. ${ }^{97}$

Een tweede relatief nieuwe firma die in de jaren 1820 enkele negotiatíes oprichtte was I.ouis Bienfait \& Zn. te Amsterdan. Het ging hierbij om de koffieplantage De Goede Verwachting en de suikerplantage Le Mast Rouge in bezit van R. Gollenstede en de drie plantages van de familie Van Sandick. Voor laatstgenoemce werd in $1829 f 200.000$ genegotieerd, waarmee de bestaande schuld aan het negotiatiefonds van F.W. en J. Hudig werd afgelost. Het verdere verloop hiervan is gedetailleerd beschreven in de studie van Oostirdie (1989:309-65). Hier kan daarom worden volstaan met de constatering dat de hypotheek op deze plantage's in 1844 had moeten zijn afgelost, maar dat in plaats daarvan in 1861 de schuld bleek te zijn opgeiopen tot $f 359.580$.

Ook met de twee andere negotiaties had Bientait geen succes. De Goede Verwachting werd in 1823 getaxeerd op ruim $f 176.000$ en ontving een hypotheek var $f 60.000$ met een looptijd van elf jaar. Men was dus we! voorzichtiger geworder. Desondanks is slechts vijf jaar rente betald en werd drie keer kapitaal a:gelost. In 1835 moest deze koffieplantage bij executie worden verkocint en bracht niet meer op dan $f 20.000$. Daarvan kon uiteindelijk een schamele $f 47,65$ per 'aandeel' worden uitbetaald, 98

Met Le Mast Rouge is het riet veel anders gelopen. Deze suikerplantage werd getaxeerci up $f 175.000$ en untving in 1825 een hypothee's van $f 50.000$ tegen een rente van 5,5\%. Hiervoor werden 50 'aandelen' uitgegeven, die in elf jaar moesten worden afgelost, te beginnen me: $f 1.000$ in 1826 oplopend

\footnotetext{
$96 \mathrm{FHB}: \mathrm{KA}-235$.

92 Deze Sociëtc:t stond onder directie van msinger \& Co. eli was in 1830 opgericht. $Z$ ij

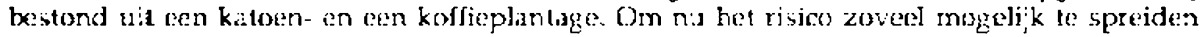
werd de suikerplantage Zoeien er bijgekocht. Vanaf dat moment ging het mis. Fr was alti; met winst gedraaid, maar die verdween door de hoge kosten die voor Zoclen moesten worden gemaakt, waaronder aanschaf van eer stoommachine, in combinatie met de dalende katoenprijzen waarmee Amu Catharina werd gecondronteerd. In 1844 werd de Sociëteit geliquideerd. Zonder Zoelen zou de winst per aandeel gedurende deze 14 jaar $f 465$ hebben bedragen, ofwel eer jarrijks rendemert van 3,."\%. De werkelijkheid was dat de aandeelhouders er $f 77$ pera andevl op hebben tucgeiegd, nog afgerien van de $f 1.003$ die het aandeel oit had gekost (Collectic-Insinger \& Co., Notulbock).

98 Men had de plariageproduktie gecaiculeerd op 33.000 pond kutlie per jaar, maar in de periode 1825-1832 werd gersiddeld niet meer dan 21.221 pond geproducerd. In iecer geval heeft Gollenstede net kapitaal nict produkticf gebruikt, want de enige uitbreiding bestond wilt twee sluizen, terwijl verder het aantal koffie-axkers en slaven in deze periode aanzienlijk daalde (CAA: PA.646, 44-48)
} 
tot $f 9.000$ in 1836 . Op de afgeloste aandelen moest bovendien een premie worden betaald van $2 \%$ oplopend tot $25 \%$.

Ook hier bleek de bepaling van de hoogte der hypotheek voorzichtiger tot stand te komen dan in vroeger tijden, want niet alleen bedroeg deze minder dan een-derde van de taxatiewaarde, bovendien bleek rekening te zijn gehouden met de produktiecapaciteit, die op 200 vaten suiker per jaar werd gecalculeerd. Hoe men echter tot deze schatting was gekomen blijft een raadsel, want in de periode 1819-1825 werden per jaar gemiddeld maar 88 vaten suiker geproduceerd. ${ }^{99}$ In de jaren daarna stceg dit tot gemiddeld 127 vaten per jaar dankzij een uitbreiding van het suikerareaal met ongeveer een-derde. Hiermee werd echter nog steeds de gestelde norm bij lange na niet gehaald. Toch was het voldoende om in ieder geval tot 1833 de hypotheekrente te betalen; met het aflossen werd al in 1830 gestopt. 100 Afgezien van deze achterstallige betalingen beliep het verlies van deze plantage in 1833 al meer dan $f 9.000$. Ook Le Mast Rouge moest daarom bij executie worden verkocht, maar bracht in 1835 toch nog $f 58.500$ op. 11: Howeel uiteindelijk per aandeel werd uitbetaald is niet bekend.

Terecht noem Oostindie (1989-348-61) de negotiaties van Bienfait cen fiasco. Dit was te wijten aan diens gebrekkige inzicht in de Surinaamse planterij en (daardoor?) rijn ongelukkige hand van zakendoen.: iz Bovendien werd het geinvesteerde kapitanl niet produktief aangewend. De enige verandering die tussen 1823 en 1833 op Le Mast Rouge platsvond, was de uitbreiding van het suikerareaa. Het had bepaald geen kwaad gekund wanneer met de hypotheek een stoommachine was aangeschaft, want in 1833 bleek men nog steeds met een beestenmolen te werken. Zo'n innovatie had wellicht veel misère kunnen voorkomen. ${ }^{i 03}$

Waarschijnlijk de laatste (poging tot een) groutschalige Surinaamse negotiatie in Nederland vond plaats in 1828 door de firma A.L. van Harpen \& $\mathrm{Zn}$. Deze firma was geen onbekende $\mathrm{n}$ de Surinaamse plantage-economie, want zij had a] vele jaren de plantages Waterland (suiker), Adrichem (koffic), Groningen on Rees en Crop (beide katoen) in bezit en

\footnotetext{
99 GAA: PA-6A6, 42; ARA: OAS, AVF, 52

100 GAA: PA-646, 43 .

1B: ARA: SOB\&W $1828 \cdot 1876,1388$

102 Rienfait had ook privé nog een suiker- en twee koffieplantages gekorht. De laatste bleken al na enige jaren volkomen uitgeput en moesten worden verlaten. De suikerplantage Dordrecht verkocht hij in 1852 voor krap de hellt van de $f 87.000$ die hij er vijftien jaar earder voor had moeten neertellen (CAA: PA-646, nrs. 20,67 cr 71).

in GAA: PA-646, 42. Dat het ook anders kon werd twec decennia later duidelijk. De ter plekke woonachtige eigenaar, J. Nuordbergh, bleck in die jaren een stoommachine te hebben geinstalleerd en de slavenrnacht met $60 \%$ ic hebben aitgebreid (Van Sijpesteijn 18.54:118-9). In 1860 werd op deze plantage zelfs de op vijf na hoogste sujkerproduktie per akker gerealiseerd (Koloniaal Verslag 1860). Hoe Noordbergh aan het benodigde kapitaal is gekomen is niet bekend.
} 
stond waarschijnlijk met nog meer plantages in contact. 104 Over de nieuwe regotiatie schtreef een informant in Suriname:

'Met verwondering heb ik in de nieuwsbladen de negotiatie van $680 / \mathrm{m}$ (f 680.000) gelezer welke door het huis van Van Harpen ditgescinreven is tert behueve var. de 6 plantages van J. Bent. Het kan zeer goed daarmede uitvallen maar de onkosten vari npaetting van Stoommolens en verdere suiker fabriek gebouwen zullen gewis een gedeeite van deze som wegslepen, en ik geloof dat sommige van de plantagien reeds onder de Plak van Colling Campbell Dent \& Co. staan, en dat men van voornemer is van de opgenomene sommen van dit huis met de nieuwe beleening an te zuiverer. Wat de negers van deze effecten bedragen, die zijn talrijk genoeg en zullen gezamenllijk over de 1000 koppen bedragen. "116

Twee van de betrokken piantages produceerden al suiker (waarvan een met een stoommoler), van de andere vier lag dat in de bedoeling en er was waarscinjrlijk voor een daarvan al een stoummachine in bestelining. De toekomst van de negotiatie werd dus genee op cor kaart gezet: suikerproduktie met benulp van moderne techniek, met stoommolens. De? Surinaamse informant schatte dat wanneer alles doorging deze groep plantages jaarlijks 1.840 vater suiker zou kunnen produceren. Hij had er echier een hard hoofi in, sprak zelís var. 'knoeyerij', wank volgens de officiële calcuiatie van he: fonds moesten alleer. al de twee reeds werkende suikerpiantages samen 1.200 vaten suiker kunnen maken. ${ }^{106}$

De argwaan bleek terecht, want in lie periode $1819-1828$ bedroeg de gezamenlijke produktie van deze twee plantages gerniddeld riet eens 500 vaten per jaar lij Ilougstwaarschijnlijk is deze negotiatie dan ook nie: doorgegaan. I Jieraan zal overigens de Belgische alscheiding mede debet zijn geweest. In ieder geva: bleek enikele jaren later een van de plar.tages kost te verbouwer, een tweede produceerie katoen, twee andere waren verlater en de shaven daarop waren. overgebracht naar de twee resterence sulkexplantages. ${ }^{138}$

Het is niet erg waarschi;nlijk ciat er na :830 nog negotiaties zijn opgericht, al was er zo nu en dar. wel sprake ven. Nog in 1845 deed een deel van de eigenaars var: suikerp'antage Vreetenourg teet voorstel $f 125.000$ voor dezé onderneming te laten negotièren. Iliervoor zouden saast de allossing van f 80.000 an schulden, de gebolwen gerepareerd, slaven angekocht en een stoommachine geinstalleerd moeten worden. In plaats van dit alles werd

\footnotetext{
I:24 Surinaamse Almanak 1824:45-85.

ios Collectie-Insinger \& Co. In forraat:eboek.

ISt Collectie-Insinger \& Co., Informat:eboek.

107 ARA: OA5, AvF, 52

1.\% Surinamse. Almanak 1834:67-111. Rond 1840 produceerde een van deze twee sulkerplantages nict mecr dan 169 vaten per jaar en telden zij samen niet meer dan circa 250 slaven (ARA: MVK, A792; Swrinalise Almanat 1844:59 101).
} 
Vreedenburg echter in 1851 verkocht aan buurplantage Ornamibo voor slechts $f 20.000 .109$

Opnieuw waren dus de regotiaties geen succes gebleken. De expansie en innovatie die de plantage-economie nodig had om te kunnen overleven kregen door deze fondsen nauwelijks enige stimulans. Evenals in de achttiende eeuw leken zij dar ook meer bedoeld om met gouden beloften beleggingskapitaal te lokken.

\subsection{De Particuliere West Indische Bank}

Ondanks de verruiming van de kredietmogelijkheden gedurende de eerste drie decennia van de negentiende eeuw, verkeerde de Surinaamse plantageeconomie eind jaren 1820 in een financieel deplorabele toestand. Als gevolg van het absenteisme en de verplichting de produkten in Nederland te verkopen heerste er in Suriname een chronische gebrek aan contanten. Als betaalmiddelen fungeerden wissels op Nederlandse handelshuizen en het zogenaamde kaartengeld. Dit laatste bestond uit door de koloniale overheid uitgegeven papiergeld - vaak gestempelde speelkaarten - waar geen speciale dekking tegenover stond. Rond 1800 was hiervan bijna 5,6 miljoen gulden in omloop; in 1811 zelfs meer dar 6,5 miljoen. 10 Hierdoor ontstonden grote koersverschillen tussen de guiden in Suriname en in Nederland. In 1811 bereikte de verhouding $\mathrm{N} f: \mathrm{S} f$ een dieptepunt van $1: 4$. Bij de teruggave van Suriname aan Nederland was dit echter weer gedaald tot 1:1,25 (Wolbers 1861:625).

De heropening van de handel met Nederland leidde er echter oprieuw toe dat baar geld de kolonie uitstroomde en het kaartenge!d deprecieerde. Tussen 1816 en 1827 liep de agio op het Surinaamse kaartengeld dan ook op van 45 naar $210 \% .11$ In : 827 werd bij Koninklijk Besluit de agio officieel op laatst genoemd percentage vastgesteld. Bovendien werd voor 2,4 miljoen aan banknoter van de Algemeene Maatschappij ter Bevordering van Volksvlijt te Brussel in omloop gebracht en voor nog eens $f 400.000$ aan zilver-en kopergeld (Wolbers 1861:626-8). De volkomen afhankelijke structuur van de Surinaamse plantageneconomie zorgde er echter voor dat dit 'harce' geld binnen de kortste keren het land weer uitstroomde, vooral natuurlijk naar Nederland.

Om aan de financiële chaos een eind te maken en de plantage-economie te helpen opkrikken, werd door de Nederlandse overheid - met voorop Koning Willem I en zijn Mirister van Marine en Koloniën C. Elout - in 1828 Johannes van den Bosch als negentiende-eeuwse 'troubleshooter' naar

KA-37, 6

110 I'ublic Record Office: Colonial Office 278, 12 en 13.

11: Collectie-Insinger \& Co., Informatiebsek. 
Suriname en Curacao gestuurd. In Suriname was zijn opdracht het bestuur te hervormen tot een doelmatig apparaat, wat hem ook redelijk is gelukt. Verder moest hij zich bezighouden met het vraagstuk van de afnemende slavenbevoiking, wat pas in 1851 leidde tot een nievw slavenreglement, en moest hij de planiage-economie van nieuwe impulsen voorzien. Dit laatste dacht hij te bereiken door absolute voorrang te verienen aan de produktie van suiker met moderne werktuigen en doo: de oprichting van de Particuliere West Indische Bank in 1829. Deze zou gaan fungeren als wisse:én kredietbank.

Volgens dit plan moest eer particuliere bark in . Nederiand een bepaald kapitaal ter beschikking houden, waarvoor de PWI-Bank biljetten zoid uitgeven miet een gegarandeercie agio van 1:1. In Paramaribo kreeg men dan. tweemal per week gelegenheid om wissels te verkrijgen op de ageriten var. de bank in Nederland. Verder werd iitdrukkelijk bepaald dat de bank kredieten zou verlenen te: uitbreiding van de suiker- en indigocultuur (Wolbers 1861:652-3).

Dit initiatief werd a: meteen gefrustreerd door de weigering vas het Ltrechtse bankiershuis Vlaer \& Ko:̈ voor dit project drie miljoen gulden beschikbaar te hovden. Ook andere bankiers b.cken hiertoe niet bereid, een duideljik tekern dat de Nederlandse 'haute finance' geen vertrowwer had in de Surinanmse piantage-economie. Het benodigde kapitaa: werd toen maar vrijgemaakt uit he: Amortisatiefonds, zodat in feite de Nederlardse overheid voor dexixing zorgde.:12

Als trveede waarborg voor de PW:-Bank moest iecuer jaar $f 150.000$ uit de Surinaamse Kolorja:e Kas worden overgemaakt naar de kas van de bank. Om bovendier. de bank een rog meer solide aanzien en cachet te geven werden in de hoofddirectie, naast iwee bezoldigde commissarissen en een secretaris, de drie hoogste koioniale amblenaren van Suriname benoemd: de Gouverneur-Geleraal, de Frocureur-General er de Contro'eur-Generaal. Ilermee was de bank eer pure overheidsorderneming geworden. I le: 'Particuliere' b!ec: in de nam van de bank gehardliaafd in de hoop dat zij dit ooit nog eens zol1 worden. In foite werd het exhter het symbool van de mislakte poging particuier kapitaal voor de Surinaamse piantage-economie te interesserer..

Dit nam niet weg dat het enthousiasme van Surinaamse planters en administrateurs voo: de opgerichte I'WI-Bank zeer groot was. De gedeprecieerde Surinamse gulden verkreeg weer zijn volle waarde (al was dat natuurlijk nie: voor iedereen voordelig) en er kwam weer ruime gelegen-

1:2 ARA: Collectie-Van den Bosch, 102: Gioeneveld Meyer 1919:34. Het Amortisatiefonds was door de Nederlandse overheid ingesteld om, met geleend geld, ce staatssch:ild af te kussen. 
heid wissels op Nederiand te trekken. Dat hiervan ook volop gebruik is gemaakt bleek toen via de bank in de jaren 1829-1831 voor $f 1.260 .000$ meer wissels werden getrokken dan wit Nederland werd overgemaak! \{Wolbers 1861:654).

Het enthousiasme werd nog eens vergroot door de mogelijkheid plantagehypotheken bij de bank af te sluiten. De bedoeling daarvan was tweeledig. Enerzijds konden hiermee ouce hypotheken in Nederland worden afbetaald, waardoor uiteindelijk minder kapitaal aan de Surinaamse geldcirculatie zou worden onttrokken. Anderzijds diende het krediet ter stimulering van de suikersector (en in mindere mate indigo), door de uitbreiding van slavenmachten en de aanschaf van stoommachines financieel mogelijk te maken. In groten getale klopten planters nu bij de bank aan om 20 'n krediet te bernachtigen. Een van hen was bijvoorbeeld de Britse planter Alexander Cameron. Deze meldde in oktober 1829 de directie van de PWI-Bank dat hij $f: 60.000$ nodig had om zijn naast elkaa: gelegen koffieplantages Lodew:jksburg en Sporksgift, met samen 212 slaven, om te bouwen tot één suikerplantage met een stoommolen. Of hij daarmee ook oude schulden wilde atlosser. is niet bekend, maar gezien de hoogte van het bedrag is dat wel waarschijn:ijk. ${ }^{113}$ In iecier geval werd Camerons verzoek gehonoreerd.

Evenals in de achttiende eeuw werden de hypotheken verstrekt op basis van de getaxeerde waarde van een plantage, maar au wel volgens expliciete richtlijnen. De basis voor de taxatie vormde het aantal aanwezige slaven, waarbij $f 1.300$ per slaaf moest worden aangehouder voor suikerplantages en $f 900$ voor andere plantages. De waarde van de overige kapitaa.goederen werd verondersteld hierbij te z:jn inbegrepen. Op grond hiervan kon de planter in eerste :nstantie een kreciet krijgen to twee-derde van de getaxeerde waarde. Een plantage die van een ander produkt op suiker overschakelde kon daarna, als de eerste 50 akkers suikerriet waren geplant, nog eens een-twaalfde daarboven opnewien. Wanneer het suikerareaal zich. opnieuw had verdubbeld mocht de taxatiewaarde en daamee het krediet worden aangepast volgens de norm van $f 1.300$ per slaaf. Bovendien mocht het krediet met een-zesde worden verhoogd op het moment dat er cen stoommachine was geinstalleerd.114

Liteindelijk werden de hypotheekaanvragen van veertien (combinaties

11.3 ARA: PWI Bank, 27. 7.0 had het handelshuis Irsinger \& Co. in 181 is en brief ontvangen van Dean Smith \& Co. to Glasgow, waaxin stond: 'A friend of ours Mr. Allexander] Clameronj of Surinam has lately purchased a property in that colony and proposed to us to come under some money advances reyrired by him for the payment - but we are obliged to decline in consequence of the colony being ceded to the Dutch'. Zij bevalen Cameron ieder. Nederlands handelshuis aan. Wie uiteindelijk met Cameron in zee !s gegaan is niet bekend.

$1: 4$ ARA: PWI-Pank, 26. 
van) plantages gehonoreerd voor een totaal bedrag van $f$ 1.257.200. De kleinste was voor A La Bonheur $(f 25.000)$ en de grootste voor Catharina Sophia en La Prévoyance ( $f$ 180.000). In totaal ging het om vier bestaande suikerplantages, twaalf koffieplantages en twee houtgronden. Tien van deze ondernemingen zouden tot vijf plantages worden samengevoegd. Van de veertien aldus overgebleven ondernemingen zouden twaalf zich met de produktie van suiker gaan bezighouden en twee set indigo. De relatie met de bank werd aangegaan voor een periode van zesentwintig jaar, gedurende welke periode jaarlijks $8,5 \%$ van het grleende kapitaal moest worden betaald voor rente en af:ossing. ${ }^{115}$

Al gauw bleek da: in een aantal gevallen toch (weer) te lichtzinnig tot het versirekken van een hypotheek was overgegaan. Zo kwam de bankdirectie er achter dat van twee hypotheker, met een gezamenlijk kapitaal van f 340.000 , geen cent was besteed aan de expansie van de plantages, maar 'alleen gestrekt hebben tot afcoening van personele schulden'.116 Ook twee andere plartages kwamen al spoedig hum hypothecaire verplichtingen niet na, warop begin jaren 1830 alie zes betrokken plantages voor de som van de schuld door te bank werder. inge'xocht.1:7

Inmidde's ging het ook in een ander opzicht slecht neet de bank. Door de grote onevenwichtigheid in de wisselhandel er. de financiële moeili;kheden van de Nederlandse overheid als gevolg van de Belgische afscheiding, moest de bank in 1831 het trekken van wisse!s op haar raarn staken. Het gevolg was dat er onmiddellijk weer een agio begon te ontstaan op de Surinaamse girlden, die begin jaren 1840 al weer tot 30 a $40 \%$ was opgelopen. ${ }^{118}$ Dit eeuwige Surinaamse probleem (zie bijlage 5) werd in 1847 weer even verlicht, toen uit Nederland een half miljoen in $z \dot{i l v e r s p e c i e ~ i n ~}$ omloop werd gebracht, waarschijnlijk via de zieitogende IWI-Bank. Lnige jaren later tekende zichi echter opnieuw een geldcrisis af, die volgens een aciministrateur

in alle handelingen eene onaangename stagnatie deed ontstaan, daar het bijna ondoenlijk was om wisse's be plaatsen; ren hicld dit gedeeltelijk voor een gevolg van den wecier titvoer van het in omlong gebragte zilver, en gedieclteliji voor eene speculatie van sommigen, om het geld vast te houden, ter: einde daardoor de houders van wissels te noodzaken om dezelver. order pari af te geven, zooals er dan ook reeds tegen 97 en 98 pet. Waren algezet'. 1:9

Wanreer nu de hypothecaire leningen var: de PWl-Barik aan de plantages een produktieve belegging waren geweest, dan had de bank toch nog een

It6 ARA: Collectie Van den Bosch, 1019.

117 ARA: PWi-Bank, 27.

II8 Wolbers, 1861:686; ARA: OAS, SOB\&CW 1828-1876, 2400.

179 Surinaams Miseum: Collectic-Branlsen, Verslagboekje Vossenturg, 1850 
solide basis kunnen krijgen. Het tegendeel bleek echter het geval te zijn, ook bij de plantages die in bezit van de bank waren gekomen. Alle goede voornemens om bijvoorbeeld van de ingekochte plartage Catharina Sophia een modelplantage van de koloniale overheid te maken en daarmee de bank een financiële basis te geven, leken gedoemd te mislukken. Zo werd in 1843 op deze plantage een vacuümpansysteem van Derosne \& Cail geïnstalleerd, die volgens I Iering (1858, II:80-1) zcker één miljoen gulden had gekost. Door onbekwaamheid van de Europese wertuigbouwkundigen liep deze tamelijk complexe machinerie nog in de experimentele fase zodanig stuk dat hij niet meer kon worden gerepareerd. ${ }^{120}$ Dit was er mede corzaak van dat tussen 1833 en 1847 de verliezen van deze plantage opliepen tot meer dan driekwart milioen gulden (Van den Boogaart en Emmer 1977:217).

Ook op de (nog) niet ingekochte plantages leek het geinvesteerde kapitaal niet optimaal te zijn aangewend. Op twee van de plantages waar de basis moest worden gelegd voor een bloeiende indigocultuur, met $f 120.000$ krediet, wilde dit gewas niel aanslaan. Stoommachines werden er dan ook nooit geinstalleerd. ${ }^{121}$ De $f 50.000$ die aan J.C.G. Spilker waren geleend om van zijn koffieplantage I Iildesheim aan de Saranacca een suikeronderneming met stoommolen te maken bleken eveneens weggegooid geld. Twee jaas na afsluiting var de kypotheck bericintte hij dat deze plantage 'voor de suikerru'tuur niet goed beantwoord ondat de zeewinden te veel nadeligen invlned op het riet veroorzaken en zulks den groei beletten'.122

ook de optimistische verwachtingen ten aanzien van de hiervoor aangehaalde plantages Lodewijksburg en Sporksgift werden niet bewaarheid. In 1829 was al 64 ha. op Lodewijksburg met suikerriet beplant en na enige jaren werd inderdaad een stoommachine geïnstalleerd. Twee decennia later had echter de samenvoeging van de twee plantages nog steeds niet plaats gevonden er. bleck het suikerareaal nog slechts 58 ha. te beslaan ${ }^{123}$ Pas rond 1860 werd de combinate een feit er kreeg zij de nieuwe raam Ailiance. Voor de produktivitejt leek deze fusie in eerste instantic geen stimulans. In 1860 en 1862 behoorde Alliance wat betreft de produktic per akker tot de slechtst producerende suikerplantages van Suriname (Koloninle Verslagen 1860 en 1862). Pas larg na de afschaffing van de slavernij zou deze onderneming tot de grotere en beter producerende

120 Hering, 1858, 11:80-1; Van den Bongaar1 er. Enmer 1977:2:6.

121 Teenstra 1835, 1:8-90; Surinaamse Almunuk 1844:59-101.

122 Spilker vroeg, daarom de PWi-Bank :Destemming, de hypotheek en de slaven te mogen oyerbrengen op zijn anderc suikerplantage, De Ecndragt aan de Commetewane. Volgen: hem bezal deze plantage 'een bijzonder goede fabricq, nament.ijk een waterwerk [sic]'. In de roop nog iets van het krediet terug, te re'n, sternde de bank in met dit voorsilel, ook al behoorde' $D$;' Eendragt met zjjn (nu) 98 slaven tot de kleinstc suikerplantages van Suriname en is er nooit een stoommachine gekomen (ARA, l'Wl-Bank, 28).

12.3 ARA: PWI-Bank, 27 in 184. 
plantages gaan hehoren, maar toen bestond de PWI-Bark al lang niet meer (Koloniale Verslagen 1882-1900).

De vijf overige verhypothekeerde suikerondernemingen hebben het niet veel beter gedaan, al werd wel overa! een stoommachine geinstalleerd. Schulden liepen op en de bank moest soms jarenlang procederen om iets van haar geld terug te zien. ${ }^{124}$ Des le merkwaardiger is het daarom dat begin jaren 1840 uprieuw een aantal plantageinypotheken door de PWI-Bank werd uitgegeven. Afgezien van twee kleine geldbedragen aan onbeduidende 'kostplantages', kregen drie koffieplantages an de Commewijne samen ruim $f 195.000$. Twer daarvan schakeiden ove: op de suikerteelt en schaften een stoommachine aan. Daarnaast kregen twee bestaande suikerplantages samen nog eens $f 200.000$. Beide kochten hiervoor stoomwerktuigen en een van de twee, De Resolutie, bleek eind ja:en 1850 zelfs tot de meest geavanceerde plantages van suriname te behoren.i25

Het is niet duidelijk waarom deze hypotheker. nog werden verstrekt op een tijdsip dat de PWI-Bank op sterver na dood was. Mogelijk had het feit dal nog wel ieder jaar $f$ I50.000 uil de Kolonia.e Kas in de kas van de bank werd gestort daar iets mee te maken. Deze bijdrage was per slot bedoeld om de geldcirculatic in Suriname enigszins op peil te houden. Wellicht vond men hypothecaire leningen de beste manier orn dit te bewerkstelligen. Daamaast zijn er toch ook allossingen en rentebetalinger gedaan aan de bank. Kennelijk werd de rentabiiiteit var dit kapitaal van minder groot belang geacht dan he: probleem van de gelicirculatie.

De balans opmakend op het tijdstip dat de eerste hypotheken geheel hadden moeten zijn afgelost (rond 1855) tekent zich het volgende beeld af. De indigocultuur was een fiasco geworden. Vrijwe! alle andere plantages hadden zich op cie suikercultuur toegelegd en stoommachines aangeschaft. Wat dat betreft was hef initialiel van $V$ an den Bosch geslajgd te noemer. In de periode 1855-1860 bieken echter slechts twee van deze plantages to: de best pruducerende van Suriname te behoren, vier lot de slechtste en de rest deed het middelmatig. Niet direct een doorslaand succes, maar bepaald ook geen fiasco. Zeker wanneer bedackt wordt dat een middelmatig prodi:cerende suikerplantage in Suriname alti,d nog met kop en schouders uitstak boven haar soortgenoten in de meeste andere Caraibische plantage-ecoromieën (zie Tabellen 29-31).

In to:aal had ce I'WI-Bank voor ruim $f 1.800 .000$ gulden plantagehypotheken afgesloten. Hoeveel er aan rente is betaald is riet bekend, aan aflosingen is echter niet meer dan circa $f 175.000$ birnengekomen. In 1854

124 ARA: PWI-Bank, nrs. 27, 28 en 182; ARA: SOB\&W 1828-1876, nrs. 511 en 3033; Kolcniar! Verslog 1858-1864.

125 ARA: PWI-Bank, 91; Henng 7858: appendix; Teenstra 1835, 1:44 45. 
bedroeg de schu!d van de (overgeblever) plantages orgeveer 1,5 miljoen gulden, terwijl in de voorafgaande periode een bijna even grote schuld uit de boeken was geschrapt. Tussen 1857 en 1862 werden negen (combinaties van) plantages bij executie verkocht. Volgens een voorzichtige schatting in 1854 had dit de bank zeker $f 330.000$ op moeten leveren, maar de werkelijke opbrengst bleef daar nog bijna $f 40.000$ onder. ${ }^{126}$

In 1870 werd de al jaren zieltogende PWI-Bank definitief geliquideerd. Het beste wat zij tot stand had gebracht, was een krachtige impuls tot innovatie. Voor het overige heeft ook deze geldschieter veel te lichtzinnig kredieter aan plantages verstrekt en te weinig controle daarop uitgeoefend. Van de $f 100.000$ die de piantages gemiddeld aan hypotheek ontvingen had veel produktiever gebruik kunnen worden gemaakt. Vooral omdat de knellende consignatieverplichtingen en provisieregelingen zoals bij de negotiaties hier niet bestonden. I tet probieem was dat met de hypothe'ken oude schulden werden afbetald. Iet was veel stimulerender gewerst voor de plantage-economie wanneer de banx die schulden buiten de hypothexen had gehouden. $\mathrm{Zij}$ had dan die schulden kunnen overnemen en meteen arschrijven. Dat zou een flinke verliespost zijn gesweest, maar met als uiteindelijix resultaat een toegenomen vertrouwen in de piantage-economie, produktief aangewende hypotheken, produktie-expansie en dus winst. De controle van de bank had dan wel veel strakker moeter zijn. $\mathrm{Nu}$ zou het geen verbazing wekken wanneer de hier besproxen planters de bedenkers zouden blijker. te zijn van het bekende Surinamse gezegde 'winti 'e wai, lanti 'e pai'. 127

\section{Mechanisatie in de suiker zonder vreemd vernogen}

In de negentiende eeuw hebben ous een twintigtal plantages krediet van derden kregen om over te schakeler. of de produktie van suiker er/of mecharisatie te financieren. Van vierenveertig andere suikerpiantages die in deze periode eveneens van moderne miachinerieën zijn voo:zien, is het veel minder duidelijk hoe zij aan het benodigde kapitaal zijr. gekomen.

De best renderende plantages zullen de innovaties uit eigen middelen hebben kunnen bekostigen. James Balfour, bijvoorbeeld, boerde $2 n$ goed dat hij voldoende kapitaal kon verzamelen om zelf de aansciaf van strommacinines voor zijn zeer geavanceerde plartage Waterioo te financieren. Een ander voorbeeld was de oude suikerplantage Sinabo aan de Commetewanekreek, waar rond 1840 een stoommachine werd geïntalleeerd. Ondanks de daaraan verbonden kosten kon in de periode 1825-1845 jaarlijks 
een gemiddelde winst van $f 3.150$ aan de eigenaars worden uitgekeerd,28

Op plantage Bleyendaal werd al sinds 1822 gesproken over de aanschaf van een stoommachine, maar het werd steeds te duur bevonden (circa $f 40.000$ ). In $1853 \mathrm{kwam}$ het er uiteindelijk toch van, maar tot die tijd was dit de laatste onderneming in Suriname waar werd gewerkt met eer beestenmolen. Toch was de voortdurende aanschaf van trckdieren ook een grote: onkostenpost. Zo werden in 1845 acht muilezels en vier Canadese paarden gekocht voor $f 3.800$. Het jaar daarop waren er al weer vijf gestorven aan de 'kwade droes' en konden slechts twee nieuwe worden aangekocht. Aangezien de eigenaars in Necierland verder 'hogelijk tevreden' waren over de prestaties van deze plartage, werd besluten dan toch eindelijk een kleine stoommachine van $f 6.600$ aan te schaffen. De ba:ans van de plantage rechtvaardigde dit ook wel, want tussen 1840 er: 1849 werd per jaar een bescheiden winst van gerriddcld $/ 2.600$ gemaakt. Bovencien dacht men met de verkoop var. de resterende dertig mulezels de aankoop van de machine te kunnen bekostigen. Fn zo gebeurde het erige jaren later ook.129

Op koffieplantage Zo:g en Hoop aan de Commewijne verliepen de zaken wee: anders. Deze plantage behoorde tot dezelfcie Sociëteit van Eigendom als Bleyendaal, die onder directie stond van de firma Wed. J. van de Poll $(v / h$ negotiatie letter $A)$. In 1829 werd besloten deze koffieplantage tot een suikerondernemirg te laten ombouwen, warvoor de totale kosten op ongeveer $f 50.000$ werden geschat. Tien aar later was de hele operatie pas achter de rug en bleek ruim het drievoudige bedrag te zijn uitgegever. Dat desondanks niemand failliet ging kwam door de steun van de Sociëteit van Eigendom. Deze verkocht namelijk twee minder hoopgevende koffieplantages uit haar fonds en liet de meerderheid van de slaver, evenals enkele gebouwen, overbrengen naar Zorg en Hoop. Daarnaast konden de cirie houtgronden die tot het fonds behoorden voor een goede prijs worden verkocht. Met deze opbrengsten kon ket grootste deel worder gedext van de ruin $f 91.000$ warmee de Litgaven van Zorg ea Hoop de inkornsten in die tien jaar overtroffen. Het restant werd boor de goede resultaten begin jaren 1840 goed gemaakt. Daarvoor had men dus wel lang geduld moeten oeferen. Vreemd vermogen was aan deze operatie niet te pas gekomen, maar zonder de steun van cie Sociëteit van Eigendom was het nooit gelukt. De benodigde slaver koncien voor niets worden geleverd er. de (veel te optimistische) kostenraming kon zonder vervelende consequenties langdurig er. ver worden overschreder.. ${ }^{13}$

32.8 RAL: Arch. Des Tombes, 179:

129 GAA: PA-600, 544 en 545.

130 GAA: ['A-600, 544 en 545. De geschiedenis van Zorg en Hloop is uitvoerig beschreven in de scripttie van Van Rensclaar (1935) waaruit ik - onk voor de geschiedenis van de PW:-Bank dankbaar heb mogen putien. 
De voorbeelden van Waterloo, Bleyendaal, Sinabo en Zorg en Hoop laten zien dat het in de negentiende eeuw moge!:jk was te mechaniseren zonder vreemd vermogen, al was op Zorg en Hoop daarbij de steun van ce Societeit van Eigendom onontbeerlijk. Waterloo en Sinabo waren nooit met schulden bezwaard geweest. Zorg en Hoop en Bleyendaal wel, maar beide plantages waren rond 1800 - dus lang voor de mechanisatie - voor de som van de schuld dow het negotiatiefonds ingekocht. Het zou echter te voorbarig zijn te concluderen dat plantages waar zonder vreemd vermogen werd gemechaniseerd in het algemeen redelijk goed rendeerden, of dat achttiende-eeuwse schulden mechanisatie in de weg stonden. Daarvoor is toch te weinig bekend over de tinanciële situatie waarin de meerderheid van de (suiker)plantages verkeerde.

De slechte gang van zaken met de negentiende-eeuswse plantagehypotheken had tot gevolg dat tegen het midden van die eeuw veel plantages, op last van schuldeisers, zoals de PWI-Bank, bij executie moesten worden verkocht. Ilet is opmerkelijk dat voor deze plandages inderdaad kopers werden gevonden. Kennelijk waren er nog genoeg kapitaalkrachtige personer die in staat waren deze plantages op te kopen. Gezien de flinke expansie van de slavempopulatie in de suikersector, bij een chronisch sterfte-overschot iigt het voor de hand dat de plantages werder. gekocht vanwege de daarop aanwezige slaven.

Al waren de prijzen die voor de geveilde plantages werden betaald een fractie van wat zi; rond 1770 hadder. gedaan, toch ging het nog om aanzienlijke kapitalen. Zo werden tussen 1849 en 1862 tenminste 46 plantages verkocht voor een gezamenlijke som. van ruim $f 1.322 .000$ (exclusief verkoopkosten). In totaal verwisselden hierbij 6.015 slaven van eigenaar, zodat een gemiddelde slaa! ongeveer $f 220$ kostte. ${ }^{131}$ Dit lijkt volkomer in tegenspraak mei de eerder gedane constatering dat in de negentiende eeuw slaven schaars en duur waren. I Herbij dient echter te worden bedacht, dat de slaven siechts 'en bloc', dus plantagegewijs, verkocht mociten worden en een koper zich gelukkig mocht prijzen wanneer de holft daarvan 'werkbaren' waren. De overigen moest hij letterlijk op de koop toe nemen. Dit gegeven was natuurlijk in die gemiddelde prijs ingecalculeerd.

Het opvallende is dat het overgrote deel van de plantage-aankopen werd gedaan door ter plekke wonende Surinaamse planters. Onder hen moet daarom flink wat kapitaal aarwezig zijn geweest. Wat te denken bijvoorbeeld van Anthony Dessé, die in 1844 (mede-)administrateur was van drie plantages. Tien jaar later was hij eigeraar van de katoenplantages Good Intent (141 slaven), Leasowes \& Clyde (stoom, 322 siaven) en Inverness $\{56$

131 ARA: OB\&W 1828-1876, 511 en 512; Collectie-Insinger \& Co., Informatieboek; Surinaams Museum: Collextie-Brantsen, verslagboekje Vossenburg 1850; CAA: PA 600, 544. 
slaven). In 1856 en 1857 kocht hij daarbij nog de katnenplantage Saxah (stoom, 300 slaven) en de suikerplantage Paradise c.a. (stoom, lopende banden, 296 slaven) voor een beürag van $f 240.000 .^{132}$ Nog opvallender was de expansiedrift van Hugh Wright, die in 1844 nog helemaal niet onder de Surinaamse planters werd genoemd. In 1853 bleek hij echter mede-eigenaar te zijn van suikerplantage De Coede Vrede (stoom, 428 s.aven) en volledig eigenaar van de katoerplantage I.ivonia (139 slaven) en plantage I fooyiand, die met zijn stoommachine, lopende banden en 660 slaven tot de best geëquipeerde suikerplantages van Suriname beinoorde. Ir. de jaren daarna kocht hij bovendien rog eens de piantages leydenshoop (katoen, 141 slaven), Hanover en De Twee Kinderen (hout, 209 slaven) en suikerplantage Bentshope (stoom, 162 slaven), waarvoor hij totaal $f 67.000$ op tafel legde. ${ }^{133}$ Wellicht had deze planter zijn xapitaal eerst elders in het Carainisch gebied verdiend en zag hij nog genoeg perspectief in de Surinaamse plartage-economie om daarin zijn geld te steken. In de meeste gevallen zal ret kapitaal echter afxomstig zijn geweest van planters die als administrateur var meerdere plantages een aariig spaarduitje hadjen weten op te bouwer. Fen positie: bijverschijnsel var deze ontwikkeing was dat het absenteisme in de suikersector tussen 185.3 en 1860 daalde van 67 naar $50 \%$. 134

Samenvattend kan vorden gesteld dat het in Surisaamse piasiages geïrvesteerde kapitaal gedurende de eerste zes decusnia van de regentiende eeuw çua bedrag geen verge:ijking kon doorstaan met het derde kwart van de achtijezlde eeuw. Toch ging het nog om vele mijoenen guldens. Dit kapitaal is met name gebruikt om de katoen- en suikersector op te bouwen, wit te breiden en te moderniseren. Als gevolg var. het funeste roofbouwbeleid in de koffiesector werd daar nog slechts mondjesmat kapitaal ingestoken. Deze sector heeft het slechte imago van de plantage-economie als geheel in belangrijke mate bepaald. Het eind achstiende eeuw ontwikkelcie wantrouwen van Necierlandse beleggers ten aanzjen van de plartage-economie lijkt nooit echt te zijn overwomnen. De negatieve resultaten vail de door de PWI-Bank verstrekte plantagehypotheken hebben dit wantrouwer opnieuw bevestigd. Toch heeft deze jank, met op de achtergrond de Nederlancse overheid, stimulerend grewerkt op de

132 Surinaamse Almanak 1844:59-101: Van Sijpeste:jn 1854:141-7; ARA: SOBAW 1828-1876, 511 en 512.

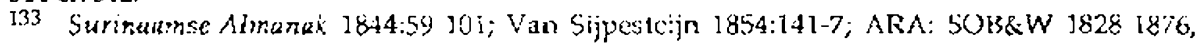
511 en 512.

134 Surinamse Álmanak 1844:59-1C1; Yan Sijpesteijn 1854:141-7; ARA: SOB\&W 1828-1876, 511 en 512 en takel $G$ L. Waarschi;ntigk lag in 1860 het absentëismepercentage nog laget, ang grian niet van alle plantageverkopen de koper bekend is, maar deze zeer waarschijn'ijk wel in Su iname woorachtig was. 
mechanisering van suikerplantages. Niet kwantificeerbaar, maar eveneens duidelijk stimulerend is de rol geweest van zowel Brits als Surinaams kapitaal. Dit was een nieuw verschijnsel in de Surinaamse plantageeconomie. De afhankelijkheid van Nederland nam daardoor enigszins af.

In het algemeen lijkt het kapitaal in de tweede helft van de achttiende eeuw niet specifiek te zijn bestemd voor de reproduktie van de plantageeconomie. Vooral het negotiatiesysteem bleek in al zijn aspecten de ultieme vorm van roofbouw. In veel mindere mate geldt dit voor het negentiendeceuws kapitaal, dat in meer oprichten werd ingezet voor het overleven van de plantage-economie. Het gevolg van dit alles was dat de Surinaamse plantage-economie in 1862 van ongeveer gelijke omvang was als bijna anderhalve eeuw daarvoox, toen de koffie haar intrede deed. Alleer waren de plantages groter en produktiever geworden. 


\section{HOOFDSTUK VIII}

\section{Wat brengt het op?}

Het is de vraag of de bezitters van Suriname altijd even gelukkig zijn geweest met lun eigendom. Zo werd in 1791 een der 'eigenaars', de WIC, in failliete staat opgeheven, made als gevoig van de gemiddeid bijna $f 75.000$ die gedurende de twee vooraigaande decennia jaarlijks op dit bezit moest worken toegelegd (Coslinga 1985:596). Het volstrekt onbetrouwbare betalingsgedrag van Surinaamse planters en kostbare expedities tegen de marrons waren er de oorzaak var. dat sinas het iaatste kwart van de achttiende eeuw de koloniale balans veijwel chromisch een deficit vertoonde. ${ }^{1}$ In. 1803 beliep de schuld van alle koioniale kassen in Suriname bijna 2,5 miljoen guiden. I let grootste dee daarvan werd gevormd door het tekort van de zogesaande Cassa tegen de Weglopers, voor het grootste deel bestemd voor de binnenlandse dnfensie. (Wolbers 1861:497-8).

Gedurende de volgende zes decennia morhten achtereenvolgens de Fngelse en Nederiandse overheid, als bezitters van Suriname, blij zijn war.neer de koloniale irkomslen de uitgaven en:gszins dexten. In de meeste jaren was dit riet het geval en moes er uit Europa vooridurend op worden toegelegd (zie Bijlage 5).

1 De beel (1984:20) schrij̧t bijvourbezid over de eerste Boni-burlog: "De kusters van de

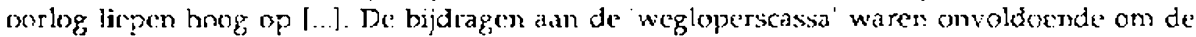
kosten van 40 milikaire poster, het korps vrijnegers 'waarvar, alleen al de oprichting in. 1772 mectr dan $f 100.000$ kosite. en de talrijke lasidragers ten behoeve van de expeciites te kunner:

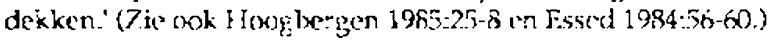

Verder is in vijwel allo plan:ageboekhoudirgen terug te viaden hoe onregelnatig bijvoorbeeld de twee belangrijkste be astingen, aan het Comproir der Hocfdgelden en de Cassa Tegen

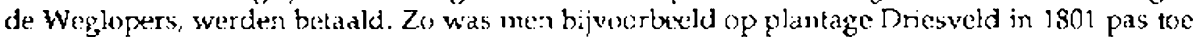
aan de hetaling voor de Wegloperskas var $179.3 \mathrm{~cm}$ werden in 1804 in een kcer alle hoofdgnlden van de jaren 1797-1804 betaald (C:Alk:Coliectie-Hudig, 570). Jriesve.d was hiermee bepaald geen ailzondering. Bovendien werd tufeinde:ijk toh adn de verp'ichtingen voldaan, wat ook niet overal gebeurde. Wolbers (1861:354) schreef dat in 1777 vonr de Cassa tegen do Wrglopers over de jaren: 773-3775 door de pianters tolaal f 474.351 nog niet was voliaan.

Een fraaj staalije van bet slechte betalingsgetrag van Surinaamse plantets in het algemeen is terug te vinden in de boekhousing van plantage Vossenburg. In 2826 hiejder de administrateurs zich daar bezig met het incasseren van isitstaande schulden. Die bleken vaak a: zeer oud te zijn, matar waren jeder jaar opizieuw in de balans oppenomen. Me: besloot daarom nic: verder terug te zoeken dan 1785: Het resultait van dit onderzonk was 'dat de morste van dezelye reeds zeer oud, en derhalve nimmer tot likwiditeis zu:len kurnen worden gebrag! laangezien] veele var die Debitcuren of Crediteuren reeds lang cood of geheel insolven:

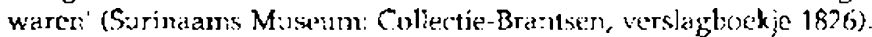


Dit alles hoeft echter nog riet te betekenen dat ook de plantages chronisch onrendabel waren. Voordat de ontwikkeling van hun rentabiliteit kar worden besproken, dient eerst enig inzicht te worcen gegeven in de kosten en baten van deze ondernemingen. Een complicerende factor daarbij is de omstandigheid dat aan beide zijden van de oceaan verschillende boekhoudingen werden bijgehouden. De ene vermeldde de inxomsten en uitgaven in Suriname, de andere die in Europa. Hoogst zelden zijn echter beide boekhoudingen bewaard gebleven, wat een goed inzicht ernstig bemoeilijkt.

\section{De kosten}

De kosten voor het opbouwen van een plantage waren formidajel. Biom (2787:133) rekent voor dat dit bij een gemiddelde suikerplantage met 140 slaven en een watermolen $f 155.000$ bedroeg. In zijn tijd waren echter al zeker een halve eeuw geen stikerplantages meer aangelegd, zodat dit een zeer fictieve schatting was. Wel kon Blom uit ervaring spreken over de vervanging var beestermolens coor watermolens die op grote schaal plaats vond. De minimale kosten daarvan, inclusief een apart kookhuis, schat hij op $f 65.000$ (Blom 1787:133). ${ }^{2}$

Het opzetten var een gemiddelde koffie- (of katoen)plantage met 124 slaven en een grote loocis kostte volgens Blom (1787:235) bijna $f 99.000$. Voor alie soorten plantages gold de aanschaf van een grote groep slaven als de belangrijkste kostenpost.

De lopende onkosten van een plantage bestonden wit een groot aantal verschillende posten. Voor eer goed inzicht is enige ordening daarin wenselijk. Het ligt voor de hand de kosten gemaakt in Suriname te groeperen tegenover die in Nederland. Dit is niet erg eenvoudig, omdat de uitgaven in Suriname nu eens niet en dan weer wel werden betaald met wissels, zogenaamde iraittes, getrokken op de koopman-bankier in Nederland, waardoor het in het laatste geval dus Nederlandse uitgaven werden. Daarnaast kunnen de kosten voor het plantage-onderhoud (produktiekosten) worden onderscheiden van de kosten v(x) he: op de markt brengen van de produkten (marktkosten). In het algemeen wercien de marktkosten vrijwel geheel in Nederland gemaakt en ook eventuele betalingen in verband met hypotheekschulden werden daar afgehandeld. Produktiekosten werden daarentegen aan beide zijden van de oceaan gemaakt.

Gebrek aan (complete) bronnen maakt het helaas onmogelijk een verantwoorde ontwikkeling van de kosten te schetsen. Op basis van de boekhoudingen van de suikexplantages Groot Marseille en Vossenburg in de 
periode 1820-1840 kan echter toch enig inzicht worden verkregen in de kostenverhoudingen. ${ }^{3}$ De totale kosten die jaarlijks werden gemaakt voor deze plantages beliepen gemiddeld bijna $f 50.000$. Hiervan namen de marktkosten $52 \%$ in beslag en de produktiekosten $48 \%$. Laatstgenoemde kosten waren als volgt verdeeld: $27 \%$ werd besleed aan benodigdheden in Suriname en $24 \%$ aan goederen uit Nederland. Verder werd $16 \%$ uitge geven aan de aankoop en huur van slaven en $8 \%$ aan betalingen aan ambachtslieden. Drie posten . belastingen, plantegestaf cn adiministrateurs besloegen ieder $7 \%$ van de kosten. De resterende vier procent werd besteed aan overige kosten, zoals medische zorg.

De onkosten die werden gemaakt voor de aanschaf van allerlei plantagebenodigdheden vormden veruit de grootste post en waren vrijwel gelijk over Suriname en Nederland verdeeld. Ongeveer een-derde hiervan bestond uit bouwmaterialen zoals hout en steen. Zo moesten alleen al voor de bouw van het nieriwe konkhuis op Groot Marseille 80.500 mopstenen, 22.000 blauwe tegels, 1.000 plavuizen, 165 vaten kalk en 82 vaten cement worden gekocht, grotendepls in Nederland. In feite werden nog veel inper materiaalkosten gemaakt, want er werd ook bij de Aucaanse bosnegers veel hout aangeschaft, alleen werd dat geruild tegen eiger. geproduceerde dram. Daarnaast werd een aanzienlijk deel van deze onkosten in beslag genomen door de leveranties van kost, met name bananen, voor de slaven.

let aantrekken van arbeid besloeg eer belangrijk deel van de produkliekosten. Ir de onderzochte periode bedroeg het gemideld aantal slaven op Groot Marseille 135 personen en op Vossenburg 255. Totaal werden in deze jaren 74 slaven aangekocht ( 25 mannen, 21 vrouwen, 2 jongens en 16 meisjes) voor een gemiddeide pri;s van $f 675$ per persoon. Bovendien werden op Vossenburg voor specifieke werkzaamheden soms ook nog slaven gehuurd.

Het normale onderhoud van de plantagegebouwen en de fabriek werd door de eigen ambachtsslaven verricht, maar als er omvangrijker werkzaamheden rodig waren, werden armbachtslieden uit de stad aangetrokken. Zo werden in deze periode op Groot Marseille een compleel nieuw kookhuis met toebehoren en cen nieuw scheprad voor de watermolen gebouwd onder leiding van eern metselbaas, een smid en cen molenmaker. Ook op Vossenburg vonden de nodige bouwwerkzaamheden plaats (zie Bijlage 8).

De belastingen bestonden hoofdzakelijk uit een personele belasting, de zogenaamde hoofdgelden ( $f 2,50$ per vol wassene en kinderen beneden 12 jaar de helft) en een defensiebelasting, de Cassa tegen de Weglopers $16 \%$ van de inkomsten uit dram en melasse, op koffieplantages $6 \%$ van de geschatte koffie-opbrengst).

3 Yames Ford Bell Librany: B1482, Atchief De Mey Van Streefkerk; Surinaams Museum: Collectie Branlsen, verslagboekjes en verantwoorde rekening. Lie cok Oestindie 1989:279-87. 
De blanke staf bestond op deze plantages uit een directeur met een salaris van $f 1.200$ tot 1.600 per jaar en een of twee voortdurend wisselende blankofficiers die $f 125$ tot 150 per jaar verdienden. De beloning van de administrateurs bedroeg $10 \%$ van de geproduceerde suiker (deze is niet in de berekening opgenomen) en $10 \%$ van de in Suriname geincasseerde gelden.

Beide plantages beschikten over en zogenaamde dresneger, maar desondanks werd ook de medische zorg grotendecls aan specialisten overgelaten. Zo hadden de plantages een vast contract met een chirurgijn a $f 1$ per slaaf per jaar, exclusief medicijnen. Deze was de gehele regio van dienst. Dit was echter niet voidoende, want verschillende malen werden zieke slaven raar kundige dresnegers op andere plantages gestuurd en gingen vrouwen vaak bij speciale vroedvrouwen bevaller. Ook daarvoor moest worden betaald. Deze prakt:jk was het gevolg van de verbeterde slavenzorg in de negentience eeuw en zal in de achttiende eeuw veel minder zijn voorgekorren.

Samenvattend kan worden gesteld ciat de plantage-onkosten voor het grootste deel werden bepaald door de enorme hoeveelheid benodigdheden (ruim 51\%) die een dergelijx grootschalig bedrijf met gebondim arbejd nodig had." Verder is het opmerkelijk dat in cen systeem dat grotendecls was gebaseerd op onbetaalde arbeid, bijna cen kwart van de produktiekosten uit geldelijke beloninger bestond. Toch is dit mincier vreemd dan op het eerste gezicht lijkt. Grootschalige, arbeidsintensieve ondernemingen die werken met gedworigen arbeid, zullen. veel kosten moeten maken voor de controle op en het beheer van die arbeid. Deze tendens werd bovendien versterkt door het verschijnsel van de absenfe eigenaars, die contro'e en beheer moesten overlaten aan goed betalde administrateurs. De rest van de loonkosten werd betaald aan specialisten, zoals molenmakers en chirurgijns. Ook zij werden uit rationele overwegingen aangetrokken, wan: wanneer daarvoor speciaal opgeleide siaven moesten worden aangekocht en onderhouden was men waarschijnlijk duurder uit en werd het niet direkt produktieve deel van de slavenbevolking te groot.

De uitgaven voor het in Nederland of de markt brengen van de plantageprodukten bestondien eveneens uit verschillende posten. Allereerst waren dat de koster, voor het vervoer var de produkten naar Paramaribo. Dit gebeurde door zogenaamde pontevoerders die met eigen boten er. slaven het goederenvervoe: van en naar ce plantages verzorgden. Waarschijnlijk bestond dit beroep in de achtriende eeuw nog niet en werd het vervoer toen nog geheel met de eigen plantageslaven geregeld. Weliswaar

4 Hier dien: wel de kantlexesuirg te worder gemakt diat genaakte kosten en noodzakelijke kasten niet altijd gelijk zijn. Voor zover valt na te gaan was dit echter bij Groo: Marseille en Vossenburg wel het geval. De slavermacht bieef in deze periode goed op peil, de gebouwen werden goed onderbouden en er werd flink in de fabriek geïnvestexid. 
waren pontevoerders niet goedkoop, maar zij leverden wel een belangrijke arbeidsbesparing op.

In Paramaribo werden de produkten steekproefgewijs gekeurd en gewogen en opgeslagen voor het vervoer raar Nederlard. Vanwege de al eerder vermelale grote kwetsbaarheid van dit transport werd de lading vrijwel altijd verzekerd bij koopman-barkiers in Nederland of Engeland. Op basis van de geschatte waarde van de prodnkten moest dan een bepaald percentage aan assurarticpremie worden betaald. In normale omstandigheden schommelde dit tussen 3 en 5\%. In tijüen var oorlog kon dit echter oplopen tot 12 en soms zelfs $25 \% .5$ Voor ce periode dat de produkten in . Veder:and in een pakhuis lagen opges.agen, werd een speciale verzekering afgesioten tegen brand.

Een voigende kostenposi vornden de diverse belastinger: die samenhingen met het op de markt beengen van de produkter. De belangrijkste daarvar waren de zogenamde 'uitgaande rechten' in Suriname. Daarnaast waren er inkomenóe rechten in Nederland, havengeld en alleriei zegels die moesten worder voldaan. Verder waren er onkosten voor pakhuishuur, de waagmeester en allerlei sjouwers.

Tot slot moesten verschillende kortingen en provisies betald worden aan de koopman-bank:er, in verband met zijn werk voor de plantage en voor het aanbrergen van de assurantie; aan de makelaar your zijn bemiddeling bij de verkoop en als delcredere, een soort borgsom, en verder warer. er nog posten als kortinger b:j contante betaling.

De relatieve verdeling van de marktiksten zag ar dan als volgf uit: vracht (54\%), provisies en kortirgen (23\%), belastingen (10\%), assuranties $(6 \%)$ en produktopslag $(7 \%)$. Wanneer de vachtkosten en assuranties worder. samengete:d blijken de marktkosten voor drie-vijfde te zijn bepaald door het transport van de produkten. De resterende twee-viffde werden opgesoupeerd door een bonte rij personen en instanties die eer graantje meepikten.

plantage- en markikosten plus een aaridi verwante onkostenposten verschaffen het volgende jeeld: belonirgen en belastinger vergden $35 \%$ van de kosten, vracht en assurantie $33 \%$ en benudigdheden en slaven $32 \%$. Ifet is opmerkelijk dat de grootste kosten werden veroorzaakt door de ange kelting van personen en instanties die zich tusser. de slaven en de plantageeigenaar in bevonder. en allemaal mee profiteerden van de produktie. Natuurlijk stoncien daar ook diensten tegenover, maax het zal de rentabiliteit niet erg ten goede zijr. gekomen.

Al is het yoorafgaande kostenbeeld afkomstig van slechts iwee suikerplantages, toch bestaat, op basis van het schaarse materiad dat voorhanden is, de indrak dat hel hier niet om een atypisch voorbeeld gaat. Bovendien 
lijkt dit beeld ook redelijk te kloppen voor koffleplantages (zie Van Stipriaan 1982:72-5). Over katoenplantages is, wat dit betreft, geen materiaal voorhanden. Over de globale kostenontwikkeling in de loop van de periode 1750-1863, kan worden herhald dat hierover geen zinnig woord is te zeggen. Het enige dat vast staat is de stijging van de siavenprijzen, de wisselvalligheid van de assurantiekosten, afhankelijk van de internationale politicke situatic, en de waarschijnlijke daiing van de vrachtprijzen in de loop van de negentiende ceuw (Oostindie 1989:284).

\section{De baten}

Ook de plantage-inkomsten kenden een Niederlanöse en een Surinaamse kant. Al moesten in principe alle plantageprodukten in Nederland worden verkocht, toch kwam. het voor dat een deel in Suriname van de hand werd. gedaan om tijdelijk lokale kosten te dekker. De Surinaamse inkomsten uit de verkoop van bijprodukten, zoals dram en melasse op suikerplantages en bananer op xoffieplantages, waren van meer structurele aard. Deze vormden een welkome bijdrage in de lokalk kostenbestrijding er maakfen vaak een flink deel uit van het totale inkomen. Katoenplantages waren wat dat betreft slechter as, omdat zij niet over dergelijke extra inkomsten konden beschikken.

Voor de achttiende eeuw zijn geer. gegevens beschikbaar die enig inzicht in deze inkomstencomponent kunnen verschaffen, voor de negentiende eeuw echter wel. Toch is het, wat betreft koffieplantages, vrijwel ondoenlijk vast te stellen hoe groot het gemiddelde aandee: was van de bananeninkomsten in het totale inkomen. Koifieplanters reageerden namelijk zeer verschillend op de achteraitgang van de koffiecultuur. De een liet de bananenaanplant voor wat hij was en probecrde nog zoveel mogelijk inkomsten wil de koffieproduktie te halen, terwijl de ander juist een steeds groter belang ging toekennen aan de neveninkomster uif banarenproduktie. 7o bestonden in de jaren 1820 op plantage Clifford Kocqshoove. de inkomsten voor slechts $6 \%$ uit de verkoop van bananen, terwijl dit begin jaren 1830 op jagtiust ruim $63 \%$ bedroeg en bijvoorbeeid plantage Katwijk rond 1850 zelfs alleen nog maar inkomsten uit banaren had. Dit laatste was overigens geen s'echte keuze, want de netto-inkomsten die dit rord I860 opleverden waren even groot als de bruto-inkomsten (nog zonder aftrek van alle marktkusteri) uit koffie rord $: 830.6$ Op basis van enkele andere

6 KII: 8853; Collectie-Insinger \& Co., Notulboek Jagtlust etc; AiRA: SOB\&W 1828-1876, 3031; ARA: OAS, Slukken gedeponeerd bij bes:uursarchieven, 7; ARA: Suriname na 1828, Gemeentebestuur, 56. Dic inkomsten van Katwijk bedroegen ruim $f 11.000$. Rond 1830 prodiceerde deze plantage gemiddeld nog $17.000 \mathrm{~kg}$ koffie per jaar. Twee decennia later was dit gedald tot niel meer dun gemiddela $2.300 \mathrm{~kg}$ per jaar en kon sieckts door de aanvullende 
plantages mag echter wel worden aangenomen dat, in ieder geval in de jaren 1820 tot 1840 , het aandeel van de bananenverkopen in de totale inkomsten van koffie-ondernemingen zo'n 15 a $20 \%$ bedroeg.

Van de neveninkomsten op regentiende-eeuwse suikerplantages is een exacter beeld te krijger. Op deze ondernemingen werd de geproduceerde dram en melasse voor een klein deel door de eigen slaven geconsumeerd en voor het overige verkocht. Dram, de dagelijkse 'sopie' voor de slaven, werd verkocht aan plantages, die deze drank niet produceerden, terwijl de melasse merendeels werd verkocht als retourvacht aan Amerikaanse scheepskapiteins, die cie kolonie van proviand en vee vooszagen. ${ }^{8} \mathrm{Fr}$ ontstonden echter problemen aan het eind van de jaren 1820 , toer in de Verenigde Staten ook steeds meer suiker werd geproduceerd. Om de eigen markt te beschermen werd daat in 1829 een zware importbelasting op melasse geheven, met als gevolg dat er veel minder Amerikaanse schepen naar Suriname kwamer. De p'anters raakten hin melasse steeds moeilijke: kwijt, waardour de prijs aanzienlijk daalde, van 40 cent per gallon in i8201829 tot 18 cent tussen 1850-1859. Daamee daalde natuu:lijk ook het aandeel van deze neveninkomsten $\operatorname{van} 29 \%$ in $1815-18: 9$ tof $14 \%$ in $1850-1859$.

Wat betreft de inkomsten uif de hoofdprodikten van de diverse typen plantages, waren de planters natuurlijk sterk afhankelijk van het prijsniveau op de Nederlandse maxkt. Al werden in de achttiende-eeawse Republiek, ne: als bij de andere Europese grootmachten, in principe mercantilistische beginselen van monopoliehande: met cie eigen koloniën aangehangen, de markt yoor tropische prociukten stond toch wagenwiji open voor buiter. landse mededingers. Zo afgeschermd als de Britse markt was, zo open stond de Nederlandse, in het bijzonder voor Franse produkten. Iierdoor was het voor Surinaamse planters in de tweede heift van de achttiende ceuw onmogelijk een overheersende positic op de Nederlandse markt te verwerven. Het Surinaamse andeel op de Nederlandse suikermarkt fluctueerde tussen de 20 en $34 \%$ in de periode 1753-1790. Het prijsniveau van suiker moet voliedig door niet-Surinaanse import zi;n bepaa'd. Het aandeel van koffie was groter en stabieler, maar verminderde geleidelijk

inkonsten uit 5.000 bosser baranen nog een schamele f 2.200 worden orgezet. Rond 1850 werden gemidde: 35.500 bussen bas:anen geproduceord (cer: bos telt ca. 80 banaren), die in Surinamis werden verkncht, zodat or dus nauwclijks marktkosten werden gemaakt.

7 Plantages Somerszorg, Beekvliet en Nieuw Rocland (GAR; Collectie-Hudig, 330-331; GAA: PA-600, 545).

B In 1827 bestond deze invoer van 'Amerikaansche waren' 11 it: 2.598 vaten bakkcljauw, 111 vaten suikerkalk, 1.759 vaten haring, $113.165 \mathrm{~kg}$ tabak, 1.853 vaten makreel, $27.372 \mathrm{~kg}$ rijst, 295 vaten zalm, 50 paarden, 4.834 vaten blum, 80 muilezeis, 563 valer. zout, 22 ossen, 187 vaten beschuil (ARA: Collectiv-Var: dern Busch, 167). 
van 50\% in 1753 tot $44 \%$ in 1786-1790 (Van de Voort 1973:150 en Bijlage 1).

Toen Saint Domingue/Haiti, de grootste Franse producent van koffie en suiker, door de slavenrevolutie begin jaren 1790 wegviel, verdween daarmee een grote concurrent van de Nederlandse markt. Dit geluk was echter van zeer korte duur, want de Napoleontische oorlogen zorgden ez voot dat de Surinaamse produkten eind jaren 1790 niet eens de Nederlandse markt konden bereiken. Een groot deel van de oogst werd toen naar andere markten verscheept, waarvan de Noordamerikaanse de belangrijkste was.9 Kort daarop moesten de Surinaamse produxten, als gevolg van de Engelse verovering, op de Britse markt gaan concurreren met bijvoorbeeld de Janaicaanse aanvoex, die vele malen groter was dan de Surinaamse.

Teruggekeerd onder Nederlandse hoede had Suriname rond 1820 niet zoveel concurrentie als voorheen te duchten op de binnenlandse markt. Tien jaar later veranderde dat al weer, toen op Java het Cultuurstelsel werd ingevoerd en de Nederlandse markt al spoedig werd uverstroornd met Javaanse suiker en koffie. Kond 1800 bedroeg de Javaanse suikerexport maar 5.000 ton en rond 1850 was dat verveelvoudigd tot 104.000 ton. De Surinaarse suikerexport groeide ook, maar slechts van 8.560 tot 15.000 tor. De koffie-export toonde het verschii tussen Java en Suriname nog dramatischer. Rond 1800 exporteerde Java 5000 ton en 50 jaar iater 71.500 ton, terwijl de Surinaamse export in diezeifcie periode daalde van 4000 naar 280 ton. 10 Vrijwel altijd stond de Surinaamse produktie in de schaduw van een concurrent, zodat haar invloed op het prijsverloop vrij gering was.

Niet-Surinaamse producenten en internationale politieke ontwikkelingen vormden dus de belangrijkste determinanter. in de prijsschommelingen op de Nederlandise markt, zoals in de periode 1780-1820, waarin de Vierde Engelse Oorlog, de Haitianse revolute en de Napoleontische oorlogen plaatsvonden (Figuur 9). Dat het prijsverloo? van koffie en suiker niel geheel parallel verliep en ook vór 1780 grote schommelingen kon vertonen, had vooral te maken met klimatologische omstandigheden dis bepaalden of de Frans-Caraibische en Surinaamse oogsten overvloedig of karig waren. Daarnaast is het waarschijnlijk dat de vraag naar koffie, een relatief veel nieuwer consumptie-artikel, minder elastisch was dan die naar suiker. Het is anders moeilijk te verklaren waarom in de periode 1775-1779, toen de markt overspoeld werd met zowel koffie ais suiker, de eerste een

9 Zo verirokker tussen i mar! en 31 december 1799 in tutaal 207 schepen uit Suriname met ruim 3.500 ton suiker, 3.115 ton koffie en 550 ton katoen. De bestemmingen waren:

$\begin{array}{lcll}\text { Verenigde Staten } & 131 & \text { Frans-Caraibische eilanden } & 9 \\ \text { Veens-Caraibische cilanden } & 20 & \text { Duitsland } & 8 \\ \text { Engeland } & 17 & \text { Brits-Caraibische eilanden } & 7 \\ \text { Berbice en Demerara } & 13 & \text { Denemarken } & 2\end{array}$

(Bron: Surinaams Museum, 496: Guluvernements journaal 1799).

10 Bonmgaard 1989:84; Deerr 1949, 1:224; Coffex: 1903:52; Bijlage 1. 
Figuur 9. Prijsverloop Surimaamse suiker, koffie en katoen 1740-1863

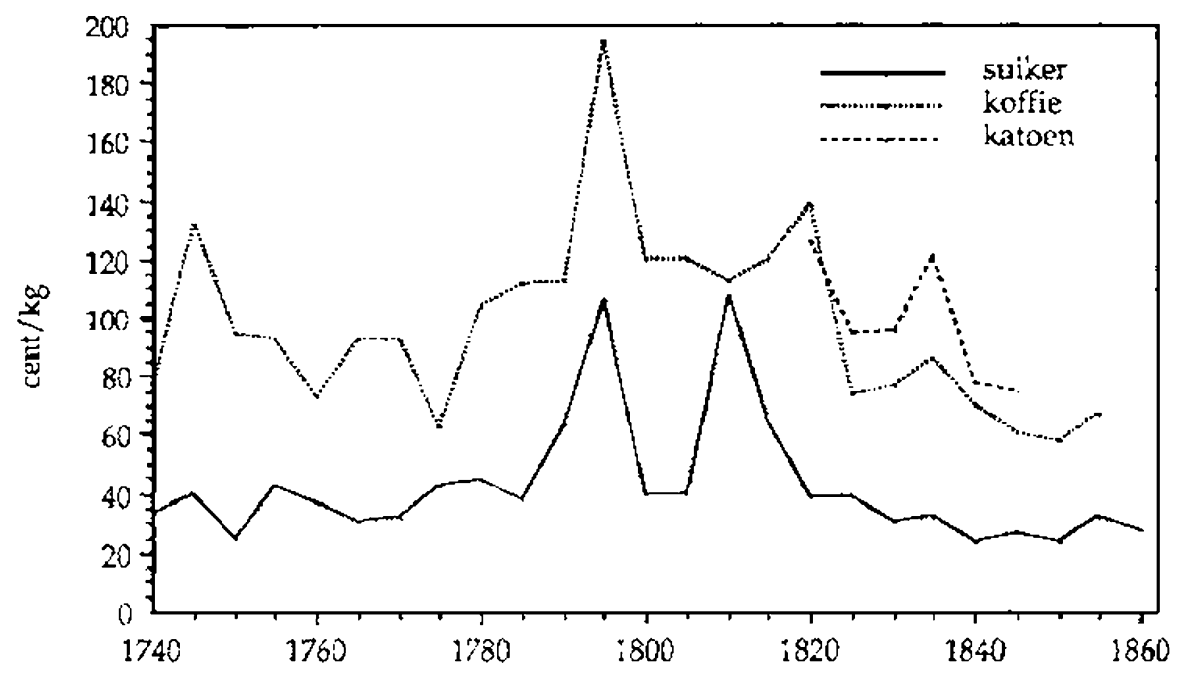

enome prissai maakte, maar het prijspeil var. de tweede bleet stijgen.

In Figuur 9 is hel prijsniveau van de periode 1795-1799 niet geheel vergelijkbaar, ondat hier Nederlandse marktprijzen getoond worden, terwijl in die jaren een groot deel van de Surinaamse export op andere markten werd verhandela. De prijzen daar zullen, onder invloed var de orlogen in. Europa, ook hoog geweest zijn. Voor de periocie 1800-1815 zijn niet Nederiandse, maar Engelse prijzen in de grafiek opgeromen, omdat de Surimaamse export toen van de Britse markt afhankelijk was. Het is overigens opmerkelijk dat in de jaren $1810-i 814$, als gevoly van de spanningen in Europa, de suikerprijs een absolual hoogtepurt bereikte, maar de koffieprijs enigszins daalde. Waarschijnlijk werd dit veroorzaakl door de nog jonge Jamaicaanse koffie-export die precies in die periobe zjir toppunt bereikte, zodat de Britse markt met koffie werd overspoeld.":

$\mathrm{Na} 1815$ daalden to siikerprijzen weer tof het vooroorlogs niveau, terwijl de koffieprijzen, uist stegen. Dit laatste had waarschijn!ijk te maken met het feit dat e: in die jaren riet zoveel concurrentie was op de Nederlandse kof źienarkt, terwij]. de Surinaanse produktie sterk achteruit was gegaan. In de ;aren 1825-1829 trok die produktie voor korte tijd weer aan en daaiden de prijzen.

Begin jaren 1830 stegen de prijzer. yets, onder invloed van de afscheiding

11 Iussen I801 en 1814 stceg de Jamajcaarse kof ic-export van 6.700 ton naar 17.000 ton (Wijliams 1975:2). 
van België. De daling zette echter al snel weer in door de grote toevloed van Javaanse produkten na 1830 . In de jaren 1850 stegen de prijzen weer, wat te danken was aan de ingevoerde vrijhandelspolitiek (1848). Deze maakte het in toenemende rnate mogelijk Surinaamse produkten daar te verkopen waar de prijzen het gunstigst waren. Zo werd van de Surinaamse suiker in 1849 nog $95 \%$ naar. Nederland vervoerd, maar was dit in 1850 al gedaald tot $51 \%$ (Reesse 1908:Bijlage XLI).

Van katoen zijn minder prijscijfers voor handen. In het derde kwart van de achttiende eeuw werd er nog niet zo veel katoen geproduceerd en was de prijs hoog en sterk fluctuerend, variërend van 186 tot 298 cent per $\mathrm{kg}$ (Bijlage 2). In de Engelse periode, toen overal meer katoen werd verbouwd, was de prijs in Engeland gemiddeld nog maar $110 \mathrm{cent}$ per $\mathrm{kg} .{ }^{12}$. Vadat de Surinaamse katoen weer voor de Nederlandse markt bestemd was, hag het prijsverloop er uit zoals weergegeven in Figuur 9.

Dat de katoenprijs in de loop van de negentiende eeuw vrijwel voortdurend daalde, had alles te maken met de gigantische groei van de Amerikaanse export van ruwe katoen. Terwijl in 1820 ook al ruim 62.000 ton werd geëxporteerd, was dit in 1840 nog toegenomen tot meer dan 265.000 ton en daarmee was de grens nog niet bereikt (Scherer 1916:420). De wereld werd overspoeld met goedkope Amerikaanse katuen. Daar kon de Surinaamse katoen geen partij aan bicden, zodat de prijs in Nederland flink daalde. Het mag daarom een wonder heten dat eind jaren 1830 de katoenprijs in Nederland zich toch voor korte tijd herstelde. Waarschijnlijk was dit het gevolg van de aangekondigde maatregelen, na de Belgische afscheiding, om de Nederlandse textielnijverheid te stimuleren, door grootscheepse export van 'katoentjes' naar Oost-Indië. Dat is ook inderdaad gebeurd, maar na de eerste enthousiaste reacties, daalde de katoenprijs weer even snel.

\section{De rentabiliteit}

Hef schaarse en chaotische bronnenmateriaal maakt het niet eenvoudig om de winstgevendheid van de Surinaamse plantages te berekenen. Bovendien hebben hypotheekschulden een zeer belangrijke rol gespeeld, maar waren weer niet alle plantages verhypothekeerd. Dit bemoeilijkt de vergelijkbaarheid van de verschillende ondernemingen. Toch is bij de navolgende berekening getracht de steekproeven zo representatief mogelijk samen te stellen, al moeten de cijfers slechts als een indicatie worden gezien.

Slaven vormden de meest constante factor en het belangrijkste 'kapitaalgoed' op plantages in alle drie sectoren. Het ligt daarom voor de hand de 
mate waarin de ondernemingen winstgevend waren te relateren aan de slavenpopulatie. Dit vergernakkelijkt de vergelijkbaarheid.

Onder winst wordt hier verstaan: de inkomsten uit verkopen in Nederland minlis uitgaven : Nederiand, traittes, rente en kapitaalaf'ossing. Voorzover de uitgaven in Suriname groter waren dan de inkomsten daar werd di: verlies gedekt door de op Nederland getrokken wissels, waardoor ook de Surinaamse kant in het winsicijfer is verwerkt. Ilet verlies kon soms ook worden berekend door de toename van de totaie schuld in Nederland Boekhoudkundig werd in die tijd geen rekening gehouden met afschrijvingen op de kapitaalgoederen. Het bronnenmateriaal makt het onmogelijk deze achteraf alsnog te berekenen. Afschr:;virgen zijn dus alleen in de wirstberekening opgenomen voo:zover er daadwerkeiijk uitgaven werden gedaan voor onderhoud of vervanging van kapitaa.goederen.

Uit Tabe. 39 blijkt dat de suikerpiartages het veel beter hebben gedaan dan de koffieplantages. Beide sectoren waren vanaf de jaren 1770 verliesgevend, maar suiker veel korter en in veel mindere mate dan koffie. Bij deze verliezen dient overigens wel te worden aangetekend dat zij zijn gebaseerd op de kapitalschuld, die voortdarend sieeg als gevolg van achterstallige rentebetalingen. In praktijk werd echter al spoedig geen rekening meer geho:den met deze sch:ald en draaiden de meeste plantages tamelijk ongestoord verder. In de negentiende eeuw waren deze schulden merendeels uit de pianiageboekhouding verwijdert en de obligaties van de heleg. gers ongezet in aancielen.

De ja:en $18: 0$ en 1820 lijken voor beide sectoren - en waarschijnlijk ook voor de katoen - zeer winstgevend te zijn geweest. Daarna daalde de wins: en sloeg bij de katoen een decennium later zeifs om in verlies. Voor zowel de koffie- als de katoensector betekende dit het einde. De winst in de suikersector groeide echter weer, al werd het peil van de jaren 1820 niet

Tabel 39. Gemiddeide jaar!jkse winst per slaaf per sector in guldens 1760-1862

\begin{tabular}{|c|c|c|c|c|c|c|}
\hline perinde & stike: & $r$ & koffie & $\mathrm{n}$ & katorn & $\mathbf{n}$ \\
\hline $1760 \div 769$ & 4 & 6 & ? & & - & \\
\hline $1770-1779$ & -15 & 7 & -51 & 23 & - & \\
\hline $1780 .: 789$ & -33 & 8 & -52 & 17 & - & \\
\hline $1790-1799$ & 23 & 10 & -50 & 18 & $?$ & \\
\hline $1800-1809$ & 8 & 8 & 30 & 15 & $?$ & \\
\hline $1810-9819$ & 21 & 6 & 40 & 11 & $?$ & \\
\hline $1820-1829$ & 60 & 7 & 20 & 10 & $?$ & \\
\hline $1830-1839$ & 8 & $1:$ & 4 & 7 & 13 & 2 \\
\hline $1840-.849$ & $: 2$ & 10 & 3 & $\hat{\mathbf{z}}$ & -6 & 3 \\
\hline $18.50-1862$ & i7 & 8 & $?$ & & -25 & 2 \\
\hline
\end{tabular}

Bron: steckproef plantagc-archieven 
Tabel 40. Gemiddelde winstontwikkeling in de suikersector 1760-1862

\begin{tabular}{|c|c|c|c|c|c|}
\hline periocle & $\begin{array}{l}\text { prijs } \\
\mathrm{ct} / \mathrm{kg}\end{array}$ & $\begin{array}{l}\text { per slaaf } \\
\text { excl. hypothecaire } \\
\text { schuld }\end{array}$ & $n$ & $\begin{array}{l}\text { per slaaf } \\
\text { incl. hypothecaire } \\
\text { schuld }\end{array}$ & $n$ \\
\hline $1750-1759$ & 32 & $?$ & $?$ & $?$ & $?$ \\
\hline $1760-1769$ & 33 & $f 16$ & 6 & $f 4$ & 6 \\
\hline $1770-1779$ & 37 & 35 & 6 & -15 & 7 \\
\hline $1780-1789$ & 37 & 19 & 8 & -33 & 8 \\
\hline $1790-1799$ & 8.5 & 54 & 10 & 23 & 10 \\
\hline $1800-1809$ & 40 & 42 & 8 & 8 & 8 \\
\hline $1810-1819$ & 86 & 26 & 6 & 21 & 6 \\
\hline $1820-1829$ & 39 & 74 & 7 & 60 & 7 \\
\hline $1830-1839$ & 31 & 34 & 10 & 8 & 11 \\
\hline $1840-1849$ & 25 & 21 & 9 & 12 & 10 \\
\hline $1850-1862$ & 28 & 19 & 8 & 17 & 8 \\
\hline
\end{tabular}

Bron: steekproef plantage-archieven.

meer gehaald. Bij dit alles dient overigens te worden onderstreept, dat het hier niet gaat om de exacte wins'cijfers maar om de trends. ${ }^{13}$

Bij de winstontwikkeling onderscheiden naar plantagesector zijn vooral de invloed van het prijsniveau en van de schuldenlast var groot belang. De ontwikkelingen in de suikersector (Tabel 40) tonen aan dat de invloed van betalingen in verband met hypothecaire schulden in de tweede helft van de achttiende eeuw zeer groot is geweest. Zonder deze zou er yoortdurend met winst zijn gedraaid. Toch is het opvallend dat in de jaren 1760 de winst relatief karig was en, gezicn het prijspeil, zal dat waarschijnlijk in het voorafgaande decennium niet veel anders zijn geweest. Dit maakt het begrijpelijk dat voor de negotiatiefondsen in die tijd de koffiecultuur veel hoopgevender leek. Waarschijnlijk was de matige winst het gevolg van grote investeringen die gedurende deze decennia werden gedaan in slaven en innovaties. Dit wordt bevestigd door de plantage die in deze steekproef het slechtst draaide, Waterwijk aan de Perica. Begin jaren 1750 werd daar de beestenmolen vervangen door een watermolen, terwijl tussen 1766 en 1770 de slavenmacht groeide van 106 naar 153 personen, bij

13 Met name de cijfers sinds 1800 disnen mel gepast wantroluwen te worden gehanteerd. In de eerste plaats, omdat in de periode 1800-1815 de gecompliceerde verhouding tussen Suriname, kngeland en .Nederland, nogal eens een chaotische boekhouding opleverde. Ten tweede, ondat de hewaard gebleven plantage-archieven vaak afkomstig zijn van plantages die het langst zijn blijven draaien. Plantages die al vroeg over de kop gingen zijn daardoor warschijnlijk in deze steekproef ondervertegenwoordigd. Dit lijkt vooral te gelden voor koffieplantages, want in de steekprocf blijven zij met winst draaien, zij het meeslal exn minimale, terwijl in werkelijkheid tussen 1824 en 3853 het aantal plantages daalde van 228 naar 67 . Het ligt vnor de hand dat deze afname veel minder zou zijn geweast wanneer dit het werkelijke winstniveau was. 
een gemiddeld jaarlijks sterte-overschot op deze plantage van ruim 3\%.14

In de jaren 1770 waren deze investeringen op de meeste plantages achter de rug en ging de suikerprijs iets omhoog, zodat de winst raar een behoorlijk niveau kon stijgen. Dat, bij gelijkblijvende prijzen, de onbelaste winst in de jaren 1780 toch weer daalde, was waarschijnlijk het gevolg van de onkosten in verband met de Vierde Engelse Oorlog. Wanneer ook de schuldenlast wordt verdisconteerd, blijkt er sprake te zijn van een steeds oplopend verlies in de jaren 1770 en $: 780$.

Explosief stijgende suike:prijzen en het feit dat een groot aantal plantages werd ingekocht voor de som van de schuld, zorgden voor een ongekend winstpeil in de jaren 1790. Gedurende de volgende twee decennia werd dit echter weer teniet gedaan door stagnerende exporten en hoge onkosten als gevolg van de Napoleontische oorlogen. Overigens blijken er in de jaren 1810 vr:jwel geen plantages meer te zijn die rekening moesten houden met een drukkende schuldenlast, want de winstrijfers mef en zonder schuld lagen op vrijwel gelijk riveau.

In de jaren 1820 steeg de winst tot recordhoogte, ondanks het feit dat de suikerprijzen weer waren gedaald to het riveau van voor 1790. Algehele stabiliteit en sterk gegroeide produxtiviteit lagen hieraan ten groridslag. Gedurende de daaropvolgende twee decennia liep de winst echter weer drastisch terng, evenals de suikerp:ijs. Toch $k$ an dit laatste niet alleen verantwoordelijk zijn geweest voor de grote winstval, want ook het weer uiteenloper van de wirst met en zonder schuld duidt op meerdere oorzaken. Dit was dan ook de periode warin veel suikerplantages grote onkosten maakten om hun slavenmacht uit te breiden en een stoommachine aan te schaffen. ${ }^{15}$ Voor een aanta: plantages werden hiertoe opnieuw hypothecaire leningen a:gesloten.

Ondanks het feit dat deze vernieuwinger en uitbreidingen ook gedurende de jaren :850 doorgingen, slabiliseerde het winstpeil zich weer, wat er op duidt dat de getroffen maa:regeler. vrucht begonnen af te werpen. Met het merendeel van de leningen was het overigens net zo slecht afgelopen als in de achttiende eeuw; opnieuw wexcier. zij uit de boeken geschrapt, zodat de winst met en zonder schuld weer vrijwel gelijk was.

Ook in de koffiesector hebben negotiat:eschuiden, prijsontwikkelingen en corlugen onmiskenbaar een rol gespeeld. Toch ziet het winstverloop er anders uit dan in de suikersector (Tabel 41). De veel grotere negatieve invloed van de negotiatieschalden of de winstgevendheid van koffie-

14 ARA: SONA, 691, 224 en 698; GAR: Collectie-Hudig, 111.

15. Deze veronderste'ling wordt ondersteund door de plantages uit de steekproef, want op de helft van deze. ondernemingen werd in deze periode cen stoommachine geïnstallecro en hun gezamenlijke slavenmach: breidde zich met een kwart uit. 
Tabel 41. Gemiddelde jaarlijkse winstontwikkeling in de koffiesector $1770-1850$

\begin{tabular}{|c|c|c|c|c|c|}
\hline periode & $\begin{array}{l}\mathrm{prijs} \\
\mathrm{ct} / \mathrm{kg}\end{array}$ & $\begin{array}{l}\text { per slataf } \\
\text { excl. hypothecaire } \\
\text { schuld }\end{array}$ & $\pi$ & $\begin{array}{l}\text { per slataf } \\
\text { incl. hypothecaire } \\
\text { schuld }\end{array}$ & $\mathrm{n}$ \\
\hline $1760-1769$ & 83 & ? & $?$ & ? & $?$ \\
\hline $1770-1779$ & 77 & $f 36$ & 23 & $f-51$ & 23 \\
\hline $1780-1789$ & 107 & 51 & 17 & -52 & 17 \\
\hline $1790-1799$ & 153 & 26 & 18 & -50 & 18 \\
\hline $1800-1809$ & 120 & 71 & 15 & -30 & 15 \\
\hline $1810-1819$ & 116 & 57 & 11 & 40 & 11 \\
\hline $1820-1829$ & 106 & 33 & 10 & 20 & 10 \\
\hline $1830-1839$ & 81 & 12 & 7 & 4 & 7 \\
\hline $1840-1849$ & 65 & 3 & 4 & 3 & 4 \\
\hline
\end{tabular}

Bron: steekproef plantage-archieven.

plantages springt meteen in het oog. Opmerkelijk is verder hoe in de jaren 1780 en 1790 de wirst in de koffiesector zich tegengesteld ontwikikelde aan die in de suikersector. In de jaren 1780 kon de winst, ondanks de hoge kosten in verband ret de Engelse oorlog, toch flink groeien, door de aanzienlijke stijging van de koffieprijzen. In de jaren negentig was dit laatste weliswaar nog steeds het geval, maar halveerde desondarks de winst. Waarschijnlijk was dit een gevolg van de omstandigheid dat veel koffieplanters gedurende de chaotische jaren 1795-:799 een grool deel ran hun oogst eenvoudig in voorraad hielden, in afwachting van rustiger tijken. Het :s frappant hoe weinig koffieverkopen er in deze periode in de boekhoudingen werden vermeld, terwijl dat bij suiker wel het geval was. De risico's verbonden aan transport in oorlogstijd waren hetzelfde, de 'houdbaarheid' van de produkten was echter nogal verschi'lend, zodat men kennelijk voor suiker een groter risico aandurfde.

Gedurende het Engels bewind bereikte de winst in de koffiesector een absoluut record. Dit was waarschijni:jk het resultaat van ecr combinatic van hoge prijzen op de Engelse markt en het drukiker van de plantageonkosten. Dit laatste kwam bij suikerplantages wat minder voor, aangezien een verwaarloosde suikerfabriek een direct gevaar vormde voor de produktie en een onderkomen koffielonds niet. Deze verondersteiling lijkt te worden bevestigd door de bevindingen van A.F. Lammens (1982:25), die meer dan de helft van de koffieplantages in 1818 omschreef als 'in afnemende staat', terw:jl minder dan een-derde van de suikerplantages een dergelijke kwalificatie meekreeg.: 6

16 Vors alle duidelijkheid: Lammens doelde waarschijnlijk naast verwaarlozing ook op de toename van de uizgephilte gronden. Een kleine steexproef onder vijf koffieplantages laat bovendien zien dat, vergeleken met de periode 1785-1794, in de jaren 1801-1810 ruim 20\% minder geld werd besteed aan het opsturen van plantagebenodigdheden. Het kan natuurlijk 
In vergelijking met suikerplantages bleef in de koffiesector de schuldenlast veel langer op de plantages drukken, omdat deze hier hoger en algemener was. Gedurende het eerste kwart van de negertiende eeuw werd ook in deze sector steeds vaker met één pennestreek een einde gemaakt aan de schulden. Erg lang heeft men daar echter niet van kunnen genieten, want de winsten, met en zonder schuld, liepen in hoog tempo terug. Anders dan. in de suikersector had dit riets to maken met eventuele innovatie of expansie van de sector. Het was slechts het teken van absoluut verval.

Het beeld van de winstgevendheid van suiker- en koffieplantages is hiermee duidelijker geworden. ${ }^{17}$ Toch zeggen de hier berekende winstniveau's op zich niet zoveel over de werkelijke rentabiliteit van de plantages. Normaai gesproken zou nu de winst moeten worden berekend als percentage var. het geïnesteerde kapitaal, waarna dit cijfer kan worcen vergeleken met de rerte die een bank in .Nederland op een belegd kapitaa: uitkeerde. Dit is helaas volstrekt onmogelijk. Li is niet eeris bij bentadering te bepaen hoevecl in de loop der tijd in de plantages is geinvesteerd. Het genegotieerd kapitaal kan hiervoor niet worden gebruikt, want niet alle? piantages, met name in de suikersector, waren verhypothekeerd. Bovendien werd na circa 178) vrijwel geen kapitaal meer genegoticerd, maar ex werd wel degelijk nog kapitaal in plantages gestoken, zij het in sterk vermindercie mate. Hier zou de hoogte van de schuld uitkomst kunnen bieden, ware het niet dat die voot een groot deel (maar hoe groot?) bestond u:t achterstallige interest, weike toch moeilijk als ge:nvesteerd kapitaal kar worden gezien. Daarnaast werd er soms we' eens iets (maar hoeveel?) van de schuld afgelosi en waren ook niet alle plantages met schuider belas:. In wat te doen nadat plantages voor de som van de schula waren ingekocht?

Fen mogelijkneid zou zijn de getaxeerde waarde van plantages te beschouwen als geinvesteerd kapitaa:. Hoewel dit misschien voor eer. enkele plantage een oplossing kan bicden (rie lamur 1987a:57-71), veroorzaakt dit op macroniveau grote problemen. De taxatiewaarde van een plantage kon in de loop der ijd aanzienlijke verschillen vertonen, mede door het - soms grote - speculatieve eiement dat er aan kleefde. Voor de schatting van net ge:̈nvesteerce kapitaa! ligt het er dan maar aan wit welk jaar eer taxatie beschixbaar $s$. Bovendien kan het aantal taxaties ir de

zjja, dat deze in plads daarvan in Surimane werden gekocht, maar zeker is dat allerrainst (Steekproef archieven plantay,es Purmerend, Zorg, en Hoop, Maria's Lust, Bękvliet en Somerizorg).

17 B:j gebrek aan voldoende (representatief) materiaal over de katoensector blijft deze hier onbroproken. 
periode na 1778 niet in de schaduw staan van het tijdvak daarvoor, terwijl er na 1830 zelfs vrijwel geen enkele taxatie bekend is.

Om toch een ontwikkeling van de rentabiliteit te kunnen laten zien, hoe discutabel ook, wordt daarom de hiervóor ingeslagen weg verder bewandeld, namelijk door de winst per slaaf te relateren aan het kapitaal dat gemiddeld moest worden geinvesteerd om hem of haar te kunnen koper. Het belangrijkste bezwaar tegen deze methode is dat de koopprijs van cen gemiddelde slaaf in de periode voor 1827 , toen er nog importen waren, anders was samengesteld dan daarna. Gedurende die eerste periode werden voornamelijk slaven gekocht die in of viak voor hun produktieve levensfase stonden, met een meerderheid aan mannen. Dit dreef de prijs omhoog. In de latere periode werden slaven familie- of zelfs plantagegewijs gekochi, waardoor het aandeel van (nog lang) niet produktieve slaven groot was, wat de prijs natuurlijk cirukte. Dat blijkt bijvoorbeeld in de jaren 1820 , toen de gemiddelde prijs van een geïmporteerde slaaf lag op $f 734$, terwijl de verkoop van twee complete slavenmachten in dezelfde periode een gemiddelde prijs van niet meer dan $f 370$ opleverde. ${ }^{18}$ Deze .wee gelijktijdig gerealiseerde prijzen maken het echter mogelijk een omrekenfactor te hanteren $(0,5)$. Daarmee $k a n$, ten behoeve van de vergelijkbaarheid, de rentabiliteit per importslaaf ook na 1827 worcien berekend (Tabel 42). De reëje prijs in de jaren 1830 en 1840 is gebaseerd op slavenverkopen, terwijl voor de laatste periode de prijs is gehanteerd die de planters in 1863 ontvingen als compensatie voor hun vrijgemaakte slaven. Deze cijfers dienen met de nodige voorzichtigheid te worsen gebruikt, maar zij geven tenminste een indicatie van de rentabiliteit.

Het spreekt varzelf dat de eerder geconstateerce invloeden die de ont wikkeling van de winstcijfers beinvloedden, ook weer in het rentabiliteitscijfer zijn terug te vinden (Tabel 42). Hypotheekschulden en oorlogen drukten met name in het laatste kwart van de achttiencle eeuw de rentabiliteit in sterke mate. Wanneer de hypotheekschulden buiten beschouwing worden gelaten, deden de plantages het echter lang niet slecht en soms zelfs uitzonderlijk goed, zoais in de jaren 1770. Dit is darl ook de reden dat in die periode nog zo'n groot aantal plantages is blijven voortbestaan en de slavernij niet werd opgeheven. Weliswaar werden de schulder nict afgelost, maar, afgezien van obligatiehouders, was het voor de meeste betrokkenen rog alleszins voordelig om de produktie voort te zetten.

In de negentiende eeuw bedroeg de rentestand in Nederland ongeveer $3 \%$. Tegen die achtergrond lijken zelfs de slaven op koffieplantages nog

18 Namelijk de slavenmachten van de plantages Johanna's Zoon en Maria's Lust (CAA: I’A$600,545)$. 
Tabel 42. Cemiddelde jaarlijkse reniabiliteit per slaaf en per sector $1760-1862$

\begin{tabular}{|c|c|c|c|c|c|c|}
\hline \multirow[t]{2}{*}{ periode } & \multicolumn{2}{|c|}{ inportslaver } & \multicolumn{2}{|c|}{ totaal slaven } & \multirow{2}{*}{$\begin{array}{c}\text { import- } \\
\text { prijs } \\
(f)\end{array}$} & \multirow{2}{*}{$\begin{array}{c}\text { totaal- } \\
\text { prijs } \\
(f)\end{array}$} \\
\hline & $\begin{array}{c}\text { excl. } \\
\text { schuld }\end{array}$ & $\begin{array}{c}\text { incl. } \\
\text { schuld }\end{array}$ & $\begin{array}{l}\text { excl. } \\
\text { schuld }\end{array}$ & $\begin{array}{l}\text { incl, } \\
\text { schtrld }\end{array}$ & & \\
\hline \multicolumn{7}{|l|}{ suiker } \\
\hline $1760-69$ & $6,2 \%$ & $1,6 \%$ & - & - & 258 & - \\
\hline $1770-79$ & 13,1 & 5,6 & - & - & 268 & - \\
\hline $1780-89$ & $4, \sqrt{3}$ & 8,1 & - & - & 468 & - \\
\hline $1790-99$ & 8,8 & 3,8 & - & - & 613 & - \\
\hline $1810-19$ & 3,5 & 2,9 & - & .- & $734^{\prime \prime}$ & - \\
\hline $1820-29$ & $10: i$ & 8,2 & 20,2 & 16,2 & $736^{4}$ & 370 \\
\hline $1830-39$ & $(19,8)$ & $(4,6)$ & 10,3 & 2,4 & - & 330 \\
\hline 184049 & $(14,2)$ & $(8,2)$ & 7,1 & 4,1 & -. & 295 \\
\hline $1850-62$ & $(12,6)$ & $(11,4)$ & 6,3 & 5,7 & - & 300 \\
\hline \multicolumn{7}{|l|}{ koffie } \\
\hline $1770-79$ & 13,4 & $-19,0$ & - & - & 268 & \\
\hline $1780-89$ & 10,9 & $-11,1$ & - & - & $4 \$ 8$ & \\
\hline $1790-99$ & 4,2 & 8,2 & - & & 613 & - \\
\hline $1810-19$ & 7,8 & 5,4 & - & - & $734^{4}$ & - \\
\hline $1820-29$ & 4,5 & 2,7 & 8,9 & 5,4 & $734^{*}$ & 370 \\
\hline $1830-39$ & $(7,0)$ & $(2,4)$ & 3,6 & 1,2 & - & 330 \\
\hline 184049 & $(2,0)$ & $(2,0)$ & 1,0 & 1,0 & & 295 \\
\hline
\end{tabular}

* $1816 \cdot 182.6$

De periode 1800-1809 is riet opgeromen ondat toen de slavenprijs in Suriraamse guldens werd uitgedrukt, wa arvan de wisselkoers niet bekend is.

Bronnen: Tabellen 18, 39-41; slavenprijzen na 1830 samergesteld ut: Surinaams Museum: Collechis-Bantien, ve-slagboek; Rapport Stantscommissie 1853:254.

korte tijd sedelijk renciabe: te hebben geprocuceerd. ${ }^{19} \mathrm{Na}$ de jaren 1820 was het met de koffiesector echter defin:tief gedaan. De rentabiliteit var de suikersector was in he: a:gemeen in de negentiende eeuw redelijk en in de jaren 1820 zelfs goed te noemen. Gedurende de jarer. 1830 werd de rentabiliteit gediukt dove grote investexingen in stoommachizes en/of omschikeling van koffle naar suiker. Daarra wist deze sector zich echter weer behoorijik te herstellen. Opripiw blijkt, dat wat hetreft de suiker, toen veruit de grootste sector ir de Surinaamse economie, de Emancipatie tamelijk ongelegen kwam. Men had geen enkele notie hoe het zou gaar. met vrije arbeid. ${ }^{20}$

13 Yie echter bed vourbethoud gemaikt in soot 15.

20 Hoe pront de onzokerheid was, blijkt uit en verslag van een vergadering die de Gouverneur op : 4 julj 1856 had bxlegd ever con experiment met de immigratie van Chirezen en arbeidess vit Madcira, als voorbereding op de: Emancipatie. Ook dis administrateur van Vossenburg was daarbij aanwezig. Dr sigenaars van deze plantage besioten echter niet meo te doen, in de eersie plaats orrciat hel plan 'te onbepaald is, zoowel ten aanzien der werkuren als daglownen en verdere voorwarden, 2 e ondat hed te zamen doen werken van vrije menschen 
Zoals ook al het geval was bij de behandeling van de produktiviteit, blijken er over de rentabiliteit in andere Caraibische plantage-economieen slechts weinig betrouwbare cijfers te bestaam. De enkele cijfers die in de literatuur worden genoemd zijn jovendien gerelateerd aan niet te controleren schattingen van het geïnvesteerd kapitaal. Dit maakt een vergelijking met de Surinaamse cijfers onnogelijk.21

Opnieuw is duidelijk geworden hoe contraproduktief de negotiaties hebben gewerkt op de Surinaamse plantage-economie. Door een rigoure:aze schuldsanering kwam de suikersector er uiteindelijk toch weer bovenop en rendeerde tot aan de afschaffing van de slavernij op een alleszins acceptabel niveau. De koffiesector bleek, ondanks een lichte opleving, ter dode opgeschreven. Daarnaast werd aangetoond dat het mercartilistisch systeem sterk in het nadeel van de plantage-economie heeft gewerkt. De verplichting alle produkten op de. Necerlandse markt te verkopen betekende dat een lange reeks personen en instanties een deel van de plantage-opbrengsten voor zich opeiste. Wellicht was het beter geweest als de produkien aan handelaars in Suriname hadden kurinen worden verkocht, zoals in de Franse Caraiben het geval was. De lijn tussen planter en koopman(-bankier) was dan veel korter geweest en de controle op eventuele kredieten vecl strakker. Bovendien was er dan ir de plantage-economie meer geld in omloop geweest, wat stimulerend had kunner werken op het plantersiritiatief.22

De Britse planters waren eveneens verplicht hun produkier. op de Europese thuismarkt te verkopen. $Z_{\mathrm{ij}}$ maxiten daar echte: de dienst uit en genoten een grote mate van bescherming. De Surinaamse produkten, daarenegen, genotern op de Necierlandse markt in het geheel geen bescherming en werder doo: buitenlandse mededingers in een hoek gedrukt.

De Nederlandse handel wilde dus van zoveei mogelijk walletjes eten. Ilet overleven van de Surinaamse plantage-economie speelde in hun belangenoverwegingen geen doorslaggrevende rol. Zij hadiden daarin in zoverre gelijk, dat toer. de buitenlandse anvoer van tropische produkten stokte de

met slaven welligt ongunsige? resultaten kan opieveren en $3 e$ ondat bet voorstel is gedaun, voór dat er hier te lande [Nederland] iets hoegenamd is hepaald, hoedarig het net de emancipatie zal gaan, en daarveor nog geer. Wet is gemaakt door de wetgevende mag:' (Surinaams Museum: Collectie-Brantsen, virs:agboekje 1856).

21 Het best gedocumenteerd zijn de berekeningen van Ward (1978) voor het Brits-Camibisch gebied. Het groatste deel van zijn cijfers is echter gebaseerd op steekproeven van niet meer dan een of twez plantages. Bovendien houdi hij geen rekening met hypotheekschulden, die er in de Engelse koloriën toch onk in grote mate geweest zijn (Pares 1960):38). 7.elfs cen trendmatige vergelijking wordt daarmee onzinrig.

22 Het is niet bekend of dit systeem in de rranse Caraiben positief voor des planters en de rentabiiteit is geweest. Het gevaar iestaat ratwurlijk dat mn aantal lokalc handelaars zich een monopoliepositie weet te verweryen en de oogst voor niet meer dan minimale prijzen opkoopt. Een situatie die zich zeker in de peasant-landbuuw van vecl niet-Westerse samenlevingen tot op de dag van vandaag vooráoet. 
opengevallen plaats door Java werd ingenomen. Het getuigt daarom van vitaliteit dat in ieder geval de Surinaamse suikersector wist te overleven door vernieuwing en uitbreiding. 


\section{HOOFDSTUK IX}

\section{Continuiteit en eigenbelang in het management}

De levensvatbaarheid van een onderneming is in hoge mate afhankelijk van de leiding. Fendracint en ondubbelzinnigheid in het beheer zijn dan ook noodzakelijke voorwazrden voor een efficiënte bedrijfsvoering er. voor de confinuiteit. Bij het beheer van de Surinaamse plantages in de achttiende er. regentiende eeuw lijkt het tegenovergesteide vaak het geval te zijn geweest. Wie zich verdiept in het heheer van deze ondernemingen, stuit al gaïw op een warnet van belangen die vaak lijnrecht tegenover elkaar stoncen, zoals tegenstellingen tussen eigenaars, koopman-bankiers en aandeelhouders in Nederland of tussen eiders verblijvende eigenaass en administrateurs. In dit hoofdstuk worden de tegenstellingen in het plantagebeheer in Suriname onder de lnep genomer.

De duidelijkste tegenstelling in het Surinaams plantagebeheer was natuurlijk inherent aan het systeem zelf: slavernij als vorm van arbeidsmobilisatie. Wanneer als belangrijkste arbeidsprikkel de zweep wordt gehanteerd, kost het weinig moeite een beeld te vormen van het latente conflict tussen bazen, die met geweld een maximale arbeidsprestatie proberen af te dwingen, en niel bij de onderneming geinteresseerde slaven, die met een minimale arbeidsprestatie of met geweld die zweep trachten te ontwijken. In de negentiende eeuw werd gepougd deze tegensteiling te verdoezelen door de slaven meer te binder aan het plantagebelang met behu'p van materiẹle lotsverbetering en kerstering. De slaven hebben hervan op eigen wijze zoveel mogelijk geprofiteerd. De tegenstelling werd ex echter niet minder om en misschien zelfs aangescherpt. In dit krachtenspel stonden de hoogstgeplaatste man in het management, de administrateur en de man aan de top van de slavenhiërarchie, de negerofficier of bastiaar, centraal.

\section{De bastiarn}

De bastiaan, of basja, vormde de meest constante factor in het plantagemanagement. Meestal was hij op de plantage geboren, of er op ;onge leeftijd gekomen. Hij kerde de onderneming en haar bewoners dus door en door en had vaak een carrière via de verschillende slavenberoepen op de 
plantage achter de rug. Als bastiaan bleef hij vaak jaren achtereen in functie en zorgde zo voor enige continuiteis in het management, waar het vaak een komen en gaan was van b.anxofficiers en directeurs.

Een goed voorbeeld biedt de koffieplantage Somerszorg. Daar werd in 1793 de slaaf Kwamina aangekocht, die ongeveer twintig jaar daarvoor in Afrika was geboren. Hij werkte eerst vele jaren als veldslaaf en werd later, wanneer is niet bekend, bevorderd tot 'veldoffirier', de hoogste positie in de slavenhiërarchie. Deze functie vervulde hij van ongeveer :817 tot omstreeks 1841. In 1845 stond hij te boek als 'gewezen veldofficier, oud en af'. In 1801 had hij de geboorte meegemaakt van zijn latere opvolger, Andries. Deze werkte in 1817 nog onder de grootste jongens op de koffiecrogerij en stond sinds circa 1820 :e boex als veldslaaf en later ook deiver. In de jaren 1830 werd Andries verschillende malen op commando' gestuurd, om dienst te doen bij bospatrouilles van de overheid tegen weglopers. Toer: gencot hij kenneli;k al het vertrouwer van zijn bazen. Ornstreeks 184 : volgde hij, op veertigjarige Iceftijd, Krvamira op ais veldofficier en behield deze functie in ieder geval tot 18.5. In de halve ee1rw dat deze twee bastians de leicing hadder over de slaven, maxiten $z$ ij dertien directeurs en waarschijnlijk veertig tol vijftig verschillende blankofficiess mee. ${ }^{1}$ Het zal duideli; $\mathrm{k}$ zijn waar de contiruiteit var. de ondernemirg lag.

Ondanks het onschatbare belang van de bastiaan, werd er door de overige geledingen van het maragement verschillend over hem gedacht. Iwee citaten maken de hierin meespelende. fegensidellinger dididelijk. Zo schroef de plarier Van Breigel ir: zijn aantekeningenschrift dat in het algemeen de bastiaan een verdienstelijke man was, door wie men slaver met de zweep liet straffen, maar dat hij riet nit zichzelf iemand moriht straffen, alleen aank'agen. Zijn beloning bestond uit 'de eer var het vertrowwen der blariken te genieten' en een dubbele portje bij cie uitdeling van slavengoecieren. Een planter of directeur moest volledig op zijn norceel kinnen afgaan 'ciaa: men juist riet altijd op de rapporten van enkelde blankoffic:ers geheel en al verirouwen kan' (Van Breugel 1824:24-5). In diezelfde tijd, omstreeks 1820, blikte een gewezen blankofficier terug op zijn carrière en concludeerde dat het beter was nooit eerl bastiaan op zijn woord te geloven, maar alt:jd zelf overal het oog op te houden. Bovendier was hij van mening dat 'men de Neger Officiers op de meeste Plantagien nú minder a:s voor 30 Jaaren mag, betrouwen als heulende zelven met de heele magt Slaaven'.2 Kortom, vertrouw nooit op een bastiaan, want 2 ijn solidariteit ligt niet bij de plantagestaf, maar bij de slaven.

Iwee conflicten worden hiermee didielijk. De p'anter of directeur

2 ARA: Collectio Van den besolt, 125 (anonymus). 
vertrouwde zijn bastiaan eerder dan zijn blanke opzichter en de laatste had - waarschijnlijk mede hierdoor - een chronisch wantrouwen ten opzichte van de bastiaan. Een begrijpelijke verhouding, aargezien de blankofficier en de bastiaan in feite dezelfde taak hadden, namelijk supervisie over de slaven in het veld en in de fabriek, maar de bastiaan beschikte door zijn kennis over meer macht. Bovendien kreeg de bastiaan wel eens een extra beloning voor een bepaalde prestatie, kon hij cer. redelijk normaal gezinslever leiden en was hij alom gerespecteerd. De blankofficier daarentegen werd zowel door de slaven als door de directeur gewantrouwd, wist door zijn korte verblijf op de plantage meestal weinig van de garg van zaken, sliep meestal alleen in een afgeschoten hokje in een van de loodsen en kon var zijn karig loon rauweiljks rondkomen.

Toch was ook de positie van de bastiaan niet te benijden. Enerzijds moest hij het vertrouwen var. zijn superieuren hebben en hun bevelen stipt navoigen, waarbij he! handhayer. van een strak arbeidsregime en het uitvoeren van straffen van grool beiang warem. ${ }^{3}$ Anderzijds moest hij ook het vertrouwen en respect hebben van de slaven en dience hij ook hun belangen te verfegenwoordigen. Dat betekende voortdurend balanceren op het scherp van de snede. Om dit te kunnen volhouden, diende de bastiaan boven äies veel prestige te genieten onder de slaven en van hen cen ruim sociaal krediet te krijgen. Had hij dit niet, dan stonder de slaven genoeg middelen ter beschikining - van pesterijen en sabotage tot en met moord om hem de uitoefening van zijn functie volstrekt onmogelijk te maken.

De bastiaan diende dus te beschikken over natliurlijk leiderschap en overwicht en kon onmogeijjk een collaborerende, gedweeë 'Sambo' zijn, die louter fungeerde als het verlengstuk van zijn meester. Bij onlusten op plantages waren dan ook vaak bastiaans op een of andere manier betrokken. Eveneens blijken er in tijden van frequente wegloperijen en marronage nogal eens bastiaans tot de weglopers te hében behoord. ${ }^{4}$ Hoogbergen (1985:49) stelt zelfs dat het meestal de bastiaans waren, die het contact met marrons onderhielden. ${ }^{5}$

3 Het algernene be'eid dat de rwarte bastiaan degene was die door de directie opgelegde lijtstraffen aan zijm medeslaven moest toedienen, was een var de psychologisch meest geratfinecrde onderdelen van de verdeel-en-heers-puititek die de planters in alle slavenkoloniën hebbern gehanteerd.

$4 \quad Z$ ie bijoorbee,d Hoofdstuk $X$ X. Een ander voorbeeld is plantage Vossenburg, waar tussen 1828 en 1834 totaal 41 slaven - dat is bijna een kwart van alle volwassenen - 52 keer weglopen. Onde: hen bevonden zich de bastiaans Profijt en Pirtje (Surinaans Mrseum: CollectieBrantsen, verantwoorde rekening).

5 'De basja wist heel vaak waar de weglopers zich ophielden. Hij stond oogluikend bezoek aan de plantages toe, hij permitterde dat van de plantages eten naar deze mensen gebracht werd. Hij handelde vaak met de weglopers en ruilde door de Martons gevangen vis en wild tegen produkten van de kustgronden. De basja was ook de man die de plannen voor massale desertie ritwerkte en zorgde dat bet voor de vlucht benodigde voedsel werd verzameld en 
$\mathrm{Na}$ onlusten op plantage Zeezigt in 1835 werden alle bastiaans afgezet en van de plantage verbannen. $Z \mathrm{ij}$ werden kennelijk verantwoordelijk gesteld voor het slavenverzet. Nog duidelijker zijn de rapporten over plantage Potribo, waar in 1828, tijdens het bezoek van een van de eigenaars uit Nederland, een aantal slaven wegloopt 'na eenige testen [ketels】 zuiker bedorven te hebben'. Later komen zij toch weer terug en worden zwaar gestraft, 'even zoo wel als de zoogenaamde bastiaan aan wiens wangedrag de bestaande verwarring en ongeregeldheid grootendeels te wijten was'. 6 Dat vlak na deze gebeurtenissen een van de trasloodsen plotseling uitbrandde kan toeval zijn geweest. Niet toevallig was dat, gedurende datzelfde jaar, de gehele slavenmacht, uítgezonderd bejaarden en kinderen, zich van de plantage verwijderde en in staking bleef totdat de directeur was ontslagen. Een dergelijke actie vereiste organisatie en leiding, zodat het voor de hand ligt te veronderstellen dat dezelfde bastiaan daar weer de hand in had gehad.

Bij het verdedigen van de siavenbelangen namen de bastiaans soms grote risico's en stelden daarmee hur eigen bevoorrechte positie in de waagschaal. Tegelijk konden zij ook groot gevaar lopen als handhavers van de orde op en vooral ook rond de plantages. Wanneer bijvoorbeeld de directeur had gehoord dat zich in de buturt van de plantage weglopers (zogenaamde schuilers) bevonden, of wanneer de slaven zich door schuilers bedreigd voelden, dan moest de bastiaan daar, gewapend, op af. Heel triest was bijwoorbeeld het incident bij Merveille in 1845. In de omgeving van die plantage zou zich een groep weglopers hebben schuilgehouden, waarop directeur Daser besloot er een gewapende groep slaven, onder leiding van de bastiaan, op af te sturen. Tegelijkertijd was er echter ook een militaire bospatrouille in die buurt actief, die de groep van Merveille aancag voor de weglopers en hen hevig begon te beschieten. Resultaat: twee doden en een gewonde, onder wie de bastiaan. ${ }^{7}$

Het leven van een bastiaan had dus zijn gevaarlijke kanten, maar hij was ook een man met macht, die het oor van de meester had en zo ook andere slaven bij hem kon aanklagen. Dit kon hij op persoonlijke titel doen, of uit naam van andere slaven. Het meest geëigende middel om een onaan-

gooderen werden ingepakt. (Hooghergen 1985:49.)

GAA: PA-600, 544.

7 ARA: CC der WI Bez. 1828-1845, 63. Een ander voorbeeld is plantage Nicuwsorg aan de Conmetewaric. Daar werd in 1795 'de $1 e$ bastiaan, Jan, des avonds te hrys koomende annge vallen, beschooten en met houwer-kappingen vermoord door schuylers' (ARA: RvP, 599), Ook gebeurde het dat in 1827 van plantage Alida aan de Cottica achttien slaven waren weggt-

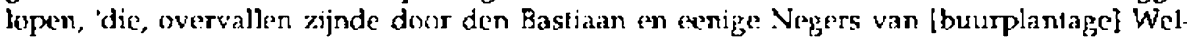
gelegen, die op den agterdam patrouille maakten om hunne kostgronden te bewaren, zich hebben verdedigd en den Bastiaan een kogel door den hals gejaagd' (Collectie-Insinger \& Co. Informatiebock). 


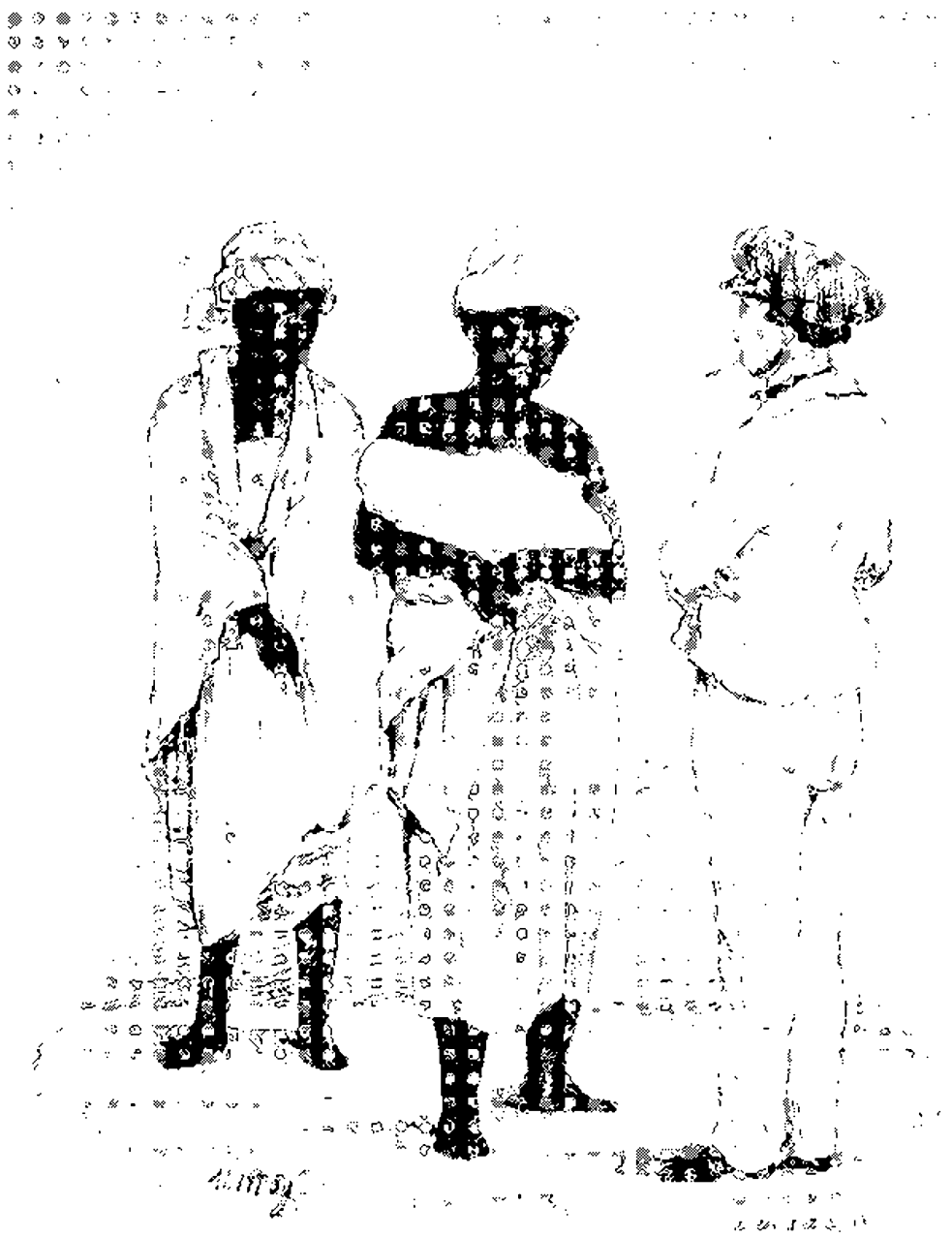

Directeur mel vroedvrouw en kraamyroww ca. 1850

(Foto-arcier KIllLV n:.1203; ith. Th Bray) 
genaam persoon weg te wexken was deze te beschuldigen van gímengerij. Dit kon vrijwel nooit daadwerkelijk worden bewezen, maar het verwekte meestal zoveel onrust, niet het minst ook b:j de plantagestaf, dat er vaak wel nar werd ge:uisterd en de beschuldigde van cie plantage werd. verwijderd." Zo werd in 1804 op Jagtiust de slaaf l'rias verkocht (voor $f 1.000$ wat aangeeft dat hij een waardevolle arbeidskracint was) 'uit hoofde. van de slegte reuk waarin hij bij de andere reegers wegens gifmengerij stond:.9 Op Vossenburg gebeurde in 1819 hetzelfde met Fmanuel, maa: daar bleef het niet bij, want enkele jaren later werden achter e.kaar ook La Fleur en Askan van gifmengerij beschuldigd. Tegen geen van beide mannen wercier. bewijzer. gevonden, alleen bleek van Askan 'dat zich dien Neger den haat der magt op den hals gehaald had, coor het beziger: van dreigementen. Toch werder beide beschuldigden naar een andere plantage verbannen, ter gerusistelling van de slaver. ${ }^{30}$

Aangezien de bastiaan bij al dit soort beschuldigingen als intermediair optrad tussen de slaven er de directie was het aan hem om te beoordelen of de problemen onderling konder worden opgelost of moesten worden doorgespeeld raar de dizectelir, cîe hoofdzakelijk op zijn advies moest afgaan. Dit gaf hem een niet onaanzienlijke mach.tspositie, die hi;, mits voorzichtig, ook ten eigen nutte kon aanwerden.

Een duidelijk voorbeeld van de maclitspusitie van de bastiaan jimmen de slavengemeerschap is het voorval dat E.J. Bartelir.k verhaalt uit de ijjd dat hij biarkofficier was op plartage 7eezigt. Op een dag merkte hij dat twee slaven niet waren komeri opdagen voor het veldwerk. Aivorens daarvan.

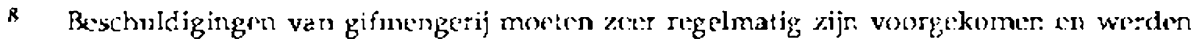
hoog opgevat, getuige het feif dat er in het plantagereglement van $1784 \mathrm{cen}$ apart artikel aan werd gewrijd: "Ton vcertienden, geent directeurs off ancie bediendens van een plantagie zullen 7ig mogen onderstan tenige pezquisitie of onderatek te doen wegens !aiten van sladaen vonr h.unne tijo voorgevallen, vocl minder na praetense wissie of vergift, daar dikwils den eene neeger den andre vit wrake mede betigt zondor bewijs; dog hem iets dazr van ter zeyde ter voren kumon de, peinoudes: zijn daar van aan zijn neesters [de gigendar of administrateur] kennis te geever. op poene des contrarie doerde :c zullen verbeuren driehonderd guldens' (Schiltkamp en De Smidr 1973, il:1072).

9 Collectie-Insinger \& Co.: notulboek Biesterbos.

13 Surinaams Museum: Collectie-3rantsen, verslagbockjc 1819 en verantwoorde rekening, 1822 en 1823 . Overigens werder. beschtildigingen van vergiftig:ng (of wisi) niet al:ijd gehonoreerd door de beschildigde van de plantage te verwijderen. Intrigreend is bet voorval dat zich in 1831 afspeelde op piantage De Nieuwe Grond. Daar waren zeer plotselirg de jonger: Cordon en zijn zus Maria overleden, terwijl tege ijk hun broer Nathijs dodelijk ziek werd, naar wel overleefde. De administrateur schreef hierover: 'de onstandigheid van den twist tusschen derzeiver moeder en den noger Kaptijn maakte dezc zaak ongetwijfeld meest bedenkelijk, en hoezeer wij ons verheugen da: er geene termen zijn gevonden om aatstgenoemder te straffer: tor zake van vergifiging, mada allewn wegens de dfgodische daden ten huize van ce negerin L.'Espérance [Kaptijns moedex] verrigt en opgevolgde absentie, zoo vertrouwen wij tog dat de directeur een waakzaam oog op hen zal blijven houden' (CollecticInsinger \& Co.: k(ppieboek). 
rapport op te maken voor de directeur, raadpleegde hij echter de slavin die voor hem de was deed en in wie iij een groot vertrouwen had:

'Als gij dat dnet, zijt gij reddeions verioren, zeide zij mij; "de twee mannen zijn voor de hoofdbastiaan gaan visschen of in zijn kostgrondje gaan werken. Gij zult zowel hem als het voik tegen u krijgen. Als gi; wacht zult ge zien, dat de anderen de twee merken [taker] van de afwezigen in hun vrijen sijd afmaken." Zoo gebeurde 't ook en ik was zeer blij niet met overhaasting gehandeld te hebben.' (Bartelink 1914:17-8.)

Kennelijk was de macht van de bastiaan zo groot, dat de andere slaven geen bezwaar hadden ook voor hem persoonlijk arbeid te verrichten. De biankofficier had zich daar maar bij neer te legger.

Het is niet onwaarschijnlijk dat de functie van bastiaan binnen de slavenmaatschappij was geinstitutionaliseerd in de vorm var het priesterschap. Zo stuitte Lamur (1985:-6-7) in zijn onderzoek naar de kerstening var. de slaven op Vossenburg op de ainwezighe:d var. eer. 'erste Baslian, wclche zu gleich der erste prister ist'. Oncer priester moet dar waarschipnlijk een 'bonuman' worden verstaan. Ook bij verschilience acties met en teger: de zendelinger op deze plantage blijken het steeds de bastiaans te zijn geweent, die als leiders optraden.

Op de buurplantage Breukelerwaard was al eerder met de kerstening begonnen. Daar werden tusser. 1821 en $: 83065$ van de circa 115 volwassean slaven gedoopt. De laatste in de rij die zich liet dopen was bastiaan Nelson (doopnaam Nicolaas). Dit kan toeva: zijn geweest, maar ook is het voorstelbaar dat Nelson voelde, toen meer da: de helft van de volwassenen zich had laten dopen, da: hij de macht over zijn volgelingen begor kwi;: te raken. Door hun voorbecid te volgen trachtte inj wellicht het verloren gegane terrein te herwinner en zijn (religieuze) ir.vloed te behouden."1

Crator. (1982:249-50) wijst er op dat in Demarara een duidelijk verluand bestond tussen de elitesiaven op de plantages en de voormannen ('chapel deacons') in de zwarte christe'.jke kerken. Bovendien bleek een aantal var deze zowel sociale aIs reigienze leiders de aanvoerders te zijn van de grote opstanden in ceze kolonie aan he: begin van de negentiende eeuw.

Oox in de Surinaamse o:ale traditie zijn aanwijzingen te vinden die de veronderstelde combinatie van bastiaar.s en religielize mach: bevestigen. Bekend is het verhaal van basja Adjuku van Geertruidenberg - of de ook wel genoemde Goed Succes - die over zo'n krachige 'winti' heette te beschikken, dat hij in staat was zweepslager die op een slavernrug neerdaalden zodarig te transformerer: dat zij alleen boor cie meesters gevoeld werden. Zo wist hij zijn mensen te beschermen tegen wrede bazen. ${ }^{\text {I }}$

12 Dit verhaal stant uitgebresd bescheven in Voorhorve er: Iichtveld (1975:92. S) en Guda 
A! zal er nog vee; onderzocht moeten worden over de intrigerende combinatie van plantagevoorman en rel:gieus leider, verenigd in de bastiaan, toch lijken er voldoende aanwijzingen te bestaan om te veronderstellen dat het meer dan een toevallig verschijnsel was. ${ }^{13}$ Buiten $\mathrm{kij}_{\mathrm{j}}$ staat dat de bastiaan iemanci was waar niemand op de piartage omheen kon. Zijn invloed op het reilen en zeilen van de onderreming kan daarom nauwelijks worden onderschat.

\section{De blankofficier}

De functie van blankofficier - ook wel schrijuer, scrifiman of bakrabasja genaamd - behoorde niet tot de begerenswaardigste op de plantage. Hij stond ais eerste op en ging als laatste rlaar bed. De hele dag door moest hij op alle werkzaamheden een toeziend oog houden en daarvan verslag doen aan de directeur. Fen blankofficier rekende eens voor dat hij iedere dag op zijn minct achttien kilometer te voet aflegde om de verschillende werkzamheden te controleren. ${ }^{14} \mathrm{Zi}$; $100 \mathrm{n}$ bedroeg in de regel $f 150$ per jaar. Mij zor: daarvar: geer. voeding behoeven te betalen, omdat hij mee at met de directeur, die daarvoor een kostgeld ontving van zijn superieuren. Maar hoe meer de directeur echter op dit kostgeid beknibje!de, hoe groter zijn inkomsten waren, zodat de blankofficier er meestal karig van a:kwam en gedwongen was aanvillend voedsel bij de slaven, of elders, te kopen. Ook zijn kledirg hield niet over en bestond valk uit nief meer dan het goed aan zijn ijf. De a: aangehaalde blankofficier schreef zelfs da: lij ce slaven om hun arbeid benijdde, ordat zij daardoor terminste warm bleven in de regentijd, terwijl hij als optichter verkleumde en doornat werd. Bovendier moest hij in die natte kleding 's avonds ook slapen, want ardere kleren had hij niet, dus 'het moet eer. zeer sterk mensch zijn om niet daar door zwaar ziek te worden': $: 5$

De behuizing van de blankofficier bestond meestal Lit een afgeschoten hokje in exir var: de plantagelondsen. Zo was er bijvoorbeeki op Vossenburg

(:985:48.51). In de laatste bundẹ staan meet verhalen over de bovenratuvrlïke k:achten van bastiaans.

13 Camrur (3985:29 32) lijkt er ze!5s al van wil te gaan dat do koppeling bastiaan-priester inderdaad de norm was. Gebasee-d op orale bronner, geeft hij twee verktaringer van de gecombimeerde figuur: 'De koppeling van sacrale en seculaire posities verschafte de bastiaanpriester voldoende macht um mogelijke kritiek op z:jn "welvarende" positie de kop in te drukken en iegelijk de extheic in de slavengemeenschap als ge'heel te handhaven'. En: 'The religieuze taak van de pricster-bastiaan was er juist op gericnt om de eenheid en de solidariteit onder de slaven to versterken met als doel hat verdedigen van deze materiele verworvenheden'.

14 ARA: Collectie-Van den Bosch, 125.

15 ARA: Collecdie-Van den Bosch, 125. 
een kamertje gemaakt in het kookhuis 'tot logies der onderdienaar', waaxin niet meer stond dan een tafel, een stoel en een staande koperen lamp; de blankofficier sliep in een hangmat.16

Zo lang de blankofficier bij een plantage in dienst was, mocht hij geen stap buiten de onderneming zetten, tenzij dit verband hield met de werkzaamheden, zoals het naas de stad brengen van produkten. Dat zijn lot in veel leck op dat van de slaven en dat zij vaak minder geacht werden dan de bastiaans, blijkt nog eens uit de woorden van de voormalig blankofficier Douglas (1936:51):

'[o]p de plantages hadden zij riets te vertellen, doch moesten alleen als toehoorders bij de bespreking omtrent de werkzaamheden, tusschen den directeur en de bastiaans, aan de voet van de trap van de woning blijven staan, en haast, een slaafsche onderdanigheid, tegenover den directeur in acht nemen:

Wat waren dat day voor mannen die, door iedereen geminacht, toch een dergelijke functie vervulden? In de meeste gevallen ging het om matrozen en soldaten, dje op een of andere manier in Suriname waren blijven hangen. Vaak rauwe en orbeholpen kerels, die gewend waren van de hand in de tand te leven. Hun ongang met de slaven getuigde meestal niet van veel tact en vaak werd er voor gewaarschuwd deze mannen seksueel in toom te houden omdat hun benadering van slavinnen kon leiden tot grote onlusten (zie Blom 1787:366 en plantagereglementen).

De blankofficiers wisselden vaak van betrekking en bleven gemiddeld niet langer dan een jaar op dezelfde plantage.17 Voor een deel zal dit het gevolg zijn geweest van hun eigen onbehouwen gedrag, anderzijds zal het de directeur vaak ook goed uitgekomen zijn. Hij kon de blankofficier laten fungeren als een soort buffer tussen hemzelf en de slaven. Het uitvoeren van impopulaire maatregelen en handhaven van een harde discipline konden worden afgewenteld op de blankofficier. Wanneer de slaven geen genoegen meer met hem namen, kon de man eenvoudig worden ontslagen. Uit een oogpunt van sociale rust en continuiteit van de onderneming was de blankofficier dus geer ideaal stanlid van de plantage; als (tijdelijke) bliksemafleider voor de directeur voldeed hij waarschijnlijk wel.

Dat blankofficieren een dergelijk leven volhielden, zal voor een belangrijk deel te maken hebber gehad met de hoop eens directeur te kunnen worden. Blom (1787:367) wijst er dan ook op dat het blankofficierschap meer moest worden gezien als een soort leerperiode, waarin alle aspecten van de planterij en het leidinggeven onder de knie moesten worden gekregen.

16 Surinaams Muscum: Collectic-Brantsen, inventaris 1878 .

17 Een steekproef onder 100 blankofficiers op de plantages Groot Marscille, Vosscnburg en Vrouwenvlij! svijst uil dal een blankotticier gem:ddeld niet langer dan 1,1 jaar op dezelfde plantage blexp. 
Volgens hem konden de goeden order hen dan al na drie jaar een directeurspositie verwerven (Blom 1787:354). De praktijk bleek echter minder rooskleurig te zijn. Uit een steekproef onder 22 blankofficiers die in de jaren 1820 werkzaam waren op Groot Marseille en Vossenburg blijkt dat slechts vijf van hen het gedurende de volgende drie decennia brachten tot plantagedirecteur; een was eigenaar geworden van een kleine kostplantage. Eén van de viji schopte het zelfs nog tot mede-administrateur van een plantage, maar de overige zestien - bijna driekwart van het totaal - bleven hun dagen slijten als blankofficier, of hebben het nict volgehouden. ${ }^{18}$ Het moet een weinig aantrekkelijk bestaan zijn geweest: gehaat door de slaver, geminacht en misbruikt door de directeurs en een tamelijk hopeloos toekomstperspectief.

\section{De directewr}

De plantagedirecteur was de hougste in rang op de onderneming. Hij werd aangesteld door de eigenaar of administrateur en has vaak al een loopbaan als blankofficier achter de rug. Soms waren hef echfer ook aan lager wal geraakte planters, die 70 de kost konden verdienen, soms ook zoons van plantage-eigenaars of administrateurs die er door hun vader op uitgestuurd waren het vak van planter te leren.

De directeurs vormden een stabielere factor op de plantages dan de blankofficiers. Een steekproef swijst uit, dat zij gemiddeld vijt-en-half jaar in dezelfde berekking werkzaam bleven. ${ }^{13}$ Dit betekent riet dat er onder hen soms geen groot verloop was, maar ook $\mathrm{kwam}$ het met enige regelmaat voor dat directeurs enkele fientallen jaren achtereen op dezeltde plantage leiding gaven. ${ }^{20}$ Dit laatste werd echter in het algemeen niet aanbevolen 'daar vreemde ogen he! beste dwingen'.21 Zo kreeg Van Breugel, eigenaar van Clifford Kogshooven, mesmalen te horen dat het van zijn voorganger niet verstandig was geweest directeur Wagener ruin 25 jaar te handhaven. Deze z.ou daardoor te 'gemeenzaam' met de siaven zijn geworden, 'daar hij bijkans alle had zien geboren worden', wat wel moest Jeiden tot plichts-

Ib Steekproef: Surinaams Museum: Collectie-Brantsen, verantwoorde rekening 1823-1828; James Ford Bell Libraty: 3 3482, verantwoorde rekening 1821 1827; Surinuamse Almanak 1834 en 1844; Van Sijpesteijn 1554:96-147.

19 Steekproef (1756-1863): Roosenburg en Mon Bijou (Oostindie 1989:79-88 en 231-3); plantage-archieven van Clifford Kocqshooven, Jagtlust, De Nieuwe Crond, Somerszorg, Vossenburg en Vrouwenvlijt. Samen kenden zij in totaal 396 jaar 71 directeuren.

20 Bijvoorbecld op plantage Clifford Kocqshooven was cne Wagencr directeur van 1786-1811 en Comvalius bleef er van 1819 tot ungeveer 1540 (KIT: Coliectie-Van Breugel). Op Vossenbure, werkte D.M. : Jhicnkamp van 18.35-18.58 (Surinaams Museum: Collectie-Brantsen, verslagboekjes) en op Driesveld kwam in 1779 J.B. de Rochebrune als direcleur, die er ook is gestorven in 1804 (CA.k: Collectic-Hudig, 561).

21 KIT: Collectie-Van Breugel. 
verzuim en verwaarlozing. ${ }^{22}$ Van dat laatste bleek overigens niets.

De directeurs oefenden de supervisie tit over alles wat zich op de plantage voordeed en bepaalden de grote lijnen van het dagelijks beleid. Het directe beheer lieten zij echter in de praktijk veelal over aan de bastiaans en blankofficiers. Wel bleven zij altijd verantwoordelijk voor het gevoerde beleid en dienden, eens in de maand, rekening en verantwoording af te leggen aan hun superieuren, vanaf eind achtticnde eeuw meestal een administrateur. In de zeer hiërarchische koloniale verhoudingen van die tijd was het hoogst ongebruikelijk wanneet de (absente) eigenaar en de plantagedirecteur direct met e!kaar in contact traden. Dit diende ajtijd via de administrateur te verlopen.

Zowel de financiële als de sociale waardering voor de directeur verschilde sterk per betrekking. In de negentiende ceuw liepen de jaarsalarissen uiteen van $f 516$ op Somerszorg tot $f 800$ à 900 op Vrouwenvlijt, $f 1.000$ à $1.200 \mathrm{op}$ Jibanon on $f 3.600$ a 1.800 op Vossenburg ${ }^{2.3}$ Op Laatstgenoernde plantage werden de directeurs, om hen te stimuleren, na eer aantal jaren tevens benoemd tot mede-administrateur, wat hen naast het directeurssalaris ook nog 3\% van de suikerproduktie en $3 \%$ van de inkomsten in Suriname opleverde. ${ }^{24}$ Het ontbrax hen op deze plantage dus niet aan waardering. Dat bleek ook toen bijvoorbeeld directeur Uhlenkamp in 1848 werd geprezen om 'zijne algemeene bekwaamheid on met de Negers om te gaan'. Men dankte het aan zijn mensenkennis dat op Vossenburg, in tegenstelling tot vele andere plantages, de slavenbevolking rustig werkte, 1e:wijl dere 'in de Kolonie nief als de handelbaarste wordt genoemd ${ }^{25}$

Zowel het beleid van de administratenr als van de directenr van vossenburg getuigen van verstardig management: een goede beloning, participatie in beleid en inkomsten en een schouderklopje op zijn tjjd wierpen hun vruchten af. Zo'n houding xon op meer plantages worden aangetroffen, maar was in het algemeen meer uitzondering dan regel (zie ook Tabel 43). Vaak eigerde de administrateur zich alle lof toe dis het goed ging met de plantage en werden alle mislukkingen afgewenteld op de schouders van de directeur. Ook werd de directeur nog al eens de dupe var. hef gekrakeel tussen de verschillende acministrateurs van een plantage. Dat bleek bijvoorbeeld in 1814 op Vrouwenvlijt die, als gevo!g van gedeeld eigendom, werd beheerd door drie verschileende administrateurs. Op een gegeven dag

23 Niet toevallig zijn in di! voorbeeld de twee plantages met de laagste salarissen kotfieen de andere twee suikerplantages. Dit was in het algemeen de regel. Leidinggeven aan een suikerplantage vereiste meer kenn:s en betekende daarom mecstal een promotie uor de directeur van ecn koffieplantage.

24 Surinaams Museum: Co:lectie-Brantsen, verantwoorde rekening 1845.

25. Surinaams Museum: Collectie-Brantsen, verslagbockje 1848. 
bleek een var hen geheel eigenmachtig een nieuwe directeur te hebben benoemd, die daarop prompt door de zittende direcieu- de toegang tot de plantage werd geweigerd. 26

Al was se relatie met de administrateur(s) soms probiematisch, zo lang de directeur mar zorgde voor een geregelde produktie en er geen buitensporige ongeregeidheden op de plantage platsvonden, was zi;n bestaan onvergelijkelijk veel beter dan dat van de blankofficier. In feite leefde hij als een konink; in zijn eigen, kleine vorstendom. Vele beschrijvingen van he: directekrsbestaan getuigen daarvan. 27 De enige overeenknmst met de blank-

26 De drie betrokken administrateurs waren Do Mrynortahagen, il. Terrel Cientil en F. Taunay. De nicuwc dircchclir was ene :.H. Schultz Jansz. die zich naar de plantage begat en de daar verblijende directeut Scharmiweber sommerde hem het gezag over te geven. Daarop

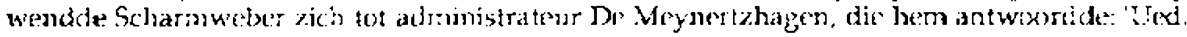
geefs de plantage ann nicmand over veor en aleer gij daartece een authorisatie door mij ondertekend bekomt, en zo kennon zjj mij nog njet. Wanneer den Heer Sxhul:z uw wedier

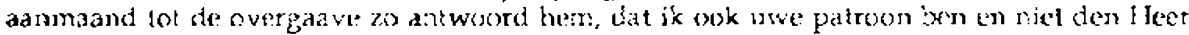
Perre! Gentil alleen, en dat hij zig dus most voorzion van en authorisatie door mij mede ondertekcnd. th vind hel lasg van den Heer 'aunay dat hij tragten wil sen directeur die in de rechter ongexefend is, te surpre'sseeren'. I loo de directeur zich uit dit lastig parket hecit gered is helaas niet bekend (Surinaatms Museum: Collecism.Mamin, bricvenmap 3).

Dis soort getuurenissen kwam vaker vour. Zeer sprekend is bjjoortecla hat incident op piantage De Zwarighejo, geaciministreerd dour J. Leach en $R$. van Rees, ieder vour een half aanderl. ia ji:li 1829 schrifft [.pach aan de pigenass van het halvo aandefi, Bariny, Brothrrs in Lorden: 'I have the honor to inform you tha: I do not acknowledge (for the half) the so narned manager (J.M. Harg) in tha: quality, he having left the plantatior since : he 20 th

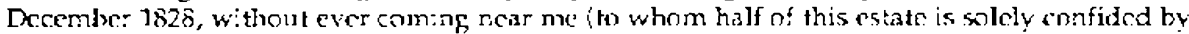
the propretors taking away witi him everythirg he had, even to the pigeons out of their house. Ori the $1 C$ th of Aprit last 1 sound on lins very plantation this same larg drunk; authorised by Mr. van Rees, wilhout my knowfledge or consert, and rot alone against my wish \& inclination, but also ageinst that of the propretors, as at variance with the intercsts of the estate, from a moral conviction that he is as unfit for it as he is dis:ionest. (Guidd Hals: Mas $18321 / 11$ (C.4.:0.1.)

27 Zic bijvoorbecld Wagenaar Hummelinck (1947), Douglas (1936:39-50), Bartelink (1914) of Lammens (1982:174). Van de laat3te komt de volghende bescirijuing van eer gemiddelce

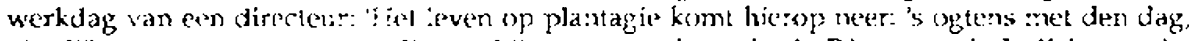
uiterlijk zes uren opstaan, cen lig, ontbij! genomen, bezoekt de Directeur, cie koffy'oots, zick het werk aldaar ra, het vee en alles, wat bij en omment hot hu:s is: - do negerkinderen dic men

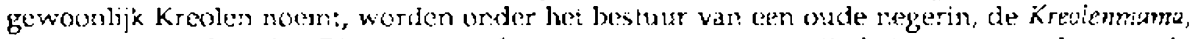
verioont, wonsthen den Directur goade morgen; staan op een rij. de jongers aan de eere, de meisjes aan de andere zijde, en klappen met ce handen: - indien het zondag is, kont ce gchelc magt voor de deur, de mans scharen zich dan ook aan de eene zijde, en de vrouwen aan de andere zijde; de negers k:jjgen een zoojpje! - hierna gaat men wandeien of te parardrijen: - de directeur gaat na de gronden, dat is het veidverk beschou wen en nazien: -voorts praat men to: elf a twaalf urem: dan gebru:kl men cen breakfast, uil veesch, visch en brood, bier en wijn bestaande: - hierra gaat mon ecn paar dur slapen, en dan, ra sish gebaad te hebber, kimt men, als ter bezoeke, in order :e voorichijn: - men georuikl onde: het kouten cen kopje Thec, wat morgendrank ol eet zoms ecrige vruchten: sen zes a zeven uren zet men zich, te miduag

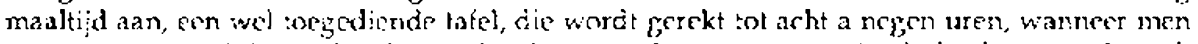
opstaat, een vartijtic maakt, danst of zici vermaakt, met praten, in de koelen avondstond, onder de gaarderij, tzi j order de bomen, of aan de waterkant: - inlusscinen gebraik! mer een kop:

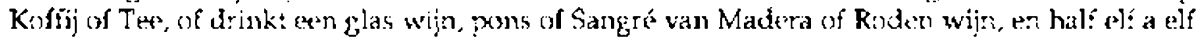


officier bestond uit de regel, dat hij onder geen beding de plantage mocht verlaten, tenzij voor dringende plantagezaken, om zijn salaris in ontvangst te nemen, of in verband met ziekte en dat dan nog alleen met toestemming van zijn superieuren. Dit werd uitdrukkelijk zo bepaald in het plantagereglement van de koloniale overheid, 'om door dat middel alle disordres zo van revolte van neegers als brand op de plantagien voor te koomen' (Schiltkamp en De Smidt 1973, II:1070).28

De dagen van de directeur werden voornamelijk gevuld met administratieve arbeid en het op gezette tijden narien van de werkzaamheden. Voor de rest werd er veel geslapen, gegeten en gedronken. Het eerste deed hij meestal in gezelschap van zijn favoriete slavin, de laatste twee bezigheden vaak met collega's uit de buurt. Al lijkt het misschien wat paradoxaal, toch leidde deze tamelijk hedonistische manier van leven nogal eens tot grote onrust op de plantages. Van vrij onschuldige aard was de situatie op Potribo rond 1860, waar de tijdelijke directeur, Bakker, onafscheidelijk bleek te zijn. van 'twee jonge slavinnen, die hem als hofdames overal vergezelden'. Nooit weken deze twee van zijn zijde, noch mochten zij door iemand benaderd worden. 'Dat op de plantage zoo vaak van blankofficiers gewisseld werd, moest toegeschreven worden aan de jaloerschheid van den directeur' (Bartelink 1914:39-11).29 Bakker bemoeide zich totaal niet met de plantage-

uren gaat men na bed.

Zodra de avond daar is, komen de bassiaans of negerofficieren, hun rapport doen, van het verrigte werk, en de negers krijgen een glas dram, de wagtrol wordt afgelezen en de wagtnegers gaan naar de hun aangewezen posten, en zo eindigt den dag.'

2s Bartelink 1914:43) beschreet het volgende incident: 'Tens mecnde een voornaam directeur zich niet aan dien regel te behocven storen en makte een sprongetje naar de stad, zonder vooratgaand verlof van zijn Administrateur. Hij meldde zich op het kantoor aan, kennisgevende van zijn aanwezigheid in de stad wegens zickte van een familielid. De Administzateur hoorde hem 200 xalm mogelijk aan en nadat de directeur uilgesproken had, zeide hij: 'Mijnheer, ik ken U niet, gij maakt gebruik van een valschen naam. De directeur, dien gij voorgeeft to zijn, is op de planlage a an de maling- Jk ga mog heden avond naar hem toe." De directeur zei niets, maar hastte zich onmiddellijk terug te keren: hij wist dat de Administrateur een man yan ce daad was en werkelijk 's avonds naar de plantage zou gaan. Als hij hem er niet vond, stond zijn ontslag erop.

Inderdaad kwam de Administrateur dien avond op de plantage en vertelde ann den direrteur dat een mijnheer op het kanroor geweest was, die zich voor hem had uitgrgeven. Wet hact volgende getij vertrok de Administratcur weer en noodigde den directeur uit met hem mee te gaan naar de stad. Deze zol1 misschien gaarne cen familielid, dat naar hij gehonrd had, ziek was, willen bezoeken.'

29 Op een gegeven dag werd Bakker weer overgeplaatst, omdat de oude directeur, Kilian, np de plantage terugkwam. Bakker Jièt daarop zijn blankofficier, Bartelink, bij zich roepern: 'Ik ging er heen en vond hem te bed met zijn beide hofdames, jeder aan cen zijde van her hod gezeten. $Z i j$ verkeerden alle drie in de grootste verslagenheid. Hij jammerde tegen mij, dat hij getacht had, hier vasten voet te hebben en nu moest weggraan en verder hoe hij 't stellen zou met de hofdames. Zij waren sla vinnen van de planlage en hij kon ze nict meenemen.

lk had altijd 't land aan hem gehad en ik kon 't niet helpen, dat ik nu mijn gemoed' tegen hem luchtte. Ik antwourdde: "Wel, mijnherer, drit" is sen stel; bindt de bxide vrouwen orn uw hais en 
werkzaamheden, terwijl Bartelink al de vierde blankofficier binnen een jaar was die op deze plantage in dienst trad. De continuilteit van de onderneming werd dus ernstig bedreigd door het liefdesleven van de directeur. Dat er overigens nog veel gevaarlijker toestanden konden ontstaan door ce lus:gevoelens van blanke managers bijikt wel uit de expliciete waarschuwing in het koloniale plantagereglement, dat er geen 'disorders' dienden te ontstaan uit 'enige vermer.gingen van blanken met de slavinnen' (5chiltkamp en De Smid: 1973, II:1069-70).

Ook het drankgebruik van de directeurs kon een ernstige bedreiging voor de orde en rust op de plantages vormen. En er werd veel gedronken in Suriname. ${ }^{33}$ Sprekerd is de hoeveelheid drank die Van Breugel meenam voor een 18-daags verblijf op zijn plantage: 50 liter bier, 160 liter wijnen, 29 liter jenever, 7,5 liter b:andewijn, 2,5 !:ter cognac en enkele flesser. champagne. ${ }^{31}$ Deze drank was in feite alleer. bestemd voor het feestmaal dat hij op de plantage moest geven voor dertig directeurs uit de omgeving, want zelf dronk hij nauwelijks. Cynisch merkle hij dar ook op dat het in Suriname de gewoonte was om het 'leven liever bij een wijnglas dan bij en uurglas af te meten' (Van Breugel 1824:17).

Hoe vro:ijk dit alles ook mag aandoen, het waren voo:al de piantagedirecterirs die, uit verveling of misschien ook uit angst voor de slavenovermacht, vee: dronken en daardoor een gevaar vormden voor de onderneming. Sommige schrijvers trachtien dit probleem te bagateliiseren. Zo stelt Nassy (1791, II:76): 'Zo ex al eenige ondex hen zijn, die zich vol dririker. en zuipgezelschappen me: hunne buuren houden, daar uit moet geer. gevolg getrokken worden ten beschuidiginge van de overige direkteiren'.

spring in de rivier, dar. heibt ge ze altijd bij 1 , int:1sschen zal ik de orders var den Administrateux gaan uitvoeren er, de bool aizcnden ter afha'ing van den heer Kilian. Ik heb de eer u te groeten." Dit zeggende, maakte ik rechtonkeer en verliet hem.- 1...]

De herr Kiliar nam, bijgestaan door twee inventariseurs, de directie sver en de heor Bakker vertrok. Het afscheid van de twee hoidames, die hij moest achterlaten, was meer dan roerend. $Z \mathrm{ij}$ schreiden haast hare oogen uit, want ze wisten, dat 't met hun princesseieven r.L gedaan was. Lou getource 't ook. De heer Kilian zond ze naar het veid en ram zijn oude

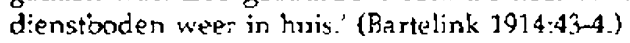

30 Zo wcrd alleen al in 1827 ingevocrd: 17.675 liter bier, 69.263 litcr wijnen (waaronder ook port en likeur) er. 172.186 liter sterke drank ( $(u m$, jenever en brandewijn). Wanneer het totia: wordr omgeslager over de voiwassen blanke bevolking (manner en vrolwer), voor wie deze drank tosh hoofdzakelijk bestemd was, dan werd in dat jaat 14] kiter alcoholica per hoof c geconsumeerd (Volwassern blanke bevolking gebaseerd op Lammens 1982:10; dranimport: ARA: Coliectie-Van den Bosch, 118). Dit is vanzelfsprekend slechts pen ruwe schatting van de gemiddelde aicoholcorsumptie, want het is niet waarschijnlijk dat vrouwen (veel) s:erke drank nuttigden, terwijl anderzijds de vrije gekleurde bevolking misschien ook een deel van deze import tot zich nam en er ook wel wi:n werd verstrekt aan zieke slaven. Bovendien is niet gezegd dat alle drank in 1827 werd geconsumerd. Dat necmt niet weg dat er zonder twijfel zeer veel werd gedronken.

31 KIT: Coliecte-Van Breuge!l. 


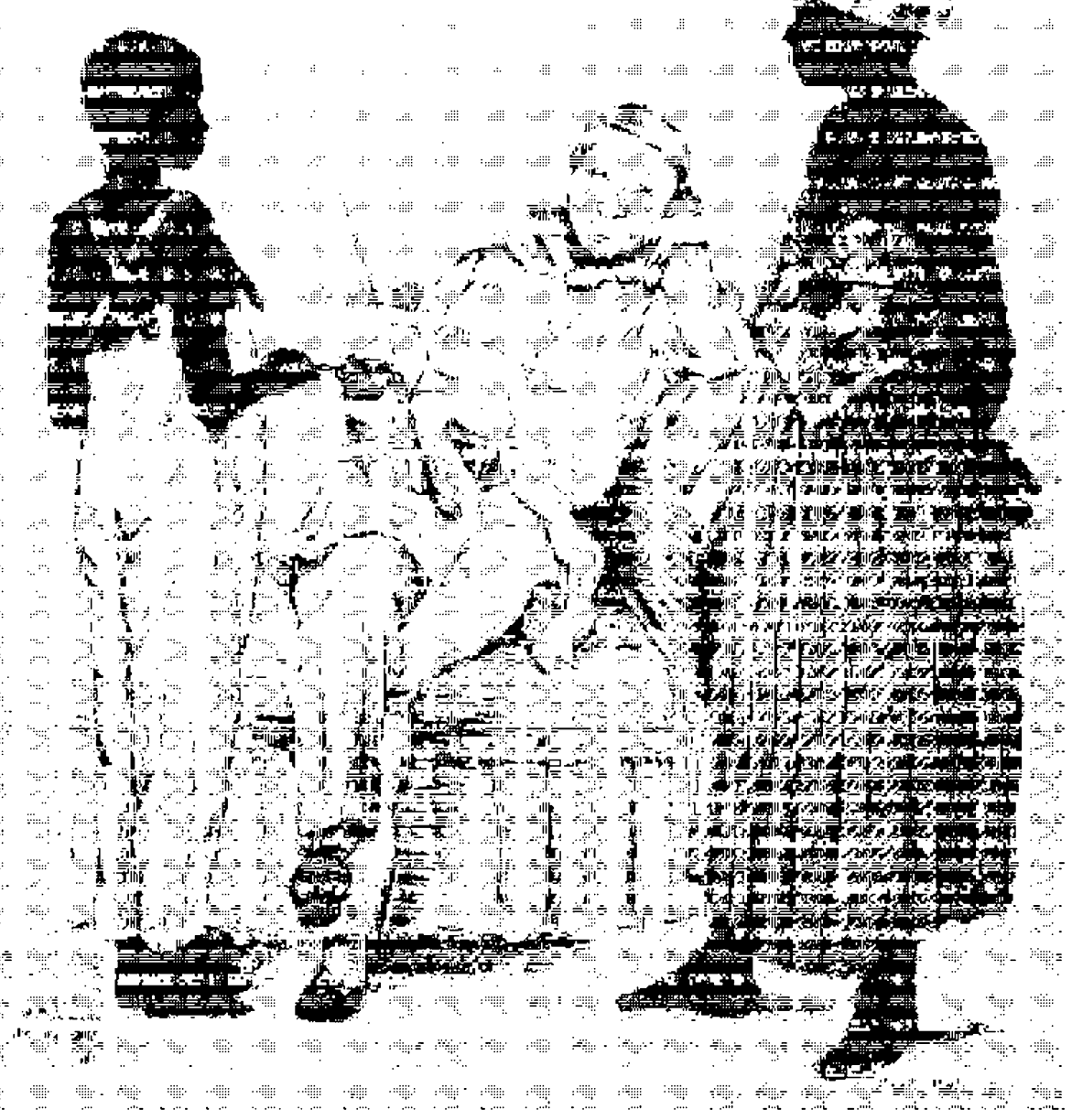

Directeur met slavin an focleboi ca. 1850

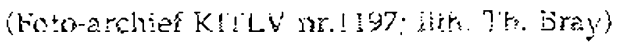


Toch moet het probleem veel groter geweest zijn dan Nassy ons wil laten. geloven. Het kan toch rauwelijks toeval heten dat in de weinige beschikbare plantage-archieven tenminste negenmaal melding wordt gemaakt van drankzuchtige directeurs, warvan er vijf om die reden werden ontslagen. ${ }^{32}$ Bovendien zal het niet zomaar zijn geweest dat in het koloniaal plantagereglement expliciet werd bepaald, dat, op straffe van een flinke galdboxte, de directeur zijn superieuren nict onfatsoenlijk mocht bcjegenen of uitschelden, 'dronken off nict' (Schiltkamp en De Smidt 1973, II:1069).

Overigens maken de beweegredenen om dronken directeurs te ontslaan genoeg duidelijk welk gevaar zij voor de plantage vormden. Op Potribo werd bijvoorbeeld in 1801 directeur Polman 'wegens dronkenschap en mishandeling van de slaaven afgezet' en in 1844 had de directeur van Zorg en Hoop 'zich zoodanig aan dronkenschap overgegeven dat alle werkzaamheden en toezigt is vervallen'. ${ }^{33}$

Natuurlijk zijn er ook heel kundige directeurs geweest, die mel veel menselijk inzicht en verstand van zaken de ondememing beheerden. Een sprekend voorbeeld daarvan was Kiliar, lange jaren directeur op Potribo. Toen zijn blankofficier eens klaagde dat hij al lange tijd geen droge draad meer aan ziju lijf had gehad en het loon te karig was om daarin verandering te brengen, adviseerde Kilian hem wat produkten uit de fabriek te nemen en deze te verkopen - iets wat in principe ten strengste verboden was - om van de opbrengst een paraplu aan te schaffen. Onder dezelfde directeur gebeurde het verder eens dat de slaven tijdens de oogst zich zeer onwillig gedroegen. Tot verbazing van de blankofficier besloot Kilian die dag een bezoek aan een collega elders te gaan brengen en nam de blankofficier mee, zodat er geen controle meer was op de werkzaamheden. Toen de blankofficier zijn verwondering uilsprak over dit volkoren ongebruikelijke gedrag antwoordde Kilian hem:

'Ik die hier jaren gewoond en op mijn pantoffels product gemaakt heb, ik ken het volk, ik weet wat het wil. Weet je wal ze mankeert? Ze willen stelen, en ik zal ze de gelegenhe:d geven om te stelen: daarom gaan wij met ons beiden van

32 1775: directeur C.F. Ebhor(s), De Hoop/Rooscuhurg; 1801: dircctcur Polman, Potritb; 1814: directeur Schramm, De Nicuwe Grond; 1824: cirecteur Esser, Kocqswoud; 1829: directeur Harg, De Zwarigheid; 1\$29: disecteur 'Jannen, Cront Marscille; 2835: djrecteur Yolichy, Vossesburg; 1844: directeur (onbokend), Zorg en Hoop.

In 1838 bezoekt G.B. Bosch plantage Dijkveld en schrijft (1843:228): "Hct was op deze plantaadje, dat ik der directeur adntrof, tije mij in een beschonken toestand bij mijne aankomst aan bond hezocht, dorh thans een der grschiktste monschen was, welke ik ergens heb aangetroffen. Dic verfoeijelijke drank! Dezelve verdierlijkt het redelijke schepsel, het pronkstuk der natuur!'

De belangrijke Fngyelse koloniale amblenaar en planter in Suriname, John Bent, liet zelfs weten, dat de plantagedirecteurs in dcze kolonie 'een soort van dronken lieden waren, die de slaven alierwreedaardigst behandelden' (Wolbers 1861:578).

33 GAA: PA-GRO, FA4. 
huis. Die a ppel vaart, die appel eet. Laten ze twee vaten suiker stelen, dat zullen ze zeker niet - maar aangeromen dat ze zooveei stelen, dan is dai nog niets. AIs ze hun zin hebben gehad, zullen ze met eens zooved ijver werken. Tegen het eind van het jaar heb ik dan zooveel vaten bover mijn calculatie en zooveel akkers rijp riet, dat ik met primo Januari weer kan beginnen te malen. Thuis komende van avond zult ge zien, dat alles uitstekend gegaan is op de plantage. Daarentegen, zou ik thuis blijven, dan zou alles siecht blijven gaan en ik zou mij kwaad maken.' (Bartelink 1914:45-7.)

Kilians voorspelling $\mathrm{kwam}$ inderdaad uit. Het zal dan ook niet voor niets geweest zijn dat onder zijn beheer Potribo behoorde tot de acht plantages met het hoogste suikerrendement per akker in heel Suriname, terwijl het niet eens over een stoommoien beschik:e (Koloniale Verslagen 1860 en 1861).

Ondanks het voorkomen van dergelijke kundige directeurs, deed het merkwaardige feit zich voor dat ook de minder bekwame toch steeds weer aan de slag kwamen. Zo namen de administrateurs van De Nieuwe Grond in 1814, na vele aarzelingen, toch Schramm in dienst als directeur, terwij: zij op de hoogte. waren vail zijn negatieve kanten, 'zijnde het veelvuldig gebruik van sterke dranken'. In dit geval pakte het goed iit, want bij zijn overlijden negen jaar later spraken zij over 'een zeer moeijijk te hersteilen verlies'34 Dit konden zi; echter var. tevoren niet weten. Bij andere directeurs was men minder fortuinijik, zodat die van het ene ontslag naar het andere hoiden. Ook de vele ongeregeldheden op plar.tages als gevolg van het directeursbeleic (zie Bijlage 9B) getuigen van de slechte kivaliteit van hun beheer. Toch werden zij te.kens weer - soms zelfs door dezelfde administrateur - in dienst genomen. Er moet dus een grote schaarste zijn geweest aan geschikte managers.

Dit impliceert dat, ondanks de hedonistische levenswijze van velen, het toch niet zo aantrekkelijk moet zijn geweest or: enn directeursfunctie te vervullen. De betaling was niet siecht, maar echt rijk zullen er maar weinigen zijn geworder. Daamaast leefde: zij in de eenzaamheid van de plantages, omringd door mensen die zij minarlitten, de biankofficiers, en die $z_{i j}$ vreesoen, de slaven. Ook de sterfte onder hen moet groot zijn geweest. Van de veertien bekende directeurs op lagtiust en De Nieuwe Grond bijvoorbeeld stierven er vijf tijdens hun dienstietrekking. ${ }^{35}$ De groep directeurs uit wie de admiristrafeurs konden putten yleef zodoende beperk:

Anderzijos was het vooruitzicht de loopbaan af te kumnen sluiten als administrateur de beste motivatie voor een directeur. Dit was echter maar voor weinigen weggelegd. Uit een willekeirige steekproe onde: 27 directeurs in 1824 blijkt dat slecht vier var: hem (15\%) in de daaropvolgende drie 
decennia een administrateurschap wisten te verwerver. De rest vertok, overleed, of bleef zijn leven lang directeur. Van de vier gelukkigen werd één mede-admiristrateur var een plantage; een ancer van twee en de derde was in 1853 nog steeds directeus, maar tevens mede-adminisłrateur van drie grote suikerplantages. De mooiste carriere maakte I.A. Tirion. In 1824 was hij directeur op I Iooyland, een grote suikerplantage. Tien jaar later bleck hij (mede-)ariministrateur van zes plantages er. in 1853 , aan het eind van zijn loophaz, zelfs van vijftien. Hij was daarmee een van de zeer weinigen die het echt had 'gernazkt' (Surinaumse Alminnkx 1824 en 1833; Van Sijpesteijn 1854:96-147).

\section{De administrateur}

Wanneer plankage-eigenars riet in de kolonie womachtig waren, werd eer. zaakwaarner.er aangesteld die het feitelijke beheer vocrde. Doordat het absenteisme altid wordt gekoppeld aan de Amsterdamse beurscrisis van 1773 , is de indruk ontstaar dat daarvan vóa het laatste kwart van de achttiende eeuw geen sprake was en dus evenmir. van administrateurs (zie bijvoorbeeld Van Lier 1977:3C-1). Niets is echter minder waar. Ook vór die tijd blijken er al administrateurs in dienst geweest te zijn van absente eigenaars (Van der Meiden i987:125-6; Oostindie 1989:329-32). Een aantal plarters had namelijk in Surname fortuin weten te maken en repatrieerde raar Europa, terwijl anderers na hü overlijden de Suriraamse bezittingern nalieten aan familieleden buiten de kolonie. Zo wijst een wiilekeurige steekprof onder 37 plantages in 1752 uit dat daarvan negen plantages in het bezit waren van absente eigenaars. "3i Halverwege de achttiende eeuw was 20 tot $25 \%$ van de eigenaars uitlandig.

Over de administrateurs uit die tija is helaas zeer weinig bekend. Dat het beheer voor absente eigenaars van plantages ook toen al een iucratieve bezigheid moer zija geweest, blijkt uit de inkomster van Gouverneur Mauricius. Naast zijn ambtelijk inkomen van $f 9 . \mathrm{CO}$ ) verdiende hij nog eens $f 10.000$ adn het beheer van vijf plantages van de gerepatrieerde S.I. de Neaie, terwijl hij onk nog ankele andere onderremingen beheerde (Van der Meiden 1987:93-4).

De verdiensten van de acministrateurs waren gerelateerd aan de produktie van de plantages onder hun beheer, war.t zij werkten op provisiebasis. De algemeen gebruikelijke provisie bestond uit $10 \%$ van de geproduceerde suiker of koffie en nog eens $10 \%$ van de inkomsten in Suriname uit verkoop van bijprodukten ais dram, melasse, bananen en hout, of bijvoorbeld uif slavenvehuur. Zo ontvingen de administrateurs van de 
suikerplantage Waterwijk, W.A. Steenbergen en W.H. Saffin, in de periode 1757-1761 samen gemiddeld twaalf oxhoofden suiker (netto-verkoopwaarde in Amsterdam ongeveer $f 975$ ) en $f 106$ contant per jaar. De directeur op deze plantage verdiende toen $f 900$ per jaar; zo hoog waren de inkomsten van Steenbergen en Saffin dus niet. ${ }^{37}$ Laaznaast beheerden zij echter nog meer ondernemingen, waaronder de uitstekend producerende plantages Mecrzorg (suiker) en Clevia (korfie). ${ }^{38}$

Dit type administrateur is in ieder geval tot 1863 blijven bestaan. Daarnaast waren er in de tweede helft van de achttiende eeuw nog de zogenaamde agendarissen en correspondenten. Zij waren de zaakwaarnemers van koopmanshuizen, negotiatiefondsen er. handelscompagnieën in Nederland. Het was hun taak er op toe te zien dat planters hun verplichtingen ter aanzien van cieze firar.ciële relaties nakwamen, verder verstrekten zij informatie over de solvabiite:t van planters en soms zorgden zij voor nieuwe kiandizie. Deze persoren haciden grote invloed, zowel op het financiele als op he: politieke vlak. Een bekend voorbeeld is Adriaan Gootenaar. In de jaren 1760-1770 was hij lid van het fiof van Justitie in Suriname, agendaris van de negotiatiefondsen Deutz/Van Marselis, Hardenhoorn en Hudig, correspondent van de Middelburgsche Commercie Compagnie on van de handelshuizen Wed. I.J. Schaap, Wed. $\mathbf{N}$. de Ruyter \& A.F. Schaap en Tellier \& Chico: (Van de Voort 1973:165-6). Afgezien van de swee piantages die hij zelf bezat, controleerde hij voor zija patroons in Nederiard ce hanciel en wandel van minstens vijftig plantages, waarin vele miljoenen guldens waren geinvesteerd. ${ }^{39}$ Daarmee was hij in de Surinaamse planterswereld iemand om wie men niet gemakkelijk heen kon.

Aan het eind var de achtiencie eeuw verloor een groot dcel van de planters hun plantages aan de crediteuren in Nederland. Sindsdien werd het absenteisme inderdaad een dominant verschijnsel in Suriname. Halverwege de jaren 1790 was slechts een-derde van alle plantages en houtgronden in bezit van ter plekke wonende eigenaars, twee-derce had cen absente eigenaar. Deze verhouding is tot aar. de Emancipatie vrijwel onveranderd gebleven (Surinaamse Almanak 1799:3-57 en 1824:45-85; Van Sijpesteijn 1854:97-140). Van die tijd af vormden cie administrate:urs dan ook de

37 GAR: Collectie-Hudig, 106 en: 111

38 ARA: SONA, 218 en 226 . Twee van dergelijke goed lopende planlages konden ten riant inkomen opleveren. Zo verdierde. de administrateur van de plartages Gront Marscille (suiker) en Utrecht (koffie), S. Fellman, in 1759 alleen al aan produkten ongeveer $f 4,000$ netto. Wellicht had hij daarnaast meer administraties en in ieder geva. was hij zels nog in het bezit van cen koffieplantage. Exn aantrekkelijke combinat:e cile hem, zolang de piantages goed draaiden, geen windejeren 2al hebben gelegd (James Ford Bell Library: B1482).

39. GAA: NA 
machtigste kiasse in Suriname. Hoe groot hun invloed was blijkt uit de volgende tabel.

Tabel 43. Administraties $1824^{*}$

\begin{tabular}{llll}
\hline administrateur van & $\begin{array}{l}\text { antal } \\
\text { administrateurs }\end{array}$ & $\begin{array}{l}\text { aantal } \\
\text { administraties }\end{array}$ & $\begin{array}{l}\text { plantages in bezit van } \\
\text { administrateurs }\end{array}$ \\
\hline
\end{tabular}

\begin{tabular}{llll}
\hline 1 plantage en tevens dir. & 2.3 & 23 & 5 \\
1 plantage (geen eig.) & 51 & 51 & 9 \\
2-4 plantages & 28 & 69 & 21 \\
5-10 plantages & 12 & 75 & 17 \\
$>10$ plantages & 13 & 349 & 17 \\
\hline
\end{tabular}

* eigenaars ter pléxke (geen administrateur): 04 met 119 plantages.

Bron: telling in Scirinamtse. Almanak 1824:45-85.

In 1824 waren er total 502 piantages en houtgronden, waarvan $188(37 \%)$ in bezit van ter plekke wonencie eigenaars. Het totaal aantal acministraties bedroeg 755 (inciusief de plantages van ter plekke' wonende eigenaars). Om niet geheel afhankeli;k te zijn van éer. administratelir en vanwege de continuïteit steldern cit absente eigenaas namelijk meestal meerdere administratrurs per plantage aan. Iit de tabei blijkt dan dat de 25 belangrijkste admiristrateurs, ieder met vijf of meer administraties, het beleid bepadden van xuim $60 \%$ van alle administraties, hun eigen plantages daz:bij gerekend. De top-13 onder hen, ieder met meer dan tien administraties, zelfs bi,na de helft. Het is daarom interessant deze laatste groep aan een nader onderzoek te onderwerpen.

\subsection{Enkele topadministrafeurs in $1824^{40}$}

Veruit de be angrijkste adminis:rateur in 1824 was C.I. Weissenbruch. Iij bezat zelf drie plantages en had daarnaast het (mede-)beheer over 71 ondernemingen. Dat betekende dat hij in zijin eentje het beleic (mede)bepaalde op 15\% van alle plantages en houtgronden in Suriname. Daarnaast maakte hij deel uit var. het hoogste politieke co'lege, de Raad van Politie en Criminele Justitie, zodat ook zijn politieke invloed groot moet zijn geweest. Hij werd omschreven als bezittence eere intacte reputatie van kunde en braafheid. Warneer hij precies naar Suriname was gekomen, is niet bekend. In ieder geval kwam: hij in 1796 rog ricet voor als planter, administrateur, of plantagedirecteur. Ir. 1811 beheerde hij echter al 17

40 Tenzij anders vermeld, is de informatic over deze dertien administratcurs afkomstig uit de Surinaamse Almanak 1796, 1824, 1834 en 1844; PRO: CO-278, 15 (voor 1811) en Van Sijpesteijn 1854-97-146 (voor 1853). Achticnde-cerisse gegever.s zijn afhomstig uit CAA: NA. De kwalificaties van de admiristrateurs zijn afkcmstig uit een lijsf van Van Breugel (KIT: Collectie-Van Breugel) en twee briever met opsommingen van administate-urs (James Ford Bell Library: B1482; Collestie Insinger \& (.o, Jaformatieboek). 
administrateur, of plantagedirecteur. In 1811 beheerde hij echter al 17 plantages. Hij overleed in 1829, ongeveer 73 jaar oud. In 1834 vinden wij ene G.C.B. Weissenbruch (een zoon?) vermeld als (mede-)administrateur van 14 plantages, waarmee de familielijn lijkt voortgezet.

Een geheel ander type administrateur was U. Wilkens. Deze was in 1798 in Suriname geboren als tweede- of derde-generatie-telg van een plantersgeslacht. Zijn vader bezat vier plantages en beheerde er nog eens drie. Zelf bezat hij op zijn zesentwintigste jaar twee plantages en was (mede-)administrateur van 24 andere. Daarnaast hield hij zich bezig met de zogenaamde 'Amerikaansche handel', de import van levensmiddelen, tabak en vee en de export van melasse via Noordamerikaanse scheepskapiteins. Ook hij was lid van de Raad van Politie. Niet voor niets werd hij omschreven als 'zeer actief maar nog te jong om partikule kunde te bezitten, en werd wat over 't paard geholpen'.

Wilkens beheerde onder meer de plantages van het handelshuis Van de poll \& Co. (de vroegere negotiaties Letters $A$ en ()). De directeurs daarvan bleken hoc langer hoe meer met hem in hun maag te zitten. Nadat hij in 1827 in Amsterdam bij zijn superieuren op bezoek was geweest, troffen zij in hem 'op ver na niet die bezadigdheid, kennis van zaken en ervaring' aan, die zij als vereiste voor zo'n functie zagen. Bovendien vermoedden zij, dat 'een deel van zijn Amerikaansche handei' bestond uit produkten van de door hem geadministreerde plantages. De maat was vol toen op een gegeven moment een pasbenoemde en zeer kundige plantagedirecteur al na vier maancien meldde, dat 'hij door den heer Wilkens zoodanig geplaagt wierdt, dat hij zonder verardering in zijne positie zijn ontslag zoude moeten vragen'" Wilkens werd daarop als administrateur voor Van de l'oll ontslagen, een zeer uitzonderlijke maatregel. Het zal hem overigens weinig hebben gedeerd, want in hetzel:de jaar wordt gemeld dat hij zijn 'Amerikaansche handel aan een kompagnieschap van Joden over gedaan' heeft en van plan is de kolonic te verlaten ${ }^{42}$ In 18.53 bleck het beheer in Nederland van zijn Surinaamse bezittingen te zijn ondergebracht bij de firma U. Wilkens \& Co. Kennelijk was hij ook aan de andere kant van de oceaan niet blijven stilzitten.

Ook Q.G. l'ichot stamde uit een oud plantersgeslacht. In zijn geval een uitgebreide hugenotenfamilie, die al vele generaties in Suriname woonde. In de jaren 1730 bezaten verschillende lichots vier plantages; in de tweede helft van de achttiende eeuw had deze familie zelfs belangen in een tiental plantages. Hijzelf bezat echter geen enkele plantage nneer, maar voerde de (mede-)administratie voor 19 andere. $1 \mathrm{lij}$ was lid van de Raad van Politie en

42. Collectie-Insinger \& Co., informaticlock 
scheen als admiristrateur 'bij uitstek aan te bevelen' met 'zeer veel kunde, maar arm innerijik'. Hij stierf in 1831 op 45 -jarige 'eeftijd. Dertier. jaar later blijkt ene F.L. Pichot mede-administrateur te zijn van enkele plantages, in 1853 zelfs van twaalf. De relatie tot Q.G. Pichot is niet beker.d, maar een naaste verwantschap ligt voo: de hand.

Over de achergrond van G.N. I.inck is niets bekend. In 1797 was hij administrateur van twee katomplantages. Zoals zo vaak gebeurde in Suriname wist hij door eer. lucratief huwelijk zijn bezit en invloed aanzienlijk uit te breiden. In zijn geval was dat met de weduwe van de pianter J.C. Vogt, die vier plantages inbracht, waaronder enkele zeer goed :enderende. In 1824 was hjj eigenaar van zes plantages en (mede-)administrateur van veertien andere. $\mathrm{Zijn}_{\mathrm{ij}}$ beheer moet op zijn minst twijfelachtig gewees: zijn, want het handelshuis Van de l'oll \& Co., met wie hij in reiatie stond, wilde herr. in 1816 juridiscin vervolgen om 'zijae chicanes en tuitvingter. te schande gemaakt 1e: zien': $:$ :

Tot slo: 5 . de la Parra. Deze had in 1824 'slecints' zever administraties, maar was daarnaast mede-eigenaar van nog eers dertien plantages. Hij was een nazaat van de groep fortugees-joodse planters die zich al in de tweede helft van de zevent:ende eeuw in Suriname had gevestigd en daar tot grote r:jkciom was gekomen. Nassy (1791, 1:96-7) vermeldt, dat rond 1730 I15 van de 401 plantages in bezit waren van joodse planters, vi;f daarvan hadden cen De la l'arra als eigenaar. De meeste van de 'joodse' plantages verbouwden suiker, enkele ook koffie. In 1824 was van de rijkdom niet veel meer over. Weliswaar hadden nog 69 'plantages' een joodse eigenaar, maar op riet meer dan 23 werd een exportgewas verbouwd. De overige waren, vaak weinig rendaiele, houtgronden. Een aantal joden had intussen toch rideuwe rijkdom weter, te vergaren ir. de handel, maar de meeste leidden. een vij marginaal bestaan als k.eine lendbouwer of ambrenaar. ${ }^{44}$

De la Parra vormde de uitzondering op deze regel. Hij was met zijn dertien plantages, die aliemaal voor de export produceerden, zelfs de grootste planter van Suriname. lioe hij dit enome bezit bij elkiar heef: gekregen is riet bekend. Weilicht dat hij eerst zijn furtuin in de handel had gemaakt om vervolgens in de periode van de grote schuldencrisis plantages op te kopen. Over zijn bekwaamheden als pianter is riets bekend. De enige kwalificat:e die aij var, een tijdgenoot meekreeg, was: 'is een Jood' en dai

43 GAA: PA-60), 544.

44. Een anonymus vertelt rond 1790: 'Zeeker Jond Van Sera [Da Fonseca], was mijne :everansicr [van zaaigoed], den zelven ivoonde tusschen de Joode Savaane, en de Post Gelderland, hij was wrol eer een gegoed nars geweest, en ecne houtgrond gehad, mat verrits alle zijne slaaven bij de Bosch. Nequers waren geloipen, zo was hij nu een old en arm man, en bewerkte met zijne hiysvrouw en beminnens waard:ge dogter, met eyge hancen een stukje grond tot kevensonde:hoid (ARA: Collechic-Van den Bosth, 125). 
was niet positief bedoeld. Zijn positie als machtige planter en 'autochtone' inwoner van de kolonie maakte hem bij uitstek geschikt voor het lidmaatschap van de Raad van Politie, maar 'Joden zag men niet gaarne in de Kaad' (Lammens geciteerd in Van Lier 1977:69). In 1824 had hij het in het koloniaal apparaat dan ook niet verder gebracht dan burger-kapitein van de militie. In 1836 werd De la Parra ondanks zijn afkornst lici van een vertegenwoordigend koloniaal bestuurscollege, de ecrste jood die hicrin een plaats kreeg.

Samen met acht andere topadministrateurs vormde deze groep een machtsblok van betekenis. ${ }^{45}$ Niet alleen hadden zij bij de helft van alle administraties een vinger in de pap, bovendien vervulden elf van de dertien gedurende hun loopbaan hoge politieke functies. Opvallend is verder dat tien van de topadministrateurs gerelateerd waren aan de Surinaamse achttiende-eeuwse planters. De meesten als nazaten van - vaak machtige plantersfamilies, Linck via zijn huwelijk met de weduwe van J.C. Vogt. Menke had zo'n achtergrond niel, maar was wel al sedert 1771 in de kolonie werkzaam. Alleen Weissenbruch en E.J. van den Bergh hadiden waarscijinlijk die binding met de vorige eeww niet. Buvendien blijken de lijner na hen niet te stoppen, maar z:jn in 1853 nog acht namen uit deze grocp op een of andere manier verbonden aan het Surinaamse plantersbedrijf. Fr was, kortom, duidelijk sprake van een netwerk van relaties warbinnen een groot deel van de macht was geconcentreerd.

Dit netwerk zou een waarborg kunnen zijn voor de continuiteit, maar dan was bekwaamheid van de participanten wel een vereiste. En dat was nu juist waar het in beiangrijke mate aan schortte. Siechts vijf top-administrateurs werden onverdeeld als xundige iiecien bestempeld. De overigen, afgezien van De la Parra over wiens kunde niets bekend is, waren te oud om nog goed te kunnen functioneren, van twijfelachtig kaliber, of conduit slecht. Deze groep beheerde toch cen kwart van a..e administraties, hun eigen plantages inbegrepen.

Waarschijnlijk zal ook onder de kleinere administrateurs het aandeel van ongeschikte managers niet anders hebben geleger. Var een groepje var negen, die drie tot negen administ:aties beheerden, werden er in ieder geval

45 De andere acht top-administrateurs in 1824 waren: J. Planteau, 'een dom rnensch, doch maakt carriere omdat [hij] njjx is' (42 administraties); F. Taunay, 'de wreedste man die in de kolonie bekend is' (aldus Golverneur bonham, geciteerd in Wolbers 1861:589) en 'inner gewikkeld in processen door deszelfs chicaneurig humeur' (2 eigen plantages, 38 administraties); J.H. Schultz Jansz., 'zer kundig in praktijk en solide in gedrag' (32 administraties); F. Beudeker, 'geene recommendatie waardig' ( 3 eigen plantages, 25 administraties); E.J. van den Bergh, 'zwak in regeering, en stelt Roomsche directeurs aan, kundig of niet' (25 administraties); S.M. Klein, 'kundig en zeer braaf (1 eigen plantage, $2 \mathrm{i}$ administraties); H. Klint, 'kundig en braaf' ( 18 administraties, tien jaar later zelfs 45); J.H. Menke, 'oud en aff' (12 administraties). 
vijf (met 32 administraties) als oniokwaam en vier ( 27 administraties) als kundig omschreven. Over de kleinste administrateurs is helaas niets bekend, maar het ligt aie: voor de hand te veronderstellen dat bij hen de verhoudingen ardess hebben geleger. Dit betekent dat op een aanzienlijk deel van de p'ar:ages de hoogste manager het optimaal functioneren var. de onderneming in de weg heeft gestran.

\subsection{Administrateurs en 'de wartheid'}

Het verkrijgen van meerdere acministraties vormde de bekroning op eer. carrière in de Surinaamse plante:ij. De verdiensten waren groot en de risico's geing. Voortdurend waren administrateurs dan ook bezig he! aântal aan hen toevertroliwde piantages uit te breiden. $Z$ ij reisden er zelfs voor naar Europa om bij everituele opdrachtgevers in he: geviei te komen en 'geen middeien van laster en onderkruyping die niet gebezigt worden' (Lammens 1982:56). Lans (1842:36) voegt toe dat het door die 'onophoudelijke kuiperijen [...] voor den cigenaar in Furopo eene moeyclijke zaak moet zijn, om een goede keuze te doen'. Dat was een waar woord, want wanneer een van de adininistrateurs kwan te overlijden ó de kolonie verliet, werden de abserte eigenaars bestookt met so.idcitaties en 'bedelarijen' van andere administrateurs(-in-spe) die op de vrijgekomen plaats aasden.

lets dergeijks overkwam de eigenaars van de goeci draaiende suikerplar:age Groot Marse:lle toen de hoofdadministrateur in 1828 overleed. Vrijwel mefeen solliciteerde ene J.T. Gardé naar tee opengevallen plaats en beval en passant een nicuws plantagedirecteur, ene Nichenke, aan. Ordat een briefw'sseling met Neúprland wel enige maanden kor. vergen deed deze Gardé zich in Suxiname maa: vast voor als de rieuwe hoofdaciministrateur. De zittende plantagecirecteur, tevens mede-acministrateur, M.E. Tannen, vertroliwde de zaak echter niet en meldde zich bij Gardé om opheidering te vragen, maar hem werd de toegang geweigerci. Daarna begon een wederzijdse kanornace var: bescinudigingen ... frauce, diefstal, alcoholisme, savenmishandeing - en scheldpartijen ('mog', 'pluimstrijker'). Voor de Nederlandse eigenaars, an wie alle brieven waren gericht, werd de zaak onontwarbaa:. Zelfs iukte het een van de betrokkener bijna, toen hij toevallig met verlor in Nederland was, de eigenaass van de plantage togen elkaar uit te speien. Doze lieten het niet zo ver komer. en wonnen advies in bij de doch:er var, een van hen, die in Suriname woonde. Op haar voorspraak werd een ander, l'ichot, als voorlopig administrateur benoemd. Deze kreeg de taak een rapport over de kemphanen op te stellen en kwam. daarin tot de voigende bevirdirgen: 
'[v]olgens het geen ik van andere directeurs, met den heer Iannen bekend, heb vernomen, schijnt het niet van waarheid ontbloot, dat hij van tijd tot tijd zich aan de dranik te buiten gegaan hee!t, en dat hij om niet sterker te spreken, in zijne regeering van negers, nu en dan eene verregaande strengheid aan den dag gelegd heeft. [...] De Heer Gardé is iemand wien ik voor alle administratie van plantaadjes geheel ongeschikt oordeel: hij is tenminste in de planterij geheel onkundig, en zijne reputatie is (te regt of te onregt wil ik riet beslisscher) niet vrij van allen biaam. INiehenke] wordt alhier in het algemeen gehouden voor een der slechtste sujetten der Kolonie. ${ }^{16}$

Klaarblijkelijk hadden de eigenaars van Groot Marseille door niet in te gaan op het gekonicel en de lasterpraatjes vas bovengenoemde heren en met het aanstellen van Pichot een goede keus gedaan.

Dat niet iedereen over zo'n goed inzicht en een gelukkige hand beschikte, bewezen de eigenaars var de suikerplartage Siparipabo. In i 801 ontving Jacques Docher, al enige jaren administrateur van deze onderneming, een brief van een der eigenaars waarin deze Docher verwet hern jarenlang veel te mooie prognoses over de produktie te hebben voorgespiegeld, terwiji 'ik geduurende uw administratie geen 1 p.cent van mijn capitaal genaci heb'. Achteraf waren er altiju dan wel uitvluchten te bedenken vour de veei geringere opbrengsten, of ook hield Docher zich gewoor: op de vlakte. Nu bleek de eigenar echter van een andere acministrateur, de bekende Anthony Blom, enige hrieven le hebben ontvangert over Docher die hem de schellen van de ogen hadden doen vailen. Het werd duideijjk dat Docher volkomen in gebreke was geblever met het zenden van produkten en met het afleggen van rekening en verantwoording. Kennelijk schrok Docher van de brief, want de eigenaar kreeg bijna per kerende post een antwoord waarin de stand van zaken op de plantage uit de doeken werd gedaan en terloops werd vermeld dat zijn vroegere, optimistische calculatie van de produktie 'cen per erreur' was. Buvendien moest er he: een en ander lussen Docher en Blom zijn vourgevallen, want de eerste vertelde een briefje te hebben ontvangen van Blom 'waarin hij mijn uitdaagt om met den deegen satisfactir te geeven of anders zal neemen...' Fr vielen gelukkig geen doden en na dit voorval verdween de scherpe toon uit de correspondentie. ${ }^{47}$

Enige jaren later repatrieerde Docher naar Nederland en na enig gekonkel werd de administratie van Siparipabo overgedragen aan. A. Koppelman, 'onder wiens bestier als directeur de plantagie soo aanmerkelijk is opgekoomen'. De eerste anderhalf jaar stuurde hij zeer rooskleurige berichten aan de eigenaars, maar van 1807 af hoorden zij niets meer van hem. Fr werden in he1 gehee! geen produkien meer naar Furopa geyonden, 
terwijl Koppelman wel wissels op hun naam bieef trekken. Na vijf jaar stelden zij ten einde raad naast Koppelman een mede-administrateur aan. Koppelman reageerde furieus en sparde meteen processer. aan om dit te verhinderen. Hij had dan ook een hoop te verbergen, want de plantage bleek sterk achteruit te zijn gegaan en verschïlende crediteuren begonnen zich te roeren. Alieen al de Surinamse belastingschald bedroeg bijna $f$ 20.000. Tot ontsteltenis van de eigenaars werd toen door de Sirriramse schuldeisers beslag op de plantage gelegd. Nu pas ontdekten de eigenaars hoe zij waren opge.ich door Koppelmar. Hij werd ontslagen en zi; adviseerden de mede-administrateur hem 'aan den Crimineelen Regter over te geeven'. 48

Ook met de opvoigers var. Koppelman hadden de eigenaars var. Siparipabo weinig geluk, want in rim zes jaar hadden zij, om uiteenlopende redenen, met vier verschillende administrateurs te doen. De benoeming van J.P.II. Kleine in 1819 leek echle: aan a:le ellende een eind te maken. Op dat momert was de pliantage wel zeer sterk achteruit gegaan ${ }^{49}$ en. bleken de schuldeisers, het lange wachten beu, ha ar bi, executie te willer. laten verkopen. Kleine wist echter met hen een sciniking, te treffen, de sequestratie werd opgehever en hij kreeg toestemming van de eigenaars om in Suriname $f 40$ à $j 0.000$ te lenen voor het doen van de nodige aankopen or de plantage er weer bovenop te heipen. Het geld werd inderdaad geleend, er werden slaver: en muileze's vour de beestenmolen gekocht en Kleine voorspelde dat rond 1823 de produktie weer 80 -100 vaten suiker per jaar zou bedragen. In 1822, 1823 en 1824 werden al ruim 60 vale!n geproduceerd. Ondanks het feit dat darmee de calculatie niet werd gehaald, schreef Kleine dat van Siparipabo veel te maken zou zijn, omdat het een overvloed van goed land heeft. Als er nog enige slaven en een stoommacinine zouden worden aangeschaft, dan 20 i hij binnen twee ;ar de prociuktie op 200 vaten jaarli;ks kummen brengen, 20 spiegelde ini; de eigenaars voor. Voor de slavenaankorp zouden deze het geld moeter voo:schieien, mat de machine zou uit de silkerproduktie kunnen worden betaald. Opnerkelijk genoug voelden zij veel voor 'dit schone plan', ondat,

45 ARA: Collectie-Copes van Cat!enturgh., 78. A: werd Koppelman dan uiteindelik uit de administratie gezet, tuck hiclden de eigen izars var: Siparipabo wel contact mel hem, o:tudat $z i ;$, op basis van eerdere belofters, hooplen dat Koppekman cie plantage zou xopen en zi; zouden dan van het gezeur af z:;n. Inderdaad cecd Koppeiman in 1813 eer: bod op de plantage, maar hij had daarbij de? brutaliteit om de $f 100.000$ dies lij owit geboden scineen te hebben, te laten zakken fot siechts $f .30 .000$, omdat hij zei nog, $; 20.000$ te gued te hebben an ondat verder de plantage in zo'n slechte staat verkccrdc! Tot in 1819 deed h; de cigenaars proposities een schurk waardig' Deze vermeden alle verdere contact met hem af.

49 Rond 1803 waren er nog 80 siaven die 70 n $80-100$ vaten suikes per jaar produceerden. Rond 1820 bleken er nog maar 41 slaven ve zijn en wercen iaarliks nict meer dan 30 vaten suike: gemalak? (ARA: Colizetie-Copos: van Catlenburgh, 7981 ). 
raar hun zeggen, in 1823 de produkten var de plantage 'veel waren vooruitgegaan'. Kleine overleed echter kort daarop en tot grote schrik van de eigenaars schilderde zijn opvolger, Q.G. Pichot, 'de staat van zaaken zodanig af, dat wij er haast moedeloos van worden'. Ook Kleine bleek dus de zaken veel mooier te hebben voorgesteld dan werkelijk hef geval was.

Volgens Pichot bevond de plantage zich nog steeds in een slechte staat en zou er een kapitaalsinjectie nodig zijn van $f 100$ a 120.000 om een werkelijke vooruitgang tot stand te brengen. Daartoe waren de eigenaars echter riet bereid, of niet in staat. Als het plan van Kleine niet ten uitvoer kon worden gebracht, dan moest de plantage maar van de hand worden gedaan. En zo geschiedde. In 1828 werd Siparipabo gekocht door de eigenaar van buurplantage Arendrust, voor een onbekend bedrag. ${ }^{53}$

Het blijft na:ukrlijk de vraag in hoeverre de hier beschreven geva:ien representatief zijn voor het algehele beleid van de administrateurs. Fen handige administrateur zorgde er vanzelssprekend voor dat zijn eventueel geknoei nooil aan het licht kwam. Toch wijzen vele rechtzaken tussen eigenaars en administrateurs in de regentiende eeuw er op dat het hier geer. incidenten betror. 51

In ieder geval laten de voorbeelden van Groot Marseille en Siparipabo zien dat in de communicatie tussen eigenaars en administrateurs de laatsten er soms bijzonder weinig moeite mee hadden de waarheid over de gang van zaken geweld aan te doen. Ir. frite warer de absente eigenaars met huid en haar aan deze lieden overgeleverd. Ook al kregen z:; op cen gegeven moment in de gaten dat e: iets riet pluis was met het beheer, dan nog was het een hele toer 20 'n malafide admir.jstrateur kwijt te raken en resteerde het probleem een opvolger :e vinden die wel kor worden vertrouwd. En zelfs dan moesten de absente eigenaars zeer alert bl:jven, want ook onder goede administrateurs was het gebruikeli; $\mathrm{k}$ om de zaken rooskieuriger voor te stellen dan zij in werkelijkheid waren.

Lelfs een man als Pichot, die in de voornoernile voorbeelden als cen van de weinigen blijk gaf de dingen bij de naam se durven noemen, leek met deze gewoonte behept te zij̣l geweest. Bij de ombol:w, rond 1830, van de slecht renderende koffieplantage Zorg en Hoop tot een suikerplantage had hij de eigenaars voorgenouden dat dit ongeveer $f 70.000$ zou kosten. Nadat het project was uitgevoerd, bieek dit tot $f 170.000$ te zijn opgelopen. Pichot was toen overigens al overleden. Zijn opvolgers voorspelden echter dat hoe dan ook deze plantage nu wel gemiddeld duizend vaten suiker per jaar zou gaan produceren. Voorzichtigheidshalve stelden de eigenaars dit naar

51 Zie ARA: Suriname na 1828, Gercehtshof; wok: Oustindie i989:329-41. 
beneden bij tot 650 aे 750 . In werkelijkheid blexen in de periode 1838-1848 niet meer dar gemiddeld 360 vaten suiker per jaar te zijn geproduceerd..$^{32}$

Voortdirend werden eigenaars in Nederland door de admiristrateurs hoopvolle vooruitzichten voorgespiegeld, waardoor zij zich trachtten te verzekeren van het behoud van hun lucratieve inkomsten. Kennelijk liesen de? eigenaars zich gemakkelijk een rad voor ogen ciadien, zo lang er maar inkomsten uit de plantages kwamen. Wanneer er toch vragen werden gesteld over ce tegenvallente resuitaten, dan had zich altijd wel een ramp voorgedaan die ait kon verklaren. Maar volgend jaar...

Natuurlijk waren er ook uitzonderingen op deze regel. Op Vossenburg werd de gecalculeercie produktie vrijwel altijd gehaald. Het zal dan cok geen toeval geweest zijn dat in de jarer. 1820 en 1830 de hoofdadministrateurs van deze plartage, Weissenbruch, Klein en Klint, tol de bekwaanste van de kolonie werden gerekend. Aangezien zij vele plantages beheerden, mag worder aangemomen dat er tock een tamelijk grote groep oncememingen was waar woord on werkelijkheid geen al te grote discrepantic vertooncen. Plantages met e:genaars ter plekke hadden ratuurlijk geen iast van dit verschijnsel.

Een laatste opmerke:ijk aspect was het aanta! acministrateurs dat in vrij korte tija de revie passceyde, ln 32 jaar volgden bijvoorbeeld op Siparipabo acht administrateurs elkaar op; bovendien bleek de langst zitiende administrateur, Koppelman, tevens de slechtste te zijn. Siparipabo vormale hierin geen wizondering. Een steckproef order zeven ylarlages wijst dit dat op eer totaai van 372 plantagejaren zich 101 administrateurs met het beleid var deze ondernemingen hebben bemoeid. ${ }^{53}$ Aangezien er gemidceld twee administrateurs tegelijk in functie waren, onder andere met net oog op de contiruiteit, besekent dit da: jedere 7,4 jaar de plantage door een nieuw admin:strateursteam werd geleid, terwiji gemiddeld iedere 3,7 jaar een wisseling plaats vond. Het is de vraag of dit de beieidsvoering op de langere termijn ten goede kwam.

Meerdere administrateurs in het beheer van een plantage veroorzakten ook vask problemen. Zo kon de benoeming van een nieuwe directeur aanleiding zija tol onderinge strabbeingern over eigen protegés. Ook het beheer in het algemeen gat nog al eers aan'ejding tot conficten. Dat bleek bijvoorbeeld iit een gesprek dat eigenaars van een achttal plantages hadden met éér van de twee aciministrateurs, Wilker.s, toen deze met verlor in

52 GAA: PA-600, 5id4. :ets soorigelijks is te vinder in de correspondentie over Peiribo, whar tussen 1840 en 1846 vijf maal door de administrateurs ecr. calculatic werd gemaakt van de verwarhte presduklic in het volgente jaar. Cermidkekd bleken dir voorspelingen $27 \%$ te boog uit te vallen.

53 Steekproct plantages De Nieuwe Grond, Potribo, Rooserburg, Siparipabo, Somerszorg, Vosscriburg en 7 ceright. 
Nederland was. Daarin lieten zij merken niet tevreden over hem te zijn, waarop Wilkens zich liet ontvallen dat hij zich met zijn mede-administrateur volstrekt niet kon verdragen, en dat men hem geen groter verdriet had kunnen aandoen, als [...] den heer Pichot nevens hem [aan] te stellen. ${ }^{54}$ Toen Wilkens even later weer naar Suriname vertrok, gaven de eigenaars Pichot, in wie zij groot vertrouwen hadden, een stille wenk te pogen Wilkens wat meer in het gareel te krijgen. Pichot proberde dit ook, maar moest daar al spoedig van afzien, omdat Wilkens zich als eerstbenoemde administrateur niets aan hem gelegen hoefde laten liggen en dat dus ook niet deed 55

Uit dit laatste blijkt dat om dergelijke conflicten tot een minimum te beperken misschien de stelregel gold: degene die het eerst was aangesteld had het laatste woord in het beleid. Dat dit riet per definitie het juiste woord behoefde te zijn laat zich rader.

\subsection{Administrateursinkomsien}

Hét motief om administrateur te worden, vormilen de aantrekkelijke inkomsten, waar slechts een minimum an inspanning tegerover stond. ${ }^{56} \mathrm{De}$ scheve verhouding tussen loon en prestatie, alsmede de geur van meerlijkheid die rond vele admiristrateursverdiensten hing, waren in het Surinaamse kolonister.wereldje sociaal volkomen geaccepteerd.5?

54 GAA: PA- $600,544$.
55 GAA: PA- $600,544$.

56 Een sprexend voorbeeld van de aantrekkelijkheid van het administrateurschap is jan Harmen Franke. Wanneer hij in Suriname is aangekomen of is begonnen als adisinistrateur is niet bekerd. In ieder geval had hi, in 1796 vicr plantages onder zijn beheer. Bij zijn dood, in 1819, bleek hij dat tot e.f plantages te hebben uitgebreid, waarmee hij behoorde to! de middelgrote ad ministratelirs. Op dat moment bezal hij Sf 17.157 in contanten en had hij van plantages en particulieren in to taal nog, $\$ f 103.310$ tegoed. Een bewijs, opnieuw, van de mogeli;kheid in Suriname zelf krediet te verkrijgen. Het totale bezit van Frarke, inclusief deze leningen, verlegenwoordigde een waarde van $S f 253.812$, of in Neterlands courant op dat moment $f$ 137.196. Fen bodrag dat in dic tijd overeenkwam met honderdmaal het jaarsaiaris van een goed betaalde plantagedirecteur (ARA: SOB\&W 1828-1876, :329).

57 In een ficticve dialoog H1Ssen hermzel! en cen administrateur, schetst Var: Breugel (1824:89) een aardig beeld van de mentaiteit onder de elite in Suriname.

[Administrateur:] 'lk heb y gezegd hoort, ziet en oordeel dan zelf, want gij kunt u geen denkbeeld maken van deze klcine Surinaamsche wereld.

- Orh dat gaat overal alzon; ir. Holland is he: kwaad sprexen oox bekend en vocral in kleine plaatsen.

- O ho! 1 let is met hier niet te vergeljjken; ix ben ock llollander, maar daar kumt mer niet bijeen als hier om fortuin te zooken op hetzeifde doelwit, adrninistratien, zoodat iemand hier een loef af te steeken item zooveel in de zak brengt en naar dit item wordt men hier geëerd en uiterlijk geach:. Men vindt hier thans tweemaal zooveel fort linzoekers 'dit schijnt helias de benaming) dan voorhen, dus is de spereling dunner geworden en de levenswijze en alles veel duurder, terwijl men soch maar zijn krediet noet zien te behouden, al is hel dan ook door schijn, wil men niet met dc nek aangezien en eensklaps behoef!ig worden, doch ieder sveet dat hovaart pijn vooral in de beurs is. 
De mogelijkheden voor een administrateur om zijn irkomen fink op te vijzelen waren legio. De enige controle die de absente eigenaars hadden, waren de verantwoorde rekeningen die zij, normaal gesproken, jaarlijks van hun administrateurs ontvinger. Daamaast wonnen de eigenaars, in het geheim, vaak inichtingen in over 'hun' administrateurs bij andere kolonisten. In het kleine pianterswereldje bleef echter weinig geheim en bovendien hadden de informanten zelf ook vrijwel altijd belangen in het plantagewezen, zodat hun informatie niet al te betrouwbaar was.

Een van de moeilijk te bewijzen, maar waarschijnlijk bij iedereen bekende, prakti,ken vormden de 'geheime vennootschapper' tussen administrateurs en handelaars in 'Amerikaanse' waren (Wolbers 1861:768-9). Buiten de goederer die uit Nederland voor de plantages werden overgezonden, kucht de administrateur amelijk plantagebenodigdheden en voedsel bij Surnaamse handelaars. Wanneer hij dil deed bij een vaste leverancie: was het voo: leem niet aantrekknlijk on bijvoorbeeld kwantumkorting te bedingen. Daazentegen was het voor hem wel voordelig een provisie voor zichzel: te vragen. Dat de handelaar dif nafuurlijk doorberekende in de prijs voelde alleen de plantage-eigeraar in zijn portemonnee.

In principe was het beloningssysteem van de administrateurs gebaseerd op loon naar prestatie. Hoe hoger de produktie, des te hoger waren ook de inkomsten van de administrateur. Daarmee dachten zij het belang van de administrateur te hebben gebonder aan dat var. hencelf, zo redeneerder de eigenaars. Ter. dele was dal ratuurlijk ook zo, maar de eigenaars zagen over het hoofd dat hun werkelijke be'ang lag in het rendement van hun bezit er. ciaar hadden de adininistateurs geen boodschap aar. Of een plantage nu met winst of verlies draaide, zij waren altijd verzekerd van inxomsten. Een. hoge procuktie was zeke: voordelig voor de aciministrateur, hoge uitgaven waren dat echter vaak ook, mede door de 'geheime vennootschappen' die hij daarbij kun dangaan.

Kleine verdiende in 1822 als administrateur van de verwatorloosde Siparipabo tota: $f: 691$ aan provisie. Dat was al $f 360$ meer dan het :oon van de directeur op deze plantage ${ }^{5 k}$ Dizernaast was het niet verwonderlijk

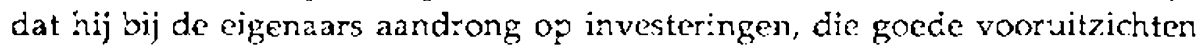
zouden bieden. Hij kon dan contracten sluiten met leveranciers en ambachtslieden die hem waarschijnlik $\mathrm{k}$ ook het nodige op'evercen. Bovendien was Kleine niet afhankelijk van Siparipabo, want inj bezat nog zes andere aciministraties. Zijn officiëie jaarinkomen zal zeker in de buurt

- Dał begrijp ik zeer z̧oed, maar men kan daarom toch braat blijven en men behoefł geer: schurk of slecht mensch te worden, zoo als men in Hollani de Jurinamers ditirijt...

58 ARA: Collextie-Copes van Cattenbiargh, 81. 
van $f 10.000$ gelegen hebben, terwijl zijn superieuren, de eigenaars van Siparipabo, in die tijd alleen maar geld toelegden op hun bezit.

Hoe meer administraties iemand bezat, des te meer mogelijkheder waren er om zijn inkomen op te voeren. Een goed voorbeeld daarvan is Hans Klint die van 1821 tot 1829 samen me: J.H. Schultz administrateur van Somerszorg was. In de periode 1829-1842 deed hij dit alleen. Tot 1829 blijken bijna alle plantages die bananen kochten van Somerszorg eveneens door Schultz te worden (mede-)geadministreerd. Schultz was nog niet overleden en Klint enig administrateur geworden of het bleken uitsluitend nog plantages onder het (mede-)beheer van Klint te zijn die de bananen van Somerszorg opkochten. Anderzijds betrok Somerszorg zijn dram en melasse altijd van de verafgelegen plantage Maagdenburg. Het was logischer en goedkoper geweest om dit bij suikerolantages in de buurt te doen, maar die werden niet door Klint beheerd en Maagderburg wel. ${ }^{5 B}$ De uitgaven speelden voor Klint dus geen rol, het ging om de inkomsten. Zo lang die maar onder zijn beheer plaatsvonden, kon hij daarvan provisie opstrijken.

In 1829 besloot Klint - waarschijrlijk niet ten onrechte - dat de gebouwen van Somerszorg grondig moesten worden opgeknapt. Hij verhuurde daartoe twee van zijn privétimmerslaven aan de plantage en verdiende daarmee $f 533$. to In diezelfde per:ode verhuurde Klint slaven vart Somerszorg aan zes verschillende plantages, waarvan vier vieien onder zijn (mede-)beheer. Een van die plantages was Vossenburg. Daar werder. in die jaren, naast Somerszorg, slaven van nog drie plantages gehuurd. Ook die drie werden doo: Klint (mede-)geaciminisiree:d.61 Verder hulicke Somerszorg sinds 1820 slaven van plantage Duringen; in 1832 werd zelfs de complete slavenmacht van Duringen op Somerszorg overgebracht. Deze twee plantages warer in bezit van dezelfde eigenaar. Boekhoudkundig kon deze huurkwestie daarom met gesloten beurzen plaatsvinden. Desondanks werd in de boeken ieder jaar eer flirke huursom opgevocrd. Was dat nict gebeurd dan had Klint daarover geen provisie kurnen ontvangen.

Uit alles blijkt dus dat Klint zijn eigen belangen nauwlettend in de gaten hield en dat deze niet altijd strookten met die van de ansente eigenaars. Van echt iliegale praktijken viel hij riet te betichten, maar er was een groot schemergebied waar geer. werkelijke controle mogelijk bleek. Halverwege de jaren 1830 verdiende Klin: aan administratieprovisie van Somerszorg en Vossenburg samen gemiddeld $f 3.188$ per jaar. Hij was op dat moment (mede-)administrateur yan nog eens 43 plantages. Ruw geschat

59 GAR: Collectie-fiudig, 335 en Surinanse Aimanak :834.

60 GAR: Collectie-Hudig, 335

6] GAR: Collectie-Hudig, 335; Surinaams Museum Collectie-Brantsen, verslagboekjes 1829 1842; Surinaamse Almanak 1834:67-111. 
moet hem dat een jaarinkomen van al gauw $f 50.000$ hebben opgeleverd. 62

Ook op een andere wijze werd nog van de beheerde plantages geprofiteerd. De plantagedirecteurs stuurden namelijk vaak 'maandelijksche cadeaux an administrateuren' bestaande uit groente, fruit, schapen, kippen, varkens en brandhout. Van Breugel schatte dit voor zijn plantage alleen al op een bedrag van $f 1.000$ per jaar. ${ }^{63}$ Bovendien was het niet ongebruikelijk dat plantageslaven werden gebruikt in het huishouden van de administrateurs te Paramaribo zonder dat daarvoor een vergoeding werd betaald. Kortom, de inkomsten van administrateurs waren vaak formidabel, zijn onkosten daarentegen miriem

Het is verwonderlijk waarom de absente eigenaars altijd zijn blijven vasthouden aan het provisiesysteem. Een vast basisirkomen gekoppeld aan een aandeel in de winst had de administrateurs waarschijnlijk veel meer aan de belangen var de eigenaars gebonden. Nu wareul het vaak niet de bezitters, maar de adninistrateurs die rijk werden van de plantages en waren de eersten met huid en haar aan de laatsten overgeleverd. Waarschijnlijk is een verankering in het beloningssysteem nooit doorgevoerd omdat het een opstard zou hebben ontketend onder de administrateurs. Het zou voor de eigenars zeer moeiljjk zijn geworden nog geschikte kandidaten voor deze functie te vinden.

Toch veranderde er op sommige piantages wel iets in het beloningssysteem van de administrateurs. In de loop van de negentiende eeuw werd het meer en meer prakijjk om de $10 \%$ provisie pas na verkoop in Nederland af te trekken van de netto-opbrengsten, waardoor er meer controle mogelijk was. Daarnaast bleek bijvoorbeeld op Vossenburg in de jaren 1840 inei provisiepercentage te zijn teruggebrachl van 10 tot $7 \%$. beloningsprincipe bleef ecleter verder onveranderd.

De Surinaamse plantagekolonie was overigens niet de enige die? te kamper had met absentë̈sme en de grote afhankelijkheid van duur betaalde administrateurs. Ir het bijzonder het Brits-Caraibisch gebied kende soortgeiijke problemen. 55 Wel vitzorderlijk was de hoogte van de admini-

62 GAR: Collec!ne-Hudiz, 335; Suriraams Museum Col:ect:e-Brantsen, verslagboekjes 1829 1842; Surinarmse Almanak 1834:\{7-111.

63 KIT: Collertir-Van Bretigel.

4. Sutinaams Museum Collectie-Brantsen, yeran:woorde rekening 1849.

65 Lares (1960:43) schrijit over het permanent gew'urden absenteisme: 'Its effects were in many ways fatal. Fven supposing that an attorncy and an oversepe were as faithful and as diligent as a resident planter - which is a very big " $i$ " indeed - the cost of absenteteism was heavy. While the absentee kept ap a princely cstablishincent in England, his attorney and overseer did the same thung at his experne in the colonies - thus there wre two estahlishments to pay for instcad of one. Many oversccrs were paid by a percentage of the crop, and a.l believed that they colid recemmend themselves to their employers by sending home a large crop of sugar. This led them to negglect the fut ure for the present, and t: encourage expenditure 
strateursprovisie in Suriname. Pares (1960:43) noemde voor het BritsCaraibisch gebied 5 aे $6 \%$ gebruikelijk en de administrateurs op SaintDomingue ontvingen niet meer dan 3\% (Cauna 1987:63). Waarom dit verschil zo groot was blijft duister. Het zal in ieder geval de rentabiliteit van de Surinaamse plantages rigt ten goede zijn gekomen.

In het plantagemanagement was de bastiaan de meest constante tactor. I Iij was meestal het langst in functie, kende de plantage het best, stond het dichtst op de werkzaamheden en zijn oordeel werd meestal serieuzer genomen dar dat van de blankofficier. Hij had geen beiang bij een maximale produktie, want dat betekende meestal ook een maximale exploitatie van de slaven, Een goede relatie met de directeur was noodzakelijk, maar zijn eerste belang - en machtsbasis - lag bij de slaven. Dat bleek ook wit zijn vaak leidende ro: bij ongeregeldheden en marronage.

De blankofficier was voor ieciereen eer. verschoppeing, had vi:jwel geer. invloed op het beleid en wisselde zeer vaak van betrekking. Ifij had geen belang bij een goede, noch bij een slechte produktie. Het enige wat hem wellicht kon motiveren was uitzicht op een directeursbetrekking, maar de kans daarop was gering.

De directeur voerde het dagelijks beheer en was, na de bastiaan, de meest constante factor in het management. Hij had belang bij rust en orde op de plantage, maar zijr. vaak uitbundige levenswijze was vaax aanleiding tot conflicten met de slaven en/of de administrateurs. Na verloop van tijd kon de eigenaar de directeur tol mede-administrateir benwemen. Maar zelfs dan zullen de meesten zich niet erg veel gelegen hebben laten liggen aan de belangen van de eigenaars; hun interesse lag meer in eer onbekommerd bestaan op de plantages. Het administrateurschap was de bekronirg van een directeurscarrière, maar dat bleek slechts voor een enkeling te zijn weggelegd.

De administrateurs vormden een klasse apart. In feite waren zij de opvolgers van de achttiende-eeuwse plantersklasse, wairaan zij dan ook nog al eens waren gerelateera. Binnen deze klasse bevond zich een kleir. groepje topadministrateurs, dat over een zeer grote economische er. poiitieke macht beschikte. Hun belangen liepen niet (altijd) parallel aan die van de eigenaars. Door het specifieke provisiesysteem hadden zij voordeel bij een hoge produktie, maar aan het laag houden van de kosten hadden zij

\footnotetext{
without considering whether the plantation could realiy afford it - that swas somebody else's business. Sorne, especially among the attomeys, encouraged expenditure for its own sake, for they were merchants drawing, a commission on stores supplied to the plantation, which yielded them a handsome income, besides the 5 or 6 per cent on the crop which they took as commission in some coionies, such as Jamaica, they had a legal right $i$ it."
} 
geen boodschap. Gebrek aan 'efficiency' was daarmee in feite al inherent aan het systeem. De grote afstand en slechte communicatiemogelijkheden bemoeilijkten de contro'e op deze zaakwaarnemers ten zeerste, terwijl de mogelijkheden om zich ten koste van de absente eigenaars te verrijken legio waren. Ook het sumelijk grote verloop maakte het moeilijk greep op hen te krijgen. Mel de wadrheid ramen zij het vaak nie: al te nauw en een aanzienlijke groep bescinikte niet cens over de benodigde capaciteiten. De goeden niet to na gesproken, lieten $z i j$ zich vaak kennen als ware potentaten die gemakkelijk in conflist konden raken met de eigenaars, de directeurs en elkaar. Voorzichtig geschat, zal bij ongeveer de helít van de plantages sprake zijn geweest van een redelijk tot goed beleid, bij de andere helft was dit twijfelachtig tot ronduit slecht.

Al met al stond het plantagenanagement in Suriname, vooral toen het absenteisme op ruime schaal voorkwam, bol van de belangentegenstellingen en was er een schrijnend gebrek aan doelmatigheid en contiauiteit. Hel paraduxale gegever dringt zich nu op dat, uit een oogpant van bedrijfsbeheer, de zwarte bastiaan misschien wel de belangrijkste en in ieder geval de meest constante factor was in het overlevern van em plantage. Hij heef: daarvan ook vaak gebruik gemaakt door rechten voor de slaven at te dwingen. Met name de absente eigenaars onterkenden ziji cruciale positie niet en konden hem dus ook niet in hun voordeel gebruiken. Bovendien maakte de hiërarchische structuur van het systeem dit vrijwel onmogelijk. voor de slaven is de bastiaan echter van onschatbare betekenis geweest in het proces van hun eigen cmancipatie. 


\section{HOOFDSTUK $X$}

\section{Slavendemografie}

Sinds hel eind van de achttiende eeuw zijn er vele uitspraken gedaan over de demografische ontwikkeling van de Surinaamse slavenbevolking. Onderzoek is er echter nauwelijks verricht. Alleen Lamur (1977, 1981, 1987a, 1987b) en Oostindie (1989) hebben de laatste jaren belangwekkende kwantitatieve gegevens gepubliceerd. Hun bevindingen zijn gebaseerd op slechts enkele plantages en/of op de laatste jaren van de slavernijperiode, zodat de vraag blijft of deze uitkomsten representatief zijn.

Toch is het belang var, sepresentatieve demografische gegevens bi;zonder groot. Niet alleen zeggen deze cijfers jets over de wijze waarop de planters omgingen met de factor arbeid, maar bovenal zijn zij een indicatie voor de levensomstandigheden op de plantages, eventuxle veranderinger daarin en de reactie daarop van de siaven. Ondat hiesbij met een groot aantal variabelen, zoals voeding, soort arbeid, zickteklimaat en creolisering, rekening dient te worden gehouden is veel onderzoek rodig. Dit hoofdstux wil een aanzet zijn tot het schrijven van de demografische geschiedenis van de Surinaamse (plantage)slaven.

Over de omvang van de Surinaamse slavenbevolking in de tweede helft van de achttiende eeuw bestaat grote verwarring in de literatuur. Price (1979a:16-7), De Beet (1984:2) en Hoogbergen (1985:39) beweren, waarschijnlijk in navolging van Van Hogendorp (1801:327-8), dat rond 1735 de totale slavenpopulatie al ongeveer 50.000 personen bedroeg. Dit aantal zou bovendien tot de afschalfing van de slavenhandel hetzelfde zijn gebleven. Met name de laatste toevopging kan nooit meer dan een slag in de lucht zijn, aangezien geen rekening is gehouden met te forse uitbreiding van de Surinaamse plantage-economie na 1735 en evennir. met de drastisch verminderde slavenimporten na 1775.

Voor het der de kwart van de achttiende eeuw komt Lamur (1977:162) met een cijfer van 75.000 personen, waarschijnlijk gebaseerd op Stedman (1988: 533). De veel geciteerde Abbé Raynal (1776, IV:355) noemt zelfs een totale slavenpopulatie van 84.500 voor dezelfde periode. In een memorie van de Riad der Amerikaansche Koloniën uit 1806 wordt tenslotte nog gewag 
gemaakt van 70 a 80.000 slaver in de periode rond $1800 . .^{\prime}$ Deze uiteenlopende aantallen laten zier hoe weinig zicht men heest gehad op de slavenbevolking in de achttierde eeuw. Over de slavenaantallen in de negentiende eeuw bestaat minder onduidelijkine:d, oncier meer door de verplichte registratie van alle slaven sinds 1827.

Op basis van primaire bronnen en met inachtneming var een veiligheidsmarge van 2 tot $3 \%$, zijn veel realistischer cijfers samengesteld. De Surinaamse slavenpopulatie bijkt zich dan a's volgt te hebben ontwikkedd:

Tabel 44. Slavenbevolking Sissiname $1752-1862^{2}$

\begin{tabular}{|c|c|c|c|c|c|c|}
\hline jaar & suiker & koffie & $\begin{array}{l}s \text { e } c \\
\text { kaloes }\end{array}$ & $\begin{array}{l}\text { o r e n } \\
\text { overig (voorname- } \\
\text { lijk hout er kosi) }\end{array}$ & Paramaribo & totaal \\
\hline 1752 & 19.008 & 16.029 & - & 534 & 2.264 & 37.835 \\
\hline 1774 & 16.584 & 37.179 & - & 3.071 & 3.089 & 59.923 \\
\hline 1795 & 12.232 & 26.710 & 4.209 & 2.204 & $(2.800)$ & 48.255 \\
\hline 1813 & 10.108 & 21.968 & 5.692 & 3.717 & 2.599 & 44,084 \\
\hline 1836 & 17.659 & 12.942 & 6.545 & 2.590 & 7.143 & 46.879 \\
\hline 1854 & 17.884 & 5.584 & 4.550 & 4.396 & 6.401 & 38.545 \\
\hline 1862 & 19.789 & 3.892 & 2.551 & 4.714 & 5.538 & 36.484 \\
\hline
\end{tabular}

Het is niet oniwaarschijni:jk dat de antallen 'overige' en 'Paramaribo' in 1836 in werkelijkheid iets hoger, respectievelijk lager zijn geweest.

Bronnen: ARA: SYS, 293; ARA: RvP, 583 en 598-600; Surimaamse Ammanak 1793:6; Public Record Office: Colonial Office 278, 5 en 18 en Treasury 75, 14; ARA: MvK, 1135 en A796; Van Sijpesteijn 1854:93-151; Kolonial Versiag 1862.

De slavenivevolking bereikte pas in de jaren 1770 haar grootste omvang en onvatte nooit meer dan ongeveer 60.000 personer. Daarna zijn de slaven voorturend in aantal verminderd met uitzondering van de periode 18131836, toen ex (to: 1827) tamel:jk omvangrijke slavenirmporter: plaatsvonden.

I Nepveu 1972-23-345.

2 De bevolkingscifiers voor 1757, 1774, en 5795 zijr. samengesteld tit de de opgavelijsten vonr de betaling van de hootdgelden. Deze opgaven kloppen nict met het wcrkclijke aantal aanwezige slaven op plantages, omdat soms kinderes onder drie jaar, soms kinderen onder twaalf jaar, riet werden olyegeven en soms nok he: totaal aantal slaven werd verzwegen. Op basis van de slavenli;sten uit de inventarissen (die wel correct zijn, aangezien de eigeraars de exacte omvang van hun bezit moesten kennen) heb ix steekproefsgewijs een vermenigvuldigingsfactor ter correctie berekend. Deze is vont $17521,1(n=4.134)$, voor $17741,41(n=6.241)$ en voor $17951,76(n=4.857)$. Deze correctie is ook toegepast op de bevolking van Paramaribo, behalve voor 1795 waarvoor geen gegeven; beschikbaar waren en die een scluating vormt gehaseerd op het gemiddelde van 1774 en 1813. De hevolkingseijers voor 1813 2ijn samengesteld uit de Engelse volksteling van 1811 en de Lists of Plantations belonging to Absentee Owners en de List of Resident Proprietors in 5urinam, beide uit 1813 . Het totale bevolkingscij!es in 1836 is eigenlijk uik 1841 , waarbij ce vermindering met het aantal piantageslaven de slavenbevolking van Paramaribo oplevert. Een dergelijke aftreksom voor Paramaribo is ook gemaakt voor 1854 en 1862. 
Een tweede in het oog springend verschijnsel is de verdeling van de slaven over de verschillence sectoren van de plantage-economie. Het blijkt dat de groei in het derde kwart van de achttiende eetiw voliedig op rekening van de koffjesector kan worden geschreven. Daarna nam de bevolking in deze sector voor de rest van de periode dramatisch af, ten gurste van eerst de katoen-, en later de suikersector.

Tenslotte is de groei in de sectoren 'overig' en Paramaribo op het eerste gezicht merkwaardig, omdat in deze periode juist zo'n groot gebrek aan arbeidskrachten op de exportplantages heerste. Toch was juist de arbeidsschaarste hicraan mede debet. Deze hac namelijk to: gevolg dat vooral op suikerplantages alle annwezige arbeid werd aangewend voor de suikerproduktie zodat er niet voldoende mankracht overbleef voo: het verbouwer. van kost, of voor de houtkap zoals op Vossenburg (Hoofdstuk IV). Slecht renderende suiker- en met name koffieplantages zoals Katwijk (Hoofdstuk vill) gingen zich hier s.u mee bezig houden, wat de groei van de sector 'overig' verklaart.

De toename van het aantal stadssiaven was waarschijnlijk ook het gevolg van het opdoeken van onrendabele plantages, waarbij de slaven voor eer. derl werden verkocht aan kapitaalkrachtige heren ui: de stad. Jet lijkt niet erg aannemelijk daf al deze slaver. deel girgen uitmaken van een lixe stadshuishouding. Veeleer zulier zij zijn verhuurd aar. andere plantages. In plaats van op naam var. een piantage stonden deze slaven nu echter op naam van een in de stad wonence particuier, waardoor $2 \mathrm{ij}$ waarschijrijijk als stadsbeworers stonden geregistreerd.

Desondanks moet het getal siaven dai inderdaad alleer. maar werd gebruikt voor het onderhouden van een huishouding in laramaribo niet worden onderschat. Zo beschikten in 181 I dertien van de belangrijkste planters met hun gezinnen, allen woonachtig in de stad, aileen al over gezamer.lijk 464 huisslaven, hat is 36 per gezin! De meeste inwoners van Paramaribo hadden eckter maximaal tien slaven in huis. ${ }^{3}$ Ordanks de atbeidsschaarste veranderde d:t ook later niet, want een steekproef onde: 69 personen in de slavenregisters van 1848 latat zien dat er nog steeds gemiddeld meer dan vijf slaven per huishouden waren. ${ }^{4}$ Het wekt dan ook geen verwondexing dat in 1826 Gowverneur Van Heeckeren klaagde over het grote aantal van deze slaven, die volgens hem met meer voordee: in de landhouw kon worden ingezet."

Ter completering van dit bevolkingsoverzicht dienen ook de vrije inwoners nog te worcien genoems. A! is deze groep in de loop der tijd flink 
in omvang toegenomen, toch bleef zij ten opzichte van de niet-vr:je bevolking altijd veruit in de minderheid. Boverdien was het geen homogene groep, want zij bestond uit vrigemazkte zwarten, blanke kolonister en een verzameling bianke en zwarte miiizairen, die al nat gelang de spanningen in de kolonie in groo:te var:eerde."

Iet kleinste deel var de vrije inwoners woonde op de plantages on bestond voornamelijk uit rirecteirs en blankofficiers. Hur. aantal schommelce gedurende de gehele periode rond de duizend. Dat betekent at iedere vrije op de plantages gemiddeld zo'n 35 slaver tegenover zich vond (rond 1774 zelfs 62). Deze scheve verhouding is ongetwijfeld bepalend geweest voor de steer oy de parantages.

Afgezier van marons en Jadianen, warover geen betrouwbare aantaller: voorhander zijn, woonde de resi van de vrije bevolking in Paramaribo of, voo: cen vee: kleiner deel, op de militaire posten in het birnenland.

Gedurende de achttiende eeliw was de meerde:heid van de vrije stadsbewoners van Europese origine ex vormaer zwarten een mindeaheid. In de negentiende eeuw werd deze verhouding volledig ongekeerd en noteerde een amoteraar in I84I (wellicht met enige spijt?) bij een geta: van $: 0.200$ stedelingen: 'waaronder siechts weinig Europeanen of hun aistammelingen'" De groei van de groep zware stedelinger. was atet alleen het gevoig van hun eigen repoduktief vermengen, maar werd bovenal veroorzaak: door het toenernend arria. gemanumitterden (vijgemaaktent). 7o werden tussen 1832 en $: 86.3$ in totaal aar. 6.328 slaven manimissiebewijzen verstrekt. ${ }^{8}$ Vrijwel zonder uitzondering vestigden deze vije Surinamers zich in of rond Paramaribo.

Voordat op de problematiek van de demografische ontwikkeing van de siavenbevolking uitvoerig wordt ingegaa:l, chienen eerst nog twee correcties te worden gemaaki op het bestande geschiedbeeld van de siavenciemografie. De eerste beireft de to:ale omvang van de slavenirmporten en de tweede de ongelijke sekseratio op de p'antages.

Veel geciteerde auteurs als Var. I.ier (1977:92) en P:ice (1976:9, 1979a:17) beweren dat gedurende de gehele slavernijperiode in Suriname tussen 300.000 en 350.000 slaver. zijn ingevoerd. Volgens anderen is deze schattirg

6 Onder zwarten worden hier zowel negers als mensen van gemenge raciale afkoms: - vaak aangecuid als mulatten of kleurlingen - verstaan. Het moge duidelijk zijn dat in een 'samen'leving als de Suriadonse de adnvezgheid yan militairen niet was gericht teger cen eventwele buifenlandse vijand wat blikt ait de gemakkelike bimenkomst van de. Fraasen en de Engelsen in $_{17}: 2,1799$ en 1802 - mear louter en alleen was bustend voor de bescherming van de plantage-economic tegen Indianen, marrons en opstand:ge slaven.

7 ARA: MVK, A792.

8 CBBS: Manumissiereğisters. 
Tabel 45. Vrije bevolking van Suriname 1752-1862 (exclusief Indianen en marrons)

\begin{tabular}{lrrrr}
\hline jaar & op plantage & in Paramaribo & lotal & militalren \\
\hline $\mathbf{1 7 5 2}$ & 1.062 & ca. 1.000 & $(2.062)$ & ca. 720 \\
$\mathbf{1 7 7 4}$ & 934 & 1.757 & 2671 & ca. 1.950 \\
$\mathbf{1 7 9 5}$ & 1.193 & 3.760 & 4.953 & $?$ \\
$\mathbf{1 8 1 3}$ & ca. 1.000 & 5.104 & $(6.104)$ & ca. 1.780 \\
$\mathbf{1 8 5 4}$ & 1.033 & 10.564 & 11.597 & ca. 800 \\
$\mathbf{1 8 6 2}$ & $?$ & $?$ & 16.479 & $?$
\end{tabular}

Het aantal Indianen en marrons werd in 1841 geschat op 8.000 (ARA: MvK, A796). Bronnen: ARA: SvS, 293; ARA: RvP, 583 en 598-600; Surimamse Almanak 1793:6; Public Record Office: Colonial Office 278, 15 en 18 en Treasury 75, 14; ARA: MvK, 1135 en A796; Van Sijpestejin 1854:93-151; Koloniaal Versleg 1862, Hoogbergen 1985:22-4 en Lammens 1982:54.

zelfs nog te laag (zie Hira 1982:72). Dit zi;n zeer grote aantallen voor een slavenbevolking die nooit meer dan. 60.000 personen heeft bedragen. Het zou dan ook het bewijs zijn van set gruweijke karakter van de Surinaamse slavernij, gruwelijker dan waar ook in he: Caraibisch gebied. Om dit te illustreren schroomi Price (1979a:i9) niet een auteur an te balen die spreekt over plantages waar in 25 jaar tjjd fot viermaal tor de totale slavenbevolking door nieuwe import moest worden vervangen. Zo'n voorbeeld is echter nietszeggend 10 Op basis van de meest recente teilingen (Postma 1990:186-212), aangevuld met eiger schattingen voor de periode na 1795 (op basis van Tabellen 44 en 46), blijkt de totale slaverimport tussen 1668 en 1830 ongeveer 213.000 personen te hebben bedragen." Hiermee is niet gezegd dat de Surinaamse slavernij niet hard was, want dat was zij wel degelijk. Alleen wordt het beedd meer genuanceerd, zodat Suriname waarschijnlijk minder heeft afgeweken van he: algernene Caraibische patroon dan vaak is gesuggereerd.

Hetzelfde geldt voor de ongelijke sekseratio op de plantages, die volgens sommigen (bijvoorbeeld Price 1979:20) werd gekenmerkt coor een oneven-

9 De opgegeven aantallen militairen zijn inclusief de zwarte korpsen. Het aantal voor 1774 is dat van 1776 toen er grote troeperversterixingen werden aangevoerd (waar de bekende J.G. Stedman deel van uitmaakte). Het aantal militairen ir 1813 betreft een opgave van Lammens yoor 1817.

10 Een dergelijke bewijsvoering is ook op andere plantage-economieèn toegepast. Zo beschrijft Williams (1978:245) de plantage-economie van Saint Domingue voor de slaven als 'the worst hell on carth' en iliustreert dat aan de hand van één planter die 405 siaven nodig heeft om in 37 jaar de bevolking van zijin planlage met :25 personen le doen toenemen.

11 1668-1795 185.443 (Psstma 1990:186-212)

1796-1808 ca. 16.000 (eigen schatking; zie Hooidstuk IV)

1816-1827 ca. 12.00? (eigen schatting; zie Hooidskuk IV) ra. 213.000 
Tabel 46. Sekseratio var slaveri pe- sectox 1753-1853 (aankal mannen per vrouw)

\begin{tabular}{|c|c|c|c|c|c|}
\hline periode & $\begin{array}{r}\text { s } \\
\text { suiker }\end{array}$ & $\begin{array}{l}c 10 \\
\text { kotfie }\end{array}$ & katoer. & $\begin{array}{l}\text { totaal (gewogen } \\
\text { genoiddeide) }\end{array}$ & $\begin{array}{l}\mathbf{n} \\
\text { slaven }\end{array}$ \\
\hline ca. $17 \bar{x}$ & 1,08 & 1,21 & - & $: 13$ & 6.443 \\
\hline ca. 1770 & 1,03 & 1,04 & - & $i, 04$ & 17.863 \\
\hline ca. 1800 & $\therefore, 06$ & $\therefore, 04$ & $0,9 \overline{7}$ & 1,02 & 8.674 \\
\hline Ca. 1830 & $\therefore, 19$ & $=, 17$ & 1,29 & 1,20 & 9.185 \\
\hline 1853 & 0,94 & 0,98 & 1,00 & 0,96 & 29.345 \\
\hline
\end{tabular}

Bronmen: ARA: SONA en SNA; SAS; Van Sijpesteijri 1854:96-148.

redig groot anal mannen. Uit Tabel 46 blijkt dat in de tweede helít van de achtfiende ceuw hel manneroverschot helemal niet 70 groot was. Alleen in de kosfiesectur was dat rond 1750 wel het geval. Op dat monent bevoud een groot deel van deze sector zirh nog in de adriegfase en voor de extrazware arbeid die cit vereisie waren ni eenmas. nieer manner dan vrouven nodig. Dat dit geen ioze veronderstelling is blijk: uit een stcekproef onder zeven sulkerpiantages rond 1725 , die op cial momen: cius in lun aanlegfase ware: ${ }^{12}$ Op iedere vrouw waren er toen 1,47 manne: Op deze zelide planlages was ab raio rond I780 vri,we genomalisoerd to: 1,24 . Dit alles betekent dat de grolone :mport van mannele gedurencis de gethele achttiende ceuw, in becijifseconomisch opzicht, getuigde van rationecl beleid, narelijx bedoelc om de grotere sterte onder de mannen op te vangen.; 3

Rond 1800 waren in de katoensector zeis meer vrouwen dan mannen werkzaam. Dit was waarschijnijk het gerolg van het feit dat de aanleg van deze nieuwe sectur eer: hoge to' aan mannen eiste, war onvoldoende import tegenorer sturad. Doordat deze eerste katoenplantages voor een deel omgrebouwde koffieplantages waren en vor eren deel hum slaven betrokken van veriaten koffieplantages, was het antal en daamee aandeel van vrouwer. hoger dan in de aanlegfase van kotfie of suiker het geval was geweest.

Opmerkeijik is het feit dat de mees: ongelijke sekseratio optraci rond 1830, toen de slavenimport definitief werd beëindigd. Uit is waarschijnlijk veroorzaak: door massale inkoop van mannen in de jaren twintig - met de defiritieve importstop in zichf -. en ingegeven door de grotere sterfte an manren dan vrowwern. Dit wordt bevestigd don: de slaversaakouen vatr elf piantages ir de jaren 1817-1828 waarbi; gemiddeld op iedere vrouw 1,41 man

12 Plantages Aurora, Le Mast Kouge, Osembo, Wayampibo, Vossenburg, L'Espérance en Ludienburg.

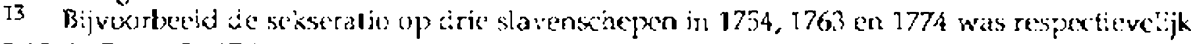
2,10, 2,45 er: 1,31 (GAR: Hu, 18, 34 c: 71). 
werd aangekocht.14 Vooral de katoensector lijkt in die laatste fase van slavenimporten van de gelegenheid te hebben gebruikgemaakt orn een grote hoeveelheid mannen te importeren in verband met de aanieg van enige tientallen plantages in Coronie en Nickerie. Als gevolg van deze ontwikkelingen sloeg het vrouwenoverschot van rond $1800 \mathrm{om}$ in een mannenoverschot rond 1830. Door de grotere mannensterfte en de importstop bleek ex aan het einde van de slavernij weer een vrouwenoverschot op de plantages te zijn ontstaan.

\section{Bevolkingsgroei}

Vrijwel altijd heeft de slavenpopulatie in haar totaliteit te kampen gehad met een sterfte-overschot. Ook hierover hebben veel schrijvers een uitspraak gedaan. Voor wat betreft de tweede helft van de achtticnde eeuw houden zowel Nepveu (1922-23:345) als BIom (1787:121) en Stedman (1988:533) de gemiddelde jaarlijkse afname van de slavenbevolking op 5\%. In de negentiende eeuw is men minder eensgezind en lopen de schattingen uiteen van 2 tot $3,5 \%, 15$ Op basis var het nu beschikbare cijfermateriaal kan de juiste ontwikkeling worden gereconstrueerd.

Voor het midden van de achttiende eeuw zijn de ramingen van bovengenoemde auteurs correct, al dient er gemiddeld nog 2,5 per duizend te worden afgetrokken in verband met marronage. ${ }^{\text {is }}$ De sclitingen van de negentiende-ceuwse auteurs zijn aan de sombere kant, zeker wanneer wordt bedacht dat in de totaalcijfers niet de gunstiger demografische gegevens van slaven op houtgronden en in de stad zijn verdisconteerd. In ieder geval is een duidelijk positieve trend waarneembar, al bleef in het algemeen tot aan de Emancipatie sprake van een sterfte-overschot onder de plantageslaven. ${ }^{17}$

Opvallend is dat deze ontwikkeiing in de koffiesector eerder is ingezet dan in de suikersector. Waarschijnlijk was dit een gevolg van het feit dat de nieuwe import in de jaren 1820 in veel grotere mate naar de suikersecior ging. ${ }^{18}$ Kennelijk had dat cen negatieve invloed op de slayenreproduktic.

14 Plantages Reekvliet, Bleyendaal, Janslust en Blokkenbosch, Nieuw Rneland, De Nieuwe Grond, Potribo, Purmerend, Zorg en Hoop, Meerzorg, Groot Marseille en Vossenburg.

15 Van den Bosch 1837 noemt: 3-3,5\% (AIRA: Collectie Van den Bosch, 108); Kuhn (1828:23): $25-3 \%$; Lans (1829:130\}: 2\% en Teenstra (1835, 13:179): 3\% per jaar.

16 Dit geldt ook voor de periode 1775-1795. Cijfer gebasecrd op steekproef in ARA: RvI', 582 en 594 .

17 In Nederland was in de periode 1830-1860 sprake van sen gebortenoverschot van 7.8 per 1.000 inwoners (Hofstee 1981:122).

18 Deze stelling is gebasemd op een steekproef van zeven suikerplantages (Romsenburg, Meerzorg, Groot Marseille, Bieyendaal, Vossenburg, Potribo en Siparipabo) en zrven koffieplantages (Janslust en Blokkenbosch, Somerszorg en Duringen, Driesveld, Nieuw Roeland, Nieuwe Grond, keekvliet en Purmerend) walarover informatic beschikbaar is over de periode 
Na het definitieve einde van de slavenimport was er sprake van eer. positieve demografische ontwikkeling. Lang cluurde deze echter niet, want in de jaren 1840 sieeg het sterfte-overschot weer aanmerkelijk. Wanneer de gegevens per jaar worden uitgesplitst, bijiken de jaren 1839 tot en met 1843 dramatisch hoge stertte-overschotter. te vertoren. Niet toevaliig trefien wi; voor deze jaren in de verslagen van administrateurs diverse vermeidingen aan varl epidemieën die juist toen in Suriname huiskie'der. ${ }^{19}$

Pas in hef laatste decennium voor de Emancipatie bestond er op de Surinaanse plantages cen wanke'. evenwich tussen gebonten en sterfte. In het algemen kan daarom worden gesteld dat voor de plenters de natuurlijke reproduktie van de arbeid altiju veel te wensen overilet en dat in een slavenleven het verdriet om de doon een veel vake: terugkerend verschijnsel was dan de vreagie rondom een gebcorte.

Nadere beschouwing van Tabel 47 leert echter ook dat er grote ver schilien voorkwamen tissen ce diverse piantagesectoren. Voor slaven, zo blijkt, moe: het lever: op suikerplantages het meest en op katoemplantages hel minst onaantrekkelijk ziji: geweesi, met kolfiepiantages in een iusserpositic. De demografische ontwikkeing in de katoensector in het tweede kwari van de achttjende? exuw stak dan ook gunstig af bij de andere twee? sectoren. Overigens zullen ook op de katoenplantages de epidemieën in de jaren 1840 merkbaar zijn geweest. De suikersertor begon van 1820 af aan eer. opmerkelijke inhalrace. Zon het louter toeva: zi,n ciat in die periode juist deze sector er financieel het bes: vooz stond (zie Tabel 39) en dus mee: mogelijkheden had voo: verbetering var. be slavenzorg?

In het licht van he: cirronisci sterite-overschot dringt de vraag zich op of het yoor de planters wellicht goodkoper was om slaven te importeren en deze maximaal te expioiteren, dan leet bevorceren var de ratuurlijke aanwas door meer en dürdere zorg an de slaven a jesteden. llelaas ontbreekt het material om daarover een uispraak to kumsen doen; boven. dien bestond dege keus sinds eind jarer 1770 in suite riet meer. De slechte finarciele situatie watin hel grootsie dec! van de plantages zich bevond belemmerde de aarkoop ran nieuwe slaver. Fer be:eid dat getoorten bevorderde kon daarom: uitkomst bieden.

1817-1829. Deze plantages importecrden gezameilijk 292 slaven, waa:va: 7b\% naar de slikerpiantagks ging-

19 Zo merkte een admiristrateur op: 'Zeer te betreuien is he: da: de stertie under de negers in de kulonie gedurende den loop van : 83 y zoc aanzienlijk is geweest, ten gcvolge van cader-

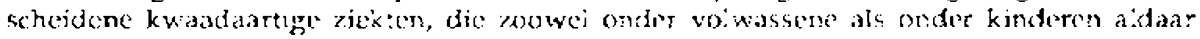
geneerscht hebben. En: een ccliega van hem maakte in 1843 melding van de boudloup loysenteriel waardoor vele plantagien en de stad laaramaribo zelve verleden jaar geteisterd zi;n

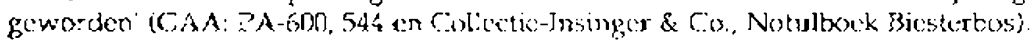


Tabel 47. Natuurljjke bevolkingsaanwas per sector 1752-1862 (jaarlijks gemiddelde per duizend slaven ${ }^{20}$

\begin{tabular}{|c|c|c|c|c|c|c|c|}
\hline periode & $\begin{array}{l}\text { suiker- } \\
\text { sector }\end{array}$ & $\begin{array}{l}\text { n } \\
\text { plant. }\end{array}$ & $\begin{array}{l}\text { koffie- } \\
\text { sector }\end{array}$ & $\stackrel{n}{\text { plant. }}$ & $\begin{array}{l}\text { katoen- } \\
\text { sector }\end{array}$ & $\begin{array}{l}\text { n } \\
\text { plant. }\end{array}$ & $\begin{array}{l}\text { totaal (gewogen } \\
\text { gemiddelde) }\end{array}$ \\
\hline $1752-1774$ & $?$ & & $?$ & & $\sim$ & & ca. $-47,0$ \\
\hline $1775-1795$ & $?$ & & $?$ & & - & & ca. $-24,0$ \\
\hline $1780-1810$ & $-29,0$ & 5 & $-18,7$ & 7 & $?$ & & $-21,9$ \\
\hline $1820-1829$ & $-30,6$ & 7 & $-15,8$ & 7 & $?$ & & -21.9 \\
\hline $1830-1839$ & $-16,6$ & 10 & $-1 i, 5$ & 12 & $+0,06$ & 5 & $-11,7$ \\
\hline $1840-1849$ & $-23,3$ & 8 & $-17,2$ & 8 & $?$ & & $-21,4$ \\
\hline $1850-1862$ & $-6,5$ & 18 & $-6,2$ & 16 & $+7,0$ & 7 & $-3,5$ \\
\hline
\end{tabular}

Het totaalciffer voor 1752-1774 en 1775-1795 geldt voor de gehele Surinaamse slavenbevolking, voor de andere jaren is het alleen van toepassing op de hier ingevulde sectoren.

Bronner: Postma 1990:186-212; ARA: SvS, 293; ARA: KvP, 583 en 598-600; Surinaamse Almanak 1793:6; Public Record Office: Colonial Office 278,15 en 18 en Treasury 75, 14; ARA: MvK, i 135 en A796; Van Sijpesteijn 1854:93-151; Koloniaal Verslag 1862; plantage-archieven; SAS en C3BS: slavenregisters.

Inderdaad blijkt na 1775 het sterfte-overscho: bijna gehalveerd in vergelijking met de voorafgaande decennia (Tabel 47). Toch zal dit vee: meer het gevolg zijn geweest van het feit dat de opbouwfase van de plantages en alle daaraan verbonden zware arbeid acnte: de rug was, dan aan een bewust beleid ter bevordering van de :eproduktie. Zo'n beleid hield namelijk hogere uitgaven in en geld was er nu juist niet. Bovendien heeft het er veel van weg dat de gedachte aan zo'n beleid niet eens bij de meeste planters opkwam, gewend als zij lange tijo warer. geweest aan ruime slavenimporten. In de correspondentie tussen Surinaamse administrateurs en belanghebbenden in Nederland in ceze periode wordt voortdurend geklaagd over het dalerd aintal slaver op de plantages, terwijl de arbeid steeds zwaarder werd. Steevast resuiteerde dit in het verzoek om geiden te

20 In deze tabe: zijr. voor de periode $1752-1795$ ook de groeicijfers van de gehe.e stavenbevolking opgenomen, aangezien voor de jaren:750-1780 geen representatieve cijfers van de plantageslaven voorhanden zijn. Deze totaalcijfers z:jn gebasperc op de bevolkingsaantallen in de jaren 1752, $1774 \mathrm{cn} 1795$ (Tabel 44) er, de slavenimporien in die periode (Postma 1990:186212). Hierbij heb ik de totale slavenimpor:en in die periodes (respectieveijik 72.641 en 15.642) opgeteld bij de bevolikingsaantalien van respectievelijk i752 en 1772 en daarvan de bevolkingsaantallen van respectievel:ijk 1774 en 1795 weet afgetrokken. Dit levert het totale afnamecijer op. Leze heb ik gedeeld op de som van de jaarlikse slavenbevolking in die jaren (respectievelijk 1.075 .338 en 1.134 .819 ). Dit ievert afnamepercentages op van respertieveli;k 4,70 en 2,41 .

De cijfers vanaf 1780 zijn gebaseerd op piantage-archievex en slavenregisters. Bij de periode 1780-1810 waren vrijwel gersn aaneengesketen reeken wijers voorhanden, zodal deze cijfers icts minder 'hard' zijn dan in in de volgende periodes. Ter vergeiijking: in die dertig jaar gaat het om 92 informatiejaren van twaalf plantages; in de voigende periode (1820)-1829) gaat het om 119 informaticjaren van veertien plantages in tien jaar. 
fourneren voor de aankoop van nieuwe slaven. Vrijwel nooit kwanen er verzoeken om meer uitgaver te mogen doen voor de verzorging van de slaven ter stimulering van de natuurlijke reproduktie.

Een enkeling dacht ove: deze problematiek wel na, maar werd dan vaak door de hachelijke financiële situatie weerhouden om ideeën in praxtijk te brengen. Dat dit tol zee: paradoxale situaties kon leiden bleek op La Singularité (Beneden-Commewijne). In 1786-1787 berichtte de eigenaar aan zijn administrateurs dat hij zecr in zijn schix was met de aanzienlijke uitbreiding van het bebouwd areaal, mazr dat de opbrengsten daarvan nog te weinig in verhouding tot de kapitaalschuld van de plantage stonden. Hi; drong er op aan de prodiktie verder te verhogen. Tegelijk verordonneerde hij echter dat van de slaven vooral niet meer arbeid mocht worden gevraagd dan zij aankonden, opdat hun aantal niet zou dalen, want zonder deseive is ecn uifgestrekte plant. gelijk Singularité een dood lighaam van geenen waarde, en het zoude mij in deese omstandigheeden voor als nog onmooglijk sijn om enige aankoop van nieuwe slaaven te doen'2i Deze man wilde in feite voor een dubbeltje op de eerste rang zitten: maximale produktie, zedeli;ke belasting van de slaven ter vermijding van een sterfteoverschot en geen extra-kosten,22 Waarsch:jnlijk was een dergelijke houcing typerend voor de plantage-eigenaars in deze periode.

Toch bleek er ook in de hoogtijdagen van slavenimporten en kapitaalovervloed al oog te z:jn voor het belang van een natuurlijke reproduklie. Zo adviseerce de administrateur van Boxel in 1768 aan de eigenaars om belalve 15 'mannegers' ook 25 'jong volkje' to kopen, die weliswar even duur waren en niet direct even produktief, maar die hij van groot nut achtte 'om een vasten stam te kweeken, en de plantagie zonder gestadige aankoop in stand te houden. ${ }^{23}$ En ook uit de correspondentie van de eigenaars yan Vredenioung (ca. 1763) bi:jk: dat deze er nauwlettend op toezagen of er wel voldoende 'aanwas van kinderer. piaats vond op hun ondernemirg. ${ }^{24}$ Beide voorbeelden zouden erop kunnen duiden dat natuurlijke reproduktie een ever. reele, dus betaalbare, mogelijkheid was als import.

IIet spreekt vanzelf dal met de afscharfing van de slavenimport de belangstelling voor het probleem van het sterfte-overshot groter werd. Allerlei verklaringen werden aangejagen, die tevens inzicht verschaffen in de behandeling van de slaver. Zo schteven de eerdergenoemde eigenaars

\footnotetext{
21 EHB: KA-120, 42.

22 Overigens swercien in :801 tocin nog 21 slaven voor deze plantage gekocht, maar in de tussenliggende periode was de bevalking dan ook teruggelopen vas: 243 tot 151 personen (EHB: KA-:20, 39).

23 ARA: Aanwinston :888, 3 D.

26 ARA: Collectie-Caikoer:, 130.
} 
van Vredenburg in 1763 bij de constatering dat er zo weinig kinderen op hun plantage werden geboren,

'dat sulks dikwils door een goed of guaad Directeur veroorsaakt werd, of die de slaave wel of qualijk behandelt, en min of meerder sorg voor de kraam vrouwe draggt, want dat niet doende, of dat de slaave niet content zijn met den directeur sou weeten sij wel een middel om de kinderen te doen slerven...' 2.5

De behandeling door de plantagestaf en zorg voor zwangere vrouwen worden hier dus van groot belang geachi voor de reproduktie van de slaven. Toch was dat in die tijd in het geheel geen gemeengoed. Integendeel, zwangere vrouwen werden vaak als lastposlen gezien die arbeidsverlies en extra monden om te voeden opleverden. Zij hoefden dan ook niet op mededogen te rekenen. ${ }^{25}$ Pas met de afschaffing van de slavenhandel door de Fngelsen kwam in dit gedrag verandering, 'en men mag dan thans de vruchtbaarheid der slavinnen als een voordeel van een effect rekenen', aldus een planter aan zijn administrateur. ${ }^{27}$ Sinds die tijd werd het dan ook steeds gebruikelijker om zwangere vrouwen te ontzien. Vaak, maar niet altijd, kregen zij de periode rondorn de bevaling gehee? vrij en behoefden gedurende een aantal weken daarvoor en daarna slechts een halve arbeidstaak ('halfmerk') te verrichten.

Daarnaast werd meer aandacht besteed aan de oorzaken van de hoge slavensterfte, die overigens niet door iecereer. als extrem hoog werd ervaren. De rechter A.F. I.ammens, een tamelijk gematigd man, bijvoorbeeld onderschreef dit niet en verzettr. zich ook tegen de - meestal door Engelsen verkondigde 28 - stelling dat hogere slavensterfte het gevolg zou zijn van structurele mishandeling in Suriname. Zo er dus al sp:ake was van een relatief hogere sterfte, dan lag dit volgens Lammens aan een combinatie van moeilijk te beïvloeden factoren, of aan de sìaven zelf. Bovendien, zegt hij, in veel gevallen 'willen zij geene kinderen aankweeken' waardoor hẹt sterfte-overschot bleef bestaan. ${ }^{29}$ Het is typerend voor de meeste verkla-

25 ARA: Collectie-Calkoen, 130.

26 Duidelijk blijkt dit uit de woorden van Kunitz (1805:76) die schreef: Vorzüglich sorgsam sey man für Schwangere; man schaffe deshalb dip auf vielen Plantagen norh herrschende Gewohnheit $a b$, diese armen Geschöpfe bis auf die lesste Stunde ihrer Niederikunf́ zu den schwersten Arbeiten anzwhalten, wodurch nicht selten Mutter und Kind in die grösste Gelahr gerathen'

27 ARA: Collectie-Copes van Catterburgh, 78.

28 Lo wordt in Wolbers (1861:567) cen brief gecifcerd van Gouverneur Bonham, die in 1814 schreef: 'Ik heb [...] 21 jaren in de West-indiën verkeerd, en in iedere kolanic heb ik steeds gehoord, dat het eene zeer zware straf voor een neger was, om hem ann een pianter in Suriname te verkoopen, en ik bevind $r u$ dat zulks warkherd is. lk ben nog in geene kolonic geweest, waar de slaven zoo slecht worden behandeld, zulk slecht voedsel en zulke sobere kleeding ontvangen en waar zij toch tot zulk een zwaren arbeid, boven hunne krachten worden genoodzaakt.

29 Volgens Lammens, die dit alles op een lexing in Suriname in 1818 verkondigde, werd het 
ringen uit die periode dat de schuld voor het sterifte-overschot minstens ten. dele bij de slaven zelf werd ge'egd.

Een zeer kenmerkende aralyse van deze problematiek door een tijdgenoot is te vinden in een rapport van Commissaris-Generaal Johannes van den Bosch uit 1827. Dit stuk geeft een zodanig helder inzicht in de denkbeelden uit die tijd, dat het hier in zijn geheel wordt weergegeven.

'De instandhouding van het negergeslacht, en het bestuur der negers is alsmede een voorwerp dal ernstige overweging verdient; het lia geene bedenking, of er heeft algemen, eere vermindering cerzelve plats, en wel van 3 à 3,5 per 100 , jaarlijks. Dat z.11:ks geen noodzakelijk gevolg is van de gesteldheid des lands bli;kt daaruit, dat de sterfte op vele plantagien, de geboorte of weirig, of in het. geneei niel overtreft, terwijl bij de boschnegers het getal schijnt aan te groeyen. Deze sterfe schijnt dus in andere onrzaken en vocral in de onzedelijkheid der negers te moeten worden gezocht, daar zeker door het ieven van érnen manmet vele vrouwen en van éére vrouw met vele manren, de venerische ziekten sterk moeter aangroeyen, waardoor de voortteeing gestremd, en de sterfte vermeerderd wordt.

De behandeing is daarop mecie van invloed; een te zware arbeid en te geringe voeding zijn hoogs: nadeeiig yoor den aangroet der bevolking en behooren te keer te worken gegaar. De regle:senten gebouwd op de beginseler. deswegens voorgesch reven, moeten dan ook zon spoecig doenlik opgestelc, en ter goedkeuring naaz Europa gezonden wcrden. Intusschen zijn cok vele geb:eken in dit opzigt aan de huishoucieliike levenswijze der negers toe te schrijven, en het is geenzints mogelijk daarin doo: het gevag of den invloed van het gouvernement of van de pianters verandering te brengen; want gelijk ieder onjeschaafd volk hechten zij ten sterkste aar. hunne gewoonten en vooroo:dee.en. Eene dierlijke voidoenirg hunrer dritten is het eenige geluk wat zij kernen en schatten. ${ }^{30}$

Van den Bosch onderkende dus wei da: er een verband bestond tussen de behandeling van de slaven en ret demoguafisch patroon. Hi; thonde zich dan ook een groot yoorstander van de invoering van stoommolens, omdat daarmee de siopende rachtarbeid kon worden afgeschalt. ln het algerneen drorg hij aan op een strakke reglementering die een goede behandeling van de slaven zou wadrorgen. Voor het overige bladden, volgens van den Bosch, de slaven de nrgatieve bevolkingsgroei in fxite and zirhzel: te wi;ien. Hun vermeend promiscue gedrag, leidend tot venerische ziektes, wras de hoofdoorzaak. 31 Het is ironisch, dat Var den Bosch niet ziet hoe hij zich zelf

sterfte-overschol vernorzakt door: de overgang wan Afrika naar Amerika, do slechte dampen van pas ontgonnen gronden, de ongelijke sekseratio, de praktijk vam slaven om c'kanr soms to vergiftugen en de sorns voorkomende or wil om kinderen te kri;gen iARA: Collectie-Van den Bosth, 137).

30 ARA: Co:lectie-Var den Bosch, 108.

31 Kuni:z (1305:73), zeif jareniang directeur op plantages, onderachrift deze visie, maar

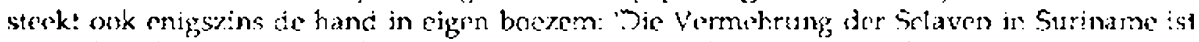
nach Verhältuis ihrer Ar.zahl nur mirtelmässig. Die Uhrsacice Gavon liegt ohnstreitig in der Ungebundenseit und Zügellosigkeił der Sclaven beideriel Geschlechts, die ir der grössten Polygame leber. Diescon: Uebel kans cin Direceve von Plantagen am leichester: dadurch 
tegenspreekt, want wanneer de 'onzedelijkheid der negers' de oorzaak was van het sterfte-overschot, dan zou dat toch ook voor de marrons moeten gelden en niet alleen voor de slaven.

Tot slot wijst Van den Bosch op het onbeschaafde, zelfs dierlijke karakter van de slaven, wat hen koppig aan hun fatale gewoontes deed vasthouden. In het licht van zijn tijd is dat geen vreemde uitspraak, want bijvoorbeeld ook een verklaard tegenstander van de slavernij als Teernstra huldigt dergelijke denkbeelden (Teenstra 1835, IJ:186). Belangrijker is echter om te weten of die koppige 'gewoorten en vooroordeeler' misschien een uiting waren van een autonome reactie op de slavernij a.s zodanig. Per slot was de voortplanting een van de weinige dingen in het leven die de slaver in. belangrijke mate een keuzemogeli;kheid bood. ${ }^{32}$

\section{Mortaliteif}

Voor eer: goed begrip van de oorzaken van de negatieve bevoikingsgroei is kennis van de factoren die deze he: mees: hebben beinvioed van belang. Daartoe moet eer. onderscheik worden gemakkt tussen de ontwikkelingen in het sterfteniveau (de mortaliteit) en het geboortenniveau (de nataliteit).

Anders dan was te verwachten, werden de hoogste sterftecijfers niet gemeten in de achttiende, maar ir de negentiende eeuw. Met rame de jaren 1820 en 1840 vertonen grote uitschieters. Het is jammer dat juist voor deze twee decentia de cijfers voor de katoensector ontbreken, maar gezien hun structureel lager niveau in de twee andere decennia, waarvoor wel cij:ers

abhelfen, dass er sich nach und nach ar. Zügelling ihrer unordcntlicher. Begierten zu gewühnen sucht, sie gut hält, und ihre. Liebe und Zutraues siele 2.11 erwerben bemiint ist; am woir xismster: bleibt jedech immet das Mittel, dass er iknen mit gutem Beispiel worangeht. Auch muss seire hauptsächliche Sorge dahin gehen, den Vencriscrikranken alle mögliche Hilfe angedeihen zu lassen: denn dieser gibt es eine grosse Mienge:

32 De eerder gecteerde opmerkingen van de eigenaars van Vrederhurg, en I.ammens over aborkis/infanticide en de onivil tot voortplanting lijken daar in icder geval op te wijzen. Ook Iigman (1984:348-9) wijst wat betreft het Brits-Caraibisch gebied op de autonome invloed van de slaven op het reproduktiepatronn: Reprodaction is more obvious'y a produc: of scrial behavior than is the pattern of mortaijy, though such bchavior may often se explained by cconomic structure. Variations on the level of slave fertility were determined not only by work regimes and material well-being but aiso by the cultural forms nt the slaves and the atfempts of masters and missionaries to alter those forms. The slaves cherishec systems of family organization learned in Africa, together with associated attitudes about the control of reproductive behavior, but these norms were partially transformed as a cirect prodiact of the mixing of Aftican ethric groups with distinct cultural heritages and the growth of the creoie population.' Met name wat betreft het laatste punt was er ten belangrijk verschii met Suriname. Daar werden gedi:rende het eerste kwart van de negentiende eeuw nog erke.e. tienduizenden Afrikanen ingevoerd en kregen zende.ingen in die tijd nog nauwe!ijks toegang tot de plantages. Hierdoor was het demografisch gedrag var: Surinaamse slaven minder doo: Europeanen beinvloed dan in het Brits-Caraïbich geebied. 
Tabel 48. Mortaliteit plantageslaven 1780-1862 (jaarlijks gemiddelde per duizend slaven)

\begin{tabular}{|c|c|c|c|c|}
\hline periode & \multicolumn{3}{|c|}{ sectoren } & $\begin{array}{l}\text { totaal (yewogen } \\
\text { gemiddedde) }\end{array}$ \\
\hline $1780-1810$ & 44,0 & 39,2 & ? & 40,7 \\
\hline $1820-1829$ & 54,4 & 46,0 & ? & 49,4 \\
\hline $1830-1839$ & 42,5 & 36,8 & 20,8 & 36,6 \\
\hline $1840-1849$ & 52,7 & 45,1 & $?$ & 50,4 \\
\hline $1850-1862$ & 36,2 & 38,0 & 30,2 & 34,6 \\
\hline
\end{tabular}

Voor de verschuiving in levensduur zie Tabel 49.

Bronnen: l'ostma 19910:186-212; AKA: SvS, 293; ARA: RvP, 583 en 598-600; Surinammse Almanak 1793:6; Public Record Office: Colonial Office 278,15 en 18 en Treasury 75, 14; ARA: MvK, 1135 en A796; Van Sijpesteijn 1854:93-151; Koloniaal Verslag 1862; plantage-archieven; SAS en CBBS: slavenregisters.

beschikbaar zijn, lijkt het aamemelijk dat de totaalcijfers inclusier de katoen in de piekjaren lager zuilen $z: j n$ geweesi. De ontwikkelingen op suiker- en koffieplantages lijken er op te wijzen dat in ieder geval tot circa 1850 geen verandering, of zelfs een lichte verslechtering, optrad in de levensomstandigheden van de slaven. Het is echter ook mogelijk dat andere factoren dan de levensomstandigheden op plantages bepalend waren voor het sterfteniveau.

In iecer geval trad, wat betreft de suikersector, gedurende de laatste periode voor de Emancipatie een duichelijke verbetering in en werd een aanzienlijk lagere mortaliteit bereikt. Dit gold daarentegen niet voor de koffie- en katoenplantages, waar de sterfte dan wel laag wass, maar hoger dan Jun laagterecords in de jaren 1830 . I Iet lijkt daarom meer dan toevallig dat juist deze twee sectorer. in de\% perioce economisch op hun eind liepen, terwijl het in de suikersector weer de goede kant op ging (zie Tabel 39) Evenmin kan het toeval zijn dat precies in deze tijd het sterk verbeterde slavenreglement van krachs werd. Beide factoren gecombineerd betekenen dan dat de leversomstandigheden op suikerplantages het meest konden worden verbeterd, ondat daar meer financiële speelruimte aanwezig was.

Toch blifft de vraag in hoeverre andere factoren dan levensomstandigheden de mortaliteit hebben beinvloed. Zo werc bij de verklaring van het gesteger: sterfte-overschot in de jaren 1840, al gesuggereerd dat een reeks van epidemieën daaraan debet was.

Op geregelde tijden werd de Suriraamse bevolking getroffen door epidemieër. De meest voorkomende en tevens meest gevreesde waren de (kinder)pokken (Variola major). Jet is ond:nidelijk of in Suriname voor 1800 deze ziekte al bestreden werd door variolatie, het kunstmatig opwekken van pokken door besmetting met een geringe hoeveelheid men- 
selijke pokstof. Wel is bekend dat de meer moderne methode van vaccinatie, inenting met koepokstof, in Suriname voor het eerst werd toegepast in 1801 door de Engelse arts J. Cadell. De weerstand tegen deze behandeling was echter groot en de aanwezige hoeveelheid van het vaccin klein, zodat bij een volgende epidemie in 1819 het gouvernement nieuwe koepokstof uit Cayenne moest laten overkomen (Oudschans Dentz 1948:156; Wolbers 1861:609). Ook daarra was de vaccinatie nog niet algemeen, want toen rond 1855 opnieuw een tameijjk goedaardige pokkenepidemie heerste, noteerde de administrateur van Vossenburg dat hij van de aanwezigheid van koepokstof gebruik had gemaakt om nu ook 'de kinderen te vaccineren waaraan dit tot nog toe niet was kurnen worden gedaan'.33 Ook tegen cholera en gele koorts werden in de loop van de negentiende eeuw door de overheid maatregelen genomen. ${ }^{34}$

In de jaren 1820 en 1840 heersten inderdaad de zwaarste epidemieën. ${ }^{35}$ Alleen al de epidemie van 1819-1820 eiste volgens Wolbers (1861:805) ruim tweeduizend doden ${ }^{36}$ Daarmee werd in én kiap suim 3\% van de bevolking

33. Surinaams Muscum: Collectic-Brantsen, Verslagbockje 1854-1855.

34 Zo werd op de Suriraamse begroting van 1832 een post opgevocrd van 16.000 voor 'quarantaine onkosten, ten gevolge van genomene maatregelen tegen de toen hier te lande uitgebrokene Cholera morbus' (ARA: Collectie-Baud, 769). Kennelijk heeft deze maatregel afdoende geholpen, want in geen enixel plantage-archief u:t deze periode wordt van deze ziekte melding gemaakt. Ook meldden de administrateurs van Vossenburg in 1857 dat in Guiana een cholera-epidemie was uitgebroken, wardoor schepen uit dat land 40 dagen in quarantaine moesten doorbrengen (Surinaams Mu:se'um: Collectio. Brantsen, verslaglowekje: 1856 1857).

35 Epidemieen in Suriname $1760-1860$

periode

1764

1777-1779

1789-1790

$1800-1801$

1819-1820

1823

1824

1826

1828

1835

1839-1844

1851

1854-1856

1857 soort epidertic

pokken

pokken

pokken

pokken

pokken

gricp

dysenterie

griep

gricp

mazelen

griep en dysenterie vcel slachtófers

gele xoorts

pokken

mazeler./'koortser' cpmorkingen

veel slachtolfers

veel slach toffers

ver slarhtoffers

ca. 2.000 slachtorsers

vcel slachto!fers

veel slarhtoifers

veel slachtoffers

7.895 besmet/ 149 dood

ongevaarljjk

Over de tweede helft van de achttiende exuw was minder informatie voorhanden dan daarna. Bronnen: plantage-archieven; Wolbers $1861: 274,362,6[9,623,726$ en 805; Koloniva! Verslag 1856.

36 In de Encyclopedis uan Suriname (Brwijning en Voorhoeve 1977:687) wordt zelfs beweerd dat mexer dan 10.00 slaven tijdens deze cpidemie overlecen. Dit ijikt mij een slag in de lucht te zijn. Ook verderop lijkt deze bron siech geinformeerd te zijn, want daar wordt gesteld dat Suriname pas sinds 1884 cen vaccinatiemogelijkheid bezat, terwijl dit toen al ruim tachtig jaar het geval was. 
weggevaagd. Vergeieken met de epicemie in 1855, was die van 1819-1820 een ware 'killer'. Gedurende datzeifde decennium werd Suriname nog eens vier keer door een epider.ie opgeschrikt, waarvan twee ernstige.

In de jaren 1830 bleef de plantages verder onheil bespaard, maar de jaren 1839-1844 kunnen niet anders dan als een rampperiude worden omschreven. Verschillende jaren achtereen teiste:den dysenterie en griep toen veel minder onschuldig dan nu .. het land en eisten vele slachtorfers. Ook de jaren daarna was het waarschijnlijk nog niet overal even gezond, want nog in 1846 meldde de administrateur var. Zeezigt "buitengewoon veel sterfgevalien onder de slaaven'.37

Het is duidelijk dat deze epidemieër. het sterftecijfer omhoog joegen. Natuurlijk speelden omstandigheder. als hygiëne, voedirg en vaccinatie een ro: in de ontvankelijkr.eid vour dergelijke ziekles, maar in die tijd mocten epidemicën toch vooral worden gezien als autonome factoren die de bevolkingsgroei in belangrijke mate beinvloedden.

Een andere factor die effect kan hebjen gehad op de mortalifeit was creolisering. Higman (1984:322-4) toont aan dat in het algemeen in het Caraibisch gebied het sterfterijfer onder Afrikanen hoger was dan onder creolen. Dit had onder meer te maken met het feit dat Afrikanen niet bestand waren tegen bepaalde z:ekies en bovendien vaak heł zwaarste werk moesten verrichten. De enige uitzondering op dit patroon vormce Berbice, waar in het algemeen het omgekeerce hel geval was. I lierover zijn voor Suriname geen cijfers beschikbaar. Gezien de vergelijkbare achtergrond van Suriname en buurland Berbice is liet niet uitgesloten dat wat dit betreft de Surinaamse mortaliteit eerder overen kwam met Berbice dan met het overige Caraibisch gebied. Bewijzen zijn er echter niet voor. De enige indicatie dat Surirame het algemere patroon volgt zou kunnen zijn dat na het definitieve einde van de slaven:mport in 1827 h.el Afrikaanse aandeel in de slaverbevolking geleideli;k moet zijn afgenomen en ook het sterftecijfer een generatie later, in de jaren 1850 , significar.t was gedaald.

kpidemieën en creolisering hebber: zich hougstwaarschijnli;k in de verschillende sectoren van de Surinaamse plantage-economie in min of meer geli;ke mate voorgedain. He! blift daarom opmerkeli;k cat de mortaliteit in de suikersector in de jaren 1850 veel sterker was gedaald dan in de andere sectoren. Oprieuw dringt zich de vraag op of veranderde levensomstandigheden daarin een rol hebben gespeeld. Dit kan worden onderzocht door na te gaan of er verandering optrac in de levensverwachting van slaven. Of simpeler gezegd: leefden slaven tegen het einde van de slavernij langer dan voorheen en zijn daarbi; sectorale verschillen aan te wijzen. 
Helaas is een steekproef van een representatieve groep slaven, overleden in een afgebakende periode, waarvan de leettijd bij overlijden bekend is, voor de achttiende eeuw riet te maken, aangezien toen vrijwel nooit de leeftijden van de slaven werden genoteerd. Dat veranderde echter na 1827 toen alle slaven verplicht moesten worden opgenomen in de slavenregisters, onder toevoeging van het, vaak geschatte, geboortejaar en eventuele datum van overlijden. Uit de registers die de tand des tijds hebben weten te doorstaan zijn inderdaad twee representatieve sleekproeven te construeren: één voor de jaren 1831-1838 en een tweede voor de periode 1859-juni 1863. Zo is het mogejijk na te gaan welke veranderingen zich binnen én generatie afspeelden.

Uit Tabel 49 blijkt dat een slaaf, ouder cian tien, wonend op een katoenplantage het langste leven beschoren was, met dien verstande dat het rond 1835 ging om een vrouw en een kwart eeuw later een man. Alvorens hier verder op in te gaan dient echter eerst te worden opgemerkt dat in alle drie plantagesectoren de levensverwachting spectaculair was verbeterd. Binnen de tijdspanne van eer. generatie was de gemiddelde :evensduur van slaver. ouder dan tien jaar met negen tot !ien jaar verlengd! Dit betekent niet alleer. dat de zorg voor de slaven in die periode flirk moet zijn verbeterd, maar bovendien dat dit proces ook al voor de jaren 1850 in gang was gezet, anders zou een dergelijke verbetering niet mogelijk zijn geweest.

Een analyse van de ontwikkeling der slaven van tien jaar en ouder leert

Tabel 49. Gemiddelde leeftijd plan:ageslaver, bij overlijden in ca. :835 er ca. 1861

\begin{tabular}{|c|c|c|c|c|}
\hline sector & $\begin{array}{l}\text { gemida. leeftijd } \\
\text { ca. } 1835\end{array}$ & $\mathrm{n}$ & $\begin{array}{l}\text { gemidd. ¿eeft:jd } \\
\text { ca. } 1861\end{array}$ & $\mathrm{n}$ \\
\hline \multicolumn{5}{|l|}{ suiker } \\
\hline $\operatorname{man}>10 \mathrm{jr}$. & 37,3 & 123 & 46,2 & 133 \\
\hline vrouw > $10 \mathrm{jr}$. & 36,0 & 75 & 47,8 & 116 \\
\hline $\operatorname{man}+$ vrouw $>10 \mathrm{jr}$. & 36,8 & 195 & 46,9 & 249 \\
\hline alle leeftijden & 27,1 & 274 & 26,0 & 471 \\
\hline \multicolumn{5}{|l|}{ koffie } \\
\hline $\operatorname{man}>10 \mathrm{jr}$ & 38,5 & 68 & 46,5 & 64 \\
\hline vrouw > $10 ; r$. & 36,4 & 4.5 & 47,2 & 62 \\
\hline $\operatorname{man}+$ vrouw $>: 0 \mathrm{jr}$. & 37,6 & 113 & 46,8 & 126 \\
\hline alie leeftijden & 29,8 & 146 & 26,7 & 231 \\
\hline \multicolumn{5}{|l|}{ katoe $\Omega$} \\
\hline $\operatorname{man}>10 \mathrm{jr}$ & 39,2 & 64 & 53,3 & 54 \\
\hline vrouw $>10 \mathrm{jr}$ & 42,6 & 44 & 48,2 & 53 \\
\hline man + vrous $>10 ; r$. & 37,6 & 108 & 50,8 & 107 \\
\hline alle leeftijden & 32,6 & 137 & 22,7 & 256 \\
\hline
\end{tabular}

De steekproef voor katoen is uit de jaren 1855-1863.

Bronnen: SAS en CBBS: slavenregisters. 
dat de suiker- en koffiesector een gelijksoortig proces hebben doorgemaakt, terwijl de katoensector een enigszins ander patroon vertoont. Bij de eerste twee is het duidelijk dat vrouwen het meest hebben geprofiteerd van de verbeteringen. Hun gemiddelde levensverwachting steeg met 11,8 en 10,8 jaar, tegen 8,9 en 8,0 bri de mannen. Sterker rog, in de jaren 1830 was de zorg voor vrouwen kennelijk zo slecht dat zij éen tot twee jaar korter leefden dan mannen, terwijl de situatie rond 1861 was omgikeerd en zij gemiddeld driekwart tot anderhalf jaar ianger in leven bleven.

Kennelijk zijn de ontwikkelingen in de suikersector harder gegaan dan bij koffie, want was de levensduut voor manlijke suikersiaven rond 1835 1,2 jaar korter, rond 1861 was dit teruggebracht to 0,4 jaar; bij vrouwen draaide de situatie zelfs om en leefden zij op suikerplantages gemiddeld een half jaar langer rond 1861. Dit cuidt er weer op dat in de suikersector meer financiële mogelijkheder tot lotsverbetering anwezig waren dan in de koffiesector.

Zoals gezegd, verliepen de ontwikkelingen in de katoensector tamelijk tegendraads. Wel nam ook daar de gemidcelce levensdum mei ruim tien jaar toe, maa: het waren de mannen die er het meest van profiteerien. Bovendien warer daar in de jaren 1830 de vrouwen degenen die het langst leefden, terwijl dat een kwart eeuw later de mannen waren. De levensduur van de mannelijke katoenslaven, die rond 1835 toch al de hoogste was van alle sectoren, werd maar liefst met gemiddeld 14,1 jaar verlengd.

Voor alle sectoren geldt dat de gemiddelde levenscuur, inclusief kinderen onder de tien jaa:, daalde. Dit werd veroorzaaki door de to'name van het aantal geboortes bij gelijk blijvende kindersterfte. In absolute aantalier stierven ex dus meer kinderen.

Wat verklaart nu die opvallende verschillen tussen ce katoensector en de twee andere sectoren? Zoals meestal zal het een combinatie van factoren zijn geweest, waarvan de geografische liggirg en de soort arbeid de belangrijkste waren. Wellicht dat ook de achtergrond van de planters een rol heeft gespeeld, want juist in de katoenbranche maaxten Britse pianters in grole mate de dienst uil.

De geografische ligging van de katoenplantages was in meerdere opzichten van belang. In de eerste plaats waren al deze ondernemingen vlak aan zee gesitueerd, waar het klimaat gezonder is dan in de rest var het land. Zo is het er veel minder nat dan in het overige plantagegebied, met gemiddeld een kwart minder neerslag en bepaalde ziektes, zoals bijvoorbeeld malaria, komen er niet, of slechts in lichte mate, voor (Bruijning er. Voorhoeve :977:341,688). Ook kan de consumptie var eiwitrijk zeevoedsel een positief effect op de gezondheid hebben gehad. Bovendien lag de helft van de katoemplantages in Coronie en Nickerie, yan waar hel relatief niet al te 
moeilijk vluchten was naar Guiana, waar al in 1834 de slavernij was afgeschaft (Hoogbergen 1978:18). Het ligt voor de hand, dat deze situatie de planters dwong hun slaven niet al te slecht te behandelen.

Naast deze geografische verschillen, waren er ook duidelijke verschillen in de soort arbeid op katoenplantages enerzijds en suiker-en koffieplantages anderzijas. Zo bestond op katoenplantages niet de terreur van de suiker(water)molen die maar een beperkte tijd kon malen, of geplukte koffiebonen die metcen gebroken en gewassen moesten worden, beice leidend tot (gedeeltelijke) nachtarbeid. ${ }^{38}$ Dit betekende tevens dat er ook niet urenlang achtereen in bedompte loodsen hoefde te worden gewerkt, zoals bit suiker en koffie. Ook is het plukken var katoen en koffiebonen een lichter karwei dan suikerriet kapper. Van even groot belang als het ontbreken var. nachtarbeid op xatoenplartages, was het ontbreken van complexe waterstelsels, zoals op suiker-en in mindere mate koffieplantages. Hierdoor kwam delven in modderige klei op katoenplantages niet of nauwelijks voor. En tenslotte werd in de katoen- en koffiesector riet geroteerd, zoda! na de eerste aanleg riet steeds opnieuw akkers hoefden te worder. angelegd.

Ilet laatste punt vormt tevens de verklaring voor de grotere stijging van de levensverwachting bij mannen in de katoenbranche dan in de andere sectoren. In vergelijking met die atdere was de katoen een zeer jonge sector en had het merendeel van deze plantages pas begin jaren dertig de aan!egfase achter de rug. Die aanleg, grotendeels mannenwerk, zal zeker zijn to! hebben geëist van de katoenslaver, zodat de levensverwachting werd gedrukt (maar desoncianks nog hoger lag dan bij koffie en siiiker).

In het algemeer. kan daarom worden gesteld dat kennelijk de levensomstandigheden op suikerplantages het slechtst waren, op koffieplanfages iets minder slecht en op katoemplanlages een stuk beter. Dat de levensverwachting van vrouwen in de katoensectur minder steeg dan eiders, had te maken met het feit dat zij in 1835 a! een relatief gunstig niveau had bereikt.

Overigens l:jkt he: er op (Tabel 49) dat vooral in de jaren 1830 mannen het zwaarder hadden te verduren dan vrowwen, want zij stierven in grotere aantaller. De verklarirg dazrvoor zou kurinen zijr dat er ook reer mannen dar. vrouwen waren op de piantages van deze steekproef. Dat blijkt inderdaad het geval geweest te zijn, maar in een mincier onevenwick.tige verhouding dan tussen de overleden mannen en vrouwen (Tabel 50), Zo stierven rond 1835 op zowel suiker- als koffieplantages meer marnen dar de sekseratio rechtvaardigde. En ondanks dat een kwart eeuw later de sekseratio was omgeciraid (er waren nu dus meer vrouwen dan mannen),

38 Ook de medicus Kuinn (i828:14-5) meldt dat nachtarbeid op katoenplantages nict voorkwam, zodat de gemidde!de arbeidstag daar het kortst was. Op koffie- en suikerplantages moest er na het oogsten meestal worden doorgewerkt 'zoo dat op koffy- dikwijls een gedeelte en up suikerplantaadjen penige dagen in de maand de geheele nachlnusl wordt opgeofferd' 
Tabel 50. Sekseratio overieden plantageslaven (azntal mannen per vrouw) in ca. 1832 en ca. 1861

\begin{tabular}{|c|c|c|c|c|}
\hline \multirow[b]{2}{*}{ sector } & \multicolumn{2}{|c|}{ ca. 1835} & \multicolumn{2}{|c|}{ ca. 2861} \\
\hline & $\begin{array}{l}\text { populatie } \\
>: 0 \text { ir. }\end{array}$ & $\begin{array}{l}\text { overleden } \\
>10 \mathrm{jr} .\end{array}$ & $\begin{array}{l}\text { populatie } \\
>10 \text { jr. }\end{array}$ & $\begin{array}{l}\text { overieden } \\
>10 \mathrm{jr} .\end{array}$ \\
\hline suiker & $\therefore, 33$ & 1,60 & 0,95 & 1,15 \\
\hline koffie & $: 29$ & 1,51 & 0,97 & 1,03 \\
\hline katoen & $\therefore, 64$ & 1,45 & 0,83 & 1,02 \\
\hline
\end{tabular}

De steekproef voor katoen is utit de periode 1855-1863.

Bronnen: SAS en C.BBS: slavenregisters.

bieven er meer mannen dan vrouwen sterven (vandaar ook die ommekeer in de sekse-ratio).

Ook in dit opzicht gedroeg de katoensector zich weer anders dan de twee overige sectoren. lle: groosste manmenoverschot van de jarer dertig slocg om in het grootsit? vrouwenoverschot rond 1861 en dat terwijl in de jaren dertig naar verlouding minder mannen stierven dan vrouwen en rona 1861 ongever evenveel vrouwen als marnen. Het is nict duidelijk of de manrelijke katoensiaven na de grote inspannirgen in de voorafgaande periode van plartage-aanleg enige tijd wercier ontzien, maar later niet meer. Ook is onbekend of er in de iussenliggende periode veel vrouweiijke siaven werden gekocht of binnengesmokkeld, wat bij die vlak aan zee gelegen plantages natuurlijk makkelijker kon dar elders.

De doodsourzaken van cie slaven en eventueie veranderingen daarin, kunnen ook rog aanwijzingen gever over veranderende ievernsomstandigheden. Wanneer d2 doodsoorzaken van 273 overleden slaven in de periode 1815-1839 worden vergeieken met die van 133 slaven in de jaren 1840-1863 blijken zich inderdad enige veranderingen te hebben voorgedaan (zie ook Bijlage iDA). Veruit de meest voorkomence doodsoorzaak was die welke werd gecategoriseerd als 'oud er afgewer'xt'. Hieronder verstoni men een natuurlikke dood ten gevolge van ouderdom. Het kon zijn dat deze mensen tevens geheel uitgemergeld of invalide waren, maar dat hoefde niet. In de laatste cecenria yoor de Emancipatie bleek ceze natuurli;ke doodsoorzaak gemiddeld met bijna 9\% te zijn toegenomen: in de periode 1815-1839 stierf iets meer dan $34 \%$ van uderdom en in $1840-1863$ was dat bijna $43 \%$. Dit duidt - in combiratie met de gestegen gemidde.de ieeftijd bij overlijden toch wel op verbeterie levensonstandigheden, a: was het alleen maar vanwege de kennelijk afgenomen vatbaarheid voor allerloi ziektes.

Ook hier blijkt weer dat de mannen er in eerste instantie hei slechtst aar. toe waren, maar hun lo: verbeterde het snelst: in de laatste periode stierven 12,7\% meex mannen door oucierdom dan daarvoor. In het algemeen kwam 
het bereiken van een 'normale' fysieke grens (oud en afgewerkt) als doodsoorzaak minder bij mannen voor dan bij vrouwen, maar in de eerste periode was dit verschil veel groter dan in de laatste.

De meeste doodsoorzaken buiten 'oud en afgewerkt' namen in de loop der tijd in omvang af. Zeer opvailend is het vrijwel verdwijnen van venerische ziektes als oorzaak van overlijden. Dit zou het gevolg kunnen zijn van het feit dat begin jaren 1840 de Moravische Broeders (de latere Evangelische Broeder Gemeente) toestemming hadden gekregen cen groot zendingsorfensief te beginnen onder de plantageslaven, waarbij zij hamerden op monogame relaties. Alleen longziektes en bilharzia kwamen in de laatste periode relatief vaker voor als doodsonzaak, wat er op zou kunnen duiden dat de hygiënische onstandigheden, met stoffige loodsen en verontreinigd water, nog steeds slecht waren.

Kindersterfte verdient aparte aandacht. Uit Tabel 49 bleek a: dat de leeftijdsgroep van overledenen beneden de tien jaar buiterproportioneel groot was en rond $186 \mathrm{I}$ zelis ongeveer verdubbeld was ten opzichte van 1835. Dit laatste was overigens het gevoig van he: grotere aantal kinderen dat werd geboren. Bovendien blijki, verhoudingsgewijs, in de kindersterfte tussen 1820 en 1863 nauwelijks iets te zijn veranderd. Alleen de zuigelingensterfte nam, om onduidelijke redener., iets toe, maar dat werd weer ruimschoots gecompenseerd door de daling var de kleutersterfte.

Tabel 51. Kinderstertate 1820-1839 en 1840-1863 (in \%)

\begin{tabular}{lccccc}
\hline periode & totaal & & a ver l e d e $\pi$ & \\
& geboren & $<2 \mathrm{jr}$ & $2-5 \mathrm{jr}$. & $6-9 \mathrm{jr}$ & total \\
$1820-1839$ & $\ldots 59$ & 21,4 & 18,1 & 3,3 & 42,8 \\
$1840-1853$ & 519 & 24,1 & 14,1 & 4,0 & 42,2 \\
\hline
\end{tabular}

Bronnen: SAS en CBBS: plantage-archieven.

Het is duidelijk dat de kindersterfte zeer bepalend was voor de mortaliteit als geheel. Verhoudingsgewijs stierven de meeste kinderen tijdens hun eerste twee levensjaren, maar ook daarna bleef he! oppassen. ${ }^{39}$ Pas wanneer de kinderen vijf jaar waren geworden, konden $z: ;$ de toekomst, wat betreft levensverwachting, met enig optimisme tegemoet zien. Op dat moment was echter wel al bijna twee-vijfde van hun potentiële leeftijdgenootjes overleden. Hoe het komt dat in die kindersterfte rauwelijks verandering optrad, valt misschien af te ieiden uit de doodsoorzaken van deze kinderen.

Het is jammer dat van een relatief groot aantal $(22,4 \%)$ de doodsoorzaak

39 Normaal gesproken worat zuigelingensterfte berekend voor kinderen beneden één jaar en niet tot twee jaar zoals hier is gedaan. Doordat geboorte- en sterftedata vaak alleen als jaartal waren aangegeven moest deze wai onnauwkeuriger aanpak worden gehanteerd. 
onbekend was, waardoor het beeld toch enigszins vertekend zal zijn (zie Bijlage 10B). Toch ijjt het geen twijfel cat stuipen $(22,8 \%$ ) en yaws (framboesia tropica) (19,3\%) de grootste 'killers' waren onder de kleine slavenkinderen. Voor geen van beide ziektes bestond een remedie, zodat de kindersterfte chrorisch hoog bleuf. In de loop van de negentiende exuw werd de leeftijdsopbouw var de slavenbevolking evenwichtiger als gevolg van het toenemend aarial kinderen (0-9 jaar) en ouderen (50+) (Figuur 10). Paradoxaal genoeg had dit tivee negaticve effecten. In de cerste plaats bleef hierdoor de stertte relatief hoog, omdat het aantal kinderen toenam en de kinderstexfte hoog bleef en ook het aandeel van oudere slaven steeg. In de tweede plaats betekende deze ontwikkeling dat he: meest produktieve deel van de bevoiking, de groep tussen 20 en 40 jaat ${ }^{40}$, verhoudingsgewijs steeds kleiner werci. Bedrijfsmatig gezien was dit een desastreuze tendens, ondat een grosiend deel van de bevolking, dai niet aan de produktic deelnam, mexesf worden verzorgi. Roud 1830 was $42,3 \%$ van de slaven produktief en in 1800 was dal nog maar $28,8 \%$. In dit liche bezier. was de Fmancipatir ecn logische stap.

Figutur 10. Leeftijcsopbolw plantageslaver ca. 1830 en ca. 1860
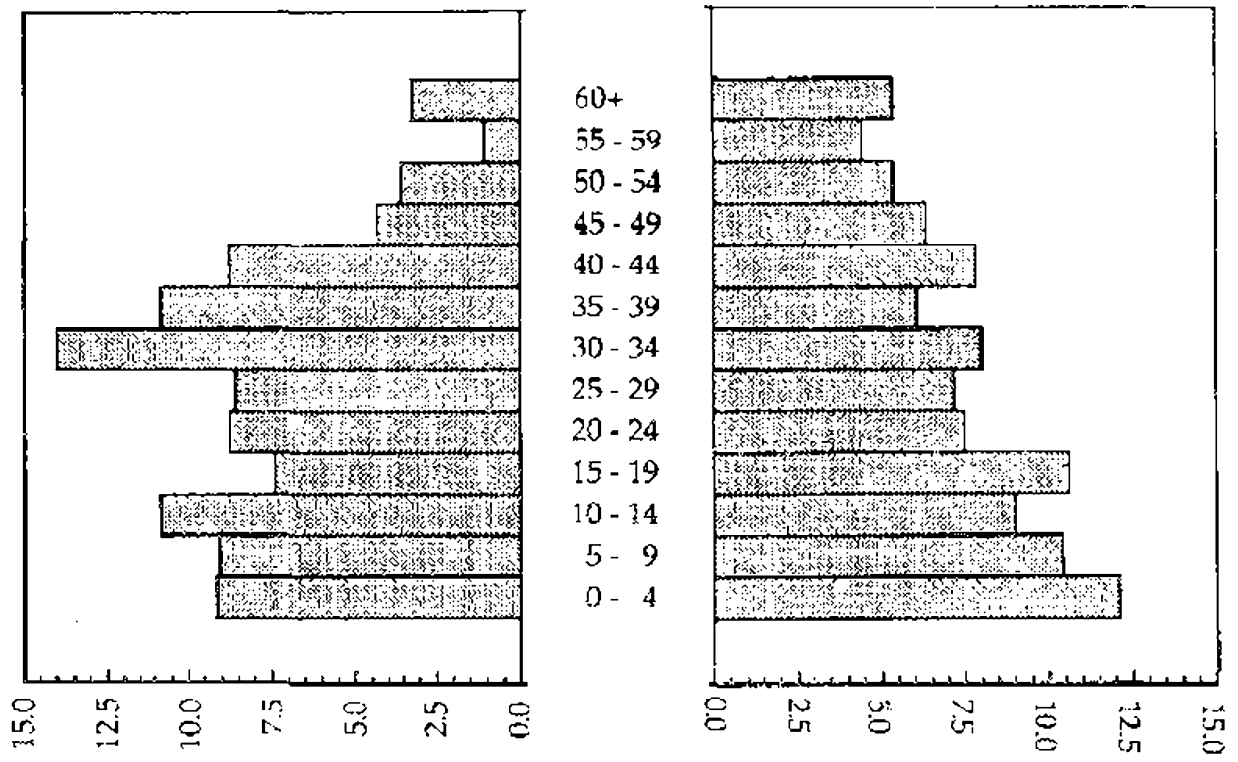

Steekproef $18.30: n=2.532 ; 1850: n=2.112$

Bronner: ARA: PWJE, 27 en 153; in SAS en CBBS: slavenregisters.

4) De gehantecrde 'eeftijdscriteria zijr gebascerć op de kwalificaties die vermeld stonder. in slavenlijster wit die periode. 


\section{Nataliteit}

In het voorafgaande werd duidelijk dat het sterfte-overschot in de loop der tijd langzaam kleiner werd. De morlaliteit is daarop slechts in geringe mate van invloed geweest. Het ligt dus voor de hand te veronderstellen dat een stijging van het geboortencijfer heeft plaatsgevonden. Dat blijkt ook inderdaad het geval te zijn geweest (Tabel 52). Het gemidideld aantal geboortes in de drie plantagesectoren steeg per duizend siaven van 18,6 in de laatste decennia van de achtriende eeuw tot 31,1 in het laatste decennium voor de Emancipatie.

Deze duidelijke stijging van het geboortencijfer is niet altijd even gelijkmatig en ook niet in a.le sectoren hetzelfde verlopen. Iet opmerkelijke is echter dat de ontwikkelinger in zowel de suiker-als de koffiesector parallel liepen aar de winstgevendkeid van beide sectoren. Door alle schulden bevonden beide soorten plantages zich eind achitiende eecuw financieel op een dieptepunt en het geboortencijfer in die sector eveneens. In het tweede kwart van de negentiende eeuw waren de perspectieven voor suiker tamelijk optimistisch (vooral in de jaren 1820) en sprong het geboortencijfer omhoog, om daarna geieicielijk te blijven stijgen. De koffie was eveneens in de jaren weer redelijk winstgevend, maar liep daarna definitiel op zijn eind. De geboortencijfers op de koffieplantages waren na het hoogtepunt in de jaren 1820 weer cen stuk lager. Alleen in het laatste decennium bernikter de geboortencijfers weer een top, zoals in de katoensector. Dit zou kunnen betekenen dat de wetgeving, door middel van het nieuwe slavenreglement, nu van doorsiaggevender invloed was dan de financieel-economische omstandigheder.

Lif dit alles zou dus kunnen blijxen dat de factor die het meest door de slaven zelf kon worden beinvloed, de reproduktie, ook inderdaad door hen werd gestuurd onder invloed van de omstandigheden op de plantages. Iet

Tabel 52. Nataliteit plantageslaven :780-1862 (per duizend slaven)

\begin{tabular}{|c|c|c|c|c|}
\hline periode & suiker & $\begin{array}{l}\text { sector } \\
\text { koffie }\end{array}$ & katoen & $\begin{array}{l}\text { totaal (gewogen } \\
\text { gemiddelde) }\end{array}$ \\
\hline $1780-1810$ & 14,4 & 20,5 & $?$ & 18,6 \\
\hline $1820-1829$ & 23,8 & 30,2 & $?$ & 27.6 \\
\hline $1830-1839$ & 25,9 & 25,3 & 20,8 & 24,8 \\
\hline $1840-1849$ & 29,4 & 27,9 & $?$ & 28,9 \\
\hline $1850-1862$ & 29,7 & $3 i, 8$ & 37,2 & $3 i, 1$ \\
\hline
\end{tabular}

Bronnen: Postma 1990:186-2:2; ARA: SvS, 293; ARA: RvP, 583 en 598-600; Surinqamse Almanak 1793:6; Public Record Office: Colcnial Office 278, 15 en 18 en Treasury 75, 14; ARA: MvK, 1135 en A796; Van Sijpesteijn 1854:93-151; Koluniaal Verslag 1862; plantage archieven; SAS en CBBS: slavenregisters. 
enige vraagteken li;kt het geboortecijfer in de katoensector gedurende de jaren 1830. Dit was het laagste van alle sectoren, terwijl al eerder werd geconstateerd dat de levensomstandigheden daar relatief het best waren. Een verklaring kan zijn dat deze sector voor een belangrijk deel pas kort van de opbouwfase in een stabielere fase was terecht gekomen en ook de zeer ongelijke sekseratio kan een rol hebben gespeeld (rie Tabelien 46 en 50).

\section{Fertiliteit}

Fertiliteit is een betere indicatie dan nataliteit voor het reproduktieniveau en de invloed die de slaven daarop kunnen hebben uitgeoefend. Het is namelijk een veel verfijnder instrument, omdat niet de relatie wordt gelegd tussen geboorteniveau en ce totale populatie, maar specifiek met vrouwen, en ook manner, in de vruchtbare levensfase.

Aan het begin van dit hoofdstuk bleek (Tabel 46) dat desekseratio van dee totale slavenbevolking op de plantages, behalve rond 1750 en 1830 , nooit dramatisch uit balans was. Deze factor lijkt daarom geen doorslaggevende rol te hebben gespeeld in het reproduktieniveau van de slaven. Toch is voorzichtigheid geboden, want voor de reproduktie is eigenlijk alleen dat deel van de bevolking van belang, dat zich in de vruchtbare levensfase (1544 jaar) bevindt. Helaas is hierover geen informatie van vóor 1830 beschikbaar. I Ioe de situatie zich daanna ontwixkelde blijkt uit Tabel 53 .

Rond 1831 was het deel van de planlageslaven dat zich in de vruchlbare levensfase bevond grool, rond cirie-vijede? van de bevolking, maar de sekseratio binnen deze groep was een stuk onevenwichtiger dan van de totale populatie, met uitzonderirg van de koffiesector. Waasschijnlijk waren voor deze sector in de vonrafgaande periode de minste slavenaankopen gedaan.

Tabel 53. Vruciatbare plasagesiaven in populatie 1831 en 1851 (15-44 jaar; aanlal mannen per vrouw)

\begin{tabular}{|c|c|c|c|c|}
\hline \multirow[t]{2}{*}{ periode } & \multicolumn{3}{|c|}{$s e t+0 r$} & \multirow{2}{*}{$\begin{array}{l}\text { lotaal (gewigem } \\
\text { gemidnelde) }\end{array}$} \\
\hline & suiker & koffie & katopn & \\
\hline \multicolumn{5}{|l|}{1831} \\
\hline totale sekseratios & 1,19 & 1,17 & 1,29 & 1,20 \\
\hline vruchtbare sekseratio & 1,39 & 1,13 & 1,76 & 3,36 \\
\hline vruchtbaar deel totale populatic & $62,60 \%$ & $52,50 \%$ & $58,60 \%$ & $57,80 \%$ \\
\hline \multicolumn{5}{|l|}{1851} \\
\hline totale seksorat:o & 0,94 & 0,58 & 1,00 & 0,96 \\
\hline vachtbare sekseratic & 0,99 & 1,10 & 1,12 & 1,04 \\
\hline vruchtbar cleel totale popuiatie & $47,50 \%$ & $47,10 \%$ & $40,20 \%$ & $46,00 \%$ \\
\hline
\end{tabular}

Steekproef vruchtbare populatie: $\mathrm{n}=3.875$ (1831) en 7.395 (1851).

Bronnen: SAS: slavenregisters en Van Sijpesteijn 1854:96-118. 
Die scheve verhoudingen in de vruchtbare populatie moeten een negatieve invloed hebben gehad op het reproduktienieveau.

Twintig jaar later was het vruchtbare deel van de populatie relatief flink in omvang afgenomen. Zowel vergrijzing van de bevolking als het grotere aantal geboortes waren hier debet aan. Daarnaast blijkt de sekseratio van de vruchtbare populatie met name in de suiker-en katoensector aanzienlijk te zijn genormaliseerd en was de koffiesector min of meer stil blijven staan. In de suikersector was de vruchtbare sekseratio zelfs ideaal te noemen. Dat de koffiesector zich zo anders gedroeg dan de twee andere sectoren zou te maken kunnen hebben met het fejt dat in die sector het verval veel eerder zijn intrede deed dan elders.

Wat deze ontwikkelingen in de sekseverhoudingen hebben belekend voor de fertiliteit kan het best worden nagegaan door de ratio te berekenen tussen het aantal kinderen in de leeftijd $0-4$ jaar en het aantal vruchtbare vrowwen, de zogenaamde kind/vrouw-ratio.

Tabel 54, Kind/vrouw-ratio 1831-1863 (kind 0-4 jaar per vrouw 15-44 jaar)

\begin{tabular}{lcccc} 
jaar & suiker & $\begin{array}{c}\text { sector } \\
\text { koffie }\end{array}$ & katoen & $\begin{array}{c}\text { total (gewogen } \\
\text { gemiddelde) }\end{array}$ \\
\hline 1831 & 0,260 & 0,435 & 0,499 & 0,368 \\
1851 & 0,434 & 0,512 & 0,633 & 0,483 \\
1863 & 0,493 & 0,646 & 0,721 & 0,549 \\
\hline
\end{tabular}

Steekproef vruchtbare populatie: $n=3.875$ (1831) en 7.395 (1851).

Bronnert: SAS: slaverregisters en Van Sijpesteijn 1854:96-148 ел voor 1863: Lamur 1987b:319.

Hicruit blijkt dat de sekseratio toch minder van invloed was op de ferliliteit dan mocht worden verwacht. Of anders gezegd: de meest gunstige of ongunstige sekseratio betekende nog niet dat ook de fertiliteit het hoogst of laagst was. Wel blijkt de normalisering van de sekseratio tussen 1831 en 1851 in zijn algemeenheid een positieve invloed te hebben gehad op de fertiliteit. Vooral de suiker- en katoensector maakten op beide gebieden een grote sprong voorwaarts.

Gedurende de gehele periode was de vruchtbaarheid in de suikersector het laagst en in de katoensector het hoogst, met een middenpositie voor de koffiesector. Hier heeft kennelijk toch weer het verschil in Ievensomstandigheden, zoals die bij de mortaliteit a an bod kwam, een rol van betekenis gespeeld. Het lijkl er dus sierk op chat de impuls tot reproduktíe bij slaven verschilde per sector, afhankelijk van de levensomstandigheden. De beste manier om dit te bewijzen zou zijn door per sector een representatieve 
groep vrouwen gedurende hun gehele vruchtbare periode te volgen. Heiaas is daarvoor onvoldoende representatief materiaal voorhanden. Wel kar. een dergelijke groep worden gevolgd zonder het onderscheid raar sector te maken. Zo xwam een steexproef tot stand van 204 vrouken, afkomstig van zes st:iker-, zes koffie- en twee katoenpiartages in cie periode 18201863.41

Van deze 204 vrouwen bléker: er totaal $48(23,5 \%)$ kinderloos te blijverl. Gegeven het overheersende marnenoverschor in deze leefti,dsgroep (zie boven), lijkt het onwarschijnlijk dat deze vrouwen geen kinderen kreger. bij gebrek aan een mar. Dit betekent diat zij of fysick nint in staat waren kinderer te krijgen, of geen kinderen wilden krijger. Welke van deze twee factoter bepalend was is moelijk te zeggen, omdat be:de door tijdgenoter, ais verklaring worden aangevoera.

Bij de vrouwen die wel kinderen ter wereld brachten, bedroeg het aanta: levendgeborenen gemikdeld 4,1 per moečer. De gemiddelde lecftijd van deze moeders bij de gejoorte van het eersie kind was 20,4 jaar er: bij het laatste kind 31,9 ;aar. Dit betekent dat do reprodukticperiode gemiddeld niet

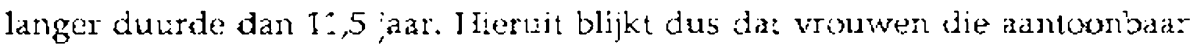
kinderen konden on ook wilder krijgen, zirh toch in belangrijks mate heperkten. Cemiddeld vier kinderen per vrouw is $7 \mathrm{kkr}$ nict veel, met rame wanner worit bedacht hat bijra twee-vijfde van de kirderen niet eens het zesde levensjaar h.aalde.

Afgezien van de tamelijk korte reprocukiierase, was ce periode thssen cie opeenvolgende geboorten, het zogenaande geboortenin:erval, relaticf ang: gemiddeld 3,7 jaar. Voor een deel valt dit te verklaren wit de :ameli; lange lactatieperiode, de periode warrir. het kind wordt gezongd, die de moeders ir: acht namen. Volgens Stedman (1988:526) werden de kinderen, vis moederliefde, iwee jaar aan de borst genouden. Gedurende lie tijd had de nocder geen seksuele gemeenschap met een mar, wart cen nieuwe zwangerschap tijders ce laciatie werd, dhus Stedrian, beschouwd als onatidurlijk en schadelijk voor het zogende kind.

Lamur (1983:142-1) wijst er op dat dit gebruik hongstwarsschijn'ijk een Westafrikaanse achtergrond had 7ijn veronderstelling dat de gemidcelce lactatieperiode zo'n 2,5 jaar duurde lijkt echter, zeker voor de negentiencie eeuw, wel wat erg lang. Het is niet onwaarsch:jn.ijk dat dit in de achttience eeuw inderdaad gebruik was, maar in de volgence eeliw werd cat door ce

4: P'antagcs Le Nast Rotigc, Bleycndaal, Perou, Potribc, Vosseaburg, Groot Marseille, l'urmerend, Beekvliet, Soriterszorg, Jansiust en Blokkenixosch, Driesveld, Jaghtlusi, Alsimo en Anna Catharina. Vour do variabele leceftijd bij het eerste en bi; het hatste kind is de steek proet aangevild met die vroawen vonr wie deze gegevens ook met zekerheid waren vast te stcller, zonder ciat hun geheie vruchtbare periode kon worcien gevolgd. Bij de'ce tivee variabele? is $n$ dan $255 \mathrm{~cm} 207$. 
slavenmeesters niet meer toegestaan. Dat althans is de suggestie die de medicus Kuhn (1828:29) wekt:

'De Negerinnen hnuden de kinderen verbaasd lang aan de borst, en indien men haar daarin geheel den vrijen wil liet, dan zoude zexer binnen de twee of drie jaren geen kind gespeend worden. Men kan echter niet verhinderen, dat zij boven het jaar het kind nog zoo lang zogen, tot het loopen kan; [...], en uit eerr punt van bijgeloof zullen zij, gedurende dat $z \mathrm{ij}$ kinderen aan de borst hebben, geene gemeenschap met den man plegen' [mijn cursivering].

Kennelijk hebben de planters hier heel bewust ingegrepen, ter stimulering van de voortplanting, dan wel uit een oogpunt van efficiëntie. Dat dit in de negentiende eeuw ook inderdaad de praktijk was (geworden), blijkt uis ale vergelijkir.g van een aantal siaveninveniarislijsten met de geboortendata. ${ }^{42}$ De gemiddelde leefli; van kinderen boven cér jaar, die nog te boek stonden als zuigelirg bedroeg bijna 19 maanden; de gemiddelde leeftijd van kinderen beneden 2,5 jaar die niet meer ais zuigeling, maar als spelend kind of kleine creol werden omschreven bedroeg eveneens bijra 19 maanden. Dit betekent dat de grens voor het zogen van kinderen op ruim anderhalf jaar lag. Aangezien vrouwen gedurende deze perioce verminderd vruchtbaar waren er. seks woor hen dan toch al taboe was, is hiermee eer. deel van het lange geboorteninterval verklaard. Dat het daarna nog eeris gemiddeld anderhalf jaar duurde voordat een volgende conceptie plaatsvond, duid! er op dat vrouwen dit zeif in de hand hielden en dus bewust voor een niezwe zwangerschap kozer.

Ir. het algemeen kan nu wel worder. gesteld dat de relatief lage fertiliteit het gevolg was van autonome beslissinger van de vrouwen. ${ }^{43}$ Kennelijk streefden zij naar een 'target family' van twee tot vier Kinderen, want uit de steekproef blijkt dat $68 \%$ van de moeders geen kinderen meer kreeg, nadat zij er twee tot vier hadden die de kritieke eerste viif levensjaren hadden overleetd.

Men zou kurren opperen dat het streven naar een dergelijke beperkte gezinssamenstelling niet werd ingegeven doo: slechte levensomstandigheden, maar door heet feit dat onder de slavernij riet in kinderen hoefde: te worden ge:nvesteerd voor de oude dag, wart voeding en kleding kregen de slaven toci wel. Met hetzelfde recht hadden zij dan echter ook tien of meer kinderen kunnen krijgen. Bovendien gaat het argument niet gehee! op, want de slaven voorzagen voor een deel ook zelf in hun behoeften, zodat

42 Plartages Vossenburg, Groot Marseille, Rustenburg, Janslust en Blokkenbosch en Somerszorg.

43 I let enige vorbthoud dat hitr nog wel dient te wordicn gemaak:, is de mogeijikheid dat niet alle geboortes wercien geregistreerd. In de plantageboekhouding lijk: alles wel heel nauwkeurig te zijn bijgehouden, maar het is mogeli;k dat ir. de (nationale) slavenregisters niet iedere alxirtus, miskraan, of doodizeborene? werd genoteerd. 
kinderen wel degelijk een steun voor de oude dag betekenden. Het kan daarom bijna riet anders dan dat de levensomstandigheden bepalend waren voor het aantal kinderen dat men kreeg. Toch blijft het de vraag in hoeverre dit geheel afhankelijk was van de bewuste keuze van vrouwen, of dat het ging om de resultante van autonome, biologische processen die afhankelijk waren van (veranderingen in) de fysieke en medische omstandigheden.

Ongetwijfeld zal hel laatste ook een rol gespeeld hebben, getuige bijvoorbeeld de afname van bepaalde ziektes. ${ }^{44}$ Toch zijn er ook aanwijzingen die de bewuste rol van vrouwer li,ken te bevestigen. In de eerste plaats toont de specifieke lactatieperiode en de bewuste onthouding van seksuele gemeenschap aan dat vrouwen irvloed uitoefenden op de reproduktie. ${ }^{45}$ In de tweede plats lijkt het meer dan toeval dat het aantal kinderen per vrouw steeg (Tabel 54) in eer. periode waarin de slaven een steeds grotere onafhankelikheid wisten te verwerven. In de volgende hoofdstukker wordt beschreven hoe slaven in toenemence mate in hun eigen voeding gingen voorzien en op alle mogeli;ke mannieren probeerden inkomsten te verwerven in verband met benodigdheden voor het slavenf.uishouden en ceremonies. In dergelijke omstandigheden werd het krijgen van (meer) kinderen niet alleen aantrekkelijker, maar zelfs roodzakelijk om te overleven. En terslotte was de toeremende inperking van arbeid door zwangere vrouwen yoor sommigen mogelijk een reden om zich cioor middel van zwangerscind enige tijd aan hot zwate werk le ontlrekken. De stijgende fertiliteit lijkt daarom een gevolg te zijn geweest van de combinatie van fysiologische processen en beslissingen van slaven in reactie op vorbeterde levensornstandigheden.

\section{Vergeligking met het Caraibish gethed}

Een vergelijking van het demografisch patroon van de Suriraamse slavenbevolking me: andere Carabische slaverpopulaties is alleen mogelijk voor de ja:en 1830. Di: leveri niet meer dar: een statisch beeld op, maar hel geeft in ieder geval een indicatie van eern antwoord op de vraag of het demograf:sth gedrag var. Sirintamse slaven afweek van het gedrag van hun broeders en zusters in ce regio. Wellitht zegt dis nok iets over verschilen ir. levensomstandigheden Fy dien: echter een voorbehoud te worden gemaakt wat betreft de vergeijjkbaarheid: de Surinaarnse cijfers zijn gebaseerd op de slavenpopulatie var. de suiker-, koffie- en katoensecior,

44 Met name de afname van venerische ziektes moet van invleed zijn geweest op de reproduklie, al hesft juist deze ziekte niel alleen een medisch biologische, maar wok ent heel duidelijke social-cilturele dimenoie.

4) Om nog maar te zwijgen van de vele malen dat in de literatuur en archicven worob gewezen op de kennis die slavinunen hadden van allerici abortiva. 
Tabel 55. Demografie Caraibische slavenpopulaties ca. 1835

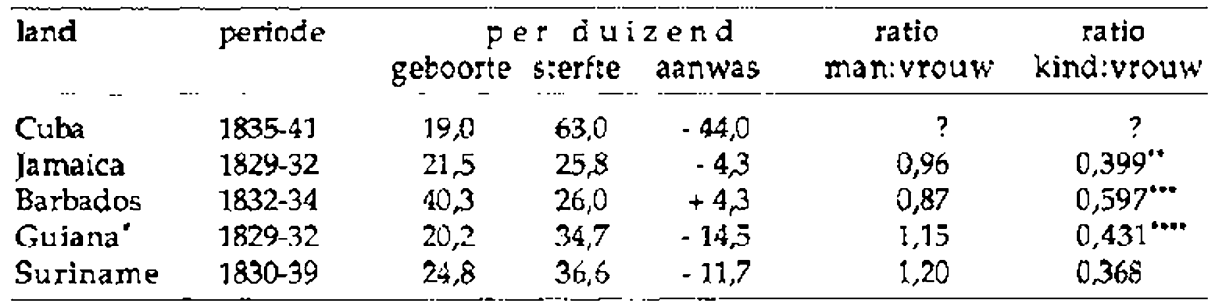

- Demarara-Essequibo.

$\because 2817$.

$\cdots \quad 1817$.

-... 1820 .

Bronnen: Higman 1984:308-10, 354, 356; Moreno Fraginals 1976:196; Lamur 1983:143; Suriname: steekproef 204 vroliwen, Tabp:en 46, 47, 48, 52, 34.

terwijl de overige Caraibische cijfers zijn gebaseerd op de tota.e slavenpopulatie.

Wat betreft de bevolkingsaanwas blijkt Suriname zich zeer gemicdeld te hebben gedragen: lang niet zo slecht als Cuba, maar niet zo gunstig als Barbados. Dat gemiddelde niveau bereikte Suriname overigens door de combinatie van een relatief hoog geboorter- mel een eveneens relatief hoog sterftecijfer. I Iierbij dient nogmaals in acht te worden genomen dat het bij Suriname alleen ging om slaven op exportplantages en bij de overige koloniën om alle slaven. 7.o bleek bijvoorbeeld het sterftecijfer van de exportplantageslaver. in Guiara hoger te liggen dan in Suriname.

Wat de fertiliteit aangat scoorcen Surinaamse vrouwen het laagst. Hieraan zullen de relatief iets langere geboorteninterval en lactatieperiode en de korte reproduxtieperiocie cebet zijn geweest. Aangezien de fertiliteit de factor was die in verhouding het meest door de slaven zelf kon worden beinvloed, zou dit er op kunnen duiden dat Surinaamse vrouwen de reproduktie bewust haag hielder, a's gevolg van (of weliicht als protest tegen) slechte levensomstandigheden. Daarraast is het mogelijk dat als gevolg van het langer voortduren van slaveninporten in Suriname, Afrikaanse praxtijken daar larger hebben stand gehouden dan in het BritsCaraibisch gebied. Ook Higman (1984:354) steit dat sommige yrouwen een veel langere lactatieperiode aanhielcen dan het toen geldende gemiddelde van 18 maander, uit verzet tegen het leven in slavernij. Volgens hem werden hiermee echter ook Afrikaanse methoden gehandhaald die waren gericht op het uitstellen van het momen: cat de borstroeding ophield, omdat de ervaring had geieerd dat meteen ciaarna de kindersterfte extra hoog was.

Hef is dus heel wel mogelijk dat in Suriname Afrikaanse gewoonten 
zoals een lang geboorteninterval $(3,7$ jaar) en lactatie ( 1,6 jaar), in vergelijking met het Brits-Caraibisch. gebied (respectievelijk 3,5 en 1,5 jaar) langer stand hebben gehouden (zie ook Lamur 1983:142). Of uit tevens als teken van verzet was bedoeld, is mogelijk, maar niet aantoonbaar. De reproduktieperiode in Suriname bedroeg gemiddeld 11,5 jaas tegen 14,0 in de Britse Caraiben.

De lage fertiliteil zou overigens ook nog k:unnen zijn beinvioed door de sekseratio, die in Suriname onevenwichtiger was dan elders. Ifier speelt echter opnicuw het gegever een rol, cat in deze cijfers alleen de Surinaamse exportplantageslaver zijn verwerkt. De sckseratio van alle Surinaamse slaven in 18.36 is echter eveneens bekend en bedroeg :0640, zodat de situatie in. Feite evenwichtiger was dan in Guiana of op Barbados. Hierdoor ijkt de negatieve invloed van de ongelijke sekseratio op de fertiliteit minimaal te zijn geweest. Wel is opvallena dat op Jamaica en barbados sprake was van een vrouwenoverschot, terwi;! Suriname, Guiana en Irinidad een tevee: aan mannen kenden. Niet toevallig waren de drie laasslgenoende de landen waar begin regentiende ceriw de meeste slaven werden geimporteerd (Drescher :977:9/4), met daaronder waarschijnlijk eern grote meerderheid aan manner.

Wat betreft de verschilien in jevolkingsannwas tussen de sectoren van de plantage-economie vormbe Suriname geen ditzondering. Overal in he: Caraibisch gebied waar sprake was van verschillende soorten plantages b.eken mortaliteit en sterfte-overschot het hoogst te zijn in. de slike:sector, wat lager in de koffjesector en het laagst in de katoensector (Higmar. 1984:328). De belangrijkste verkiaring voor de demografische verschilen tussen de sectoren moet volgens Ifigman (198:332-6), als in Suriname, worden gezocht in de gewasaflarkelijke zwaar:e van de arbeid.

Het blijkt dat de bevolkingsanwas op Surinaarse plantages in het algemeen gunstiger verliep dan in Cujana. Dat was vooral te danken aarhet flink hogere geboortenniveau, voorai op koffie- on suikerpiantages. Trgelijk was ech:er ooi het sterfteciffer in die beide sectoren in Suriname hoger dar. in Guiana. Dit zou er op kunren duiden cat de arbeidsomstandigheden ir. Suriname (iets) zwârder waren dan in Guiana. Opnieuw vormt de Surinaamse katoensector een u:tzondering. Daar lagen zowe: stcrfie- als geboortenciffers een flink stuk lager dan in Guiana. Wiellicht waren de arbeidsomstandigheden in de Guiamese katoen zwaarder, zeker is in ieder gevai dat ir de Striraamse katoen de sekseratio van de vruchtbare bevolking zodanig uit balans was (Tabel 53), dat het gebourtencijfer hieronder sterk had te lijden. 
Tabel 56. Bevolkingsaanwas per sector, Suriname en Guiana* ca. 1835 (jaarlijks gemidulelde per duizend slaven)

\begin{tabular}{lccc}
\hline land en sector & geboorte & ster/te & groei \\
\hline su i k e r & & & \\
Guiana 1829-1832 & 20,2 & 40,4 & $-20,2$ \\
Suriname 1830-1839 & 25,9 & 42,5 & $-16,6$ \\
k of f i e & & & \\
Guiana 1829-1832 & 17,3 & 32,0 & $-14,7$ \\
Suriname 1830-1839 & 25,3 & 36,8 & $-11,5$ \\
ka t o en & & & \\
Guiana 1829-1832 & 26,2 & 25,1 & $+1,1$ \\
Suriname 1830-1839 & 20,8 & 20,8 & 0,0 \\
alle sectoren (gewogen gemiddeIde) & & \\
Guiana 1829-1832 & 20,8 & 39,0 & $-18,2$ \\
Suriname 1830-1839 & 24,8 & 36,6 & $-11,7$ \\
\hline
\end{tabular}

* Demarara en Essequi:io

Bronnen: Itigman 1984:326 en 699; Tajellen 47, 48, 52.

Samenvattend kan worden gesteid dat Suriname weliswaar op sommige punten afweek van het gangbare demografische patroon in het Caraihisch gebied, maar zeker niet in zodanige mate dat dit de stelling zou rechtvaardigen dat Surimaamse siaven het veel slecinter hadden dan elders. Daarnazst bljjkt dat rond 1835 het creoliser:ngsproces in. Suriname zeer waarschijnjijk minder vergevorderd was dan in het Brits-Caraibisch gebied.

\section{Creolisering en samenstelling wan het hutshouken}

In verband met de relatiei geringe fertiliteit in he: Caraïbisch gebied is vaak gewezen op het grote aandeel van in Afrika gejoren slaver (in tegerstelling tot de U.S.A.), waardoor Atrikaanse tradities, zoals langdurige lactatie, veel langer stardhielden. Over Jamaica merkte Craton (1971:15-6) bijvoorbeeld op dat ra de afschaffirg van de slavenhandel de Afrikaznse slaven door hun toenemende ouderdom relatief onvruchtbaar waren. Ook daarvoor waren zij dat overigens al en was de sterfte onder hen eveneens hoger dar. bij creoolse, op Jamaica geboren, siaven. Crator. stelt dan ook dat hoe groter het aandeel van creoolse slaven in de bevolking, des te groter de kans op een natuurlijke bevoikirystoename was.

Snelle creolisering zou dus een gunstig effect zebber op de slavenreproduktie. Of Surirame ook aan dit beeld bean:woordt blijft voorlopig de vraag, aangezien gedetailleerd materinal hie:over ontbreekt. De schaarse gegevens die desondanks voorhanden zijn lijken deze stelling erhter niet te onderschrijven. Zo kar de levensloop van 94, in de periode 1790-1808 
aargekochte, slaven van vier plantages worden gevolgd. ${ }^{47}$ De sterfte onder hen blijkt nogal mee te vallen, want gemiddeld zijn deze Afrikaanse slaven. na aankoop rog 21,6 jaar in leven gebleven. Er van uitgaande dat zij een gemiddelde ('ideale') aankoopleeftijd van 15 jaar haoden, dan waren zij bij overlijden ongeveer 36 jaar oud. Dit komt overeen met de sterfteleeftijd van alle slaven in die periode (zie Tabel 49).

Daarnaast laat Clifford Kocqshooven, de enige plantage die informatie geeft over de fertiliteit van zowel Afrikaanse als creoolse vrouwen, zien dat in 1824 de elf Afrikanse moeders gemicldeld 2,8 kinderen hadden en de tien creoolse moeders $2,9.68$ Geen significant verschil derhalve. Verregaande conclusies kunnen hier echter evenmin aan worden verbonden.

Tussen het derde en het laatste kwart van de achttiende eeuw daalde in Suriname het sterfte-overschot onder alle siaven met ongeveer de helft (Tabel 47). In diezelfde periode daalce ook het aandee] van Afrikanen in ce plantagebevolking van gemidcield 7I naar $52 \%,{ }^{49}$ Het sterfte-overschot nam dus veel sneller aś dan het aandeel Afrikanen en dit zal. waarsch:juli; $k$ meer te maken hebber gehad met het feit dat de zware aaniegfase van de plantages voorb:j was dan met creolisering. Dat ijk: te worden bevestigd door ce omgekeerde ontwikkeling gedurende hef eerste kwart var de negentiende eeuw, toen weer enkele ilenduizenden Afrikanen in Surirame werden ingevoerd. Find jaren 1820 moet daardoor fiet Afrikanse aandeei in de bevolkirg weer een stik groter zijn geweest dan rond 1800 . De gunstiger sterfte- en geboortencijfers var de jaren 1830 (Tabellen 48 en 52) geven echter geen aar.leiding te veronderstellen dat dit een negatief effect heeft gehad.

Een laatste factor tenslotte, cie vaak door tijdgenoten werd aangehaald a's bepa.end voor een lage fertiliteit, zou de geringe duurzaamieid zijn geweest van de man-vrouw-relaties, Ook de medicus F.A. Kuhr. (1828:25) had daarover een uifgesproken mening. Ilij steit dal de slaven in Suriname, doo: hun beperkte verstandelijke vermogens, geen idee hadden van een monogame relatie, al waren er wel manner en vrouver die 'zeer kuisch en huisselijx me: elkande: leven. De meesten volgden echter, volgens hem, een zeer promiscue leefwijze, 'die de voortteling zecr hinderlijk :s'.

Vergeleken met veei tijdgenoten is Kuhn nog tamelijk genuanceerd in zijn stellingname, want hij erkent dat niet alle slaven zo'n 'vrije en onzedelijke leefwijze' betrachtten. Cijfers daarover geeft hij ech.ter njet en de moralistische toonzetting doet vermoeden dat hetgeen hij suggereert geen objectieve informatie is. Dat is veel meer het geval met het rapport van timmerbaas E.H. Röman (:828), die jarenlang als blanke verschoppelirg

47 Plantages Janslust en Blakkenbosth, Somerszorg en Duuringen, Driesveld en Vossenburg.

48 KIl: Coliectie-Van breughel.

49 Steckproef in ARA: SONÁ in de periode :750-1769, $\mathrm{n} \cdot 3.347$; en 1780)-1809, $\mathrm{n}=2.208$. 
tussen de slaven had geleefd. Bij hem geen gemoraliseer en wel een kwantificering over de samenstelling var de huishoudens. Hij begint met te stellen dat riet alle slaven op een plantage in een hut woonden en, naar ik veronderstel, ook geen relatie met een ander onderhielden, want

'deze negers die dan geen yerblijf hebben, ten minste hier toe geene vaste plaats, slingeren zich overal in de opene fabrieken, in nat en koude, zonder deksel [deken], slapen naast het vuur, op zijn best op een stuk plank [...] Onder de slaven zijn [er] die aan elkanderen leven als man en vrouw; als dit plats vind dan is zulk een paar nog wel gelukkig in vergelijking van andeten, want dan bereid de vrouw de spijs terwijl de man de bezorging van hout, visch of anderzints op zich necmt; maar dit vind bij allen geen plaats; [...] op cen plantage die honderd koppen slaven heeft, kan men rekenen dat onder dit getal op zijn best Tien à twaalf familles van dien aata zijn; dat is te zeggen Tien a twals paren die op deze wijze te zamen leven; een derde van de magl zijn kinderen, grote jongens en meisjes, en de rest oude, gebrekkige, en van die soort van ongelukkigen die alleen op zich z.e.fs verlaten zijn.'50

Bij een steekproef onder 46 plantages in de jaren 1820 bleek inderdaad ongeveer een-derde van de slavenbevolking fot de kinderen te worden gerekend. 51 De ouden er gebrekkigen makkten ongeveer een-zesde deel uit, of ruim een kwart van de volwassenen. Waneer dius ook Römans schatting van het aantal samenwonende volwassenen correct is, dan zou dat betekenen dat ongeveer twee-vijfde van de 'survbare' volwassenen geen vaste partner had. Dat is inderdaad een vrij aanzienlijk aantal en zou de fertiliteit in niet geringe mate nebben beinvloed.

De enig echt kwantificeeroare plantage in dit opzicht is opnieuw Clifford Kocqshooven. Toen de, in Nederland wonende, eigenaar deze plantage in 1824 bezocht, heeft hij van alles wat zijn onderneming betrof uitgebreid aantekening gemaakt en daaronder was ook een lijst wie met wie in welke woning samenleefde. Vooropgesteld kan worden das op deze plantage iedereen in een woning leefde en dus niemand zijn heil in de fabriek hoefde te zoeken. In totaai woonden op deze koffie-onderneming in 42 worirgen 139 slaven, van wie er 8716 jaar of ouder waren. Van de 42 huishoudens bestonden er 14 uit man en vroww met kinderen en nog eens 7 zonder kirderen. Dat is dus precies de helft var alle huishoudens. Daarnaast waren er 16 eenouder-gezinnen (bijna twee-vijfde van de huishoudens), waarvan tien bestonden wit eer vrouw met kinderen en zes uit een man met kinderen. Dan was er nog een liwishouden warin een oude man leefde met een jongere man, die waarsclijnlijk niet zijn zoon was, en een huishouden van een man met twee vrouwen. Tenslotte waren er dan nog twee vrouwen en een man die alleen woonden. 
Het is riet eervoukig om op basis van zo'n momentopname jets te concluderen over de seiksuele mobiliteit. Toch lijkt het feit dat de helft van de huishoudens bestond uit wat wij een kerngezin kunnen noemen (man en vrouw, eventuee: met kinderen) er op te duiden dat ongeveer de helft van de volwassenen een tamelijk stabiel leven leidde. ${ }^{52}$ Van de kinderloze paren was er een lat nog aan het begin stond var. een gezinsleven (respectievelijk 17 en 23 jaar oud) en drie paren die daarvour al te oud waren (gemiddelde leeftijd 48 jar). Van de resterende drie paren was de man gemiddeld 34 en de vrolw 29 jaar.

De andere helft van de huishoudens bestond uit eenouder-gezinner. en alleenstaarden. Deze groep zor eerder in aanmerking xomen voor he: predikaat van een instabiel reiatieleven. Wanneer wij echter hur leeftijden in ogenschouw nernen, dan lijkt het waarscinijnlijker dat het merendeeis weduwen en weduwnaars waren. Slechts twee alleenstaande ouders me: kinderen waren beneden de dertig jaax (respectievelijk 23 en 29); de gemiddelde leeftijd var, de overiger, was 43 jaar. De op zicnzelf levende man en twee vrouwen waren respectieveli;k 38,50 en 38 jaar, dus al tamelijk oud voor die tid en waarsciijnijik niel meer (zo) seksueel actief.

Let lijkt er dis op a at er eer reer grote mate aan seksuele stabiliteit heerste. Dat beeld kan echter worden bijgested. In de eerste platis was er nog de man $(27$;ar) die met twee vrouwen iecfde (een Afrikanse van 38 en een Creoo:se van $31 ;$;ar); al valt natuurlijk nooit m.et zekerheid te zeggen of hij ook met beiden een relatie orderhield. Verder is op basis van de leeftijden vast te stellen dat bij de gezinnen met kinderen in minsters drie gevallen de mar. rooit de vader van al de kincieren kor zijn geweest. En tensiotte is er nog een groep riet aan bod gekomen: cie menser, boven ce vijftien ;aar die nog niet zelfstandig woonder. Leze groe? bestond u: 16 mannen (gemiddelde leexti; 20 jair) en 5 vrouwen (gemiddelde leeftid 22 jaar). Een var deze vxouwen had een kind. Warneer wij hie: de twee eerder genoemde alleensiande moeders van 23 m 29 jaar bij betrekken, dan ligt het voor de hand om te veroncerstellen dat in ieder gevai deze drie vrotwen (wisselende?) relaties orderhiclden met al gebonden of nog thuis wonende marnen, eventueel var buiter de planiage. De rest var. de groep niet-gebonden manren en vrouwen kwam dus of seksueel (nog) niet aan zijn of haar gerief, of moest het hebben van wisse'ende, incidentele con-

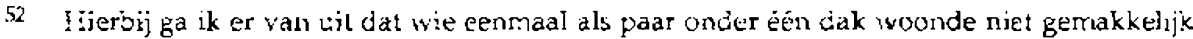
wisselende contacten zal hehion onderhouden, gezien de grows soriale controle in deze kleine gemeenschappen. Dit hoe!t natuurlijk niet te bettkeren dat deze relaties ook ievenslang stand hiclden. Meerdere malen wordt in de archieven melding gematakt van gewclddaden gepiecgu doser mannen die het niet kowden veristopalen dat hur yro:dw hen verlaten had (bijve Surinaams Museum: Coliectie-Brantsen, verslapboekje i 330 ; ARA: RvP, 982). Dit betekent echter tevens dat he! niet a's volkomen normaa: werd geaccepteerd om van de ene partner naar de volgende over te stappen.
} 


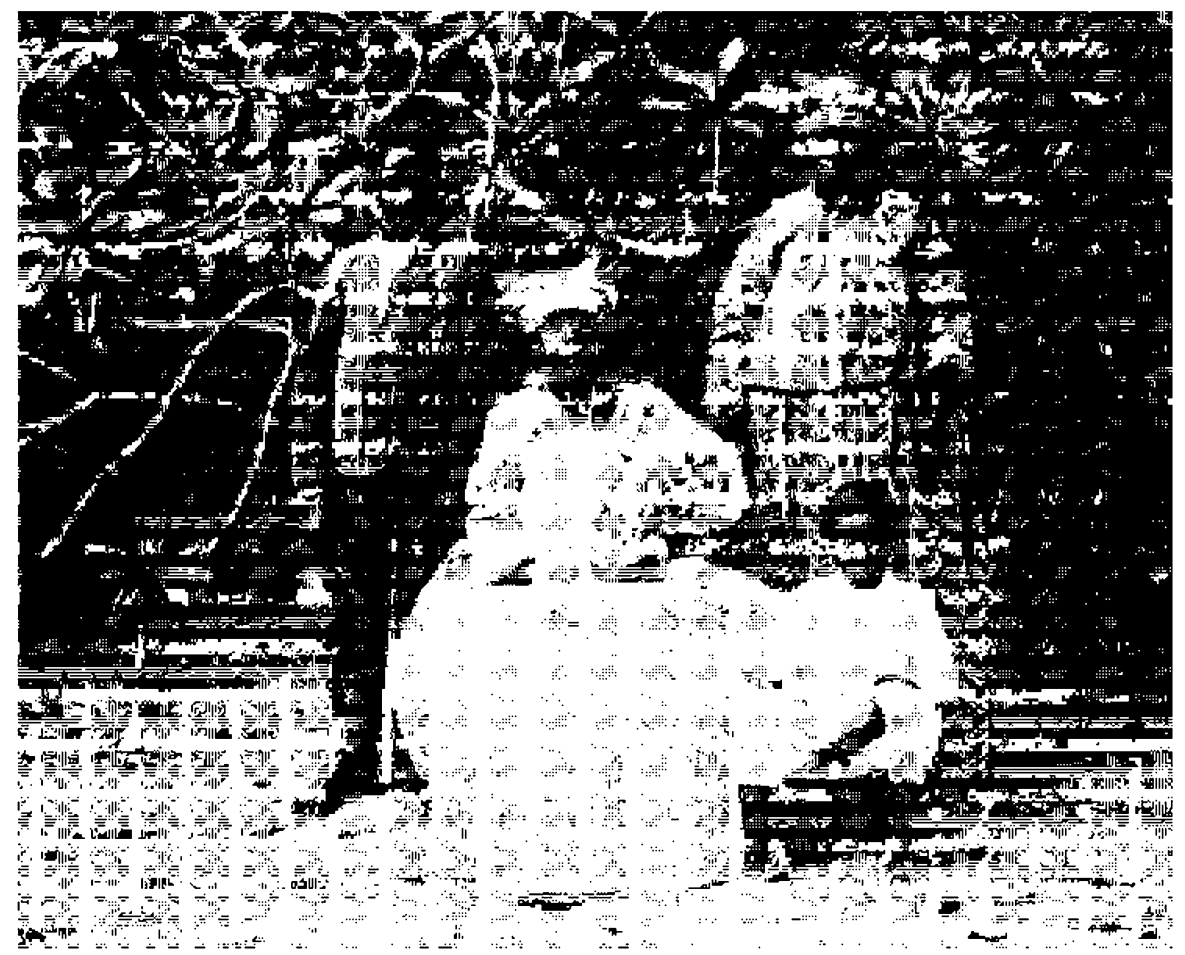

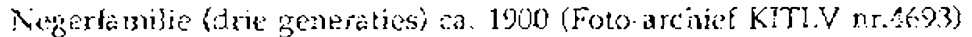


tacten, of moest zijn of haar heil op een andere plantage zoeken (wat overigens ir. die tijd aiet ongebruikelijk was).

Het beeld dat zo, in ieder geval van deze plantage, ontstaat is er een var. overheersende stabiliteit, waarin seksuele mobiliteit echter zeker niet ontbrak. De veronderstelling van vee tijdgenoten dat de slaven er maar eer. beetje op los leefden, lijkt overtrokken. In de recente literatuus over de rest van hef Carä̈bisch getied wordt die vermeende dominante promiscuiteit eveneens steeds meer afgewezen en de relatief grote anwezigheid van de 'nuclear family' benadrukt (bijvoorbeeld Morrissey 1989:81-i 00).

Hoe representaief de hier onderzochte plantage was, valt niet te zeggen. Ook andere auteurs op dit gebied (Lamir 1985; Oostindie 1989) bieden wat dat betreft weinig houvast. 53 Het erige dat wel vast staat is dat het reproduktieniveâu op Clifford Kocgshooven zeer dicht bij het landelijk gemiddelde lag, namelijk 2,8 kinderen ouder dan twee jaar per moeder (landelijk: 2,6 ) en een geboortencijer in ce jaren 1820 van 29,0 promille (landelijk 30,2).

Ook het argumerit van buitensporige promiscuilteit als verklaring voor de geringe vruchtbarheid lijkt daarmee nies sterk. I fiermee workt nog eens benadrikt dat de verklaring daarvor eerder gezocht moel worder in het veranderende lecfmiliew var de slaven, de biolngisch-medische verbeteringen en autonome beslissirgen van vrouwen.

Samenvattend blijkt dat de demografische ontwikkeling van de Surinaamse plantageslaven doorslaggevend werd beinvioed door maatregelen ter voorkoming var epidemieër. en invoe:ing van verbeterde - en voor de planters strengere - slavenreglemen:en. Deze verarderingen leidden tot een duidelijke daling van het sterftecijer aan het eind van de slavernij. Bovendien

53 Voor de plar.age Roosenisur concludeert Oostindie (1939:164): 'Verregaande conciusies kunnen ui: het voorgaande moej':jk ivorder getrokken. De afwezigheid var. echtgenoten en vaders in deze [Emancipatie] registers betekent immers rieb noodzakelijk dat in het familieleven de man inderciaá slechts eer. passant was. Hct is bovendien nict uitgesloten cat de 'vrijgezelien' van Zooscrburg op antere plantages 'zuzvelijks' relaties onderhielden, die tit dit Fmancipatieregister rict kunnen blijken. Anderzijds geven deeze bronnen toch onk geen aanleiding de gangbare not:e te verwerpen dat matrifccaliteit en de afwezigheid van het kerngezin karaktoristick waren voor de Surindarse plantageslavernij.'

De conclusirs van l.amur (1985:39 401) over Vossenbirg, zijn: 'Duidelijk 'blijk: dat er virschi. lende man/vrouw relaties voorkwamen op Vossenburg tussen :\$47 en 1878. Polygamie en monogamie, twecouder tr. eetn-otder gezinnen. Over promiscuiteit werden echter geer. gevallen vermeld door de 2 sukelingen, wat betekent dat het worschijnged niet vaak voorkwam, 20 het 2ich al voordeed.

Wat dus rest is cen beeld van verschillende naast clkat bestaande relatievormen met een waarschijnlijk tamelijk hoge matrs an stahiliteit, vermengd met een seksuele moraai die waarschijnlijk wel wat losser was car. in Europa, maar vas de bijna dierlijke 'vrije en onzedelijke lcefwijze waarover in de toenmalige literatuu: zo vadk werd gesproken blijft weinig over. 
stegen geboortencijfer en fertiliteit het snelst in de suikersector waar de financiele ruimte het grootst en de economische vooruitzichten het beste waren. Het hoogste geboortencijfer (in de ;arer. 1850), de hoogste fertiliteit, de langste levensverwachting - van slaven ouder dan 10 jaar - en het laagste sterftecijfer werden bereikt in de katoensector waar ce arbeidsomstandigheden en geografische 'igging het gunstigst waren. In het algemeen kan worden gesteld dat de stijging van de fertiliteit waarschijnlijk in belangrijke mate werd bepaald door de autonome keuzen van de vrouwen zelf. Of en hoe de levensomstandigheden inderdaad veranderden zal hierna aan de orde komen. 


\section{Veranderingen in de arbeids- en levensomstandigheden van de slaven}

In het vorige hoofdstuk werd gesuggereerd dat de verbeteringen in het demografisch patroon samenhingen met veranderingen in de levensomstandigheden van de slaven. Siwpersad heest in dit verband gewezen op de lotsverbeteringspolitiek aie de overlieid trachtte deor te voeren sinds de rapportage van Commissaris-Gemeraal Van der. Busch over de toestand van de kolonie in i827. Deze politick is volgens Siwpersac (1979:125-263) grotendeels mislukt. Vanlit de optiek van de overneid, warop Siwpersad zich baseert, is deze conclusie terecht. Vanuit de optiek van de slaven, of liever gezegd de plantageprak:ijk, was caarentegen iedere verbetering, hoe minuscuul ook, er een. Daarom zal in dit hoofdstuk worden onderzocht in hoeverre er sprake was van ve:betering in kwantificeerbare materiële zaken als arbeid, voeding, kleding, behuizing en medische zorg.

\section{Arbeia}

Op de vraag of de arbeic van lie slaven in de loop der tijd zwaarder of lichter is geworden, is geen afcioend antwoord te geven. Het zicht op deze kwestie word vertroebeld door zoveel verschillende factoren, waarover geer. materiaal voorhanden is daf hier za: moeten worden volstaan met xiet meer dan enkele indicaties.

De ontwikkelirg van de produktie per (veld)slaaf kan in ieder geval niet als indicatie worden gebruikt, omdat daarin het produktievermogen var. grond en gewassen en de stand van de technologie ir hoge mate medebepalenci zijn geweest. In feite is het gemiddelde met exportgewassen bebouwde areaal dat door één veldslaaf voor zin o: haar rekening moest worden genomen de enige representatieve en $k$ wantificeerbare indicator in dit opzicht:

Uit F:guur 11 blijkt duidelijk dat er geer. sprake was van een ondubbel-

1 Hier is bewust geknzen voor de arbeidslast per veld-slaaf, omdat het aandeel der nietproduxtieve slaven in de loop der tijd steeg, waardoor een berckening gebascerd op alle slaven exn vertekening zou upleverem. De produktie per veldslaaf pe: sector werd reeds besproken in Hoofdstuk V. 
Figuur 11.

Gemiddeld exportareaal per veldslaaf $1770-1854$

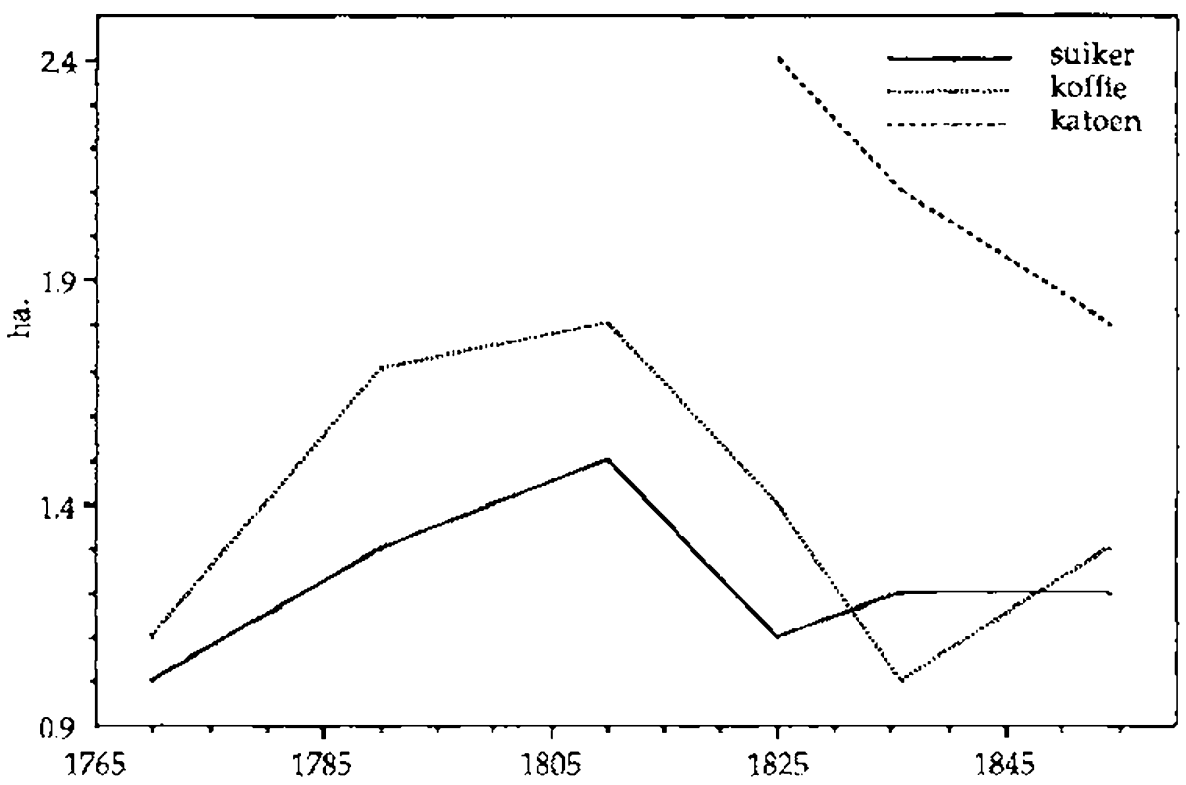

zinnig ineaire ontwikkeling. Het arbeidstekort aan het eind van de achttiende en begin negertiende exuw leidde er toe dat in die periode de arbeidsdruk het hoogst was. Nieuwe slavenimporten in de daaropvo:gende periode zorgden voor een verlichting van de gemiddelde arbeidstaak. De expansic van ved suikerplantages zorgde daarna weer voor een enigszins verhoogde arbeidsdruk in deze sector. Toch was de toevined van slaven afkomstig van verlaten plantages groot genoeg om deze druk riet meer tot het niveau van rond 1800 te laten stijgen. In de katoen- en koffiesector daalde de arbeidslas: na de jaren 1820, omdat daar van expansie geen sprake mee: was. Alieer: in de koffiesector nam aan het eind van de slavernij de druk op de veldslaven weer toe, omdat het koffie-areaal mirder in omvang was afgenomen dan het antal veldslaven. ${ }^{2}$

Overigens was de grootte var: het areaai per veldslaaf omgekeerd evenredig aan de arbeidszwaarte in de betreffende scctor. Zo was het werk

2 Wanneer er niet meer genoeg handen waren om cen suiker- of katoenakker te besverken moesten deze gronden, vanwege de kortere levensduur van deze gewassen, vrij snel worden opgegeven. Koffiebomen bleven in dergelijke omstandigheden veel langer bestaan, zodat er nog marginal van werd geoogst. 
aan een suikeraiker nu eenmaal vee: arbeidsintensiever dan aan een katoenakker (jijvoorbeeld het verschil in onderhoud van waterstelsels), zodat een suikerveldslaaf een minder groot oppervlak voor zijn rekening kon nemen dan zijn collega in de katoen.

In het algemeen kan worden gesteld dat gedurende de laatste halve eeuw van de slavernij de arbeidsbelasting per veidslaaf erigszins lichter was geworden in vergelijking met de halve eeuw daarvoor. Bovendien werd in de negentiende eeuw meer gebruik gemaakt van huurslaven in piekperiodes.

Ook in andere opzichten begon men in de negentiende eeuw de werkende slaven iets meer te ontzien. Op sommige plantages wert de lengte van de arbeidsdag ingekort en verisween de nachtarbeid, of moest deze worden gecompenseerd met vrije dagen (zie volgende hoofdstuk). Deze maatregel werd overigens pas algemeen gedirende het laatste decennium. van de slavernij. Daarnaast nam de zorg voor zwangere vrouwen toe. Gedurende de achttencle eeuw werd met hin positie in het geheel geer. rexening gehouden en moesten zij gewoor. doorwerken. Volgens Ieenstra (1835, JI:10i) was het in zij: tijd echter gewoonte geworden om zwangere. vrouwen van de zesde maand af een gehalvee:de arbeidstak op te leggen, hen na de geboote en tot twee maanden, en soms zeifs drie tot vier maander, vrijaf te geven er, tot het kind één jaar was geworden, opnieuw niet meer dan eer. halve taak te laten verichten. Het slavenreglement var. 1851 ging zelfs nog verder, door zwangere vrouven van de vijfde maard á een lichte taak te geven, van de zevende maand van de 2 wangerschas af tot drie maanden na de bevalling heiemaai geen arbeid, daarra drie maanden licht werk bij huis en dan nog eens zes maanden een gehalveerde taak op het veld (Gouvernementsblad 30-8-1851). Ook al zal niet iedere planter zich aan deze regels heboer. gehouden, het leidde in het algunieen toch tot aanmerkelijke verbetering voor de vruiwer. Dit zal voor cen groot des? zijn ingegeven door de zorg om hef arbeidstekort en her voortdurend dalende hevolkingscifer, maar toch mogen ook humanitaire motieven nie: helemaai worden nitgevlakt.

Hetzeifde geldt voor kirderarbeid. In de acnttiende-eeuwse inventarissen stonden slaven to: twaalf jaar als kind te boek; na die leeftijd werden $z$; ; to: de volwassenen gerekend. Waarschijn]ijk had dit echter meer te maken me: het feit dat vanaf twaalf jaar voor hen het volle pond aan belastingen moest worden betaald, dan met het opleggen van een voiwassen arbeidstaak. Blom (1787:374) schrijft nameijk dal in zijn 1ijd siaven pas van ongeveer nur. achisienke jaar af geschikt werdern bevonden voor veleiwerk en dat zij var: Iun tiende of twaalide' jair af 'toi lighter werk' werden gebruikt. Dat kinkt alleszins redel:jk, maar de vraag is of dat ook cis praktijk was. Aangezien in de rapporten die de plantagedirectetr bijhield werd anngetekend wanneer 
jongens en meisjes 'onder de mans en wijven gebracht' en daarmee volwassen werden verklaard, is dit inderdaad na te gaan. De schaarse achttiende-eeuwse gegevens wijzen dan op een leeftijdsgrens van gemiddeld 15 jaar. ${ }^{3}$ Over de negentiende eeuw is meer informatie beschikbaar.

Uit een steekproef van zes suiker-en koffieplantages blijkt dat in de periode 1817-1839 in de praktijk meisjes in het algemeen al op zestienjarige leeftijd als volwassen werden beschouwd terwijl jongens al ruim 18 waren voor ze onder de volwassenen werden getangschikt. Op suikerplantages kregen (vanwege het arbeidstekort?) kinderen eerder een volwassen arbeidstaak opgelegd dan op koffieplantages: meisjes waren 14,2 jaar oud en jongens 16,6 jaas op de suikerplantages tegen 18,7 en 19,7 op koffieplantages. Bovendien is het essentieel dat de leeftijdsgrens in de loop van de negentiende eeuw in het voordeel van de slaven blijkt te zijn verschoven. Gemiddeld was de leeftijd van een volwassen verklaarde man en vrouw nu ruim 21 jaar. Op suikerplantages lagen de gemiddelde leeftijden in de periode 1840-1855 op 18,8 jaar voor vrouwen en 21 jaar voor manien. Voor de koffiesector waren de leeftijden 22,9 en 21,3 jaar. Dit is opnieuw een texen dat de arbeid voor de slaven enigszins werd verlicht.

Toch dienen aan deze verbeteringen geen al te optimistische conclusies te worden verbonden. Verlichting van de arbeidstaak roor sammige groepen slaven kon verzwaring betekenen voor de rest. Ook kon bijvoorbeeld de uitputting van een plantage resulteren in de verschuiving van het bebouwd areaal naar achter op de plantage, wat de arbeid $z$ waarder maakte.

\section{Voeding}

I Iet is niet eenvoudig een duidelijk, kwantificeerbaar beeld te krijgen van de voedselvoorziening der slaven, laat staan van veranderingen daarin. Wat de voeding van de slaven de planter kostte of de kapitalswarde van de kostgronden, is wel in de brornen vermeld. Dat geldt echter niet voor visvangst, jacht, of kostgrondjes die onder verantwoordelijkheid van de slaven zelf werden onderhouden.

De voedselvoorziening van de slaven heeft de overheid voortdurend beziggehouden. De reden daarvan wordt spoedig audidelijk uit de lange serie plakkaten, notificaties en reglementen die in de loop der tijd zijn afgekondigd om de planters te dwingen voldoende kost voor hun slaven te

3 GAR: Collectie-Hudig, 329,454 en 457. In 1786 schreef de administratcur van Somerszorg dat 'men ten minsten 15 jaaren moel wagten aleer men van de Aangeboorne in het veld eenig dienst heeft' (GAR: Collectic-Hudig, 317).

4 Over katoenplantages on:brcekt de benodigde informatie. Voor deze steekproef zijn de archieven van Somerszorg, Jarlust en Blokkenbosch, Driesveld, Vrouwenvlijt, Vossenbung en Grool Marscille gebruikt. 
verbouwen (zie Schiltkamp en De Smidt 1973). Dat het daaraan dus vaak heeft ontbroken, staat buiten kijf. Deze bezorgdheid van de koloxiale overheid werd dan ook in belangrijke mate ingegeven door de angst voor hongeroproeren als gevolg van verwaarlozing van slaven.

Op iedere plantage dierde daarom een bepaald gedeelte yan het areaal mel voedselgewasser: te worden beplant, de zogenaamde kostgrunden. Het overgrote dee' hiervan werd gebruik: voor de verbouw van bananen, welke deels rauw en deels gekooki of gebakken werden geconsumeerd en volgens alle auteurs het hoofduestandidel van hef voedsclpakket van de slaven vormde. Daarnaast werden op de meeste plantages ook tajers (Araceae

Tabel 57. Akkers kost per slaat 1760-1850

\begin{tabular}{|c|c|c|c|c|c|c|c|c|}
\hline & & & & & & & & \\
\hline sector & 0.1760 & M & ce. 1795 & $\mathbf{n}$ & ca.1830 & $\pi$ & ca.1850 & $n$ \\
\hline suiker & 0,26 & 37 & 0,39 & 38 & 0,37 & 27 & 0,23 & $: 3$ \\
\hline koffie & 0,25 & 48 & 0,33 & 54 & 0,28 & 33 & $?$ & 3 \\
\hline katoen & - & - & 0,22 & 12 & 0,17 & $: 4$ & $?$ & 4 \\
\hline gemigdeld & 0,26 & 8.5 & 0,31 & 104 & 0,27 & 74 & $(0,17)^{*}$ & 20 \\
\hline
\end{tabular}

* in dit gemiddelde ziju ook de cijers ver vier koffje- en drie kaloenpiantages verwerk:; deze antalien warer. te pering om bi; de afzonderlijke sectoren als representatie: te gelden.

Bromen; steekproe: ARA: SONA en SNA, plaritage-archieven.

xanfhosoma) verbouwd - warvan zowel de knol als het blad wordt gegeter en verder cassaves (Marihot esculenta), eveneens en knulgewas.

Wanreer nu de gemiddelde grootte van de arealen kostgrond, zoals die in de plantage-invertar:ssen staan apgegeven, per sector en in de loop der tijd met elkaar worden vergeleken (Tabel 57), dan springen twee ontwikkelingen in het oog. De eerste is dat na een aanvarkeijke uitbreiding van het aantal kostakkers per slaat gedurende de tweede inelit van de achttiende eeuw, cit aantal tijdens de volgende vijftig jaar dramatisch terugliep. Het tweede dat opvalt is dat het voor een slaaf, althans in dit opzicht, beter toeven was op een suikeplantage dan in een van de andere plantagesectoren.

Wat betrelt de koffiesector komen deze cijfers echter niet overeen met de werkelijke voedselvowrziening op de piansages. Hier werden namelijk de merste baranen geplant als schaduwboon voor de koffic; in de achtfiende eeuw gebeurde dat alleen bij de ;onge aanplant, in de regentiende eeuw bij aile koffiebomen. Daarom hoeiden or minder dan bi; suiker het geval was, speciale kostgroncien te worder. aangelegd.

Dit gold niet voor de katoenplantages, terwijl daar toch de m.inste kostgronden per siaaf werden aangetrotfen. De verkiaring hiervoor is dezelfde als voor de irkrimping van het kostareal in de regentiende eeuw op 
koffie- en suikerplantages. Het arbeidstekort in die periode noopte de planters er toe de slaven zoveel mogelijk in te zetten in de prociuktie van exportgewassen, zodat er steeds minder kost op de plantages zelf werd verbouwd. Tegelijk bleek het antal plartages dat zich specifiek op de verbouw van voedselgewassen was gaan toeleggen, tusser. 1824 en 1860 te zijn toegenomen van 13 naar 49.5 Door deze specialssatie is het onmogelijk na te gaan of de voedselvoorziening van de slaven er ook werkelijk op was achteruitgegaan. Wel is voor een aantal jaren het totale areaal bekend waarop in de plantagedistricten voedingsgewassen werden verbouwd. Daaruit blijkt dat er in 18360,28 kostakker per slaaf beschikbaar was, in 1849 0,32 en in $18600,29.6$ In tegenstelling tot hetgeen de gemiddelden in Tabel 57 suggereren, lijkt de kostsituatie in de negentiende eeuw dus min of meer stabiel te zijn gebleven. Het is echter niet bekend in hoeverre de steeds groeiende bevolking van Paramaribo eveneens van deze kostgronden afhankelijk was. Warneer dit in hoge mate het geval was, dar. zou er toch sprake zijn geweest van achterlitgang voor de slaven.

Nog minder is bekend over de kostgrundjes die de slaven in eigen beheer bewerkten. Voigens de literatuus uit die tijd waren cergelijke grondies eer. algemeen verschijnsel op te plantages. Blom (1787:381) schrijft hicrover:

'[m]en geeft aan hex ook een stuk land, hetgeen men dan negergronden noemd; $z y$ verdelen dat onder elkanderen zoo, dat een ieder van hen een zeker gedeelte voor zich heeft, hetgeen zy dan op hun Zondagen, ieder naar welgevallen bevierken, en met veelderhande soorten van peul- en aardvruchten beplanten'.

Hartsinck (1770:915) is wat specifieker over de gewassen die op de slavenkostgrondjes werden verbouwd en roemt als knolgewassen de jams (Dioscoreaceae alata en trifida), bataat (Ipomoea Datatas) en cassave (Manihot esculenta), verder maïs (Zea mays), bananen (Musa soorten) en Spaanse peper (Capsicum frutescens). Hij vergeet echter de populaire tajer die in veel plantagedocumenten wel wordit genoemd evenals de verschillende soorter pesi's (I'apilionaceae). Interessant is bovendien de vermeldiag in de inventaris van plantage Kleinslus: (1792) van 'Loango l'ease', wat er op zou kunren duiden dat slaven (of slavenhalers) zaden dit Afrika cadden meegenomen.

Fen steekproef onder plantages in de periode 1770-186.3, leverde twaale inventarissen op (alle vóór 1830) waarir de omvang van deze negergronden' word: beschreven. ${ }^{8}$ Hieruit blijkt dat iedere slaaf gemiddeld bijna

5 Surinamse Almanak 1824:45-85 en Kolonianl Verslag 1860.

6 ARA: MvK 1813-1849, 1135; Koloniale Verslagen 1849 en 186:.

7 ARA: SONA, 279. Loango was de benaming vwor hel gebied dat zich titstrekte van het huidige Kameroen tot Angola.

8 Plantages Alkmaar (1798), Cannewapibo (1789), Elk 't Zijn (1795), Groot Chatillon (1802), Groot Marseille (1770), Libanon (1795), La Liberlé (1782), Manheim (1797), Mon B3:joux 
0,1 akker (dat is ruim 4 are) tot zijn beschikking had. Of hierin tijdens de laatste decennia van de slavernij verandering is gekomen, is niet bekend. Het is echter waarschijnlijk dat de omvang van deze grondjes toemam naarmate een groeiend aantal plantages in het geheel geen algemene kostgronden meer onderhield. In 1836 behoorde al $15 \%$ van de ondernemingen tot deze categorie. 9 Indien de planter alle kost voor de slaven had moeten aankopen, dan zou dat een enorme aanslag op zijn begroting hebben betekend, zodat het voor de hand ligt dat hij meer grond ter beschikking stelde waarop slaven in hun vrije tijd hun eigen kost konden verbouwen. Duidelijke gegevens over zo'n ontwikkeling ontbreken echter.

De hierbovengenoemde gewassen vormden overigens niet het enige bestanddeel van het voedselpakket der slaven. Volgens het slavenreglement van 1784 diende er eens per jaar ook vis te worden uitgedeeld, wat door Blom (1787:118) wordt gepreciseerd in: 4 pond bakkeljauw (dat is gedroogde en gezouten heek of schelvis) en 18 tot 20 haringen. Hij geeft overigens zelf toe dat sommige planters meer en andere minder vitdeelden aan de slaven. Bij gebrek aan veriere gegevens wordt er hier van uitgegaan dat het door Blom genocmde gem:ddelde correct is. In de loop van de negentiende ceuw is in deze additionele voedselverstrekking opmerkeljjk veel veranderd. Niet alleen word ingezouten vis toen meer dan eens per jaar uitgedeeld, er kwamen andere produkter bij en ook de hoeveelheden gingen omhoog.

Er blijkt dus een zichtbare verbetering te hebben plaatsgevonden in de voedselverstrekking aan de slaven (zie Bijage). De gezamenlijjke hoeveelhejd ingezouten vis steeg met maar liefst $66 \%$, gort en blom gingen het bananen-en cassavemeel aanvullen en rijst $\mathrm{kwam}$ er als belangrijke voeding bij. Opvallend is de grote hoeveelineid zout die werd geconsumeerd. Wanneer de hoeveelheid van Catharina Sophia enigszins overeenkomt met dic van de steckproef, dan zou, nog afgezien van alle zoute vis, per hoofd bijna een pond zout per week zijn gebruikt. Ifierop wordt later nader ingegaan. Daarnaast blijken ook de uitgedecide hoevelheden genotmiddelen als dram (voornamelijk voor de mannen), melasse (voornamelijk voor vrouwen en kinderen) en pijptabak (voor mannen en vrouwen) aanzienlijk te zijn toegenomen.

Ondanks de merkbare verbetering bleef de voedselverstrekking toch nog, onder het niveau van de gouvernementsplantage Catharina Sophia, die op haar beurt niet eens helemaal voldeed aan de door de koloniale overheid gestelde normen (zie Van den Boogaart en Ernmer 1977:212). Vergeleken met de jaarlijkse uiddeling die Blom roeint was cie vour uitgang aanzienlijk.

(1825), Nieuw Hoop (1786), Rooscr.burg (1788) en Wayampibo (1784).

9 ARA: MVK 1813-1849, 1135. 
De vermeerdering en uitbreiding van het voedselpakket waren in belangrijke mate het gevolg van het rapport De voeding van den neger in Suriname (MuIder 1847), gebaseerd op een onderzoek dat op initiatief van de koloniale overheid in 1846 had platsgevoncen onder leiding van de Utrechtse hoogleraar scheikunde G.J. Mulder. Hij vergeleek de voedings waarde, met name eiwitten, van hetgeen een Nederlandse soidaat van overheidswege in die tijd ontving met de gemidcelde voeding van een Surinaamse slaaf. Zijn conclusie was dat de slaaf slechts $46 \%$ van de voedingswarde van een soldatenrantsoen kreeg. Ijij stelde darbij het slavenrantsoen op gemiddeld $1 \mathrm{~kg}$ bananen(meel) per dag en cen pond gedroogde vis per week (Mulder :847:19). Voorzichtigheidshalve voegde hij aan het eind van zijn rapport rog wel toe dat vis en wild in zijn onderzoek niet waren opgenomer. omdat de beschikbaarheid daarvar. sterk afnar:kelijk was van plaatselijke omstandigherien: 'aan de rivieren en aan het strand der zee gelden dus andere regelen' (Mulder 1847:33-4).

Daarmee lijkt Muider zich toch niet al te zeer te hebjen verdiept in het leven van de slaven, want in Suriname warer, alle plantages aar. cen rivicr of langs de zee gesitueerd en achter de meeste ondernemingen bevond zich bos en dus ook wild. Dat de slaven ook in die bossen gingen jagen wordt nergens vermeld, maar we: beschikten vec: plantrges over én of meerdere jagerslaven, die het wild voor de dis van de directeur mosten verzorgen.:0 Het ligt voor de hand dat deze jagers ook de slaven niet vergaten, want $z$ ij deden hin werk geheel zelístandig en bleven vaak meerdere dagen achter eikaar weg. Rivier- en zeevis moeten in ieder geval tot het rormale voedselpakket hebben behoorc, want etielikke malen verwijzen de bronner. naar visvangst door slaven. Zo vertelt Stedman (1988:496) hoe hij op een gegeven moment plantageslaven aar zija solciaten laa: uitleggen hoe bepaalde vishaken en fuken kunnen worden vervaardigd. "

Ook werden bi; de jaarlijkse uitdeling van siavengoederen, in ieder geval in de negentiende eeuw, vrijwel altija vishaken aan de slaven verstrekt. Op Croot Marseille kregen bijvoorbecid in 1824 de 132 slaven - mannen, vrouwen en grotere kirderen - samen 600 vishaken. 12 Dif grote aantal is tevens een indicatie dat ex vaak werd gevisis. Ook in de achttiende eenw werden soms vishaken verstrekt, maar he: lijkt er sterk op dat het eigen

Ic Het is niek onnogelijk dat deze praktijk in de loop der tijd sterk is afgenomen bij gebrex aan wild in de bosser. Hoogbergen (985:63) meldt dat al sijdens de Boni-oorlogen wild overal schaars was geworden en in de neggentiende eeduwse plantage-inventarissen komen irderdaad minder jagersiaven voor.

11 Een ander voorbeeld is te vinden bi: Kappler (1854:158), die verhaalt hoe in Coronie een bekende wegloper werd ontdekt en gevangen genomen door slaven dis bezig warent te vissten. Verder vermeldt Gosiinga (1990:170) dat in 1804 'the governor received the news th:at blacks, fishing along the coast, had been attacked by the English'.

12 Jamess Ford Bell Library: B 1482. 
initiatief van de slaven in de negentiende eeuw veel meer ruimte kreeg. Zo werd op Somerszorg begin jaren 1790 voor de visvangst alleen een sieepnet uit Nederland opgestiurd, terwijl een halve eeiw later iedere slaaf gemiddeld 15 vishaken kreeg uitgereikt. ${ }^{13}$

Ook hebben de slaven ander dierlijk voedsel gegeten, want vrijwel overal waren zij in de gelegenheid er enig pluimvee op na te houden. Blom (1787:383) medt hierover:

'Men staat hen toe dal zy enig pluymvee als henaen en eenden aankweken, hetgeen buyten nadeel der plartagie kan geschieden, dat hen tot verversching strekt, en oox wel verkogt word. Daar zy dan iets andexs, het zy versnapering; of een mooy stuk iywaat, en andere sieraden voor in de plaats nemen. Dit moedigt hen grotelyks aan. Egter zal men hen siet toelaten, varkens te kweken; dat z.y anders zeer gaarne doen, om de grole winsten die daarvar komen. 7.o hast zy daar veriof toe hebben, dan ziet men in weynig tyd meer dan honderd varkens by hun woningen, die zovee. kust a.s tayer en benannes (zynde dit hun gewone voedsel) opeten, dat de slavere dain tens'otte zeif groot gejrek ann kost krygen.'

Met name pluinvee diende dus als anvullend voedsel er. tevens als handelswaar. Of deze eigen pluimveehouderij in de loop der tijd toenam, is niet bekend. Toch is het in dit verband opvallend dat bijvoorbecld op Santa Barbara in geen var de achttiende-eeuwse :nventarisser. het p'uinvee van de slaven de moeite van het vermelden waard werd gevonden, terwijl in de inventaris var. 1858 sprake was van. 'een merigte pluimvee we.ke de slaven toebehoort'. ${ }^{14}$ Wellicht dat ook op dit gebied de slaven in de negentiende eeuw meer ruim!e voor eigen initiatief kregen. De koloniale overheid was ez ir ieder geva: voorstander vall, getuige he: slaverneglement var: 1851. Daarin werd expiciet gesteld dat het 'sedert lang' gebruix was de slaven in hun vrije tijd eigen grondjes te laten bebotwen en pluimvee te laten houder. en dat dit coon de 'gezagvoerders' diende te worden aangemoedigd 15 Kennelijk werd dit een goed middel geacht om de slaven

is GAR: Collectie-Hudig, 688 en 343 .

14 ARA: SONA, 215 en 223; A. A: Sur Adm.y.13n., 130.

15 Gouvernementsjlad 30-8-1851. Dat he: eigen siavenin:tiatief ook inderdaad de aigemene praktijk was geworden, blijkt nog eens uit de observatics van Kappler (1854:53) over een gemidde:de plantage:

'de negerwor:ingen bevinden zich in de onmiddelijike nabijheic van den molen of der fabrieksgebouwen, en makcm, wanneer de pian agie aanzienlijk is, gehele dorpen jil. [...] izondom de huizen, die regelmatige stratan vormen, planten de negers spaanche perper, k.alebasboumer: er.z.; tevens wemelt het or van piuimgecier:e en varkens.'

Een ander sprekend voorbeeid is te vinden in barte'ink \{1914:15), die ir. 1855 een Nederlandse scheepskapisein rondleicide? op plantage 7cerigt:

'Deze veriargde het arbeidersterrein tc zicn. Daar gekomen zag bij voor alle woningen het volk bez: $;$ met het siachten van kippen er eenden en het schoonmaken vari visch enz.

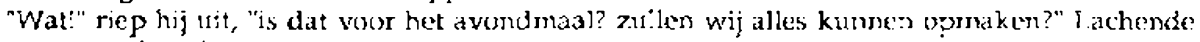
antwoordde ik hem:

"Heer kapitein, hier wordt voor den directeur njet geslacht - vocr hem wordt in zijn eigen kewken geslarhl en toebcreic; wat hier geslacht wordt is voor het gebraik var he! volk zelf." 
tevreder te houden. Evenmin is het uitgesloten dat de koloniale overheid, in het zicht van de Emancipatie, een stimulerirgsbeleid ging voeren ter voorbereiding van de slaven op een leven als 'peasanf'.

Dat een groeiend deel van de voeding inmiddels door de slaven zelf werd verzorgd, lijkt te worden bevestigd door de toename van de verstrekking van zout. Het is zeer onwaarschijnlijk dat dergelijke hoeveelheden door de slaven zijn geconsumeerd. Meer voor de hand ligt de veronderstelling dat een groeiend deel is gebruikt voor het inmaken van vlees, vis en eventueel groente. Ook al zou een deel van deze inmaak niet zija gebruikt voor de eigen consumptie, maar voor de handel, dan nog onderstreept het de toenemende onafhankeijkheid van de slaven op het gebied van de voedselvoorziening. Het tapport van Muider lijkt dus een te somber beeld ie hebien geschetst, a.: is het zeker van invloed geweest op de bepalingen omtrent voedselverstrekking in het nieuwe slavenreglement van 1851 .

De drinkwatervoorziening vormde op veel plantages een groot probleem. De meest bovenstroomsgelegen plantages konden gebruik maken van het rivierwater, maar de meercerheiri van de plantages lag aan de benedenioop van de rivieren en kreken, waar het water brax was. Boverdien waren daar de meeste koffieplantages gesitueerd, die het vuile water waarir. de bonen waren geweekt en gewassen daarin loosden, zodat het geheel stinkend word, en door geen beest, veel minder door een mensct kan gecironken worden' (Blom 1787:350).

Op plantages waar het areaal was doorsneden met zandritser. werd de oplossing gevonden in het slaan van putten in die ritsen. Gedurende de regenperiodes stond daarin voldoende gefiltreerd water, maar tijuens de droge periodes waren zij al snel uitgeput of bevatten nauwelijks drinkbaar water. Noodgedwonger dronken de slaver daar dan toch van, 'waardoor veeltyds zeer kwade koortsen en buyklooper: ontstaan, dic van groote er: nadeelige gevolgen zyn' (Blom 1787:350).

Op de meeste plantages installeerde men daarom een grote bak waarin opgevangen regenwater werd beward. In de achtiende ee:aw kwamen deze reservoirs nog riet overal voor, in de negentience eeuw waren $z i$; algemeen in gebruik. Een gemiddelde regenbak kon zo'n 75.000 :iter wate: bevatten. Ook in dit opzicht blijki er in de loop der tijd voor de slaven een

"Hoe", riep hi; nug verbaasder wit, "eet het volk hier kippenvleesch?"

"Zoo is het."

Ik liet hem den grooten kipperikweek der slaven zien, maaxle hem er opmerkzaam op, dat vele manren afwezig waren. Ze warer niatr het stand om te visschen.

Het samenieven der slaven was uitstekend. Zij deelden ailes met elkaar. Een deel ging, na den. arbeid voor de plantage, visscher., een ander dee! verbouwde extratjes voo: den kost en elk kreeg eer'ijk zijn aandeel van het eer en ander. 
(lichte) verbetering te zijn opgetreder. De opslagcapaciteit van deze bakken bleek namelijk te zijn opgelopen van geniddeld 399 liter per slaaf in de tweede helft van de achttiende eeuw, tot gemiddeld 454 liter in de eerste helft van de regentiende eeuw. ${ }^{15}$ Desondanks traden, in geval van langdurige droogte, vaak grote problemen op. Zo rapporteert de administrateur van Vossenburg in 1846 en 1856 dat de slaven groot gebrek aan drinkwater hadden, en 'dag en rachi zochten zij daarmaar op de verlaten plantagies en elders'. 17 lieruit blijkt overigens, dat in zo'n noodgeval de slaven tamelijk mobiel waren en toxsiemming kregen de plantage te verlaten on drinkbar water to zocken

Hoe onmisbaar rok voor de drinkwatervorzien:ng, toch vormden de regenbakken tegelijk een bedreiging voor de gezondheid van de slaven. Er is namelijk weinig fantasie voor nodig on: de regenbak voor te stellen als een broeinest van allerlei ongedierte, die de verspreiding van besmettelijke ziektes in hoge mate moet hebben bevorderd. Dat men zich daar wel van bewust ivas, bleek uit een rapport over, upnieuw, Vossenburg. Daar had in 1833 in sterke mate dysenterie geheerst - er waren zelfs vier kinderen aan gestorven - wal werd toegeschreven aan de 'gevo'gen van het 5 legte Drinkwaier door de zwate droogte veroorzankt' in J fet gevadr werd dus zeker onderkend, maar ex viel weinig tegen te doen.

\section{Kleding en benodiguhaten}

Voor kieding en andere benodigdheden waren de slaven vrijwel gehee: afhankelijk van hetgeen hen door de planter werd verstrekt. Zo'n uitdeling gebeurde meestal eens per jaar, in combinajie met het zogenaamde Nieuwjaarsspe!, waarbij de slaven enige dagen vrijaf hadden en een darspariij mochten organiserer. Bovendien werken bij zo'n gelegenheid extra rantsoenen dran en melasse uitgedeeld ter verhoging van de 'feestvreugde'. Blom (1787:118) schrijft hicrover:

'Men is gewoor by he: nieuwe jaar een uytdeeling aan de sla aven te doen, beslaande gewoonlyk wyl een hoed, zes ellen wit Osnabrugs linuen welke labtste hen dient voor en slapplaken; de mannen twee sen de vrouwen vier ellen Vries bont [katoen], dienende om te bedekken hetgeer. de eerbatheid verbiedt te zien; de mannen een wambuis van blatiw Vries gemaak:; vervolgens ieder twee pont laback, zes korte pypen, vier ponl gedrongde viscl, bakkeljaduw genoend, arhttien of twintigy haringen en wat zout

ITij voegl er nog aar. toe, diat officiers en ambachtsslaven in het algermeer iets meer en kinderen en bejaarden meestal iets minder ontvirgen.

16 Steckprocf inventarisisen in ARA: SONA en SNA en plantage-archieven.

17 Surinaams Museum: Collectie-Brantsen, verslagbolekjes 1846 en 1856.

is Surinaams Museum: Collectie Brantsen, verslagbock je 18.34 . 
Algemeen werd in de toenmalige literatuur opgemerkt dat de plantageslaven meestal vrij schaars waren gekleed - de kinderen tot een bepaalde leeftijd liepen zelfs geheel raakt rond - en de stadsslaven iets beter. De mannen hadden meestal alleen een kamisa (schaamdoek) om en de vrouwen een rok of panji (lendendoek). Kennelijk kleedden zij zich luchtig en functionee!. Dat de slaven er daarbij vaak 'slordig en haveloos' bijliepern, zoals Lammens (1982:111) opmerkt, mag nauwelijks verwondering wekken, aangezien zij zeker een jaar met de uitgedeelde kledingstof moesten doen. Ferder is het verbazingwekkend te lezen dat de slaven er in slaagden op feestdagen mooi voor de dag te komen, hetgeen juist suggereext dat zij op bepaalde kledingstukken heel zuinig waren. 's

Sinds de tijd van blom moeten de uitdelingen behoorlijk zijn verbeterd, gezien de opsomming die Lammens (:982:112) daarvan rond 1820 gaf (zie Bijlage 11B). In ongeveer vier decennia was de kwantiteit vergroot en het assortiment aanzienijik viigebreid. Iammens voegt er bovendien aan toe, cat de eliteslaven, officiers, ambachts- en hiisslaven, meestal meer en van betere kwaliteit kregen.

Om na te gaan in hoeverre Lammens voorstellirg van zaken strookte met de plantagepraktijk, is in Bijlage $11 \mathrm{~A}$ de gemiddelde uitdeling per hoofd berekend van drie plantages rond 1800 en drie, waarvan één dezelfde, rond 1835. Opnieuw is er sprake van een duidelijke verbetering in de loop van de negentience eeuw. Sommige artikelen, zoals boeseroenen, tondelúoos er. vuurstaal, spiegels en vishaker, die rond 1800 nog niet tot het pakket behoorden, werden rond 1835 wel uitgedeeld. Bovendien dient te worder. bedacht dat rond 1840 het aandeel var kinderen en bejaarden, dic kleinere porties kregen, in de tntale populatie een stik groter was dan rond 1800 . De gemiddelden var. 1835 worden daardoor zelfs nog iets gedrikt in vergelijking met 1800 .

Met de invoering var een nieuw piantagereglement in 1851 zijn de

19 Lammens (\$982:110-1) beschrijił de siavenkleding als volyt: voor zoverre zij geklepd gaan, dekken de marner bii, voorkeur het bovenlijf, en de yrouwen het onderlijf beneden de borsten, en schouwders: wanneer de neger een grofïinne (hier makxa gencemci) kort rokje, een hoed een grove linne lange broek ann heeft, is hij welgekleed, meestal lonpt hij zonder broek. [...] De v:ouwen dragen meesta] zeer ruime lange vrouwe rokker, welke zij boven de borst vasimaken, [..], ork wel cen los jak van veren opon, en op den rug laag uitgesneden, [... J, zoms worden de borsten ir. pen doek gevangen, die agter op den nug is vastgeknoopt, ock knopen $7: j$ een aantal doeken, bover de heuper, om het lijf: - in plaats van de bovengemeide lange rok, slaan zij ruime lappen stot, [...], om het lijf, dic tot op het halve been nederdalen, welke men paanties noemt: - om het hockd hethen zij veelal enn doek gewonden. [...] Algemeen zijr. zij zee: slordig en haveloos op hume klederen, of ce kniën en de billen door den broek hangen, of de vrouw rok in twintig repen gessheurt is ts hun onverschillig, allexn het ogenblik, dat z:j humne uitdeling ontvangen geeft hun genoegen dog is het, dat zij op een danspartij of rogenaamd spei komen, dan komen mooije klederen en opschik voor den dag, en mer. vind, onder de slaven, we! hecle pronkertjes.' 
Litdelingen omvangrijker geworden en is de controle daarop waarschijalijk verscherpt, getuige de hoeveelheden die in 1853 werden verstrekt aan de slaven van de gouvernementsplantage Catharina Sophia (zie Bijaage 11D). Ook al ging het hier om een modelplantage waarvan het voorbeeid niet door iedereen zal zijn gevolgd, toch vormt het een indicatie van de vouruitgang sinds 1800 . Enige voorzichtigheid is hier echter wel op zijn plaats. De aanschaf van al deze slavergoederen was duur en kon het budget van weinig florerencie plantages verre te boven gaan. Nief voor niets merkte Kuhn (1828::2-3) op dat de wettelijk voorgeschreven hoeveelheden alieen werden uitgedeeld 'bij goede financiële omstandigheid' en dat op soinmige plantages de slaven in geen twee of drie jaar iets kregen 'dat naar kleeding gelijkt'. Het wekt dan ook weinig verbazing dat men zich met name op koffiepiantages riet aan de voorgeschreven normen hield en uil geldgebrek de uitdeling slechis eens in de twee jaar liet plaatsvinden. ${ }^{20}$

Dat de meeste plantages de groeiende, voorgeschreven hoevee'heden slavengoederen niet meer konden oporengen blijkt tevens uit een versoepeling van de wetgeving in dit opzicht. In het siavenreglement van 1851 wordt nog gesteld dat de witdelingen jaarijks moeten plaatsvinden, maar al in 1854 wordt dit veranderd in vitdelinger. om de achttien maanden, met ongeveer ge.ijkblijvende hoeveelheden (Gouvernementsbladen 30-8-1851 en 1-9-1854). Kernelijk nolde de wetgever achter de feiten aan. Dat de uildelingen aan de slaven er desondanks sedert ce achitiende eeuw merkbaar op waren vooruitgegaan li;kt echter boven elke twijfel verheven.

\section{Behuizing}

De woningen van de slaven bevorden zich altijd in de buirt van het overige gebouwencomplex, niet ver af van de rivier, vooraan op de plantage. De korte afstand tussen plantagegeboliwen en slavenwoningen was bedoeld ter verhoging van de controle, maar desordarks vormde het slavencomplex meestal een tamelijk zelístardig dorpje. De locatie van zo'n dorp was van groot belang. Volgens Blom (1787:384) moest het in ieder geval cer. droge plaats zijn en Kulin (1828:13) stelt dat goed gehouwde huizen 'op eenen verheven zandigen bodem' de gezondheid van de slaven zeer ten goede komen.

Dat beide auteurs 20 aandringen toch vooral op een droge ondergrond bij voorkeur een zandrits - te bouwen, duidt er op dat dit lang niet altijd het geval was. Aangezien veel slaven op een matje op de grond sliepen, bete-

20 Zo meldde de administrateur van koffieplantage De Nierwe Grond in 183: dat 'de uitde'ingen aan de slaven voortaan slegts, evenals op de meeste andere koffyplantagien, om de fwee jaren behoren te geschieder' (Collectie-Insinger \& Co., brievenboci). 


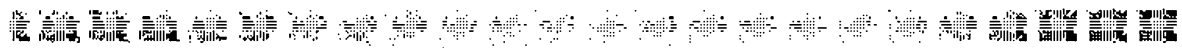

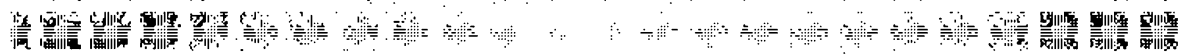

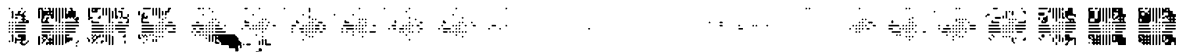

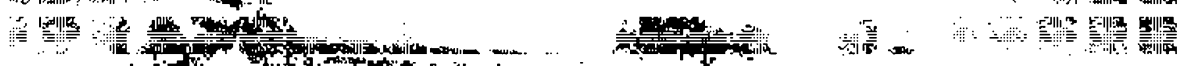

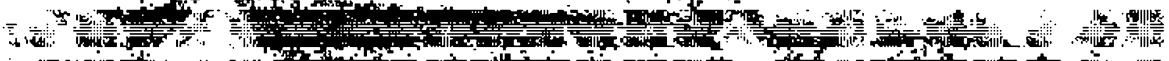
$\because$,

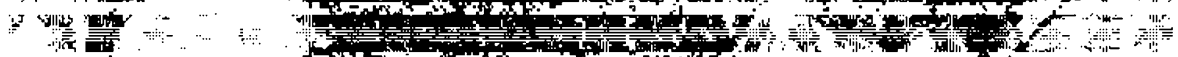

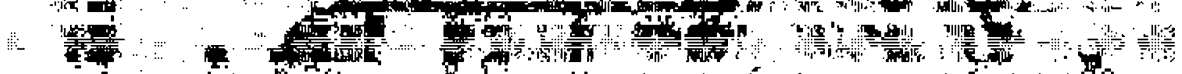

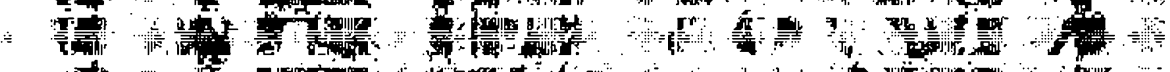
He lo a

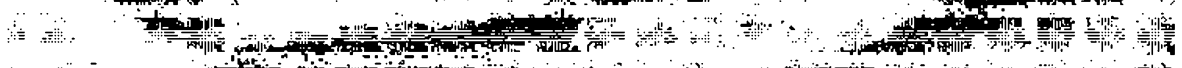

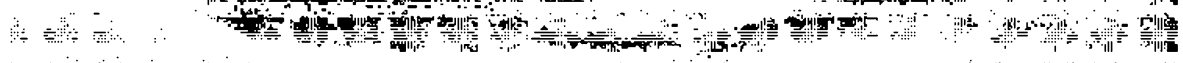

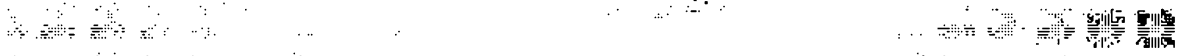

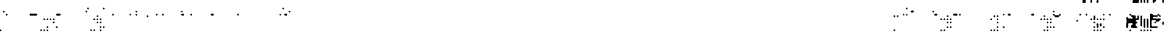

Plantaadje negerhuizen ca. 1850 (Foto-archief KITLV nr.1207; litho Ih. Bray) 
kende een vochtige ondergrond een ernstige bedreiging van de gezondheid. Het valt niet na te gaan of in het algemeen de locatie van de woningen in de loop der fijd is verbeterd. Toch lijkt dit niet onaannemelijk. De koloniale overneid had zich, getuige het ontoreker, van rege:s, nooit iets gelegen laten liggen aan de slavenbehuizing. In het siavenreglement van 1851 worden er echter opeens vier artikelen aan gewijd. Op straffe van een flinke geldboete wordt onder meer bepaald dat het schoorhouben, de waterlozing en het onderhoud van het slavendorp to: de verantwoordelijkheid van de meester behoren. 21

Dat dit geen loze bepaling is gebleven, blijkt uit de werkzaamheden die in dat verband op erburg in 1856 werden verricht (Oostindie 1989:151). Of de navoigirg aigemeen was is niet bekend, want het feit dat er ir dit verband meermalen boetes zi;n uitgedeeld (Van den Boogart en Emmer 1977:209) wijst er op dat pianters zich niet aan de regels hieiden, maar ook dat er toezicht op werd gehouden. In ieder geval was het probleem officieel gesignaleerd, zij het wederom laat.

De woningen zelf zijn in de ioop der tijd sterk veranderd. Halverwege de achtiende ceriw bestond het slavendorp meestai uit een verzarneling losstaande hutter, van 'roakde posten in de: grond, met pallisade omslagen en pien gedekt'.22 Deze hutier werden coor de slaven zelf gebouwd en orderhouden. In de loop var de negentiende eeuw werden dergelijke woningen op de meeste plantages vervangen door zogenaamde blokwoningen. Dit waren lange, houten gebouwen, meestal rustenc op stenen reuten of een stenen voet, met houten vloeren, het dak bedekt met cirgels ${ }^{23}$ (houten dakspanen) en verdeeld in: meercere woningen van een of meer vertrekken. Rond 1760 bestond $40 \%$ van de siavenwoningen ijt blokwoningen; veertig jaar later was dit $54 \%$ en in $: 845$ was dit percentage verder gesteger. to: $81 \%{ }^{24}$

Voor de hygiëne en ce gezondheid van de slaven was dit een positieve ontwikkelings. De rokerige? en vischtige hulten zonder vensters, met een enkele deuropening en een vulipiats an het midden, werden door droge en luchtiger geboluwen vervangen. Of deze verandering onk in sociaa: opzicht door de slaven op prijs werd gesteld is twijfelachtig. De planter J. Roux constateerde in het algemeen grote ontevredenheid met deze

21 Gouverne:nestsb:ad 30-8-185: ' 'Het onde:houd, de waterlozing en het schoonhouden van de plaats der negerwoninger. may nooit aan de elgen zorg en besclikking der slaven overgelaten worden. De meester zal dit werk steeds als hem angaande, hetzi; door de siaven, hetzjj door anderen daartoe geschikt, doen vertichten.'

72 Dit is de standaard omschrijving in de plantagc-inventarissen. Ronde poster: steunhout; pallisade: bepaalde houtsoort dic op de mecste plantages aanwezig was; pien of pina: blad vas een palmboom.

23 Het woord cingel is afkomstig van het Engelse 'shing:e'.

24 Sterkproef ARA: SONA en SNA, plantage-archicven. 
nieuwe wonnvorm en merkte op dat de slaven veel liever in zeifstandige hutten bleven wonen, 'dan zijn zij meer vrij; zij wonen niet gaarne zoo digt op elkander' (Rapport Stantscommissie 1855:305). De Surinaamse slaven stonden daarin niet alleen, want ook op andere Caraibische plantages bleker. słaven hutten te prefereren boven blokwoningen (Higman 1984:218-23).

Sociaal gezien ginger de slaven er dus niet op vooruit, maar ook de fysieke ruimte bleef beperkt. Gemiddeld had een slaaf in cie periode 17501863 tussen de 4,3 en $4,5 \mathrm{~m}^{2}$ woonruimte tot zijn of haar beschikking. Alleen tusser 1790 en 1810 lag dil wat lages $\left(4 \mathrm{~m}^{2}\right)$, omdat er foen gemiddeld 5,2 in plaats van 4,1 slaven een vertrek dcelden. ${ }^{25}$ Aan het einde van de achttiende en het begin van de negentiende eeuw was de woonruimte van de slaver. het meest beperkt. Waarschijnlijk was dit het gevolg van de slechte financië.e situatie waarir de meeste plantages zich toen sevorder, zodat er geen geid was de slavenwoningen of andere gebouwen te onderhouden. Het aantal bewoonbare huizen daalde herdoor sneller dan het aantal slaven, zodat meer slaver. met minder huizen genoegen moesten nemen. Voor er. na deze periode van wonir.gschaarste bleek de woonsituatie van de slaven vijwel gelijk te zijn. De enige verbetering bes:ond daarom uit de kwaliteit van de woningen.

\section{Medische zorg}

Bij de bespreking van de slavenmortaliteit kwam naas voren dat Suriname gedurende de achttiende en negentiende eeuw door vele epiciemieën is geteisterd. Tevens werd gecorclideerd dat, al waren factoren ais hygiëne, voeding en medische zorg van invloed op de ontvankelijkheid voor deze ziektes, deze toch gezien roeten worden als autonome verschijnselen; de bestrijding was afhankelijk van de stand van de medische wetenschap. Tot op zekere hoogte geldt dit natuurlijk ook voor niet-epidemische zicktes en ongevallen. Toch zou een eventnele loename van de medische zorg weilichi iets meer dudelijk maken over veratuderingen in de levensomstandigheder van de slaven, omdat niet-epidemische ziektes voor het ziektepatroon yan grotere invloed zijn dan epidemieën. Bij ce beschrijving van de epidemische ziektes werd overigens duidelijk dat wanneer de medische grenzen werden verlegd in Suriname tameiijk vroeg en kracitdadig werd gereageerd. Dat in geval van een epidemie de vrije bevo.king even erg werd bedreigd als de slaven, zal hierin natuurlijk een ro! heiben gespeeld.

Een eerste indicatie van verandering in de medische zorg is te virden in de vergelijking van twee rapporten van de suikerplantages Aurora en Meer- 
7.org uit respectievelijk 1739-1740 en i 857-1858.26 Hierin werd bijgehouden welke slaven voor welke ernstige ziektes naar de cokter in de stad werden gestuurd. Beide plantages lagen niet ver van Paramaribo. Van Aurora blijken dar. Is van ce 183 slaven (10\%), ieder éen keer naar de dokter te zijr. gestuurd; van Meerzorg 63 van de 323 slaven (bijna 20\%), waarvan er zever. meer dan eens girgen. Aangezien het niet voor de hand ligt te veronderstellen dat de slaven in 1857-1858 tweemaai 70 veel als in $1739-1740$ getroffen werden door enstige ziektes en gebreken ... het verbeterde demografisch patroon makt dit bijvoorbeeld zeer onwaarschijn.ijk - ijjkt het ex dus op dat siaven veel eerder naar de dokter werden gestuund car. voorheen.

Het zou op deze plats te ver voeren uitgebreic op al.e vermeide ziektes in te gaan. In ieder geval is cuidelijk dat in beide listen de meeste ziektes te maken hadden met slechte ingiëniscie (zercn ex zweren, ougziektes) en arbeidsomsiandigheden (verwonde lecternden, verlarnming?). Die leef- en arbeidsomstandigheden waren kennelijk nic: zoveel weranderd Anderzijds maakt de vee: 11itgebreidere lijst van Meerzorg duidelijk dat niet alleen de medische diagnostiek was verbeterd, maar bovendien dat er veel eerder werc ingegrepen door cie patient naar de dokter te sturen. Dat is een vooruitgang te noemen. ${ }^{27}$

Een tweede indicalic dat de medische zorg vooruitging, was de toename van het bedrag dat per siaaf daaraan werd besleed. Een steekproef order vijitien plantages wijst uit dat in de periode 1750 -1800 jaarijks gemiddeld f 1,82 per sla werd besteed an medische zong, kosfern van gemeesheren, vroedvrouwen, medicinen en hulpmiddelen. In de jaren 1830- 863 was dit bedrag met ruim $40 \%$ gestegen tot $f 2,58.28$

Fen derde aanwijzing voor de toename van de medische slavenzorg vormt de verbeterir.g van de ziekerhuisjes op de plantages. In de achttiende eeuw beschikle cen groot deel van de plantages $(23 \%)$ riet over een aparte hospitaalyoorziening, of had niet meer dan cen stukje van eer. bedriffs-

26 ARA: Aanwinsten :939, IV-3; ARA: SOBB FV: 828-1876, 3C36.

27 De zicktcs war het orn ging waren de volgende: op Aurura leden negen patiënten aar. zeren en zweren en vipr aan prikhen, pon k:ad had exen koffiphonn in z:jn oor gestoken, terwijl venerische ziekte er. verlamming ieder éen slachtoffer eiste. Van twee paciêriten was de ziek!e onbckend. Op Mecrzorg ledkn de meeste pationten (13) aar oogziektes, clf s!aven hadden verwonde ledemater en ang, pers plf mevere ledon aan zweren en zeren. Acht patiönten hadden last var. bleckzucht, vier van vencrische zickten en vier van wo:mzicktcn. Tetanus,

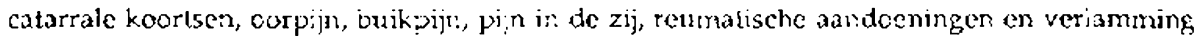

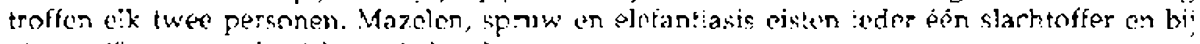
vicr pationten was de zickte onbekcnd.

25 Stecixproef i750 1800: 7o informaticjaren var de plantages Aurura, Watlerwijk, Dries

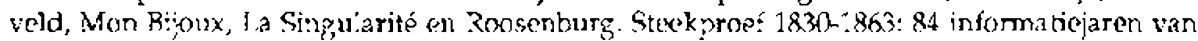
de plantages Clifford Koccshooven, Vrouivenvlij:, Somerszo:g, Goosen, Catharina Sophia, Libanon, "Peron, Vossenburg eri Rix senbu:g. 


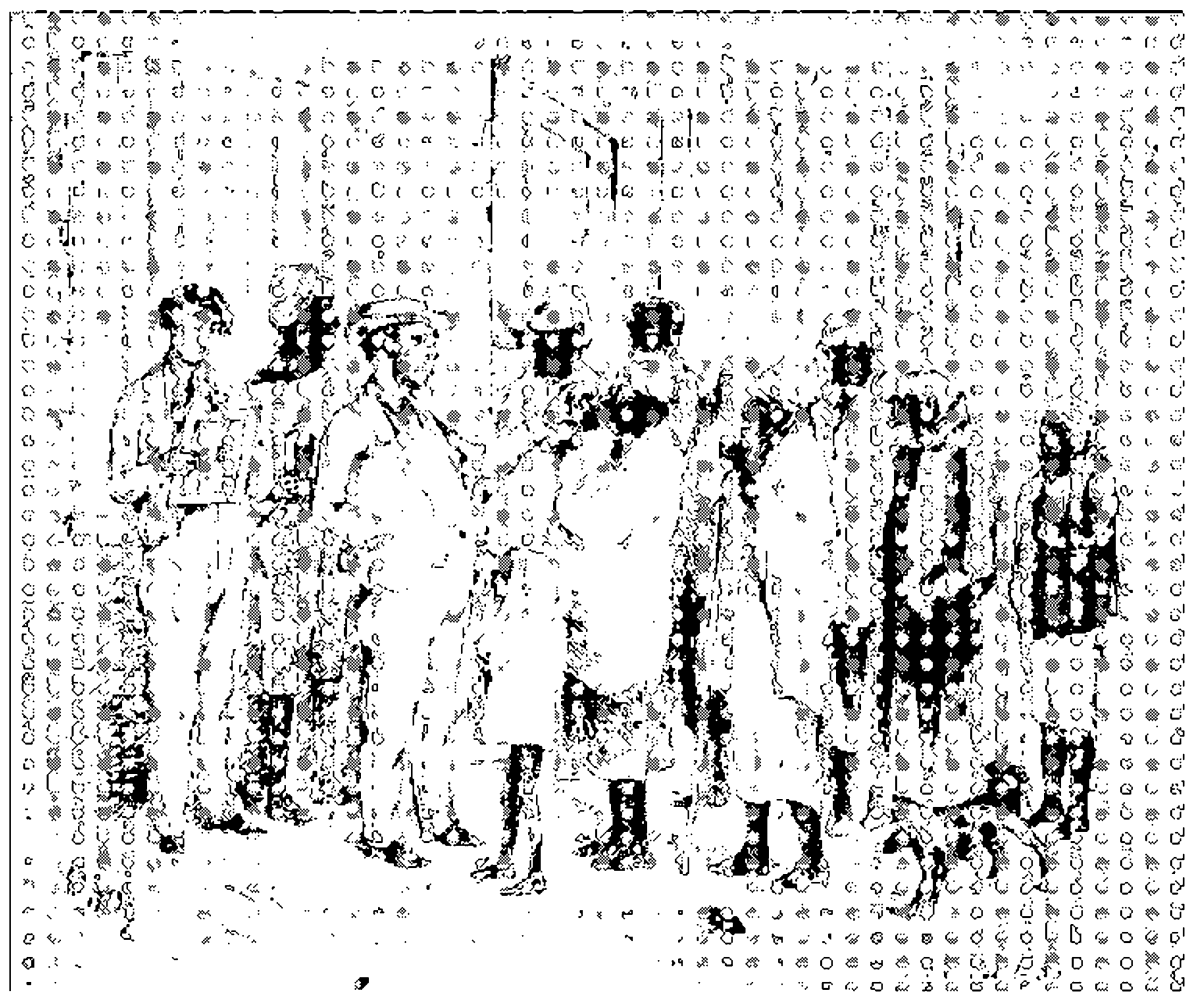

Bezoek van een direnteur in het slavenhospitaal ca. 1850

(jolo archief KJILV ns.1210; litir. Th. Eray) 
gebouw daarvoor afgeschoten (40\%).27 In het laatste geval bestord zo'n 'miultifunctioneei' gebouw grotendeeis uit magazijnen en veestailen, lietgeen de hygiëne bepaald niet ten goede zal zijn gekomen. En ook al was er in die tijd wel een apart gebour voor de zieken, dan zeg: de veelgebruikte benaming jaashok (voor de yawspatiënten) al voldoende over de kwaliteit daarvan. Molenmaker Röman merkte zelfs op dat de verpestende stank die uit zo'n hok opsteeg genoeg was om de gezondste mens ziek te maken ${ }^{30}$

In de negentiende ecuw werden op de meeste plantages aparte hospitaaltjes gebonwd, veela: op een stener. voet of stenen neuten en met een goede doorluchting. Liteindelijk blee'k siechts $6 \%$ niet over zo'n voor. ziening te beschikken. Bovendien bleken deze getouwren bijna twre keer zo ruim te zijn opgezet als de hospitaaltjes uit de achttiende eeuw, want de hospitaalruimte per siast steeg van $0,28 \mathrm{~m}^{2}$ in de periode : $750-1800$ tot $0,5 \bar{J}$ $\mathrm{m}^{2}$ in de jaren 1820-1863.31 Illustratief voor deze ortwikkeling was bifvoorbeeld piantage Libanon aan de Cottica. In 1752 stond er in he: geheel geen ziekenhuis; in 1763 was in de korenschuur een stukje afgeschoten als jaashuis en bevonden zich ook nog 2 schapen en 35 geiten in.dit gebouw; in 1772 werd er een gebouwtje verceeld in 1 wee ziekenkaners en exes ruinte waar de was werd gedarn on in 1835 stond er dan toch eea zelfstandig hospitaaltje van $44 \mathrm{~m}^{2}$, met gescheiden kamers voor marnen en vrouwer. en voorzier. van houten britsen. ${ }^{32}$

De medische zorg voor de slaven was in hancien var vier groepen mensen. In de stad bevonden zich a:tsen en gespecialiseerce vroedvrouwen met hun eigen hospitalen. $\mathrm{Zij}$ vormder. de kivalitatieve top van de medische stand. Vaarnaast waren er de chirurgijns die zich in de plantagedistricten hadden gevestigd. De meeste piantages hadden eer: abonnement bij zo'n mar. lopen, dat één gulden per siaa! per jaar kostte, waarvoor de chirirgijn dan regelmatig visites moest xomen afleggen. De medicus Kuhn (:828:39) schreef over deze plantage-artsen, dat zij

'met ritzondering van eenige weinige, alle in militairen of scheepsdienst in het land gekomen [waren], en hetbes zich hier gevormd tot hetgene, wat zij thans zijn, dat is, zoncier de goede te na te teeden, serschen van weinig grondige kennis in hun vak, welke naar een, zexeren slender te werk gan, en bij iedere gelegenheid van eenig belang zeer verlegen staan [... . Hel krediel dat zij als Heel- e: Geneeskundige bezitlen, is zeer gering, en nimt zeldern workt ook dal nog, nit hoofde van hur gedrag, en geringe urenschenkennis, verminderd of geneel weggeno:ner.'

29 ARA: SONA : SNA, plintage-imchieven.

3) ARA: Collectie-van den bosch, 122.

31 ARA: SONA en SNA, plantage-archieven.

$3 \hat{2}$ ATR: SONA, 193, 216 2:n 238; ARA: SNA 182.8-184.5, 108 
De medische capaciteiten van dergelijke chirurgijns waren dus beperkt. Voordat een zieke slaaf echter in handen van een dergelijke 'dokter' terecht kwam, was hij meestal reeds enige tij ziek es. hadden anderen zich al met zijn constitutie bemoeid. De eerste diagnose bij een ziek gemelde slaaf werd gesteld door de piantagedirecteur. Deze liet daarop de zieke verder over aan de zorg van de zogenaamde dresneger, een (soms zeer kundige) slaaf die special was belast met de ziekenverzorging. ${ }^{33}$ Pas wanneer de zicke na enige dagen nog steeds geen tekenen van herstel vertoonde werd de chirurgijn erbij gehazld.

Overigens werd lang niet iedere slaaf die zich bij de directeur ziek meldde ook als zodanig behandeld. Het was in het belang van de plantagestaf om zo weinig mogelijk zieken en zoveel mogelijk mensen op het veld te hebben. Op ziekmelding zonder, voor de directeur, aanwijsbare oorzaak konden dan ook sancties staan. Heel duidelijk werd dit geiilustreerd op plantage De Herstelling, waar een ruir. hospitaal was neergezet, bestaande u:t twee gescheiden kamers voor zieke mannen en vrouwen en voorzien van een 'gemak', maar tevens met 'boven eer. prison voor die geene die zich ziek houden...34

Ondanks deze weinig rooskleurige schets van de situatie waarin een zieke plantageslanf terecintkwam, veranderde er toch het een en ander ten goede. De pokker verdwenen in de negentiende eeuw grotendeels door vaccinatie, de overheid nam matregeien ter voorkoming van cholera en ook de lepralijder werd zoveel mogeijk geisoleerd. Wat dit laatste betreft is men vanaf 1830 , onder leiding van het Collegium Medicum, voortvarend te werk gegaar. Ieder cie een lepralijder kon aanwijzen, or.tving $f 25$ beloning en de planter die zijn leprelize slaven niet aangaf, hing een boete van $f 200$

33 Foe dat in zijn we:k ging, vertelt oprieus: molenmaker Röman: Niu word! ecn neger zick, en meld zich des morgens aan: de Directeur voelt hem me! zekere eerbaarheid de pois, en beschuuwt zijo tome, ondeelt hij dat hij wezentlijk ziek is dan wordt hem een laxants geadministreerd (wat rubarber of chalappe zm als het vali) en dan in he: hospitaal opgesloten, vercers wo: dt er niet meer naar omgezien; des avords brengt de zoogenaamde dresnegcr of doctor rapport varn de gene die uit het hospitaal naar het werk gegaan zijn, narar de overbii;vende word zelden gevraagd, of ten zij, zij te zieltogen liggen. De volgendo morysen als de ziekte zich niet gebeterd heeft, dan wo:dt hem ean emetick of brakk-middel gediend, heip dit ook nict, dan wordt hun de vo'gende dag wal kina, of antispasmedicum pecder gegevcra, en help dat dan ook niet, dan wordt na verloop van alzon drie a vier dagen een Chirurgijn van do rivier geroepen die bjjwijlen menschen zenden in hur. plats die nieł veel van de zaak vergeten [begreper] hebben) a's bijwijlen de neger niet meer te reciden is.' (ARA: Collectie-Va: den Basch, 142.)

Röman was de man die jarenlang als blanke verschoppeling tussen de slaven had gewoond en enkele van zijn ervaringen op papier stelde, ter advisering van Commissaris-Ceneraal Van den Fosch. Wat hij hier beschrijft was zeker geen uitzondering, maar wordt ook door andere auteurs, bekend met de plantagepraktijk, bevestigd a.s standaardprocedure, zje bijvoorbeeld Wageraar Hummelinck (1947:34); Kuhn (1828:63-4); Douglas (1936:42).

34 ARA: SOB\&S 1828-1976, 3029. 
boven het hoofd ${ }^{3} \overline{5}$ Tot dan toe was de praktijk op plantages geweest on lepreuze slaven te verbannen naar de rand van het terrein, waar zij nog vaak diens: deden als sluiswachter. Nu moesten zij echter voor het Collegium verschijnen, dat hen, na de ziekte te hebben geconstateerd, afzonc naar de speciaal ingerichte leprozerie Batavia aan de Coppenamerivier. ${ }^{36}$

Op deze wijze werden tussen 1831 en 1855 in totaal 2.813 mensen voor het Collegium geleid, van wie 1.289 als besmet verkiaard naar Batavia werden afgevoerd (Duchassairg 1858:233). Sommige slavengemeenschappen werden door deze matzegeler. zwaar gefroffen, zoals op Somerszorg, waar in 1830 van de 84 slaven drie mannen en twee vrouwen (samen 6\%) naa: Batavia moesten vertrekken. ${ }^{37}$ Ordanks het sociale ieed dat hiermee werd aangericht, moet deze algemene maatregel de gezondheidssituatie wel ten goede zijn gekomen.

Waarschijnlijk is ook verder de zorg voor de zieke slaven in de negentiende eeuw toegenomen. Lo zegt Bartelink (1914:10), da: hij in 1855 als opzichter op Zeez:gt in teder geval tweemaal daags de slaver in het hospitaal moest bezoeken er. hen iedere morgen van verse kost voorzag. De administrateurs van De Nieuwe Grond bijvoorbeeld, kreger: ir: 1822 varl de eigenaars ir: Nederland én ons kir.inesulfact, met medische handeriding, opgestuurd, als koortswerend middel voor de slaven ${ }^{38}$

Daarnaast mag niet worden vergeten dat zieke slaven niet totaal afharke.ijk waren van blanke kwakzalvers, maar ook het lot (steeds meer?) in eigen hancien namen. $Z$ o waren volgens Bosch (1843:184) 'de negers veela: druk in de weer om zich ze'ven te genezen'. De creolisering zorgde er voor dat de slaver. steeds beter bekend raakter. mel middelen en kruiden uit hun directe omgeving en op sommige plantages liepen zeer beixwame diesnegers rond. Zo werd op Elsenhagen in 1795 f 55 betald a an de dresreger Abraham voor hel genezen van een slavin van kwaadaariige zeren, die 'door ce bianke chirurgijns voor ongenees:ijk geach:' waren. ${ }^{37}$

Een duidelijke ontwikke.ing ir. de slavengeneeskunde treffen wij aan bi; Kuhr: (1828:41), wameer hij het hecft over de zogenaande dresmama's ${ }^{40}$ :

35 Bosch (1843:132) en nij vervoi,t: 'en de slaaf, die, wan verdacht gehouder, en daarom door een zeker teeken om den arm aangeduid, het waagde, zich in het openbaar in de nabijhejd van andere menschen te vertomen, ontving honderd slagen'

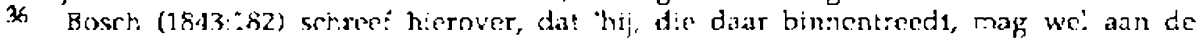
woorden welke Dante voor zi ine hel schrecf: "zeg alle houp varwel!' denken; want weinigen, zeer weirriger: treden voor de 'weede naa' over dex drempel van dit huis des jam:ners'.

37 GAR: Collectis Iindig, 331

38 Collectie-insinger \& Co., brievenboéx.

39 GAA: PA-600, 60)3.

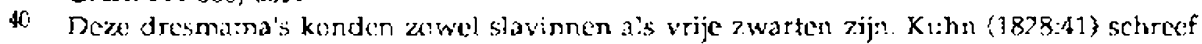
verder nog over hen dat 'onder hart zijn de gezondheidspriestercessen, die het orakel raad. pleger en der. ligtgelosvigen eene goede of onge.ukkige uitkomst voorspellen. Zij hebben ouk den naam van de geteeine kachter var vele irlandsche kruijen te kennen; ziekten dour 
'Ialanvankelijk waren zij belast met het toezigt over de Jawspatiènten; lang. zamerhand begonnen zij de aanwending van geneesmiddelen, tot dat zij, zoo als thans, geheele ziekenhuizen houden, kwijlkuren en quarantaines, enz. toedienen. De invloed dezer Dresmama's op de geneeskundige administratie is thans zeet gewigtig.'

Inderdaad kreeg deze Afro-Surinaamse geneeskunde een grote invloed en werd niet alleen door de slaven, maar ook door blanken te hulp geroepen.

In het algemeen was de geneeskundige zorg voor de slaven zeker vooruitgegaan. Er werd meer geid en eerder aandacht aan de zieke slaven besteed; er kwamen meer, betere en grotere hospitalen op de plantages; besmettelijke ziektes werden van overheidswege bestreden en, als bij de voedselvoorziening, leek er meer rimirte te zijn voor het eigen initiatief van de slaven.

Al met al is het niet vergezocht te stellen dat de materiële onstandigheden van de plantageslaven er tussen 1750 en 1863 duidelijk op waren vooruitgegaan. In geen van de onderzochte gevallen ging het om schokkende, dramatische veranderirgen. Soms was het riet meer dan een indruk van verbetering, zoals bij de arbeid; soms was het een geleideijjke, maar duidelijke ontwikkeling, zoals bij de voeding en de medische zorg; een enkele keer was er na een duidelijke verjetering sprake van een lichte terugval, zoals bij de uitdelingen van kleding en benodigdheden; en tenslotte kon het gebeuren dat een materië.e verbetering een versiechtering van het leefklimaat betekende, zoals bij de behuizing. Oncianks gebrek aan kwantitatief bewijs lijkt er daarnaast sprake geweest te zijr. van een groeiende onafhankelijkheid van de slaven, een tendens die overigens ook in andere Caraibische plantagekolonien is waargenomen (zie Higman 1984:210-2). In Suriname gold dit vooral de verzorging var primaire levensbehoeften en in mindere mate ook de medische zorg. Die grotere invloed op het eigen lot moet voor de slaven fysiek en vooral ook psychisch van grote betekenis zijn geweest. Deze verarderingen waren mede in de hand gewerkt door de koioniale overheid die, zij het in een zeer laat stadium, zich de belangen var de slaven wat meer was gaan aantrekken. Aan het eind van de slavernij werd zelfs :amelijk streng toegezien op de naleving van de slavenreglernenten. ${ }^{4}$ : Het is bepaald niet denkbeeldig dat de Surinaamse bevolkingsgroe heel wat positiever was geweest wanreer dit veel eerder was gebeurd.

betoovering en bezwering aangebragt, 'sehooren onder haar gebied.'

41 Tussen 1853 en 1862 werden gemiddeld per jaar 45 plantagemanagers of eigenaats door de koloniale overheid ter verantwoording geroepen, omda! zij zich niet, of slechis gedeeltelijk, hiclden aan de voorschrifen in de s'avenreglementem. De meeste gevailen betroffen onvoldoende uitdeling van kleding, gevolgd door verwarlozing van de slavenwoningen of ziekenverblijyen. Slechts een gering aantal gevalien had te maken met voedseltekort (Van den Boogaast en Fimmer 1977:2099). 


\section{HOOFTSTLK XII}

\section{De ijzeren vuist wordt gehandschoend}

Materiële zaken zij̣ nafuurlijk niet a'léén bepalend voor de kwaijteit van het leven. $\mathrm{Zij}$ zijn we! het gemakkelijkst aan te duiden er het best te kwantificeren. De minder goed meetbare aspecten van het leven zijn echter minstens zo jepalend voor de kwaliteit daarvan. Het gaat daarbij onder meer om social-culturele omstancigheden en de wijze waarop de wisselwerking tussen de belangrijkste groepen in eea samenleving wordt vormgegeven. In een plantagesamenlevirg gaat het vanzelfsprekend om de interactie tussen vrije blanken en z.warte siaven en de eventicle veranderinger daarin. Aangezien dit aspect van het plantageleven vrijwe: geen kwantificering toelaat, heeft dit hoof fistuk een veel impressionistischer karakter dan de rest van deze studie. Er is zoveel mogelijk getracht de representativiteit van de gebruikte voorbeelden aan te geven; de schaasste aan bronnen makkte dit echter niet alti; $d$ mogelijk.

Besiudering van de verhudingen in de achitiende-en negentiende-ceuwse Sisrinaanse plantagesamenleving levert een aantal terugkerende verschijnselen op, die zijn samen te vatten onder de noemers angst, geweld en segregatie. Kiarblikkelijk vormen deze drie begrippen de sleutel tot die samenleving. Fen van de meest duideli;ke illustraties van citt tenomeen is te vinden in eer rapport van Commissaris-Generaal Vaa den Bosch. uit 1827. Hierin wordt over c̀e slaven onder meer gezegd:

'Fene dierlijke voldoering humer driften is het eenige geluk wat zij kennen en schatten; in huane dagelijksche huishouding hebben z:j een graad van orafhankelijkheid verkregen, die de betecgeling hunner titspat:ingen moeyelijk maakt, en tikwerf de pogingen daartoe zelfs gevaatijk anet zijn. liet ken niet worcen betwijfeld of ze gevoele: al he: overwigt van hun getai, en den invioed die het middel om in de bosschen te vlugten, en zich met de baschnegers te vereenigen, hua op het gemoed humer mesters verschaf. Hunate weigering on de piantag:en te verlaten, waarop zij geboren z:jn, en de wijze waarop zij zich in die gevallen gedagen, hebjer: genoegzaar: doen zien, dat zij hunne krachten kennen en weten ain te venden, wanneer eer. algemeen jelang, onderlinge overeenstemming te weeg breng: Niet ib́n planter durit tegen de algemeene opinis zijner negers penen mantrege! dioorzetien, hetgeen meermalen is gebleken, en het is voorzeker alleen hun bepaald verstand, hunne opvoedirg, en de krachl de: gewounte, die hun belet in andere opzigten met vereende pogirgen naar én doel te sireven. Doo: enn zeer voorzigtig maar 
tevens vast gedrag, en irzonderheid door eene betere godsdienstige opleióing, mag men hopen de driften der negers te beteugelen er verbetering te weeg te brengen, doch verzuimt men thans daartoe de gelegenheid, of wordt daaraan eene verkeerde strekking gegeven, dan kan men in de toekomst niet anders dan gewigtige en treurige gevolgen te gemoet zien.' [Mijn cursivering.]

Deze tekst is zeer kenmerkend voor de omslag in het denken van de planters die begin negentiende eerw heeft piaatsgevonden. Uit iedere regel spreekt de latente angst van de planters voo: de macht van de slaven. Deze vrees heeft bestaan zolang er sprake was van slavernij, maar de wijze warop de planters hebben getracht het gevaar te bezweren veranderde. In de achttiende exuw was hef vooral fysiek geweld waarmee zij hun slaven in 'behoorlyke onderwerping' hielden." In de negentiende eeuw blijkt dit, getuige Van den Bosch' advies, piaats te maxen von een mee: psychologische aanpak aan de hard van 'een zeer voorzigtig maar tevens vast gedrag' en 'eene betere godsdienstige opleiding'.

Angst en segregatie spreken ook uit de manier waarop de pianters altijd hun dominante positie hebben trachien le legitimeren, nameijk door de zwarte mens te reduceren tot een dicrlijk niveau. Die dier.ijke voldoering hunner driften' en 'hun bepaald verstand' waren voor Van den Bosch echter reden om te proberen de slaven te civiliseren, terwijl in de arhttiende eeuw het dierlijke van de negers nog werd aangegrepen om hen niet tot de menselijke soort te hoever. rekenen en hen daarmee 'apart' te ionden. Dat ce slaven die opgelegde racia.e scheiding overigens positief hebben weten te gebruiken door een eigen werelc te scheppen, blijkt uit de niet te beteugeler. onafhankelijkheidsdrang die zij kennelijk begin negentiende eeuw in hur. dagelijks leven tentoonspreidden.

Angst, geweld en segregatie zullen worden beschouwd aan de hand van de vraag o: er verbeteringen voor de slaven optraden en wat de reactie van de slaven was op het systeem en verarderingen daarin.

\section{Angst en gezveld}

Gedurende de gehe.e slavernijperiode hebben pianters in angst geleef voor het getalsmatig overwicht van de saven. Om te voorkomen dat de angstige visioenen van opstand en: moord ook realiteil zouden worden, hebben de planters altijd gebruik gemaakt van een rigide systeem var. sirafien en tegelijk van een verdeel-en-heers-politiek om het siavenoverwicht te ondermijnen. Dit laatste aspect is gedurerde de slavernij vrijwel onveranderd gebleven. Mulattenslaven werder al:ijc bevoorecht bover 'zwarte'

ARA: Collectie-Var den Bosch, 10 s.

2 Hartsinck (1770, II:918) schrij!t De Slaaven moeten in bchoorlyke oncerwerping gehouden en met strengheid beshandelt worden'. 
slaven, onder meer doordat zij in principe geen veldarbeid hoefden te verrichten. Huisslaven (meest mulatter), ambachtsslaven en zwarte officiers vormder de elite binnen de strakke slavenhiërarchie en ontvingen bij de jaarlijkse uitdeling van slavengoederen een grotere portie dan gewone veldslaven, die op hun beurt weer meer kregen dan de oude, afgewerkte slaven. Door deze bevoorrechting werden sommige slaver nauwer aan de planters gebonden en konden zij tegelijk gemakkelijker in de hand worden gehouden door (dreigen mel) slralkortingen op de rantsoenen.

Daarnaast vormcien met name de huisslaven het oog en oor van de planter voor hetgeen zich voordeed in de slavenkwartieren en ook verraders konden meestal rekenen op een willig oor van de planter. Ook dit zal een zekere tweespalt teweeg hebben gebracht en de angst, die cie planters zo graag bij de slaven wilden inboezemen, hebben gestimuleerd. Andere middelen die de planter ter beschikking stonden om de slaven aan zich te binden, of waar hi; juist mee kon dreigen, waren het vermeerderen of onthoucien van de dagelijkse 'sopie' (bexertje dram) en hel beloven of (dreiger. met) verbiecien van een meerdaagse danspartij. Lat dit laatste een probaat middel was blijkt uit ce woorden van de voormalige plantagedirecten J.D. Kunitz (1805:350). Met enige verbazing constateert hij dat in het algemeen de slaven zich de 'moedwilligste griilen' later. welgevallen, zolarg eer directeur man iedere twee of drie marder een darspartij toestaat.

Als bet waar is wat Klinitz hier beweert, dan moet het verbieden van zo'n darspartij een zeer gevoelige straf zijn geweest. Overigens blijkt uit geen van de negentiende-eeuwse plantage-archieven dat er vaker dan tweemaal per jaar een zogenaarid nieuwjaars- of middeljaarsspel werd gegeven. Zo'n spel xor: ve:e dagen duren. Op Meerzorg (Surinamerivier) werd bijvoorbeeld einci jaren 1850 slechts eenmaal pe: jaar een spel gegeven, maa: dan wel acht of aegen dagen achtereen; op Nieuw levant werd in :831 eenmaal zes en eenmaal vijf dagen gedanst en op Siparipabo hadden de slaven in december 1821 zelfs veertien dagen achtereen vri; ${ }^{3}$ I let is niet onmogelijk da: ir. Kuni:z' tijd vaker werd gedanst, maar can waarschijnlijk slechts voor een dag.

Dat een dansverbod als pressiemidde: kon worden gebruikt, bijjkt uit cie rapporten van Vrouwenvli;t. In. de jaren 1835-184I waren ce slaven op deze plantage zeer onrustig (zie dit hoofdstuk 3.1). In die jaren werd slechts

3 In hat algemeen kregen de plantageslaven rond de jaarwisseling enkele dagen vrij, vandaar de naam nieuwjaarsspel. Dan worden de slavengocderen uitgedeeid, evenals een extra portie dram. Bowendien moht er ged:1rende die dagen (luidnsehtig) gemusiceerd en tot diep in de nacht gedanst worden, Aan di: jaarlijkse hoogtepunt waren de slaver zeer gehecht. ARA: SOB\&W 1828-1876, 3036; Surinaams Museum: Collectie-Mamir; ARA: Collectie-Copes van Cattenisurgh, 81 . 
driemaal een spel aan de slaven gegund. In de daaropvolgende periode 18421848 was de rust op Vrouwenvlijt teruggekeerd en werd tienmaal een spel gegeven. ${ }^{4}$ Deze vermeerdering van danspartijen zal niet de aanleiding, maar zeker een beloning voor de terugkeer van pais en vree zijn geweest.

Het gebruik van dergelijke pressiemiddelen en het hanteren van een verdeel-en-heers-politiek kunnen worden gerar.gschikt onder de noemer psychisch geweld. Daarnaas: waren de planters er rotsvast van overtiigd dat angst inboezemen door lijfstraffen het meest probate middel was om de slaven onder de duim en aan het werk te krijgen. Deze opinie werd gelegitimeerd met de stelling dat negers van nature lui waren. Met zachte hand zoll bij hen niets te bereiken zijn, zodat zij 'eenigsints straf moeten behandelt en geregeerd worden' (De Eexsgezind heid 1804:147).

Hoe wi; dit 'eenigsints straf' moeten begrijper. beschrijft Hartsinck (1770:916)

'Indien de Slaaven wegloopen of anderszins miscioen, worden zy strengelyk door de Bomba [zwarte officier] gegeesseld met een Zweep van Pita, en de raauwe Huid vervolgens met P'ekel, Limoensap en Piment of Spaarsche l'eper gewreeven, welke pyn hen niet litt wreedheid madralleen un het verderf te beietten word aangedaan. Ook straft men hen veeltyds met een (zo genaamde) Spaansche Bok.'

Laatstgenoemde straf was de meest gev:eesde onder de slaven. Het slachtoffer werd kromgetrokken rond eer. in de groni stande stok, waarna hij met een bos twijgen zolang op de bilien werd geslagen to: er geen huid neer op zat. Het kwam nog al eens voor dat slaven een dergelijke afstraffing niet overieefden. Dit zal dan ook de reden geweest zijn om de straf in i 828 te verbieden op de piantages. Er konden nog wel Spaanse Bokken worden toegediend, maar alleen tegen betaling, door een overheidsdienaar op het fort Zeelandia bij Paramaribo. Hiermee was deze wrede stra: nog riet uitgebannen, mat het staat buiten kijf dat nij veel mirder frequent werd toegepast dar in de achttiende eeuw. " Vijftien aar later werd deze strat overigens geheel afgeschaft. ${ }^{5}$

Het meest concreet over de alledaagse strafrnaat op plantages aan het eind

4 Surinaams Museum: Collertir-Mamin

5 Verschillende negentiende-eeuwse :echtzaken tonen aan dat er ook toen nog allerlei excessen op de plantages voo:kwamen (zie o.jvosrbecle Lammens 1982:117\%. Het feit telter dat dit in een adntal geva'len ook inderdaad tot processen en veroordelingen 'eidde, toxn: wol aan da: het hier meer on uitzonderingen ging, dar: om de normale gang van zaxen.

6 Surinaams Muselum: Collectie-Erantsen, Verslagbockje 1843. De administrateurs var Vossenburg schreven namelijk: 'het Gouvernemen: heeft namentlijk op ecre ontvangene aanvraag om eenen Neger op het Fort Zeelandia met tamarinde roeden te doen atstraffe:t, geantwoord dat deze wijze van straffen op die plats voortaan volstrekt niet meer zoude worden toegestaa:'. 
van de achttiende eeuw is opnieuw de directeur Kunitz. ${ }^{7}$ Hij vermeldt, dat er een 'dracht' (van waarschi;nlijk 25 tot 50 ) zweepslagen stond op het te laat versch:jnen op het veld of niet volbrengen van ce opgelegde taak. Voor zware verg:ijpen liet hij - in overeenstemming met het siavenreglement 80 zweepslagen toedienen op het naakte oncerlijf, wat eveneens de strafmaat was voor slaven die heimelijk de plantage verlieten om de nacht door te brengen bij han partner op een andere plantage.8

Ook in deze straffen kwam - zij het laat - in de loop der negentiende exuw verandering. In 1842 kondigde Gouverneur J.C. Rijk aan dat piantagedirecteurs in de tockomst niet meer dan 25 zweepslagen mochten opleggen aan volwassen marnen, 15 aan volwassen vrouwen, tenzij ze zwanger waren en 10 tot 15 aan slaven tusser veertien en zestien jaar. Na een persoonlijk onderzoek naar het vergrijp mocht de eigenaar of administrateur deze st:af eventueel verdlibbeler. In het algemeen :aadde de Gouverneur echter aan zoveel mogelijk de lijsstraffen te vervangen door bijvoorbeeld opsluitirg, in boeien klinken, slaven orthouden van drank en lekkenijen. ${ }^{9}$

Wat was nu de frequentie wadmee dergelijke straften werden opgelegd? Dat is rnet geen mogeli; kheid aan te geven. Alleen wameer slaver. waren weggelopen en weer gevangen, werd in de plantagerapporten relding gemaakt van hun afstraffing, soms met de toevocging 'voor zes maanden in de boeyen geklorken'. Pas a an het eind van de siavernij werden sporadisch strafregisters bijgehouden voor de kleinere vergrijpen. Daarnaast kor de behandeling van slaven per regio verschillen. In het algemeen werden s.aven op plantages aan de rand van het plantagegebied (de zogeraamde bovenlandse plantages) met grotere omzichtigheid benandeld dan die op centraler gelegen ondernemingen (de benedeniandse plantages). Op de eerstgenoende waren namelijk de riogelijkheden tot weglopen veel groter en contacten met marrons veel gemakkelijker dan op de laatste. I Ieel duidelijk bijkt cal uit brieven van de eigenaar van Crawassibo aan de Boven-Comnewijate, die in 3785-1786 dan zijn administrateur scheef da: men met deze slaven op zijal tijd moet weten te geven en nemen. Kort daarvoor waren de opstandige slaven op buirplantage Wayampibo hard-

7 Kunitz (1505:52, 349 en 320-2). Kunitz was begonnen als blankofficicr in 177\% op plar.tage Slootwijk en werkie in dic funclic onder andere oux nog op A La Bonheur. Later k.om. hij op tot diresteur, onier mier op de plantages Fautuenibergue en Cinoppenomb.

8 Volgens het slavenreglement van 1784 (Śchilikamp en De Smidt 1973, 11:1071) mochten piantagedirccteuren en blarkoficicren stratten 'van vijfentwintig tol vijftig, egter na exigentie van zazken uiterlijk tachtig ordinaire matige sweepsiagyen, toe te dienen ap het onderlijf en op geen andre piaatse des lichaams en wel ios offte ook wel staande teegens een paal off post gebondem, zonder den släaff die gestraft rvord te moger upbinden of yan den grond opheisschen; dewij] wij verstian dat alle andre en swalardere straffer [20ials de Spaanse box] aileen door den eygenaar off administrateur zal moeten geschieden off op hunne schriftelijke ordre:

9 ARA: Colfectie- Tsragmans, 122. 
handig afgestraft, zodat door dit 'exempel', volgens de briefschrijver, de slaven op Crawassibo nu 'met een zagt lijntje tot haare pligt zullen te brengen zyn: 10

Geven en remen was dus het devies in de bovenlanden. Zo nu en dan werd daarom een voorbeeld gesteld, gevolgd door de politiek van 'een zagt lijntje'. Het handhaven van een dergelijk wankel evenwicht was voor de planters kennelijk veel moeilijker dan - met harde hand - de orde handhaven in de benedenlanden. Was dit wankel evenwicht verstoord, dan kon dat voor een planter tot traumatische ervaringen leiden. ${ }^{1}$

Het lag dus gehee' aan de orstandigheden hoe vaak slaven een afstraffing moesten ondergaan. Het zou overdreven zijn om geheel af te gaan op de woorden var Kunitz (1805:350) die schreef over de gesel, die hun ruggen nooit de ge.egenheid geeft te genezen'. Evenmir. zou het correct zijn geheel te vertrouwen op de woorden van de administrateur van Groot Marseille, die driekwart eeuw ra het voorafgaande de slaven daar zó gewillig vond 'da! Ir.aanden lang geen een zweepslag of de minste straf voorvald'.12 De werkelijkheid moet daar ergens tussenir hebben gelegen.

Aan het eind van de slavernij is echter ecn duidelijk meetbare verbetering opgetreden. Er werd nu zelfs af en toe cen strafregister bijgehouden op de plantages. Fn al zal dit nief het meest plichtsgetrouw bijgehouden plantagerapport $\mathrm{zijn}$ geweest, toch geeft het een indicatie van de veranderde omstancigheden. Zo werden gedurende negen maarden van het jaar 18511852 op Somerszong (met totall 66 slaven) de volgende straffen geroteerc: wegens plichtsverzu:m: 2 vrouwer. 15 zweepsiagen ieder en : man 25 zweepslagen gegeven; wegens orutailteit: 1 vrouw 15 zweepslagen; wegens slecht koffieplukiken: 'eenige mansnegers \& meiden' 15 zweepslagen; en tenslotte de jor:gen Eclips 'eene vaderlijke correctie gegeven'. 13

Met de invoering van een nicuw siavenreglement in 1856 werden de

10 ErBB: KA-120, 42. Fen ander voorbeeld is te vinden bij Van Feeckeren (1826:74): De slaven op de grensplantagien, geheel verbrocderd en vermaagschapt met de Bosch-negers, gelijk ik daarvan ooggetu:ge ben gewtest op Bergendaal on Victoria, zouden in zoodarig geval [bextexeld wordt in geval van opstand of een marronoverval] weinig te vertrouwen zijn, daar zij bovendien derzelven meerderen vrijheid aan de nabjjheid de: Bosch-negers te danken hebber, als uit hoofde van welke zjj noodwendig moetent ontzies worder' [mijn cursivering].

Il lets dergelijks spreekt althans uit eer: brief van de nieuw aangestelde administrateur van Groot Marseille die in 1756 over zijir. voorganger schreef: 'Op plantage Marcellie gaa! het teegens woordig reedeijik we. maer het heeft mijn reets wat moeyte gekost en säi mij nog wel reykelijk kosten eer die slaeven wcedur om op een goede voet gebragt sijn, sijade deselve al te ver in disorder geraekt, sijnde nooyt gestrafft wijl den Heer un den Werff wont deselve bang geweest is en somtijds 15 maenden sonder booven :e koomen heet! passeeren laeten en als sijn Ed. dan boven op de plart. quaam dan bestraffte hij nooyt deselven al waeren somtijds vijff off mexr slaeven eenige maesden 'ang weg gewees! die sig hier off daer verborgen hadden' (James Ford Bell Library, B1482; brief 4-8-1756 van S. Felimann aan J.G. de Mey; mijn cursivering). 12 James Ford Bell L:brary, B 1482; brief 1825 van administrateur Wolff aan J.G. de Mey.

13 GAR: Collectie-T3adig, 341. 
straffen nog iets meer verlicht en ook de frequentie waarmee zij werden uitgedeeld'lijkt te zijn afgenomen. ${ }^{14}$ Op een katoenplantage met 217 slaven werden althans in de laatste 17 maanden voor de Emancipatie 'slechts' aan twee mannen (waarvan éen tweemaal) en drie vrouwen (één tweemaal) lijfstraffen uitgedeeld van 10 tot 15 zweepslagen. Verder moest een man 14 dagen dwangarbeid verrichten in l'aramaribo en werden drie mannen en drie vrouwen voor 2 tot 6 dagen opgesloten. Deze straffen werden opgelegd vanwege plichtsverzuim, luilheid, brutaliteit en verzet tegen de zwarte of de blankofficier, ongeregeldheden op het veld of in de regerhuizen en wegloperij. 5 Niets duidt er op dat dezce plantage cen uitzondering zou hebben gevormd.

Het mag duidelijk zijn dat de ijzeren vuist waarmee de slaven zo lang waren geregeerd inmiddels was omkleed mel een ruwe handschoen. De zweep, het symbool van onderwerping bij uitstek, verdween echter nooit helemaal. Het is overigens de vraag in hoeverre de planters hun doel, disciplinering door het inboezemen van angst, met dit rigide strafsysteem bereikten. De reaclies van de gestratten liepen uiteen van smeekbeden om vergiffenis, of onverschillig ondergaan van de straf, tot en met alle mogelijke vormen van verzet. En ook bij de omstanders riepen strafoefeningen nog al eens averechtse reacties op. Duidelijk blijkt dit wit de constatering van Kunitz (1805:87) dat bij zo'n strafexecutie Da aber bei dergleichen Gelegenheiter die Sclayen gern zusammenhalten und den Verbrechter nicht selten vor den Augen des Directeurs im Triumph wegführen', it

\section{Segregatie}

De wijze waarop blank en zwart in Suriname met elkaar dienden om te gaan werd in de loop der tijd vastgelegd in een uitgebreid stelsel van geschreven en ongeschreven regels, dat het best kan worden omschreven

\footnotetext{
14 Maximumstralfen die cen plantagedirecteur mocht uitdelen:

Slavenrcglement 1851

geen dram of melasse yoor 14 dagen

14 dagen in een kettingboei klinkeu

14 dagen opsluiting

Zweepslagen net de gewone zweep:

nuan 25

niet-zwangere vrouw 15

jongens 14-16j\%. $\quad 15$

meisjes $14-16$ jr.

(Bronnen: Gouvernementsbladen van deze jaren).

Slavenreglement 1856

idem

idem

idem

15

10 gecn

15 Bonnen: Gouvernementsbladen van de

16 Ook werden herhaald pogingen gedaan gestraften te bevrijden (zie ook Van Deursen 1975:214 en ltira 1982:170)\%.
} 


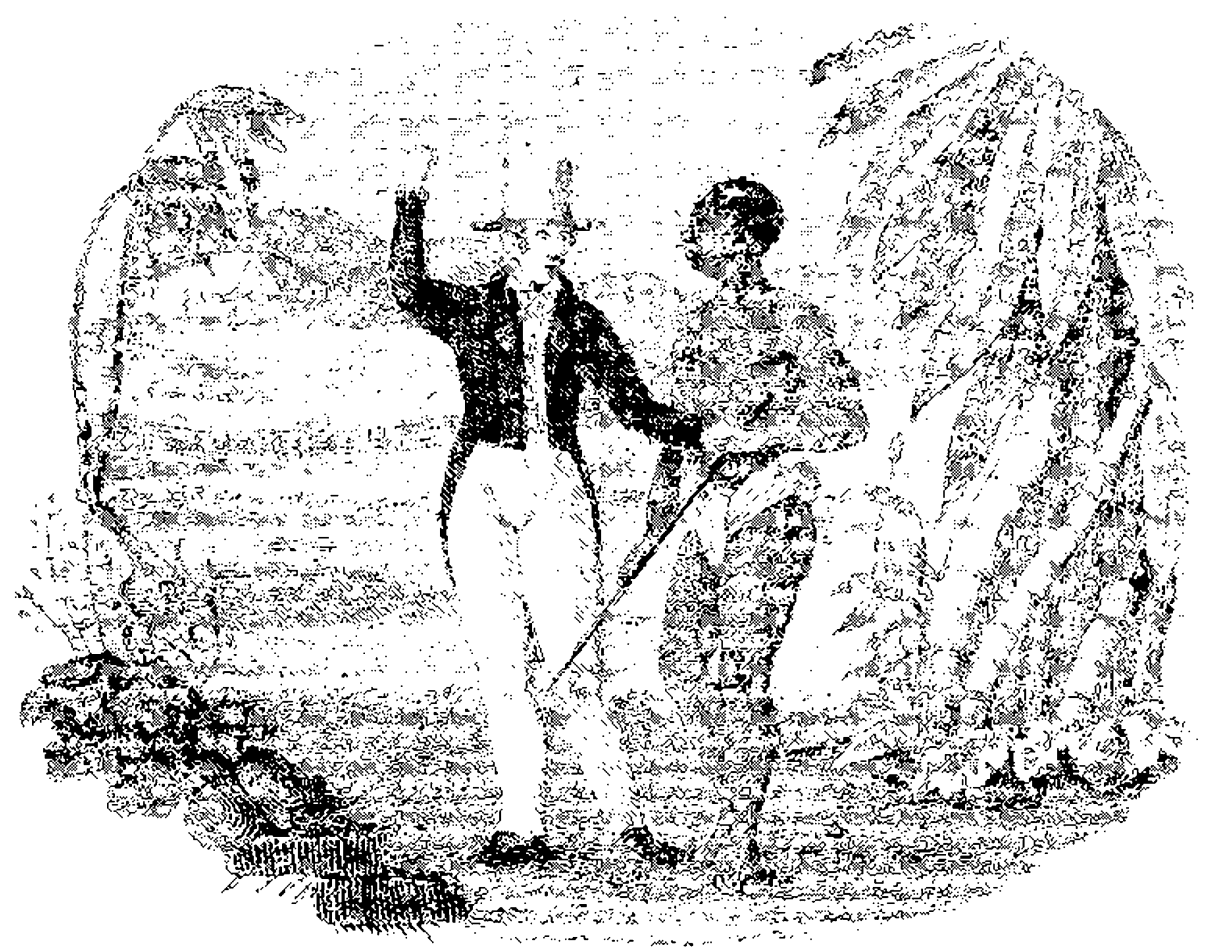

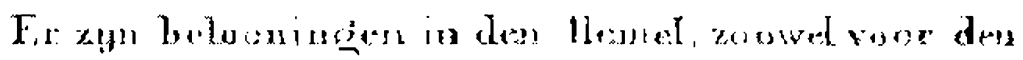

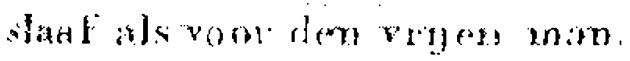

Een illustratieve abeedding van de plartersmoraa'

(Van breugel 1843: itelpazina) 
met de term segregatie. In cit systeem hadden de blanken voornamelijk rechten, de siaven vooral plichten en de vrije niet-blanke bevolking een wankele positie daartusserin.

Slaven dienden 'behoorlijk respect' aan de blanken te betoren en moesten op straat voor hen opzijgaan. Zonder uiturakkelijke, schriflelijke toestemming van de meester mochten slaven zich niet buiten de plantage begeven. Zij mochten verder niets bij zich dragen dat op een wapen kon lijken, laat staan dat hen ooit eer vergunring tot het bedienen van een geweer mocht worden ditgereikt. Ais teken van h:ir oncierworpenheid was het slaven verboden schoenen, kolisen, opgetoomde hoeden, gouden sieraden of juweien te drager. Hoezeer blanken aan ceze nauw omschreven bepalingen hechtten, bleek bijvoorbeeld toen in 1849 aar de slaven van de gouvernementsplantage Catharina Sopnia schoenen waren verstrekt en een administrateur bezorgd opmerkte dat dit op andere plar.lages wel eens tut grote unnust omier de slaven zou kimen leiden ${ }^{17}$

Fir waren echier riog veel ingrijpender regels. Zo was tot 1784 ieder seksuepi contact tusser. z.wart en blank of ícieel verbocier. Dit druiste eciter zo zeer in tegen de heerserde graktijk van gebruik van slavinner voor de seksuele lüsten var. de blanke mar. dat dit na die tiju alleen nog strafbaar was wanneer er 'eenige disorders op de plantagien' uit ontsionden. Waagde daarentegen een zwarte man het om seksueel contact te hebben ret een blanke vrouw, dan moest hij dit, wanneer de reiate uitkwam, met de dood bekopen (Van Lier 1977:55-6).

Deze segregatie ging nog veel verier aangezien voor a we wet slaven geen personen waren, maar roerende goederen. Dit beteikende dat zij formecl geen enke: burgerrecht hadden, dat zij in prircipe geer bezit konden hebben ('dingen' kunnen geen andere dingen bezitten) en dat zij bijvoorbeeld geen wettig huwelijk konder. sluiten. Het laatste was overigens ook een geloofskwestie, aangezien trouwen een kerkeli;ke aangelegenheic was. Als onderdeel van de segregatie verhinderden de planters echter dat slaven - zo zị dat al wilden - overgingen tot het christelijk geloof, want

'Id]e Hemel was voor geene Swarten gemaakt, die viaren alle des Duyvels, die moesten mear Werken en to: hun [de planlers] playsier ayn. Want Le Blarken waren alle Gusien kirderen, en de Negers alle des Dayvels kirdeyen, om [voor] hun Koffy en Siyker te pianten geschapen. ${ }^{118}$

17 Letterlijk scinreef hij: 'dat varwege den Gouverneur der Kolonie aan de Slaven der Cowvernements Plantage Catharina Sophia ern aatal paren schoencin $2:$ jn uitgedeeld, eene daad door allen die mat het Karakte: der Negers bekend zijn a's zepr ongepast geonrdepld en die alle Belanghebbenden met zorg vervulde daar he: niet te vocrzien was welken invlocd deze handelwijze op de rust onder de Negers van andere Bezittinger zoude vitoefenen (Surinaams Muspum: Collectio-Brantsen, versighboekje 1849).

if Aldus enke:e achtiiende-eeuwse planters, opgetekend door de predikant Kals er. geciterd in Lichtwe:d en Voorhoeve 1950i1/26. 
In de negentiende eeuw kwam er enige verandering in de wettelijke segregatie. Zo werd in 1828 in het nieuwe regeringsreglement voor de Westindische koloniër het 'onregtvaardig beginse:' afgeschaft dat slaven als zaken moesten worden beschouwd (Gouvernementsblad 1828, no. 3). Voortaan wercen zij dus juridisch als mens erkend, zij het onmondig, over wie de eigenaass 'eene vaderlijke fucht' dienden uit te oefenen.

Sommige veranderinger vonden in die periode snel algemene ingang, met name onder invloed van Commissaris-Generaal Van den Bosch. Nog in 1821 had een commissie, die zich berighield met de wenselijkheid van invoering van het christelijk huwclijk voor slaven, daarover een ondubbelzinnig negatief advies ritgebracht. 19 Zes jaar later kwam Van den Bosch tot precies de omgekeerde conclusie. Als een rationeel manager somde tij in zijn rapport alle voordeles op die de planters zouden hebben bij kerstening en auwelijksplicht van de siaven, zoals het verdwijnen van marronage en de vorming van eer. hech: gezinsleven. Bovendien vergat hij niet te me.den welk kerkgenoosschap in dat opzicht het meest bij de plantersbelangen aansloot, nameijik de Moravische Broeders die tegen geweld waren en 'lijdzaamheid' predikten. ${ }^{20}$ I Iet mag dan ook geen loeval heten, dat juis: deze religieuze oroederscinap beter bekend als Elernnhutters of Evangelische Broeder Cemeente - net belangrijkste kerkgenootschap in Surinaine werd. In het algeneen hebben deze zendelinger. zich het lot van de slaven zeker aangetrokken en getracht hun levensomstandigheden zoveel mogelijk te verbeteren. De fundamenter, van het systeem lieten zij echter onaangeroerd en dat was precies wat Van àn. Bosch voor ogen had gehad (Lamur 1985:43-4).

In praktijk is de segregatie iang riet altijd volgens de letter van de wet gehanteerd. Onm:skenbaar groe:de er eer. vrijwel onoverbrugiore psychische kloof tissen zwart en blank. Iegelijk zat hef systeern echter zo vo: paradoxen dat de theorie soms ver verwijderd was van de praktijk. Op zee: duidelijke wijze werd dit angetoond door Mirty eu Price (1976:13), die dan

19 Zij concindeerden dat in het algemeen 'de natuurijke geaard heid der Negersiaven welke als woest, veranderlijk van aard, trouwhoos in de liefde, hoogst minnenijdip, wraakģierig en ecr.s ecn wrok hebbende gezet onverzoenlijk, worder afgeschildcrd, ondeugden welker vereeniging zich tegen de vrijwillige en getroliwe onderwerping aan de Chris!edike huwelijks Wet aankant' (ARA: Collertie? Van den Busth, 139).

20 'De godsdienstige beschaving die alle andere pogingen tot het wclzjin der ncgers za! moeten vooraf gaan, zal tevens meer en meer tot het invoeren der huwelijkcn, en langs dien weg tot huisschelijkheid en onderling verband kunnen leiden. Hixt gevolg hicrvan zal wederom zijn een groote gehechthejd aan de plaats hunncr woning, daar het yoor eene geheele famille moeye.ijker valt te ontvlugten, dan your eer enkeld persoon. De lectstellingen der Moravische Broeders schingen overigens, voor het algemeen belung, ac meeste vooridevlen an te bieden, omiat zij het gemoed stemmen tot eene geduldige lijazamieid en tevredenheia met de aanwezige bestemming en afkeer inboezemen om die getweldatig te veranderen.' (Mijn cursivering; AISA: Collectic-Van den 3osch, 108.) 
ook tot de conclusie kwamen dat het icee van een samenleving die verdeeld zou zijn in twee hermetisch gesloten raciale sectoren niet meer was dan 'the masters' ideal, never achieved'.

Al konden de planters een juridisch onderscheid maken tussen (blanke) mensen en (zwarte) 'dingen' die zij het liefst als machines of dieren wilden zagen, toch waren het juist de menselijke kwaliteiten van deze 'dingen' waarvan zij iedere dag gebruik maakten en waarvoor zij tevens bang waren. Geen 'ding' of die: kon de taken vitvoeren die de siaven kregen opgedragen en alleen een mens kon in opstand komen op een manier die de plantexs de stuipen op het lijf joeg. In te dagelijkse werkeijjkheid draaide het nu juist om het contact tussen de groepen en niet de scheidirg van elkaar. De vele ge- en verboden waar de segregatie op was gebaseerd, werden dan ook in praktijk vaak met vocten getreder.

Duidelijk is dit te zien aan het verbod op seksucel contact tussen de rassen. In praktijk was het voikomen normaal dat blanke mannen seksueel verkeer hacider met zwarte vrouwen ${ }^{2 i}$ (zodat de wet maar werd aangepast) en ook relaties tusser blanke vrouwen en zwarte mannen zijn een enkele keer in de openbaarheid gekomen (zie Van Lier 1977:55-6). Vaak zullen eerstgenoemde contacten onder fysieke of psychische dwang van de blarke man hebben plaatsgevonden, naar toch zijn e: ook veel (langdurige) interraciale verbinterissen tot stand gekomen zonder dic dwang. Zwarte vrouwer kunnen hierin een middel hebben gezien om een bevoorrechte? behandeling te krijgen, of om te stijgen op de sociale ladider en uiteindelijk misschien zelfs de vrijheid te verkrijgen. Fn wie zegt dat er ook geen liefde in het spel kan zijn gewees:? in iede: geval werd op deze wijze de strikte rassenscheiding veelvuldig op een individueel niveau doorbroken, rnet als resultaat een intensief inter:aciaal contact.

Dat ciergelijke verhoudingen we'licht vaker yoorkwamen dan soms wordt verondersield, blijkt uit he: voorbceld van De Nicuwe Grond. In de periode 1780-1855 voerden daar achtereenvolgens zeven directeuss het bewind, waarvan er vijf de zwarte vrouw met wie zij hadden samengeleefd en/of de bij haar verwekte kinderen vrijkochten. Een van hen was D. Coenders, die in 1831 voor het vrijkopen var. zi;n vrouw jarsje, de grote kinderen Naatje, Paulina en Willem en twee kleine kinderen moest betaien met een 'jonge manneger' en $f 2.575$ in cortanten. Voor Coenders moeten dat zeker twee tof drie jarinkomens zijn geweest, wat wel iets zegt uver zijn relatie met Jansje. ${ }^{22}$

2! Een stcekproe? onder 48 plantagepopliaties in de negentiende ceuw wijst uit dat $3 \%$ van de plantageslaver als mulat te boek stond (ARA: SONA en S:VA; plartagc-archieven).

22 Collectie-Insinger \& Co.: notuljoek Biesterbos en brievenboek. Voor soortgelijke manumissie op de plantages Roxsinburg en Mon Bijou, zie Oostindic 1989:167-9 en 268-7). Dat de genoemde plantages geen titzonderingen vormden bewijst de volgende steekproef: 
Ook andere regels die de segregatie kermerkten werden op grote schaal overtreden. Zoals gezegd, mochten slaven zich niet op eigen gezag buiten de plantage begeven. Toch was het, zeker in de negentiende eeuw, een veel voorkomend verschijnsel dat slaven een partner op een andere plantage hadden en daar, zonder toestemming, de nacht girgen doorbrengen. Dit moet vaak oogluikend zijn toegestaan, want hoe anders kon bijvoorbeeld de administrateur van Zeezigt in 1843 schrijven dat zijn slaven thans 'met de slavenmagt der nabij gelegene plantaadje Dageraad [...] bijna één famielje' uitmaken, zodaf Zeezigt niet kan worden verkocht. ${ }^{23}$

De paradoxen zijn bijna te talrijk om op te noemen. In principe konden slaven bijvoorbeeld geen bezit hebben en tegelijk was het hun verboden met blanken handel te drijven (ter voorkoming van diefsta')! Die handel is echter nooit uit te bannen geweest en vrijwel alle slaven hadden wel enig bezit. Zo zeer zelfs dat op basis daarvan sprake ljjkt te zi;n van enige sociale differentiatie. Lo wilde Nepveu bi; de jaarlijkse uitdeling, wat betreft bepaalde gebruikswoorwerpen, de oude slaven overslaan, omdat hij het niet redelijk vond dat zij 'die ' $t$ minst verdiener en die 't rijkste sijn (mijn

\begin{tabular}{|c|c|c|c|}
\hline Plantage & Periode & Vrouwert & Kinderen \\
\hline Clifford Kexchshovven & $1800-1854$ & 4 & 4 \\
\hline Iagtlust & $1830-1843$ & 1 & 5 \\
\hline Vossenburg & $2818-1863$ & 2 & 9 \\
\hline Alsino & $1831-1863$ & 2 & 4 \\
\hline Bleyendaal & $1838-1863$ & 2 & $:$ \\
\hline
\end{tabular}

Bronnen: plantage-archieven SSS en CBBS; slave:uregislers.

23 Collectie-Insinger $\& 0 .$, Brievenboek Zeezigt. Overigens kwam dit verschijrsel ook in de achttiende eeluw reeds voor, al werd hel toen waarschijnijik strenger bestreden. 7 o verhaalt Kunitz (1805:82-6) dat vrouwen wel vier of vijf uur per nacht in kleine korialen naar andere plantages voeren am hur, geliefden te ontmoeten, of zjj brachten 'ihren eignen Männer ode: Brüder dahin und holen sie des Motgens um 4 Uhr wieder von da ab'. Ondanks Kunitz' dreigement met 80 zweeps'agen voor degenen die zich om deze reden 's nachts van de plantage verwijderden veranderde er nict vecl. Daarom ging hij er toe over de bastiaan (en niet hijzelf:) 's nachls die huizen te laten controleren warvar. hij vermocdale dat de slaven afwezig zouden zijp. Binnen enkeie dagen had hij zo al vier vrouwen betrapt die zich van de piantage hadden verwijderd. 'Dass die Züchtigung für eine solche Ausschweisung sehr hart war, kann man leicht denken'.

Baekhoudt (1874:71), dic in de jaren 1840 in Suriname woonde en daarvan verslagy deed in exn boek, noende de moeite die slaven er voor over hadjen om relaties op andere plantages te onderhouden als een der 'proeven van des negers onvermoeidheid en kracht'. Daarbij getft hij als voorbeeld een slaaf op Jagtlust. Deze was 'in de laatste tijd gewoon geweest van 's morgens 6 tot's avonds 6 op het veld te arbeiden en na afloop hiervan - ondanks 't verbod z:jns meesters - vier uren ver naar eene andere plantage te loopen, grootendeeis tot aan de knieen door hot water, teneinde bij zijn meisje den nacht deor to brengen, hoewel die nacht slechts kort zijn kon, daar hij vóór 6 uur 's morgens op Jag!lust moest zijn teruggekeerd. Dit verhaal werd Boekhoud! verteld door de directeur van Jagtlust, die dus weet had van de situatie, het ook had verboden, maar er kenneijik toch weinig tegen deed. 
cursivering) 't meeste zoude krijgen'; dat zou maar tot jaloezie onder de jongere slaven leiden. ${ }^{24}$ En Röman schreef in 1827 zelfs: 'als een slaaf niets bezit, kan [hij] ook geene vrouw krijgen'25, zodat het verwerven van bezit voor slaven van groot belang moet zijn geweest.

Ook ten aanzien van het uitdrukkelijke verbod slaven een geweer of andere wapens in handen te geven zijn overvloedig voorbeelden van het negeren van deze regel aan te wijzen. Veel plantagedirecteurs hielden van een welvoorziene dis en lieten dartoe slaven op wild jagen.26 Ook kwam het voor dat slaven geweren kregen om de plantage te verdedigen tegen marronovervallen. Zo bleek bijwoorbeeld dat op Anna's Burg (Cottica) in I791 van de tien aanwezige geweren er ' 4 onder de reegers en 2 onder de bastiaans' waren verdeeld.27 Daarnaast beschikten, zeker in de negentiende eeuw, de meeste slaven over een zogenaamd matrozenmes vour liuishoudelijke doeleinden en kregen de mannen een scheermes. Bovendien werd cen grool deel van de arbeid verricht met kapmessen (houwers) en bijlen. Ondanks het wettelijk verbod waren de slaven dus vrijwel altijd bewapend.

Het mag inmiddels dridelijk zijn dat de segregatie in praktijk soepeler werd gehanteerd dan de regels in feite toelieten. Die flexibiliteit hadden de planters nodig, om zich als kleine minderheid te handhaven en de plantage-economie draaiende te houden. De teugels moest men ne eenmaal wel eens laten vieren. In die flexibiliteit-in-praktijk zat waarschi;nlijk juist de kracht van het systeem, waardoor het zo lang stand heeft kunnen howden

Zonder dat het de bedoeling van de planters was hebben de slaven waarschijnlijk in belangrijke mate geprofiteerd van de segregatie. In het betrekkelijke isolement van inun 'apartheid' wisten zij in de loop der tijd een eigen wereld te creëren, waarin de druk var. de blanke wereld kon worden weerstaan. Zo on:stonder geheel eigen :alen, godsdiensten, muziek, verhalen- en liederentradities, die het zeifbewlistzijn van de slaven stimu-

\footnotetext{
24 FHB: KA-120, 42 .

25 ARA: Collecie-Van den Bosch, 142

26 Bijvoorbeeld op plantage l’oclwijk Exsciikkc de timmerslat in 1772 over cen fijn jachtgeweer. In datzelfde jaar siuurde de dirocteur twee slaven cr nut geweren op unt 'zijnde Roy en Willem om te jagen en te zien of ze sporen van Weploopers ontdekken konde' (geciteerd in De Bcet 1984:120). Dat lasts:e is woarschijnljijk gebelrd, maar in plaats van dc aanwezigheid van de marrons te melden hebben zij contact met len geiegd en de overval beraamd die twee dagen later op de plantace plaatsvond.

Meestal waren het de clitcslaven (bastiaans en ambachtslaven) dic vrij met cen geweer mochten rondlopen. Dat blenk op Anna's Burg en I'oelwijk (Koy was dresneger) en was evencens het geval op Badenstein, libanor en Mon Bijou gedurende de lastste decernia vân de achtriende eeuW (ARA: SONA 266 en 7C5; Oostindie 1989:268).
}

27 ARA: SONA, 70)8. 
leerden en getuigden van hun ongebroken persooniijkheid (zie ook Mintz en Price 1976).

Vooral op de plantages was er sprake van twee duideijjk verschillende leefwerelden. Tussen zwart er. blank was een soort consensus gegroeid om elkaar met rust te laten zo lang de nomale gang van zaken in beide samenlevingen niet werd verstoord. Dat de slaven daarbij veel beter op de hoogte waren van hetgeen zich in de blanke wereld aśspeelde dan omgekeerd staat buiten kijf. Wanneer er veranderingen op til waren, zoals de afschaffing van de slavernij in Surinames buurlanden, de introductie van rieuwe slavenreglementen, of plannen om de slaven naar een andere plantage over te brengen, dan waren zij daarover vaak larg voor de officiële bekendmaking al ingelicht. In ieder plantershuis waren nu eenmaa: altijd slaver. aanwezig, zodat hur. weinig kon ontgaar var. blanke zeden en gewoonten in het algemeen, en zaken die hun specifiek betroffen in het bijzonder. Omgekeerd hadden blanken weinig weet van hetgeen zich in cie slavenwoningen afspeelde. Dat bleek vaak letter:jjk uit het feit dat weggelopen slaven soms lange tijd in de slavenwoningen op andere plantages verborgen werden gehouden, zonder dat de blanke staf dat merkte. ${ }^{28}$

Ook hun culturele lever. wisten de slaven uitstexend voo: de biariken verborgen te houden. Natuurlijk kwamen de blarker wel in aanraking met de uiterijke kenmerken daarvan, maar de inhoud en betekenis ontging hen veelal. Een duidelijk voorbeeld daarvan was de slavenzang. Niet alleen tijdens de danspartijen, maar ook gedurende de arbeid werden door de slaven aller.ei liederen gezongen. Volgens Kuritz (1805:287) deden zii, dit om de tijd se doden en uit niets bijjkt, dat hij zich bewust is van het sociaal commentaar of de geheime boodschappen, die vaak ir dergeijke liederen waren verwerkt. ${ }^{29}$ Zelfs de schrijver van het Neger-Engelsch Woordenboek, H.C. Focke (1855:102-7), drukt zich heel voorzichtig uit - 'het schijat', 'ik stel mij voor dat' - als hij een aantal liedteksten moet verklaren. Van eer. aantai woorden kent hij niet eens de beteken:s en ra de (letterlijke) vertaling van één zo'n tekst geeft hij ronduit toe dat het ook een woordspeling kan z:jn, 'waar de negers gansch riet warsch van $2 \mathrm{ijs}$ '.

28 Lin zelis als men er wei weet van had, dar was het nog nict eenvoudig zo n wegloper in ce 'negerhuizen' te vangen. Dat bleek bijwoorbeeld bij de slad Adam van Vrouwenvlijt. Van hem was bekend, dat hij altijd wegliep naar de vlakbi: gelcgen Vricndsbelcid en OuGersorg (waar hij wellicht en vrouw had; zie dit hoofdstuk 3.1). Toch duusde het in aprii $1842 \mathrm{ruim}$ tien dagen voor men hem daar, voor de zoveelste maa', in de 'regerhuizen' te pakken kre'g.

Ook het voorval op Clifford Koqshooven, waar in het siaverdorp acht jaar na de dood var. directeur Wagener plotseling cen zilveren potagelepel en 8 dito vorkeri opdoken die aan suem hadden toebehoord, getvigt nie? var een strak toezicht op do slavenhuishoredingen (KIT: Coliectie-Van Breugel, uiktrekselbrievenóck).

29 'Während den nächtliches: Arisciten pllegen die Sclaven mit Singen die Zeit zur verkürzen und dann hör! man Virtuosen und Virtuosimnen aller Art: 
Al konden de blanken de taal die door de slaven was ontwikkeld wel spreken, toch begrepen ze deze niet volledig. ${ }^{30}$ Van Breugel (1842:90) schrijft dat voor hem de taal 'iets beeldrijks en raadselachtigs' had en dat het een blanke alleen na een langdurig verblijf in de kolonie lukte zich goed met een slaaf te verstaan. Dat overigens die beperkte toegankelijkheid ook doelbewust door de slaven werd nagestreefd blijkt uit cie woorden van Teenstra (1835, II:209-10), die na een zesjarig verbliji in Suriname schreef:

'Ben ik nog zeer onbedreven in het gewone Neger-Engelsch, nog veel onbedrevener ben ik in het zoogenaamde Vara, Cropina en Para; het eersie is het gewone Neger-Fngelsch, hetwelk bij iedere syllabe (ten einde onduidelijk voor de Blorken te zijn) met pa, pi, poe enz. verlengd wordt' (mijn cursivering).3:

Wellicht het meest verborgen voor de blanken bleef het godsdienstig leven van de slaven. Hartsinck (1770:902) bijvoorbeeld, die op andere gebieden toch zeer goed was geinformeerd, komt wat dat betreft niet verder dan enkele onzinnige opmerkingen en algemeenineden. Zo zouden, volgens hem, sommige slaven geloven dat de mens was geschapen door een grote spin genaamd Anansie en 'Jan Compaar' was de raam van hun oppergod. Daarnaast kenden $z i j$, aldus Hartsinci, ook nog mindere goden en werkten zij met heiligdormmen, offerandes en fetis;en, 'met welken zy ook hunne Eeden en bezweringen betekenen'.

In later tijd werd wel wat meer bekend over de shavenreligie, maar ook lammens (1982:108), die doorgaans over zeer gecietailleerde kermis beschikte, beperkte zich tot de uitspraak dat

'Id'e negerslaven geloven dan een Waternuma, adr spoken, aan een Azema, dat een geest is, die zich met het vleesch van menschen cn dicren voed, aan Treeft, dat is een verboden iets: - dir te e:en, zoms aan te raken, geeft vlekken, zeeren, ziektens, alschoon niets minder waarschijnli $k: s^{\prime}:^{32}$

30 In Suriname vond de communicatie tusscn biank cr zwart plaats in hel Neger-Engels, of Sranan Tongo zoals wij nu zcgger. ln dit opzichl badden cie siaven zich dus niel aangepast aan de meesters, maar de mepsters aan de shiven: een bewijs van de kracht van cie slavencultuur. Dit ging zelfs 20 ver, dat Nassy (1791:51) opmerkte dat de in Suriname geboren - voornamelijk Joodse - piantersvrouwen niet in staat zijn 'om de ziel var, eer. gezelschap uit te maaken, door onkunde der taalen, die haar beronft van die leevendige verkeering, van dat aangenaam gesnap, 20 natuurlijk eigen aan de sexe, en daarenboven geduirigibjk kiappende in 't kieger. Engelsch en omrirgd z:jnde van Negerianen' (mijn cursivering).

31 Gijvoorbeeld 'dagoe' (hond) wert dan 'Haparnopoe'. Van de twee andere varianten vermoedde Teenstra dat $z \mathrm{j}$; werden verlengd met ra, ri, roc en ga, gi, goc.

32. Lammens (1982:108) voegt daar nog aar. toe: ' $\mathrm{Zij}$ zijr: vol bijgelovigheden: - beschouwen

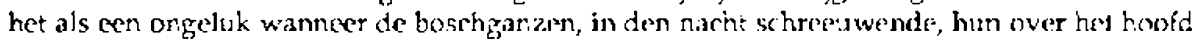
vliegen: - het doden van een spin, veroorzaakt het breken van een glas: - men mag niet vragen na den naam van eene plantagie, die men voor bij yaart, of men krijgt kras (ongemaklijk) water. Zij stellen, tot beveijliging van hunne eigendmmen, kalebassen met I.ederen opgesiert en andere zaken; - dit noemen zij Obians, die hun veel door de Loekemans worden gegeven: komen zij in een kreek of water daar zij lang niet hebben gevaren, of waar zij onbekent zi;n, zo nemen zij den hoed at, dopen zich en offeren een Eij, banaan, of icts dergelijks aan 
Hij voegt daar nog aan toe dat de slaven een godsdienstige dans hebben, genaamd Watramama, die vanwege haar zeer opwindend karakter ten strengste was verboden, maar welke zo veel doenlijk in het geheijm gedanst' werd.

Op Vossenburg tenslolte werd een god aanbeden die de nam A Dangra droeg, wat op zich al 'diep geheim' betekend zou hebben. In 1849 kwam aan het licht dat voor deze godheid, op eer. vur lopen in het bos achter de plantage, al sinds jaren een heiligdom werd onderhouden. Dit fungeerde niet alleen als religieus centrim voor de slaven van Vossenburg, maar voo: alle omliggende plantages. Directeur Uhlenkamp, die op dat moment al dertien jaar op Vossenburg woonde, had daar tot dan toe kennelijk geen weet van gehad (Lamur: 1985:15-6).33

Een aatste aspec: waarin de scheiding van leefwerelder. een stimulans voor de slavencultuur heef betekend, waren de vormen van verwantschap die werden ontwikkeld. Doordat slaven lange tijd waren buitergesloten van christelijk huwelijk en burgerrech: konden zi; hun eigen verwantschapsrelaties definiëren. Planters hebben zich voor die verwantschapsreliaties nooit geinteresseerd, zodat daarover in de pantage-archieven niets is terug te vinden. Toch lijkt bij de huidige stand van onderzoek alles er op te wijzen dat bij de piantageslaver. verwantschap nieł overheersend in patrilineaire lijn werd gedefinieerd (zoals bij de blanken), maar in matrilineaire lijn, zoa's vaak gebeard in West-Afrika (Mintz en Price 1976:35; l loogbergen 1985:416-23).

Daarnaast ontwikkelden $z$ :ch verwantschapsbanden die nie: biologisch, maat cen symbolisch of sociaal furdament hadden. 7o ontstond bijvoorbeeld de symbolische verwantsciap van 'sippi', in het begin gebruikt om de band te benoemen tussen slaven die met hetzelfde schip van Afrika naar Suriname waren vervoerd, later voor siaven die tot dezelfde plantage behoorden (Mintz en Price 1976:22). Ook kwam net regeimatig voor dat weeskinderen zoncier verwanten door een familie als pleeginderen werden opgenomen, of dat alleenstaande volwassener. (vrouwen én manner. in cen familie werden opgenomen als pleegrnoeder of plecgvader voor weeskinderen binnen die familie ${ }^{34}$ Bij de toewijzirg van familie-

Watermami, Watergodes of Nim.phs van de kreek.

33 De onbekendheid van ce blanken met slavenreliygies wordt nok aitgebreid aangetoond door Van Lier (1983:17-27). Eer. uitvoe:ige beschrijving van de religie van de (ex-)slaven in het Paragebied is te vinden in het werk var. Wooding (1972). Zeer intormatief over he: geheime karaktor er de samenbindende kracht van religie in een Caraibische samenleving, zijn de eerste hoofdstukken in het werk van Lagderre (1989:7-38).

34 Fen steckproef onder de 189 verwantengroepen op negen piantages in 1863 wi;st uit, dat in elf daarvan pleegkinderen, een plecgvader, of een pleegmeder wares opgenomen on in een verwantengroep bleek een geheel a'leenstaande oude nar. te zijn opgenomen (s!cekproef in Emancipaticregisters CBBS, plantages Bleyendaal, Croot Marseille, Jagthist, Le Mas! Rouge, 
namen aan de slaven in 1863 (zie Van Stipriaan 1990) kregen pleegkinderen en pleegouders dezelfde nam als de familie door wie zij waren opgenomen. Dit gebeurde onder andere op aanwijzing van de slaven zelí, waarmee de verwantschap ook officieel werd vastgelegd.

De siaven hebben de segregatie dus aangegrepen om een geheel eiger. cultuur te scheppen, die de eigen identiteit, he: zelfbewustzijn en de onderlinge solidariteit niet weing hebben bevorderd. In tegenstelling fot wat met het systeem werd beoogd, werden de siaven dus niel meer onderworpen, maar juist onafhankelijker. Een van de weinigen dide dit in cle gaten had was Conmissaris-Generaal Van den Bosch, die dan ook nict voor nicts ricest getrach: de aparthe:d zovee: mogeijk te doorbreken en de slaven een blanke beschaving op te dringen.

\section{De macht van de slaven}

Vaak wordt de vraag geste:d waarom de saven in Suriname - of elders in het Caraibisch gebied - die hun onderdrukkers in aantal toch veruit overtroffen, riet massaal in opstand zijn gekomen en hun juk hebben aigeworpen. Mooi is het antwoord da: Eigent Genovese (1981:1) in dif verband gaf met betrekking tot de slaven in het zuiden van de Verenigde Staten:

Nothing could be more naive - or arregant - than to ask why a Nat lurnet Iopstandeingemleider] did not appear on every plantation in the 5outh, as if, from the comfo:t of our ijving rooms, we have a right to tell others, and retrospecively at that, when, how, ard why :o risk their lives and those of their loved ones'.

Dit antwoord brengt de vraag terug tot menselijke proporties. Betexent dit dan dat de Surinaamse slaven hun lot gelaten heboen gedragen? Zeker nie:. Siaverni; en verzet zijn in Suriname altijd onlosmakelijk veroonden fenomenen geweest. Juist hei feit dat er zoveel mogelijkieden lot verzet waren, zou er wel eens de oorzaak var kumien zijr. cat het nooit tot een massaic opstand is gekomen. Overbekend zijr: de constaste marrorage en daaruit voortv'oeiende ooriogen in de achttiende eeww. ${ }^{35}$ Deze deden zo nid en dan wel re plantagekolonie op haar grondvesten wankeler, maar verminderden tevens de druk cie kon leiden tot pen massale opstand. Marronage was dus een alternatief voor o:stand. Dit betekent ecinter allerminst dat de slaven die niet wegliepen geen verzet boden, noch dat na het beëindigen van de marronoorloger. geen marronage meer piaatsvond. Wel lijkt zich, gedurerde de laatste tachtig jaar van de slavernij, een verandering af te tekenew in het karakter van het vercet. 
Hoogbergen (1985:54) schat dat in de achttiende eeuw jaarlijks ongeveer 300 slaven wegliepen, waarvan een-derde definitief wegbleef. Van het einde van die eeuw af tot aan de Emancipatie bleef het jaarlijks aantal officieel geregistreerde weglopers waarschijnlijk even groot, wellicht zelfs iets groter, maar was het aantal slaven dat definitief wegbleef aanmerkelijk kleiner. ${ }^{36}$ Dit was niet alleen het gevolg van de pacificatie van de marrons die weglopers nu dienden uit te leveren, of van de grotere effectiviteit van de negentiende-eeuwse bospatrouilles (zie Iloogbergen 1978), maar evenzecr van het feit dat weglopen een andere functie had gekregen.

Gedurende de achttiende eeuw werd marronage vooral ingegeven door een combinatie van het verlangen naar vrijheid en vlucht voor het rigide plantageregime. ${ }^{37}$ Als gevolg van deze, soms ook door planters erkende 38 , vrijheidsdrang bereikten in de tweede helft van de achttiende eeuw marronage, plantage-opstanden en marronovervallen op plantages een dramatisch hoogtepunt (Bijlage $8 \mathrm{~A}$ ), evenals de koloniale reactie (zie bijwoorbeeid Stedman 1988 en Hoogbergen 1985). Hierbij mag niet worden vergeten dat de overgrote meerderheid van de slaven in die periode nog in vrijheid was geboren en dus wist waarvoor zij het leven op het spel zette. Bovendien was in principe iedere wegloper welkom in de marondorpen diep in het bos.

Na de vredesverdragen me: de Nijukas (1760), de Saramakarers (1762) en de Matawai (1767) en het einde van de Bori-oorlogen (begin jaren 1790), nam de kans voor weglopers af om zich blijvend bij de nu gepacificeerde marrons te vestigen. Er werder. in orbewoonde gebieden en soms zelfs vlak achter de plantages nog wel nieliwe weglopersdorpen gesticht, maar vaak waren deze geen lang leven beschoren en het gebeurde ook minder dan in de achttiende eeuw. Veel van de wegloperijen in deze periode waren dan ook niet bedoeld om definitief de vrijheid te zoeken eil van daaruit even-

3 Op 1 januari 1840 stonden 77 slaven in S:ariname, exclusiet Corunic en Nickerie, officieel te boek als (sinds jaren) weggelopen. Vijf jaar later bedroeg dik aantal 792 . In de tussenliggende periode waren per jaar gerr.ddeld 260 slaven weggelopen, maar ook 257 geretourncerd. Deze aantallen zullen waarschijnlijk in praktijk hoger zijn gewevst, omdat lang riet alle (knrtstondig) wegpelopen en weer gevangen slaven aan de autoriteiton werden doorgegeven (ARA: MVK, A796).

${ }_{37}$ Dit blijkt duidelijk uit de woorden van een der marrons in hel jelegerde dorp Bockoe. Deze was ooit weggelopen van plantage $l_{\text {A }}$ Paix en riep nu zijn belegeraars toe dat sij ock mannen wayren en dat de Ejjgenaar van La Paix de Neegers deede werken tot 's avonds dat het donker waar en daar geen Neeger konde (uitlhoulin' lgeciteerd in De Beet 1984:107; mijn cursivering). Zie verder Price (1983) over de molivatie tot weglepen als ondercieel van de? orale geschiedenis van de Saramakaners.

38 Niet de minste onder hen, A. Salonthay van Salonthay, schreef in 1775: 'het vermeniguuldigen der Weglospers is ourspronkelijk to socken in de natuurlijke Zugt tor Vrijheid, die in alle redelijke Schepselen gevolgelijk cok in de Slaaven is. [...) De voornaamste reden is, dat ze niet werken willen, om dat men hun tegen regt en billijkhcid voor Slaaven varkogt had.' (ARA: SvS, 510) 
tueel de plantage-economie te bestoken. Het was ru veel meer een vorm van sociaal protest, gericht teger specifieke omstandigheden, of het zich tijdelijk onttrexken aan het plartageregime om even stoom af te blazen, terwijl het ook kon zijn dat men langere tijd bij een partner op een andere plantage wilde blijwen. Men trachtte belargen en rechten te verdedigen en eventueel uit te breiden. De meest voorkomende conflictsituaties in de regentiende eeuw hadden dan ook te maken met specifieke problemen rondom een directeur, verzwaring van de arbeid, te lang uitblijven van een danspartij of uitdelirg van slaverguederen en de (evertuele) overplaatsing van een complete slavermacht naar enr andere plantage (Bijlage 8B). ${ }^{39}$

Het spectaculaire karakter van de achtiende-eeuwse opstanden en marronoorlogen hebben in de literatuur het negentiende-eeuwse verzet volledig overschaduwd. Zo besteedt Hita (1982) in zi, in geschiedenis van het verzet niet meer dan een tiental pagina's aan deze periode en Siwpersac (1979) stelt alleen de vraag waarom er geen massale opstanden uitbraken in de negentiende eeur. Daame wordt niet alleen de irtensiteit van het negentiende-eeuws verzet tekort gedaan (Bijlage 8), maar bovendien wordt het veranderde karakter ervan niet onderkend. Een a ar.tal voorbeelden kan dit verduidelijker.

\subsection{Weglopen op Vyouwenvlijt $1834-1848$}

Op deze koffieplantage, gelegen aar. de Hoes Heienakreek, leefden in 1834 158 slaven 40 Daarvan liepen er gedurende de volgende veertien jaar 27 $(.7 \%)$ in total 38 keer weg. Acht var hen waren vouwen, allen veldmeiden, van wie Monkie, Sabina en Wilhelmina er in slaagder definitief weg te bijyen. De anderen werden steeds na periocies, die varieerden van enkele dagen tot enkele maanden, weer opgepak:. Voor een groot deel gebeurde dit door slaven var. Vrouwenvijt zelf, die daarvoor een vanggeld kregen van drie gulden. Jacobus wist op die manier alleen al achttien gulden to verdienen. Dit was ook nief zo'n moeilijk karwei, want voorzover het staat aangetckerd - ce meeste veglopers werden aangetraffen ir. de kostgronden of siavenwoningen var plantages binren een straa: van niè meer dan één of twee kiloneter rond Vrouwenviijt. Dit duid: er op dat zij niet van pian waren zich definitiet te verwijderen, maar zich alleen, on wat voor reden ook, tijdelijk wilden terugtrekken. Zij moesten hier wei wat voor over hebben, want het was hun bekend dat zij bij terkigkeer een geduchte afstraffing konden verwachten; sommigen

39 De hier aangegeven verandering in het karakter van het verzet dient hatliurlijk nict a.s absoluut te worden opgevat, maar als cen accentverchisiving waarvan marynage en sociaal protest ce uitersten waren. Zee: illustratie! in dit verband waren de ontwikkelingen o? plantage Roosenburg tussen 1759 en 1856, zoals die zijn beschreven door Oostindie (1989:182-8).

to Surinaams Museum: Collectic-Mamin. 
werden zelfs voor enkele maanden in een hals- of enkelboei geklonken.

Dit overkwam de meest frequente wegloper, veldslaaf Adam, zelts meerdere malen. Toch liep hij in de periode 1838-1843, het jaar waarin hij stiers, in total acht keer voor kortere of langere tijd weg. Niets kon hem weerhouden en steeds weer werd hij op dezelfde plantage, Vriendsbeleid en Oudersorg, opgepakt. Van hem lijkt het dus nog minder waarschijnlijk dat hij wegliep on weg te blijven. Ilet ligt daarom voor de hand te veronderstellen dat hij op die plantage cen vrouw had. Het waren overigens niet alleen veldslaven die wegliepen. Ook de timmerlieden Zondag en Premier verdwenen een kecr, evenals loodsbastíaan George. De laatste werd daarop gedegradeerd tot veldslaaf, wat opnieuw duidelijk makt dat de consequenties zwaar konden zijn.

Over de oorzaak yan de veelvuldige absentie op Vrouwenvlijt ontstaat meer duidelijkheid wanneer ook de rol van de blanke staf er bij wordt betrokken. Op deze plantage bestond die staf altijd uit een directeur en een blankofficier. In vijftien jaar tiju blijken hier zeven directeurs en zevertien blankofficiers de lakens te hebber uilgedeeld. De meeste wisselingen vonden plaats tussen 1837 en 1841: vier directeurs en acht blankofficiers kwamen en gingen. Het zal dan ook geen toeval zijn dat juist in deze jaren de meeste wegloperijen plaatsvonden: 32 van de 38 . Het kan zijn dat het weglopen niet meer inhipld dan het uitdagen van deze steeds wisselende machthebbers. Van Deursen (:975:214) gat zelfs zo ver een vergelijking te maken met de reactie var schoolkinderen op een nieuwe leraar. Dat is echter wat al te gemakkelijk geredeneera. Natuurlijk zal er ook een element van uitdagen en de-gelegenheid-te-baat-nemen hebben meegespeeld, maar de sancties waren veel te zwaar on dit als de verklarende factor op te voeren. Veel waarschijnlijker is het dat de slaven door hun gecirag lieten zien dat zij hel beu waren iedere zoveel manden aan de hand van een nieuwe meester te mocten wennen. Dit wordt door de ontwikkelingen op Vrouwenvlijt na 1841 gestaafd. Ook toen vonden er nog wisselingen plaats, alleen bleven de directeurs nu gemiddeld drie en de blankofficiers één jaar. In die zeven jaar liep, afgezien van Adarn, nienand meer weg.

In 1849 werd eens te meer duidelijk hoezeer onrust onder de slaven het gevolg was var ongewenste verarderingen. Toen in oktober van dat jaar de plantage zou worden verlaten en de slaven moesten overgebracht raar suikerplantage Dijkveld, stelde de bevolking van Vrouwenvlijk zich daar zodanig tegen te weer dat er mi'itairen aan te pas moesten komen om de onlusten neer te slaan. Zes hoofdschuldigen werden zwaar gestraft. Uiteindelijk vond de verhuizing toch plaats, maar opnieuw hadden de slaven duidelijk gemaakt dat zij niet alles zonder meer slikten. ${ }^{4}$ : 


\subsection{Overplaatsing van slavenmachten}

Het verval van sommige plantagesectoren (koffic en later katoen) en de expansie van andere (katoen en suiker) hebben er voor gezorgd dat in de negentiende eeuw op grote schaal verplaatsingen van complete slavenmachten hebben plaatsgevonden. Zo zijn alleen al tussen 1851 en 18624.595 slaven van 47 plantages overgebracht naar andere ondernemingen.42 Dat dit vaak met grote problemen gepaard is gegaan laat zich raden. Het merendeel van de slaven was inmiddels in Suriname geboren en had op 'zijn' plantage wortel geschoten. Ieder hoekje van zo'n plantage was bekend, evenals iedere bewoner daarvan. Men had er eigen offerplaatsen en heiligdommen. De navelstrengen lagen er begraven, net zoals de (voor-)ouders, wicr geesten eveneens op de plantage huisden. Juridisch mochten de plantages dan het eigendom zijn van de planters, emotioneel waren zij het bezit van de slaven. Vandaar dat verhuizing naar een andere plantage als een levensgrote bedreiging werd ervaren. Daar kwam bij dat het meestal ging om slaven afkomstig van koffie-, katoen- en houtplantages, die werden overgeplaatst naar suikerondernemingen, waarvan iedereen wist dat daar de arbeid het $z$ waarst was. Ook kon het gebeuren dat bij de verkoop van een plantage de slavenbevolking opgesplitst werd verkocht. Dat betekende dat vrienden en familieieden van elkaar werden gescheiden en zich in hun nieuwe woonongeving geplaatst zagen tegerover een grote gemeenschap met lang bestainde vriendi- en verwantschapsrclaties waar zij riet gemakkelijk toegang toe kregen s? Op alle mogelijke manieren hebben de slaven

42 CBBS: slavenregisters.

43 Wettelijk was het (sinds 1782) verboden noeders en kinderen gescheiden te verkopen en sinds 1811 was ook de 'partiële verkoop van slavenmachten aan banden gelegd, zodat daarvoor speciale toestemmirg van het gouvernement nodig was. Desondanks kwam het loch voor, omdat individuele slaven voor veel hogere prijzen verkocht konden ivorden dan een compicte slavcnpopulatie (onder wie ecn groot aantal niet-werkbaren). Dat de autoriteiten hiervan wel op de hoogte waren biijk? uil de woorden van gouvemementssecrelaris I. de Veer, die in 1839 schreef dat het 'do afkedring van het Couvernement moe! opwipkken dat zoo als in den laatsten tijd reclal het gebruik is gew'est, de slavenmagten vaneen gerukt - verbrokkeld - en van hunnc betrekkingen algescheiden verkochl wordin, daarbij zoodanige separate verkoop de man van de vrnuw, de vader van de kinderen etc. gescheiden wordende, dit behalven de verwijdering van de plaats waaraan de slaven door geboorte of langdurig verblijf gehecht waren, belialven de verandering van werkzaamheden welke dikwijls op de gezondheid der slaven een nudeligen invloed uifoefent - een hoogst ongunstige indruk op de gemoedsstemming dier voorwerpen moet te weeg brengen, welke tot balorigheid, desertie en soms tot ontijdigen dood aanleiding geeft' (GAR: Colleclie-Hudig, 168).

Overigens was gesplitste verknop niel altijd in het nadeel van de slaven. Zo blijkt bij de verkoop van de 44 slaven van plantage Bergerac, dat Willem, Hendrik, Hermanus met zijn moeder Adriana en l'roserpina met haar dochtertje zich wilden afscheidcn van de rest en de wens kenbaar maakten te worden gekocht door de butrplantage Vossenburg als hebbende daar familie en betrekkingen: Hun verzock werd ingewilligd, al was het alleen maar omdat de administrateur var Vossenburg door deze gunst een grote inzet van dcze slaven verwachte (Surinaams Museum: Collectic-Brantsen, verslagbosekje 1839). 
zich dan ook tegen dergelijke overplaatsingen verzet. Soms met succes, maar in de meeste geval.en trokken zij echter toch aan het kortste eind en werd de sterke arm ingeschakeld om hen uiteindelijk tot verhuizen te dwingen. Desondanks werd iedere keer duidelijk hoezeer de planters met de macht van de slaven rekening cienden te houden.

Zo werd bijvoorbeeld in 1788 overwogen de slaver van koffieplantage Beerensrust over te brengen naar de suikerpiartage Potribo, die in handen was van dezelfde eigenaars. Deze betwijfelden echter of de slaven zouden gehoorzamen en v:oegen zich. af of het niet beter was hen naar een van hun andere koffieplantages over ie brengen. Om van dit probleem verlost te zijn, besloten zij uiteindelijk Beerensrust maat te verkopen. Enkele jaren later werd echter bericht dat de verkoop nog steeds geen doorgang had kunnen vinden, omdat 'de slaaven op geen ander effect met nut konden getransporteerd worden'. Tot 1802 is het de siaven gelukt te blijven zitten waar ze waren. In dat jaar werd de plantage echter verlaten en moesten zij toch naar elders verhuizen. ${ }^{44}$

Vijftien jaar later werden deze eigenaars met een identieke situatie geconfronteerd, toen zij de 122 slaven van Overtoom en Vreeland (hout) wilden laten overbrengen naar enkele van hun koffieplantages. De admin:strateurs berichtten echter dat dit onmogelijk was, ondat slaven van houtgronden 'tot andere werken zeer ongeschikt zijn' en bovendien 'de negers in Para niet goedschiks zouden te brengen zijn, als zeer ain hunne gronden gehecht'. Tegen wil en dank hiclden de eigenaars daarom de situatie nog twaalf jaar bij het oude, wazrna zi; deze op zich goed renderende onderneming wisten te verkoper. De nieuwe eigenaar, S. de ia Parra, was wel zo verstandig de slaven op Over:oom en Vreeland te laten bl:jven, zodat uiteindelijk bij de Emancipatie deze plantage nog steeds door inmiddels 193 slaven werd bewoond. Zij hadden duicelijk aan het langste eind getrokken. ${ }^{45}$

Dat het ook anders kon lopen blijkt uit de gebeurtenissen op suikerplantage Siparipabo. In 1828 werden de 44 slaven van deze volkomen uitgeputte plantage opgekocht door de eigenaars van buurplantage Arendrust, met het doel hen naar deze onderneming over te brengen. Bij cie uitvoering van dit plan bijikt echte: een beroep op de autoriteiten te moeten worden gedaan, want tot grote verbazing van de nieuwe eigenaar verzetten de slaven zich 'met verregaande onbescheidenheid' tegen de verhuizir.g. Er werd een gerechtelijke commissie, vergezeld door militairen, op afgestuurd, die het verzet de kop indrukte,

44 GAA: $\Gamma A-600,543$.

45 GAA: PA-600, 544; Van Sijpesteijn 1854:104-5; CBBS: emancipatieregisters. Bekende Surinaamse families als Venetiaan, Merkil, Ceder, Bruinhart en Purperhart zijn nakomelingen van deze slavenmacht. 
'en van de wederspannigen [zijn] sommigen voor het voorhoofd gebrandmerkt, anderen in dubbelde bandietenboeyen gekluisterd, na eerst streng met roeden gestraft te zijn; de geheele Commissie met militairen is de strafoefening gaan bijwonen en vervolgens heeft de geherle magt zirh willig getoond naar Arendrust op te breken waar $z \mathbf{i j}$ thans werkt'.

Het verzet mocht dus in dit geval niet baten. Sterker nog, ruirn twintig jaar later werd ook Arendrust verlaten en moest de complete bevolking (opnieuw) verhuizen naar plantage Rust en Werk, die in een heel andere streek lag. 46

Het was overigens geen automatisme dat de autoriteiten in dit soort gevaller de planters terzijle stonden. Dat bleek in het geval van de slaven van houtgrond Waicoribo (Boven-Commewijne). In 1833 waren zij overgebracht naar de dicht in de buturt gelegen suikerplantage Fauquenburg. In hoeverre dit tot verret had geleid is niet bekend, mar toen de eigenar hen veertien jaar later opnieuw wilde overplaatsen on nu naar de voor hen verafgelegen plantage Susannasdaal (Beneden-Suriname), weigerden de meesten hieraan mee te werken en liepen zij weg naar hun oude wonphaats Waicoribo, waarmee zij zich duidelijk het meest verbonden voelden. Eigenaar I. de Lyon deed daarop enkele vruchteloze pogingen de slaven toch nog zo ver te krijger, maar ten lange leste zag hij zich genoodzaakt de hulp in te roepen van de overheid. Gouverneur R.F, van Raders bleek echter niet bereid voetstoots aan dit verzoek om bijstand te willen voldoen. In plaats daarvan vertrok hij per stoomboot naar Waicoribo om de slaven 'door kracht van overreding' tot verhuizen te bewegen. De letterlijke respons van de slaven is niet bekend, maar Van Raders omschreef het als 'geheel strijdig tegen den eerbied'. Ten einde raad legde hij daarom de kwestic maar voor aan Minister van Koloniën J.C. Baud. Deze besliste dat de verhuizing niet kon doorgaan, omdat dit niet zonder gewe.d zou kungen plaatsvinden, hetgeen 'strijdig zou ziju met he: algemeen belang der kolonie', 47 Voor het eerst bleek de overheid nu eens duidelijk de kan.t van de slaven te kiezen, zij het uit zuiver pragmatische overwegingen.

De angst van slaven yoor overplaatsing kon overigens ook wel eens in het voordeel van planters werken. Dat bleek op Bleyendaal, waar, na een antal rampspoedige jaren, in 1833-1834 de administrateurs adviseerden de

46 ARA: Collectie-Van den Eosch, 107; Collectie-Insinger \& Co., Informatieboek: Van Sijpesteijn 1854:110-11.

47 Daarnes: had de ksuss af mocten zijn. Toch blijken des slaven van Waicoribo zich in 18.53 op Susannasdaal te bevinden. Aangezien het gebruik van geweld kan worden uitgesloten, zal De Lyon grote concessies gedaan moeten hebien om de slaven zo ver te krijgen. De onstandigheid dat zij op Susannasdaal zij an zij noesten werken met 33 vrije arbeiders alkomstig van Madeira, maakt dit des te aznnenclijket. Te veel onderscheid tussen de slaven en dezc vrije arbeiders zou ongetwijfeld opnieuw tol grote mocilijkhcden hcbben geleid (GAK: CollectieI Judig, 108; Van Sijpesteijn 185.4:96.7). 
onderneming te verlaten en de slaven over te brengen naa: Zorg en Hoop. Zij waren er zich van bewust dat dit zou leiden tot 'onaangenaamheder' en wegloperij, maar 'met eenige vastheid' dachten zij dit we! op te kunner: lossen. Natuurlijk kwam dit plan de slaven ter ore, met als gevolg dat in 1834 een aantal van hen 'ongenoegen met hinnen directeur' kregen en (alvast) tijdelijk werden verbannen naar Zorg en Hoop. Daar kreeg men de opdracht hen zo goed mogelijk te behandelen, in de hoop dat zij na afloop van de straf met positieve verhalen over deze plantage op Bleyendaal zouden terugkeren. Dit zou dan het verzet moeten smoren. Wat de teruggekeerden hebben verteld is niet bekend. In ieder geval heest dit staaltje 'bedrijfspsychologie' niet gewerkt en kozen de slaver. voor een geheel andere strategie.

Deze tactiek kwam er op neer dat zij zowel zichzelf als de administrateurs tevreden stelder. In het besef nameijik dat zij waarscijin.lijk op de piantage konden blijven ais er weer een goede produktie werd gerealiseerd, girgen zij harder werken. De gem:ddelde jaarproduktie steeg dan ook van i39 vaten in de periode 1830-1834 naar 268 vaten in de daaropvolgende vijf jaar. Natuurlijk werkten ook externe omstandigheden, zoals gunstige seizoenen, aan deze stijging mee, maar toch is het opmerkeli; $k$ dat ook de administrateurs de verbetering in be:angrijke mate hebben toegescinreven an de jiver 'en goede gezindheid' van de slaven. De verhuisplamen verdwenen dar. ook van tafel en in plaats daarvan werder: zelfs 59 slaven van plantage Beekvliet naar Bleyendaal overgebracht. Ifet is riet bekend in hoeverre deze nieuwkomers door de slaven var Bleyendaal is ingeprent zich eveneens gehoorzaam en ijverig te gedragen. Wel is het opvaller.d dat deze groep, die enige jaren daarvoor nog ernstige ongeregeldheder had veroorzaaxt in hun vorige woonpiaats, zich nii 'gewillig en ondergeschikt' gedroeg.

De administrateurs waren in ieder geval duidelijk onder de irdruk van de manoeuvre der slaven. Zeifs tien jaar na het gebeurde berichtten zij dat aan de slaven van Bleyencaal 'steeds nog ne: oncierscheiding wierd gedacht'. Het mes sneed in dit geval dus aan twee kanten, met ais gevolg dat de slaven in ieder geva? tot 1863 op deze plantage zijn bli;ven wonen.48

De vijf hier geselecteerde voorbeeiden van de zeker dertien bekende gevallen waarbij overplaatsing van slaven tot grote problemen leidde (Bijlage 8B) tonen duidelijk aan dai de siaven opkwaman voor hun belangen. Ook al trokken $z i$ niet alti, $d$ aan het langste eind, de pianters dienden terdege rekening met hen te houden. Bovendien bleek de koloniale overheid, uit een oogpunt van orde en rust, niet (meer) altijd vierkant achter de planters te siaan, maar oox wel eens de bescherming van slaven voorop te stellen. 


\subsection{Slaven eisen hun recht op}

Vrijwel altijd hadden conflicten tussen slaven en hun directeur te maken met de behande:ing en het tomen aan verworvenheden van de slaven. Omwille van hur carrière zullen veel directeuren getracht hebben dergelijke ruzies te verzwijgen. Dat dit lang nief altijd 'ukte, was een gevolg van het feit dat de slaven hun protest zó duidelijk wister vorm te geven dat het wel tot Paramaribo, tol de administrateurs of eigenaars, moest doordringen. Vooral in de regentiende eeliw hebben deze meestal gehoor aan de protesten moeten geven, wat in veel gevalien leidde - zij het soms met tegenzin - tot het onislag vas: de directeur in kwestie.

Zo berichtten de administrateurs van Jagtiust in 1803 dat de nieuwe directeur, Borgstede, al na enkele dagen was ontsiagen, vanwege problemen met de slaven. Deze waren fe wijten aan zijn 'criticq humeur', waarover de slaven 'hem onderhouden hadien'.49 Hetzelfde lot ondergir.g in 1845 de directeur van Zorg en Hoop, want hij functioneerde voigens de administrateurs niet naar wens en bleek 'ievens bi; de negermagt in minachting te zijn. geraakt'. 50

Illustratief in ait verband is de loopbaan van J.L. Guicherit. In :835 werd hij aangeste.d als directeur op de katoerplantage Zeezigt, waarbij ce admin:strateurs hem omschreven als een kundig persoon, van onbesproken zedelijk gedrag, kortom een braaf en oppassend mar'. In datzelfie jaar braken echfer grote orlusten uit op de plantage. Met enige verbazing constateerde administrateur J.L. Karsseboom toen dat de oorzaak daarvan alicen maar te vinden was in eene altegroottc ambitie van Guicherit dit Effect te pousseren en eene strikte regering intevoeren'. Ambitieus was Guicherit inderdaad, want in een paar maanden tijd had hij ruim 64 ha. nieuw land laten inpolderen. Daarnaast eiste hij var. de slaven, die sinds jaren gewend waren om acht uur met ce arbeid te beginnen, om zes uur op het veld aanwezig te zijn. Hij wierp de lont in het kruitvat toen hij de slaven voo: het nieuwjaarsspel dat zij tegoed hadden slech's vier dagen vrijaf wilde geven, omdat er sne: een partij katoen voor een klaarliggend schip moest worden afgewerk:. Tot dan toe hadden zij echter steeds acht dagen vrij gehad om te dansen, zodat Gujcherit hun een tweede dansperiode in het voorititzicht stelde dis zij de kius snel klaarder. De slaven hadden echter zo genoeg van Guicherits aanpai, dat zij na de eerste vier vrije dagen niet kwamen opdagen. Fvenmin gingen zij echter door met het nienwjaarsspel, want nog eens vier cagen bleven zij in hun woningen en gingen toen pas weer aan het werk. Een stil, maar duideli;k protest om niet met hun verworven rechten te marchar.deren. 
Dit alles kwam de administrateur ter ore, die daarop de zwarte officiers naar de stad onfbood. Deze verschenen echter niet 'onder voorwendzel dat de magt negers hun hierin tegenlield'. Daarmee was de zaak echter nog niet afgelopen, want toen Glicherit exkele dagen later drie slavinnen bestrafte, omdat zij hun werk slecht deden legden de overige vrowwen het werk neer en liepen 'in tumult' van de plantage weg. Met marronage had dit overigens niets van doen, want bij een verderop geiegen militaire wachtpost gaven zij zich vrijwiliig over.

Het is duidelijk dat Guicherit geen krediet (meer) had bij de slaver, die inclusief de bastiaans - een grote onderlinge solidariteit vertoonden. Fr was weinig voor nodig om de vlam in de pan te doen slaan en het stille protest veranderde in een luidruchtige actie. Opvallend is dat niemand zich vergreep aan Guicherit en dat het wegiopen van de vrouwen een demonstratief karakter lijkt te kebben gehad. A!s zij echt hadden willen weglopen, was dat niet met zoveel 'tumult' gebenrd. Bovendien trokxen zij zich niet verder terug dan de plaats waar een aantal van her in vroeger jaren had gewoond (de plartages Lunet!e en De Beste aan de Vredenburgerkreek) en gaven zij zich wel heel gernakkelijx over aan de daar anwezige militairem.

Pas op dat moment togen de twee administrateurs, Van Rees en Karsseboom, op pad om zelf op de piantage een onderzoek in se stellen. Zij moeten zich daarbi; tame:ijk ongemakkeijk hebben gevoeid, wart een van deze twee

'moet bekennen nog nooit [zo] een bratalen magt meiden gezien te hebben; de geesten waren zoo opgewonden dat waarij;k de grootste koelbioedigheid en bedardheid vereischt wierd om aeze Crisis ret beleid doortestaan niet tegenstaande de pl. dour de burgerij gewayend bezet was".

Niet zonder erige trots vermelden de administrateurs dat zij na anderhaif uur de rust hadden hersteld. De houding van de slaven dwingt echter meer respect af, want ondanks de op heri gerichte wapens van de iurgermilitie gaven zij luidkeels Litirg aan hun protest en formuleerden hun grieven. Volgens de aciministrateurs hadden zij klachten over het vele werk en de zware straffen die zij kregen - 'waarvan zij niet de minste bewijzen konden produceren' - en verder over 'verscheidene niets beduidende ingen', waaronder wellicht de arbeidsijden en het recht op acht dager. dansspel. De administrateurs oordeelden ecinter dat Guicherit niets te verwijten vie: en dat het allemaal maar baldacigheid' was. De 'belhamels' kregen daarom een ernstige afstraffing en de zwarte officierer. werden uit hin functie ontheven en samen met vier vrouwen var de pianiage yerbarren, waarschijnlijk naar een suikerplantage. Daarmee was de kous echter nog niet af, want miet lang daarna kwam de slavenmacht opniexw in beweging tegen Guicherit, die toen eindelijk werd ontsiagen. De slaven hadden het pleit 
gewonner en hun protestacties bleken een effectief middel om rechten en verworvenheden te verdedigen. Een aantal van hen heeft daar echter wel een hoge prijs voor moeter betalen. 51

$\mathrm{Na}$ de voorgaande gebeurtenissen verliezen wij Guicherit enkele jaren uit het oog, om hem dan te zien opduiken als directeur op Zoelen. Order zijn beheer werden daar ir. 1838 een stoommachine geïnstalleerd, nieuwe suikerrietaanplantingen gedaan en zestig slaven ter assistentie overgebracht van Jagtlust. I lij blijk! dus nog nog niets var: zijn ambities en voortvarendheid te hebben verlores, al waren dit nafuurli; $\mathrm{k}$ geen initiatieven van hem alleen. Maar ook anderszins was er weirig veranderd, want in 1839 ontvingen de administrateurs berichten over 'herhalde weglooperij' en 'onoverkomelijk groote onwil' onder slaven van Jagthust om op Zoelen te werken.

In plaats van eniggzins in te binden volhardde Guicherit ir. dezelfde houding, zodat ook de slavenmacht onrustig bleet. De administrateurs besloten dat het misschien zou kunnen helpen om de slaven van Jagtiust bij toerbeurt op Loelen :e laten werker, maar ook dat haalde de druk niet van de ketel. Sterker nog, Guicherit ging na zelfs ruzie maken met de directeur van Jagtiust, voor wie de controle op 'zi;n' slaven er, door toedoen van Guicherit, niet gemakkelijer op was geworden. Inmiddels had Guicherit toch kunnen weten dat het met een onwillige slavenmacht kwaad kersen eten was en dat hij caar bovendien zijn werkgever bepaaid geen dienst mee bewees. Onatwendbaar stevende hij dus weer op zijn ontslag aí, dat in 1842 incerdaad zijn beslag kreeg. ${ }^{52}$

Opnieuw vercivi;nt Guicherit eer poos;e uit het gezichtsvelc, maar in 1851 bleek hij te zijn aangesteld as cirecteur op De Nie:swe Grond. Meteen. ging het weer mis, want de administrateurs maakten met grote ongerustheid melding var. de 'onwillighe:d' die de slaven hadden getoond bij zijn aanstelling er. de straffen die daar het gevolg var waren. Wellicin was Cuicherits reputatie hem al vooruitgesnedd, of was hij weer te voortvarend van start gegaan. In ieder geval lukte het hem opnieuw om birner de kortste keren de slaven tegen zich in het harnas te jagen. Fn nog steeds was het hem niet duidelijk dat uiteirdelijk hij degene was die an het kortste eind zou trekien. Hernieuwde ongeregeldheden in de daaropvolgende jaren en de suggestie van de administrateurs om een kleine uitdeling te doen, wijzen er op dat hij de slaven weer veel te kort hield. Voor de zoveelste maal waren het weer de slaven die het van hem wonnen, wan: begin 1854 werd Guicherit door eer andere directeur vervanger, van wie

51 Alle gegevens over Zeezigt: Collectie-Insinger \& Co.: Iníormatiebock.

52 Collectie-:-nsinger \& Co.: Notulbock. 
men hoopte dat die 'zich beter met de negers zal weten te verstaan'.,53

In geen van de bovengenoemde gevallen was er sprake van geweld of agressie van de kant van de slaver. Steeds wisten zij echter op overduidelijke wijze kenbaar te maken dat $z i j$ zich in hun rechten en verworvenheden voelden aangetast. En het waren de slaven aan wie uileindelijk werd toegegeven. 54

Wanneer er nieuwe, meestal mildere, slavenreglementen werden ingevoerd, ontstonden vaak grote belangentegenstellingen tussen planters en shaven. De planters wiláen het liefst op de oude voet doorgaan en trachtten de regels zo flexibel mogelijk te interpreteren. De slaven daarentegen eisten een strikte naleving van de nieuw verworven rechten en liefst nog een beeije meer. Heel duidelijk bleek dat bij de invoering van het verniewwde slavenreglement in 1856 , die op veel plantages tol grote spanningen leidden. Zo ook op Vossenburg ${ }^{55}$, waar de administrateurs in december meldien

'dat de geregelde gang van zaken op Vossenburg geheel verstoord en op dat ongenblik daar alles in wanorde en onnust was: Sedert het gewijzigde Slavenreglement in werking was gekomen had vooral de bepaling dat de verlorene nachtrust moes: worcen gerestitueerd, de gemoederen der Slaven in gisting gebragt, niet alleen op de plantagier. met waterwerken, madr ook met stoom, ja zelfs op koffy plantagien, daar de negers over het algemeen weigerachtig warer. om na zes ure des middags iets meer te doen, en riettegentaande de Heer Uhlenkamp de Slaven nauwkelirig had bekend gemaakt met de juiste bepalingen van het reglement, en dit, in zijne gualiteit niet alleen van directeur en mede Administrateur mar tevens als kapitein van de divisie waarin Vossenburg gelegen is, toch wel geloof verciende bij de Negers, zoo hadden zij evenwel in navolging van andere magten in hunuen on wil volha:d zonder zich dan iets te storen. Het gevolg daarvan was geweest dat 13.11. Admin. zes negers in handen van de Procureur Generaal hadden gesteld, doch de regering begreep dat het vooreerst voldoende was om het volk door dien hoofdambtenaar met het reglement bekend te doen maken, cloch de slaven hadden deze toegevendheid

53 Collectie-insinger \& Co.: Brievenbuek.

54 Dat deze tactiek voor de slaven de meeste vruchten afwierp is lang niet altijd door onderzoekers van het negentiende-eeuws verzet begrepen. Zo constateerde A.rh. van Deursen (1975:215) met enige verbazing: 'Wet wat machtsvertoon lukt het doorgans ook cen handvol blanken de orde weer te herstel'en' en ": 7 ]elfs bewapende slaven laten het niet aankomen op een directe strijd net cen kieine blanke minderheid'. Het was echter ook niet dc becioeling van de slaven om het tot een gewelddadige confrontatie le laten komen. $\mathrm{Zij}$ gaven een demonstratie var hun machl om te Iaten zien dat met de door hen veroverde rechten en belangen niet mocht worden gesold. Verzct was voor hen dan ook niet keuze tussen opstand, gehoorzaamheid, of weylopen, zoals Van Decrser. stelt, maar een strategie gericht op het verdedigen en uitbouwen van belangen wasmee zoveal mogelijk iecfruimte binnen het systeem kon worden veroverd.

55 Alle gegevens over Vossenburg, Surinaams Muscum: Collectie-Brantsen, verslagboekjes 18.56 en 1857 . Soms konden de eisen nog veel verder gaan dan in het hier beschreven geval, zoals bleek in 1861 op piantage Berg en Dal, waar de negers verklaarden geen siaaf meer te willen zijn en voortaan loon voor hun arbeid wilden ontvangen (13ira 1982:168). 
aangemerkt als een bewijs dat zi; niet meer gestraft zouden worden, en niettegenstaande de toesprazk van den Procureur Generaal was daardoor de wanorde overal toegenomer, en de Slaven deder op het oogenblik op de meeste plantagien wat zij verkozen.'

Het is duidelijk dat de slaven zoveel mogelijk uit de nieuwe regeling trachtien te halen en lak hadden aan de blanke autoriteiten. Deze wilden in exste instantie het conflict riet laten escaleren en probecrden via overreding de orde te herste.len. Toen dit niet bleek te likken werd een stoomboot uitgerust, waarmee de procureur-generaal, vergezeid van een detachement militairen, optrok naar de opstandige plantages. Ook Vossenburg werd aangedaan, maar er vond geen strafoefening plaats, omdat 'er geene bepaalde belhamels of opruyers kondea worden aangewezen'. Bovendien vertelden de siaven het nieuwe seglemen: niet goed begrepen te hebben, waarna zij beloofden zich voortaan aan de wet te houden.

De slaven wisten dus duidelijk éen from: te vormen, maar bonden in op hel moment dat er niet méer uif de situatie te halen viel. Overigers werd de ecrste bastiaan wel dit zijn functie ontheven, omdat hij verantwoordelijk werd gesteld voor de abominabele suikerproduktie die het gevolg was van de onge:egeldheden. Ook werden citeindelijk nog vier s.aven voo: enige tijd raar verafgelegen plantages verinannen. De rust keerde daarop ir.derdaad terug en a:les ging, volgens de directeur, weer naar behoren. We: hielden de slaven zich zeer stipt aan de nieuwe regeling rond de restitutie van nachtarbeid, 'waarvan cie negers zooveel mogeijjk partij trokken, zonder dat er veel tegen gedaan konde worder:.

Natuurlijk xon verzet ook andere vormen aannemen. Len heel subtiele vorm spreekt uit een notificalie van 1763, die daarna nog verscheidene maler is afgekondigd. Daarin werden alle blanken gemaand slaven te straffen die 'zingen of spreeken mogte [...] op een wijze die hun quaadgezindheid of lust in oproer ende in asters der olanken aanwijsen' (Schiltkamp en De Smidt 1973, I1:767-8). Shaven hielder ervan spotliederer. te componeren, waarin allerle: social commentaar was verwerkt en die $z i$; kenneli,k openlijk ten gehore jrachten. Dat d:t het bloed oncier de nagels van de blanken vandaan haalde, bli;kt we: wit deze notificatie en de vele herhalingen ervan.

Een ander verschijnsel waar de pianters weinig tegen konden beginnen was brandstichting. Zeer bekend is de brand die in 1832 een groot deel van Paramaribo in de as legde en was aangestoken door Cojo, Mentor en Present. Maar ook op de plarioges kwam deze vorm van verzet voor, zij het dat e: reestal niets viel te bewijzen. Het kan daarom toeval zijn dat op een nacht in 1798 op Beekvliet plotseling de timmerloods on het korenhuis 


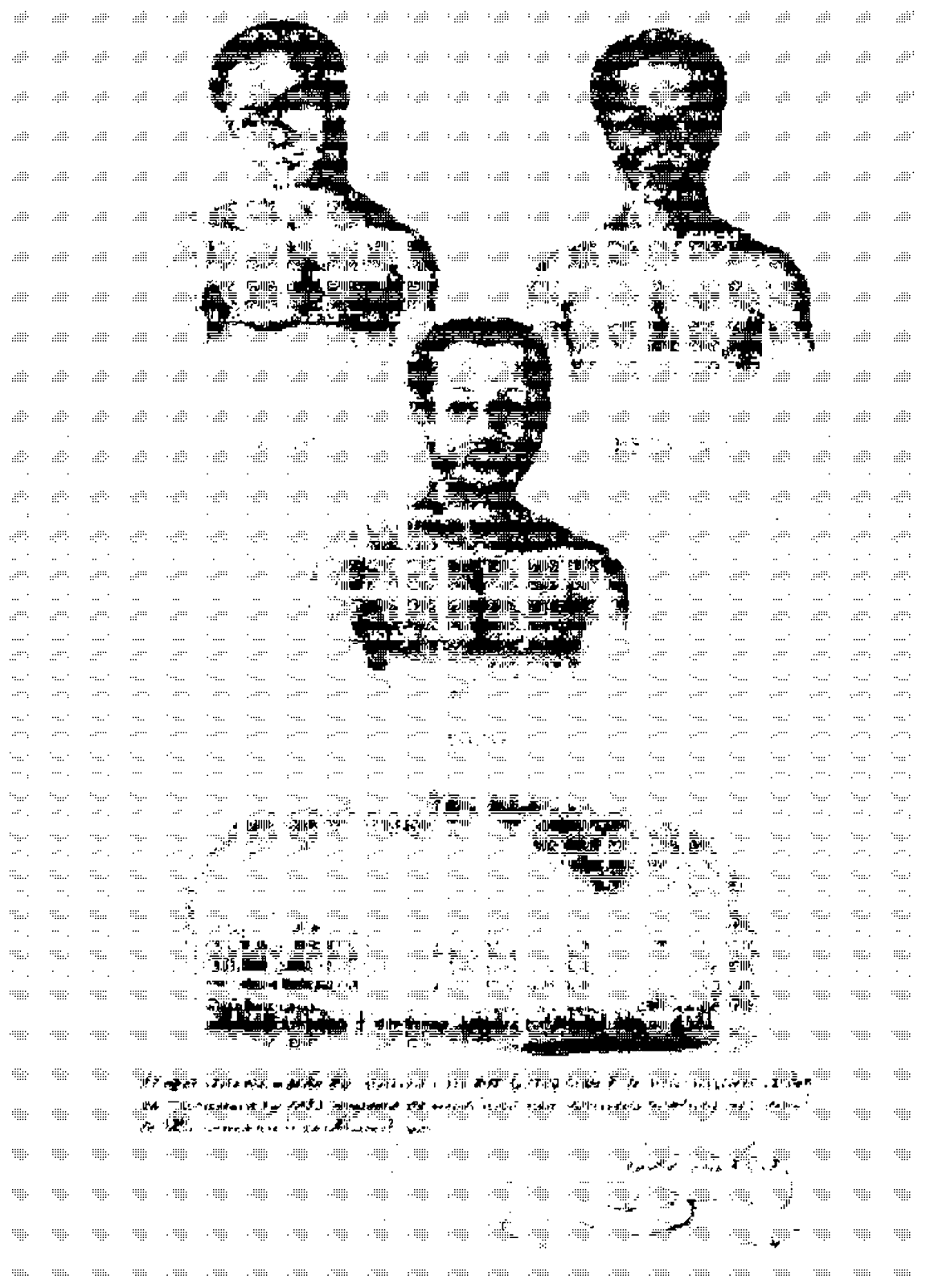

Negessiaver. welke bij vcunis van het Ceregtshof te Suriname op Gen 26er. Jandarij 1833, wegens de misdaad van Brands:ich:ing, enz. levend :e Paramar:bo veribrand zijn (Teens: 38 \& 2 to. titelpagina) 
afbrandden. ${ }^{56}$ Of Vossenburg, waar op een thacht in 18.30 twee trasloodsen volledig in as werden gelegd, maar geen spoor van brandstiching werd gevonden (men hiel'd dus wel rekening met de mogelijkheid!). Zou het dan toeval zijn dat de enige brand van deze omvang waar Vossenburg in de negentiende eeuw mee te maken kreeg, precies voorviel in het jaar met het hoogst aantal weglopers; tevens het jaar dat de administrateurs opmerkten dat de slavenmacht 'niet undergeschikt gehouden kan worden, wanneer hun moedwil en baldadigheid niet op eere serieuze wijze beteugeld wordt'57; en (dus) ook het jaar waarin het hoogste aantal slaven - onder wie liefst twee bastiaans - op fort Zee.andia werd afgestraft? Nogmaals, te bewijzen valt er niets, maar de relatie lig: wel erg voor de hand.

lets duidelijker lag het op Roosenburg, waar in 1856 het molen- en kookhuis volledig door brand werd verwoes: Over brardstiching werd eerst niet gesproken, maar jaren later achtte men opzet toch het mees: aannemelijk (Oostindie 1989:182). Het enige concrete bewrijs voor deze vorm van verzet is te vinden in de archieven van Clifford Kocqshooven, waar ir. 1821 de slaaf Frans in boeien. wera geklonken vanwege een poging tot branistichting. ${ }^{58}$

Ten prachtig voorbeeld van de subticle vorm die verzet kon aannemen en waaruit opnieuw de macht van de slaven spreekt, is het voorval dat Van Breugel in 1823 te horer kreeg van de directeur van Maria Petronella. Deze had onverwachte bezoekers te eten gekregen, waardoor hij genoodzaakt was bij de slaven enige kippen te kopen. Deze lieten echter weten dat zij die nu niet korden missen, wat hun zoete wraak was voor een door ceze directeu: genomen maatregel die 'hen riet aangenaam was geweest'. Het gevolg was dat hij nu kip moest kopen bij de slaver. van een ardere plantage, die meteen begrepen wat er aan de hand was 'en zij trekken dan eene lijn door hunne 'xoopwaren disurder te slijten' 59 Slaven van verschiller.de plantages

36 CAA: IPA-610, 564.

57 Surinaams Museum: Collectie-Brantsen, verslagboekje 1830.

58 KIT: Collectie-Van Breugel.

59 KIT: Collectie-Van Breugel, ;ournaai- in di: zeifde bandgeschreven joumaal gexeft Van Breugel nog een ronos voorbeeld van wat nok hij omschrijft als 'de magt der slaven over do blanken'. Wanneer hij zijn plantage voor de tweede maa: bezoekt mogen de slaven weer een nieuwjaarsdanspartij houden, waarbij het volgende vovrvalt: 'des morgens stond de gehecle magt von den deur, en toen ik verscheen verzorhten zij; mij np eerie leuniningstoe! te gaan zitten; ik werd onder verscheidene hoera's en 'ied;es het pein in processie - geheel in de hoogte - rondgedragen; ik zwaaide mel mijn pet, betoonde vele vreugde; doch rajpr hart was met nog veel grootere vecugde bezield toen ik weder grond voelcie. De dimkteur viel dezelfde eer, hoewel korter rondgedragen, te beurt; er. nu was het de beurt van den biankofficier die zij gewonelijk uit zijne woning gaan halen; doch daar hadden z:j ni get'n zin in; alzoo dezen niet naar hun zin handede: door wat al te streng te zijn. De direkteur liet hen vriendelijk verzoeken om den blankoffic:er te halen; doch zonder eenig gevolg; hij liep ze've saar de magt en verzocht het nogmaals vriendelijk, dat eveneens vruchteloos afl:ep; nu riep de direktetr mijne hulp in, waar tegen ik zeer wis gehoor te verleenen, daar ik mij ongaarne aan reme 
bleken dus uitstekend in staat elkaars belangen te verdedigen. Zij wisten daarbij de directeur gevoelig op zijn nummer te zetten, want waar was zo'n man nu beter te treffen dan in zijn eigen portemonnee? De directeur op zijn beurt restte niets anders dan zich maar aan te passen.

Uit alle aangehaalde voorbeelden van verzet blijkt dat er sinds he: eind van de achttiende eeuw veel was veranderd. Grootschalige plantage-opstanden of marronoorlogen kwamen niet meer voor, mar het verzet was er niet minder om geworden. Marronage bestond nog steeds, maar had grotendeels een andere functie gekregen. Verplaatsing van slavenpopulaties leidde tot grote conflicten, die meestal de verhuizing niet konden verhinderen, maar wel duidelijk de verlangens van de slaver etaleerden en sorns lejdden tot compromissen of gunstiger voorwaarden. Tientallen conflicten deden zich voor tussen slaven en management (vaak in. de vorm van een werksta. king), waarbij het meestal ging om de werktaken, dan wel - anachronistisch. gezegd - de secundaire arbeidsvoorwaarden. Oox op dil gebied wister. de slaven uitstekend voor hun belangen op te komen en trokken zij zelfs meestal aan het langste eind. Op subilele en ovix minder verfijnde wijze werden de protester vorm gegeven, maar vrijwel nooit loidde het, van de kant van de slaven, tot grof fysiek geweld. Op deze wijze wisten zij steeds meer ruimte te veroveren en vonden, vaker dan in de achttiende eeuw, de koloniale overheid aan nun zijde 60

De slavenbevoiking besiond ook nief meer overwegend, zoals in de achttiende eeuw, uit in vrijheid geboren en weinig gewortelde Afrikaanse 'immigranten', maar uit geboren Surinamers met gevestigde traditjes en belangen. Hun strijo was dan ook minder gericht tegen het systeem van plantageslavernij op zich en meer gericht op het veroveren van zoveel mogelijk manoeuvreerruim.te. ${ }^{61}$ Dat be:ekent wel dat de slaven nu hechter aan het systeem waren gebonden dan voorkeen, evenals overigens de planters aan hun slaver.

wrigering bloot wilde stellen; mij werdt rog,tans verzekerd dat ik geene weigering zou ondergaan; waarop ik de magt terug liet komen, can dezelve eene pathetieke aanspraak deed - daar ik nu de taal rezds zooverre magtig was - en het gten met ten 'lang leve pikien massera'

iang leve den cigenaar beantwoord werdt; dadelijk ook haalden zij nu den blankofficier, on droegen hem met eene stoel rond; het had evenwel meer van eene lijkstatie als vreugde betoon; en nadat zij hem wederom op den grond hadden geze!, hielden zij hem etne redevoering, die, volgens het verhaal van der direkteur, zeer just en krachtig moet geweenst zijn, alzos de blankofficier wel wat driftig en streng was."

60 De veranderende houding van de overheid wordr uitgebreid behandeld door Siwpersad (1979).

61 Ook Oostindie (1989:188) wijst er in zijn studie van Roaserburg en Mon Bijou op dat op deze plantages het slavenverzet steeds meer werd gekenmerkt door het laten gelden van rechten en het opbouwen van een onderhandelingspositic. 
Veranderingen in het karaxier van het verzet zijn ook in andere Caraíbische slavenmaatschappijen geconstateerd. De titel van Genoveses studie (1981) zegt wat dat betreft al genoeg: From rebellion to revolution. Hij benadrukt daarin dat tot eind achttiende eeuw verzet voornamelijik werd georganiseerd door Afrikanen (de meerderheid van de bevolking met de minste rechten ${ }^{62}$ ) en gericht was op het herstellen van een Afrikaanse levenswijze. Deze vorm van verzet was volgens Genovese niet revolutionair of 'modern', maar restauratief. Varaf het laatste kwart van de achttiende eeuw kreeg het slavenverzet een revolutionair karakter, onder invloed van het ideeëngoed van de Amerikaanse en. Franse revolutie, waarmee de slaven vitstekend bekend waren. Niet alleen de revolutie op Saint Domingue/Haiti was daarvan het gevolg maar alle regentiendeeeuws slavenverzet vond nu plaats 'within an international bourgeoisdemocratic mainstream' (Genovese 198:125). Het waren niet langer de Afrikanen, mar juist de creolen die het revolutionaire voortouw namen, omdat het niet meer ging om het herstellen van een Afrikaanse levenswijze, maax de omverwerping van he: systeem. En dus concludeert Genovese (1981:101): "t)he Africans had raised formidable rebellinns; the creoles were threatering revolution:

Voor Suriname geldt deze stelling niet. Eerder :ijkt het omgekeerde het geval te zijn geweest. De achttiende-eeuwse opstanden en marronoorlogen waren gericht op een omverwerping van het slavernijsysteem, terwijl het negentiende-eeuws verzed trachtte zoveel mogelijk ruimte binnen het systeem te veroveren. Evenmin is er aanieiding te veronderstellen dat Europese revolutionaire ideeër de Surinaamse slaven zouden hebben aangezet tof opstand. Wel een bron van inspiratie vormcien politieke ontwikkelingen waarbij slaven zelf betrokken waren, zoals de revolutie op Haiti en (geruchten over) de Emancipatie.63

In. zijn onderzoek naar slavenverzet in he: Brits-Caraỉsisch gebied kwam Craton (1982:243) eveneens to: de conclusie dat het de eigen vastberadenheid van de slaven was 'to make, take, or recreate a life of their own' en niet een (revolutionaire) inspiratie uil Europa. Wel makkten, volgens hem, de siaven bij hun verzet gebrik van de verdeeldheid, chaos en paranoïd

(2) As a result, the accommodation of the creoles may have llowed less from their easier adjustment to slavery thar. from their cultural distance from and even antipathy to the Africans, no doubt complicated by the creoles' access to more privileged positions on the plantations and in the towns and cities. A revolt that aspired to the resturation of an African way of life could have liftle appeal for creoles who had become partially Furopean in their emergence as Afro-Americans." (Genovese 1981:98-9.)

63 $\mathrm{Bij}_{\mathrm{ij}} \mathrm{de}$ afschaffing van de Afrikaanse slavenhandel in Suriname schreef do administrateur van Clifford Kocqshooven, 'dat de geest en denkwijze der slaven sedert 1791 [het jaar waarin de s"avenopstand op Hailti litbrak] veel verandert is, doch evenwel bedaard b:ijven' (KII: Collectie-Van 3reugel, uittreksel-brievenboek). Lie verder wok Bijlage 9B. 
angst' van de blanke machthebbers, die het gevolg waren van de revoluties in de Verenigde Staten, Frankrijk, Haiti en Latijns-Amerika (Craton 1982: 162-5). Het doel was echter niet om ook een rol te spelen in de 'bourgeoisdemocratische', of 'liberale' revolutionaire strijd van blanken, maar (meer) vrijheid veroveren voor zichzels.

Ook Craton ziet een verschuiving van de Afrikaanse overheersing in het slavenverzet naar een dominantie van de creolen. Afgezien van de veranderde samenstelling van de bevolking door de gestopte slavenimporten begin negentiende eeuw, was dit het gevolg van het algehele proces van creolisering. Slaven raakten steeds meer geworteld in het Caraibisch gebied, waar zij hun eigen culturen en instituties ontwikkelden en steeds meer rechten wisten te veroveren, zodat 'rebellion offered the open-ended extension of gains already won' (Craton 1982:251). Naluurlijk, zeg! Craton, is vrijheidsdrang aitijd de belangrijkste motivatie van slaververzet geweest. De vorm en het doel waren echter veranderd. De negentiende-eeuwse vrijheidsdrang was veel meer gaan lijken op die van een onafhankelijke 'peasantry'. Craton spreekt over de slaven in deze periode dan ook als 'proto-peasants', die al lang ervarir.g hadden met zelfstandige vormen van kleine landbouw, die deelnamen aan de geldeconomie en een eigen cultuur hadden ontwikkeld. ${ }^{64}$ Het regentiende-eeuws slavenverzet moet daarom volgens hem worden gezien als een belangenstrijd van 'proto-peasants'.

Deze uitdagerde analyse lijkt de werkelijkheid van Caraibische slavenmaatschappijen dichter te benaderen dan de interpretatie van Cerovese. In elk geval verklaarl het de ontwikkeling van het verzet in Suriname beter Het is daarom van belang na te gaan in hoeverre ook de Surinaamse slaven in de regentiende eeuw als 'proto-peasants' kunnen worder omschreven. ${ }^{65}$

64 [']]he freedom sought seems to have become that of an independent peasantry, a way of life about which the slaves had quite clear notions and of which, in most areas, they had already considerable experience. [M]any West Indiar, blacks were already what has been termed 'proto-peasants' well before the end of cormal slavery. In addition the slaves worked their provision grolinds using their own necthods with minimal supervision, and their new status was also demonstrated by the way in which the slaves had developed an internat marketing system quite independently and had managed to enter the casin economy on their own terms. More decply, the slaves retained and developed concepts of family and $x$ in quite beyond the comprehension and control of the master ciass and a concept of land tenure that was in contradiction to that of the dominant European culture. In brief, for ordinary siaves freedom meant bxing iree to be small farmers, working for the plantations, if at all, conly for wages and on their own terms. They wanted to live in family units, to have ready access 10 land of their own, and to be free to develop their own cLlture [...]. These basic aspirations varied according to the condisions in each of the colonies.' (Craton 19B2:252.)

65 Een duidelijice defiritie var. wat onder een 'proto-peasantry' moet worden verstaan wordt noch door Craton, noch door Mintz (1961), die het eerst deze term in de Caraibische context gebruikte, gegeven. In exen iatere publikatie? schrex? Mintz (1974:152): 'The proto-peasantry, then, are slaves who later became peasant freedmen, either through emancipation fas in the case of Jamaica) or revolution (as in the case of Haiti), and whose particular repertories of agricultural skills, craft techniques, crops and all else represen: important "blendings" of 


\section{Surinaamse slaven als 'prota-peasants'}

De vraag of ook Surinaamse slaven in de negentiende eeuw aan de hand van de door Craton genoemde kenmerken als 'prolo-peasants' kunnen worden bestempeld, kan gedecltelijk meteen positief worden beantwoord Al eerder werd namelijk duidelijk dat ook Surinaamse slaven een geheel eigen en onafhankelijke cultuur hadden ontwikkeld en eveneens op een geheel eigen manier verwantschap definieerden.

Ook slaven als tamelijk onafhankelijke agrarische producenten kwamen al even ter sprake in het voorval op Maria l'etronella, waar de directeur veel moest betalen voor zijn kippen. Daar bleek dus het plantagemanagement soms voor zijn voedselvoorziening afhankelijk te zijn van de slaven. Dat deze handel van slaven geen uitzondering was en zich veel verder uitstrekte dan enkele bijeengelegen plantages, blijkt uit Van Breugels algemene observatie: 'zij houden kalknenen, eenden, kippen enz; en doen daar tot aan de stad Paramaribo negotie in'.66 Hoe die handel zich voltrok blijft duister. Dat er produkten van en door plantageslaven in de stad op de markt werden gebracht staat buiter kijf. Bovendien was het aanbod zeer gevarieerd:

'Men vindt er twee [markten] die rijkelijk voorzien zijn van vruchten die het seizoen biedt, zoals ananas, pompelmoes, sinaasappelen, acajou, guave, sapodilla, markuesa, papaja, marmelados, watermeloenen, cantaluupe en vele anderen. Men ziet er ook veel gevagelte waarvan het land krioelt, kalkoenen, eenden, kippen, enz. en verder zijn er groenten zoals bananen, groene kool, wortels, peterselie, pimpernel, andijvie, uien, aardappelen, verschillende soorten sla, spaanse peper, kamperfoelies, cassave, hetzij als brood, hetzij als wortel en nog veel meer. Het zo' te ver voeren dit alles te beschrijuen. De verkoop gebeurt gewoonlifk door negerslaven en creolen wan de plantages of van de combé's [buitenwijken], begint om zes uur 's morgens en duurt tot ongeveer drie of vier luur in de namiddag.' (Benoil 1980:34; mijn cursivering.)

traditional and new materials. Commonly among such peasantries today, onc finds both African religious elements; African crops and European, $A$ sian, and Amerindian crops; African food-processing terhniques and food-processing techniques from many other areas; and so on. Those of a proto-peasane past form the largest Caribbcan peasant catcgory, both numerically and in terms of historical origins. But this category has remained rather poorly deined, in contradistinction in other categories of rural agrarian people in the region.' Dit hiengt ons ook niet veel verder. Uit de beschrijvingen van de Caraibische 'proto-peasantry van Mintz en Craton kunnen echter ecn aantal centrale elementen worden ondersheiden. linnen de context van een plantage-eronomie gebaseerd op slavernij, gaat het om een agrarische bevolking met een geheel eigen cultuur, produktietechnieken en gewassen, die - voor geld en gedurende slechts een beperkl deel van hun $1 \mathrm{jjd}$ - produceren voor een lokale markt, die zij voor een groot deel zelf in handen hehben, maar waarvan zij voor hun reproduktie slechts in geringe mate afhankelijk zijn.

to KIT: Collectis Van Breugel, journaal. 


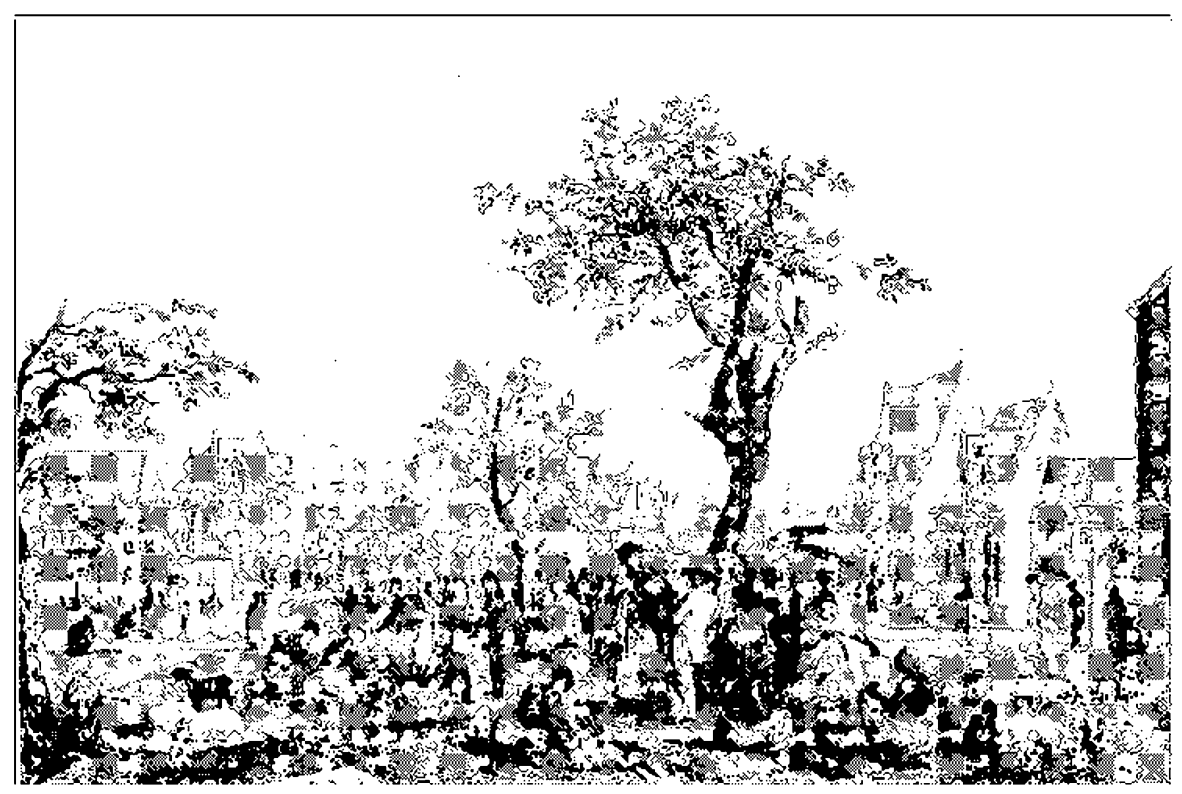

Gezitht op de grole matkt roor groenten, fruit un pluimvee

(Bencit 1080 foto 13 ) 
Op deze manier verwierven de plantageslaven enige inkomsten, welke volgens Van Breugel 'tot opschik besteed' werden.67

Over de wijze waarop de agrarische produktie van de slaven plaatswond is helaas niets bekend. Het is niet onwaarschijnlijk dat planters en overheid deze eigen produk!ie hebben gestimuleerd. $Z 0$ was er in 1858 op Santa Barbara 'een menigte plimvee hetwelk de slaven behoort' en beschikten zij over 'eigene kleine kostgrondjes door hen tot eigen voordeel bebouwd' .8 Het voordeel caarvan was dat de planters zich minder hoefden te bekommeren on de voedselvoorziening van de slaven en de inkomsten die de slaven daaruit eventueel verwierven hielden hen tevreden. Lammens (1982:113) merkte riet voor niets op dat het goed was om de slaven pluimveehouderij en dergel:jke toe te staan, want 'dit maakt hun gehegt aan de plantagie en aan den meester. Anders gezegd: wie wat heeft, heeft ook wat te verliezen en zal daarom ook niet zo gauw (definiticf) weglopen of in opstand komen.

Er waren vooral in de negentiende eesw echter nog meer manieren waatop slaven wat geld verdienden. Kundige mannen en vrouwen konden door het genezen van slaven of assisteren bij bevallingen een aardig cerstje vergaren en op sommige plantages raakte het in gebruik om kraammoeders na de bevalling een douceurtje van enkele guldens te geven, ter stimulering van de bevolkingsgroei.69 Ook voor ambachtslaver was het niet zo moeilijk iels te verdienen. In hun vrije tijd verrichtten zij reparaties of maakten zij

\section{6i KIT: Coliertise Van Bre:1ge!, joumaal.}

68 ARA: Suriname na 1828 Administratie van Financien, 130. Zie verder ook Hoofdstuk XI.

69 Enkele vooribelden: Op Vossenourg verdiende de vierde bastiaan J'rofijt alleen al in 1825 en 1826 Sf 60 voor het genezen van enkeles slaten (Surisaams Museum: Collectie-Brantsen, kasrekeningen).

De in 1811 geboren slaaf Adolf Frederik word door zijn meester in de leer gedaan bij dr. Steglich en later dr. Gravenhorst. Hij wordt een veelgevraagd geneeskiandige en weet zich op zijn 36 jaar vri; te kopen. Mij is dan bekend ais dr. A.F. Gravenbergh (Oudschans Deniz 1931:147-152).

In 1858 werdt voor de slavin Truitje van Meerzorg $5 f 12$ betaald aan de slavin Joharna van plantage Tourtonne voor assistentie van 'Truitje 'die nnverwachts aan de stad gekraamd heeft' (ARA: SOB\&W 1828-1876, 3036).

Groot Marseille was bijwoorbeeld eun van de plartages vaar de zwangere vrouwen al in de jaren 1820 en'kele guldens 'ter hand gesteld' kregen.

Op het gebied van de geneeskunde vinden wij overigens oprieuw een bewijs van de kracht van de slavencultuur, want Nassy (1791, 11:55-60) beschreef eind achteiende eeuw a; hoe de behandeling door blanke geneesheren 'word: ornut gemaakt, door dien men er, in 't algemeen, de zoogenaande gereezingen der Negers meê vermengt; en deeze speelen daar eene graote rol met hunne kruiden en voorgewende genexzingen, wwel onder de Christenen als onder de Jooden; want niet?egenstaande het bedrog van deeze lapzaivers, en de afschuwelyke plegtigheden waarvan zy zich bedienen, en welke vooral den geenen, cie belydenis van eenen Codsdienst doen, orwaardig zyn, worden zy in Suriname als voor l'rofeeten gehouden. En even verderop schampert hij: 'Het is genneg, dat men zwart van kleur $7 y$, om meer dingen te konnen doen dan al'e blanke Geneesmeesters te samen. Dit blinde vertrouwen doet de vrouwen dikwyls, en in verscheyden opzigten, tot eene zeer wraakbaare ligtgeloovigheid vervallen.' 
allerlei voorwerpen voor de verkoop. Daarnaast kregen $z i j$ vaak wat toegestopt als zij extra arbeid hadden verricht, of een gecompliceerde klus hadden weten te klaren zonder (dure) hulp van buitenaf.70

Minder legale middelen om aan geld te komen werden evenmin door de slaven geschuwd. Afgezien van de handel in allerlei voorwerpen die werden verdonkeremaand uit de direcleurswoning of andere plantagegebouwen, werd ook wel eens een deel van de produktie verduisterd en verhandeld. Zo meldde de directeur var De Nieuwe Grond in 1842 dat op de verlaten buurplantage Beninenburg regelmatig 'verdachte' vrijlieden verblijf hielden. Hij had bij her een hoeveelheid bananentrossen aangetroffen die daar 'niet anders dan door de slaven uit den buurt konden zij bijeen gebragt'.7!

Ook de (soms twee-)jaarlijks uitgedeelde slavengoederen werden voor de handel gebruikt. Dat blijkt althans wit de woorden van Kuhn (1828:86-7) wanneer hij de pianters aanraad: de verstrekte kledingstukken te merken en deze regelmatig te controlerer. Volgens hem was dat de enige methode om aan de kwanselarij der Negers in het verkoopen hunner zoo noodige kleedingstukken paal es. perk te stellem'.

Door al deze vormen van inkomsterverwerving moet op den duur een aanzienlijke hoeveelheid geld onder de slaven in omloop zijn gekomen, die niet alleen aan 'opschik' werd besteed, maar ook als sparmiddel diende. Dat bleek ijvoorbeeld toen in 1854 werd besloten binnen twee maanden een aantal oude muntsoorten uit de roulatie te nemer. Volgens de Koloniale Raad was deze termijn veel te kort, omdat vele plantageslaven in het bezit zijn van vele oude mumtstukken: ${ }^{72}$

Kortom, het lijkt er op dat in de negentience eeuw al een basis is gelegd voor wat veel later de 'hosselcultuur' is gaan heter, functionerend in een informeel economisch circuit. Natuurlijk betekende dit niet daf slaven er rijk van werden. Slechts een enkeling I ikte het zichzelf vijj te kopen. Het betekent daarentegen wel dat de siaven betrokken werden bij de geldeconomie en daardoor steeds meer gebonden raakten aan het systeem. Dit. sluit direct aan bi; de eerdere constatering dat het karakter van het negen-

70 Enkele vorbeelden: Op Meezzo:g wordt, vanwege de ziekte van twee kuiperslaven, in 1858 aan de overige kuiperslaver $f 6$ betaald 'voor het meerdere malen dan hunne dagelijksche taak van 6 suikervaten' (ARA: SOB\&-W 1828-1876, 3036).

Op Vossenburg maken de timmęrslaven in 1851 geheel zelfstandig en nieuwe houken stoel voor de molen, waardoor 'enige Honderde Guidens' worden uitgespaard op een molenmaker. 'Als eene beloning voor hun goecie werk hadder H.H. Adm. aan de Plantagie timmerlieden $f 50$ ten gescherke gegeven' (Surinaams Museum: Co'lectie-Brantsen, verantwoorde rekening 1851).

71 Collextie-Insinger \& Co., Notulboek.

72 Geciteerd in Van Deursen 1975:218. Hierin wordt verder ook verhaald yan een der bastiaans van plantage Vermaak, die in 1847 naar Paramaribo reisde met een trommel 'papiergeld van de slaven' on dat bij de bank te gaan inwisselen tegen zilver. 
tiende-eeuws verzet werd getypeerd cioor verdediging en uitbouwen van veroverde rechten en belangen. In combinatie met de relatieve verzachting van het slavernijregime in deze.fde periode, wordt daarmee de indrik opnieuw versterkt dat het gedrag en de positie van de negentiende-eeuwse slaaf in belangrijke mate verschilden van zijn achttiende-eeluwse voorganger. Nog steeds werd hem door de planter een bepaalde hoeveelheid arbeid en discipline opgelegd. Meer en meer ging de slaaf zelf daarvan echter de grenzen bepalen, daarbij enigermate gesteund door de overheid. Daarnaast had hij een eigen cultuurwereid geschapen, verrichtte hij ook arbeid ten eigen bate en nam hij deel aan de geldeconomie. Het op alle mogeiijke manieren verwerven van inkomsten lijkt een belangrijk facet te zijn geworden van het negentiende-eeuwse slavenlever. Volgens Mintz (1974: 155), die op Jamaica hetzeifde verschinsel constateerde, werd geld onder andere een middel om respect mee af te ciwirgen, ook bij de blanken. Het verhoogde het gevoe! van eigenwaarde, waardoor het enerzijds kan worden beschouwd als een teken van toenemende Westerse invloed, maar tevens als uitirg var. verzet. Het feit dat na de Emancipatie veel slaventamilies hun gespaarde geld hebben gebruikt om verlaten plantages te kopen (Heilbron 1982) diddt er niet alleen op dat grondbezit vom hen van speriale betekenis was, maar is tevens een indicatie dat het doel van het slavenverzet steeds meer verbonden was geraakt aar. een 'even a's onafhankelijke. 'peasant'.

Het is nog iets te voorbarig on de negertiende-eeuwse plantageslaven in Suriname definitief als 'proto-peasants' te typeren. Daarvoor zal eerst nog meer onderzoek moeter. worcen gedaan naar de omvang en de structuur van de onafhankelijke slavenproduktie, de hancielsnetwerken, de gegenereerde inkomsten en het bestedingspatroon. Toch zijn er al volduerde aanwijzingen om zo'n typering in ieder geval niet a's lichtzirnig van de hand te wijzen.

Betekent dit mu dat de achttiende-eeuwse sla af moeten worden gexien als een riet-gecompromitteerde held en de regentiende-eenwer als een door het systeem ingekapselde materialist? Bepaald niet. $\mathrm{Zij}$ moeten riet worden beschouwd als twee losstande antagonisten, mar als gemeenschappelijke deelnemers aan een continu proces van overleven. Juist dan dwingt het alle respect af te zien hoe de slaven op geheel eigen wijze, zowel materieei als immaterieel, een relatieve onafhankelijkheid hacden weten op te boliwen en te beschermen. De emancipatie had daarom al lang voor 1863 een aanvang genomen. 


\section{HOOFDSTUK XJII}

\section{De dynamiek van overleven}

In deze studie is met Suriname als voorbeeld onderzoek gedaan naar de dynamiek van een plantagekolonie gedurende de slavernij. Door de plantage centraal te stellen kon een verbinding tot stand worden gebracht tussen de twee denkwijzen die het onderzoek nat deze samenlevingen tot $\mathrm{nu}$ toe hebben gedomineerd, namelijk een politiek-economische en een sociaal-culturele benadering. Zo kon het functioneren van de plantage worden geanalyseerd, evenals de rol die alle betrokken actoren daarin hebben gespeeld. Aangezien de uitkomsten yan deze analyse geldigheid moesten hebben voor het geheel van de plantage-economie, werden op micro-niveau de gegevens van enige honderden plantages gebundeld tot representatieve stcekproeven. Op basis daarvan konden uitspraken worden gedaan op macro-niveau over ontwikkelingen in de plantage-cconomie in.

Het resultaat van deze benadering is onder meer dat met een groot aantal historiografische misvattingen kan worder afgerekend en dat vergelijking mogelijk is met andere Caraibische plantagekoloniën. Het belangrijkste is echter dat kan worden aangetoond dat de Surinaamse plantage-economie voortdurend in beweging is geweest en een karakteristieke dynamiek vertoonde. Deze werd gekenmerkt door de interactie tussen twee dominante processen, roofbouw en overleven, waar de zorg voor de reproduktie centraal stond. Ook bleek de plantage-economie riel één vormloos geheel te zijn geweest, maar een samenstel van verschillende sectoren, waarin het ritme en de invloed van de processen duibelijk verschilde. De veranderíngen die hierdoor tussen 1750 en 1863 in de: Surinaamse plantagekolonic zijn teweeggebracht worden hieronder nog eens vanuit verschillende invalshoeken getoond.

Halverwege de achttiende eeuw was Suriname het commerciële eigendom van de Geoctroyeerde Sociëteit van Suriname, onder supervisie van de Nederlandse Staten-Generaal. Gezamenlijk benoemden zij een Gouverneur, die als hoogste gezagsdrager in de kolonie belast was met het dagelijks bestuur. Meestal waten deze Gouverneurs voordien nog nooit in Suriname geweest en bovendien was het verloop onder hen groot. Toch verkregen zij soms aanzienlijke belangen in de plantage-economie. Dat betckcnde echter 
niet dat hun positie stabiel was, want de machtige planterseite betwistte vaak hun formele gezag. Slepende conilicten en gebrek aan continuiteit in beleid en bestuur waren het gevolg.

Wettelijk was vastgelegd dat de enige functie van de kolonie bestond uit de produkt:e van tropische gewassen (eerst voornamelijk suiker, later ook koffie en katoen) voor de Nederlandse markt en dat alle daarmee verband houdende economische activiteiten in het moederland moesten plaatsvinden. Suriname zorgde a.leen voor grond en verder moesten alle andere produktiemiddelen en benodigdhecien uit Nederland, en Afrika, worden ingevoerd. Hierdoor was de plantagekolonie met harden en voeten gebonden aan de Nederlandse economie. Over:gens was ook de economische politiex van Engeland en Frankrijk op zulke mercantilistische principes gebaseerd.

Dit systeem vertoonde een aar.tal zwakke plekken. Zo was het transport een kwetsbare schakel; oorlogen, natuurgeweld en piraterij yormden een constante bedreiging voor een geregelde aanvoer en jitvoer. Daarnaast kon de WIC, een van de eigenaars van Suriname, al spoedig niel meer voldoen aan de verplichte leverantie van slaven waarop $z i$; het monopolie bezat. Deze negotie is toen door particuliere siavenialers overgenomen. Voor de WIC, een mercantilistisch instituut bij uitstek, betekende dif het begin van het einde. Find achttiende eeuw werd zij opgehever, evenals de Geor. troyeerde Sociëteit van Suriname, waarin zij toen nog voor ce helft participeerde.

Ook werd dit sterk protectionistische stelse! door Nederland minder consequent gehandhaafó dan coor de concurrenten. In tegenstelling tot bijvoorbeeld het Britse systeem genoten de Surinaamse produkter. geen enkele bescherming op de Nederlardse markt. Altijd hebben zij moeten corcurreren met buitenlandse produkter. Bovendien werden in de achttiende eeuw enkele van Surinames direcie mededingers met Nederlands kapitaal gefinancierca. Dit alies was een gevolg van het feit dat de Nederlardse handelsnatie tot bloei was gekomen door als intermediair op te treden tussen andere landen, die produktiegebieden van veel grotere omvang beheersten. Deze positie wilde Nederland ten koste van alles behouden, zodat weinig aandacht werd besteed aan de produktie in de 'eigen' kolonie Suriname, laat staan dat die door protectie zou worden bevoordeeld. Economisch gezien had Suriname daarom alleen maar plichten en nauwelijks rechten. En aangezien het beheer over de plantagexolonie in handen was gegeven van een comnerciële insteliing die voor een belangrijk deel was gebaseerd op een zieltogende WIC, lieten de Nederlandse machthebbers zich weinig gelegen liggen aan Suriname. Daar komt bij dat er, in tegenstelling tot Engeland en Frankrijk, in het algemeen geen naliwe banden bestonden tussen de plantersklasse ir. Suriname en de machtheboers in Nederland. 
Aldus kregen de Surinaamse belangen geen politieke steur. De achttiendeeeuwse relatie tusser Nederland en Suriname was door dit alles eenzijdig en werd gekenmerkt door gebrek aan bescherming. Kortom, er was nauwelijks aandacht voor de reproduktie van de plantage-economie.

In de loop van de negentiende eeuw veranderde de verhouding tussen beide landen ingrijpend. Nederland was binnen de wereldeconomie teruggevallen naar het tweede of derde plan, de machtige handelsklasse had betekenis verloren, 'moderne' industrialisatic was nog niet op gang gekomen en de bestuursvorm was nu een constitutionele monarchie. In 1848 was Suriname een directe kolonie van de Nederlandse staat geworden, bestuurd door een Gouvemeur die verantwoording verschuldigd was aan de Koning en zijn Minister van Koloniën. Bestuur en rechtspraak, voorheen in handen van de Gowverneur en de planterselite, waren nu gescheiden en werden, naast de toch nog machtige planters en administrateurs, dour professionele ambienaren verricht.

Ir het algemeen werd ru meer andacht besteed aan de vormgeving en uitvoering van het koloniaal beleid. Tr werden initiatieven genomen ter stimulering van de plantage-economie en, uit goedbegrepen eigenbelang, kwam er meer aandacht voor de slaven (betere juridische status, nieuwe reglementen, voedingsonderzoek, stimuleren van kerstening). Ook werd, vooral onder druk van Engeland, de import van slaven definitief stopgezet en begonnen in de jaren 1840 , eveneens als gevolg van internationale en binnenlandse pressie, de eerste discussies over het emancipatievraagstuk.

Het eenzijdige exclusiviteitsbeginsel, dat nooit helemaal waterdicht was geweest, blexe weliswaar nog lang de relatie tussen Nederland en Suriname bepalen, maar werd in de negentiende eeuw steeds meer uitgehold. Zo gingen Surinaamse handelaars, die niet uitsluitend op Nederland waren gericht, een steeds belangrijker rol spelen in de plantagekolonie, het kapitaal kwam niet meer alleen uit Nederland en Britse planters in Suriname werd toegestaan hun produkten in Engeland op de markt te brengen. Uiteindelijk werd in 1848 het officiële monopolie op de handel met Suriname afgeschaft, zodat de plantage-economie nu niet meer per definitie aan de Nederlandse markt was gebonden. Verder was het transport veiliger en sneller geworden, zodat de communicatie tussen beide landen ook vlotter verliep.

Kortom, het beleid van de Nederlandse overheid veranderde geleidelijk en onder druk van de onstandigheden. Langzamerhand $\mathrm{kwam}$ de nadruk te liggen op het overleven van de plantagekolonie. Dal betekende dat er meer aandacht werd geschonken aan de reproduktie van alle elementen die deel uitmaakten van de plantage-economie. Dat moest onk wel, want voor de Nederlandse staat ... niet voor de economie - betekende Suriname een 
jaarlijkse verliespost. Alleen al uit kostenoverwegingen was het daarom noodzaak voorwaarden te scheppen waardoor de plantage-economie optimaal en harmonieus kon functioneren.

De rol van de Nederlandse koopman-bankiers is in de loop der tijd eveneens sterk gewijzigd. Tot halverwege de achttiende eeuw waren zij weliswaar belangrijk, maar nog niet dominant in de plantage-economie. Zij verrichtten voor de Surinaamse planters, tegen betaling, alle noodzakelijke transacties in Nederland, voorzagen hen van een rekening-courant en waakten er voor dat deze niet te hoog oplirp. Daarbij was sprake van cen wederzijdse afhankelijkheid, want wanneer de planter niet meer bij hem in het krijt stond kon deze zonder enig bezwaar een relatie aangaan met een andere koopman.

Met de oprichting van negotiatiefondsen, onder hun directie, maar voorzien van vreemd vermogen, wisten de koopman-bankiers in het derde kwart van de achttiende eeuw deze situatie radicaal te veranderen. Door het overvloedig verstrekken van hypotheken, die niet op de werkelijke produktiewaarde van de plantages waren gebaseerd, wisten $x \mathbf{i j}$ de planters volledig aan zich te binden. Zelf liepen zij nauwelijks risico - het ging voornamelijk om beleggingskapitaal van derden - en zij waren voor lange tijd verzekerd van de uiterst lucratieve provisies die zij op alle handelingen voor de planter én het fonds hieven. Toen de planters niet meer in staat bleken de geleende gelden terug te betalen, maakten $z$ ij van de gelegenheid gebruik de betrokken plantages voor de som van de schuld te kopen.

Voor de meeste obligatie- en aandeelhouders in de fondsen betekende dit een gevoelig verlies, al sprongen degenen die hun stukken bleven vasthouden er op den duur vaak beter uit dan wel is gesuggereerd. De koopman-bankier bleef echter verzekerd van de aanvoer van produkten (vaak op zijn eigen schepen) en van zijn provisies. Bovendien bepaalde hij nu, voor zover mogelijk vanuit Nederland, het te voeren beleid op de plantages. In praktijk betekende dit dat ten koste van alles zo veel mogelijk moest worden geproduceerd tegen zo min mogelijk kosten. Zorg voor zulke kostbare zaken als reproduktie en innovatie van de produktiemiddelen was daarom niet zijn eerste belang. Wanneer op een gegeven moment ook voor de fondsdirecteur de plantage nauwelijks meer rendabel was, probeerde hij deze te verkopen, vaak aan een in Suriname woonachtige planter die de slaven goed kon gebruiken. Na aftrek van zijn eigen provisie werd het restant van de verkoopsom, voor zover aanwezig, als laatste afbetaling aan de overgebleven aandeelhouders uitgekeerd.

Op die wijze hebben de negotiatiefondsen zichzelf op den duur opge geten. Hiermee was de koopman zijn provisiehandel $\mathrm{kwijt,} \mathrm{maar} \mathrm{meestal}$ was hij dan al lang niet meer in Suriname geïnteresseerd en had zijn activiteiten op andere gebieden, bijvoorbeeld Nederlands-Indië, gericht. Het 
gevolg was dat de koopman-bankiers, die rond 1780 bijna vier-vijfde var de ongeveer 400 plantages aan zich gebonden wisten, halverwege de negentiende eeuw geen rol van betekenis meer speelden in de Surinaamse plantage-economie (een-zesde deel van de 189 plantages was toen nog in bezit van fondsen).

Meer dan wie ook zijn deze fondsdirecteuren de exponenten geweest van het roofbouwproces. Zij waren het dic de Surinaamse plantagekolonie met enorme kapitalen overspoelden, zonder rekening te houden met de reproduktic daarvan. Weliswaar leidde dit tot een spectaculaire expansie van de koffiesector, maar door hun toedoen werd diezelfde sector ook weer om zeep geholpen. $\mathrm{Zij}$ waren degenen die genoegen namen met opgeblazen en frauduleuze taxaties. $Z \mathrm{jj}$ waren het ook die er geen moeite mee hadden dat ondeskundige parvenu's met opgedrongen hypotheken tot planters werden gebombardeerd. En $z \mathrm{ij}$ waren het die de beleggers volstrekt in het ongewisse lieten over de gang van zaken, hen met muoie beloftes bleven paaien, of hen eenvoudig voorlogen. I Iet enige dal voor de koopman-bankiers telde waren de vele provisies die zij op alle transacties konden opstrijken. Dat door dit kortzichtige beleid de beleggers hun kapitaal kwijtraakten deerde hen nauwelijks. Laat staan dat zij er zich om bekommerden dat door hun niet te bevredigen behoefte aan omzet de (koffie) plantages steeds meer uitgeput raakten en de slaven steeds harder moesten worden opgejaagd.

De gevolgen van deze vorm van roofbouw waren verstrekkend. Het vertrouwen van het Vederlands kapitaal in de Surinaamse plantage-economie was voor lange tijd geschokt en heeft zich nooit meer geheel hersteld. Absenteisme werd een dominant verschijnsel en had de heerschappij van, vaak ondeskundige, administrateurs tot gevolg. De koffiesector stierf een langzame dood, waarvan de gevolgen, zoals de steeds moeizamer strijd tegen het water, ook in de rest van de plantage-economic voelbaar waren. Het mag bijna een wonder heten dat niet de gehele plantage-economie werd opgedoekt.

Dat dit einde er toch niet kwam was het werk van planters die minder op roofbouw en meer op overleven waren gericht. In de achttiende eeuw waren deze vooral te vinden in de suikerbranche, in de negentiende eeuw ook in de nieuwe katoensector. Suikerondernemingen vormden de oudste sector van de plantage-economie en sommige planters behoorden in de tijd van de negotiaties al tot de tweede of derde generatie. Dit kan er toe hebben bijgedragen dat men in deze sector veel meer zorg droeg voor de reproduktie, al gold dat niet de slaven. Zo was rotatie een algemeen aanvaarde praktijk en innoveren geen onbekend verschijnsel. Ook financieel ging men doordachter te werk, want ongeveer de helft van deze sector was niet met een negotiatiefonds in zee gegaan en het lijkt er op dat, als men dat 
toch deed, het geleende kapitaal produktiever werd gebruikt dan in de koffiesector.

Het gevolg was dat deze sector veel minder gehavend de negentiende eeuw is ingegaan dan de koffieplantages. Daarbij bleek de op reproduktie gerichte mentaliteit niet verloren te zi;n gegaan, wanl de suikerondernemingen toonden zich, $\infty$ in vergelijking met elders, zeer innovatiee. Dit leidde niet alleen tot nieuwe expansie, maar bijvoorbecld ook tot de snelste demografische groei in de plantage-economie. Dat dit inderdaad samenhing met een traditioneel andere mentaliteit dan in de koffiesector blijkt uit de kwaliteit en achtergrond van de dertien besproken topadministrateurs in 1824. Van de zes die a.'s kundig te boek stonden, waren er vijf met familiebanden verbonden aan de achttiende-eeuwse planterselite met belangen in de suiker. Van de zeven minder goed bekend staande topadrinistrateurs hadien slechts twee zo'n achtergrond.

Natuurlijk leed ook de suikersector onder de schuidencrisis en waren er eveneens planters die niet innoveerden. Hiendoor vermirderde tussen 1750 en 1810 het aantal plantages met bijna een-derde, de siavenbevolking met bijra de helft en het suikerareaal met ruim een kwart. De totale produktie bleek echter in 1810 weer op hetzelfde niveau te liggen als in 1750. Ook dit was een teken van de meer op reproduktje gerichte mentaliteit die in deze sector heersie en de plantages de veerkracht verschafte om in de negentiende eeuw tot rieuwe bloei te komer.

Het waren echter rie: alieer suikerplanters die het overleven van de plantage-economie hevben bewerkstelligd. Begin negentiende couw kwamen er twee nieuwe groepen planters bij die de katoensector hebben opgebouwd. Men kan zelfs zeggen dat het ging het om drie groepen, want een klein deel van hen bestond uit voormalige koffieplariters die op tijd hun plantage hadden omgebouwd tot een katoenondememing. Op zich was dit een teken van overleven, maar hun aanpak getuigde soms nog van een roofbouwmenta.iteit door hun te lange doortelen met dezelfde bomen, het toenemend aantal bomen per akker en het gebrek aan vernieuwing. Daarnaast kwam er een groep katoenplanters die vooral bestond uit gefortuneerde admiristrateurs. Toen veel plantages voor spotprijzen werder. verkocht namen $z \mathrm{ij}$ hun kans waar en begonnen katoer te verbouwer. Anderen stichtten zelfs nieuwe plantages langs de noordoostkust van Suriname. Sommigen van hen waren behept met de oude roofbouwmentaliteit, terwijl ancieren een meer innoverende aanpak voorstonden. Het laatste zal in belangrijke mate een gevolg zijn geweest van het feit dat zij hun plantages voor een groot deel met eigen kapitaal hadden opgebouwd.

Daarmee was tevens cen nie:uw element in de plantage-economie geintroduceerd: de groei van een lokale kapitaalııarkt. Voor een deel draaide deze op de fortuiner die een aantal administrateurs in hun functie als 
zaakwaarnemer hadden verdiend, voor een ander deel op het geld van lokale handelaars die rijk waren geworden met de import van plantagebenodigdheden. Deze laatste groep was opgekomen ten gevolge van de verbroken verbinding met Nederland tussen 1795 en 1816. De aanvoer van benodigdheden om de plantagekolonie draaiende te houden stokte en een aantal handelaars zag zijn kans schoon om dit gat in de markt te vullen. $\mathrm{Zij}$ betrokken hur waren van elders en verkochten deze tegen hoge prijzen, en vaak in geheim vennootschap met de administrateurs, aan de plantages. Eenmaal gevestigd wisten zij ook na 1816 hun positie te handhaven en vergaarden soms grote rijkdom.

Dit nieuwe, lokale kapital van administrateurs en handelaars is een typerend voorbeeld var de wisselwerking tussen roofbouw en overleven. Enerzijds was het gegroeid ten koste van de rentabi.iteit van plantages, anderzijds werd het opnieuw in de plantage-economie geinvesteerd door middel van lenirgen, vaak tegen woekerrentes van 8 tot $12 \%$, waarvoor onder andere stoommachines werden aangeschaft.

De tweede groep die de plantage-economie heeft gestimuleerd waren de Britse planters die in hel kielzog var. de Engelse bezetting in Suriname en Guiana neerstrcken. Zij verschaften de toegang tot een nieuwe kapitaal- en afzetmarkt (Engeland) en toonden zich in het algemeen voorstander van innovatie. Door hun toedoen werden nieuwe plantagegebieden ontsloten in Nickerie en Coronie en groeide de katoensector int tot een belangrijke nieuwe pijler van de plantage-economie. Daarnaast bezaten zij ook erikele van de grootste en meest geavanceerde suikerplantages, met name Water100, Burnside, Nursery en Alkmaar. Zij hebben zelfs erkele koffieplantages nog tot het einde van de slavemij draaiende weten te houden. Dat he: demografisch patroor. van de katoerslaven zoveel positiever was dan elders kan echter niet op hun conto worden geschreven. Ook niet-Britse katoenplantages vertoonder. dif beeld, zodat dit moet worden toegeschreven aan specifiek aan deze sector eigen factoren, zoals het soort arbeid en de? geografische ligging. In ieder geval is ir deze studie duidel:jk geworden dat processen van roofbouw en overleven sterix af'ankelijk waren van het type planter dat in de verschillende sectoren actief was.

Een andere opvallende verancering in de plantage-economie was het toegenomen belang van het management. Vooral de rol van de administrateurs werd sinds eind achttiencie eeuw sterk bepatend voor het beleid op de plantages. De adminisirateurs vormden echter geen compleet nieuw verschijnsel zoals wel eens wordt gesuggereerd, want ook voor die tijd was al sprake van abserieïsme. Wel gingen absenteisme en de invloed van administrateurs na de schuldencrisis een overheersende rol spelen in de plantage-kolonic. Suriname was daarin niet uniek, want ook in het Brits- 
Caraíbisch gebied deed zich een soortgelijke ontwikkeling voor, als gevolg van verschulding aar Britse handelshuizen. In de Franse en Spaanse plantage-economieen was dit minder het geval, omdat daar koopmanbankiers in de kolonie zelf actief waren (Pares 1960).

Administrateurs vormden de nieuwe elite in het negentiende-eeuwsc Suriname, al waren zij deels ook verwant aan de oude plantersfamilies Het verkrijgen van zoveel mogelijk administraties was hun belangrijkste drijfveer en zij toonden zich zeer vindingrijk in het ontwikkelen van methodes om zich ten koste van de beheerde plantages te verrijken. Daarnaast bleek de kwaliteit van hun beheer wisselvallig en was het verloop tamelijk groot. Vaak waren het lastige heerschappen die in allerlei rechtszaken waren verwikkeld, wat het management niet ten goede kwam. Toch waren de eigenaars in hoge mate aan hen gebonden. De keuze aan administrateurs was beperkt en de controlemogelijkheid gering. Die afhankelijkheid bleck nok uit het, voor de eigenaars, onvoordelige beloningssysteem, dat desondanks nooit essentieel is gewijzigd. In plaats van de beloning te koppelen aan de winst van de onderneming, kreeg de administrateur een vast percentage van de produktie plus een percentage van de lokale verkoopopbrengsten. Zo werd hij wel geprikkeld tot hoge omzetten, maar niet tot kostenbeheersing.

Het zou echter bezijden de waarheid zijn om de administrateurs louter negatief af te schilderen. Weliswaar verloren zij nooit het eigenbelang uit het oog, maar er lieperı wel degelijk ook capabele administrateurs rond. Dat hun beleid niet altijd vruchten afwierp was nogal cens het gevolg van de frustrerende zuinigheid van absente eigenaars, die vooral geïnteresseerd waren in het saldo aan het eind van het jaar. Ook had een aantal administrateurs een deel van het vergaarde kapitaal opnieus in de plantageeconomie geïnvesteerd, door middel van leningen en in eigen plantages, en namen sommigen innoverende maatregelen.

De, op het eerste gezicht, sterke gelijkenis tussen de rol van de achttiendeeeuwse koupman-bankier en de negentiende exuwse administrateur gaat daarom niet geheel op. Het is waar dat beiden het eigenlelang primair stelden. Ook konden beiden zich verrijken ten koste van de plantages, zonder zelf veel risico te lopen en verstonder zij de kunst hun opdrachtgevers te paaien met winstverwachtingen die zelden uitkwamen. Beiden hebben daarom processen van roofbouw in hoge mate bevorderd. Het grote verschil is echter dat administrateurs zich in de kolonie bevonden, daar vaak grote persooniijke belangen hadden en sommigen een belangrijke rol speelden in de lokale politiek. Hun inzicht in en betrokkenheid met de plantage-economie was daardoor groter, waardoor zij meer aandacht aan de reproduktie besteedden. I Iun gedrag foont opnieuw de interactie aan tussen roofbouw en overlever. 
In de plantage-economie is de positie van slavenopzichters of blankofficiers in de loop der tijd nauwelijks veranderd. Fun sociale status was laag, hun gedrag ruw en carrieremogelijkheden gering. Zowel slaven als managers schopten tegen hen aan. Het verloop onder deze opzichters was dan ook extreem hoog, wat niet bevorderlijk was voor de rust en continuïteit op de onderneming.

De rol van de plantagedirecteur veranderde daarentegen wel. In de achttiende eeuw woonde het grootste deel van de eigenaars in Paramaribo, zodat zij het dagelijks beheer op de plantage overlieten aan een directeur. Diens beherr werd echter nauwlettend in de gaten gehouden en de planter was regelmatig op het bedrijf aanwezig om de werkzaamheden in ogenschouw te nemen. Het belang van de directeur en de nuimte waar binnen hij enigszins zelfstandig kon opereren werden echter groter naarmate het absenteisme toenam. Weliswar nam de administrateur de controlerende taak van de planter over, maar zijn betrokkenheid was toch minder groot en vaak moest hij zijn aandacht over meerdere plantages verdelen. Hierdoor kreeg de directeur meer invloed op het functioneren van de plantage, waar hij soms zelfs als mede-administrateur werd aangesteld, en nam het toezicht op zijn beleid af. De geisoleerde planlage beschouwde hij als zijn koninkrijkje waarover hij op autocratische wijze de scepter zwaaide. De eenzaamheid van zijn bestaan en de spanning die het leven tussen een overmacht van slaven - gemiddeld één directeur op 126 slaven in 1836 - met zich meebracht, deed hem nogal eens in een hedonistische levenswijze vervallen. Ook waren er ambitieuze directeurs die de slaven onder druk zetten om zoveel mogelijk te produceren. Hiermee hoopten zij hun superieuren te behagen en de kans te yergroten zelf nog eens administrateur te worden, wat overigens maar een enkeling lukte. Beide sourten directeurs vormden een bedreiging voor de continuilteit van de onderneming, omdat zij met hun gedrag de slaven tegen zich in het harnas joegen en daarmee het wankel evenwicht op de plantages verstoorden. Onenigheid met de directeur leidde dan ook regelmatig tot onrust, of zelfs oproer onder de slaven.

Natuurlijk zijn er ook vele directeurs geweest die met verstand van zaken en tact leiding hebben gegeven op de plantages. Dat bleek bijvoorbeeld uit het feit dat, in vergelijking met de andere blanke managers, het verioop onder hen minder groot was. Gemiddeld bleven zij 5,6 jaar op dezelfde plantage in functie, tegenover blankofficiers 1,1 en administrateurs 3,7 jaar. Er waren zelfs directeurs die echt verknocht raakten aan 'hun' plantage, wat onder meer blijkt uit de tientallen jaren die sommigen er doorbrachien en waar zij, weilicht vaker dan wel eens wordt gesuggercerd, een stabiel gezinsleven mel een zwarte vrouw hadden opgebouwd. Itet is daarorn moxilijk de directeur in zijn algemeenheid te typeren als een duidelijke representant van de roofbouwmentaliteit, of van de mentaliteit gericht op overleven. Ik 
heb de indruk dat het eerste type vaker voorkwam dan het tweede. Het is echter niet onwaarschijnlijk dat dit het gevolg is van het 'problematisch' gedrag van eerstgenoemden, waardoor zij meer dan normale' directeurs worden genoemd in de plantage-archieven.

In dit overzicht van de wijzigingen in het plantagemanagement ontbreek1 alleen nog de positie van de zwarte bastiaan. Zijn rol kan echter niet los worden gezier van veranderingen die betrekking hadden op de slavenbevolking als geheel. Weliswaar heeft de bastiaan altij een bemiddelende rol gespeeld tussen slaven en blanken, maar als het er op aankwam, verbond hij zijn lot meestal aan dat van de slaven. Bovendien zijn er aanwijzingen die doen vermoeden dat de bastiaan zijn leiderschap niet alleen kreeg opgelegd door he: blanke maragement, maar dat dit was geïstitutionaliseerd in de slavergemeensciap in de vorm van he: priesterschap. Het ligt daarom voor de hand te veronderstellen dat een bastiaan als opzichter werd gekozen yarwege zijn 'natuurlijk' leiderschap. Hij zal daarom tevens een stimulerende rol hebben gespeeld in de processen die de wereld van de slaven in de loop der tijd hebben veranderd.

In het derde kwart yan de achttiende eeuw bereikter de slavenimporten uit Afrika een absoluut hoogtepunt als gevolg van de expansie van de plantageeconomie en het hoge sterfte-overschot. Hierdoor bestond het grootste deel van de slaverbevolking in die periode uit in vi:jheid geboren Afrikanen, die weinig waren geworteld in de Surinaamse samenleving. Dat verhinderde overigens niet dat het !eggen van de fundamenten van een AfroSurinaamse cultuur, waarmee al in de zeventiende eeuw was begornen, voortging. Het betekende a:leen dat Westaírikaanse invloeden sterk in deze cultcur aanwezig bleven.

Gedurerde diezelfde periode muet ook de arbeidslas: van de slaven een absoluut hoogte-, of liever gezegd, cieptepunt hebben berejkt, vanwege de snelle uitbreiding van de piartage-coromite. On die te realiseren moesten namelijk in vrij korte tijd duizenden kilometers trenzen worden gegraven in de zware klei. Het waren vooral deze werkzarmheden die een hoge tol van de slaven eisten, want na deze periode bleek het sterfte-overschot met de helft af te nemen. Bover.dien bleé op suikerplantages, waar het werk aan de waterstelsels het meest intensief was, het sterfte-overschot ook relatief het grootst. Deze slopencie arbeid, het harde regime en het volkomen negeren door pianters en overheid van de erbarmelijke levensomstardigheden moeten de slaven tol warhoop hebber gedreven. Dat bleek ook uit de orale geschiederis var de Saramakaners, waarin twee eeuwen later nog steeds de graafwerkzaanheden en dez behandeling door planters als belangrijkste motieven worden genoemd on weg te lopen van de plantages.

De combinatie van al deze factorer maakt het weinig toevallig dat in 
diezelfde periode ook het slavenverzet naar een hoogtepun: groeide. De kolonie was in een bijna constante staat van alarm vanwege de voortdurende slavenopstanden en overvallen op plantages, vaak gevolgd door massale marronage. Alleen door een verdeel-en-heers-beleid te voeren wisten de blanke kolonisten zich staande te houden. Deze politiek was gebaseerd op veel geweld teger sommigen (met name de slaven in het centrur van het plantagegebied en de Boni-marrons) en toegeeflijkheid jegens anderen (met name de siaven aan de periferie van het plantagegebied en de Aukaner-, Saramakaner- en Matawai-marrons). Op de plantages bestond een strakke hiërarchie, gebaseerd op kleur (geprivilegieerde mulatten versus negers) en functie (bevoorrechte eliteslaven, zoals bastiaans, ambachtslieden en huisslaven, versus de veldslaven). Hierdoor wisten de planters zich te handhaven, maar niet meer dan dat. He: verzet is namelijk nooit verdwenen en het is opvailend hoe daaraan juist door eliteslaven, met name bastiaans, leiding is gegeven.

Het achitiende-eeuws verzet had een element van wanhoop in zich; men had toch niets meer te verliezen. De enige uitweg om zich ie onttrekken aan de plantage-economie was door met de dood voor ogen in opstand te komen of weg te lopen. Ook de lage gebonrtencijfers uit die tijc zouden met deze houding te maken kunnen heiben. Evenals de dood was de voortplanting eer. van de weinige aspecten in het leven die slaven zelf enigszins in de hand hadden. Het is nie: denkbeeldig dat door de erbarmelijke levensomstar.digheden slaven niet aileen fysiek minder in staat waren kinderen te krijgen, maar daarvoor ook jewust kozen. Uit wanhoop of uit daadwerkelijk verzet ontrokken zij weliicht ook op die manier leven aan het systeem.

Het zou vee! te ver gaan om deze frontale confrontatie met het systeen te omschrijven ais cen soort zelfroofbouw. Daarvoor werd het teveel beheerst door de pure drang tot overieven. Toch lijkt de houding van de slaven. meer te zi;n gekenmorkt door defensieve reacties op het onderdrukkingssysteem, dan door offensieve, toekomstgerichte acties om levensverbetering af te dwingen. Natuurlijk was weglopen gericht op een leven in vrijheid, maar de ontberingen die dit vergde maakten de keus veeleer to: een wanhoopsdaad can een toekomstgerichte keuze. Dat blijkt onder meer uit het feit dat moeders met kinderen veruit in de minderheid waren onder de weglopers. Ook keerden deserteurs soms na verloop van tijd op hun schreden terug en bij overvallen op de plantages gingen de slaver. lang niet altijd (vrijwillig) met de marrons mee.

Ialverwege de negertiende eeuw was dit beeld totaal gewijzigd. Nog steeds kwamer weglopen en verzet veelvuidig voor, maar het karakter was veranderd. De meeste deserteurs waren in het geheel niet van plan zich definitief aan de plantage-economie te ontrekxen. Zij gebruikten het weg- 
lopen als vorm van protest tegen bepaalde veranderingen op de plantage, of ze wenster eenvoudig voor enige tijd op bezoek te gaan bij geliefden of verwanten. Tevens fungeerde het als een manier om even stoom af te blazen. De sancties die er op stonden namen de slaven voor lief. Regelmatig kwam het voor dat de gehele slavenmacht zich verwijderde naar de rand van of net buiten de plantage. In zo'n geval kan niet eens meer van weglopen worden gesproken, maar ging het puur om een werkstaking om bepaalde eisen kracht bij te zetten. Weglopen was niet langer het doel op zich, maar het middel om een doel te bereiken. Dat wil niet zeggen dat 'traditionele' vormen van weglopen niet meer voorkwamen, want ook in de regentiende eeuw hebben zich nog nieuwe groepen marrons gevormd en voor de slaven in Coronie en Nickerie vormde na 1834 het 'vrije' buurland Guiana een Ionkend perspectief. Evenzeer hebben zich al in de achttiende eeuw werkstakingen voorgedaan en ook toen was niet iedere wegloper van plan zich definitief bij de marrons aan te sluiten. Het gaat dan ook om een geleidelijke, maar niettemin structurele verandering.

Het meest duidelijk is deze verandering te zien aan het verzet dat vrijwel onvermijdelijk volgde op pogingen complete slavenmachten naar andere plantages te laten verhuizen. Met alle mogelijke midcelen stelden slaven zich daar tegen te weer en eisten op hun 'eigen' plantage te blijven. Meestal konden alleen met geweld en intimidatie dergelijke verhuizingen worden afgedwongen, terwijh het ook voorkwam dat aan de eisen van slaven werd toegegeven. Dit hevig verzet tegen verhuizing was het gevolg van een proces van creolisering: slaven waren geworteid geraakt op de plantage en zagen die op $z^{\prime} n$ minst als hun emotioneel eigendom. $Z$ ij waren er geboren, hun navelstrengen lagen er begraven en zij woonden er hun leven lang met verwanter en met de geester var hun voorouders. Ieder plekje was bekend en had vaak een speciale betekenis. Ondanks alle repressie is er altijd meer geweest dan alleen wanhoop, verdriet en woede. Slaven hebben onk gewoon gelééfd op de plantages. Er is gefeest en getreurd, liefgehad en geruzied, allemaal binnen de begrenzing van een tamelijk kleine gemeenschap. Bovendien hadden zij er steeds meer rechten verworven en was het de plaats die hen de middelen verschafte deel te nemen aan de geldeconomie. Een verhuizing zou daarom betekenen dat zij weer helemaal opnieuw moesten beginnen in een vreemde omgeving waar de aanwezige bevolking zich door hun komst eveneens in hun rechten bedreigd voelde. Het was daarom het verzet van Surinamers die zich in hun rechten en toekomstverwachtingen gefrustreerd zagen.

Ook de veelvuldige conflicten met plantagedirecteurs getuigdern van deze nielswe vorm van verzet. Als slaven zich tekort gedaan voelden in hun rechten, of bepaalde verwachtingen werden gefrustrecrd, dan maakten zij luid en duidelijk hun onvede kenbaar. Meestal trok in zo'n geval de 
directeur uiteindelijk aan het koriste eind. Kortom, het slavenverzet werd niet langer gekenmerkt door een wanhopige reactie tegen een gewelddadig systeem dat zich ondanks alles staande wist te houden, maar door een meer toekomstgerichte strijd waarin de bescherming en uitbouw van verworven rechten centraal stonden en waartegen de machthebbers steeds minder verweer hadden.

Als gevolg van de defiritief beëindigde slavenimporten, het sterfte-overschot en de toenemende druk van de koioniale overheid zagen de planters $z i c h$ gedwongen meer aandacht te besteden aan de levensomstardigheden van de slaven. Geleidelijk aan werden verbeteringen doorgevoerd met betrekking tot de arbeid, voeding, kleding, behuizing, medische zorg en rechtspositie. Bovendien bleek het voor planters soms efficiënter bepaalde voorzieningen, zoals voeding en medische zorg, meer over te laten aan het initiatief van de slaven zelf. Al deze veranderingen betekenden een verzwakking van een der fundamenter van de plantagexolonie: de theoretisch absolute segregatie van blank en zwart. Siaven ressorteerden, net als vrijen, onder het personenrecht, zij werden niet meex ritgesloten van christelijk geloof en onderwijis en het verwerven van bezit was niet langer verboden.

Parallel aan deze ontwikkelingen vonden ook in de slavenbevolking zelf grote veranderingen plaats. Na een opieving in de jaren 1820, toen voor het laatst grote groeper. slaven in Suriname werden ingevoerd, was het Afrikaanse aandeel in de populatie steeds verder teruggeloper. Dit betekende dat een meerderineid van de slaven nu in de kolonie zelf was geboren, soms a: tot de derde generatie behoorde en in min of meer hechte gemeenschappen van verwantergroepen leefde. Tege:ijkertijd hadden de slaven het relatieve isolement van hun segregatie aangegreper om de AfroSurinaamse culturur te versterken en verder uit te bouwen. Dit vormde een belangrijke stimulans voor hun weerbaarheid en zelfbewustzijn.

Ais onderdeel van de materiële cultuur, en op een gegeven moment zelfs gestimuleerd door de planters, waren de slaven zich in hun vrije tijd steeds meer gaan toeleggen op de kleine landbouw, veeteelt en visvangst. Hierdoor maakten zij zich niet alleer. minder afhankelijk van de voedseluitdelingen, maar bovendien bood het de gelegenheid handel te daijen. Over de omvang van die handel is nog weinig bekend, maar het heeft er alle schijn van dat de plantage-economie steeds afhankelijker werd van deze produktie.

Ook op andere wijze namen de middelen om inkomsten te verwerven toe, zodat geld een steeds belangrijker roi ging spelen in de slavengemeenschap. I liermee werden allerhande bezittingen aangeschaft en eer. enkeling lukte het zelfs z:ch vr:j te kopen. Deze groeiende deelname aan de geldeconomie had diverse gevo:gen. Enerzi; ds werd hierdoor het gevoel van eigenwaarde verhoogd en versterkte het de relatieve onafhankeli;kheid, 
anderzijds werden slaven meer aan de piantage-economie gebonden. Bovendien zette het een proces in gang van sociale differentiatie. Zo kon het gebeuren dat een bastiaan andere slaven voor zichze:f liet werken.

Deze ontwikkelirger. hebben grote invioed gehad op het gedrag van slaven. Dat bleek bijvocrbeeld uit de ormiskenbaas positieve demografische ontwikkeling. Door autonome factoren, zoals regelmatig terugkerende epidemieën en de gebrexkige medische kennis, bieef het gemiddeide mortaliteitsniveau hoog, zodat tot het eind toe de totale piantagebevolking te kampen heeft gehad met een sterfte-overschot. De levensverwachting van volwassen slaven, het geboortencijfer en de fertiliteit namen echter toe. Met name het laatste is een belangrijk gegeven, omdat hierbij niet alleen medisch-biologische factoren eer. rol speelden, maar tevens beslissingen van de slaven zelf. Zo is het opva:lend dat ir. de suikersectoz, die van oudsher werd gekenmerkt door de slechtste levensomstandigheden en het meest negatieve demografisch patroon, de srelste vooruitgang werd geboekt. Ilier waren dan ook de meest zichtiare verbeteringen, zoals afschaffing van de rachtarbeid, doorgevoerd. Bovendien waren de financiële middelen ruimer en het toekomstperspectisef rooskleuriger dan in andere sectoren. Deze positieve factoren kunnen suikerslaven er toe hebben aangezet meer belang te gaan hechten aan hur. reproduktie. Tussen 1831 en 1863 steeg in de suikersector de fertiliteit dan ook met $90 \%$, terwijl de koffie en katoensector niet verder kwamen dan 49 en $44 \%$. Daarnaast zou in het algemeen de wens om meer kinderen te krijgen kunnen zijn gestimuleerd door het toenemend belang dat bezit kreeg in de slavengemeenschap. Meer kinderen betekende meer handen voor de eigen produktie en een verzekering voor de oude dag.

Samenvattend kan de transformatie van de slavenbevolking het bes: worden gekarakteriseerd als een proces waarir overleven, in de meest brede betekenis, een steeds belangrijke: rol speelde en waarbij niet-gewortelde Afrikaanse slaven zich ortwikkelden in de richting van een Surinaamse 'proto peasantry'.

Nu de veranceringen van alle betrokxenen de revue zijr. gepasseerd kan de dynamiek var de plantagexolonie als geheel worden samengevat. Het bijikt dat roofbouw een onuitwisbaar stempel heef: gedrukt op het finctioneren van de verschillende sectoren van de Surinaamse plartage-economie en alle betrokken deelnemers. Dit proces heeft vele slachtoffers gemaakt (slaven, planters, obligatiehouders, de koffiesector) en slechis weinig winnaars geker.d (koopman-barkiers, aciministrateurs). I let gevolg was dat de plantage-conomie aan het eind van de slavernij kleiner dan een eeuw daarvoor en structureel onderontwikkeld was. Builer de suikersector vond nauwelijks enige economische activiteit van belang plaats. 
Dat de plantage-economie niet voortijdig an haar einde kwam, was te danken aan het gelijktijdige proces van overleven, warin juist de reproduktie centraal stond. Dit proces verliep deels autonoom, deels als reactie op roofbouw. Een duidelijk voorbeeld daarvan vormt de katoensector. De basis voor deze sector werd gelegd door koffieplanters die, na eerst hun plantage door roofbouw aan de rand van de afgrond te hebben gebracht, om te overleven overschakelden op katoen. In hun beleid waren vaak nog sporen van roofbouw, zoals te lang en intensief telen met derelfde grond en gewassen en gebrek aan innovatie, te vinden. Een tweede impuls kreeg de katoensector van administrateurs, die een deel van hun kapitaal, dat zij via roofbouw op de rentabiliteit van door hun beheerde ondernemingen hadden vergaard, investeerden in onder andere katoenplantages en leningen waardoor planters konden innoveren. Ongeveer de helft van de katoensector tenslotte, werd opgebouwd doot Britse planters, die geen Surinaams roofbouwverleden hadden, vers kapitaal inbrachten, geheel nieuwe plantagegebieden ontgonnen en in het algemeen vernicuwend te work gingen. Kortom, de relatic tussen roofbouw en overleven is uiterst complex. Bovendien laat de verdere ontwikkeling van de katoensector zien dat naast de dominante rol van beide processen ook andere, autonome factoren van belang zijn geweest. Deze sector raakte namelijk in verval door haar ongelijke strijd tegen het oprukkende zeewater, door regelmatige insectenplagen en door de explosieve groei van de Noordamerikaanse katoenproduktie waar uiteindelijk geen van de Caraibische plantage-economieën tegen opkon.

Toch bleek ook een tamelijk autonome factor a!s natuurgeweld niet los te staan van processen van roofbouw en overleven en vormcle het een deel van de specifiek Surinaamse dynamiek. 'lyperend was de constante strijd die moest worden gevoerd tegen het water. Om ook in de toekomst te kunnen overleven, moesten de complexe waterwerken voortdurend worden vernieuwd en uitgebreid. Hierin toonden de planters zich in het algemeen tamelijk reproduktief. De tol die deze werkzaamheden van de slaven eiste kan echter niet anders dan met roofbouw worden omschreven. Voor de slaven was deze arbeid vaak de aanleiding om in verzet te komen of weg te lopen, een verschijnsel dat op zich al een gecompliceerde combinatie van roofbouw- en overlevingselementen bleek te bevatten. Bovendien werd overleven in de strijd tegen het water moeilijker naarmate meer plantages ten gevolge van roofbouw werden verlaten. Opnieuw blijkt hoe complex de interactie lussen deze twee processen is verlopen.

Ook wanneer wij voor het moment de slaven even buiten beschouwing Jaten is het vinden van een verklaring voor de verschillen in instelling van de diverse betrokkenen niet eenvoudig. Ilet zou al te simpel zijn deze alleen toe te schrijven aan het verschil tussen mercantilisme en kapi- 
talisme. Bij de eerste stond de handel primair en kwamen produktie en zeker reproduktie op de tweede plaats, terwiji die verhouding tijdens de opmars van het kapitalisme steeds meer werd omgekeerd. Ongetwijeld zal dit wel een rol hebben gespeeld. Zo is het opvallend dat de grootste stimulators var: roofbouw in de achtiende eeuw, de Nederlandse koopmanbankiers, tevens de spil waren van de grootste handeismacht in de wereldeconomie. Even opmerkelijk in de regentiende eeuw is de innoverende rol die planters hebber gespeeld afkonstig uit het meest kapitalistische land ter wereld, Engeland.

Toch vormt dit geen afdoende verklaring. Minsters zo belangrijk lijker. verschillen die samenhingen met de aard van het specifieke produkt en de plaats waar ce voornaamste beleidsbeslissirgen werder genomen. Halverwege de achttiende eeuw had bijvoorbecld de produktie van suiker op plantages in de Amerika's al een geschiedenis van ruim twee eeuwen. Dit produkt had van een stabiele plaats op de wereldmark1 en kende eer: lange traditie van technologische vernienwing. Met koffie lag dat volkomer. anders. Dit was een nieuw en veelbelovend produxt dat stormenderhand de wereldmarkt veroverde, maar waamee m.er. nauwelijks en:ige ervaring had. Het was een typisch 'boom'-produkt, waarmee kapitalen konden worden verdiend, maar dat zijn duurzaamheid als plantageprodukt nog moest bewijzen. Veel meer dan bij suiker was men daarorn uit op snelle successen, want als genotmiddel kon het cen modegril blijken te zijn. Iet gevoly was dat de reproduktie veel minder aandacht kreeg. De ontwikkeling van katoen hield het midden tussen deze twee. Men was in Europa al van oudsher met dit produkt bekend en de waarde ervar had zich al bewezen. Het werd echter pas sinds de Industriële Revolutie als plantageprodukt in de Amerika's geint:oduceerd, vanwege de nieuwe mogelijxheden van grootschalige, industriële verwerking. Katoen werd daardoor eveneens een 'boom'-produkt, maar hoefde mirder dan koffie te bewijzen dat het var. blijvend belang was. In principe was hierdoor meer ruinte aanwezig om zorg te besteden aan de reproduktie.

Ook anderszins waren processen van roofbouw en overeven afhankelijk van het specifieke produkt. Het ene gewas deed nu eenmal een grotere aanslag op de bodem dan het andere. Bovendien verschidten de vereiste locatie, de stand van de techniek en de aard van de werkzaamheden per produkt. Dit betekende dat de mate waarir. roofbouw op de arbeid werd gepleegd ook afhankelijk was van het verbouwce gewas. Duidelijk bleek dat uit de verschillende demografische ontwikkelingen.

Ook de plaats waar de belangrijkste bedrijfsbeslissingen werden genomen, heeft een rol gespeeld in de mentaliteitsverschillen. Zo kwamen de meeste koffieplanters in de tweede helft van de achttiende eeuw geheel in de greep van de koopman-bankiers in Nederland. De laatsten zijn met hun over- 
vloedige kredieten en aandringen op maximale produktie de motor geweest van het roofbouwproces in deze sector. Eens te meer was dit het geval, nadat zij na de schuldencrisis eigenaar werden van deze ondernemingen en dat vaak tot ver in de negentiende eeuw zijn gebleven. Het absenteïsme was in deze sector dan ook zeer hoog.

De suikersector was minder in de greep van koopman-bankiers, zodat vaker beleidsbeslissingen in het belang van de piantagereproduktie en bovendien ter plaatse werden genomer. Toch werd ook hier het absenteisme wijdverbreid. Hef verschil met de koffiesector was echter dat absente eigenaren van suikerplantages meestal geen fondsdirecteur waren en slechts één plantage bezaten, waarvoor zij zelf het financiële risico droegen. Zij waren daarom meer verbonden met het wel en wee van de plantages. Daaraan dient echter onmiddellijk te worden toegevoegd dat juist hierdoor hun beleid niet ais zeer innoverend of reproduktief kon worden gekenmerkt, maar eerder behoudend was. I let ging dus om een gradueel verschil.

Ioe paradoxaa: het ook klinkt, voor beide sectoren gold dat, door het hoge absenteïsme, een belar.grijk dec: van de beleidsbesissingen weer in de plantage-conomic zelf werd genomen. De administratelirs hadden zich namelijk onmisbaar weten te maken en bepaaiden in belangrijke mate het beleid op de plantages. Afgezier van het spekken van hun eigen portemonnee, waaraan $z \mathrm{ij}$ zich zonder uitzondering schuldig hebben gemaakt, bleek het sterk afhankelijk van de persoon of het beieid roofbouw dan wel reproduktie stimuleerde.

De grootste prikkel tot overleven kon ongetwijeeld worden aangetroffen op plantages met een ter plekke aanwezige eigenaar cie niet in de tang van een negotiatiefonds zat. Daar richtte men zich op het voortbestaan var. de onderneming, mer. was niet afhankelijk van een admiristrateur en beslissingen konden relatief snel worden genomen. Dergelijke ondernemingen werden in de negentiende eeuw het meest aangetrofien in de katoes.- en in mindere mate in de suikersector. Niet toevallig waren dit ook de sectoren die de meeste tekenen van (over)leven hebben gegeven. Mentaliteitsverschillen kunnen daarom worden verklaard uit het 'type' beleidsmaker, zijn economische achtergrond en de plaats waar hij zich bevond. Bovendien speelde ook de aard yan het produkt een rol.

Het zal overigens duidelijk zijn dat in het algemeen roofbolw nooit voor honderd procent heeft overheerst, zelfs niet bij fondsdirecteuren. Dat iigt ook voor de hand, want in dat geval was de koek wel heel snel op. Vrijwei altijd konden daarom ook elementen van overleven worden aangetroffen. Aangezien confbouw per definizie een einciig proces is, kregen processen van overleven langzamerhard de overhand. De consequenties van roofbouw waren echter zo ingrijpend dat deze hef succes van overleven hebben beperkt. 
Nog één vraag resłeert, namelijk hoe de dynamiek van de shaven kan worden verklaard. Het antwoord daarop moet worden gezocht in hun cultuur en het vermogen om van de nood een deugd te maken. Grote groepen mensen met verschillende culturele achtergronden werden bij elkaar geplaatst in cen sifuatie van exploitatie en segregatie. Om te xunnen overleven was samenwerking een eerste vereiste. Dere coöperatie werd geinstitutionaisseerd in een gemeenschappelijke cultuur, die onder de dekmantel van de segregatie kon worden opgebouwd. Hiermee konden de slaven zin en richting geven aan hun leven en het verschafte de veerkracht zich te verzetten tegen de chronische roofbouw die op hen werd gepleegd. Eerst was dit verzet nog voornamelijk passief van karakter en vaak gekenmerkt door het zich onttrekken aar: de piantage-economie, waarna zij overigens als marrons vaak in het offensief gingen. Naarmate de slaven en hun cultuur hechter verankerd rakten in de piantagekolonie werd hun ovexievingsstrategie offersicver en maakten zi: gebruik van de zwakte en afhankelijkheid van cic plantersklasse doo: steeds meer rechten te verwerven. Deze verzetscultuur heeft hen in staat gesteld het slavernijsysteem van binnenuit uit te hollen, waardoor zijzelf, en niet de politieke of economische machthebbers, de belangrijkste factor zijn geweest in hun eigen emancipatie.

In vergelijking me: andere Caraibische koloniën bleek Suriname soms achter te :open (Emancipatie, koff:etechnologie, bemesting), soms vooruit (suikertecho'ogie, bloei en verval var de koffiesector) en meestal kwam zi: als tameli; $k$ gemiddeld wit de bus fomvang en 'output van de plantageeconomie, invloed var het absenteisme, demngrasische ontwikkeling, ontstaan van een 'proto peasantry'). Bi; elkaar geeft di: voldoende aanleicing te veronderstellen dat het Surinaamse beeld redelijk representatief was voor de Caraibische ontw'jkkeling in het algemeen. Toch week Suriname op twee belangrijke onderdelen af van het regiunale patroon. Dat waren ce geringe bescherming die de plantage-economie in de achttiende eeuw van het moederland kreeg in vergeli;king met de Britse en Franse gebieden en de strijd tegen het water die, behalve jn Guiana, nergens zo'n bepalende rol heeft gespecld als in Suriname.

Wat betekent dit voor he: onderzoek var andere plantage-economieën? De vele overeenkomster. duiden er op dat er voldoende aanleiding is andere Caraibische plantagekoloniën aan een zelfde soort analyse te onderwerpen. Tegelijk laten de verschillen zien dat daarbij de eigen historische dynamiek van de onderscheiden samenlevingen nooit uit het oog mag worden verloren.

Dat het onk voor andere plantage-economieën zin kan hebben cen zelfde benadering te hanteren blijk: wit de vele misvatingen, in zowel de Suri- 
naamse historiografie als de internationale discussies, die nu kunnen worden rechtgezet. Door de plantage centraal te stellen en uitvoerig te putten uit het in meerderheid kwantitatieve archiefmateriaal van deze ondernemingen is een veel completer, zij het ook complexer, beeld van het functioneren van de plantage-economie ontstaan. Het blijkt bijvoorbeeld dat de opvatting van de plantagekolonie als een statische samenleving volstrekt onhoudbaar is, evenals het idee dat na een blociperiode alleen sprake zou zijn geweest van rechtlijnig verval. Ferder lijkt het inherent aan het functioneren van een piantage-economie dat er voortdurend beweging was, onder andere als reactie op achteruitgang. Want het kan niet worden ontkend dat de Surinaamse plantages bij de overgang van de achttiende naar de negentiende eeuw in verval waren geraakt. Tegelijk waren echter al krachten werkzaam die verantwoordelijk waren voor nieuwe bloei en exparsie in de plantage-econom:e. In andere Caraibische koloniën waren dergelijke golfbewegingen en nieuwe initiatieven eveneens te zien, zodat ook daar kan worden getwi; feld aan het beeld van starheid en verval.

Tevens is op basis van de vermeende statische toestar.d van plantageeconomieén en de overvloedige a anwezigheid van goedkope slaverarbeid beweerd dat slavernij een obstakel vormde voor innovatie, dat slaven niet in staat of bereid zouden zijn met moderre technologie te werken en dat zodoende Emancipatie een economische noodzaak was. In Suriname bleek daarvan geen sprake. Slaven werden steeds duurder en schaarser, er werd op redelijk grote schaal geïnoveerd, slaven bleken me! de nieuwe technologie uitstekend uit de voeten te kunnen en te willen en voor de voortgang van het innovatieproces kwam de Emancipatie bijzonder ongelegen. Aangezien Suriname niet de enige vernieuwende plantageeconomie was, ligt hel voor de hand dat ook elders de veronderstelling niet opgaat.

Daarnaast is het duidelijk dat het onmogelijk is tot be kern van het functioneren van de plantage-economie door te dringen, wanneer deze wordt opgevat als een monolithisch geheei van suikerplantages. De plantage-economie bestond tit meerdere sectoren met eigen karakteristieken en een eigen dynamiek. Juist deze verscheidenneid en de onderlinge wisselweriking waren verantwoordelijk voor beweging en verandering in de plantage-economie. Ook blijkt het verschil tussen sectoren van grote invioed geweest te zijin op de demografische ontwixkeling van slaven. Slechts weinig Caraibische plantage-economië̈n hebben maar uit één sector bestaan, zodat mag worden verondersteid dat in het algemeen sectorale verschillen een grote rol hebben gespeeld in het functioneren en de ontwikkeling van Caraibische samenlevingen. Daaraan is tot nog toe rauwelijks aandacht besteed.

Uit alles blijkt dat de wijze waarop de Surinaamse plantage-economie heeft gefunctioneerd slechts ten dele kan worden verklaard uit externe 
factoren. Juist de interne factoren, de wisselwerking tussen invloeden van binnen en buiten en niet te vergeten de rol van de diverse actoren werpen licht op de dynamiek van de plantage-economie. Dit impliceert dat ook voor andere Caraibische plantage-economieën de verklaringen van 'dependistas' (zoals A.G. Frank) en 'plantation economists' (zoals G.L. Beckford) herziening behoeven.

Opmerkelijk is het transformatieproces dat de Surinaamse slaven ondergingen. Ook elders is dit geconstateerd, maar de stelling dat dit proces was beïnvloed door - en dus moet worden geplaatst in de stroom van 'bourgeois-democratische revoluties' die sinds eind achttiende eeuw in de Westerse wereld op gang kwam lijkt niet terecht, zoals ook Craton (1982) concludeert. Een dergelijke opvatting gaat voorbij aan het eiger, zelfstandige karakter van het transformatieproces en lijkt opnieuw te veel de externe factoren te benadrukken. Veel vruchtbaarder lijkt het meer onderzoek te doen naar de vraag hoe door het ontstaan van 'proto-peasantries' slaven hun eigen emancipatie (mede) hebben bewerkstelligd.

Tot slot wordt in de Caraibische historiografie veelvuldig melding gemaakt van processen van roofbouw, zij het dat men zich meestal beperkt tot de ecologie. De ontwikkelingen in de Surinaamse plantagekolonie maken het aannemelijk dat de bredere, meer structurele vorm van roofbouw, zoals die in deze studie ter sprake kwam, ook elders een sleutelrol heeft gespeeld. Bovendien waren halverwege de negentiende eeuw vrijwel overal in het Caraibisch gebied plantages nog steeds overheersend, zodat mag worden verondersteld dat processen van overleven daar eveneens van fundamentele betekenis zi,n geweest. Het blootleggen van deze processen en hun interactie maakt in het geval van Suriname duidelijk waar de kern van de dynamiek in het geheel van de plantage-economie moet worden gezocht. Deze benadering lijkt daarom ook voor andere plantageeconomieën zinvol. Bovendien kan het de basis vormen voor nieuwe inzichten in de (onder)ontwikkeling van deze samenlevingen na de slavernij. In ieder geval geldt voor Suriname dat ook vandaag nog het leven in deze voormalige kolonie in hoge mate wordt beheerst door de strijd tussen roofbouw en overleven. 
A.A. van Stipriaan - 978-90-04-25979-9 Downloaded from Brill.com $\odot 4 / 26 / 2023$ 03:31:44PM via free access 
BIJLAGE 1

\section{Surinaamse export van suiker, koffie, katoen en cacao 1700-1869}

\begin{tabular}{|c|c|c|c|c|}
\hline jaar & sliker $(\mathrm{kg})$ & koffie (kg) & katoen $(\mathrm{kg})$ & $\operatorname{cacao}(\mathrm{kg})$ \\
\hline 1700 & 3.465 .000 & & & \\
\hline 1701 & 3.481 .500 & & & \\
\hline 1702 & 3.488 .760 & & & \\
\hline 1703 & 3.531 .000 & & & \\
\hline 1704 & 3.993 .000 & & & \\
\hline 1705 & 4.243 .800 & & & \\
\hline 1706 & 484.523 & & & \\
\hline 1707 & 6.104 .753 & & & \\
\hline 1708 & 4.001 .333 & & & \\
\hline 1709 & 6.072 .330 & & & \\
\hline 1710 & 5.168 .130 & & & \\
\hline 1711 & 7.110 .263 & & & \\
\hline 1712 & 7.489 .515 & & & \\
\hline 1713 & 4.807 .605 & & & \\
\hline 1714 & 7.269 .405 & & & \\
\hline 1715 & 6.445 .643 & & & \\
\hline 1716 & 5.820 .953 & & & \\
\hline 1717 & 4.802 .325 & & & \\
\hline 1718 & 4.103 .715 & & & \\
\hline 1719 & 5.714 .363 & & & \\
\hline 1720 & 6.428 .483 & & & \\
\hline 1721 & 8.530 .005 & & & \\
\hline 1722 & 9.855 .945 & & & \\
\hline 1723 & 6.842 .220 & & & \\
\hline 1724 & 8.519 .940 & 2.814 & & \\
\hline 1725 & 7.322 .78 .3 & 23.043 & & \\
\hline 1726 & $8 .: 94.973$ & 71.351 & & \\
\hline 1727 & 8.797 .965 & 103.687 & & \\
\hline 1728 & 8.525 .880 & 115.081 & & \\
\hline 1729 & 8.662 .005 & 136.083 & & \\
\hline 1730 & 8.943 .000 & 251.834 & & \\
\hline 1731 & 7.669 .695 & 265.016 & & \\
\hline 1732 & 9.027 .480 & 550.574 & & 1.584 \\
\hline 1733 & 6.849 .645 & 394.549 & & 1.347 \\
\hline 1734 & 7.421 .040 & 628.518 & & 1.778 \\
\hline
\end{tabular}




\begin{tabular}{|c|c|c|c|c|}
\hline jaar & suiker $(\mathbf{k g})$ & koffie (kg) & katoen (kg) & $\operatorname{cacao}(\mathrm{kg})$ \\
\hline 1735 & 5.666 .018 & 688.168 & & 1.938 \\
\hline 1736 & 8.423 .333 & 810.183 & & 7.275 \\
\hline 1737 & 7.114 .883 & 1.628 .214 & & 8.467 \\
\hline 1738 & 7.473 .923 & 1.200 .630 & & 15.158 \\
\hline 1739 & 6.313 .230 & 1.592 .467 & & 28.476 \\
\hline 1740 & 7.995 .240 & 2.485 .623 & & 38.927 \\
\hline 1741 & 8.369 .790 & 2.431 .724 & & 82.006 \\
\hline 1742 & 10.128 .690 & 1.378 .351 & & 112.529 \\
\hline 1743 & 6.573 .540 & 1.503 .507 & & 128.446 \\
\hline 1744 & 7.372 .860 & 1.748 .561 & & 203.511 \\
\hline 1745 & 7.541 .490 & 1.196 .388 & & 337.375 \\
\hline 1746 & $6.498,030$ & 1.288 .932 & & 273.618 \\
\hline 1747 & 5.984 .220 & 2.050 .001 & & 176.918 \\
\hline 1748 & 6.622 .770 & 703.774 & & 160.431 \\
\hline 1749 & 7.504 .530 & 1.583 .511 & & 143.948 \\
\hline 1750 & 10.148 .820 & 1.768 .170 & & 169.441 \\
\hline 1751 & 9.290 .820 & 2.165 .649 & & 102.654 \\
\hline 1752 & 9.346 .920 & 2.678 .240 & & 156.609 \\
\hline 1753 & 5.042 .400 & 1.444 .325 & & 70.160 \\
\hline 1754 & 6.363 .720 & 3.175 .373 & & 72696 \\
\hline 1755 & 5.417 .940 & 1.436 .286 & & 42.666 \\
\hline 1756 & 7.425 .330 & 3.381 .814 & & 81.856 \\
\hline 1757 & 5.995 .770 & 4.349 .243 & & 53.702 \\
\hline 1758 & 4.949 .340 & 3.394 .6413 & & 61.921 \\
\hline 1759 & 6.183 .210 & 5.429 .657 & & 51.006 \\
\hline 1760 & 6.934 .620 & 5.103 .214 & 646 & 64.214 \\
\hline 1761 & 7.317 .420 & 5.449 .875 & 567 & 71.362 \\
\hline 1762 & 7.247 .130 & 6.119 .801 & 3.058 & 56.614 \\
\hline 1763 & 7.217 .100 & 6.856 .141 & 4.351 & 59.554 \\
\hline 1764 & 6.807 .900 & 4.727 .195 & 17.171 & 65.525 \\
\hline 1765 & 6.639 .930 & 6.904 .500 & 25.390 & 80.26 .5 \\
\hline 1766 & 7.141 .860 & 6.194 .199 & 69.257 & 123.424 \\
\hline 1767 & 7.006 .230 & $6 . \$ 32.301$ & 107.971 & 124.769 \\
\hline 1768 & 7.185 .420 & 6.174 .590 & 124.633 & 216.245 \\
\hline 1769 & 7.395 .630 & 7.003 .537 & 115.791 & 163.125 \\
\hline 1770 & 6.171 .480 & 3.484 .200 & 85.785 & 103.454 \\
\hline 1771 & 8.017 .560 & 7.160 .287 & 108.310 & 256.398 \\
\hline 1772 & 7.477 .200 & 6.945 .599 & 58.938 & 192.158 \\
\hline 1773 & 6.633 .360 & 7.349 .872 & 68.298 & 194.457 \\
\hline 1774 & 5.802 .480 & 6.715 .893 & 61.037 & 287.704 \\
\hline 1775 & 7.708 .320 & 10.115 .970 & 77.860 & 389.211 \\
\hline 1776 & 6.318 .720 & 6.950 .010 & 117.755 & 274.673 \\
\hline 1777 & 6.367 .320 & 10.107 .281 & 86.916 & 314.531 \\
\hline 1778 & 7.628 .040 & 8.236 .881 & 176.105 & 389.066 \\
\hline 1779 & 6.696 .720 & 5.732 .909 & 213.975 & 390.289 \\
\hline
\end{tabular}




\begin{tabular}{|c|c|c|c|c|}
\hline jaar & suiker (kg) & kotfie (kg) & katoen ( $\mathrm{kg}$ ) & cacao $(\mathrm{kg})$ \\
\hline 1780 & 6.161 .220 & 5.681 .539 & 199.594 & 310.135 \\
\hline 1781 & 1.050 .270 & 2.017 .223 & 30.863 & 92.683 \\
\hline 1782 & 5.270 .460 & 5.527 .174 & 237.313 & 419.637 \\
\hline 1783 & 7.425 .600 & 5.879 .285 & 427.746 & 520.813 \\
\hline 1784 & 7.650 .630 & 7.800 .004 & 415.728 & 306.005 \\
\hline 1785 & 7.687 .680 & 4.893 .650 & 46.5 .207 & 335.068 \\
\hline 1786 & 5.516 .550 & 6.488 .085 & 468.350 & 328.970 \\
\hline 1787 & 6.140 .160 & 6.064 .878 & 462.984 & 401.362 \\
\hline 1788 & $?$ & $?$ & $?$ & $?$ \\
\hline 1789 & 6.089 .070 & 5.574 .653 & 510.453 & 329.483 \\
\hline 1790 & 8.442 .000 & 7.428 .138 & 471.790 & 258.732 \\
\hline 1791 & 7.669 .600 & 6.648 .310 & 490.173 & 285.629 \\
\hline 1792 & 6.820 .000 & 3.522 .321 & 565.135 & 59.566 \\
\hline 1793 & 2.167 .600 & 157.754 & 51.653 & 14.920 \\
\hline 1794 & 9.713 .400 & 5.596 .845 & 611.585 & 175.222 \\
\hline 1795 & $?$ & $?$ & $?$ & $?$ \\
\hline 1796 & $?$ & $?$ & $?$ & $?$ \\
\hline 1797 & $?$ & $?$ & $?$ & $?$ \\
\hline 1798 & $?$ & $?$ & $?$ & $?$ \\
\hline $1799^{*}$ & 3.534 .000 & 3.114 .472 & 553.098 & $?$ \\
\hline $1800^{* *}$ & 1.750 .000 & $?$ & $?$ & $?$ \\
\hline $1801^{44}$ & 10.250 .000 & $?$ & $?$ & $?$ \\
\hline 1802 & $?$ & $?$ & $?$ & $?$ \\
\hline 1803 & $?$ & $?$ & $?$ & $?$ \\
\hline 1804 & 11.310 .750 & 3.789 .864 & 1.303 .380 & 64.337 \\
\hline 1805 & 5.177 .250 & 3.050 .755 & 675.350 & 136.744 \\
\hline 1806 & 9.914 .400 & 5.072 .097 & 798.070 & 92.602 \\
\hline 1807 & 10.730 .250 & 2.462 .353 & 984.490 & 69.026 \\
\hline 1808 & 8.765 .100 & 3.780 .819 & 818.220 & 59.933 \\
\hline 1809 & 7.812 .000 & 1.909 .036 & 596.310 & 55.275 \\
\hline 1810 & 8.555 .180 & 3.290 .123 & 962.260 & 44.123 \\
\hline 1811 & 10.019 .840 & 3.678 .094 & 705.510 & 56.165 \\
\hline 1812 & 7.201 .200 & 2.180 .535 & 551.070 & 59.780 \\
\hline 1813 & $?$ & $?$ & $?$ & $?$ \\
\hline 1814 & 7.131 .720 & 2.213 .914 & 745.810 & 52.355 \\
\hline 1815 & $?$ & $?$ & $?$ & $?$ \\
\hline 1816 & 5.784 .415 & 2.421 .560 & 533.567 & 45.348 \\
\hline 1817 & 6.734 .482 & 4.226 .072 & 699.186 & 56.727 \\
\hline 1818 & 9.437 .133 & 4.211 .089 & 699.808 & 48.745 \\
\hline 1819 & 7.704 .502 & 2.795 .088 & 637.729 & 17.151 \\
\hline 1820 & 9.766 .952 & 2.407 .519 & 664.117 & 4.358 \\
\hline 1821 & 10.637 .638 & 2.299 .366 & 1.359 .532 & 5.278 \\
\hline 1822 & 5.043 .238 & 2.274 .488 & 1.262 .599 & 30.043 \\
\hline 1823 & 10.4 .52 .297 & 3.423 .816 & 944.701 & 34.480 \\
\hline 1824 & 11.432 .216 & 3.145 .604 & 1.226 .341 & 35.690 \\
\hline
\end{tabular}




\begin{tabular}{|c|c|c|c|c|}
\hline jaar & suiker (kg) & koffie (kg) & katoen $(\mathrm{kg})$ & cacao $(\mathrm{kg})$ \\
\hline 1825 & 11.907 .853 & 2.098 .288 & 1.164 .804 & 58.053 \\
\hline 1826 & 10.963 .572 & 1.921 .334 & 773.850 & 7.980 \\
\hline 1827 & 12.942 .122 & 1.557 .654 & 1.337 .085 & 23.223 \\
\hline 1828 & 13.609 .889 & 2.778 .801 & 793.226 & 64.623 \\
\hline 1829 & 14.783 .645 & 1.478 .079 & 784.721 & 47.443 \\
\hline 1830 & 16.539 .650 & 3.010 .539 & 981.528 & 8.995 \\
\hline 1831 & 14.445 .853 & 1.490 .335 & 669.806 & 22,901 \\
\hline 1832 & 13.418 .562 & 1.233 .452 & 557.864 & 11.605 \\
\hline 1833 & 13.357 .330 & 1.568 .686 & 669.571 & 7.933 \\
\hline 1834 & 14.801 .047 & 1.095 .615 & 769.038 & 3.868 \\
\hline 1835 & 18.886 .930 & 1.076 .275 & 520.204 & 15.535 \\
\hline 1836 & 18.400 .626 & 1.644 .995 & 636.785 & 64.113 \\
\hline I837 & 12.500 .850 & $1.325 .4 € 8$ & 853.865 & 42.269 \\
\hline 1838 & 14.969 .267 & 944.930 & 568.640 & 78.542 \\
\hline 1839 & 16.295 .942 & 1.181 .290 & 787.625 & 27.383 \\
\hline 1840 & 17.156 .948 & 1.730 .951 & 996.628 & 91.492 \\
\hline 1841 & 15.693 .323 & 969.420 & 733.535 & 43.223 \\
\hline 1842 & 16.583 .978 & 791.035 & 717.350 & 58.123 \\
\hline 1843 & 16.081 .808 & 1.311 .944 & 448.679 & 61.547 \\
\hline 1844 & 17.706 .640 & 979.655 & 560.670 & 36.308 \\
\hline 1845 & 14.893 .633 & 854.240 & 420.253 & 52.148 \\
\hline 1846 & 12.133 .642 & 149.842 & $i 75.430$ & 9.233 \\
\hline 1847 & 15.043 .098 & 353.4077 & 499.407 & 41.357 \\
\hline 1848 & 17.103 .721 & 711.956 & 378.643 & 75.627 \\
\hline 1849 & $15.560 .60 !$ & 308.699 & 362.838 & 59.248 \\
\hline 1850 & 15.565 .223 & 376.982 & 453.370 & $8251 \mathrm{I}$ \\
\hline 1851 & 13.232 .607 & 153.697 & 453.209 & 73.960 \\
\hline 1852 & 15.597 .709 & 677.553 & 491.778 & 117.443 \\
\hline 1853 & $16.949,166$ & 281.756 & 445.739 & 112.138 \\
\hline 1854 & 16.882 .669 & 360.139 & 303.232 & 116.216 \\
\hline 1855 & 17.373 .765 & 229.819 & 518.355 & 119.490 \\
\hline 1856 & 36.887 .256 & 511.224 & 344.094 & 154.241 \\
\hline 1857 & 15.948 .496 & 123.130 & 275.312 & 180.038 \\
\hline 1858 & 11.592 .981 & 233.076 & 290.410 & 184.639 \\
\hline 1859 & 13.939 .713 & 264.791 & 268.607 & 229.958 \\
\hline 1860 & 17.014 .958 & 169.756 & 308.822 & 271.868 \\
\hline 1861 & 16.321 .030 & 73.7 .36 & 180.234 & 283.023 \\
\hline 1862 & 17.397 .056 & 182.149 & 189.304 & 355.900 \\
\hline 1863 & 13.682682 & 140.770 & 187.078 & 307.961 \\
\hline 1864 & 10.220 .854 & 90.504 & 139.075 & 380.270 \\
\hline 1865 & 7.806 .402 & 119.742 & 174.177 & 330.925 \\
\hline 1866 & 9.278 .662 & 14.077 & 128.022 & 456.085 \\
\hline 1867 & 10.582 .089 & 9.262 & 241.293 & 505.330 \\
\hline 1868 & 11.296 .591 & 20.954 & $?$ & 651.880 \\
\hline 1869 & 9.800 .110 & 7.721 & $?$ & 425.028 \\
\hline
\end{tabular}


* export 1 maart-31 december

* import in Engeland

Bronnen: Nassy 1791, 11:161; Van de Voort 1973:237; GAR: Collectie-Hudig, 165; Public Record Office: Treasury 278, 7 en 12; Surinaams Museum: Gouvernementsjournaal 1799; Drescher 1984:58; Surinaamse Almanak 1824-1849; Koloniale Versiagen 1850-1870.

Het gewicht van suiker wordt meestal opgegeven in oxhoofden (later ook vaten). Dit blijkt een zeer onbetrouwbare maat, omdat de inhoud van een oxhoofd in de loop der tijd steeds groter is geworden. Op basis van archieven waarin zowel het gewicht in oxhootden als in ponden werd gegeven is een standaard voor het oxhoofd geconstrueerd. Hieronder wordt het nettogewicht in Suriname en in Nederland gegeven, omdat tijdens het transport de suiker door vochtverlies 14 a $15 \%$ in gewicht afnam. De standaard ziet er als volgt uit (afgerond op $5 \mathrm{~kg}$ ):

Standaard nettogewicht van een oxhoofd/vat suiker

\begin{tabular}{lcc}
\hline periode & in Suriname & in Nederland \\
\hline $1740-49$ & $330 \mathrm{~kg}$ & $275 \mathrm{~kg}$ \\
$1750-59$ & 330 & 275 \\
$1760-69$ & 330 & 275 \\
$1770-79$ & 360 & 300 \\
$1780-89$ & 390 & 325 \\
$1790-99$ & 400 & 335 \\
$1800-09$ & 450 & 375 \\
$1810-19$ & 515 & 435 \\
$1820-29$ & 545 & 460 \\
$1830-39$ & 575 & 485 \\
$1840-49$ & 600 & 505 \\
$1850-59$ & 640 & 540 \\
$1860-69$ & 700 & 595
\end{tabular}

Bronnen: plantage-archieven; Public Record Office: Colonial Office 278, 12; Public Record Office: Treasury 75, 10-11. 
BIJLAGE 2

\section{Prijs van Surinaamse suiker, koffie en katoen in Nederland 1740-1864*}

\begin{tabular}{|c|c|c|c|}
\hline jaar & suiker & koffie & katoen \\
\hline 1740 & $?$ & 80 & \\
\hline 1741 & 32 & 72 & \\
\hline 1742 & 28 & 72 & \\
\hline 1743 & 34 & 68 & \\
\hline 1744 & 36 & 86 & \\
\hline 1745 & 38 & 100 & \\
\hline 1746 & 42 & 140 & \\
\hline 1747 & 42 & 138 & \\
\hline 1748 & 36 & 148 & \\
\hline 1749 & $?$ & ? & \\
\hline 1750 & 22 & 100 & \\
\hline 1751 & 24 & 96 & \\
\hline 1752 & 24 & 96 & \\
\hline 1753 & 26 & 94 & \\
\hline 1754 & 28 & 84 & \\
\hline 1755 & 42 & 104 & \\
\hline 1756 & 42 & 102 & \\
\hline 1757 & 40 & 78 & \\
\hline 1758 & 46 & 82 & \\
\hline 1759 & $?$ & $?$ & \\
\hline 1760 & 36 & 72 & \\
\hline 1761 & 40 & 70 & \\
\hline 1762 & 42 & 74 & \\
\hline 1763 & 36 & 76 & \\
\hline 1764 & 30 & 74 & \\
\hline 1765 & 30 & 78 & 236 \\
\hline 1766 & 26 & 78 & 226 \\
\hline 1767 & 30 & 94 & 158 \\
\hline 1768 & 32 & 106 & 150 \\
\hline 1769 & 30 & 104 & 134 \\
\hline 1770 & 32 & 114 & 130 \\
\hline 1771 & 34 & 110 & 140 \\
\hline 1772 & 30 & 92 & 140 \\
\hline 1773 & 30) & 76 & 166 \\
\hline 1774 & 32 & 66 & 188 \\
\hline
\end{tabular}




\begin{tabular}{lrrr}
\hline jaar & suiker & koffie & katoen \\
\hline 1775 & 32 & 56 & 236 \\
1776 & 32 & 60 & 232 \\
1777 & 40 & 58 & 238 \\
1778 & 52 & 66 & 210 \\
1779 & 54 & 72 & 186 \\
1780 & 54 & 78 & 198 \\
1781 & 58 & 134 & 280 \\
1782 & $?$ & 156 & $?$ \\
1783 & 30 & 66 & 190 \\
1784 & 32 & 84 & 198 \\
1785 & 34 & 96 & 116 \\
1786 & 32 & 98 & 268 \\
1787 & 40 & 112 & 298 \\
1788 & 42 & 126 & 264 \\
1789 & 44 & 124 & 188 \\
1790 & 46 & 102 & 192 \\
1791 & 54 & 100 & 206 \\
1792 & 72 & 118 & 264 \\
1793 & 72 & 118 & 282 \\
1794 & 70 & 121 & 192
\end{tabular}

(Gegevens over de jaren :795-1815 ontbreker.)

$\begin{array}{lllr}1816 & 70 & 100 & ? \\ 1817 & 66 & 100 & ? \\ 1818 & 66 & 132 & 244 \\ 1819 & 54 & 148 & 196 \\ 1820 & 48 & 173 & 152 \\ 1821 & 43 & 159 & 136 \\ 1822 & 34 & 151 & 124 \\ 1823 & 37 & 121 & 116 \\ 1824 & 34 & 92 & 94 \\ 1825 & 43 & 94 & 110 \\ 1826 & 40 & 88 & 100 \\ 1827 & 42 & 70 & 86 \\ 1828 & 38 & 60 & 86 \\ 1829 & 31 & 56 & 88 \\ 1830 & 28 & 54 & 88 \\ 1831 & 29 & 66 & 80 \\ 1832 & 31 & 84 & 82 \\ 1833 & 31 & 91 & 106 \\ 1834 & 29 & 85 & 118 \\ 1835 & 34 & 93 & 144 \\ 1836 & 37 & 79 & 142 \\ 1837 & 29 & 95 & 110 \\ 1838 & 32 & 79 & 102\end{array}$




\begin{tabular}{|c|c|c|c|}
\hline jaar & sujker & koffie & katoer \\
\hline 1839 & 29 & 8.3 & 108 \\
\hline 1840 & 27 & 80 & 88 \\
\hline 1841 & 24 & 77 & 88 \\
\hline 1842 & 20 & 74 & 76 \\
\hline 1843 & 24 & 58 & 66 \\
\hline 1844 & 23 & 59 & 68 \\
\hline 1845 & 30 & 58 & 64 \\
\hline 1846 & 27 & 59 & 76 \\
\hline 1847 & 28 & 59 & 90 \\
\hline 1848 & 21 & 55 & 68 \\
\hline 1849 & 26 & 69 & $?$ \\
\hline 1850 & 25 & 63 & 98 \\
\hline 1851 & 24 & 54 & 80 \\
\hline 1852 & 23 & 52 & 90 \\
\hline 1853 & 26 & 60 & $?$ \\
\hline 1854 & 24 & $6:$ & $?$ \\
\hline 1855 & 26 & 64 & 58 \\
\hline 1856 & 34 & 65 & 58 \\
\hline 18.57 & 38 & 73 & 66 \\
\hline 1858 & 31 & $?$ & $?$ \\
\hline 1859 & 29 & 66 & $?$ \\
\hline 1860 & 30 & $?$ & $?$ \\
\hline 1861 & 27 & $?$ & $?$ \\
\hline 1862 & 25 & $?$ & $?$ \\
\hline 1863 & 26 & $?$ & $?$ \\
\hline 1864 & 26 & $?$ & $?$ \\
\hline
\end{tabular}


BIJLAGE 3

\section{Exportwaarde Surinaamse suiker, koffie en katoen 1740-1864*}

\begin{tabular}{|c|c|c|c|c|}
\hline periode & $\begin{array}{c}\text { suiker } \\
f\end{array}$ & $\begin{array}{c}\text { koffie } \\
f\end{array}$ & $\begin{array}{c}\text { katoen } \\
f\end{array}$ & $\begin{array}{c}\text { totaal } \\
f\end{array}$ \\
\hline $1740-44$ & 2.588 .335 & 1.451 .580 & & 4.039 .915 \\
\hline $1745-49$ & 2.638 .828 & 1.792 .342 & & 4.431 .170 \\
\hline $1750-54$ & 1.959 .733 & 2.088 .656 & & 4.048 .389 \\
\hline $1755-59$ & 2.545 .591 & 3.060 .008 & & 5.605 .599 \\
\hline 1760.64 & 2.621 .550 & 4.124 .925 & & 6.746 .475 \\
\hline $1765-69$ & 2.093 .751 & 6.093 .638 & 145.829 & 8.333.198 \\
\hline $1770-74$ & 2.158 .161 & 5.651 .329 & 98.302 & 7.907 .792 \\
\hline $1775-79$ & 2.923 .678 & 5.052 .241 & 286.323 & 8.262 .242 \\
\hline $1780-84$ & 2056.911 & $5.237,880$ & 526.014 & 7.820 .805 \\
\hline $1785-89$ & 2.378 .591 & 6.190 .36 .5 & 1.168 .450 & 9.737 .406 \\
\hline $1790-94$ & 4.259 .071 & 5.067 .936 & 945.490 & 10.272 .497 \\
\hline $1795-99$ & $?$ & $?$ & $?$ & ? \\
\hline $1800-03$ & $?$ & $?$ & $?$ & ? \\
\hline 180409 & 3.580 .650 & 4.012 .985 & 948.900 & 8.542 .535 \\
\hline $1810-14$ & 4.524 .842 & 3.181 .546 & 815.278 & 8.521 .666 \\
\hline $1815-19$ & 4.720 .897 & 4.385 .750 & 1.417 .364 & 10.224 .031 \\
\hline $1820-24$ & 3.746 .265 & 3.658 .450 & 1.347 .940 & 8.752 .655 \\
\hline $1825-29$ & 4.939 .236 & 1.449 .705 & 915.552 & 7.304 .493 \\
\hline $1830-34$ & 4.282 .646 & 1.200 .838 & 694.850 & 6.178 .334 \\
\hline $1835-39$ & 5.274 .204 & 1.057 .317 & 804.644 & 7.136 .165 \\
\hline $1840-44$ & 3.266 .187 & 811.101 & 549.022 & 4.626 .310 \\
\hline 184549 & 3.110 .413 & 279.391 & 275.546 & 3.665 .350 \\
\hline $1850-54$ & 3.822 .645 & 212.312 & 296.278 & 4.331 .235 \\
\hline $185.5-59$ & 4.791 .123 & 181.436 & 339.316 & 5.311 .875 \\
\hline $1860-64$ & 4.035 .511 & $?$ & 200.863 & $?$ \\
\hline
\end{tabular}

* vijfjaarlijks gemiddelde

Voor de periode 1804-1814 zijn de prijzen aangehouden die Surinaamse produkten op de Engelse markt opbrachter.

Bronnen: zie Bijlagen 1 en 2. 
BIJLAGE 4

\section{De Surinaamse plantage-economie 1713-1890}

A. Plantages producerend yoor de export 1713-1890

\begin{tabular}{rrrrrr}
\hline jaar & suiker & koffie & katoen & cacao & totaal \\
\hline 1713 & 171 & - & - & - & 171 \\
ca. 1750 & 141 & 225 & - & - & 366 \\
ca. 1770 & 111 & 295 & - & - & 406 \\
ca. 1790 & 102 & 248 & 39 & - & 389 \\
ca. 1810 & 100 & 235 & 48 & - & 383 \\
ca. 1825 & 95 & 178 & 73 & - & 346 \\
1836 & 105 & 137 & 52 & - & 294 \\
1854 & 91 & 62 & 30 & 6 & 189 \\
1862 & 86 & 37 & 15 & 23 & 161 \\
1890 & 14 & - & - & 72 & 86 \\
\hline
\end{tabular}

Bronnen: Bijlsma 1921:325; kaarten De Lavaux 1737 en 1770; ARA: RvP, nrs. 293, 583, 598-600, 605-607; Strinaumse Almanak 1797, 1825, 1891; Public Record Office: Treasury 75, 14 en Colonial Office 278, ARA: Collectie-Van den Bosch, 161; ARA: MvK 1813-1849, 1135; Van Sijpesteijn 1854:96-147; Koloniale Verslagen 1854 en 1862

B. De Surinaamse suikersector $1750-: 862$

\begin{tabular}{lccccc}
\hline periode & $\begin{array}{c}\text { aartal } \\
\text { paantages }\end{array}$ & slaven & $\begin{array}{c}\text { veld- } \\
\text { slaven }\end{array}$ & $\begin{array}{c}\text { suiker- } \\
\text { areaal (ha.) }\end{array}$ & $\begin{array}{c}\text { produktie } \\
\text { (kg) }\end{array}$ \\
\hline ca. 1750 & 141 & 19.008 & 9.835 & 8.742 & 8.981 .330 \\
ca. 1770 & 111 & 16.584 & 8.411 & 8.744 & 7.194 .890 \\
ca. 1790 & 102 & 12.232 & 5.243 & 6.943 & 7.643 .867 \\
ca. 1810 & 100 & 10.108 & 4.196 & 6.425 & 8.795 .673 \\
ca. 1825 & 95 & 12.352 & $\mathbf{5 . 9 2 5}$ & 6.459 & 11.434 .547 \\
1836 & 105 & 17.659 & 7.367 & 8.674 & 16.596 .135 \\
1854 & 91 & 17.884 & 7.442 & 8.750 & 17.068 .533 \\
1862 & 86 & 19.789 & 7.876 & 8.903 & 16.911 .014 \\
\hline
\end{tabular}

Bronnen: zie Bijlage 4A; aantal slaven: zie Tabel 44; veldslaven en koffie-areaal 1750-1825: extrapolaties van steekproeven in ARA: SONA, SNA en plantagearchieven waarbij $n=44(1745-1755), n=35(1765-1775), n=28(1783-1795), n=12(1800-$ 1810) en $n=18$ (1820.183); alle gegevens van 1836: ARA: MvK 1813-1849, 1135; gegevens 1854: Van Sijpesteijn I854:96-147 en Koloniaal Verslag 1854; gegevens 1862: Xoloniaal Verslag 1862. Produktie: Bijlage 1, driejaarlijks gemiddelde rondom genoemde jaartallen, behalve 1790: 1790-1792. 
C. De Surinaamse koffiesector $1750-1862$

\begin{tabular}{|c|c|c|c|c|c|}
\hline periode & $\begin{array}{c}\text { aantal } \\
\text { plantages }\end{array}$ & slaven & $\begin{array}{l}\text { veld- } \\
\text { slaven }\end{array}$ & $\begin{array}{c}\text { koffie- } \\
\text { areaal (ha.) }\end{array}$ & $\begin{array}{c}\text { produktie } \\
(\mathrm{kg})\end{array}$ \\
\hline ca. 1750 & 225 & 16.029 & 9.332 & 7.765 & 1.839 .110 \\
\hline ca. 1770 & 295 & 37.179 & 20.087 & 22.499 & 5.882 .675 \\
\hline ca. 1790 & 248 & 26.710 & 12.390 & 22.615 & 5.866 .256 \\
\hline ca. 1810 & 235 & 21.968 & 10.668 & 19.339 & 2.959 .084 \\
\hline \multicolumn{6}{|l|}{ ca. } \\
\hline 1825178 & 17.363 & 8.132 & 11.025 & 2.388 .409 & \\
\hline 1836 & 137 & 12.942 & 5.943 & 5.557 & 1.348 .893 \\
\hline 1854 & 62 & 6.031 & 2.382 & 3.126 & 290.571 \\
\hline 1862 & 37 & 3.892 & $?$ & 1.503 & 132225 \\
\hline
\end{tabular}

Bromen: zie Tabel 17, behalve dal de grootte van de steekproeven respectievelijk bedroeg: 44, 36, 28, 12 en 18 .

D. De Surinaamse katuensector 1825-1862

\begin{tabular}{rccccc}
\hline periode & $\begin{array}{c}\text { aartal } \\
\text { plantages }\end{array}$ & slaven & $\begin{array}{c}\text { veld- } \\
\text { slaven }\end{array}$ & $\begin{array}{c}\text { katoen- } \\
\text { areaal (ha.) }\end{array}$ & $\begin{array}{c}\text { produktie } \\
(\mathrm{kg})\end{array}$ \\
\hline ca.1825 & 73 & 8.290 & 4.145 & 10.062 & 1.054 .998 \\
1836 & 52 & 6.545 & 3.360 & 6.630 & 570.234 \\
1854 & 31 & 4.650 & 2.125 & 3.896 & 422.375 \\
1862 & 15 & 2.551 & $?$ & 1.961 & 185.472 \\
\hline
\end{tabular}

Bronnen: zie Tabel 17; steekproef 1825: nl=13.

E. De Surinaamse cacaosector $1854-1862$

\begin{tabular}{rcrcc}
\hline periode & $\begin{array}{c}\text { aantal } \\
\text { plantages }\end{array}$ & slaven & $\begin{array}{c}\text { cacao- } \\
\text { areaal (ha.) }\end{array}$ & $\begin{array}{c}\text { produktie } \\
\text { (kg) }\end{array}$ \\
\hline 1854 & 6 & 478 & 372 & 115.948 \\
1862 & 23 & 1.225 & 1,255 & 348,044 \\
\hline
\end{tabular}

Bronnen: zie Tabel 17. 
BIJLAGE 5

\section{Financiële balans Surinaamse overheid 1790-1863*}

\begin{tabular}{lcc}
\hline periode & saldo positief $(f)$ & saldo negatief $(f)$ \\
\hline $1790-1794$ & 127.676 & 47.014 \\
$1809-1815$ & & \\
$1829-1834$ & 29.855 & 135.014 \\
$1835-1839$ & & 60.010 \\
$1840-1842$ & & 225.186 \\
$1845-1849$ & 208.225 \\
$1850-1854$ & 293.387 \\
$1855-1859$ & 638.577 \\
$1860-1863$ & & \\
\hline
\end{tabular}

- meerjaarlijks gemiddelde

Van de ontbrekende jaren zijn geen gegevens bekend.

Rronnen: Public Record Office: Colonial Office 278, 12, 13 en 14; ARA: CollectieBaud, 769; Benjamins en Snelleman 1914-17:297. 
BIJLAGE 6

\section{Waarde van de Surinaamse gulden 1712-1847}

\begin{tabular}{ll}
\hline periode & Nf $100=S f \ldots$ \\
\hline 1712 & $109 \cdot 120$ \\
$1750-1799$ & 20 \\
1811 & 500 \\
1816 & 258 \\
1817 & 175 \\
1818 & 173 \\
1819 & 185 \\
1820 & 200 \\
1821 & 250 \\
1822 & 260 \\
1823 & 280 \\
1824 & 308 \\
1825 & 301 \\
1826 & 311 \\
$1840-1846$ & $130-140$ \\
1847 & $103-104$ \\
\hline
\end{tabular}

Bronnen: Wolbers 1861:91, 625 en 686; GAR: Collectie-Hudig, 11:; GAA: NA, 12681; Collectie-Insinger \& Co., Notulboek Biesterbos en Informatieboek; ARA: SOB\&W 1828 1876, 2400; Surinaams Museum, Collectie-Brantsen, Verslagboekje 1850. 


\section{Warrand van plantage Leliëndaal 1745}

Wij Mr. Johan Jacob Mauricius, Gouvemeur Genesaal over de Kolonie Suriname rivieren en districten van dien mitsgaders Collonel over de Militie derzelve landen etc. etc. etc. Vergumnen en concedeeren mits deesen uit kragten der resolutie van haar Ed. Groot Achtbare de Heeren Directeuren der Fd. Sociteit deezer Colonie, dedato 18 November 1744 aan den Edelen Achtbaren Heer Dirk Guldensteeden, Raad van Policie en Criminele Justitie deezer landen, om in allodialen eigendom op te nemen en erfelijk te mogen besitten een stuk land van vijfhonderd akkers, gelegen in de rivier Commewijne aan de regterhand in het opvaren beginnende aan de tweede rits, meteen face van dertig kettingen, mits hij hetzelve stuk land behoorlijk cultiverende en binnen den tijd van achtien maanden na de gedaane opmeting daarop sette een bekwam woonhuis, en dat bij deese vijfhonderd akkers bij continuatie altoos sullen moeten zijn en blijven geaffecteerd ten minsten twee siaaven; dan sal hij ook binnen den tijd van tien jaren ' $t$ selve land niet mogen verkooper, verhandelen, wegschenken of op eenigerlei wijze van meester te doen veranderen, ten sij bij versterven of insolventie. Eindelijk zal hi; gehouden zijn daarvan te laaten vervaardigen vier even gelijke kaarten, en dezelve neevens deeze warrand ter Secretary deeser Kolonie te laaten registreeren en ons daarvan behoorlijk te doen blijken, alles op poene dat het voorsz. vergunde land ipso facto wederom zal vervallen aan de Edele Socileil. Aldus gedaan en metons zegel bekragtigd aan Paramaribo deesen 21 January 1745

3.j. Mauricius

(Bron: ARA: SOB\&W 1828-1876, ]084) 


\section{Innovaties in het kookhuis op Vossenburg 1822-1862}

1822 Het oude keteiwerk in het kookhuis wordt uitgebroken en een nieuw 'volgens de Engelsche uitvinding' (Jamaica train) geünstalieerd, die een hogere graad van koking en betere kwaliteit suiker oplevert;

1824 de molen wordt hoger geplaatst en een rieuw scheprad wordt ingehangen, met ais resuitaa: meer perskracht;

1826 de trekgaten van de twee schoorstenen worden verkleind, wat een beter brandstofrerdemen: oplevert;

1829 de suikerketels worden anders opgehangen en de twee distilleerketels worden uitgebroken en opnieus ingenangen om hen optimaal van het vuiur te laten profiteren;

1831 de Engelse suikerpreparateur Boothe wordt gecontracteerd; hij adviseert bij de bereicing gebruik te maken van de okezplant, die een betere kwaliteit suiker zou opleveren;

1829-1834 de aanschaf van een stoommachine wordt overwogen en afgewezen, omdat dit een (te) grote investering vergt en 'daar een goed gesitueerde [water]molen niet doo: een Stoommachine in allen deelen en zoo als veele zich voorstellen overtroffen word:';

1836 de waterkom voor de molen en het scheprac worden verbreed; dit geeft de molen meer perskracht;

1837 er wordt een reservekas gevormd waruit onverwachte uitgaven voor de suikerfabrick kinuen worden betald an waand ooit een stoummachine kan worden aarigeschatt;

1839 er wordt een nieuw molenwerk geplats: waarin de houten, verticaal geplaatste rollers zijn vervangen door ijzeren, horizontaal geplaatste exemplaren; dit levert oprieuw extra perskracht op;

1840 een rieuw, rus cabbel, scheprad word: ingehangen;

1846 de waterkom word uitgediept en de muren vernieuwd, waarvoor 35.000 stenen uit Nederland moeten komen;

1848 de plantagedirecteur bepleit opnieuw de installatie van een stoommachine; dit word andermaal als te kostbaar argeweren;

1851 het ketelwerk wordt vemicuwd en de constructic enigszins a angepast, wat een beter branostofrendement oplevert;

1852 de eigenaars (in . Nederiand) vragen aan de administrateurs een rapport op te stellen: over de werking van de centrifugaal:oestellen op Visserszorg en La Renconire;

1853 ingenieur Spong vervangt de houten stcelvoeten van het molenwerk door twee ijzeren; 
1855 de houten kamwielen van het molenwerk worden door jjzeren kamwielen vervangen;

1857-1862 in een van deze jaren is waarschijnlijk toch een stoommachine geplaatst.

Bronnen: Surinaams Museum: Collectie-Brantsen, verslagboekjes 1822-1857.

Het is niet geheel zeker of er na 1857 inderdaad nog een stoommachine is gekomen. Lamur (1985:49) schrijft dat op deze plantage in 1862 een ketel van de stoommachine defect was. In een latere publicatie over Vossenburg (Lamux 1987a:49) stelt hij dat de stoommachine ergens tussen 1832 en 1851 moet zij乃 geplaatst. Dat is echter te vroeg, want in die periode worden voortdurend verandexingen aan het waterwerk aangebracht (zie boven) en ook Hering (1858, III: appendix) meldt dat in iecker geval in 1857 nog met een watermolen op Vossenburg werd gewerkt. 
BIJLAGE 9

\section{Opstandigheid op plantages}

A. Marronaanvallen en opstandigheid op plantages 1750-1800

\begin{tabular}{|c|c|c|c|c|c|c|}
\hline jaar & plantage & marron & $\begin{array}{c}\text { opstand, } \\
\text { aanval }\end{array}$ & $\begin{array}{c}\text { massale } \\
\text { marronage }\end{array}$ & staking & complot \\
\hline \multirow[t]{2}{*}{1750} & Bethlehem & & * & & & \\
\hline & Div. Joodse pl.'s & & & + & & \\
\hline \multirow[t]{6}{*}{1751} & Pl. v. A.B. Bibas & * & & & & \\
\hline & Pl. v. Walraaven & - & & & & \\
\hline & Zorghoven & - & & & & \\
\hline & Grond Weltevreden & - & & & & \\
\hline & Mayacabo & * & & & & \\
\hline & Overtoom & & & * & & \\
\hline \multirow[t]{3}{*}{1752} & Victuria & * & & & & \\
\hline & Pl. v. S. de la Parra & * & & & & \\
\hline & Bigrar & * & & & & \\
\hline \multirow[t]{2}{*}{1733} & Victoria & * & & & & \\
\hline & Emveria(?) & * & & & & \\
\hline \multirow[t]{5}{*}{1754} & Moria & “ & & & & \\
\hline & Crond aan Wanica & $*$ & & & & \\
\hline & L'Espérance & & & * & & \\
\hline & Osembo & " & & & & \\
\hline & Maagdenburg (rempatie) & • & & & & \\
\hline 1755 & Bleyenburg & • & & & & \\
\hline \multirow[t]{4}{*}{1756} & Ia Paix (Tempat:e) & * & & & & \\
\hline & Jodensavanre & & & & & * \\
\hline & Pl. v. Stolberg & * & & & & \\
\hline & La Providerce & - & & & & \\
\hline \multirow[t]{7}{*}{1757} & LËspérance & - & & & & \\
\hline & Pl. v. Grootveld & & * & & & \\
\hline & La Paix (Tempatie) & & * & & & \\
\hline & Wolvega (Tempatie) & & * & & & \\
\hline & Beerenburg (Tempatie) & & * & & & \\
\hline & Maagdenburg (Tempatie) & & - & & & \\
\hline & I.'Hernitage (Tempatie) & & * & & & \\
\hline \multirow[t]{5}{*}{1758} & Nieuw Java & $*$ & & & & \\
\hline & Palmeneribo & $*$ & & & & \\
\hline & L'Espérance & * & & & & \\
\hline & 's Ileerenveen & - & & & & \\
\hline & Goode Vrede (poging) & & * & & & \\
\hline
\end{tabular}


1759 Goed Accoord

Onobo

Joskemomoo

Le Mast Rouge

Soribo

Roosenburg

1760 Overbrug

Oostwaard

176] Retour/Retiro

BoxeI

1763 Naccaraccibo

Boxe!

I765 Jockemombo

Maasstroom

Pl. v. Du Cretot

1766 Rietwijk

Vier pl.'s in Para

1768 Capoerica

's Haagenbosch

Rust Lust

Maasstroom

1769 Rust Lust

Grond van Balantier

Gustaafsdazl

Goudmijn en Ostage

1770 Mon Désir

1771 Coermotibo

's Haagenbosch

Hulshoff

$V$ ergeleeger

Bockensteyn

L'Espérance.

1771 Grond van Germano

Montauban

Montpellier

Capoerica

I772 Nieuw Roosenbeek

Poelwijk

la Paix

Mon Désir

Clemensburg

I.ustrijk

1773 Martenszorg

Grond van Smit \& Donze!

Suynigheid

Perou

Nouvelle Espérance

Grond yan Nieboer 
1774 Kortenduur

Groot Marseille

Copie

De Verwagting

1775 Altona

Schoonauwen

's Haagenbosch

Hulshoff

Killenstein Nova

Rac à Rac

1776 Berg en Dal

Vossenburg

Wayampibo

1778 Nieuw Tímotibo

Hanover

1781 Maagdenburg

Nahamoe

1784 's Haagenbosch

Auka

Carthago

1789 Claarenbeek

Remoncourt

Ia Solitude.

Auka

Welgevonden

1795 Meulwijk

Picardie

Vreeland

La Rencontre

Maagdenisurg

1799 Roosenburg

(14)

(5)

(2)

Deze opsomming is niet volledig, met name wat het gaat om massale marronage in het algemeen en ernstige ongeregeldhecten en opstanden in de jaren 1780 en 1790. Niet alle marronaanvallen op plartages lukten, soms werden zij met behulp van de slaver afgeslagen. Bij massale marronage is minimaal $10 \%$ van de plantagebevolking betrokixen. In veel gevallen werden de weglopers overigens achterhaald. 
B. Opstandigheid op plantages 1820-1863

\begin{tabular}{|c|c|c|c|}
\hline jaar & plantage & vorm & annleiding \\
\hline 1820 & Hope & staking & $?$ \\
\hline 1821 & $\begin{array}{l}\text { Union/Diamond/ } \\
\text { Paradise/Good } \\
\text { Intent/Waterloo }\end{array}$ & $\begin{array}{l}\text { complot van een } \\
\text { opstand ontdekt }\end{array}$ & $?$ \\
\hline 1821 & Rustenburg & onwilligheid & directeur/arbeid \\
\hline 1821 & Goed Accoord & onwilligheid & straf/arbeid/voeding \\
\hline 1822 & $\begin{array}{l}\text { Maria Petronella } \\
\text { Echtenrots }\end{array}$ & $\begin{array}{l}\text { staking } \\
\text { opstand }\end{array}$ & $\begin{array}{l}? \\
\text { wsch. directeur }\end{array}$ \\
\hline 1823 & Dordrecht & ongeregeldheden & scheiding van families \\
\hline 1824 & Groot Marseille & ongeregeldheden & arbeid/uitdeling \\
\hline 1824 & Nieuw Meerzorg & staking & arbeid \\
\hline 1825 & Berlijn (Para) & ongeregeldheden & straf van 2 slaven \\
\hline 1826 & Johanna's Zoon & ongeregeldheden & verhuizing \\
\hline 1828 & Siparipabo & ongeregeldheden & verhuizing \\
\hline 1828 & Alida & complot ontdekt & \\
\hline 1829 & Catharina Sophia & (wordt zeer gehein & aden) \\
\hline 1829 & Potribo & staking & arbeid \\
\hline 1829 & Nw. Welgetroffen & (marronoverval) & \\
\hline 1829 & Nw. Weergevonden & (marronoverva!) & \\
\hline \multirow{2}{*}{1830} & Zorg en Hoop/ & & \\
\hline & Pusmerend & onwilligheid & verhuizing \\
\hline 1832 & Leasowes & staking & dansen \\
\hline 1834 & Bleyendaal & ongeregeldheden & mogelijke verhuizing \\
\hline 1834 & Beekvliet & ongeregeldheden & verhuizing \\
\hline 1834 & Susannasdaal & ongeregeldheden & straf/arbeid/uitdeling \\
\hline 1834 & $\begin{array}{l}\text { Onoribo en } \\
\text { Overtoom }\end{array}$ & $\begin{array}{c}\text { 'veldslag' tussen } \\
\text { de slaven }\end{array}$ & gesto'en werktuig \\
\hline 1834 & Berg en Dal & ongeregeldheden & $?$ \\
\hline 1834 & Victoria & staking & verkoop slaven \\
\hline 1835 & Zeezigt & ongeregeldheden & arbeid/dansen \\
\hline 1835 & Hanover & ongeregeldheden & directeur/uitdeling/dansen \\
\hline \multicolumn{2}{|c|}{$1835-36$ Coronie } & \multicolumn{2}{|c|}{ messianistische beweging en conplat } \\
\hline 1837 & Victoria & onwilligheid & behandeling door directeur \\
\hline 1837 & Belwa arde & ongeregeldheden & $?$ \\
\hline 1837 & Burnside & \multicolumn{2}{|c|}{ poging tot oproer en rebellie verijdeld } \\
\hline \multicolumn{2}{|c|}{ 1838-43 Jagtlust/Zoelen } & onwilligheid & $\begin{array}{l}\text { verplaatsing slaven in } \\
\text { wrede directeur }\end{array}$ \\
\hline 1841 & Heel Suriname & onwilligheid & emancipatiegeruchten \\
\hline 1841 & Forgue & \multicolumn{2}{|c|}{ openlijke rebellie tegen eigenaar en overhe:d } \\
\hline 1842 & Nieuwe Grond & unwilligheid & directeur \\
\hline 1843 & Maasstroom & ongeregeldheden & directeur? \\
\hline 1843 & Sinabo & onrust & aanklacht tegen dir. \\
\hline 1843 & Bentshope & ongeregeldheden & $?$ \\
\hline 1843 & Ellen & ongeregeldheden & voedselgebrek \\
\hline
\end{tabular}




\begin{tabular}{|c|c|c|c|}
\hline 1844 & Kroonenburg & ongeregeldheden & $?$ \\
\hline 1845 & George I Iendrik & staking & verhuizing \\
\hline 1847 & Waicoribo & onwilligheid & verhuizirg \\
\hline 1847 & Catharina Sophia & ongeregeldheden & arbeid \\
\hline 1848 & Leonsberg & ongeregeldheden & $?$ \\
\hline 1848 & Ponthieu & weglopen & verhuizing \\
\hline 1849 & Waterloo & spanningen & $?$ \\
\hline 1850 & \multicolumn{3}{|c|}{ Coronie (div. plantages) schip overmand en massale desertie } \\
\hline 1851 & Nieuwe Grond & onwilligheid & directeur \\
\hline 1852 & Katwijk & ongeregeldheden & verhuizirg \\
\hline 1853 & Mon Bijou & onwilligheid & verhuizing \\
\hline 1854 & Nieuwe Grond & ongeregeldheden & directeur \\
\hline 1856 & Roosenburg & staking & arbeid \\
\hline 1857 & [Heel Suriname] & $\begin{array}{l}\text { ongeregeldheden } \\
\text { en stakingen }\end{array}$ & $\begin{array}{l}\text { interpretatie vas het } \\
\text { nieuwe slavenreglement }\end{array}$ \\
\hline 1861 & De Vreede & ongeregeidheden & eigenaax \\
\hline 1861 & Hamburg & ongeregeidheden & $?$ \\
\hline 1861 & Hazard & ongeregeldheden & $?$ \\
\hline $186 !$ & Susannasdaal & ongeregeldheden & $?$ \\
\hline 1861 & Waterland & ongeregeldheden & $?$ \\
\hline 1861 & Berg en Dal & ongeregeldheden & slaven eisen loon \\
\hline 1862 & Schoonoord & ongeregeldheden & straf van een slaaf \\
\hline 1862 & $\operatorname{Rac} a \operatorname{Rac}$ & massale desentie & $?$ \\
\hline
\end{tabular}

Deze opsomming is niet vollecig, met name in de jaren 1850 zou er, gezien alle samenvoegingen van slavenmachten en de discussie over Emancipatie, meer kunnen zij̧n gebe:1rd.

Bronnen: Müller 1973:48-50; Hoogbergen 1983:105-6, 1985:444-9, 1990:49-53; H Heckers 1923:73-9; Hira 1982:164-70; Oostindie 1989:182-7, 272; GAA: PA-646, 544 en 545; Collectie-Insinger \& $\mathrm{CO}$ : Surinaams Museum Collectie-Brantsen, verslagboekjes; ARA: RvP, 599; ARA: Gouverneur-Generaal der West-Indische Bezittingen 18281845, 15-65; ARA: OAS Gouvernementssecretarie, 14; ARA: Collectie-Copes van Cattenburgh, 78. Met danx aan Frank Kriesels, die alle gouverneursjoumaals tussen 1828 en 1845 doorwerkte. 
BIJLAGE 10

\section{Doodsoorzaken}

A. Doodsoorzaak plantageslaven ouder dan 10 jaar 1815-1839 en 1840-1863

\begin{tabular}{|c|c|c|c|c|c|c|}
\hline \multirow{3}{*}{$\begin{array}{c}\text { doodsoorzalak } \\
\mathrm{n}\end{array}$} & \multicolumn{3}{|c|}{$1815-1839$} & \multicolumn{3}{|c|}{$1840-1863$} \\
\hline & $\operatorname{man}$ & vrouw & samen & $\operatorname{man}$ & vrouw & samen \\
\hline & 142 & 131 & 273 & 77 & 56 & 133 \\
\hline & $\%$ & $\%$ & $\%$ & $\%$ & $\%$ & $\%$ \\
\hline onbekend & 10,7 & 15,4 & 12,9 & 11,8 & 12,6 & 12,2 \\
\hline oud en afgewerkt & 28,9 & 39,8 & 34,2 & 41,8 & 46,1 & 44,0 \\
\hline dysenterie & 9,2 & 6,9 & 8,2 & 2,7 & 3,7 & 3,1 \\
\hline tbc en pleuritis & 9,2 & 4,7 & 7,1 & 7,9 & 10,8 & 9,1 \\
\hline bilharzia & 5,6 & 2,3 & 4,1 & 6,6 & 3,7 & 5,4 \\
\hline malaria en filaria & 7,0 & 4,7 & 6,0 & 7,9 & 3,7 & 5,4 \\
\hline beroerte/hartziekte & 7,0 & 0,8 & 4,1 & 5,3 & 3,7 & 4,6 \\
\hline meselijke zeren & 5,6 & 6,2 & 6,0 & 0,0 & 18 & 0,8 \\
\hline griep/verkoudheid & 2,8 & 3,2 & 30 & 2,7 & 18 & 2,4 \\
\hline yaws (framboesia) & 2.1 & 1,5 & 18 & 0,0 & 18 & 0,8 \\
\hline lepra & 0,7 & 2,3 & 1,5 & 0,0 & 3,7 & 1,6 \\
\hline pokken & 1,4 & 0,0 & 0,7 & 0,0 & 0,0 & 0,0 \\
\hline tetanus & 0,0 & 2,3 & 1,1 & 0,0 & 1,8 & 0,8 \\
\hline in de kraam & - & 5,4 & 2,6 & - & $3, \Omega$ & 1,3 \\
\hline verdronken & 1,4 & 1,5 & 1,5 & 5,3 & 0,0 & 3,1 \\
\hline geweld & 3,5 & 1,5 & 2,6 & 2,7 & 0,0 & $1, \overline{5}$ \\
\hline overig & 4,9 & 1,5 & 2,6 & 5,3 & 1,8 & 3,9 \\
\hline
\end{tabular}

Bronnen: plantage-archieven.

Steekproef uit de verantwoorde rekeningen van de plantages Groot Marseille, Vossenburg, Livorno, Rustenburg, Meerzorg, Somerszorg, Janslust en Blokkenbosch, Driesveld en Vrouwenvlijt.

Er zijn geen katoenplantages in deze steekproef opgenomen.

Sommige ziektes zijn in deze tabel samengenomen, omdat de verschillende beschrijvingen riet anders mugelijk maakte:

oud en afgewerkt = verval van krachten, verzwakt, gebroken, (geheel) malinker;

dysenterie = loop, bloedloop, gratuwe loop;

tbc en pleuritis = (uit)tering, borstkwaal, pleuris;

bilharzia $=$ waterzucht;

malaria en filaria = koortsen, koorts en zwellingen, zwelziekte;

venerische ziekte en ongeneeslijke zeren = venerisch, venerische zeren, ongeneeslijke of verouderde zeren; 
geweld = geëxecuteerd ( $3 x$ ), vermoord ( $3 x)$, zelfmoord $(1 x)$, kapwond $(2 x)$;

overige: lamheid $(2 x)$, vallende ziekte $(2 x)$, verharding van de baarmoeder (Ix), geofagic (IX), kanker (1x), beklemde breuk (1x), hersenontsteking (IX), in de suikertest gevallen en verbrand $(1 x)$, in visgraat gestikt (1x).

B. Doodsonzzaak kinderen jonger dan 10 jaar $1815-1863(n=290)$

\begin{tabular}{lc}
\hline doodsoorzaak & frequentie (\%) \\
\hline onbekend & 22,4 \\
stuipen & 22,9 \\
yaws & 19,3 \\
tetanus & 5,2 \\
koortsen (malaria?) & 4,8 \\
bx & 4,8 \\
dysenterie & 3,4 \\
kinkhoest & 2,4 \\
subiet/overval (wiegedood?) & 2,4 \\
bilharzia & 2,4 \\
filaria & 2,4 \\
verzwakking & 1,7 \\
griep/verkoudheid & 1,4 \\
pokken & 1,0 \\
lepra & 0,7 \\
overig & 2,8 \\
\hline
\end{tabular}

Bronnen: plantage-archieven.

Steekproef uit de verantwoorde rekeningen van de plantages Groo: Marseille, Vossenburg, Iivorno, Rustenburg, Meerzorg, Somerszorg, Janslust er. Blokkenbosch, Driesvelc en Vrouwenvlijt.

Er zijn geen katoenplantages in deze steekproef opgenomen. 
BIJLAGE 11

\section{Uitdelingen per slaaf}

A. Uitdeling per slaaf ca. 1880 en ca. 3835

\begin{tabular}{lcc}
\hline artikel & co.1800 & ca.1835 \\
\hline hoeden & 0,8 & 0,8 \\
buffels (jassen) & 0,7 & 0,8 \\
boeseroenen (hemden) & -5 & 0,6 \\
ellen linnen en katoen & 13,5 & 24,9 \\
matrozenmessen & 0,7 & 0,7 \\
scheermessen & 0,4 & 0,3 \\
tondeldoos en vuurstaal & - & 0,6 \\
vuursteren & 0,3 & 2,8 \\
scharen & 0,4 & 0,4 \\
kammen & 0,7 & 0,5 \\
spiegels & - & 0,7 \\
vishaken & - & 2,4 \\
naainaalden & 7,3 & 4,9 \\
ons naaigaren & 0,3 & 0,3 \\
\hline
\end{tabular}

De gebraken getallen doen wat vreemci aan, maar zijn het gevolg van de berekening over de totale populatie, dus inclusief kleine kinderen en bejaarden, die in het algemeen mincler ontvingen dan de rest.

Waakrokken werden op de plantages in deze steekproef alleen uitgedeeld aan de officiers en een enkele ambachtsslaaf. Uitdeling van lange broeken en kralen kwam op deze plantages niet voo:.

Bronnen: plantage-archieven Somerszorg, Duuringen, De Oude Bijenkorf, De Jonge Bijenkorf, Livorno, Groot Marseille, Concordia en Vossenburg. 
B. Uitdeling per slaaf ca, 1820

\begin{tabular}{|c|c|c|c|c|}
\hline & $\operatorname{man}$ & vrouw & jongen & meisje \\
\hline 1 waakrok (jak) & * & & & \\
\hline 1 buffel (jas) & * & * & & \\
\hline I hoed & $*$ & * & * & $*$ \\
\hline 1 lange broek & $*$ & & & \\
\hline 1 boeseroen (hemd) & $*$ & & & \\
\hline ellen linnen en katoen & 21 & 24 & 14 & 14 \\
\hline 1 matrozenmes & $*$ & $*$ & $*$ & $*$ \\
\hline 1 tondeldoos & * & $*$ & * & \\
\hline 1 vuurstaal & $*$ & & & \\
\hline 4 vuurstenen & $*$ & & & \\
\hline I schaar & & * & & \\
\hline $1 \mathrm{kam}$ & $*$ & * & & \\
\hline 1 spiegel & * & * & & \\
\hline 6 vishaken & $*$ & $*$ & * & $*$ \\
\hline 6 naainaalden & * & $*$ & + & $*$ \\
\hline 16 streng garen & * & * & * & * \\
\hline 1 streng kralen & & $*$ & & $*$ \\
\hline
\end{tabular}

Bron: Lammens 1982:112.

C. Gemiddelde voedselverstrekking ca. 830 -ca. $1855^{*}$

\begin{tabular}{lccc}
\hline produkt & $\begin{array}{l}\text { (a.1830 } \\
(\mathbf{n}-4)\end{array}$ & $\begin{array}{l}\text { ca.1855 } \\
(\mathrm{n}=4)\end{array}$ & $\begin{array}{c}\text { Catharina Sophia** } \\
(1857)\end{array}$ \\
\hline bakkeljauw & 42,7 pond & 67,2 pond & 86,0 pond \\
haring & 6,3 pond & 11,0 pond & 12,9 pond \\
makreel & 1,3 pnd & 6,2 pond & 4,2 pond \\
gart en blom & 10 pond & 3,4 pond & 10,4 pond \\
rijst & - & 40,9 pond & 466,2 pond \\
zout & 0,04 vat $^{* * *}$ & 0,07 vat*** & 51,8 pond \\
melasse & 3,8 liter & 12,0 liter & $?$ \\
dram & 13,6 liter & 27,5 liter & $?$ \\
tabak & 4,1 pond & 5,9 pond & $?$
\end{tabular}

* (per jaar, per slaaf)

* Ter vergelijking is de 'model'-gouvernementspiantage Catharina Sophia in de tabel opgenomen.

*.* De inhoudsmaat van een vat is niet bekend.

De verstrekking van bananen is niet opgeromen in de tabel, omdat de exacte hoeveeiheden meestal niet bekend zijn.

Bronnen: Van den Boogaart en Emmer 1977:212; Oostindie 1989:154 en 450; plantage-archieven Vrouwenvlijt, Clifford Kocqshooven, Groot Marseille (alle ca.1830), Somerszorg (ca.18.30 en 1855), Goosen, Roosenburg en Vossenburg (alle ca.1855). 
D. Uitdeling per slaaf per hoofd ca. 1852

\begin{tabular}{|c|c|c|c|c|}
\hline & mannen & vrouwen & jongens & meisjes \\
\hline Waakrokken & 1 & - & - & 1 \\
\hline Officiershoeden & 1 & - & - & - \\
\hline Roode wollen hemden & 1 & ! & 1 & \\
\hline Fllen wit Osnabrïcixs linnen & 10 & 12 & 6 & 6 \\
\hline Ellen Vriesch bont & 8 & 8 & 6 & 6 \\
\hline Ellen calico & 1 & 6 & 0.5 & 5 \\
\hline bllen wit katoen & - & - & - & - \\
\hline Osnabrücks linnen broeker & 1 & 1 & 1 & - \\
\hline Osnabrücks linnen boeseroenen & 1 & 1 & - & 1 \\
\hline Mutsen & 1 & 1 & $?$ & 1 \\
\hline Bonte doeken & 1 & 2 & 1 & 1 \\
\hline Naaigaren & 6 & 6 & 3 & 3 \\
\hline Naalden & 5 & 5 & 5 & 5 \\
\hline Vischhoeken & 10 & 10 & 5 & 5 \\
\hline Vuursteenen & 5 & $\xi$ & - & - \\
\hline Tonteldoozen en stalen & 1 & ! & - & - \\
\hline Matroozenmessen & 1 & $:$ & 1 & 1 \\
\hline Scheermessen & 1 & - & - & - \\
\hline Spiegels & 1 & : & 1 & 1 \\
\hline Kammen & 1 & $:$ & 1 & 1 \\
\hline Scharen & 1 & 1 & 1 & 1 \\
\hline
\end{tabular}

Waakrokken en officiershoeden alleen uitgedeeld aan de hoofdheden, en wit katoen alleen aan de gecioopter.

Onder jongens en meisies werden gerangschikt $z i j$, die of op het veld df bij huis en in de fabrieken werkzaam waren.

Bгол: Rapport Staatscommissie 1853:242. 


\section{Plantagebronnen}

officiële plantagenaam / slavennaam / ligging

1 inventarissen en taxaties

2 negotiatie, hypotheek, schuld, verkoop van de plantage

3 produktie, inkomsten, uitgaven

4 overige informatie over de plantage

Accaribo / Grampranasi / Suriname

1 ARA: SONA, $255 ; 258$

2 GAA: NA, 12725, 12749, 12764, 12766, 15648, 15649

Agenoria / Siramacca

1 ARA: SONA, 296

Akkerboom / Beneden-Commewijne

I Surinaams Nuseum: Coliectie-Mamin

2 GAA: NA, 12725, 12733, 12748, 12780

Alkmaa r / Goedoe Vrouw / Beneden-Commew:jne

I ARA: SONA, 20:, 290

2 GAA: NA, 10818

Alsimo / Oehlers / Warappa

1 ARA: SONA, 287, 290,707, 841

Alyda ( $\mathrm{V} / \mathrm{h}$. Roosendaal) / Coltica

1 ARA: SONA, 266, 288, 291

2 GAA: NA, 12679

Anna Catharira / Van Omroe / Matapira

1 ARA: SONA, 296, 841, Collectie-Insinger \& Co.

3 Collectie-Insinger \& Co.

Anna Maria / Saramacca

1 ARA: SONA, 840

Anna's Burg ( $v /$ h Schepmoet) / Cottica

1 ARA-SONA, 290, 691, 695, 697, 700, 708

2 GAA: VA, 12369, 12847

Anna's Gift / Warappa

1 ARA: SONA, 297

Anna's Rust / Stoekroe / lapoeripa

1 ARA: SONA, 232, 241,695,696

2 GAA: NA, 12727, 15647; GAA: PA-600, 545

3 GAA: PA-600, 545 
Anna's Zorg (v/h Meyershoop) / Goedoe Vrouw / Warappa

1 ARA: SONA, 227, 228, 277, 692; GAR: Collectie-Hudig, 363, 372, 384

2 GAA: NA, 12849; GAIR: Co.lectie-1 judig, 362, 366, 370, 376

3 GAR: Collectie-Hudig, 374-381, 685-687

Arendsrust / Di Losie / Boven-Commewijne

1 ARA: SONA, 192, 262

Aurora / Pauluskreek

1 ARA: SONA, 263; ARA: Aanwinsten 1939 IV, 3

3 ARA: Aanwinsten 1939 IV , 2, 3

Baderstein / Voogtoe / Warappa

1 ARA: SONA, 222, 234, 703, 704, 708, 841

2 GAA: NA, 12740, 12760, 12761, 12763, 12773; GAA: PA-600, 545

3 GAA: PA-600, 545, 545A

4 GAA: PA-600, 543-545A

Barbados / Schasie / Warappa

1 ARA: SONA, 280

2 GAA: NA, 10558

Barbara, Santa / Baroeba Kommisi / Surirame

1 ARA: SONA, 215, 223; ARA: AvF na 1828, 130

Beekenhorst / Beneden-Commewijne

1 ARA: SONA, 200

Beekvliet / Cottica

I ARA: SONA, 227, 240, 255, 699; CAA: PA-600, 546

2 GAA: NA, 1271:; GAA: PA-60C, 545

3 GAA: PA-600, 545, 545A

4 GAA: PA-600, 543-545A

Beerensrust / Suriname

1 ARA: SONA, 22:, 229, 239, 292, 691, 692, 698, 965, 703

Z GAA:PA.600, 545

3 GAA: PA-600, 545, 545A

4 GAA: PA-600, 543-545A

Bel à Soir / I’auluskreek

I ARA: SONA, 297

Beigard (later: Johan en Margarethal / Kerkigror. / Beneden-Commewijne 1 ARA: SONA, 2:8

Berlijn / Bareen / Beneden-Commewi;ne

1 ARA: SONA, 200, 733, 704

Bethlekem / Buven-Commewijne

I ARA: SONA, 189, 191, :94, 227, 234, 701, 704

2 GAA: NA, 12674, 12761; GAA: PA-600, 54.5

3 CAA: PA-600, 545, 545A

4 GAA: PA-600, 543-545A 
Bleyendaal / Pauluskreek

I ARA: SONA, 193, 227, 241, 691,692

2 GAA: NA, 10535, 12672, 12677, 12716; GAA: PA-600, 545

3 CAA: PA-600, 545, 545A

4 GAA: PA-600, 543-545A, 557

Bleyenhoop / Cottica

1 ARA: SONA, 192, 222, 24i, 266, 689, 691, 692, 696, 699, 700

2 EHB: KA-8

Bodenburg / Saffijn / Matapicia

3 ARA: SOB\&W 1828-1876, 1259

4 ARA: SOB\&W 1828-1876, 1259

Boxel / Suriname

1 ARA: SONA, 191, 210, 236, 691, 832

2 GAA: NA, 12723, 12740, 12756, 12773

4 RAU, Archief-Des Tombes, 1790

Breukelerward / Bigi Koederki / Boven Commewijne

1 ARA: SONA, $194,300,702$

Broederhoop / Van Ha'm / Warappa

I ARA: SONA, 708

Brouwerslust / Brouwroe / Beneden-Commewijne

1 ARA: SONA, 202, 205, 705; ARA: IPWIB, 27

2 GAA: NA, 106:7, 12693

Bruynsburg / Boven-Commewijgre

1 ARA: SONA, 706

Buys en Vlijk / Bois: / Motkreek

1 ARA: SONA, 218

2 GAA: NA, 12678

Bij Geluk / Mijnertzhagen / Matapica

1 ARA: SONA, 708

Bijenkort, De (Oude en Jonge) / Pikien Saron / Cottica

1 GAA: PA-646, 19

2 GAA: NA, 10560

3 GAA:PA-646, 17-20

Cabo Verde (later: Jothan) / Suriname

1 ARA: SONA, 195

Canrewapibo / Snijman / Boven-Commewijne

1 ARA: SONA, 234, 236, 241, 257, 250, 283, 698, 707

2 GAA: NA, 16324, 16365, GAA: PA-225, 60

Carwassibo / Boven-Commewijne

1 ARA: SONA, 241,70B; EIIB: KA-120, $2 B$

2 GAA: NA, 12727

$4 \mathrm{EHB}: \mathrm{KA}-120,42$ 
Catharina Sophia / Soekroegron / Saramacca

1 ARA: PWIB, 27, 146

3 ARA: PWIB, 147-169; Koloniale Versiagers $1849-1862$

4 ARA: PWIB, 126-145, 170

Claarenbeek / La Cassi / Boven-Commewijne

1 ARA: SONA, 691

Clevia / Suriname

1 ARA: SONA, 218

2. GAA: NA, 12737

Clifford Kocqshooven / Kokkoe / Warappa

1 ARA: SONA, 692, 699, 705; KIT: B.853 Collectie-Van Breugel

3 KIT: $B .853$

4 KrT: 3.853

Clyde / Coronie

1 ARA: SONA, 834

Concordia / Boven-Comurewijne

1 ARA: SONA, 206, 209, 213, 237, 259, 289, 696, 699, 704

2 GAA: NA, 12673, 12696, 12862, 12877; EHB: KA-8

Confiance, La / Suriname

I ARA: SONA, 193, 221, 690, 695, 697, 703; CAR: Collectie-Hudig, 521, 523

2 GAA: NA, 10514, 15644, 15694; CAR: Collectie-\{1udig 540-547

3 GAR: Collectje-1 Iudig 540-547,685

4 GAR: Collectie-Hudig, 507-547

Constantia I / Cottica

1 ARA: SONA, 218

Constantia II / Santi / Natapica

1 ARA: SONA, 270, 704; GAA: NA, 12749

2 GAA: NA, 12381, 12382, 12392, 12729, 12734, 12753, 12754, 12766

Crommelins Gift / Kokonassi / Taporipa

1 ARA: SONA, 260

2GAA: NA, 12725, 16341

Dageraad, De / Van Omroe / Motkreek

1 ARA: SONA, 296

2 ARA: Collextie-Van den Bosch, 1.58

Dankbaarheid, De / Berensi / Saramarca

1 ARA: SONA, 838

Des Tombesburg / Van der Wervie / Boven-Commewijne

1 ARA: SONA, 297

2 GAA: NA, 12394, 12738, 12757, 12772

Descanso / Paria / Surirame

1 ARA: SONA, 192, 284, 691

2 GAA: NA, 10535, 12415, 12418

Diligence, La / Moesë Hendrikie / Suriname

I ARA: SONA, 192

2 GAA: NA, 10505 
Dordrecht / Suriname

1 ARA: SONA, 214, 227, 234, 253, 695, 698, 835; GAA: PA-646, 68

2 GAA: NA, 12873, 16326; GAA: PA-225, 60; GAA: गA-646, 67

3 GAA: PA646, 70, 71

Drie Gebroeders, De / Suriname

1 ARA: SONA, 191, 256, 276, 691, 697, 698

2 GAA: NA, 12675, 14537

Driesveld / Tessier / Tapoeripa

1 ARA: SONA, 226, 700, ; GAR: Collectie-Hudig 561, 578

2 GAR: Collectie-Hudig, 556

3 GAR: Collectie-Hudig, 558-570, 685-687

4 GAR: Coliectie-Hudig 550-580

Duuringen / Di Han / Matapica

1 ARA: SONA, 197, 198, 2:4, 697, 704; CAR: Collectie-Hudig, 350, 359

2 GAA: NA, 12856; GAR, Collectie-Fudig, :68, 355

3 GAR: Collectie-Hud:g, 3:7, 325, 356, 357, 685-687

4 GAR, Collectie-Fiudig, 156, 317, 318, 360

Dijkveld / Suriname

1 ARA: SONA, 192

Eendragt (later: De Dageraadi) / Kakrakoe / Commetewane

1 ARA: SONA, 209, 2:4, 695, 704; ARA: PWIB, 28

2 GAA: NA, 10815, 12728, 16387

Ejk ' Zijn/ Irafas: / Cottica

I ARA: SONA, 187, 192, 199, 240, 289, 689.695, 835

Ellen (v/h Nooyt Gedagt) / Trotor / Beneden-Commewijne

1 ARA: SONA, 203, 205, 223, 232, 255, 699, 836; ARA: ORRW 1828-1876, 926-I

2 GAA: NA, 11398, 12434, 12733

3 ARA: OB\&W 1828-1876, 926-1

Elsenhagen / Coltica

1 ARA: SONA, :90, 209, 691, 692,703

2 GAA: NA, 10619, 12675

3 GAA: PA-600, 581, 587, 588, 599, 60:, 602,603,604, 1268

4 GAA: PA-600, 581, 587, 588, 599, 60:, 602, 603,604, 1268

Embaras, L' en Venlo / Lamra / Beneden-Conmewijne

1 Surinaams Museum, Collectie-Mamin

Ephrata / Jakoe / Cottica

1 ARA: SONA, 200, 216, 218, 235, 689

2 GAA: NA, 10634, 32513

Espérance, $\because$ / Suriname

1 ARA: SONA, 156, 22:, 236

2 GAA: NA, 10261, 12712, 12735, 12747

Eustatius, Sint / Baboen / St:riname

1 ARA: AvF na 1828,130

Fortuin / Baki / Commetewane

1 ARA: SONA, 257, 289, 839 
Frederici's Gift / Beersnijdri / Saramacca

1 ARA: SONA, 295, 832

Fredertks Lust / Andree N'jan Joe Oppo / Warâppa

1 ARA: SONA, 294, 840; ARA: SNA, 108

3 Collectie-Insinger \& Co., informaiieboek

Geertruidenberg / Saatie / Cottica

1 ARA: SONA, 201, 213; ARA: PWIB, 27

Celderland / Suriname

1 ARA: SONA, 260

2 GAA: NA, 12755

George Hendrik / Pikien Feerski / Matapica

1 ARA: OB\&W 1828-1876, 3026

3 ARA: OB\&W 1828-1876, 3026

4 ARA: OB\&W 1828-1876, 3026

Goede Verwachting, De / Wenni / Molkreek

1 ARA: SONA, 192, 286, 296, 692, 695, 698; GAA: PA-646, 46

2 GAA: NA, 12674, 12690; GAA: PA-646, 44, 45, 48

3 GAA: PA-646, 45, 48

Goede Vreede, De (v/h Aboa Pas) / Patra / Surirame

1 ARA: SONA, 187, 189,689

2 GAA: NA, 15238

Goud Intent / Nickerie

3 Koloniale Verslagen 1849-1858

4 Koloniale Verslogen 1849-1858

Groningen / Linkie / Tapoeripa

1 ARA: SONA, 263

2 GAA: NA, 12727

Groot Chatillon / Suriname

1 ARA: SONA, 192, 211, 237, 282, 292, 295, 695, 697; ARA: AvF na 1828, 130

2 GAA: NA, 10584, 12674, 12689

Groot Marseille / Jacob: / Cottica

I ARA: SONA, 294, 689; James Ford Bell Library $B 1482$

2 James Ford Bell Library, B:482

3 James Ford Bell Liorary, B1482

4 James Ford Bell I ibrary, B:482

Guadeloupe / Spierien / Beneden-Commertijne

1 ARA: SONA, 199, 264, 837

2 GAA: NA, 11378, 12482

Guilgal / Suriname

1 ARA: SONA, 691

2 GAA: NA, 12676

Hamburg / Kowoesoe / Cottica

I ARA: SONA, 706

Hamburg / Saramacca

1 ARA: SONA, 841 
Hanover / Para

I ARA: SONA, 192, 211, 235, 263, 703, 832

2 GAA: NA, 10565, 12674, 12689; GAA: ?A-600, 545

3 GAA: PA-600, 545, 545A

4GAA: PA-600, 543-545A; ARA: SOB\&W 1828-1876, 1949, 3027

Hazard / Ouson / Boven-Commewijne

1 ARA: SONA, 698, 700; ARA: AvF na 2828,131

2 GAA: NA, 12434, 12437

Hegt en Sterk / Stolkroe / Beneden-Commewijne

1 ARA: SONA, 294

2 GAA: NA, 12438; EHB: KA-120, 20

Herstelling, De / Saffin / Warappa

I ARA: SONA, 282; ARA: SO8\&W 1828-1876, 3029

2 GAA: NA, 15652

3 ARA: SOB\&W 1828-i $876,889,3029$

Hildeshein: / Jekri / Saramacca

1 ARA: PWIB, 27

Hilgens Court / Saramacca

1 ARA: SONA, 295

Hoopwijk / Hoer Helenakreek

1 ARA: SONA, 708

2 GAA: NA, 12720, 12761, 12856

Hooyland/ Di Hooi / Boven-Commewijne

I ARA: SONA, 195, 203, 2:2, 295

Youttuin / Para

1 ARA: SONA, 209, 227, 292

Huwelijkszorg / Borgterti / Saramacca

1 ARA: SONA, 832

Jagtlust / Suriname

1 ARA: SONA, 223, 701,706, 841

2 GAA: NA, 12721; Collectie-Insinger \& Co., nolulboeken

3 Coilectie-Insinger \& $\mathrm{Co}$., notwiboexen

4 Collectie-Insinger \& $\mathrm{Co}$, notuiboexen

Jans Lust en Blokixenbosch / Brokkoe / Hoer Helenakreek

I ARA: SONA, 193, 221, 692, 701; GAR: Collectie-1 Hudig, 454

2 GAA: NA, 10530; GAR: Collecie-Hudig, 410-449

3 GAR: Collectie-Hudig 458, 659, 685-687

4 GAR: Collectie-Hudig, 399-474

Johanna Charlotte / Pikien Voogroe / Matapica

I ARA: SONA, 840

Johanna's Zoon ( $\mathrm{v} / \mathrm{h}$ Elizabeths Zoon) / Pinari / Matapica

1 ARA: SONA, 228, 234, 263, 692,697, 699

2 GAA: NA, 12737, 12877; GAA: PA-600, 545

3 GAA: PA-50C, 545, 545A

4 CAA: P'A-60C, 543-545A 
Katwijk / Juliaansi of Van Meeri / Beneden-Commewijne

1 ARA: SONA, 265, 283, 291, 692, 707; ARA: SOB\&W 1828-1876, 926-1

3 ARA: SOB\&W 1828-1876, 3031; EHB: KA-37, 10

Kent / Saramacca

1 ARA: SONA, 839, 841

Killensteln / Beneden-Commewijne

1 ARA: SONA, 214, 222, 223, 701; ARA: SNA, 108

2 GAA: NA, 16350

Kleinhoop / Wolfoe / Cottica

1 ARA: SONA, 279, 282, 292

2 GAA: NA, 12495, 12696, 12697

Kleinslust / Klein / Tapoeripa

1 ARA: SONA, 195, 692; ARA: SOB\&W 1828-1876, 3032; ARA: ?WIB, 27

2 GAA: NA, 12680, 12880

Kockswoud / Koikkoe / Perica

1 ARA: SONA, 691

Kroonenburg / Domini / Beneden-Commewijne

1 ARA: PWIB, 27

2 GAA: NA, 12706, 12418

3 ARA: SOB\&W 1828-1876, 3033

Laarwijk / Suriname

1 ARA: SONA, 691

Leasowes / Coronie

1 ARA: SONA, 834

Leliëndaal / Addewien / Beneden-Commewijne

1 ARA: SONA, 195, 255, 258, 265, 691, 703; ARA: SOB\&W, 1084

2 GAA: NA, 10286

Libanon / Cottica

1 ARA: SONA, 193, 216, 238, 286, 295, 702; ARA: SNA, 108

2 GAA: NA, 12730, 12771; GAA: PA-646, 58

3 GAA: PA-646, 58, 59

Limeshoop (later Bentshope) / Limieshopoe / Warappa

1 ARA: SONA, 293

Livorno ( $\mathrm{v} / \mathrm{h}$ Woutvliet) / Wovriti / Suriname

1 ARA: SONA, 189, 193, 276, 691, 695, 698, 701; GAA: PA-646, 7

2 GAA: PA-646, 6

3 GAA: PA-646, 9-11

4GAA: PA-646, 1-4, 8

Lodewïjksburg (later deel van Alliance) / Lemmersie / Matapica 2 GAA: NA, 12869

3 ARA: PWIB, 184

Iunenburg / Peiri / Cottica

1 ARA: SONA, 156, 197, 221, 235, 253, 266, 270,689

2 GAA: NA, 8962, 12880, 12424; GAA: ?A-600, 544; EHB: KA-235

3 ARA: SOB\&W i828-1876, 3034 
Lust en Rust / Schexpien / Suriname

1 ARA: SONA, 210, 215, 226, 229, 703, 838; Surinaams Museum, Collectie-Mamin

2 GAA: NA, 12462, 12730, 12736, 12756, 15626

3 Surinaams Museum, Collectie - Mamin

4 Surinaams Museum, Collectie-Mamin

Lust tot Rust / Pikien Cron / Beneden-Commewijne

1 ARA: SONA, 296, 703; AKA: Collectie-Gülcher

Lustrijk / Saillé / Boven-Commewijne

1 GAA: NA, 12731

2 GAA: NA, 12729, 12736, 32749

Ma Retraite / Ferran / Bocinkreek Paramaribo

1 ARA: SONA, 242, 297, 285, 837; EHB: KA-120, 21, 43

3 EHB: $K A-120,21$

4 F.HB: KA-120, 42

Maagdenburg / Suriname

1 ARA: SONA, 174, 191, 228, 229, 6S8, 702; ARA: AvF na 1828, 130

2 GAA: NA, 16323

Maasstroom / Bereden Commewijne

I ARA: SONA, 227, 696, 699

Mambreporiah / Suriname

1 ARA: SONA, 692

Mantheim / Cottica

1 ARA: SONA, 194, 195, 289; ARA: SOB\&W 1828-1876, 3035

Maria Petronella / Spaan / Warappa

1 ARA: SONA, 214, 216, 240, 275, $83 \overline{5}$

Maria's Lust / Di Sarti / Tapoezipa

I ARA: SONA, 232, 239, 695,699

2 GAA: NA, 12737, 12778; GAA: PA-600, 545

3 C.AA: PA-600, 545, 545A

4 CAA: PA-600, 54.3-545A

Mariënburg / Broen of Di Hooy / Beneden-Commewijne

1 ARA: SONA, 195, 203, 204, 212, 266, 697, 699, 702, 708

2 GAA: NA, 12355, 12389, 12739, 12761, 12784, .6383

Mast Rouge, L.e / Kroesau / P'erica

1 ARA: SONA, 156, 223, 239, 262; GAA: PA-646, 42; ARA: AvF na 1828, 130

2 GAA: PA-646, 40,41, 43

3 GAA: PA-646, 43

Meerzorg I ( $v /$ h Sawacante $) /$ Hazison / Suriname

I ARA: SONA, 226; ARA: Collectie-Berg, 349

3 ARA: SOB\&W 1828-1876, 3036; EHB: KA-37, 16; ARA: Collectie-Berg 349

4 ARA: SOB\&W 1828-1876, 3035; EHB: KA-37, 16; ARA: Coliectie-Berg 346.354

Meerzorg II / Hattriman / Tapoeripa

1 ARA: SONA, 199, 270, 279, 696, 704

2 GAA: NA, 10554, 12430, 12451, 12501 
Merveille / Adjakka / Suriname

1 ARA: SONA, 205, 207, 227, 257, 279; ARA: AvF na 1828, 130

Misgunst / Heemskerki / Motkreek

1 ARA: SONA, 838

Mislukt Bedrog ( $\mathrm{v} / \mathrm{h}$ Jerusalem) / Bekkrie, of Forrec / Tapoeripa

1 ARA: SONA, 260, 285, 297, 692, 695, 697, 698, 837

2 GAA: NA, 16323

Mon Bijou / Dipérou / Cottica

1 ARA: SONA, 217, 692; GAR: Collectie-Hudig, 239

2 GAR: Collectie-1 Iudig, 190-20\%; GAA: PA-646, 30-37

3 GAR: Collectie-Hudig, 257, 685-687

4 GAR: Collectie-Hudig, 190-283; GAA: PA-646, 26-39

Mon Trésor / Pichotoe / Beneden-Commewijne

1 ARA: SONA, 201

Morgenstar, De / Lysnaari / Saramacca

1 ARA: SONA, 297

Morgenstond, De / Bekkrie / Suriname

] ARA: SONA, 285, 297, 837

Munnikkendam / Heersskerki of Basierg: / Cotkica

1 ARA: SONA, 707

2 GAA; NA, 12722, 12723, 12777

Naaldwijk / Motkreek

1 ARA: SONA, 297, 707

2 GAA: NA, 12722, 12732, 12846, 16335; GAA: PA-600, 545

3 GAA: PA-600, 545,545A

4 GAA: PA-600, 543-545A

Nahamoe / Namoe / Suriname

1 ARA: SONA, 706

2 GAA: NA, 12682, 15278

3 ARA: SOB\&W 1828-1876, 3040

4 ARA: SOB\&W 1828-1876, 3040

Nieuw Hazard ( $q / \mathrm{h}$ Venetia Nova) / Suriname

1 ARA: SONA, 228, 708; GAR: Collectie-1iudig, 489, 504, 506

2 GAR: Collectie-Hudig, 480-488

3 GAR; Collectie-Hudig, 494, 503, 68.5-587

4 GAR: Collectie-Hudig, $480-510$

Nieuw Levant / Lavanti / Cottica

1 ARA: SONA, 193

4 Surinaams Musen:n, Collectie-Mamin

Nieuw Roeland (v/h N"Euw Goeci Accourd) / Rollo / Beneden Commewijne

1 ARA: SONA, 241

2 GAA: NA, 11357, 11377, 11415; GAA: PA.6C0, 545

3 GAA: PA-600, 545, 545A

4 GAA: PA-600, 543-545A 
Nieuwe Crond, De / Njoegron / Beneden-Commewijne

1 ARA: SONA, 191, 223, 703, 704

2 Collectie-lnsinger \& Co., notulboek Biesterbos

3 Collectie-lnsinger \& Co.', notulboeken

4 Collectie-Insinger \& Co., notulboeken

Nieuwe Hoop/ Boven-Commewijne

1 ARA: SONA, 258, 267, 284, 699, 703

2 GAA: NA, 12728, i2729, 12730, 12772; GAA: IA-600, 626

Nieuwsorg / La Sali / Commetewane

1 ARA: 5ONA, 259, 270, 279

2 GAA: NA, 12379, 12351, 12423, 12501

Nouvelie Fspérance, Ia / Espransi / Cottica

1 ARA: SONA, 238, 286, 295, 301; ARA: S:VA, 108

2 GAA: NA, 12730; GAA: PA-646, 53-59

3 GAA: PA-646, 58.59

4 C.AA: PA-646, 52-59

Novar / Coronie

1 ARA: SONA, 837

Nursery / Nickerie

4 ARA: PWIB, 27

Nut en Schadelijk / Schaddreen / Beneden-Commewijne

1 ARA: SONA, 201

Nijd en Spijt / Granic / Beneden Commewijne

1 ARA: SONA, 706, 708

2GAA: NA, 12467

Onoribo / Dan / Para

1 ARA: SONA, 690, 691, 701

2 ARA: SOB\&W 1828-1876, 2182

Osembo / Para

1 ARA: SONA, 156, 191, 690

2 GAA: NA, 10527

Overtoom / Juran / Para

1 ARA: SONA, 240, 695

2 GAA: NA, 12713; CAA: PA-600, 545

3 CAA: PA-600, 545, 545A

4 GAA: PA-600, 543-545A

Oxford/ Coronie

1 ARA: SONA, 839, 841

Iaaix, La / Cottica

1 ARA: SONA, 692,702

2 GAA: NA, 10261, 10393

Paradise / Nickerie

I ARA: SONA, 300

Peperpot / Peprepatoe / Suriname

1 ARA: SONA, 193, 262 


\section{Perou / Cottica}

1 ARA: SONA, 238, 286, 295; ARA: SNA, 108

2 GAA: $P^{2} A-646,53-58$

3 GAA: PA-646, 58,59

4 GAA: PA-646, 52-59

Picardie / Picantri / Beneden-Commewijne

1 ARA: SONA, 269

2 GAA: NA, 14192

Pieterszorg / Paroea / Beneden-Commewijne

I ARA: SONA, 289, 840, 841

Poelwijk / Bekri / Perica

1 ARA: SONA, 200, 236, 285, 297, 8.37

2 GAA: NA, 12348, 12359, 12373, 12418

Ponthieu / Gieskie / Beneden-Commewijne

1 ARA: SONA, 269, 833

Potribo / Goeyaba / Boven-Commewijne

I ARA: SONA, 697

26AA: NA, 10282, 10771; GAA: PA-600, 545

3 GAA: PA-600, 545, 545A

4 GAA:PA-600, 543-545A

Poule, La / Saramacca

1 ARA: SONA, B3S

Prévoyance, Ia / Saramacca

1 ARA: PWIB, 27

Providence / Nickerie

1 ARA: SNA, 108

Purmerend / Mouritie / Beneden-Commewijne

1 ARA: SONA, 221, 266, 287,696

2 GAA: NA, 12672, 12717, 12722; GAA: PA500, 545

3 CAA: PA-600, 545, 545A

4 GAA: PA-600, 543-545A

Quamabo / Surname

1 ARA: SONA, 192

2 GAA: NA, 12756

Rac a Rac / Bigi Rakraki / Suriname

1 ARA: SONA, 192, 265, 691: ARA: SNA, 108

2GAA: NA, 8574, 10451, 12404, 12405, 12499

Rencontre, La / Larikondre / Suriname

1 ARA: SONA, 193, 196, 199, 201, 214, 227, 228

Resolutie, De / Suriname

1 ARA: SONA, 296; ARA: SNA, 108

2 ARA: Collectie-Var. den Bosch, $: 58$

Reynsdorp / ?ikien Baki / Marapica

1 ARA: SONA, 289, 839 
Reynsfort / Pikien Kakrakoe / Warappa

1 ARA: SONA, 295

2 GAA: NA, 16365

Richelieu (later Hoop en 7.org) / Pauluskreek

1 ARA: SONA, 691

2 GAA: NA, 10535

Roosenburg / Sandiki / Boven-Commewijne

1 ARA: SONA, 206, 211; GAI: Collectie-Hudig, 229, 221, 239

2 GAA: NA, :0261, 12374; CAR: Co:lartie-Hudig, 37, 156; GAA: PA-646, 30-32, 35-37

3 GAR: 685-687; GAA: PA-645, 32, 33, 37

4 GAR: Collectle-Hudig 114-284; GAA: PA-646, 26-39

Rust en Werk / Granmangron / Beneden-Commewijne

1 ARA: SONA, 193, 296, 701

2 GAA: PA-6CO, 1266

4 ARA: Collectie-Gülcher

Rustenburg / Saatie / Perica

1 ARA: SONA, 201, 215, 700, 706; ARA: I'WI8, 179

2 GAA: NA, 12633; 32734,12736

3 ARA: PWI3, 178-182; ARA:SOB\&W 1828-1876, 2224; Koloniale Verslagen 18581862

4 ARA: IWWI3, 178-182; ARA:SOB\&W 1828-1876, 2224; Koloniale Verslagen 18581862

Saltzhalen / Bossee / Commetewane:

1 ARA: SONA, 195, 213, 263,702, 707; CAA: PA.646, 63

2 GAA: NA, 12747, 12784; GAA: PA-646, 60-62

3 CAA: PA-646, 64-66

4 GAA: PA-646, 60 66; ARA: SOB\&W 1828-1876, 1576

Sans Soucis / I Iaer Helenakreei

I ARA: SONA, 293

2 GAA: NA, :6323

Saphir / Bereden-Com:newijne

1 ARA: SONA, 226, 706, 838

2 GAA: NA, 10476,12723

Schaapstede / Schapoe / Beneder-Coinmewijne

1 ARA: SONA, 288, 842; ARA: SNA, 108

Scheeveningen / Scheefneid / Wajamoe

1 ARA: SONA, 298

2 GAA: NA, 12759, 12855

Schoonond / Salie / Beneder-Commewine

1 ARA: SONA, 189, 283

2 GAA: NA, 12744, 12781

Simplicité, La / Varenhorsoe / Suriname

1 ARA: SONA, 707

2 GAA: NA, : $: 34.38$ 
Sinabo / Ganda / Commetewane

1 ARA: SONA, 204, 214, 242, 276, 691

3 ARA: Aanwinsten 1888, 3D; RAL: Arch. Des Tombe, 1791

4 ARA: Aanwinsten 1888, 3D; RAL: Arch. Des Tombe, 1790, 1791

Singularité, La / Nové / Beneden-Commewijne

1 ARA: SONA, 242; FHB: KA-120, 14, 21, 39; ARA: SOB\&W 1828-1876, 1035

3 EHB: KA-120, 39; ARA: SOB\&W 1828-1876, 3043

4 EHB: KA-120, 42; ARA: SOB\&W 1828-1876, 3043

Siparipabo / Ma-rika / Boven Commewijne

1 ARA: SONA, 253, 256, 838; ARA: Collectie Copes van Cattenburgh, 76

3 ARA: Collectie-Copes van Catterburgh, 72, 74, 75, 81

4 ARA: Collectie-Copes van Cattenburgh, $76-79$

Somerszorg / Di Haan / Tapoeripa

1 ARA: SONA, 203, 210, 220, 223, 691, 696, 704; GAR: Collectie-Hudig, 301, 329

2 GAA: NA, 10535, 10544; GAR: Collextie-Hudig 285-315

3 GAR: Collectic-Huaig, 322-325, 330, 331, 659, 685.687

4 GAR: Collectie-Hudig, 156, 284-341

Soribo / Perica

1 ARA: SONA, 293, 708

Spieringshoek ( $v /$ h Alteveel) / Spirien / Beneden-Commewijne

1 ARA: SONA, 202, 209, 242; EIBB: KA-120, 12, 26

2 GAA: NA, 10514, 12725

3 EHB: KA-120, 26; Surinaams Museum, Collectie-Mamin

4 EHB: KA-120, 42; Surinaams Museum, Collectie-Mamin

Sporksgift (later deel van Alliance)/ Makniri / Matapica

1 ARA: SONA, 197, 202, 214, 218, 284, 290, 695

2 GAA: NA, 12710; GAA: PA-603, 545

3 GAA: PA-600, 545, 545A; ARA: PWIB, 183

4 GAA: PA-6C0, 543-545A; ARA: PWIB, 183

Stolkertsvlijt / Storkroe / Hoer Helenakreek

1 ARA: SONA, 294

2 GAA: NA, 12438, 12489, 12500)

Stolkwijk ( $v /$ h Stolkertsiurg) / Storkroe / Motkreek

1 ARA: SONA, 193, 241, 296, 689; ARA: SNA, 108

2 GAA: NA, 12418

Susanna's Daal / Moeseerși / Suriname

1 ARA: SONA, 235

2 GAA: NA, 12858

Suynigheid, De / Collica

1 ARA: SONA, 201

Theodora Susanna / Motkreek

1 ARA: SONA, 708

Toledo ( $\mathrm{y} / \mathrm{h}$ Roobank) / Moesantoe / Suriname

1 ARA: SONA, 192, 2:0, 289, 691, 692,696, 706

2 GAA: NA, 12674,12722 
Tourtonne / Kokonassi / Boomkreek Paramaribo

1 ARA: SONA, 224, 225, 697, 698, 841; ARA: SOB\&W 1828-1876, 967, 3044

2 GAA: NA, 10553, 10566, 10582, 16341

Tout Lui Faut / Suriname

1 ARA: SONA, 192

2 GAA: NA, 12395, 12401

Twee Gebroeders, De / Motkreek

1 ARA: SONA, 216

2 GAA: NA, 12438, 12489, 12674

Tyrol / Saramacca

1 ARA: SONA, 296

Utrecht / Boven-Commewijne

1 ARA: SONA, 708

4 James Ford Bell Library, B1452

Vaderszorg en Carelsdeel / Pikier. Beiti / Matapica

I ARA: l'WIB, 27

Visschershaven / Di Hopoe / Motkrezk

1 ARA: SONA, 838

Visscherszorg / Roe of Bereri / Beneder-Commewijne

1 ARA: SONA, 2C2, 235, 258, 691, 708

2 GAA: NA, 10774

Vlaardingen / Cottica

1 ARA: SONA, 263

2 GAA: NA, 12747, 13917

Voorzorg / Beneri / Motkreek

1 ARA: SONA, 259, 279, 696, 704, 707

Vossenblirg / Mosika Di Vroe / Boven-Commewijne

1 ARA SONA, 262; Surinaams Miseum, Coliectie-3rantsen

3 EHB: KA 87, 9, 14.18; Surinaams Muse:1m, Coliectie-Brantsen

4 FHB: KA-87, 1-18; Surinaams Muse:1m, Collertie-3rantsen

Vredenbirg / Para

1 ARA: SONA, 235, 256, 267, 692, 697, 836; EHB: KA-37, 6

2 GAA: NA, ID578; EHB: KA-8; EHB: KA-37, 6

3 EHB: KA-8; EH:B; KA-37, 6

4 ARA: Collectie-Calkoen, 130; EHB: KSA-37, 6

Vreeland / Surimane

1 ARA: SONA, 222, 224, 235,692,696,698

2 GAA: NA, 8040, 12580, 10586

Vriendsbeleid er: Oudersorg / Beneri / Beneden-Commewijne

I ARA: SONA, 191, 201, 208, 2:0, 212,695, 706

2 GAA: NA, 106:9, 12857

Vriesenburg Nova / Reyziger / Tapoeripa

1 ARA: SONA, 263 
Vrieshoop / Hoer Helenakree'x

I ARA: SONA, 704

2 GAA: NA, 15690

Vrouwenvlijt / Novee / Hoer Helenakreek

1 ARA: SONA, 222, 700; EHB: KA-120, 2; Surinaams Museum, Collectie-Mamin

2 GAA: NA, 12720; EHB: KA-37, 13-15; Surinaans Museum, Collectie-Mamin

3 EHB: KA-37, 15; Suriraams Museur, Collectie-Mamin

4 Surinaams Muselim, Collectie-Mamin

Waterland / Suriname

1 ARA: SONA, 253

2 GAA: PA-600, 1226; FHB: KA-37, 4

Waterwijk / Kau Wroko / Perica

l 224, 226, 237, 691, 698

2 GAA; NA, 12433; GAR: Collectie-Hudig, 106, 111

3 GAR: Collectie-Hudig, 106, 108, 1:1

4 GAR: Collectie-Hudig, 106-109, 111

Wayampibo / Wayambo / Boven-Commewijne

1 ARA SONA, 262; Surinaams Museum, Collectie-Brantsen

3 EHB: KA-87, 9, 14-18; Surinaams Muselim, Collectie-Brantsen

4 EHB: KA-87, 1-18; Surinaams Museum, Collectie-Brantsen

Jlant, 't / Pauluskreek

1 ARA: SONA, 193, 262

2 GAA: NA, 10771

IJvershoop ( $v / h$ Largenhoop) / Wajamoekreek

1 ARA: SONA, 215

2 GAA: NA, 12882,16329

Zeezigt / Bakki / Motkreek

2 GAA: NA, 15814; Colectie-lnsinger \& Co., notulboek

3 Collectie-Insinger \& Co., notulboek

4 Collectie-Insinger \& Co., notulboek

Zoelen / Beneden-Commewijne

1 ARA: SONA, 252, 258, 596, 700

2 Collactie-Insinger \& Co., nofulboek; EH3: KA-235

3 Collectie-Insinger \& Co., notulboek; ARA: Collectie-Van den Bosch, 160

4 EHB: KA-120, 42; Collectie-Insinger \& Co., notuilboek

Zorg en Hoop / Pisotoe / Beneden-Commewijne

1 ARA: SONA, 207, 216, 234, 255, 695

2 GAA: PA-600, 545

3 CAA: PA-600, 545, 545A; ARA: SOB\&W 1828-1876, 3048

4 GAA: PA-600, 543-545A

Totaal 218 plantages 


\section{Bibliografie}

Aankekeningen

1856 'Aanleekeningen, mededeelingen, opmerkingen, vragen enz.', WesiIndiz 1:301.

Abrahams, Roger D. (ex.).

1985 Afro-American folk tales; Stories from black traditions in the New World. New York: Pantheon.

Adamson, Alan $\mathrm{H}$.

1972 Sugar without sluves; The political ecunomy of British Guiana, 18381904. New Haven/London: Yale University Press

Ament

1836 De culluur en behandeling der Westindische koffy en indigo, beschreven en vergeleken met die der zelfde producten in Oost-Indië. Kampen: Van Fiulst.

Anstey, Roger

1975 The Atlantic slave trade and British abolition 1760-1810. London: Macmillan,

Bartelink, E.J.

1914 Hoe de tijden veranderen; Herinneringen van een ouden planter. Paramaribo: Van Ommeren.

Beckford, George L.

1983 Persistent poverty; Underdevelopment in plantation economies of the Third World. London: Zed Books. [Oorspronkelijk verschenen 1972]

Beckles, Hilary McD.

1989

Natural rebels; A social history of women in Barbados. London: Zed Books.

Beel, Chris de

1980

People in between; The Matauni Maroons of Surinam. Meppel: Krips. [Proefsch:ift Rijksuriversiteit Utrecht.]

1984 De eerste Boni-ourlog, 1765-1778. Ltrecht: Centrum voor Caraibische Studies, Rijksuniversiteit Utrecht. [Bronnen voor de studie van Bosneger samenievingen 9.]

Benjamins, I.D. en J.F. Snelleman (exis)

1914-17 Encyclopaedie van Nederlandsch West-Ináië. 's-Gravenhage: Nijhoff. Bennett, J.H.

1967 Bondsmen ard bishops; Slavery and apprenticeship on the CodringEon plantations of Barbados, 1710-1838. Berkeley/Los Angeles: University of California Press. 
Benoit, P.J.

1980

Reis door Suriname; Beschrijuing van de Nederlandse bezittingen in Gidyana. Zutphen: Walburg Pers. [Oorspronkelijk verschenen als Voyage a Surinam; Description des possessions Néeriandaises dans la Guyare. Bruxelles: Société des Beaux-Arts, 1839.]

Best, Lloyd

1968

'The mexhanisms of plantation-type econumies; Outlines of a model of pure plantation economy', Social and Fconomic Studies 17:283-323.

Blom, Anthony

1787 Verkandeling van den landbouw in de Colonie Suriname. Amsterdam: Smit.

1801 Veroolg van den Surinamschen landman. Paramaribo: Engelbrecht. Boekhoudt, $W$.

1874 Uit mijn verleden; Bijdrage tot de kennis vart Suriname. Winschoten: Van der Ven.

Boogaart E. van den en P.C. Emmer

1977

'Plantation slavery in Surinam in the last decade before kmancipation: the case of Catharina Sophia, in: Vera Kubin en Arthur Tuden (eds), Comparative perspectives on slavery in Newo World plantation societies, pp. 205-25. New York: Annals of the New York Academy of Sciences.

Boomgaard, Peter

1989 Children of the colonial state; Population growth and economic development in Java, 1795-1880. Amsterdam: Free University Press. [CASA Morographs 1.]

Boomgaard, Peter en Gerr Oostindie

1989 'Changing sugar technology and the labour nexus; The Caribbean, 1750-1900', Nieurve West Indische Gilis 63:3-23.

Busch, C.B.

1843 Reize in West-Jndiz en door een gedeelte van Zuid- en NoordAmerika. Derde deel: Reize naar Skriname, in briezen. Utrecht: Bosch.

Boxer, C.R.

1976

Zeevarend Nederland e'n zijn wereldrijk, 1600-1800. I.eiden: Sijthoff. Vertaling van: The Dutch seaborne empire, 1600-1800. Londan: Hutchinson, 1965).

Braak, C.

1935

Het klimaat yan Nederlandsch West-Indië. Den Ilag: Rijks Liigeverij.

Breugel, G.P.C. van

1842 Dagverhal van eene reis naar Paramaribo en verdere omstreken in de koloniz Suriname. Amsterdam: Sulpke.

Bruipining, C.F. en J, Voorhoeve (ecis)

1977 Encyclopedie var Suriname. Amsterdam: Elsevier.

Bush, Barbara

1982

'Defiance or submission? The role of the slave woman in slave resistance in the British Caribbean', Immigrants and Minorities 1:16-39. 
Bijlsma, R.

1921-1922 'Surinaamsche plantage-inventarissen uit het tijdperk 1713-1742', West-Indische Gids 3:325-32.

Camplell, Mavis

1988 The Maroons of Jamaica, 1655-1796; A history of resistance, collaboration and betrayal. Granby: Bergin and Garvey.

Capelle, H. van

1901 Bijdrage tot de kennis der culfures in Suriname. Amsterdam.

Cardoso, C.F.S.

1977 "Ihe formation of the coffee estate in 19th century Costa Ricia, in:

K. Dunran en I. Routledge (eds), Land and labor in Latin America, pp. 184-207. Cambridge: Cambridge Liniversity Press.

Carrington, Selwyn H.H.

1984 'Econocide - myth or realify? The question of West Indian decline, 1783-1806', Boletin de Estudios Latinoamericanos y de! Caribe 36:1349.

Cauna, Jacques

1987 Au temps des isles à stucre; Histoire d'une plantation de SaintDomingue an XVIlle siècle. I’aris: Karthala et ACC:.

Coffee

1903 Coffee; Lxtensive information and statistics. Amsterdam: De Bussy.

Craton, Mirhas:

1971 Jamaican slave mortailty; Fresh light from Worthy Park, Longville and the Tharp estates', lournal of Caribbean History 3:1-27.

1978 Searching for the invisible man; Slaves and plantation life in Jamaica. Cambriage, Mass./Lundon: Farvard University Press.

1982 Testing the chains; Resistance to slavery in the British West Indies.

Ithaca: Comell University Press.

Craton, Michael er James Walvin

1970 A Jomaican plantation; The history of Worthy Park 1670-1970. London/New York: Aïen.

Dadzie, Stella

3990

'Searching for the irvisible woman; Slavery and resistance in Jamaica', Rase en Class 32-2:21-39.

Davis, David Brion

1966 The problem of slavery in Western culture. Ithaca: Cornell Iniversity Press.

1975 The problem of slavery in the age of revolution, 1770-1823. Ithaca: Cornell Liniversity Press.

Debien, Gabriel

1941 Une plantation de Saint-Domingue; La sucrerie Galbaud du Fort, 1690-1802. Cairo: l'nskitut français d'Archéo'ogie orientale.

1956 Ctudes Antillaises. Paris: Colin.

Deerr, Noel

1949 The history of sugar. Jondon: Chapman and Hal: 2 Delen.

Deursen, A.Th. van

1975 'De Surinaamse negerslaaf in de negentiende eevw', Tijdschrift voor Geschiedenis 88:210-23. 


\section{Douglas, Ch.}

1936

Enige eigenaardigheden en typische merkwaardigheden uit de geschiedenis van de planterij in Suriname. Paramaribo: z.n.

Drescher, Seymour

1977 Econocide; British slavery in the era of abolition. Pittsburgh: University of Pittsburgh Press.

\section{Duchassaing, $P$.}

1858 'Over de elephantiasis Arabum in West-Indië; Met een nawoord betreffende deze ziekte in de kolonie Suriname van Dr. Landré', West-Indië 2:209-33.

Dupuy, Alex

1989

Haiti in the world economy; Class, race and underdevelopment since 1700. Boulder/London: Westriew Press.

Eensgezindheid

1804 Verzameling van uitgezochte verhandelingen, betreffende der landbouw in de kolonie Suriname; Opgesteld door het Landbouwkundig Genootschap: De Eensgezindheid, gevestizd in de devisie Matappika. binnen dezelve kolonie. Amsterdam: Gartman en Uylenbroek.

Einaar, J.F.E.

1934

Bijdrage tot de kennis van het Engelsch tusschenbestuur van Suriname, 1804.]816. 7.p.z.n. [Proefschrift Rijksuniversiteit L.siden.]

Elkins, Stanley $\mathrm{M}$.

1959 Slavery; A problem in American institutional and intellectual life. Chicago: University of Chicago J'ress.

Emmer, Pieter $\mathrm{C}$.

1974 Engelond, Nederland, Afrika en de sfavenhandel in de negentiende eeuw. I.eiden: Brill.

Engerman, Stanley L.

1985 'Economic change and contract labour in the British Caribbean; The end of Glavery and the adjustment to Emancipation, in: D. Richardson (ed.), Abolition and its aftermath: the historical context, 1790 . 1916. pp. 225-44. London: Trank Cass.

1986 Slavery and emancipation in comparative perspective; A look at some recent debates', lournal of Economic History 46:317-39.

Engerman, Stanley L. en E.D. Genovese (eds)

1975 Race and slovery in the Western hemisphere; Quantitative studies. Princeton: Princeton University Press.

Essted, Hugo A.M.

1984 De binnenlandse oorlog in Suriname 1613-1793. Paramaribo: Anton de Kom Universiteit.

Focke, H.C.

$1855 \quad$ Neger-Engelsch woordemboek. Leiden: Van den Heuvel.

Fogel, Robert W. en S.L. Engerman

1984 Time on the cross; The economics of American Negro slavery. Lanham/New York/London: University Press of America. 2 Delen. [Oorspronkelijk verschenen 1974.] 
Frank, André Gunder

1979 Dependert accumulation and underdevelopment. New York/ London: Monthly Review Press.

Freyre, Gilberto

1986 The masters and the slaves; A study in the development of Brazilian civilization. Berkeley/Los Angeles: University of Californiz Press. [Oorspronkeijk verschenen. 1933.]

Fritschy, J.M.F.

1988 De patriotten en ke financiën van de Bataafse Republiek; Hollands krediet en tie smalle marges voor een nieuw beleid (1795-1801). 's-Gravenhage: Stichting Hollandse Historische Reeks.

Genovese, Eugene D.

1965 The political econony of slavery. New York: l'antheon.

1967 'Rebelliousness and docility in the negro slave; A critique of the Elkins thesis', Civil War History 13:293-314.

1976 Roll, Jordan, roll; The world the slaves made. New York: Vintage. [Oorspronkelijk verschenen 1972.]

1981 From rebellion to revolution; Afro-American slove revolts in the making of the New World. New York: Vintage. [Oorspronkelijk verschenen 1979.]

Goslinga, Corne'is $\mathrm{Ch}$.

1971 The Dutch in the Curibtean and on the Wild Coast, 1580-1680. Assen: Van Gorcum.

1985 The Dutch in the Caribben and in the Guianas, 1680-1791. Assen/ Maastrich: Van Gorcum.

1990 The Dutch in the Caribbean and in Surinam, 1791/5-1942, Assen/ Maastricht: Van Gorcum.

Gouvernements-Bladen

1856-1857 Gouvernements-Bladen van de Kolonie Suriname; 1816-1855.

Rotterdam: Nijgh.

Goveia, Elsa V.

1965

Slave society in the British leeward Islands at the end of the eightenth centuny. New Haven: Yale University Press.

1970 The West Indian siave laws of the eightegnth century. Jamaica: Caribbean University l'ress. [Ourspronkelijk verschenen 1960.]

Green, William $A$.

1976 British slave emancipation; The sugar colonies and the Great Experimen: 1830-1865. Oxford: Clarendon Press.

Groenveld Meyer, W.L.

1919 Memorie betreffende het oprichten van eer bank voor de Nederlandsche West-ladische bezittingen', Economisch IJistorisch Jaarboek 5:33-59.

Groot, Silvía W. de

1963

From isolation towards integration; The Surinam Maroons and their descendants (1845-1863). 'The Hague: Nijhoff. IKITLV, Verhandelingen 80.] 
1985

'The Maroors of Surinam: agents of their own emancipation', in: D. Richardson (ed.), Abolifion and its affermath; The historical context, 1790-1916, pp. 55-79, London: Frank Cass.

1988-1989 'Het Korps Zwarte Jagers in Suriname; Collaboratie en opstand', Oso 7:147-61, 8:7-21.

Guda, Trudi (samensteller)

1984

Aleks de Drie; Wan tori fu mi eygi srefi. Paramaribo: Ministerie van Onderwijs, Wetenschappen en Cultuur.

1985

Aleks de Drie: Sye! Arki tori! Paramaribo: Ministerie van Onderwijs, Wetenschappen en Cultuur.

Gülcher, C.F.

1943

'Een Surinaamsche koffieplanter uit de 18 de eeuw (S.L. Neale)', West-Indische Gids 25:41-59.

Hall, C.J.J. van

1933 De cultuur van Surinanusche koffie. Amsterdam: De Bussy.

Handler, Jerome S. en F.W. Iange.

1978 Plantation slavery in Barkados; An archaeological and historical investigation. Cambridge, Mass.: Harvard University Press.

Hartsinck, Jan Jacob

1770 Beschryving van Guiana, of de Wilde Kust, in Zuid-America. Amsterdam: Tisienburg. 2 Delen [Facsimile-uitgave: Amsterdam: Enmering, 1970.]

Heckers, A.A.

1923

Het district Nickerje; Geografische aanteckeningen en geschiedkundig overzicht. Paramaribo: z.n.

Heeckeren, E.L. van

1832

Verslag van den stauf van het Surinaamsch Landbouwkundig Geneotschap 'Prodesse Conamsr'. Paramaribo: z.n.

Heeckeren van Waliën, G.P.C. van

1826

Aantekkeningen, betrekkelijk de kolonie Suriname. Arnhem: Thieme.

Heilbron, Waldo

1982

Kleine boeren in de schaduw van de plantage: De politizke ekonomie von do na-sinvermijperiode in Suriname. Z.p.:z.n. [Proefschrift Universiteit van Amsterdam.]

Hering, C.J,

1858

De kulluur en bewerking van het suikerriet bevattende de meest volkomene en nuauwkewrigste theoretische en practische beschrijving van hat suikertict en deszelfs bewerking [...l, ten gebruike der planters in al de Nederiandsche overzeesche bezittingen. Rotterdam: Nijgh. 3 Delen.

Higman, Barry $W$.

1984 Slave populations of the British Caribbean, 1807-1834. Baltimore/ London: johns Hoṕxins University Press.

Hindess, Barry en P.Q. Hirst

1975

Pre-capifalist modes of production. London: Routledge and Kagan. 
Hira, Sandew

1982

Van Priary tot en met De Kom; De geschiedenis van het verzet in Suriname, 1630-1940. Rotterdam: Futile.

Hoetink, Harry

1972

'Surinam and Curaçao', in: David W. Cohen en Jack P. Greene (eds), Neither siave nor free; The freedman of African descent in the slave societies of the New World, pp.59-83. Baltimore/London: Johns Hopkins University Yross.

Hofstee, E.W.

1981

Korte demografische geschiedenis van Nederland van 1800 tot heden. Haarlem: Fibula-Van Dishoeck.

Hogendorp, D. van

1801 Siukken raakende den tegenuoorägen toestand der Bataafsche bezittingen in Oost-Indï̈ [...]. Den Haage/Delft: z.n.

l loogbergen, Wim S.N.

1978 De Sirimanse weglopers van de 19e eruw. Utrecht: Centrum voor Caraibische Studies, Rijksuniversiteit Utrecht. [Bronnea voor de studie van Bosreger samenlevingen 1.l

1983 'Marronage en Marrons 1760-1863; de niet-gepacificeerde Marrons van Suriname', in: Glenn Wiliemsen (ed.). Suriname: de schele onafhonkilijkheid, pp.75-1:0. Amsterdarn: Arbeiderspers.

1985 De Boni-oorlogen, 1757-1860; Marronage en guetilla in Oost-Surinome. Utrecht: Rijksuniversiteit Litrecht, Centrum voor Caraibische Stidies. [Bronnen voor de studie van Bosneger samenlevingen 11.]

1990 'llet verband lussen marronage en slavenopstanden in Suriname', SWI Forum 7:28-60.

Hudig Dan., J.

1922 De West-Indische zaken van Ferrand Whale; Hudig 1759-1797. Amsterdam: De Bussy.

James, C.L.R.

1984 The black Jacobins; Toussaint I. Ouverture and the San Domingo revolution. Londion: Allison en Busby. [Oorspronkelijk verschener. 1938.]

Jong, Th.P.M.

1966

De krimpende horizon van de Hollandse kooplieden; Hollands weivaren in het Caraibisch Zeegebied. Assen: Van Corcum.

Jonkers, A.

1953

'Hoofdtrekken var de ontwikkeling van Suriname en de Nederlandse Antillen', Wiest-Indische Gids 24:113-59.

Kappler, A.

1854

Zes jaren in Suriname; Schetsen en tafereelen wit het maatschappelijk en miltuire leven in deze kolonie. Utrecht: Dannerfelser.

Koloniaal Versiag

Koloniaal Versiag; Bijlage van het verslag der Hankelingen van de Tweede Kamer der Staten-Generaal. [Ondertitel varieert.] 's-Gravenhage: Algemeene Landsdrukkerij. 
Kuhn, F.A.

1828

Beschouwing van den toestand der Surinaamsche plantagieslaven; Eene oeconomisch-geneeskundige bijdrage tot verbetering deszetven. Amsterdam: Sulpke.

Kunitz, J.D.

1805

Surinam und seine Bewohner oder Nachrichten uber die geographischen, physischen, statistischen, moralischen und politischen Verhältnisse dieses Landes während einer zwanzigjährigen Aufenthalts daselbst, yesammelt. Erfurt: Beyer und Maring.

Kunst, A.J.M.

1981 Recht, commerrie en kolonialisme in West-Indië. Zutphen: Walburg Pers.

Laguerre, Miche! $S$.

1989 Voodoo and politics in Iatit. Basingstake: Macmillan.

Lammens, Adriaan F.

1982 Bijdragen tot de kennis zan de Kolanie Suriname l...l fijajok 18161822. Onder redactie van G.A. de Brujne. Amsterdam: Vrije Liniversiteit, Geografisch en Planologisch Instituut, Leiden: Koninklijk Instituut voor Taal-, Lanci- en Volkenkunde, Caraibische Afdeling.

Lamur, Humphrey E.

1977 'Demography of Surinam piartation slaves in the last decade before emancipation: The case of Catharina Sophia', in: Vera Rubin en Arthur Tuden (eds), Comparative perspectives on siavery in New World plantation societies, pp. 161-73. New York: Annais of the New York Academy of Sciences.

1981 'Demographic performance of two slave populations of the Dutch speaking Caribbean', Boletin de Estudios latinoamenicamos y del Caribe 30:87-102.

1983 Westafrikanse invloed op cie demografische ontwikkeling van Surinamse plantageslaven in de 190 eeuw?', Oso 2:139-48.

1985 De kerstening van de sloven van de Surinaamse planfagr Vossenburg, 1847-1878. Amsterdam: Lniversiteit van Amsteriam, Antropologisch-Sociologisch Centrum.

1987a The production of sugar and the reproduction of siaves af Vossenburg, Suriname 1705-1863. Amsierdam: Centre for Caribbean Studies. [Caribbean Culture Studies 1.]

1987b 'Fertility differentials on three plantations in Suriname', Slavery and Abolition 8:313-35.

Lane, Ann J. (ed.)

1975 The debate over slavery; Stanley Llkins and his critics. Urbana: University of :llinois Pross.

Lans, W.H.

1829 Proeve over de oorzaken van verval en de middelen fot herstel der Surinaomsche plantaadjen. 's-Gravenhage/Amsterdam: Van Cleet.

1842 Bijdrage tot de kennis der kolonie Suriname. 's-Gravenhage: Nederlandsche Maatschappij van Srhone Kunsten.

Ixomte, 11 .

Le coton. Paris: Carré et Vaud. 
Lennep Coster, G. van

1836 Herinneringen mijner reizen naar onderscheideng werelddeeten. Amsterdam: Sxhleijer. 2 Delen.

Lente, Dick van

1990

'Work in progress; Technology in Dutch society during the nineteenth century', Tractrix 2:1-13.

Levine, Lawrence $W$.

1977

Black culture and black conciousness; Afro-American folk thought from slavery io freedom. Oxford: Oxford University Press.

Lewis, Arthur W.

1954 'Economic development with unlimited supplies of labour', Manchester School 24:13:-91.

Lichtveld, LM. en \}. Voorhoeve (eds)

1980 Suriname; Spiegel der vaderlandse kooplieden. 's-Gravenhage: Nijhoff. [Oorspronkelijk verschenen 1958.]

Lier, R.A.J. van

1977 Samenleving in een grensgevied; Een socianl-historische studie van Suriname. Amsterdam: Emmering. [Oorspronkelijk verschenen 1949.1

1983 Bonuman; Een studie san zeven religieuze specialisten in Surinome. Leiden: Irstitute of Cultural and Social Studies. [ICA Publication 60.]

Long, Norman

1990 'From paradigm lost to paradigm regained? The rase for an actororiented sociology of deveiopment', European Review of Latin American and Caribiban Studies 49:3-25.

Mandle, Jay $R$.

1972

'The plantation econonry; An essay in definition', Science and Society $36: 4962$.

1973 The plantation economy; fopulation and economic ehange in Guyana, 1838-1960. Philadeiphia: Temple University Press.

Marte, R.

1984 Lstadisticas y documentos historicos sobre Samto Domingo (1805 1890). Santo Domingo: Ediciones Musen Varional de Historia y Geografia.

Mathurin, Lucille

1975 The rebel woman in the British West indies during slavery.

Kingston: The Afriran-Caribbean Institute of jamaica.

Meiden, G.W. van der

1987 Betwist besfun; Een eeuw strijd om de macht in Suriname, 1651-

1753. Amsterdam: Bataziscine Leeuw.

Meuien, W.W. van der

1904 'Beschrijving var: eenige Westindische plantageleeningen; Bijdrage tot de kennis der geldbelegging in de achttiende eeuw', Bijdragen en Mededealingen van het Historisch Genootschap 25:490-580.

Mintz, Sidney $W$.

1961 'The question of Caribbean peasantries; A comment', Caribbean Studies 1:31-4.

1974 Caribbean transformations. Chicago: Aldir. 
1979

1985

'Slavery and the rise of peasantries', Historical Reflections 6:215-42.

Sweetness and power; The place of sugar in modern history. New York: Viking Penguin.

Mintz, Sidney W. en R. Price

1976 An anthropological approach to the Afro-American past; A Caribbean perspective. Philadelphia: Institute for the Study of Human Issues. [ISHI Occasional Papers 2.]

Mintx, Sidney W. en S. Price (eds)

1985 Caribbean contours. Baltimore/London: Johns Hopkins University Press.

Moreno Fraginals, Manue!

1976

The sugar mill; The socioeconomic complex of sugar in Cuba, 17601860. New York/London: Monthly Review Press. [Oorspronkelijk verschenen als El Ingenio, 1964.]

1985

Plantations in the Caribbcan: Cuba, Puerto Rico and the Dominican

Republic in the late nineteenth century', in: M. Moreno Fraginals,

F. Moya Pons en S.L. Engerman (eds), Between slavery and free labor;

The Spanish-speaking Caribbean in the nineteenth century, Pp. 3-24.

Baltimore/London: Johns Hopkins University Press.

Morrissey, Marielta

1989 Slove women in the New World; Gender stratifiration in the Caribbean. Lawrence: University Press of Kansas.

Müller, M.

1973

'Tien jaren Surinaamse guerrilla en slavenopstanden, 1750 1759', Tijdschrift voor Geschicdenis 86:21-50.

Mulder, G.J.

1847

De voeding van den Neger in Suriname. Rotterdam: Kramers.

[Nassy, David et al.]

1791 Geschiedenis der Kolonie van Suriname; Behelzende derzelver opkomst, voortgang, burgerlyke en staatkundige gesteldheid, tegenwoordigen staat van koophandel, en eene volledige en naauwkeurige beschryving van het land, de zeden en gebruiken der ingezetenen; Geheel op nisuw samengesteld door een gezelschap van geleerde joodsche mannen alaar. Amsterdam: Emmering. [Facsimile-uitgave: Amsterdam: Emmering, 1974.]

[Nepveu, Jan]

1922-1923 Over de bodemgesteldheid en suikerplantage-exploitatie in Suriname 1765 (volgens de annotatie var Gouverneur Jan Nepveu); Met een naschrift door Mr. R. Bijlsma', West-Indische Gids 4:341-9.

Nieboer, H.J.

1900 Slavery as an industrial system of production. The Hague: Nijhoff.

Oostindie, Gert J.

1982 De Cubaanse spoonwegen, 1830.1868; Infrastruktuur en ekonomische besluitvorming in een Caraibische plantage-ekonomie. [Doctoraalscriptie Vrije Iniversiteit Amsterdam.l

1989

Roosenburg en Mon Bijou; Twee Surinaamse plantages, 1720-1870. Dordrecht/Pruvidence: Foris. [KITLV, Caribbean Series 11.] 
Oostindie, Gert en Alex van Stipriaan

1991

Anthony Blom en het "vervolg van den Surinaamschen land. man", Oso 10:136-46.

Oppel, A.

1902

Die Baumwolle nach Geschichte, Anbau, Verarbeitung und Handel, sowie nach ihrer Stellung im Volksleben und in der Stadtswirtschaft. Leipzig: Duncker und Humblot.

Oudschans Dentz, $F$.

1931 'Van slaal tot geneesherr', West Indische Gids 13:147-52.

1946 'Lit de geschiedenis van de koffiecultuur in Suriname', Het Landbouwkundig Tijdschrift 58:49-51.

Panday, R.M.N.

1959 Agriculture in Surinam, 1650-1950; An inquiry into the causes of its decline. Amsterdam: Paris.

Pares, Richard

1960 Merchants and planters. Cambridge: Cambridge University Press.

Posthumus, N.W.

1943 Nederlandsche prijsgeschiedenis. Leiden: Brill. 2 Deien.

Postma, Yohannes

1975 'The Dutch slave trade; A quantitative assessment', Revue Française d'Histoire d'Outre Mart 62:232-43.

1990 The Dutch in the Atiantir slave tradr, 1600-1815. Cambridge: Cambridge University Press.

Price, Richard

1973 (ec.) Maroon societies; Rebei slave communities in the Americas. New York: Anchor.

1976 The Guiann Marouns; A historical and bibliographical introduction. Baltimore/London: Johns Hopkirs Liniversity Press.

1979 'De marrons van Suriname; Een historische inleiding', Mededelingen van de Stichting Surinams Museum 28:10-54.

1983 Tirst time; The historical vision of an Afro-American people. Baltimore/London: Johrs Hopkins University Press.

1990 Alabj's worh. Ba'timore/Loncon: johns Hopkins University Press.

Purseglove, J.W.

1968 Tropical crops; Dicotyledons 2. London: Longmans.

1972 Tropical crops; Monocotyledens 1. London: Longmans.

Quintus Bosz, A.J.A.

1954 Drie enuwer grondpolitiek in Suriname; Fen historische siudie vun de achtergrond en ds ontwikkeling van de Surinaamse rechten op de grond. Assen: Van Gorcum.

1971 Geld, credietbehoeften en negotiaties in Suriname voor 1865. Paramaribu: Lniversiteit van Surirame. [?naugurele rede 112 i971.]

Rapport Stratscommissie 1853

1855 Eerste Rapport der Staatscommissie benoemd bij Koninklijk Besluit van 29 November 1853, no. 66, tot het voorstellen van maairegelen ten acnzien van de slaven in de Nederlandsche koloniën; Suriname. Den I laag: Van Cleef. 
Raynal, G.F.

1776

Wijsgeerige en stakkunlige geschiedenis van de bezittingen en den koophandel der Furopunanen in de beide Indien. Amsterdam. 6 Delen. [Oorspronkelijk verschenen als Histoire philnsophigue ef politique des eitablissemens et du commerce des Européens dans les deux Indes. Amslerdam: z.n., 1773.]

Reesse, I.).

1908 De swikerhankel van Amsferdam wan het begin der 17e fruw lot 181.3; Fen bijdrage tot de handelsgeschiedenis des vaderiands, hoofdzakeitik uit de archiever verzameld en samergesteld. Haarlem: Kleynenberg.

Renselaar, Corry van

1985 Pichotone: Beleid en management van de Surinarmse pluntage Zorg in Hoop, 1760-1863. [Doctoraa]scrip:ie Vrije Liniversiteit Amsterdam, Subfacuiteit Geschiedenis.]

Rodriquez, D.W.

1961 Coffe'; A short economic history with special reference to jamaica. Kingston: Ministry of Agriculture and :ands.

Roland Holst-Van der Schalk, H

1902 Kapitan! en arbeid in Nederiand: bijarage tot de economische geschiedenis der 39de ceww. Eerste deel. Amsterdam: Scep.

Rostow, Walter W.

1962 Stages of economic growth. lomion: Macmillan.

1978 The world economy; History and prospect. London: Macmilan.

Roth, $\mathrm{H}$.

1929 Die Uebererzekgung in der Welthandelsumre Kaffee. Jena: Fischer.

Scherer, J.A.B.

$1936 \quad$ Cotton as a worid power. New York: z.n.

Sxhilkamp, J.A en J.Th de Smidl (eds)

1973 West Indisch Plakantbock; Plakaten, ordonnartiön en andose unetten witgeraardigd in Suriname, 1657-1816. Amsterdam: Emmering.

Schomburgix, Roberl H.

1840 A description of British Guiana gecoraphical and statistical; Ex. hibiting its resources and capabilities, together with the present and future condition and prospects of the colony. :ondon: Simpkin, Marsinall.

Scinuler, Monica

1979 'Afro-Amer:can slave cuiture', fisiorical Reflections 6:121-38.

Schwartz, Stuart B.

1985 Sugar piantations in thr formation of Brazilian soriety; Bahia, 1550-

1835. Cambridge: Cambricige University Press.

Sheridan, Richard 3 .

1970 The developinent of the plantations to 1750; An era of Westindian prosperily, 1750.375. Barbados: Caribbean University l'ress.

1985 Doctors and slaves; A molical and dentographic histony of slavery in the British West Indies, 1680.18.34. Cambridge: Cambridye iniversity Press. 
'Changing sugar technology and the labour nexus in the British Caribbean, 1750-1900, with special reference to Barbades and Jamaica', Nieuwe West-Indische Gids 63:59-94.

Siwpersad, I. P.

1979

De Nederlandse regering on de afschaffing van de Surinaamse slavernij (1833-2863). Groningen: Bouma's Boekhuis, Castricum: Hages.

Stant

1873

'Staat van den oogst van koffie op Java en der koffieprijzen, 18711872', Staatkundig en Staathuiskundig Jaarboekje 25:276-7.

Stedman, John Gabrie]

$1988 \quad$ Narrative of a five years expedition against the revolted negroes of Surinam; Transcribed for the first time from the original 1790 manuscripl. Edited, and with an introduction and notes, by Richard Price and Sally Price. Baltimore/Loncion: Johns I lopkins University Press.

Stein, Stanley J.

1953 'The passing of the coffee plantation in the I'araiba Va.ley', Hispanic American listorical Review 33:331-64.

Stipriaan, Aiex A. van

1982 Hoe Somerszorg op de koffic kwam; Fen Surinamse knfiuplantage, 1754-1856. [Doctoraalscriptie Vrije Uriversiteit Amsterciam.]

1989 The Surinam ra: race; Labour and techrology on sugar plantations, 1750-:900', Nieriwe West-Indische Gids 63:94-118.

1990 'What's in a name; Slavernij en naamgeving in Suriname tijdens de 18e en 19e peliw', Oso 9:25-47.

Suivant, L. et al. (eds)

1973 Encyclopédie Antillaise. Point-a-Pitre: De Sormeaux. 6 Delen.

Surinaams(ch)e AlmanaklAlmanach

1788-1912 Amsterdam, 's-Grayenhage, Paranarijo [: diverse uilgeverijen].

[Onregelmat:ge publikatie.]

Sijpestei;n, C.A. van

1854 Beschrijuing van Surmame; Historisch-, gengrafisch- on statistisch averzigt uit officiẹele bromer ójjeengebragt. Jen Haag: Van Cleef.

Tannenbaum, Frank

1946 Slove and citizen. New York: Vintage.

Teenstra, M.D.

1835 De landbouz in de kolonie Surinume voorafgegalan door erne geschied- en natuurkundige beschouting dint kolonie. Groningen: Eekhoom. 2 Delen.

Temminsk Groll, C.L. et al.

1973 De architectuur van Surname, 1667-1930. Zutphen: Walburg Pers.

Thompson, E.T.

1960 'The plantation cycle and problems of typology', in: Vera Rubin (ed.), Caribbean Studies; A sympositm, pp. 30-46. Washington: University of Washirigton Press. [Oorspronkelijk verschenen 1957.] 
Tomich, Dale

1989

'Sugar technology and slave labor in Martinique, 1830-1848', Nieuwe West-Indische Gids 63:118-35.

Trouillot, Michel-Rolph

1982

'Motion in the system; Coffee, color and slavery in eighteenth-century Saint-Domingue', Review 5:331-88.

Ukers, W.H.

1922

All about coffee. New York: The Tea and Coffee journal.

Voegen van Engelen, I. van

1786-1788 De Surinaamsche Ariz. I'aramaribo: Poppelman. IFacsimile-uitgave: Utrecht: Natumwetenschappelijke Studiekring voor Suriname en de Nederlandse Antillea (Natwurhistorische reeks 4), bezorgd door G.A. Lindeboom, 1981.]

Voorde, P.K.J, van der

1957

De bodemgesteldheid van het ritsenlandschap en van de oude kustvlake in Suriname. Z.p.:Z.n. [Proefschrift Landbouwhogeschool Wageningen.]

Voorhoeve, Jan en Lirsy M. Lichtveld (eds)

1975 Creole drum; An anthology of Creole literature in Surinam. New Javen/London: Yale Liniversity Press.

Voort, J.P. van de

1973 De Wesindische plantages van 1720 tot 1795; Financien en handel. Findhoven: De Witte.

Wagenaar Hummelinck, $P$.

1947 'Het dagelijksche lever: op de Surinaamsche koffie-plantage 'Kokswoud" in 1828', West-lndische Gids 28:33-41.

Wallerstein, Immanuel

1974 The modern world-system; Capifalist agriculture and the origins of the Ekropenn world-conomy in the sixteenth century. New York: Academic Press.

1980 The modern world-szstem II; Mercantilism and the consolidation of the European world-economy, 1600-1750. New York: Academic Press.

1989 The modern world-system III; The second era of grcat expansion of the capitalist world-economy, 1730-1840. New York: Academic Press.

Ward, J.R.

1978

The profitability of sugar planting in the British West Indies, 16501834', Eccnomic History Review, 2nd series, 30:197-213.

1988 British West Indian slazery. 1750-18.34; The process of amblioration. Oxford: Clarendon Press.

1989 The amelioration of British West Indian siavery, 1750-1834; Technical change and the plough', Nienwe West-Indische Gids 63:41-59.

Watts, David

1987 The West Iridies; Palterns of development, culture and environmental change since 1492. Cambridge: Cambridge Uriversity Press.

White, Deborah G.

1985 Ar'nt I a woman? Female slaves in the plantation South. Vew York: Norton. 
Willemsen, Glenn F.W.

1980 Koloniale politiek en transformatieprocessen in een plantage-economie; Suriname 1873-1940. Amsterdam: Kaal.

Williams, Eric

1978

From Columbus to Castro; The history of the Caribbean 1492-1969.

London: Deutsch. (Oorspronkelijk verschenen 1970.]

1980 Capitalism and slavery. London: Deutsch. [Oorspronkelijk verscheren 1944.]

Williams, R.L.

1975 The coffee industry of fanaica. Kingston: University of the West Indies.

Wilson, Ch.

1966 Anglo-Dufch commerce and finance in the eighteenth century. Cambridge: Cambridge University Press. [Oorspronkelijk verschenen 1941.)

Wolbers, ].

1861 Geschiedenis van Suriname. Amsterdam: De Hoogh. [Facsimileuitgave: Amsterdam: Emmerirg, 1970.]

Wolf, Eric R,

1982 Europe and the people without history. Berkeley: University of Califomia Press.

Wooding, Charies J.

1972 Winti; Een Afroamerikaanse godsajenst in Suriname; Een cultureelhistorische analyse van de religienze verschijnselen in de Para. Meppel: Krips. [P'roefscinift Lniversiteit van Amsterdam.] 


\section{Geografisch register}

A La Bonheur 226, 249, 373

Adrichem 39, 244

Alida 279

Alkmaar 73, 111, 174, 352, 414

Alliance ( $\mathrm{v} / \mathrm{h}$ Lodewi; $\mathrm{k}$ sburg en

Sporksgift) 250

Alsimo $188,335,380$

Amsterdam 15, 30, 37-8, 69, 146, 218, $223,225,228,238,242-3,296$

Anno Catharina $62,97,115,143,188$, $191,243,335$

Anna's Burg 381

Antigua 28-9, 139

Arenästust 302, 390-1

Argent Court 232

Aruba 22

Aurora i69, 315, 363

Aventure, I.' 157

Badenstein 91,381

Barbados 5, 23, 28-9, 67, 138-9, 161, 175, $338-9$

Batavia (leproserie) 367

Beekenhorst 121

Beekvliet 77, 85, 109, 154, 232, 263, 271, $316,335,392,398$

Beerensrust 390

Belwaarde 121

Beninenturg 436

Bentshope (v/h Limeshoop) 255

Berbice 51, 150, 208, 228, 237, 264, 325

Berg en Dal 374, 396

Bergerac 389

Berlijn (Commewijne) 179

Beste, $D e 394$

Bleyendaal 95-6, 117, 25.3-4, 316, 335, $380,384,391-2$

Bleyenhoop 212-3
Boekoe (Buku) 386

Boxel $81,121,319$

Brazilië $8,22-3,46,76,134,146,159-61$, 170,183

Breda 226

Bremen 233

Breukelerward 282

Britse (Engelse) Caraíben 10, 26, 31, 44, $\because 39,150,169,183,264,307-8,322,338-$ $40,401,414-5,425$

Brussel 246

Bruynsburg :21

Buitenrust 178-9

Burnside 52,73, 111, 414

Cannawapibo 226, 352

Carelsdeel zise Vadersorg er. Carelsdeel

Catharina Sophia 52, 11:, 169, 178-80, $197,240,249-50,353,359,363,377$

Cayenne 324

Clevia 294

Clifford Xocgshooven 262, 285, 341.2, $363,382,399,401$

Cnoppenombo 373

Commetewanekreek 75, 250, 252, 279

Commewijne $78,80,89,236,241,251$, 253

Commewijne (Beneden) 50, 55, 80, 84$5,94,121,173-4,177-9,206-7,319$

Commewine (Bover) 50,:10, 171, 179, 373,391

Coppename 51, 367

Corantijn 52

Coresburg 226

Coronie $52,63,72,80,91,93,97,122$, $141,187-90,237,316,327,354,386$, 414,419

Costa Rica 159 
Cottica $50,85,127,146,171,175,212$, 279,381

Crawassibo 373-4

Crommelinsgift 226

Cuba 5, 28-9, 46, 56, 76, 134, 138-40,151, $154,175,178,181-2,338$

Curaçao 7,22

Dagerand, De 98, 239, 380

Deens Caraibisch gebied 208, 264

Demarara $150,237,264,282,340$

Den I laag 107

Denemarken 264

Des Tombesbuig 110, 157

Domburg 176

Dominica $: 33$

Dordrecht 213, 226

Drie Gebroeders, D: 93, 118, 175

Driesveli 257,316, 335, 341, 350, 363

Duitsland 264

Duringen $306,316,341$

Dijkueld 226, 291, 388

Eendragt, De 250

EIk 't Ziin 352

Ellen (v/h Nooyt Gedagt) 84

Elserhagen 367

Engeland 22, 25-7, 30, 32, 38, 52, 107, $183,229,231-3,235-7,239,241,245$,

$264,403,414,423$

Espérance, L' 215

Essequibo 51, 150, 339

Eylunt, 't 96

Fackertshoop 226

Fauquenbergue 373,391

Felix 183

Tiskarie 39

Forgue 240

Fortuyn 't 75

Frankrijk 27, 30, 32, 402, 409

Franse Caraibern 25-6, 31-2, 44, 107, : '32, $175,178,183,264,274,415,42.5$

Frederiksburg 236

Frederiksiust 141-2

Geertruidenberg 282

Gelderland (mi.itaire post) 297
Glasgow 248

Goed Succes 226, 282

Goede Hoop, De 226

Goede Voruachting, De 243

Goede Vrede, De 255

Good Inient 97, 254

Goosen 363

Goudmijn 121, 178

Granmangron 39

Grenada 28-9, 138-9, 143, 208, 237

Groningen 153, 244

Groot-Brittannië zie Engeland

Groot Chatillon 171, 226, 352

Groot Marseille 66, 169, 175, 258-60, $284,291,294,299-300,302,3 i 6,335-6$, $350,352,354,374,384,405$

Guadeloupe 28-9, 138, :40, 150-1, 171, 175,181

Guiana (Brits), Guyana 5, 28-9, 133-4, $13840,143,150,178,181-3,185,200$, $324,328,338-9,414,4: 9,425$

Gulana (Frans) 1, 138

Guyana zie Brits Guyara

Guyana's 1

Haiti zir Saint Doming:ue

Hambirg (Saramacca) 52, 162, 240

Hamptoncourt 52

llanover 255

Hazará 52

Hegl ent Sterk 82-3, 156

Hersteling, De 1:5,187, 190, 193

Jildesheim 250

Horrr Helenakjeex (Orleanakreek) 50 , 89,387

Hoop, De 291

Hoopwijk 121, 226

Hooyland 73, 75, 111, 171, 255, 293

lberisch Schiereliand 22

inverness 255

Jagtiust $27,84,115,154,158,228-9,243$, $262,281,285,292,335,380,384,393$. 395

Jamaica $28-9,31,46,56,68,76,79,133-4$, $138-40,151,159-61,175,178,181,197$, $338-40,402,407$ 
Janslust en Blokkenbosch 316, 335-6, 341,350

Java $31,46,76,146,155,264,266,275$

Joden Savanne 33, 74, 297

Johan en Margaretha 179

Johanna Charlotta 184

Johanna's Zoon ( $\mathrm{v} / \mathrm{h}$ Johanna's Hoop) 272

\section{Katwijk 262}

Kent 52, 178, 240

Kleinslust 352

Kocqswoud 291

Kroonenburg 35, 157, 169

Latijns-Amerika 402

Leasowes 190

Leasowes \& Clyde 254

Leliëndaal 80,226

Leydenshoop 255

Libanon 127, 171, 286, 352, 363, 381

Liberié, La 352

Liverpool 190

Livonia 255

Livorno ( $\mathrm{v} / \mathrm{h}$ Woutsvliet) 114, 169, 241

Lodewijksburg 159, 248, 250

Lunden 30, 41, 228, 235-7, 287

Lunenburg 163, 169, 315

Lungtte 394

Maagdenburg (militaire post) 80

Maagdenburg 306

Marasstroom 179

Madeira 273, 391

Mannheim 352

Maria Petranella 399, 403

Maria's Lust 106, 232, 271-2

Mariënburg 114

Marokko 233

Martirique 2, 5, 28-9, 67, 138, 150-1, 155, $171,175,181$

Mest Rouge, lee 243-4, 315, 335, 384

Matapicagebied 12: $188,\{96,207$

Natapicakreek/kanaal 50,62, 115, 183,

$187,191,231$

Mauritius 171

Meerzorg (Surinamerivier) 50, 71, 84, $169,177,180,294,316,363,371,405-6$
Meerzorg (Tapoeripa) $189-90$

Merveille 163,279

Mislukt Bedrog 96

Mocha 46

Mon Bijou 18, 285, 352, 363, 379, 381, 385,400

Montauban 221

Montpellier 221

Motkreek 50, 97-8, 186-7, 231, 238

Mijn Vermaak 157, 406

New York 31

Nickerie $52 \cdot 3,60,63,72,80,91,93,97$, $122,141,: 87-9,237,240,316,327,386$, 414,419

Nieuw Amsterdam, fort 206

Nieuw Roeland 109, 261, 315-6

Nicutue Grond, De 106, 120, 228-9, 281, $285,291-2,303,316,359,367,379,395$, 406

Nienue Hoop 353

Nituwe Levant 146, 371

Nienwrust 56

Nieuwsorg 279

Noord-Amerika zie Verenigde Staten

Nooyt Gedagt zie Ellen

Nursery 52,73, i11, 414

Onderneming, De ( $v / h$ Moeite en Zorg) 226

Onverwagt (Tempatiekreex) 79

Oost-Indië zit Tava

Orarjekreek zie Vredenburgerkreek

O-leanakreek zio Hoer Helerakreek

Ornamibo 246

Osembo 315

Overtoom en Vreeland 390

Oxford : 88

Paix, La 386

Paza 50, 102, 117, 390

Paradise 52, 178, 255

Paramaribo $20,33-4,50,78,99,101,107$. $114,168,212,237,241-2,247,260-1$, $307,311-4,317,352,363,372,375,393$, $397-8,403,406,416$

Patience, La 232

Pauluskreek 95-6 
Peperpot 112, 148

Perica 50, 118, 171, 193, 268

Pernambuco 23

Perou 335, 363, 385

Perseverance (Coronie) 190

Poelwijk 381

Potribo $110-1,279,288,291-2,303,316$, $335,385,390$

Prévoyance, la 249

Providence 240

Pruisen 145, 233

Puerto Rico $5,46,151$

Purmerend 271, 316, 335

Rees en Crop 244

Rencontre, La :777

Resolutie, DE 1:1, 174, 240, 251

Roobonk 55-6

Roosenturg 18, 285, 291, 303, 316, 345, $353,361,363,379,385,387,399-400$

Rofterdam 237

Rust en Werk 39, 111, 391

Rustenburg 118, 169, 180, :93, 336

Saint Croix 28-9

Saint Domingue/ haïti 2, 8, 28-9, 31-2. $46,56,76,93,132-3,138,143,150-2$, $154,158-60,171,183,264,303,314$, $401-3$

Saint Kitts 289

Saint Vincent 28-9, 13.3, i.39

Saltzthaien 75

San Domingo 15I

Sangsue, Ia 226

Sans Souci 226

Santa Barbara 355, 405

Santiago de Cuba 154

Sarah 255

Saramacca 51-3, 60, 72, 91, 119, 122, :30, $162,173,240,250$

Sea Island (VS) 187

Seuland 187

Sinabo 252,254

Singularite, $1.178,169,319,363$

Sint Eustatius 22

Sint Maarten 22

Siparipabo 300-3, 305, 316, 371, 390

Slootwijk 373
Somerszorg 57, 59, 96-7, 263, 271, 277, $285-6,303,306,316,336,341,350,355$, $363,367,374$

Soribo 171

Spaans Caratbisch gebied 1, 171,415

Spanje 22

Sporksgift 157, 248, 250

St. Ann 159

Surinamerivier 50-2, 55, 70, 84, 93, 95, $114-5,121,154,165,171, i 74$, i77-8, $240,39:$

Susannasuaa! 391

Tahjti 171

Tapoeripakreek/kanaal 50,59,96, 153, i 89,221

Tempatickreek 79

Tobago 22, 138, 208

Toledo zie Roobank

Tourtonne 226, 405

Trinidad en Tobago $5,28-9,133,138-40$. $143,175,181,208,339$

Tu:kije 183

Twee Kinderen, De 255

Utrech: 32

Utrecht 294

Vaderszory en Carelsded! 62, 142

Vassouras 160

Verenigde Staten 3, 25, 166, 183, 263-4, 340,402

Vertrouwen, 't 111

Verwachting. De 56

Victoria 374

Vide Bokteille 226

Visscherszorg 106, :73, 177

Vlieland 27

Viugt en Trouw 226

Vossenburg $18,27,67,110-1,166,169$, $179-81,193,233,257,259-60,278,281-$ $6,291,303,306-7,312,315-6,324,335-$ $6,341,345,350,357,363,380,384-5$, $389,396-7,399,405-6$

Vredenburg :02, 117, 245-6, 319, 322

Vredenburgerkreek (Oranjekreek) 50 $1,93,96-7,187,190,231,238,394$

Vreeland 121 
Vriendsbeleia en Oudersorg 89, 382 , 388

Vronwenvlijt 89, 121, 130, 284-6, 350, $363,371,382,387-8$

Waicoribo 391

Warappakreek/kanaal 50-1, 91, 93, 96$7,115,141,187,190,231$

Waterland 244

Waterloo (Nickerie) 52, 73, 111, 178-9, $240,252,254,414$

Waterwijk 169, 268, 294, 36.3

Wayampibo 27, 169, 233, 315, 353, 373

Welgelegen 279

West-Afrika 22, 384

Wolffs Capoerica 169
Woutsuliet zie Livorno

Wijklust 56

Yenen 46

Landvoort 27

Zeeland 23

Zeelandia (fort) 372,399

Zeezigt 78, 97-8, 186-7, 191, 238-40, 279, $281,303,325,367,380,393$

Zoelen 241-3, 395

Zorg en Hoop (Commewijne) 78, 94-5, $109,178,227,232,253-4,269,291,302$ $316,385,392-3$

Zorguliet 39, 21C,

7warigheid $187,190,238,287,291$ 


\section{Personen- en zakenregister}

Aerssen van Sommelsdijck, C. van 23, 37, 70

Akeren, $P$. van 213

Algemeene Maatschappij ter

Bevordering van Volksvlijt 246

Amsincq, P. 70

Amsinca, $\$, 70$

Arp, M. van (fonds) 220

Augerstein, J.M. 158

Avilar, S. d' $93-4$

Bakker 288

Balfour, J. 179, 239, 252

Balfour van Burleigh, fant. Van 71

Baring Brothers ( $\&$ Co.) 30, 236, 238, 287

Bartelink, E.J. 281, 288

Baud, J.C. 391

Bexkford, G.L. 427

Beet, C. de 17

Bent, I. 41, 235, 237, 245, 291

Berewout, F. 228

Berg, farm. 71

Bergh, E.J. van den 298

Beudeker, F. 298

Bienfait \& 7.n., L. (fonds) 243-4

Biesterbos, P. (fonds) 228, 230

Blom, A. 131, 147, 189, 195, 258, 300, 353,358

Blomberg 222

Bonham, P. 52, 235, 298, 320

Boogaart, E. van den 18

Borch, A. ter 224

Bosch, G.B. 29]

Bosch, J van den 246, 251, 321-2, 347, $366,369-70,378,385$

Bosch Reitz, G.J.A. 201

Boxel-Van Gelre, wed. 81

Breugnl, G.j'C. van 195, 277, 285,
$289,295,307,399,405$

Broeke \& Walraven, Van den

(fonds) 242

Broen \& Zn., M. (fonds) 206

Bruinhart, fam. 390

Cadell, J. 324

Cameron, A. 73, 248

Canteron, wed. A. 73

Campbell, M. 8

Campheli (Dent) \& Co., C. 237, 245

Cape'le, $\mathrm{H}$. van 195

Cassa tegen de Weglopers

(Wegloperskas) 257, 259

Caucanas, J. 226

Ceder, fam. 390

Changuion, P. 70

Chenuzens Linsixsay 197

Chevalier \& I'ortielje, Le (fonds) 225

Clifford (\& Z.n.) (fonds) 30, 225

Clifford \& Chevalier (fonds) 225, 230

Coenders, D. 379

Collegium Niedicum 366

Columbus, C. 1

Committee tot de: Zaken van de Colonièr en Bezittingen op de kust van Guinea en in

Amerika/Rad voor het Bestuur van de West-Indische Bezittingen en Coloniën in Amerika en op de kust van Guinea 38

Comptoir der Hoofagelden 257

Comvalius 285

Couke, fam. R. 238-40

Court of Policy zie Hof van Politie

Craton, M. 8-9, 340, 402-3, 427

Croix, La 218

Crommelin, W. 39 


\section{Daser 279}

Debien, G. 158

Derosne \& Cail 250

Dessé, A. 254

Deursen, A.Th. van 396

Deutz, W.G. (fonds) 205, 209, 212, 223,294

Docher, J. 300

Douwe Figberts 24

Duvoisin, B. 195

Ebber(s), G.F. 291

Fekhout, fam. 7!

Eensgezindheid, De 196

Elias, B.J. 43

Elkins, 5.M. $7-8$

Elout, C. 246

Emden, E. van 118

Emmer, P.C. 18

Engerman, S.L. 10

Essed, H.A.M. 17

Esser 291

Evangelische Broeder Gemeente Suriname (EBGS) 330, 378

Eyken Sluyters, T.Y. 201

Eys, fam. D.J. van 71

Fellman, S. 294

Fogel, R.W. 10

Fonseca, da/Van Seca 297

Frank, A.G. 427

Franke, J.H. 304

Freyre, G. 8

Friderici, J.F. de 39, 51-2, 171, 195, $233-4$

Gardè, J.L. 299-300

Genovese, E.D. 8, 401-2

Goldberg 26

Gollenstede, R. 243

Gootenaar, A. 105, 121, 195, 197, 211, 215, 294

Goslinga, C.Ch. 17, 205

Graafland, C. 105, 121, 195, 211

Gravenbergh, A.F. 405

Gravenhorst 405

Groot, S.W. de 8,17

Guicherit, J.L. 393-5
Hageman, R (fonds) 219-20, 224

Hansbach 146, 154

Hardenhoom (fonds) 212, 294

Harg J.M. 287, 291

Harpen \& $\mathrm{Zn}$., A.L. van (fonds) 245

Hart, fam. De 230

Hartsinck, J.J. 196, 383

Harvie 190

Hatterman, J.D. 189-90

Heeckeren, E.L. van 196, 312

Heeckeren Brandsenburg, fam. Van 71

Helm Boddaerd, C. van den 70

Hering, C.J. 192-3, 196

Herkul, fam. 390

Hermael \& Van den Bosch (fonds) 212

liermhutters zie Evangelische

Broeder Gemeente Suriname

Higman, B.W. 10

Hira, 5. 17

Hoetink, H. 7

Hof van Civiele en Crimincles

Justitie 43

Hof van Civiele Justitie 38

Hof van Politie (en Criminele

Justitie) $38,43,217-8,237,294$

Holdridge, J. 193

Hoogbergen, W. 8, 17

Hope, firma 30

Hudig, F.W. (\& J.) (fonds) 217, 221, 243,294

Humber, J. 159

Hurgronje, A. 70

Hurgronje, $P, 70$

Huijssen van Kattendijke, fam. 71

Insinger ( $\&$ Co.), H.A. 191, 228, 238-9, 243,248

James, C.L.R. 8

Jervey, fam. 71

Karsseboom, J.L. 393.4

Kennedy, W. 217

Kilian 288-9, 291

Klein, S.M. 298, 303

Kleine, J.P.H. 301-3, 305 
Klint, H, 196, 298, 303, 306

Koloniale Raad 43-4, 406

Koppelman, A. 300-1, 303

Kuhn, F.A. 341

Kunitz, J.D. 371,373

Labat, J.B. 196

Lact, De 196

Lammens, A.F. 270, 314, 320, 358

Lamur, H.E. 17-8

Lans, W.H. 188

Leach, J. 287

I.ennep, firma Van 30

Lever \& De Bruyne (fonds) 220

Liex, R.A.J. van 8,17

Linnaeus, C. 196

Linck, G.N. 229, 297-8

Linck, wed. 243

I.oseken 212

Lyon, y. de 391

Macintosh, W. 72

Marselis, gebr. J. \& Th. van (fonds) $209,223-4,294$

Marx, K. 3

Mauricius, J.j. 39, 293

Menke, J.H. 298

Mesquita, D. B. de 201

Mesquita, gebr. De 72

Meynertzhagen, De 241, 287

Middelburgsche Commercie Compagrie 294

Mintz, S.W. 9, 17, 403

Moravische Broeders zie.

Evangelische Broeder Gemeente Suriname

Morrissey, M. 9

Mulder, G.J. 354, 356

Nassy, D. de I. Cohen 289,291

Neale, J. de 70

Neale, S.L. de 70, 146, 293

Neck, firma Van 30

Nederlands-Brits gerecintshof, (gemengd) 107

Nederlandsche Hardelmaatschappij 239

Nepveu, J. 39-40, 50-1, 69, 155, 157-8,
$195,212,218-9,258,380$

Neufville \& De Wolff, De 225

Niehtrnke 299-300

Noordbergh, J. 244

Notten, firma Van 30

Nuys \& Meerhout, Van 206

OFerral 56

Ommeren, W.I. van 232

Oostindie, G.J. 17-8

Panday, R.M.N. 16

Parra, I. de la 201

Parti, S. de la 72, 297-8, 390

Particuliere West Indische bank (PWI Bank) 247, 249-52, 254-5

Passalaigue, J. 12]

Passalaigue, Th. (fonds) 206

Perret Gentil, H. J. 287

Pichot, F.L. 297

Pichot, Q.G. 297, 299, 302, 304

Planteau, ]. 298

Ploos van Amstel 222

Politieke Raad 38, 43

Poll (\& Comp.), H. (en wed. I.) van de (fonds) $217,221-2,224,228,230$, $232-3,253,296-7$

Polman 29:

Priary 50

Price, R. 8-9, 17

Prodesse Conamur 196-7

I'urperhart, fam. 390

Raad van (Amerikaansche)

Koloniën 38,310

Raad van Politie 296, 298

Raders, R.F. van 391

Raye, ]. 195

Raymal, G.F. 196

Reed, N. 157

Rees, R. van 287,394

Rochebrune, J.B. de 285

Rochetrau, J. 106

Röman, E.H. 341, 365-6, 381

Roux, J. 361

Ruyter \& A. F. Schaap, wed. N. de 294

Rijdenius, P. (fonds) 224 
Rijk, J.C. 373

Saffin, W.H. 294

Salontha van Salonthay, A. 219, 386

Sanches 110, 201

Schaap, wed. J.J. 294

Scharmweber 287

Schelling 195

Schramm 291-2

Schuler, M. 9

Schultz (Jansz.), J.H. 287, 298, 306

Schwartz, S. 8

Simeon 155

Siwpersad, J.P. 17, 347

Smith \& Co., Dean 248

Sociëteit van Suriname, Geoc:troyeerde $23,38,44,51,79-80,: 58$, 408-9

Spjlker, J.C.G. 250

Staten-Generaal 24, 26, 32, 38, 44, 4t8

Stedman, J.G. 314

Steenbergen, W.A. 294

Steenbergen \& Portielje (fonds) 225

Steglich 405

Straalman, M. 70

Surinam Absentee Sexuestered Property Commission $41,235-6$

Taets van Ameronger, fam. 71

Tamnen, M.E. 299-30G

Tannenbaum, F. $6-7$

Taunay, F. 287, 298

Teenstra, M.D. 149, 196-7, 322

Tellier \& Chicot 294

Thijm, wed. L. (fonds) 212

Tirion, H.A. 293
Tyndall, I. 187

Uhlenkamp, D.M. 285-6, 384, 396

Veen, Van der 146

Veer, J. de 389

Venetiaan, fam. 390

Verboom, A. 70

Verenigde Oost-Indische Compagnie (VOC) 22

Vermeilen 94

Vis, fam. 71

Vlaer \& Koll 247

Vlissingen \& Dudok van Heel, Van :18

Vogi, J. 201

Vogt, (wed.);C. 297-8

Voort, J.P. van de 205

Wagerer 285,382

Weissenbruch, C.L. 295, 298, 303

Weissenbruch, G.C.B. 296

West \& De Hart, Van 242

West India Interest $31-2,14$

West-Ind:sche Compagnie (WIC)

22-4, 26, 30, 37, 105, 205, 257, 409

Whitmee \& Co., J. 157

Wilde, De 94

Wilkens, L'. 296, 304

Willem I, Koning 246

Williams, E. 4

Wolbẹrs, J. 15

Wolf, 11.M. 232

Wollf, ?. de 225

Wolfing 241

Wright, H. 72, 255 